GLOBAL ASIA

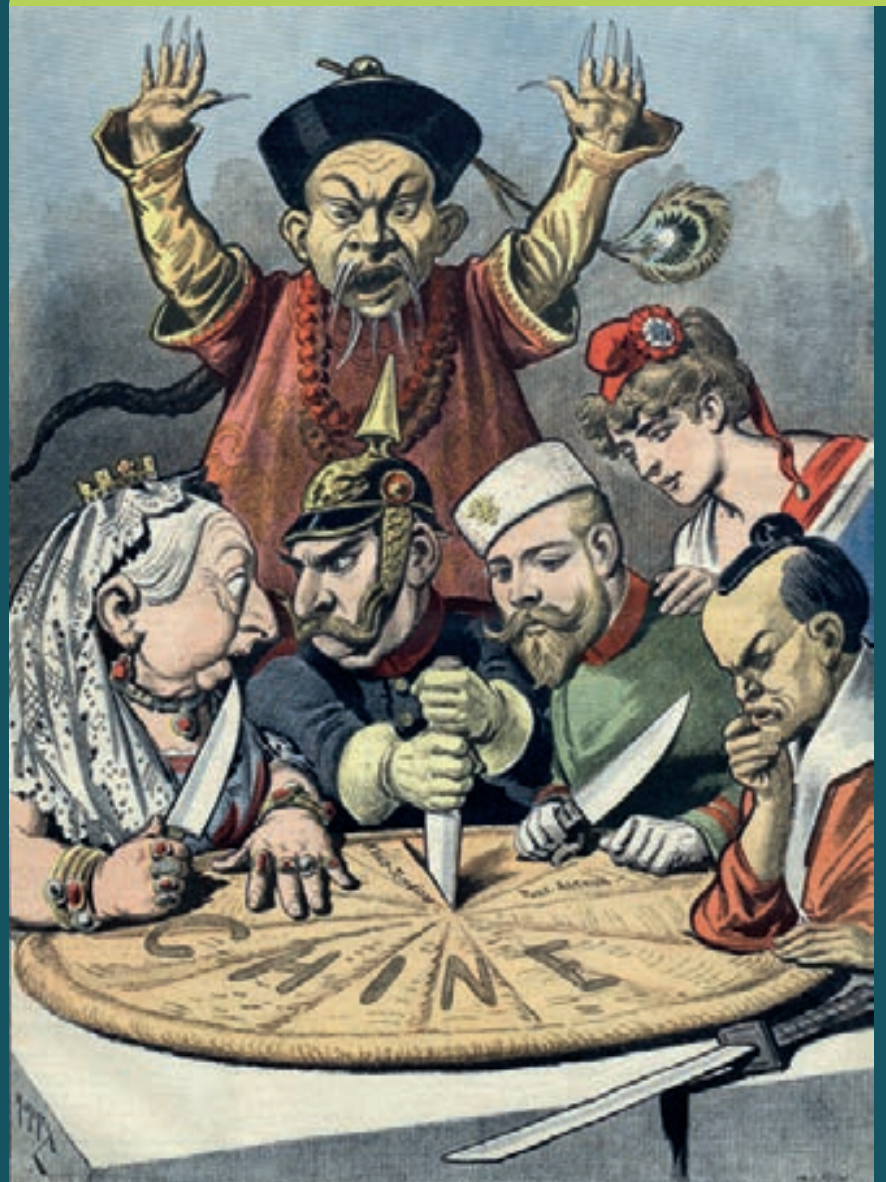

Kees van Dijk

Pacific Strife

\title{
The Great Powers and their Political and Economic Rivalries in Asia and the Western Pacific, 1870-1914
}


Pacific Strife 


\section{IIAS Publications}

International Institute

for Asian Studies

The International Institute for Asian Studies is a research and exchange platform based in Leiden, the Netherlands. Its objective is to encourage the interdisciplinary and comparative study of Asia and to promote (inter)national cooperation. IIAS focuses on the humanities and social sciences and on their interaction with other sciences. It stimulates scholarship on Asia and is instrumental in forging research networks among Asia Scholars. Its main research interest are reflected in the three book series published with Amsterdam University Press: Global Asia, Asian Heritages and Asian Cities.

IIAS acts as an international mediator, bringing together various parties in Asia and other parts of the world. The Institute works as a clearinghouse of knowledge and information. This entails activities such as providing information services, the construction and support of international networks and cooperative projects, and the organisation of seminars and conferences. In this way, IIAS functions as a window on Europe for non-European scholars and contributes to the cultural rapprochement between Europe and Asia.

IIAS Publications Officer: Paul van der Velde

IIAS Assistant Publications Officer: Mary Lynn van Dijk

\section{Global Asia}

Asia has a long history of transnational linkage with other parts of the world. Yet the contribution of Asian knowledge, values, and practices in the making of the modern world has largely been overlooked until recent years. The rise of Asia is often viewed as a challenge to the existing world order. Such a bifurcated view overlooks the fact that the global order has been shaped by Asian experiences as much as the global formation has shaped Asia. The Global Asia Series takes this understanding as the point of departure. It addresses contemporary issues related to transnational interactions within the Asian region, as well as Asia's projection into the world through the movement of goods, people, ideas, knowledge, ideologies, and so forth. The series aims to publish timely and well-researched books that will have the cumulative effect of developing new perspectives and theories about global Asia.

Series Editor: Tak-Wing Ngo, Professor of Political Science, University of Macau, China

Editorial Board: Kevin Hewison, Sir Walter Murdoch Distinguished Professor of Politics and International Studies, Murdoch University, Australia / Hagen Koo, Professor of Sociology, University of Hawaii, USA / Loraine Kennedy, Directrice de recherche, Centre d'Études de l'Inde et de l'Asie du Sud, École des Hautes Études en Sciences Sociales, France / Guobin Yang, Associate Professor, Annenberg School for Communication, University of Pennsylvania, USA 


\section{Pacific Strife}

The Great Powers and Their Political and Economic Rivalries in Asia and the Western Pacific 1870-1914

Kees van Dijk

Amsterdam University Press 


\section{IIAS Publications}

International Institute

for Asian Studies

\section{Global Asia 5}

Cover illustration: Illustration from supplement to Le Petit Journal, 16th January 1898

Cover design: Coördesign, Leiden

Typesetting: Crius Group, Hulshout

Amsterdam University Press English-language titles are distributed in the US and Canada by the University of Chicago Press.

$$
\begin{array}{ll}
\text { ISBN } & 978 \text { 90 } 89644206 \\
\text { e-ISBN } & 9789048516193 \text { (pdf) } \\
\text { NUR } & 692|697| 754
\end{array}
$$

(C) Kees van Dijk / Amsterdam University Press, Amsterdam 2015

All rights reserved. Without limiting the rights under copyright reserved above, no part of this book may be reproduced, stored in or introduced into a retrieval system, or transmitted, in any form or by any means (electronic, mechanical, photocopying, recording or otherwise) without the written permission of both the copyright owners and the authors of the book. 


\section{Contents}

Foreword

1 Steam and Istmus Canals

2 Rivalries in the Western Pacific $\quad 21$

In search of new markets and political influence 22

$\begin{array}{ll}\text { The great Russian-French combination } & 29\end{array}$

China's Open Doors $\quad 35$

Great Britain's search for an ally $\quad 39$

3 Planters, Traders and Labour in the South Pacific 43

$\begin{array}{ll}\text { The ocean of the future } & 48\end{array}$

The white settlers $\quad 5^{\circ}$

Labour traffic $\quad 5^{2}$

Commerce and politics $\quad 53$

$\begin{array}{lr}\text { Conflicts over land } & 56\end{array}$

Policing the Pacific $\quad 58$

4 Fiji: The Start of Anglo-German Rivalry in the Pacific 63

$\begin{array}{ll}\text { Germany's ambitions } & 66\end{array}$

$\begin{array}{ll}\text { The reign of King Cakobau } & 69\end{array}$

$\begin{array}{ll}\text { The aftermath of annexation } & 73\end{array}$

5 The Samoa Conflict $\quad 81$

An American takes control $\quad 84$

Weber goes on the offensive 90

6 Germany Enters the Colonial Race $\quad 97$

$\begin{array}{lr}\text { Australian claims and fears } & 102\end{array}$

$\begin{array}{ll}\text { The Moresby annexation } & 105\end{array}$

$\begin{array}{ll}\text { Bismarck's Reichstag debacle } & 108\end{array}$

The New Guinea expedition 111

The Queensland annexation 113 
7 The New Guinea Protectorates 121

The hoisting of German flags 122

The hoisting of British flags $\quad 124$

Australian astonishment and indignation $\quad 131$

New negotiations and hoisting of flags $\quad 133$

$\begin{array}{lr}\text { A different style of diplomacy } & 135\end{array}$

The Anglo-German colonial honeymoon $\quad 138$

The wider South Pacific 142

8 Great Britain, Russia and the Central Asian Question 147

Persia and Afghanistan and the threat to India 149

Russian moves and British countermoves 154

9 Samoa Remains a Source of International Tension $\quad 161$

Germany presses on 162

$\begin{array}{ll}\text { The Tonga Islands } & 167\end{array}$

$\begin{array}{ll}\text { Civil war in Samoa } & 170\end{array}$

10 The Emerging Economic World Powers 177

$\begin{array}{lr}\text { Germany's world politics } & 177\end{array}$

America's large policy $\quad 186$

$\begin{array}{ll}\text { Asia for the Asians } & 189\end{array}$

$\begin{array}{ll}\text { Building strong navies } & 191\end{array}$

The American-Japanese naval race 195

11 Great Britain, France and Southeast Asia 201

The French military expeditions to Tonkin 204

$\begin{array}{ll}\text { The end of the Kingdom of Ava } & 217\end{array}$

12 The French Expansion Westwards into Southeast Asia 227

$\begin{array}{ll}\text { The Franco-Thai war } & 231\end{array}$

Continued British-French rivalry $\quad 236$

The Anglo-French Declaration $\quad 241$

13 Russia, Japan and the Chinese Empire 245

The Sino-Japanese War $\quad 252$

Russo-Japanese strife over Korea $\quad 263$ 
14 Thailand and Beyond $\quad 267$

$\begin{array}{ll}\text { The Race for Yunnan } & 270\end{array}$

An ambitious Governor-General $\quad 278$

$\begin{array}{ll}\text { The Malay Peninsula } & 283\end{array}$

15 The Scramble for China: The Bay of Jiaozhou and Port Arthur 295

The consequences of military defeat $\quad 298$

$\begin{array}{ll}\text { Port Arthur } & 310\end{array}$

16 The British Reaction: Wei-Hai-Wei $\quad 317$

$\begin{array}{ll}\text { Wei-hai-wei } & 323\end{array}$

$\begin{array}{ll}\text { Railway concessions } & 330\end{array}$

17 The Scramble for China Continues: Guangzhouwan and Tibet 337

The Boxer Rebellion 340

The British incursion into Tibet $\quad 346$

How far to enter into Tibet $\quad 351$

The Anglo-Tibetan Convention 355

18 The Failed Annexation of Hawaii 359

American interests in Hawaii $\quad 361$

$\begin{array}{ll}\text { The white settlers take charge } & 365\end{array}$

$\begin{array}{ll}\text { Annexation or not? } & 373\end{array}$

19 The United States Becomes a Colonial Empire $\quad 381$

$\begin{array}{ll}\text { The Japanese spectre } & 382\end{array}$

The Philippines, unexpected spoils of war $\quad 386$

$\begin{array}{ll}\text { The American Empire } & 398\end{array}$

20 The Partition of Samoa $\quad 401$

New negotiations $\quad 405$

Samoa under foreign rule $\quad 413$

21 The Russo-Japanese War $\quad 417$

$\begin{array}{ll}\text { Preparing for war } & 420\end{array}$

The Anglo-Japanese Alliance $\quad 423$

The Korean question $\quad 428$

The Russo-Japanese war $\quad 431$ 
22 Great Britain's Search for Secure Colonial Frontiers 439

The South Pacific 440

The Entente Cordiale $\quad 446$

The Anglo-Russian Convention $\quad 451$

The Persian Question $\quad 457$

23 The United States, Japan and the Pacific Ocean 463

Japan's role in the Pacific $\quad 465$

$\begin{array}{ll}\text { American-Japanese relation } & 471\end{array}$

Russia and Japan guarding their spheres of influence 474

Japan and Russia consolidate their position in China $\quad 483$

Japan and the Pacific 486

24 Epilogue $\quad 489$

$\begin{array}{ll}\text { Bibliography } & 499\end{array}$

$\begin{array}{ll}\text { Index } & 511\end{array}$

List of Treaties, Agreements and Joint Statements mentioned $\quad 521$ 


\section{Foreword}

This book grew out of another one: The Netherlands Indies and the Great War. Writing it made me realise how much international developments in the Pacific in the previous decades had shaped Dutch anxieties about the Netherlands being able to hold on to its colony in the East. The conduct of the mighty colonial powers of those days, quarrelling over acquiring new territory and trying to expand their spheres of influence, made the Dutch position in what the Dutch considered their colony and their sphere of influence in Southeast Asia appear far from safe. The feeling was that the powers were dividing up the Pacific and a large part of Asia amongst themselves and that the Netherlands Indies could well fall prey to an unscrupulous nation stopping at nothing to satisfy its territorial appetite. The Netherlands was a weak country, without a strong army and navy. It would be unable to repel an invasion of the Netherlands Indies or prevent other countries from establishing footholds in those parts of the archipelago where Dutch control was weak or non-existent. The data collected to sketch the background of these Dutch anxieties, which for reasons of space could not be dealt with in detail, forms the basis from which the present study about the rivalries between the powers in Asia and the Western Pacific between 1870 and 1914 grew. The year 1870 was selected as the starting point because of the opening of the Suez Canal in November 1869 and the birth of the German Empire in January 1871, when Wilhelm I, King of Prussia, was crowned Emperor of Germany.

In the three decades that followed, Great Britain and Germany quarrelled over New Guinea, the Bismarck Archipelago, Fiji and Samoa. France and Great Britain competed over control of continental Southeast Asia and became involved in a series of diplomatic conflicts about establishing protectorates in island groups in the South Pacific and actually annexing some of them. The United States became entangled in the dispute over Samoa and annexed the Philippines and Hawaii, while Japan became a power in its own right. By 1900, a possible disintegration of China and the efforts of the powers to gain as much as they could from China's weakness or to prevent contenders from doing so had added a new dimension to the rivalries between the powers in the Pacific. Clashing foreign economic and political interests in China made for speculation about a great war that might erupt at any moment; a war on an unprecedented scale involving, as it would, most if not all of the powerful nations of the day. There was no such confrontation, but the Russo-Japanese War of 1904-05 allowed 
Japan to take possession of South Manchuria and Korea and added to the suspicion that Japan was aiming at naval supremacy in the Pacific. Japan building a strong navy, and the retreat from Asian waters of the British fleet, needed in Europe to face the German danger in the North Sea, was viewed with anxiety not only in the Netherlands Indies but also in Australia and New Zealand. Japan's growing military might also prompted a naval race between the United States and Japan. Americans came to consider Japan a threat to recently acquired Hawaii and the Philippines, and even did not preclude a Japanese invasion of America's unprotected west coast.

This study focuses on the Western Pacific and the Far East, but the relations between Great Britain and Russia in Central Asia, suspicious of each other's intentions in Afghanistan and Persia, both countries bordering on India, also had to be taken into account. India was Great Britain's most valued colonial possession and loomed large in British strategic and commercial considerations on how to proceed in China and Southeast Asia. For Russians, the western and northern border of Afghanistan were regions where it could, when necessary, put pressure on the British and thus pin down British troops in India that might otherwise be deployed elsewhere. In this way, Central and East Asia became interwoven as one theatre where the strategic game was played and moves and countermoves were contemplated.

Writing about the past means a lot of sitting in libraries and archives. My thanks goes to their staff, but there is one person I want to thank in particular: Dr G.P. Rouffaer, adjunct secretary of the KITLV (Royal Netherlands Institute of Southeast Asian and Caribbean Studies) between 1898 and 1909. He is long dead, but we owe it in part to him that the KITLV has such a fantastic collection of books - not only its renowned collection on Indonesia, but also on the rest of Asia and the Western Pacific. Rouffaer's broad-minded, liberal acquisition policy was not always understood by those in charge, who refused to spend money on books that they believed did not fit into the collection, but Rouffaer usually found ways to ensure that the books which he found worthwhile ended up in the KITLV collection. Many of those books I used for this study. People like Rouffaer deserve to be remembered. Without them, many libraries would not be what they are now.

Current librarians will immediately recognise Rouffaer's predicament. In recent decades, for reasons of money and available space, acquisition criteria have become increasingly narrow. Both academic and public libraries are threatened with closure or drastic financial cuts. Among 
the victims is the KITLV Library. It has been incorporated in the Leiden University Library and does not exist anymore as an independent institution. This unfortunate event is an additional reason to thank those who were always ready to help me and other visitors of the reading room: Rini Hogewoning, Josephine Schrama, Sven Aalten, Nico van Rooijen and Alfred Schipper. 



\section{Steam and Istmus Canals}

On 17 November 1869 the French Imperial steam yacht, L'Aigle, leading a procession of ships, was the first vessel to sail the Suez Canal. On board was Eugénie, Empress of France, wife of Napoleon III. The naval pageant was the climax of days of festivities celebrating the opening of the canal. There were balls, fireworks and public entertainment on a grand scale, while the streets of Alexandria were decorated with flags and arches. At night lighted torches on roofs illuminated the city. In the harbour the men-of-war and merchantmen displayed coloured lanterns. The host was Ismail, the Khedive of semi-independent Egypt, whose predecessor, Muhammad Said, had allowed Ferdinand de Lesseps to draw up plans for the digging of the canal and for a new harbour, Port Said.

To underline the international importance of the occasion European royalty were well represented. Among those who had travelled to Egypt were Franz Joseph I, Emperor of Austria-Hungary; Crown Prince Friedrich III of Prussia; Grand Duke Michael of Russia; and Prince Hendrik, the brother of the Dutch king. The British delegation was a more modest one. Great Britain was represented by Henry Elliot, British ambassador to the Ottoman Empire rather than by a member of the royal family; no better illustration of the fact that the canal was, first and foremost, a French project, constructed by a French engineer and largely financed by French money. Due to their concerns about an advance in Egypt by France, their political and colonial rival, and the easier access to India the new shipping route offered France, the British had viewed the digging of the canal with distrust, doing their best to wreck the project. For similar reasons, the Ottoman Sultan, Abdulhamid II, was conspicuously absent. He could hardly attend a ceremony in a part of his Empire that in the past, by military might, had forced Istanbul to grant it independence in all but name, while he also feared a decline of the traditional trade routes in the region. Fortified in his reservations by British diplomats he had opposed the project from the start (Palmer 1992: 132).

Little more than a year later, towards the close of the Franco-Prussian War - which would lead to the dethronement of Napoleon III - another impressive ceremony took place, this time in France. On 18 January 1871, in the Hall of Mirrors in the Palace of Versailles, Wilhelm I, king of Prussia, was crowned Emperor of Germany. Present at this exclusively German party were princes, grand dukes and other representatives of the nobility of the individual states and of important mercantile free cities, such as Hamburg 
and Bremen, numerous military officers and other German dignitaries; and, of course, Otto von Bismarck, Prime Minister of Prussia, the first Chancellor of the new German Empire and the architect of the meeting, of Prussia's foreign policy and of German unification. Though the ceremony was not as grand as the painting from 1885 by Anton von Werner wants us to believe - many of the officers present were in simple field dress (Steinberg 2011: 307) - it was a manifestation of a German patriotic spirit on French soil. For the first time the Kaiserhymne, the Prussian national anthem Heil dir im Siegerkranz (Hail to Thee in Victor's Crown), resounded as the semi-official hymn of the new Empire.

There was still a third important ceremony that took place around the same time, albeit with less pomp and with no royalty or aristocracy present: the driving in of the last spike into the track of the American Transcontinental Railway at Promontory Summit in Utah on 10 May 1869. The railway connecting the American east and west coasts offered new perspectives for trade with Australia, New Zealand and China (and looking in the opposite direction, with Europe). The opening of the Suez Canal and the completion of the Pacific railroad, the Straits Times would write in January 1870 in Singapore, were 'two vast enterprises destined to exert

Figure 1 Suez Canal around 1890

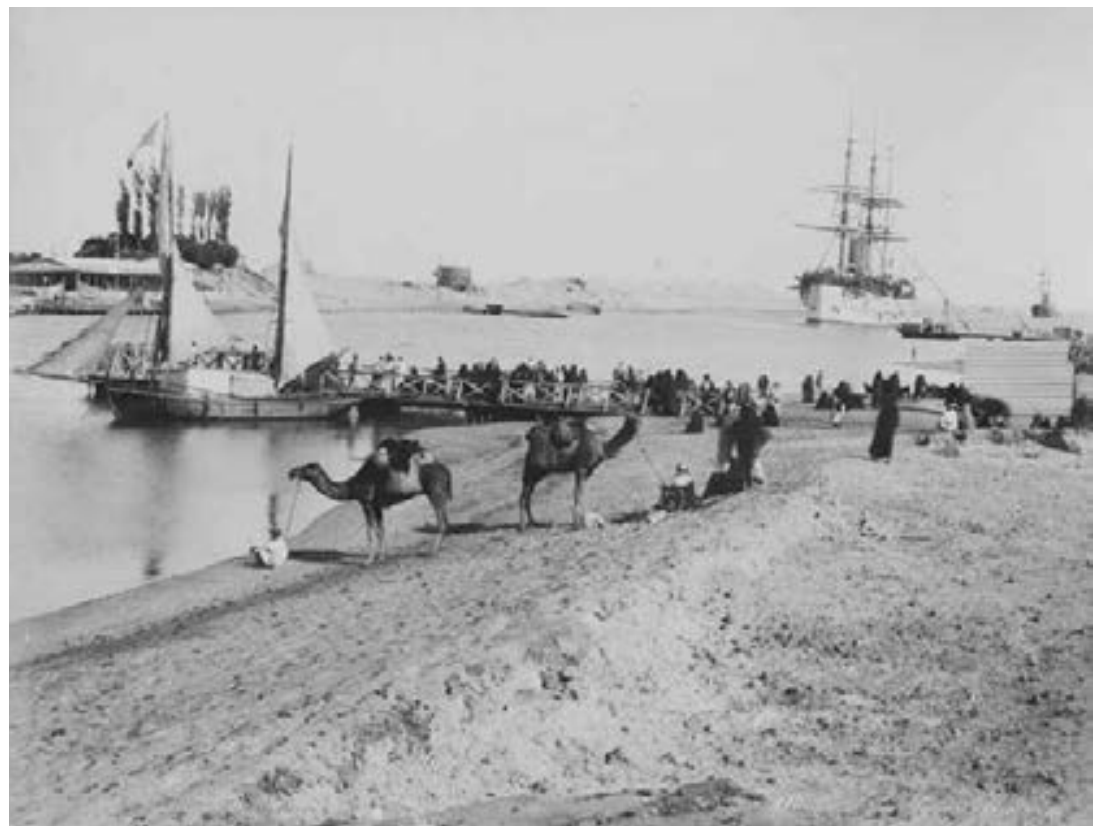


a mighty influence upon the trade of the world, and to revolutionize that of the entire East' (Bogaars 1955: 101).

The Suez Canal drastically shortened the journey from Europe to India and the Far East. Combined with the replacement of sailing vessels with steamships, which took place around the same time, the possibility to sail the Canal soon led to a boost in trade and passenger travel. The Persian Gulf, India and Asia were to experience an influx of ships and European residents, including, as Margaret MacMillan (1988: 21) and others have pointed out, women, changing not only the composition but also the way of life of the foreign communities that had sprung up in Asia. To the south, Australia, New Zealand and the islands in the South Sea saw a similar intensification of sea traffic. The replacement of sailing ships with steam-propelled ones not only enhanced European shipping and trade in the Pacific, it also boosted sea traffic from the west coast of the United States into the Pacific.

Some fifteen years later, on 7 November 1885, at Graigellachie in British Columbia, the last spike on the Canadian transcontinental railroad was driven, with its terminus at Port Moody near Vancouver. The Canadian Pacific Railway gave Great Britain and its colonies an additional stake in trans-Pacific trade. Russia did not lag far behind. In 1891 construction of the Trans-Siberian Railway, connecting St Petersburg with Vladivostok on the West Pacific north coast, was started, a sign of Russia's aim to expand eastwards into north Asia. Sometimes the locomotive, that other steam-powered means of transport enabling fast communication, worked in tandem with the steamship. Sometimes it acquired a significance of its own as a means to penetrate deep into a country. Railways were essential in the opening up of the Asian continent and in expanding influence. They were a medium of 'peaceful conquest' (Doumer 1905: 343). It was not just trade people were thinking of. After the Prussian victory in 1866 over Austria and in 1870 over France had demonstrated how important the movement of troops and equipment by rail could be for victory on the battlefield, railways entered the strategic considerations of military experts and laymen. They had not only become avenues of trade - and of civilisation some would stress - but also instruments of military advance and defence. Railways, the London newspaper The Outlook wrote in May 1902, referring to China, were 'the source and agencies of all power. From the railway line proceed all military influence and effective political action' (Cunningham 1902: 189).

One of the side effects of faster and intensified communication was that in trade and politics the home country could expand its hold over its overseas possessions. Decisions were increasingly taken at home by the government officials and cabinets, and by directors and boards of commercial 
companies, rather than on the spot in Asia and the Pacific. The telegraph was an equally important contributing factor in realising this, allowing for frequent contact between the home government and company headquarters and its representatives abroad, also, or especially so, at moments of crisis. An overland connection running from London through Germany, Russia, Southeastern Europe and Iran to Calcutta, had been completed in January 1870. In that same year a more secure - from a British perspective - direct submarine telegraph cable link between London and Bombay also became operative. From Madras the line was extended to Singapore and Hong Kong, bringing the whole of the Far East within its reach.

A greater European and American presence in the Pacific, combined with a new sense of colonial grandeur in the first half of the 1880s, first in France and thereafter in Germany, made the Pacific an arena of fierce competition between the powers. Steam meant speed and made it possible to sail irrespective of wind directions and currents, but it also had its setbacks. Coals had to be stored on board ship where space was limited. On long voyages, steamers, whether they were warships or merchantmen, had to bunker at coaling stations, the possession of which became of vital importance. Colonies required coaling stations en route. Trans-Pacific shipping made the same necessity felt and had seen to it that Samoa, Hawaii and other Pacific island groups had acquired a new strategic importance. In the considerations of contemporaries coaling stations, also serving as naval bases, were not just important for own trade and the protection thereof, they could also be used as a base from which to attack the shipping lines of rivals with what the Germans sometimes called Handelsstörer, warships which had the specific task of disrupting the enemy's trade. How effective such a strategy could be would only become apparent in the first months of World War One, with the exploits of the German raider, the Emden; her operations in the Bay of Bengal, the Andaman Sea and along the Malay coast led to panic in British India, Ceylon and the Malay Peninsula. When, pursued by British, French, Russian, Japanese and Australian warships, she raided the port of Penang she single-handedly sank about twenty Allied vessels, including a French torpedo boat and a Russian cruiser. When, in times of war, access to coaling stations was denied fleets either had to take along coalers, as the Russian fleet - which used Singapore as a coaling station for decades - did when it sailed from the Baltics to the Far East during the Russo-Japanese War of 1904-05, or coalers had to be directed to faraway seas in advance, as Germany did to supply its raiders on the eve of World War One.

For a long time, Great Britain had been the only European nation that could rely on its own network of coaling stations in the Pacific. France had 
conquered Indochina, but because of the three regular shipping lines it established connecting Saigon with Manila, Bangkok and Singapore - only the latter was viable - it did not arrange for a coaling station until 1891 (Lanessan 1895: 207). Before that date, French merchantmen and warships on their way to and from Saigon took in coals in Singapore. Saigon only got its own bunker facility after Singapore's acting Governor, Sir Frederick Dickson, banned the coaling of foreign warships without government permission in 1890 (Bogaars 1955: 114-5). Germany, in fact, never succeeded in building a network of coaling stations in the Pacific that could successfully support its navy in times of war. This was a consequence of, but also one of the reasons for, the decision of German naval command to opt for the construction of a strong offensive fleet in European waters - even temporarily sacrificing its naval presence in the north Pacific - also intended to serve as a deterrent for an attack on its colonies.

Once steam power had become more efficient than wind power, governments, navies, owners of passenger and freight ocean-going shipping lines, all went in search of suitable coaling stations. The consequences of this were felt first in the South Pacific, where the increase in sea traffic would contribute to the opening up and subsequently submission to Western rule of the island groups located there. Establishing an exclusive coaling station and preferably also a naval base became an additional reason, besides economic exploitation, to look for land in Samoa and other Pacific island groups. By 1900 there were no independent island states left in the Central and South Pacific; the last to lose its independence being Samoa. All had become German, British, French or American. To the north, in China and Southeast Asia, coals had a political significance in another way. Steam power made coals a strategic commodity, even, in the words of a contemporary author, a 'valuable material of war' (Norman 1884: 188). Control of coal mines became essential and, as these words indicate, entered the discussions about relations between the powers and provided yet another impulse for colonial territorial expansion.

In the early 1870 , it had not immediately dawned upon everybody what prospects the sailing of the Suez Canal and the replacement of wind with steam power offered. In the words of a senior Hong Kong colonial civil servant in those days, Dr Ernst Johann Eitel (1895: 571-2), Hong Kong, the British naval base and entrepôt port in the Far East, experienced a 'complete revolution'. Yet, as he recollects twenty-five years later,

as it took Hongkong merchants several years to realize how much nearer, to London Hongkong now was, so it took Her Majesty's government and the 
British public several decades of years to realize the increased political and strategic importance Hongkong had assumed [...] in the general scheme of British Colonial defence, and its subsequent need of first class fortifications.

Shipping and commerce had flourished, but another reason why Hong Kong had grown in importance for British colonial interests was that it was the only coaling station for the British navy in the Far East, and this in a time of 'universal employment of steamers in the navies of all great Maritime Powers' (ibid.: 572). There had also been misconceptions. In Singapore, like Hong Kong a port of transhipment, it was erroneously feared that the opening of the Suez Canal would hurt its trade with nearby ports (Bogaars 1955: 119). In fact, the Suez Canal only increased the economic importance of the city. With ships no longer having to round Africa, of the three possible routes on the way to or from the Far East - through the Straits of Malacca, by way of the Sunda Strait or passing through the waters between the Moluccas and New Guinea - only the first remained a viable option, at the same time adding to the strategic importance of the coast of continental Southeast Asia. In Shanghai, a different reaction had prevailed. The city experienced a financial crisis due to speculation inspired by too optimistic a belief in what the Suez Canal would mean for China trade (Wright 1908: 91).

Not all British merchants and politicians had been as ignorant as the words of Eitel suggest. Shipping companies immediately saw the advantage. In November 1869 , the British $\mathrm{P} \& O$ passenger ship Delta, part steamer, part sailing vessel, emblematically sailed in the wake of the L'Aigle. Six years later, the British took control over the running of the Suez Canal. In November 1875, after Ismail had gone bankrupt, the British government, without consulting Parliament, bought Ismail's shares in the Suez Canal Company and, as a result, acquired almost half of the total number of shares. The British Prime Minister, Benjamin Disraeli, told the House of Commons in February 1876 that the purchase of the shares had been a 'political transaction', aimed at securing the route to India and other British possessions in the East. ${ }^{1}$ Again, a few years later, in 1882, Great Britain strengthened its grip still further by occupying Egypt, intervening as powers were prone to do when domestic disturbances threatened their economic interests and the lives of their nationals. Egypt remained a nominal province of the Ottoman Empire, but from then on was ruled by the British and their Consul General. It brought the British immediate gains, but diplomatically Egypt became a 
millstone around Great Britain's neck. British control over Egypt remained a major bone of contention for years to come between Great Britain and France, with Germany trying to exploit Anglo-French animosity.

The second ceremony, the coronation of Wilhelm I, not only signified the unification of Germany. Within less than two decades, Germany would claim its place among the mightiest nations in the world, its leaders dreaming of supplanting Great Britain as the most important power of the day, economically and military. During the initial years of its existence the young German Empire still behaved as a purely European continental power, as one of the major actors in the diplomatic manoeuvring in Europe. In the course of time, Germany's aspirations grew. Though they were given a different name, Schutzgebiet (protectorate) or Pachtgebiet (leased territory), colonies were acquired in Africa, the Pacific and China; transforming Germany from a continental European power into one that had global ambitions and interests.

From the beginning, once it was decided that Germany should have its own overseas possessions, plans were ambitious. In June 1884, Bismarck linked the German colonisation policy with expansion of the German consular network, the establishment of coaling stations, and the setting up of new passenger shipping lines to China and Australia (Koschitzky 1887-88 I: 158). There was one drawback. For its overseas possessions, Germany had to turn to regions not yet colonised by other European nations: parts of Africa, Pacific islands and, ultimately, China. Initially, in Asia the ambitions of German businessmen and politicians made Samoa, New Guinea and a number of other islands in the South Pacific hotspots of international tension. By the end of the century attention shifted from the Southern to the Northern Pacific, to China, raising the stakes considerably. Manchuria, Korea and China became the object of bitter international competition. 'The Far East, which a year ago was an uncommon, has since become a familiar phrase in the terminology of International Politics,' wrote Lord Curzon (1896: ix), one of the political heavyweights of those days, and a stubborn one for that, in the introduction to the fourth edition of his book about international developments in Asia in 1896. Another British author, William A. Pickering (1898: 264), an equally influential contemporary Asia expert who, among other things, had won his spurs for his role in Malaya as colonial civil servant in charge of Chinese affairs, argued that China was far more important for British economic interests than Turkey, that other great flashpoint of international rivalry and conflict.

There was also an event that had not yet taken place, but for decades, at least since the 1830 , had cast its shadow: the opening of the Panama 
Canal. It should have been a grand ceremony, but on the date the festivities were planned, 15 August 1914, World War One had already started and all plans for an impressive opening had to be cancelled. The significance of the Panama Canal (it could also have become the Nicaragua Canal) was at least as great as that of the Suez Canal. It would, it was ventured in advance, make the Pacific the future centre of world trade, outshining the importance of the Atlantic Ocean. Or, as a Japanese author wrote, the canal would revolutionise the Pacific Ocean and make it 'the platform of commercial and political enterprise' (Inagaki 1890: 21, 47). Though still undug, the canal featured prominently in the assessment of the strategic importance of, and international rivalry over, a series of small South Pacific islands, which, the argument was, could serve as valuable and strategically located coaling stations along the route between Australia and New Zealand and the Panama Canal. In the closing decades of the nineteenth century, the Panama Canal came to figure with equal prominence in scenarios about the economic and political importance of the north Pacific and the international rivalries developing there. One scenario was that between the United States and Japan. In both countries, the military consequences of a canal cutting the Central American isthmus loomed large in strategic thinking. In Japan army Inspector General, Yamagata Aritomo, predicted in 1888 that the Panama Canal, combined with completion of the Canadian Pacific Railway and the Russian Trans-Siberian Railway, would make East Asia a new focus of Western imperialism for which Japan had to prepare (Drea 2009: 70). For the United States, the Panama Canal was no longer just a passage that would stimulate sea traffic between its east coast and Asia and its west coast and Europe; the shortened route it allowed American warships to take from the Atlantic to the Pacific became a vital element in the considerations of those who planned for the defence of the country against a new potential aggressor: Japan. 


\section{$2 \quad$ Rivalries in the Western Pacific}

Between 1870 and 1914 six countries became involved in competition over economic and political influence in the Western Pacific. Three of them were old established colonial powers: Great Britain, France and Russia. The others were relative newcomers: the United States of America, Germany and Japan. The United States had entered the scene after Great Britain had recognised its independence in 1783. Germany and Japan gained economic prominence, which allowed them to look for overseas expansion, only in the closing decades of the nineteenth century. It was Germany, with its ambition to become a world power, complete with a mighty commercial fleet and navy and its own outposts and colonial possessions in Africa and the Pacific, that set in motion a development that culminated in the dividing up of the Western Pacific. Japan and the United States would become important players in the Western Pacific, a little later, at the close of the century. There were still other colonial powers in Asia - the Netherlands, Spain and Portugal - but, being not very powerful, they played a very minor role in the power struggle that evolved. With other countries seeking new colonies and coaling stations, their main concern was guarding what they considered rightfully theirs; with Spain being forced to dismantle its colonial empire by the end of the century.

Initially, what happened in Asia and the Pacific was partly the result of the existing coalitions and animosities between the European nations, not only brought about by their interaction in Europe itself but also in the Near East, Africa and Latin America. The relations between the powers in Asia and the Pacific were perhaps the most complex of all. While in other parts of the world only a limited number of powers were involved, in the Asia-Pacific region all of them were implicated; not just the European powers, but the United States and Japan as well. As elsewhere, along with the conflicts between the powers in Asia and the Pacific, which had the potential to change the international balance of power, came outbursts of patriotism, if not xenophobia, and a frenzied press.

The international tension, which arose out of the aim to control new territories or inflated fears about the intentions of other powers, added to existing ill feelings and prejudices and created new ones. At certain moments, it was even feared that clashes over colonies, protectorates or spheres of influence might escalate into war in Europe, if not into a worldwide conflict. Or, as one member of the British House of Commons said in 1898 , 'we cannot conduct a war with a European Power in a far-distant country without having the fear of a war in Europe continually before 
us.' ${ }^{\prime}$ Others shared this view. Among them was the already mentioned Pickering, who warned that as Great Britain's European rivals lacked coaling stations and powerful fleets in the Far East, any armed conflict over influence in that region would be fought out in Europe (Pickering 1898: 277). Charles William de la Poer Beresford, $1^{\text {st }}$ Baron Beresford (1899: 441), also a person whose opinions counted in those days, was afraid that the rivalry between the powers in China might well result in 'war between the European nations'. Though it would not come to this, such predictions formed an integral part of contemporary political considerations and analyses. Having to take into account the possibility of war also made the powers exercise constraints in pursuing their colonial ambitions.

Strategic concerns, at times bordering on paranoia, and commercial expectations which were not always borne out by the facts, played a role in the international rivalries that would come about, and would also manifest themselves in the fields of culture and the sciences. As did national pride and fervour, which perhaps were even stronger outside patria than at home. In Asia and the Pacific foreigners celebrated their national festive days and on such and other occasions national anthems, patriotic songs and feux de joie resounded. As one contemporary noted in the mid-18gos about the British in Asia, 'for the national Flag he cares a great deal. Loyalty is his passion; and the toast of "The Queen" is drunk with as boisterous a fervour in Far Kathay as it is at a Unionist banquet in St. James's Hall' (Curzon 1896: 420). Another traveller was struck by the fact that the French flag could be seen 'everywhere in every conceivable place' in Tonkin and in Guangzhouwan, a recently acquired concession by France in China (Cunningham 1902: 10). Germans in China, the missionaries included, raised their flags and on occasion broke into renditions of Heil dir im Siegerkranz and other patriotic songs (Esherick 1987:80). Where they could, the powerful nations also tried to outshine each other in Asia in grandiose power architecture, imposing

political ceremonies, and the pomp that surrounded the life of their consuls and ambassadors and of their mercantile community abroad.

\section{In search of new markets and political influence}

Where colonies or protectorates could not be won, efforts to gain political and economic influence set the powers apart. In the late nineteenth

1 Gibson Bowles in House of Commons on 1-3-1898 (hansard.millbanksystem.com/ commons/1898/mar/o1/independence-of-chinese-territory). 
century, 'sphere of influence' (in contemporary literature often written with capitals) became a popular term in international diplomacy and political analyses and speculations. Alternative terms used were 'spheres of interest' and 'spheres of influence or interest', at times even 'spheres of special interests'; and briefly, in northeast and south China, around the turn of the century, 'spheres of railway influence'. Germans spoke about Interessen-Sphäre, Interessengebiet, and ökonomische and geographische Gravitations-Sphären; the French about sphères des intérêts, sphères d'influence and zones d'influence. On rare occasions, when the claims of one or more powers were questioned, people spoke of 'spheres of pretensions'. Yet another word used was preponderance. Because he, like some of his compatriots, might not have approved of the term 'spheres of influence', the British Prime Minister Salisbury, in 1898, would talk of a 'partition of preponderance' as an alternative to actual territorial expansion (Beresford 1899: 165).

The emerging rivalries manifested themselves in conflicts over land and the recruitment of labour necessary for the cultivation of estates, in competition over mining concessions and in a race for new business opportunities and new markets for a growing industrial output at home. Big rivers, which only increased in importance as objects of international rivalry after the replacement of sailing vessels with steamships, railways and, in a less spectacular way, macadamised roads, were also part of the fray. Good roads and railways were 'the best pacificators' (Colquhoun 1902: 365). In China and Southeast Asia, where the physical terrain was often not conducive to long-distance transport over land, access to and control over navigable big rivers, which criss-crossed the region, became one of the sources of discord between Great Britain and France; also because moving passengers and freight over such waterways required no or much less investment than the construction of railways.

The right to construct and manage railways was even more frequently disputed. Above all in China and the Ottoman Empire construction of railways was a politically highly sensitive undertaking. As symbols of economic and political penetration and allowing for the transportation of troops and for the expansion of commercial interests at the cost of rival nations, such infrastructural projects became part the strategic game. Financiers considered railways a good investment, and industry at home could profit from the production of locomotives, carriages and rails. What also played a role was the fact that gaining a concession to build a railway line pre-empted another power from doing the same, excluding the competitors being an essential element of colonialism. 
One way to gain the upper hand and to get the concessions and gain markets was to control local governments by means of force or diplomacy (a lavish reception for visiting foreign rulers could also help). Additional influence was sought by sending military instructors to modernise armies and navies and civil advisers to organise or reorganise the financial sector and the customs service. Although the benefits of such adviser ships were clear - as late as 1912 the British bemoaned that German advisers had seen to it that the Chinese army was not equipped with British weapons (Lawton 1912: 1370) - even their mere appointment was already considered a coup. Often, these and other perks were an outcome of the rivalries between the powers. At times, however, the jealousies between the powers and the animosities their actions evoked in the country they were quarrelling about provided smaller European states - and even other powers - with a niche to step into.

Political and economic interests were intertwined. Consuls, sometimes with their own 'escort' or guards, and commercial and political agents had to stimulate trade, keep an eye on the activities of citizens of rival nations, or simply served as markers of foreign presence. In 1892 George Nathaniel Curzon, or The Lord (later The Earl) Curzon of Kedleston, observed about Persia that it was 'a country where commerce can be pursued with political objects, where mercantile agents are frequently diplomatic emissaries in disguise, and where the command of trade routes and bazaars is capable of being used as a preliminary to territorial acquisition' (Curzon 1892 I: 177). Persia was not exceptional. In 1906, discussing the policies of the foreign powers in China, another author noted that 'diplomacy stalks its political prey under cover of commercial and industrial enterprise, while commerce and industry strike at competition through open or surreptitious diplomatic wire-pulling' (Millard 1906: 220). Two decades earlier the situation had not been much different in the Pacific island groups. Foreign traders and estate owners assumed political roles to protect and advance their commercial interests, turning to the homeland for diplomatic and military backing. At times, travellers and explorers, ethnographers, archaeologists and other scholars took the lead. Some were at least as interested in market potentials as in the people and the natural environment of the regions they traversed. Their expeditions, in some contemporary literature referred to as politico-scientific missions, aroused much suspicion (Norman 1884: 101). The explorers might be viewed by the local population as well as by governments and citizens of rival nations, and not always incorrectly so, as trailblazers of colonial expansion, reconnoitering the terrain and collecting valuable strategic information. 
Sometimes, governments were urged on or found themselves in dire straits by proponents at home and abroad of an aggressive, expansionist policy. In developing its policy in the South Pacific, London had to deal with political pressure from Australasia. People in Australia and New Zealand had their own territorial ambitions. Reports about attempts by Germany, France or, for that matter, any other nation to establish itself in the South Pacific, which often were not much more than rumours, invariably elicited strong and, at times, almost hysterical responses in Australia and New Zealand. London should not allow other powers to acquire what should be Australasian territory. Bismarck called such aspirations excessive claims (maszlose Ansprüche). The French author Lorin (1906: 400) dismissed the demands as bluff, full of intemperance of words and testifying of rough diplomacy, while The New York Times (13-6-1886) characterised them as 'rather absurd, not to say greedy'. As London was usually, at best, reluctant to comply, politicians in Australia and New Zealand tended to accuse the home government of lethargy and of losing out to other, more energetic nations. At play was a mix of territorial aspirations, economic ambitions, and fears in Australia and New Zealand; fears for unfair economic competition and the military aggression of others. In 1901 members of the Australian Federal Parliament even speculated about a combined German, French and Russian naval attack on their country (Hiery 1995: 13). Three years later, the Sydney Daily Telegraph wrote that Australia could not 'afford to allow foreign nations to establish themselves within a day or two's steam of Sydney, Newcastle, Brisbane, and the other eastern ports of Australia' (Australia 1904: 18). At that moment, with the rise of Japan, a racial element had entered the mix.

Equally expansionist - or alarmist, the two were often difficult to tell apart - in the British Empire could be members of the civil service in the colonies, the military there, and the Chambers of Commerce, at home and abroad (where they often were of an international composition). At times in Asia, they played a role comparable to that of politicians in Australia and New Zealand in the South Pacific. In 1886 a Liberal member of the House of Commons, $\mathrm{H}$. Richard, observed that it was 'a general fact that our countrymen, especially in the East, have a perfect passion for annexation'.

Other powers also had their overambitious civil servants and military officers abroad. In Germany, in the 1880 s, Bismarck even invented a new disease, morbus consularis, to explain the behaviour of the German consul in Samoa. In Central Asia, an advance by Russian military officers left them without support by St Petersburg, which had to take into account its formal negotiations with London. Meanwhile, in north Asia Russian 
'military chauvinists', as the British ambassador to Russia called them in 1901, complicated matters. ${ }^{2}$ Their activities, coupled with the scheming of expansionist officers and politicians in St Petersburg, created an impression in London of Russian policy being extremely untrustworthy and erratic, often resulting in action that was the opposite of the guarantees given by the Russian government. In France, ambitious colonial officials had far more daring plans with regard to south China than Paris could or would afford for reasons of domestic or foreign policy. In Hawaii, a self-willed American consul, though he might have had the impression that he acted in line with what his bosses in Washington were aiming at, proclaimed a protectorate in 1893; this would later be disowned after a change in presidency.

The first conflicts in the Pacific, in the closing decades of the nineteenth century, centred on the island groups in the south and involved Great Britain and Germany. That such a confrontation lay in store became visible after 1874, after Great Britain had annexed Fiji and German settlers complained in Berlin about the unfair way they were treated by the British. A decade later, when Germany staked out its first overseas claims, the efforts by Berlin to gain recognition in London of its rule in the territories it had acquired turned into a full-scale diplomatic conflict with Great Britain. In the end Berlin got what it wanted. Then, and later, the British need for support against pressure from Great Britain's traditional rivals, France and Russia, in Egypt and Afghanistan, presented the opportunity to gain concessions from London. London found itself hard pressed, as it would so often. In 1884 Prime Minister William Ewart Gladstone confided to his Colonial Secretary, the Earl of Derby, that Germany could do 'extraordinary mischief to us at our one really vulnerable point, Egypt' (Kennedy 1985: 92). Three years later, his successor, the Marquess of Salisbury, used the word blackmail (Lowe: 1990: 57). The conflicts between Germany and Great Britain over Fiji, Samoa and New Guinea were bitter ones. The German historian Walter Nuhn (2002: 12, 67 ) even singles out the Samoa conflict as an important impulse for Berlin to aim at a navy that could compete with the British one, and thus as an early impetus to the Anglo-German naval race, but he could have mentioned Fiji and New Guinea as well.

Already having huge colonial possessions, and facing the danger of overextension, Great Britain was a more hesitant and more selective coloniser than Germany. Successive British governments did not look forward to new Crown Colonies, new annexed possessions or new protectorates. When they could, they confined themselves to trying to prevent others from taking 
hold of such territories. Apart from its conflicts with Germany in Africa and the Pacific, Great Britain quarrelled with France over North Africa and the New Hebrides. In Asia, French and British interests were at odds in southern China and Thailand. British politicians and the British public watched with apprehension how Russia expanded south, into the Caucasus and Turkistan, as well as in north Asia, threatening British interests in the Middle East and China and, it was feared, ultimately in British India; the colony that took centre stage in British strategic considerations in Asia.

There was a British alternative to territorial expansion. British economists, of which those of the Manchester School - in Germany known as der Manchesterliberalismus or das Manchestertum - were most prominent and influential, had begun to regard colonies and protectorates as an economic burden, with 'free trade' offering better perspectives (Legge 1958: 16). Free trade, as opposed to the imposition of discriminatory or 'hostile' tariffs and custom duties, became such a dogma, and the suspicion of evil intent of the other was so great, that the British even saw quarantine measures to prevent the spread of the plague as a mercantile manoeuvre, deviously instituted by their economic rivals (Echenberg 2007: 99). An additional argument used in Great Britain, first with regard to the South Pacific and later on in relation to China and Afghanistan, was that establishing a protectorate or occupying territory inevitably implied keeping the local population in check, and required a costly and difficult military presence.

British politicians in the Colonial and Foreign Office tended to concur, though power rivalries might induce London to decide on colonial aggrandisement. The British, as their politicians never tired of lamenting in the closing decades of the nineteenth century, had a lot on their plate. Great Britain was a country with a vast empire, vast global commercial interests, and thus vast problems. ${ }^{3}$ To the British public, and also to the politicians, it must have appeared that around the globe Great Britain was moving from one instant 'crisis' or longer-lasting 'question' to another. Once a compromise or stalemate had been reached about a conflict in one spot in the world, complications arose elsewhere. New territory was added to the Empire in Asia and the Western Pacific, but in some cases only hesitantly so and in others in reaction to the perceived threats by other powers. Or, as Colonial Secretary Edward Henry Stanley, $15^{\text {th }}$ Earl of Derby, phrased it in the House of Lords in 1883, when the taking control over New Guinea was at stake: 'Speaking generally, I should say - and I think it is the general

3 Sir E. Grey in House of Commons 5-4-1898 (hansard.millbanksystem.com/commons/1898/ apr/05/far-east). 
feeling of this country - that our responsibilities are already heavy enough, that our Possessions, scattered as they are, over every part of the world, are sufficient to require the utmost care and vigilance, and that it is not desirable to increase either the one or the other'. ${ }^{4}$

At that moment, in the mid-188os, the word annexation had a negative connotation in Great Britain. Colonel Edward Bosc Sladen, an officer in the Indian Army and a passionate advocate of the occupation of Upper Burma soon to take place, complained at that time that it was considered 'an offensive term and [that] the policy which advocates it is condemned as unjustifiable and out of date' (Browne 1888: 111). International developments contributed;'annexation was a word foreign to the English language, it was invented by the Americans to make that which was wrong to appear to be right', Lord Stanley of Alderley - almost certainly having American plans for Hawaii in mind - was to state in the House of Lords in $1883 .{ }^{5}$

Ten years later, when the gravity of Pacific rivalry had shifted to the north, to China and continental Southeast Asia, not much had changed, except for the fact that British public opinion at home cared more about the British position in the Far East than in the South Pacific. In October 1893 the then Secretary of State for India, Lord Kimberley, struggling with the problem of how to keep the French out of Thailand, complained about 'the enormous increase of our responsibility which goes in every quarter of the world ... [and] ... an indisposition to maintain the forces necessary to uphold our rule. ${ }^{6}$ A similar remark was made about defending spheres of influence in China. Beresford (1899: 441) pointed out that 'defending and administering huge sections of a country with bad roads, teeming with a population absolutely hostile to foreigners, and foreign domination' would involve huge costs. He foresaw an even greater danger. A partition of China in spheres of influence could only mean disaster: the creation of 'gigantically expensive European military frontiers in the Far East, with no strong Chinese buffer between them' and thus 'war between the European nations' (Beresford 1899: 441-2). A buffer in those days being the panacea to keep European powers in Asia from each other's throat. This was the answer Great Britain had found to protect India; the creation of buffer states, keeping the armies of the enemy, Russia and France, as far away as possible.

4 Derby in House of Lords 2-7-1883 (hansard.millbanksystem.com/lords/1883/jul/2/ motion-for-papers).

5 Stanley of Alderley in House of Lords 2-7-1883 (hansard.millbanksystems.com.lords/1883/ july2/motion-for-papers).

6 Kimberley to Lansdowne 5-10-1893 (Chandran 1977: 96). 
To avoid conflict, ideally territory won by different powers should be a good distance away from each another, and visits of foreign warships to nearby waters or foreign economic enterprise in adjacent regions were viewed with much distrust. The French did not want the Germans in Hainan, near the concession the French had gained in southern China. Great Britain did not want the French in Portuguese Macau (Macao), near Hong Kong; not to speak of having Russia advance in Afghanistan or Tibet or the French in Thailand or Burma.

While the powers in the South Pacific contesting each other's island groups were mainly Germany, Great Britain and France, the initial players to the north in Asia were Great Britain, France and Russia. Russia's colonial expansion brought the country into conflict not only with Great Britain but also with Japan, a country where feelings of patriotism ran at least as high as they did elsewhere. Russia and Japan first fought a diplomatic battle and then a real war to decide to whose sphere of influence Manchuria and Korea belonged; the Japanese successes were greeted by Japanese at home and abroad with 'Bansai celebrations'.

Almost until 1900, the United States played a less belligerent role in the Pacific. The United States had its advocates of territorial expansion in the Pacific, but for most of the nineteenth century it was as reluctant to acquire new territories in the Pacific as Great Britain was, and partly for the same reason, the costs and efforts involved. There had been some exceptions, making the country an active participant in the Pacific rivalry. Washington had as early as 1842 warned other nations that they should stay away from Hawaii. The United States also became caught up in the Samoa crisis, which at certain moments bordered on open warfare. As the headline in The New York Times of 24 February 1899 read, the 'Powers Were Near Warfare'. What it aimed at was 'annexation of trade', as Secretary of State James G. Blaine phrased it in a speech in 1890 (LaFeber 1998: 106). At times, and especially with regard to Hawaii and Samoa, Washington had not precluded annexations, but invariably opposition in Congress proved too strong.

\section{The great Russian-French combination}

Russia's moving forwards in the direction of India, Persia and China was partly motivated by territorial ambitions, and partly by the intention to forestall the presumed territorial ambitions of the British (Soroka 2011: 2). It was also leverage for Russia in its conflicts with Great Britain over the Ottoman Empire, hoping to tie down British troops in India. 'To keep England 
quiet in Europe by keeping her employed in Asia', Curzon concluded in 1889, was 'the sum and substance of Russian policy' (Berryman 2002: 3). Antipathies and distrust of the intention of others were mutual. In Russia, Anglophobic sentiments and apprehension about British colonial intentions matched anti-Russian feelings and fears in Great Britain. Russia would, the British Foreign Secretary Edward Grey observed in retrospect, 'trouble the Indian frontier on the one side', while its government was always afraid the British 'were going to obtain some advantage towards their frontier'? Animosities became so intense that in 1901 the British ambassador in St Petersburg, Charles Stewart Scott, could write about a 'strongly cemented wall of distrust \& suspicion' among the public in both countries. ${ }^{8}$ In 1902, discussing the situation in Persia, his counterpart in London told the British Foreign Secretary, the Marquess of Lansdowne, that both countries were 'in the habit of becoming needlessly excited about comparatively trivial incidents in that and other parts of the world'. ${ }^{9}$

The Russian move into Central Asia caused much anxiety in Great Britain, but it was Russia's advance in north Asia in particular, viewed by the British with a mixture of awe and admiration, which was the immediate cause for Great Britain's search for allies at the close of the nineteenth century. More to the east, the French thrust into continental Southeast Asia, inspired by a combination of economic motives, efforts to regain the status of a power after 1871, and the desire to seek compensation for the British preponderance in Egypt, was a development viewed with apprehension in Great Britain. It only added to the mutual distrust and animosities that coloured Franco-British relations as much as they did Russo-British ones. Frenchmen recapitulated how much damage the British had done to their overseas interests in the past; alarmist Britons were sure, as one of them formulated it, that '[j] ealousy of England's commercial supremacy' was 'a national trait of the French character' and that, of old, French policy had been inspired by the desire 'to damage English trade and to ruin English commerce' (Norman 1884: 2-3).

The combined Russian-French threat was considered the greater after Paris and St Petersburg, both with ambitions in Asia, had - on French initiative -started talks in 1891, culminating in the Dual Alliance of 1894. Though the Alliance was a defensive pact against European adversaries,

7 Grey in House of Commons 27-11-1911 (hansard.millbanksystems.com/commons/1911/nov/27/ sir-edward-greys-statement).

8 Scott to Lansdowne 18-4-1901 (PRO FO 800 140).

9 Lansdowne to Scott 10-5-1902 (PRO FO 539 81). 
Germany and Austria-Hungary, the treaty did have its implications for the relations between the powers in Asia. The new-found cooperation gave France the political and indirect military backing for its adventures in Southeast Asia and south China. It offered Paris, in the words of one French author, himself a proponent of an active colonial policy, the chance to accelerate the creation of its colonial empire, and thus also the opportunity to enhance its status as a great power (Lorin 1906:488). For Russia, the Alliance provided some backing for its moving forwards into Central Asia and north China, which in Great Britain made for the doom scenario of a concerted encroachment on India by Russia from the West (and perhaps from the North) and by France from the East, from their expanding possessions in continental Southeast Asia. As an opposition Member of Parliament described it, the danger loomed of 'a double-barrelled opposition to the progress of the British Empire in the East'. ${ }^{10}$

To some British opinion makers, Great Britain's rivals seemed intent on striking at the very existence of the British Empire. Its prosperity depended on Asia. Great Britain, to use the words of its Prime Minister, Disraeli, was more of an Asian than a European power (Kennedy 1985: 80). Disraeli's statement mirrored a wider held view by the British, also expressed by Curzon (1892 I: 4), that the future of Great Britain would not be decided in Europe, but in Asia, and especially so in India. Four years later, and now also with threats to British interests in China in mind, Curzon (1896: 414) would again argue that Great Britain was before anything else an Asiatic dominion'.

There was also China to consider. Great Britain had gained a dominant position in the China trade, but the share of other powers was increasing. China was viewed as a potentially immense market. It became the prize to win, except for the British, who thought they would lose out if other powers gained control over parts of it. Losing part of the Chinese market might bring ruin and mass unemployment at home. With their inflated egos, Pickering (1898: 260-1) and other Britons were sure that British expansion over the world was 'for the benefit of every other nation', while rival powers were out for territorial gain 'as a weapon against the prosperity of British trade - that is, the existence of the inhabitants of these islands'. Pickering (1898: 261) also sketched the implications of such a selfish Russian, German or French policy; testifying to a latent anxiety, brought to the fore in times of crisis when people worried about the loss of colonies or export markets:

10 R. Temple in House of Commons 30-3-1894 (hansard.millbanksystem.com/commons/1894/ mar/3o/france-and-siam). 
'While every extension of our empire means food and clothing for the working men of the British Isles, every appropriation of territory by any other nation means the shutting out of manufacturers from that market', not to speak of the falling away of the imports of foods and raw materials Great Britain needed (ibid.: 269).

In the closing years of the nineteenth century, the encroachment of the powers upon China, with Russia active to the north and France to the south and with Germany demanding its share, worried the British, especially those who foresaw the demise of British might in the world. In the Far East, Great Britain was 'confronted by the powerful opposition of Russia and France, combined with the jealousy of the Germans', Pickering (1898: viii), a vowed opponent of foreign - that is, non-British - spheres of influence in China, wrote. He saw in Russia and France a real menace: "[A]t every point where our expansion of empire for the vital interests of our people is concerned, Russia and France are ready to thwart us' (ibid.: viii). Worse, as he had written earlier in the London and China Telegraph, they were 'checkmating' Great Britain 'in every part of the world, from Abyssinia to Washington, from Bangkok to Herat' (ibid.: 267). In Russia and France similar observations were made, but with Great Britain in the role of the menacing villain.

In Great Britain there was no shortage of pessimistic or alarmist observations in books and speeches about the deplorable position of the Empire and the threat new German, Russian and French acquisitions posed, or could pose, to British trade and thus prosperity. In March 1898, E. Ashmead-Bartlett, an outspoken Conservative Member of Parliament, gave an overview of the failure of the Liberal governments of Gladstone and the Earl of Rosebery vis-à-vis what he called 'the great Russo-French combination'. He presented a gloomy picture of what had transpired:

Sir, it must have occurred to everyone that, during the past five years since 1893 - this country has been steadily pushed down-hill in many parts of Africa, in Asia, and in other quarters of the globe. ... I need only mention Africa - West, Central, East, and South - Madagascar, Siam, Tunis, the North-Western Frontier of India, China - North and South - the Ottoman Empire, and the Mediterranean. Everywhere there has been British retreat and British repulse. ${ }^{11}$

11 Sir Ellis Ashmead-Bartlett in House of Commons 1-3-1898 (hansard.millbanksystem.com/ commons/1898/mar/o1/independence-of-chinese-territory). 
He did not mention the eastern north coast of New Guinea and the Bismarck Archipelago, which had fallen to Germany a decade earlier. Such assessments were enduring. In 1912 a British journalist, Lawton (1912: 1311), wrote in an exhaustive survey of the international complications in China that the British government was 'always accused of pursuing a policy of acquiescence towards claims of other Powers in the Far East'.

The progress Russia made in Asia reaped admiration elsewhere in Europe. In 1899 one German observer wrote that Russia had slowly but steadily gained the upper hand over Great Britain in Central and East Asia: 'All the time Russia succeeded to sooth England through diplomatic negotiations and to move forward inexorably on its way' (Krahmer 1899: 186-7, 200). His evaluation of Great Britain's policy was less positive. It was 'indecisive and in no way energetic ... here as well as there, always bending to Russia's will, "bravely" retreating for its ambitions' (Krahmer 1899: 199). Some even foresaw the end of the British empire. In Java, the newspaper De Locomotief predicted that the British days in the Far East were numbered. It would only be a matter of time before the Russian army would march into British India (Handelingen 1877-8 II: 704, 715).

For a long time, British politicians had considered it out of the question that Great Britain would ally itself with another power. In May 1898, the Earl of Kimberley, a former Foreign Secretary, could still express his dismay over the prospect that Great Britain was 'to abandon the principle ... of not engaging in what are commonly called entangling alliances with other powers. ${ }^{12}$ He expressed his displeasure over the prospect that London might have to go in search of formal allies shortly after Germany and Russia had forced the Chinese to lease them land in the north of the country along the Pacific coast. On 6 March 1898, Germany had leased the Bay of Jiaozhou (Kiaochow, Kiautschou) with its harbour Qingdao (Tsingtao, Tsingtau) on the coast of the Yellow Sea. Later, in the same month, Russia acquired the Guandong (Kwantung) Leased Territory, including Port Arthur (Lüshun, present-day Lüda).

In a sense, Russia had been pushed in this direction. After the Crimean War of $1853^{-56}$, when the Black Sea was 'neutralised' and its warships were no longer allowed to sail it (a condition of force until 1871), Russia reversed its aim of moving deeper into Ottoman territory. Writing about the international consequences of the war, one recent study asserts that Russia 'would withdraw from great power politics for the foreseeable future' (Steinberg 2011: 129). In fact, what St Petersburg did was to look for other 
directions of expansion, in Central and East Asia, remaining a power to be reckoned with and giving others, especially the British - who had tried in vain to continue the war exactly to prevent this - a lot to worry about. Its role in Asia became even more pronounced after May 1897 when Russia and Austria-Hungary agreed to preserve the status quo in the Balkans. In 1899, in St Petersburg, the Minister of War, General Aleksey N. Kuropatkin, bluntly told the British envoy, Scott, that Russia intended to strengthen its military presence in Central Asia for defensive as well as offensive purposes against India; although he added, with regard to the latter possibility, 'God forbid it. ${ }^{13}$ To the north, Beijing became a 'substitute' for Istanbul (Taylor 1971: 302).

In particular, the Russians taking possession of Port Arthur and the direct threat it posed to China made a great impression in the rest of the world. With a naval station near Beijing, and its troops along the north border of China, Russia might have acquired a unique position enabling it to put pressure on the Chinese government. Port Arthur also gave Russia a vantage point in its conflict with Japan over who would become the dominant power in South Manchuria and Korea. How necessary it was to strengthen its position there had become evident in 1895 when Russia, not yet capable of making a fist of its own in Manchuria, needed all the diplomatic support it could muster to deny Japan in China the foothold it had gained on the Liaodong Peninsula during Sino-Japanese War of 1894-95. St Petersburg sought and won German and French support against Japan. The resultant Tripartite Intervention or 'Far Eastern Triple Alliance' forced Japan to give up its territorial gains. On the question of forcing Japan out of the Liaodong Peninsula, the British Prime Minister Rosebery declined to side with Russia, but he also did not come out in support of Japan

To counterbalance the German and Russian leases and to save face, Great Britain, which up to then had always presented itself as the champion of the territorial integrity of China, leased Wei-hai-wei, almost directly opposite Port Arthur. Soon after, the French would follow suit, leasing Kwangchowan in south China. The United States, as much an advocate of free trade in China as Great Britain was, refrained from demanding a territorial concession in China. Instead, it established a firm footing in the Far East by annexing Hawaii in August 1898 and replacing Spain as colonial ruler in the Philippines a few months later. 


\section{China's Open Doors}

The land leases put the question of free trade at the centre of public attention. A new term entered the political vocabulary: the Open Door. In 1899 Beresford (1899: 1) observed that the 'British and American public have been quite bewildered by the controversy which has raged during the last year over the relative merits of the "Open Door" and the "Sphere of Influence". Colonies and spheres of influence gave a power special commercial privileges, to the detriment of the trade of others; and 'an Open Door' in China - or, as the wider phrase ran, 'an Open Door to all the world' - was the logical choice for countries reluctant or unable to gain such concessions for themselves. The American journalist Millard (1906:182) even suggested that the British had invented the phrase to protect their large and still dominant mercantile interests in China. Free trade was also the avowed policy of the United States, that is to say, where it concerned the Far East. Latin America and the United States were a different matter (LaFeber 1998: 30, 48-9). In commercial circles in the United States, Russia, Germany and France were depicted as protectionist colonial powers, and thus a threat to American trade in China (LaFeber 1998: 375-8). What London and Washington wanted

\section{Figure 2 Charles Beresford}

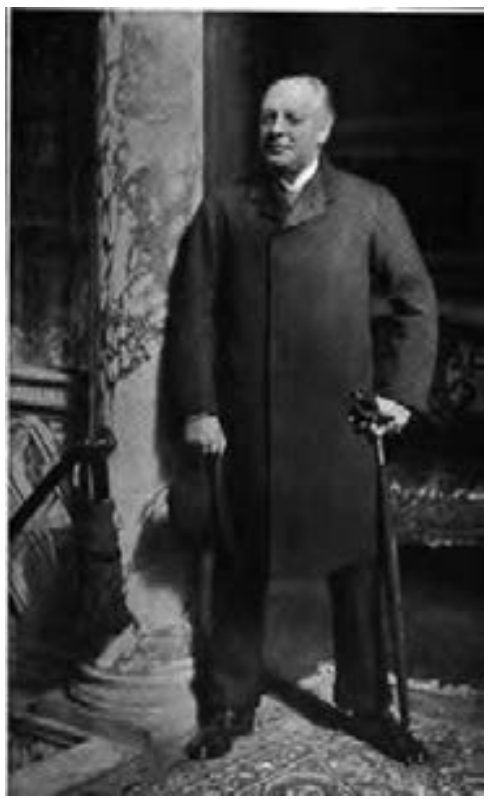

Source: Beresford 1899 
to forestall were higher customs tariffs and higher railway charges for their products, special harbour dues for their ships and unfair competition where it concerned investments - railways were a particular source of concern - in those parts of China that had come under the control of another power.

Alarmed British merchants in China warned that the falling of Port Arthur into Russian hands might be the beginning of the end of the Open Door policy, the end of free trade in China, which they and other Britons were not tired of repeating, had been the British aim since 1842, since the First Opium War, when Great Britain had been the first to force China to open sea and inland ports to foreign trade. It was asserted in Great Britain that once Russia or France - Germany was less frequently mentioned - got hold of new territory they would install protectionist tariffs or would take other measures to close the region to British trade. People expressing such worries may well have had the practice of European nations in Africa in mind; and with respect to Asia, French policy in Indochina. It could also not be excluded that trade would be monopolised. Only a few years earlier, in 1893, the French government had instructed its administrators overseas to buy, if possible, all the products they needed in France.

The great champion of the British mercantile campaign in favour of free trade in China was Beresford, promoted in 1898 to rear admiral. He was the voice of an important pressure group, the British Associated Chambers of Commerce. In August 1898, the association invited him as 'an officer of naval or military experience' to investigate in China how effective the protection was that the Chinese government could provide British merchants. ${ }^{14}$ The book Beresford published about his mission, The break-up of China, went further. It was a 500-page plea in favour of an Open Door, so arranged that it gave the impression that he voiced the opinion not only of the British merchants active in China, but also of the entire foreign business community in China and of the Chinese engaged in foreign trade.

Beresford did not only travel to China. Afterwards he visited Japan and subsequently the United States, which in the closing years of the 1890 s had established its dominance in South America and viewed China as an attractive potential new market (LaFeber 1998: 100, 379). Beresford found support in both countries. In Japan, he gained the impression that 'the political as well as the commercial classes are determined to maintain an "Open Door" in China' (Beresford 1899: 421). In the United States, where he did his best to propagate some sort of Anglo-American alliance, businessmen

14 Stafford Northcote, President of the Associated Chambers of Commerce to Beresford (cited in Beresford 1899: 448). 
were 'unanimously' in favour of free trade in China (ibid.: 432). As it had done in Great Britain, the Bay of Jiaozhou and Port Arthur had made a great impression in the United States. Newspapers were full of speculation about what the implication for American trade would be (LaFeber 1998: 352, Beresford 1899:427). The developments in China gave rise to much reflection and a rethinking of foreign policy. Relations with Russia, previously cordial, cooled. In November 1896, about a year before a Russian squadron would sail to Port Arthur, the American ambassador in St Petersburg had already gained the impression that the Russian government had lost any interest in preserving friendly relations with the United States (LaFeber 1998: 323). Washington turned away from Russia and towards Great Britain, with whom its relations had been cool for most of the century, and Japan.

International tension over developments in China was building to such an extent that people began to speculate about a world war involving the major powers of those days. In 1898 a British Member of Parliament, T. Sutherland, ventured that a dismemberment of China could well result in a war his generation would not see the end of: 'The struggle would be gigantic'. ${ }^{15}$ In the same year, Edward Grey warned that Great Britain 'could not have war in China and peace in Europe'. He called 'the question of China' the most important of the problems faced by Great Britain in the world. The disputes between the powers over Africa, which up to then had taken pride of place over entanglements in the Western Pacific, would not lead to war. China might. ${ }^{16}$ China far outshone the commercial importance of Africa. No matter how much the powers might be quarrelling over the partition of Africa, the economic value of this continent remained of little significance. One who vented this opinion was Alfred Thayer Mahan, an American naval historian whose work had influenced strategic thinking and naval build-ups all over the world. 'In regard of commerce, the fewness and backwardness of its inhabitants', Mahan (1900: 16o) wrote, Africa was 'a field of minor importance'. In Africa, one member of the British House of Commons remarked in 1898, 'the people do not wear clothes, and where people do not wear clothes, there is very little you can sell to them'. ${ }^{17}$ In France a similar opinion was vented. A Chinese needed more goods than an Arab or people from Africa (Chambre 1898a: 450). On top of this came the Samoa

15 Sutherland in House of Commons 10-8-1898 (hansard.milbanksystem.com/commons/1898/ aug/10/appropriaton-bill).

16 Grey in House of Commons 8-2-1898 (hansard.millbanksystems.com/commons/1898/feb/o8/ address-in-answer-to-her-majestys-most-gracious-speech).

17 T.W. Gibson Bowles in House of Commons 1-3-1898 (hansard.millbanksystem.com/ commons/1898/mar/o1/independence-of-chinese-territory). 
crisis two years later, involving the British, American and German navies. All this made one Dutch author predict in a military magazine published in the Netherlands Indies that a 'Great War', an 'enormous struggle, which will stir the whole world', was probably only weeks and certainly not more than a few months away (X 1900: 239). Others shared this acute sense of pessimism, predicting serious international complications over China and the wider Pacific. In 1902 the British author Colquhoun wrote that in the Pacific 'the future of more than one Great Power would be decided'. There, 'the great struggle of the twentieth century' would take place (Colquhoun 1902: vii). Elsewhere in the same book, he called 'the question of the Pacific' the 'world-problem of the twentieth century' and presented the Pacific as the 'new theatre in which the world drama is to centre' (ibid.: 27).

Port Arthur formed the catalyst of a fundamental change in London's foreign policy. Russia leasing Port Arthur was seen as the ultimate proof of its stealthy encroachment on the British interests in Asia, though for some British politicians the comforting thought was that Russia's designs in northern Asia would relieve pressure on India, Afghanistan and Persia. Prospects looked all the more gloomy because in the closing decades of the nineteenth century Russia was still considered to be a powerful nation commanding an impressive fleet and a mighty army. Great Britain had a strong fleet, but a weak army. British land forces were undermanned. At the time of Port Arthur, the British army suffered from a lack of troops, making it difficult for army command even to man the British garrisons at Malta and Gibraltar. There were doubts that the British army could perform well in a land war; an impression that seemed to be confirmed at the turn of the century by the poor performance of British troops in the initial phase of the Boer War. It was feared that the British army would never be able to stem a further advance of Russia, which was essentially engaged in an expansion over land. To make matters worse, at sea, the British fleet in the Far East might not be able to take on the combined fleets of Russia, which already by 1893 commanded the world's third largest navy (and after the Sino-Japanese War in anticipation of a confrontation with Japan would strengthen its Pacific Fleet), and France with the second most powerful fleet in the world (and in the worst scenario also that of Germany), without redirecting warships from Europe, and the risk this entailed for the British naval position at home in Europe (Berrymen 2002: 5; Padfield 2009: 66, 73).

To alert the British government merchants in Yingkou (Newchwang), Beresford wrote a letter home in December 1898 setting out the dangers posed by the Russians pressing forward into Manchuria: "[S]hould Manchuria pass into the hands of that Power, not only would this "door" be "closed" but 
British interests in China would be seriously menaced, and the unopposed absorption of these provinces, with the hardy and spirited peasantry, would inevitable be the prelude of a successful march southwards towards India' (Beresford 1899: 51). In view of the distance between Manchuria and India, the fear of Russian gains in north Asia seems far-fetched, but it was coupled with the belief that Russians were masters in turning people in the regions they had conquered - whether it was in China or in Central Asia - into excellent soldiers, fighting new wars of expansion for them (a practice the British in India were well familiar with).$^{18}$

\section{Great Britain's search for an ally}

Being aware that the rival forces infringing on its position in Africa and Asia had become too strong for Great Britain to stand on its own, politicians in London went in search of allies. They did so on the European continent and elsewhere in the world, where Japan and the United States were the most likely candidates for such a partnership. On the European continent, it appeared, allies were not easy to find. There the British reputation, as Prime Minister Salisbury observed in February 1898, was 'by no means pleasant, and by no means advantageous'. ${ }^{19}$

Russia, redirecting its attention to the Far East, brought London a new partner. In January 1902, Great Britain signed its very first defence treaty ever. It did so with Japan. It was the best ally to halt a Russian advance in north Asia; and was even seen by some as Great Britain's 'natural ally'. ${ }^{20}$ In particular, the strong fleet Japan was building made an impression. A pact with a naval power suited London well and had already been contemplated for some time. A naval power, in the words of Lord Kimberley, former Secretary of State for India and former Foreign Secretary, would 'always be of more consequence as a friend to this country in that quarter of the world than any other Power'. ${ }^{21}$ Friendly relations with Japan, Curzon (1896: 413) also argued, would assure Great Britain 'the continued command of

18 Only rarely was an opposite scenario suggested: a British-led Chinese army withstanding the Russian threat to India from the north (Browne 1888: 451).

19 Salisbury in House of Lords 8-2-1898 (hansard.millbanksystem.com/lords/1898/feb/o8/ the-queens-speech-reported-by-the-lord-chancellor).

20 E. Ashmead-Bartlett in House of Commons 27-3-1896 (hansard.millbanksystems.com/ commons/1896/mar/27/france-and-siam).

21 Kimberley in House of Lords 17-5-1898 (hansard.millbanksystems.com/lords/1898/may/17/ occupation-of-wei-hai-wei). 
the ocean routes'. The accord provided Japan with the freedom to engage Russia in a war in northern Asia. With the new Anglo-Japanese Alliance it was unlikely that Russia's Dual Alliance partner, France, would come to the assistance of Russia and declare war on Japan, as this would provoke Great Britain to join in.

Contrary to London, Tokyo was prepared to go to war. It wanted revenge for the humiliation by the Triple Intervention of 1895 , had its own plans for Manchuria, and feared that the ultimate aim of the Russian expansion was Korea, a country that Tokyo regarded as falling within Japan's sphere of influence and as being essential to its own defence. The American author Millard (1906: 27) wrote that, around 1900, he had heard 'Japanese officers of high rank' speak of a Russo-Japanese war 'as a certainty of the near future'. British politicians were well aware of the belligerent mood in Japan. In April 1901, the Japanese ambassador in London, Baron Hayashi Tadasu, told Lansdowne that Japan would 'certainly fight' to prevent Russia from taking control of Korea (Massie 1993: 339). In France the prospect of a Russo-Japanese War made Paris recoil from its Dual Alliance commitment; among other reasons, because naval experts were not sure that the badly-led and -trained Russian navy would perform well in a sea battle (Padfield 2009: 88). Paris opted for an Entente Cordiale with Great Britain, where politicians wanted to have some of their international problems out of the way. Taylor (1971: 417) even writes that 'The Far East, and the Far East alone, caused the Anglo-French entente'. In April 1904, both countries settled their long-standing colonial differences.

On 8 February 1904, the Japanese navy attacked the Russian Pacific Fleet at Port Arthur and in Korea. Though victorious at sea, Japan could not press on on land. A stalemate developed and, as Japan's leaders had feared, the country could not financially sustain a war that showed signs of dragging on. In September 1905, peace was concluded. The war drastically changed power relations in the Pacific. Russia ceased to be a major player in the Far East, though it remained a menacing force. Japan's role in Asia and the Pacific only became more prominent, ushering in a third phase in the relations between the powers in the Pacific. At stake was control over the Pacific, with the United States and Japan as the main protagonists; and also at odds over the dominant position Japan had gained in Manchuria after the Russo-Japanese War. The possibility of a confrontation between the two made for doubts about London's wisdom of aligning with Japan and created a new focus of conflict between Great Britain and its largest Pacific colonies. In Australia and New Zealand, fear of Japanese aggression and unmistakable anti-Japanese racial feelings tended to dominate public 
opinion, finding their expression in clear sympathies for the United States where such sentiments were also manifest.

For the European powers, the centre of gravity shifted back to Europe (with the Near East and the north coast of Africa again gaining prominence in the struggle between them for political influence and territory); leaving it to the United States and Japan to determine which one of them would become the dominant power in the Pacific. The main reason for the shift was growing tension in Europe. There, Germany prepared for war with Great Britain, not in Asia; perhaps this is the reason why public enthusiasm for Germany's adventure in Asia, if it had ever existed, evaporated (Wertheimer 1913: 132). Another reason was that Germany's Pacific adventure could hardly be called an economic success. The fact that the South Pacific had been divided up, and that in the Far East the European powers no longer had much to win, facilitated the moving back to Europe. Treaties involving Great Britain and its position in Asia and Africa also contributed: the AngloJapanese Alliance, and what would become known as the Triple Entente: the Entente Cordiale of April 1904, in which London tried to settle its colonial disputes with Paris, and the Anglo-Russian Convention of August 1907, dealing with Central Asia. 



\section{Planters, Traders and Labour in the South Pacific}

In July 1879, the Dutch Consul General for Australia, New Zealand and Tasmania informed his Minister of Foreign Affairs in The Hague about a treaty just concluded between the German Empire and Samoa. With the French in New Caledonia, the British in Fiji and the Germans having obtained for the first time a firm footing in Polynesia, he concluded that a miniature Europe was taking shape in the Pacific. ${ }^{1}$ He wrote about developments in the South Pacific in which the lead in European expansion had been taken by adventurers, enterprising individuals and commercial firms, turning to their respective governments to protect their newly acquired wealth and concessions or to assist them in keeping law and order. The 'civilised powers' as their statesmen continued to refer to their states, here and elsewhere, became caught up in the machinations of their nationals and consuls abroad, who at times with little scruples and backed by warships and Western firepower strove for local hegemony.

Around 1870, the South Pacific was 'empty' land: a part of the world inhabited by what Europeans considered to be uncivilised or semi-civilised peoples, governed by their own chiefs and rulers. Few Westerners had settled there and Western-dominated trade and economic exploitation were still in their infancy. Within years this was to change when cultivation of copra and cotton promised high returns.

An additional reason to turn to the island groups in the Pacific was the strategic importance attached to them for shipping. In a time that steam power was replacing wind power, ocean-going shipping companies, traders and, in their wake, governments started to look at them as a junction of inter-Pacific sea routes. Fiji was said to be located along the highway of commerce' between Australia and Panama, and to be well-suited as a place of naval rendezvous (Legge 1958: 29). Among those contemplating establishing a base there was the British Admiralty. In 1859 the British Admiralty wrote that Great Britain had 'valuable possessions on either side [of the Pacific], as at Vancouver and Sydney, but not an islet or a rock in the 7,000 miles of ocean that separates them' (Legge 1958: 32). There seems to have been almost no exception. Invariably, location entered the arguments of

1 Dutch Consul General in Melbourne to Minister of Foreign Affairs 10-7-1979 (ARA FO A-dos. 111). 
people pleading for European settlement and control. A prospectus from the Australasian Colonisation Company boasted that a harbour might be developed on the northeast coast of New Guinea, which was 'in such position as would command the Trade of China, Japan, California, British Columbia, and the shores of the Northern Pacific Ocean, with all its Islands'.

Completely unclaimed the South Pacific was not. In Australia and New Zealand politicians and a large portion of the general public considered the South Sea their reserve, advancing commercial and strategic reasons to substantiate their claims. With regard to Fiji, for instance, and nicely summing up the arguments, it was stated in 1870 that rule by a non-British power 'would naturally and necessarily be distasteful and prejudicial commercially in time of peace to the Australian possessions of the Crown and might be dangerous in time of war' (Ward 1976: 200). In Australia the different colonies - New South Wales, Queensland, South Australia, Tasmania, Victoria and Western Australia - focused on different portions of the South Pacific. Fiji figured prominently in the calls for the annexation made in New South Wales, where as early as the beginning of the nineteenth century there had been a strong belief that Fiji was an integral part of its territory. In Queensland, New Guinea and the adjacent New Britain Archipelago were a major cause of concern. In New Zealand, itself only a colony since 1840, covetous eyes were cast on Samoa, Fiji and Tonga. In all cases, aspirations went further and, in fact, included the whole of the South Pacific. In 1883 Victoria and the other Australian colonies submitted plans to the government in London for an annexation not only of New Guinea but also of the New Hebrides (present-day Vanuatu), the Solomon Islands and - in the words of the then Colonial Secretary Derby - 'those very large and almost entirely unknown islands which lie to the north and north-east of New Guinea, and which occupy, collectively, an area larger, I should think, than that of France or Germany'.

The home government did not look forward to such annexations. They were costly, and an occupation was likely to lead to confrontations with the local population of the islands, which in those days had an image that was a far cry from the tourist resorts they are associated with today. To contemporary Europeans, the islands were populated by warlike, cruel savages, given to cannibalism and head-hunting. Germany initially also acted with prudence. Bismarck contended himself with stressing the principles of free trade, of equal treatment of German ships and merchants all over

2 Derby in House of Lords 2-7-1883 (hansard.millbanksystems.com.lords/1883/july2/ motion-for-papers). 
the world. At the same time, Germany, like other nations, was not averse to concluding treaties with local rulers; treaties of which the wording and content closely resembled those the European states entered into amongst themselves. Expressions were used such as 'peace and amity' and 'most favoured nation', the latter a phrase to prevent other nations from getting special, exclusive rights (Bennion 2004: 14). If one power acquired unique privileges or concessions these should be accorded to earlier treaty partners as well. Some treaties even included provisions for reciprocal rights. In an early treaty from 1837, France promised the people of Hawaii that when they travelled to France they would 'be received and protected like the most favoured foreigners' (ibid.: 16).

The same bias characterised European-initiated political ceremonies. Public proclamations of annexations were meant to make an impression on the local population, but the firing of the guns of warships and the salutes ranging out only frightened them. The spectacles were, first and foremost, important to the few Germans or Britons who attended such ceremonies. It was the only way in which Europeans knew how to impress. When, for instance, the Germans installed their favourite as king of Samoa in 1887, 'the new king was given a royal salute of twenty-one guns' and 'marched through the town by the commodore and a German guard or honour' (Stevenson 1892: 70).

Figure 3 Station of London Missionary Society on Aroani Island, Papua New Guinea

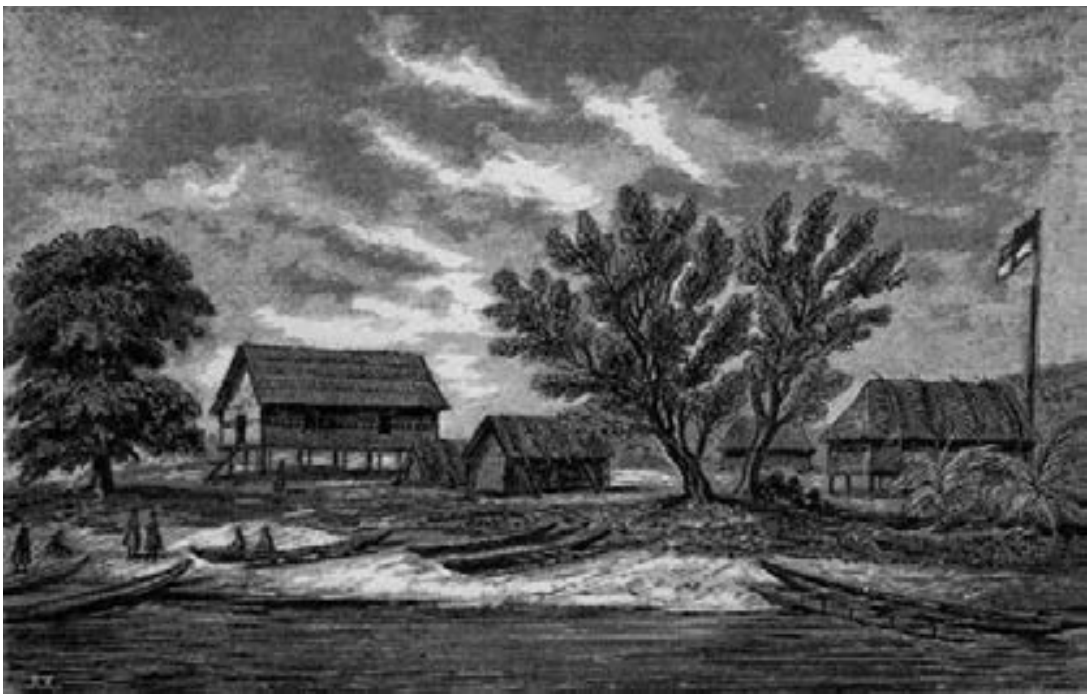

Source: Finsch 1888 
In the South Pacific it was the protection of trade interests and not territorial expansion that first involved the German Empire in an international dispute. The scene was the Sulu Archipelago. For Spain, the islands formed part of the Philippines of which, at that time, it was lord and master. Sulu was also an Islamic region and its inhabitants, just as the Muslims of the Island of Mindanao in the southern Philippines, had resisted the advance of Spanish rule for centuries. In the early 1870 s, in order to enforce its suzerainty on the Sultan of Sulu, Spain put up a naval blockade. The aim, the Spanish government stressed, was to prevent Sulu from sending to sea its 'piratical vessels'. ${ }^{3}$ The blockade was not only intended to keep ships in, but also had to prevent free trade. In 1873 the Spanish seized a British and two German ships trying to run the blockade. At least one of the three, the German brigantine Marie Louise, was declared a 'good prize' by a Spanish tribunal. In early 1875, moreover, on hearing that a German and an English ship were to sail from Hong Kong to the Caroline and Palau Islands, east of the Philippines, the Spanish consul in Hong Kong claimed Spanish sovereignty and the right of his country to levy customs duties in these island groups. Berlin and London protested in concert. In their eyes the islands were free territory, not under the jurisdiction of any European nation. Consequently, no restrictions could be placed by Spain or any other nations on trade there by Europeans merchants. Both governments stressed that they knew of no treaty substantiating Spanish rule over the Caroline and Palau islands. Spain also did not exercise an active administration. Without such evidence of a real Spanish rule there could be no talk of any special Spanish rights. For a similar reason Germany and Great Britain contested suzerainty of Spain over the Sulu Archipelago, backing the authority of the Sultan of Sulu and not the Spanish claim. Or, as the British government insisted in 1882, any right that Spain might have had in the past 'must be considered to have lapsed owing to the complete failure of Spain to attain a de facto control. ${ }^{4} \mathrm{By}$ that time, Spain had made some progress in extending its administration, but its advance was a hazardous adventure and Spanish rule was far from uncontested. In 1877 a Spanish naval squadron had occupied and destroyed Jolo, the capital of Sulu, but as a captain of a Dutch ship, which visited the island two years later, observed the place was 'still a completely on a foot of war defended seat of a Spanish Governor' (Koloniaal Verslag 188o: 55). The argument advanced for de facto control, or, as it was also worded, effective occupation, would only gain in importance as an international 
legal argument, and thus as a factor in disputes over colonial expansion, after the Berlin Conference of 1884-85. The conference, called by Bismarck to discuss the partition of Africa, accepted the Principle of Effectivity, the fact that effective control was a prerequisite for declaring a region a colony.

In the 186 os and 1870 s, when it was still largely a 'free for all' zone, the South Pacific became the arena of fierce competition for companies and individuals, trying to carve out a niche in the international economy. Initially, land was cheap, but as was usually the case when Europeans became interested in land, this soon changed and land titles became a valuable competitive commodity and a prime source of conflict. The South Pacific, which in the past had not attracted much attention, suddenly became a region of great expectations and dreams of unlimited economic prospects, and plantation owners, traders and labour recruiters made their appearance.

Whereas in the 185 os only a handful of Europeans and Americans settled in the South Pacific, a number of its islands suddenly experienced an influx of Western settlers, some with surprisingly good education, uprooting local society. Especially the Fiji islands acted as a magnet. Their 'Sea Island cotton' were of an exceptional quality, and many stories circulated in Australia about how cheap land and labour were and how great a profit could be earned (Forbes 1875:107-8). Between 1864 and 1870 scores of Australians and New Zealanders were drawn to Fiji and other island groups by an economic depression at home and the prospects of profitable cotton cultivation and quick commercial gains. New Zealanders had yet another motive to leave: the destruction wrought by the Maori Wars (Forbes 1875: 276). The Australian doctor Litton Forbes, who was one of those who tried their luck in Fiji, wrote about a rush and shiploads of adventurous spirits leaving Australia for Fiji, culminating in 1871 in a 'stampede' (ibid.: 2-3). Expectations were high 'and though few had any real knowledge on the subject, all seemed to take for granted that the Islands must be exceptionally fertile and rich' (Forbes 1875: 3). According to a contemporary estimate, the number of foreigners in Fiji grew from 30 or 40 in 1858 to 830 in 1867 and 2,000 in 1873 (Ward 1976:160).

In Samoa, the growth of the white community was less spectacular, but the consequences were as least as dramatic. We may get an impression of how the Islanders viewed those strangely dressed newcomers, the power they represented, and the conflicts they fought out amongst themselves from what Stevenson (1892: 153) writes about Samoa: 'None would have dreamed of resisting those strange but quite unrealised Great Powers, understood (with difficulty) to be larger than Tonga and Samoa put together, and known to be prolific of prints, knives, hard biscuit, picture-books, and other luxuries, as well as of overbearing men and inconsistent orders'. 


\section{The ocean of the future}

The Pacific, a Dutchman remarked at the end of the 1870 s, promised to lose more and more of its cachet. On the one side, America's west coast was growing in importance and had become linked by rail with the more populous east. On the other side were Australia, Japan and China, countries, he stressed, with great economic potential (Handelingen 1878-1879: 96). Over time its importance, in economic terms and as a source of international conflict, would only increase in peoples' minds. In the United States, Secretary of State John Hay made a similar remark around the turn of the century: 'The Mediterranean is the ocean of the past, the Atlantic Ocean of the present, but the Pacific is the ocean of the future' (Danusaputro 1986: 313). The Pacific Ocean was 'a new-comer into the broad world interests', the renowned naval historian Alfred Thayer Mahan (1900: 192) asserted.

People were drawn to the region by unrealistic expectations about its economic potential and the riches to be gained. There were the prospects of opening up new land for agricultural estates, producing copra, cotton or sugar cane, and dreams of striking it rich by discovering valuable minerals and precious metals. Enterprising spirits set out to dig for gold and diamonds, or to locate copper and coal fields. The South Pacific became a region to look to; one where people could still operate freely without the constraints of a strong colonial or indigenous administration. The South Pacific attracted new companies as well as old established ones, along with adventurers and fortune seekers. Some tried to make their fortune by setting up companies and printed brochures conjuring up visions of gold fields and rich mines or profitable agricultural endeavours. Others went to the islands as prospector, planter or merchant, or as commercial agent or employee of the larger plantation or trading companies. A few planters became rich, but many would only cultivate a tiny plot of land and often had hardly any expertise at all when they started to work the land (Forbes 1875:55-6, 86).

That not many succeeded and that much of the talk about golden opportunities was a mere fantasy did not matter. Nor did the more sober voices of those who rejected economic adventures and political aggrandisement. They usually argued the opposite and stressed the low economic potential of the Pacific islands and the high costs of colonisation. One voice of warning came from the Governor of New South Wales, W. Denison. As early as 1860 , he called into mind the havoc resulting from the Maori Wars in New Zealand, in which land had been a main issue, and spoke out against annexation of Fiji: 
The inevitable result of the introduction of a white population except under the strictest possible regulations, will be a war of races, and although the ultimate success of the European element would be certain, yet as the Fijians are more numerous than the New Zealanders and more concentrated, as the climate is less adapted to Europeans, the cost of an attempt to maintain the supremacy of the white population, will be comparatively great and the loss of life enormous (Legge 1958: 33 ).

Not to be forgotten are the missionaries and their societies - at times powerful pressure groups at home - and who sometimes, as the saying went in the United States, where one primarily had the situation in the north Pacific in mind, were in the vanguard of trade. The first British missionaries to preach on the islands belonged to the London Missionary Society (LMS), which had started its work in Tahiti at the end of the eighteenth century and in the course of the years would send its missionaries to Samoa, Tonga, Fiji and New Caledonia. From Australia the Wesleyan Methodist Missionary Society (WMMS) had been active in Fiji, Tonga, Samoa and the Solomon Islands since the 1820 s. Around the same time, French Roman Catholic missionaries established themselves in the South Pacific. The 'Picpus Fathers' of the Congregation of the Sacred Hearts of Jesus and Maria were mostly active in Tahiti, the Marist Brothers in Tonga, Fiji, Samoa, New Caledonia and the New Hebrides (Press 2008: 46-9).

The presence of the missionaries in the South Pacific and their effort to convert the population contributed, as Legge (1958: 23-4) writes, to 'the problem of anarchy in the islands'. Being successful in spreading Christianity among the Islanders, such missionaries were drawn into local politics and civil wars; if only because conversion was often accomplished through the mediation of local chiefs (Press 2008: 48). Missionaries and priests also tended to side with their co-religionists or with those most conducive to the dissemination of their system of belief. As such, and added to this the antagonism between Roman Catholics and Protestants missionary societies or between different denominations within one faith, they also became party to the rivalries between the powers and their nationals to control island groups. Their nationality and denomination became an argument in the disputes over which power should take control of island groups. Mutual distrust ran deep and mirrored the discussion about free trade. On the British side, for instance, it was feared, as the Prime Minister of New Zealand, Robert Stout, articulated in February 1886, that 'in the Pacific especially, occupation by France is thought to mean the granting of privileges to the Roman Catholic Church that are not 
granted to any other religious body'. ${ }^{5}$ Not all missionaries, moreover, were saints and occasionally - though this remained an exception - they joined in punitive actions against Islanders. They also, like the other settlers, ran the risk of being murdered by Islanders, which could initiate retaliation.

\section{The white settlers}

Whalers, fishermen out to catch bêche-de-mer (trepang, sea cucumber or sea slug, for which there was high demand in China), and collectors of sandalwood and tortoise shells also came to the islands, as did sea captains, sailors and deserters of warships and merchantmen. Others set up as shopkeepers or owners of hotels and bars. Arms dealers, agents specialised in the recruitment of labour, and people on the run from justice or their creditors completed the European communities that took shape in the Pacific islands. And, notwithstanding those who behaved well who went there too, they were unruly communities of Europeans, Americans, Australians and New Zealanders that took shape. Race and feelings of white superiority definitely also played a role. The white settlers looked upon the Islanders as 'biologically inferior beings', and acted accordingly (Hopkins-Weisse 2002: 2). While in Fiji, Forbes (1875: 95) observed that the Samoan wife of a poor planter did not join dinner 'because a coloured person is no more allowed in Fiji than in India or the Southern States of America to eat with a white man'.

The way these immigrants conducted themselves often could not pass the moral standards of puritanical outsiders who visited the islands. About one such alien settlement, Apia in Samoa, it was reported as early as 1856 that it was 'composed of a heterogeneous mass of the most immoral and dissolute Foreigners that ever disgraced humanity' (Gilson 1970: 170-80). Apia was, another qualification went, 'the Hell of the Pacific' (Masterman 1934:173). A similar remark can be made about Levuka, Fiji's former capital and the main foreign settlement on the islands, which had acquired quite a reputation for its hard-drinking population and the many bars in town. In the early 1870 s, half of its houses were hotels and bars, many German-owned. 'Swilling gin and brawling', one contemporary wrote, 'are the principal amusements' (Gravelle 1983: 120). Another noted that drinking was 'portentous' and that

5 Stout to Agent-General 27-2-1886 (Papers related to the proposed acquisition of New Hebrides by France, no. 8, atojs.natlib.govt.nz/cgi-bin/atojs?a=d\&d=AJHR1886-I.2.1.2.5, accessed 1-9-2012). 
'every man seemed harassed by a perpetual thirst' (Forbes 1875: 15-6). He also identified the reason: boredom.

The newcomers operated in an anarchistic, lawless environment. Traders, the British civil servant, Sir Peter Henry Scratchley, wrote, 'are often reckless, unscrupulous, brutal and piratical. They cheat the natives and are apt to appeal to their revolvers' (Legge 1956: 43). Forbes (1875:155) also noted that the traders lived 'literally, rifle in hand, in the midst of constant danger and excitement', adding that most of the profit usually went to the Australian firms that employed them.

The climate, malaria, dysentery, cholera and violence all took their toll. Trading posts were established and closed down again. One region especially hit was New Ireland. Otto Finsch (1888: 23), an eye-witness of what transpired in the South Pacific, wrote about the island: 'Here a station has to be abandoned because the trader died of climate fever, was killed or chased away, there another one is set afire by the natives in retaliation for "cooked", that is by white-men-burnt-down huts, or is left voluntary because it is not profitable'. He hardly had a more optimistic tale to tell about New Britain: 'Since the first trader set foot on the soil of New Britain and shot the first native, triggering the right of blood feud that is in force here, a considerable amount of blood has been shed in the New Britain Archipelago and murders have been committed on both sides' (ibid.: 24). Though rough and cruel, many of these traders, Finsch (1888: 261) suggests, were scaredy-cats. They fled at the first sight of trouble, which is understandable, as on the same page he calls attention to 'the many bloody tragedies' in the still young history of the trade settlements in the South Pacific.

The traders exchanged local products, first of all coconuts, against hatchets, knives, fishhooks, beads, scrap iron, tobacco (especially American 'Nigger Head' Smoking Tobacco appears to have been popular), jaw harps, gin and the like, and, though at different times and different places this was forbidden, firearms and ammunition. Finsch also provides some insight into the life of the smaller traders. For most of the time they lived in isolation in hostile surroundings. They built themselves simple dwellings, out of necessity constructed in the style of the houses inhabited by the Islanders and with the same materials. Most of the time they were on their own, lonely figures in an unfamiliar environment. Equipped with a supply of sugar, salt, flour, petroleum, tobacco, gin and other such necessities, they had to wait for months for the next boat to arrive. Though sometimes their wives joined them, most of the traders were single. Consequently, their affairs with local women were a not infrequent cause of animosity and violence between them and the Islanders (ibid.: 261). Contemporary visitors were impressed 
by the amounts of liquor consumed. As in the cities, many a trader in his outpost drank heavily: 'But the gin, the gin! That is usually the source of evil! It plays a rather big, evil role, and how few there are who are satisfied with a moderate enjoyment of schnapps' (ibid.: 261).

\section{Labour traffic}

The recruitment of Pacific Islanders as labourers for the plantations, in which British, French, American and German agents and ships were involved, proved a major source of conflicts between Europeans and with the local population. In the South Pacific labour was scarce. Estates were in constant demand of labour that, not insignificantly, in Fiji was called black ivory. On larger island groups, such as Samoa and Fiji, where foreigners established cotton, coconut and sugar-cane estates, as well as in Australia, agricultural workers had to be brought in from elsewhere. Labour traffic was so intense that it could even result in labour shortages on the same islands where the estate workers were recruited. Especially in Queensland demand for labour was high and a steady influx of Islanders - the only non-whites allowed into Australia - was necessary to keep the sugar-cane estates running. In Queensland, where domestic colonisation only took off in the 186os, the first Pacific workers were brought in in 1863 (Hopkins-Weise 2002: 2-3). ${ }^{6}$ Between 1863 and 1904, around 62,00o labourers from the Pacific islands were shipped to Queensland alone to work its estates (Scarr 1990: 172).

Control over island groups meant control over its labour force. One of the regions on which attention focused was the New Britain Archipelago. German economic presence there was strong. In the early 1880 s, its islands had become one of the major labour recruiting regions for German estate owners in Samoa and Fiji. Inroads by other traders and labour recruiters, especially from Queensland, were detested. Competition could take a violent form. As an example can serve a conflict involving 'German Charley', a copra collector employed by the German Robertson \& Hernsheim Company on one of the islands of the New Britain Archipelago. When a vessel from Queensland started to recruit labour in his resort, apart from trying to convince the Islanders that they would be roasted and eaten in Queensland, he also fired at the Queensland crew, who in return set fire to his hut (The Argus 27-10-1884).

6 Recruitment of Islanders in Australia and New Zealand probably started in the late 1840 s (See Brookes 1941: 176). 
Sometimes Islanders could put up a fight. In other instances they were powerless. Armed with poisonous spears and arrows they had to defend themselves against recruiters equipped with firearms. In 1884 Papuans recruited for work on Queensland estates recalled crews of labour vessels who 'as long as they were within reached of the missionary ... were not cruel, but when away from mission influence or supervision ... got guns, etc., burnt the villages, and took the men away by force' (Lyne 1885:125). In cases where Islanders had signed a contract voluntarily it may well be that they did not understand what the consequences were and had no idea of the conditions on the estates they were sent to. They did not realise that they had to work long hours, that the work was strenuous, and that their treatment on the plantations would be harsh. Or, as other Papuans from New Guinea, who had been promised that they would only be away from their home village to work on a Queensland estate for 'three moons', related when they found out that they had to work for three years, 'they wept bitterly, and they ran away from the estate because so many natives were dying, and because they were beaten' (ibid.: 127-8).

The hostility and fear created by the labour recruitment among the indigenous population would only increase over time. Islanders hit back and took revenge, which in turn led to reprisals by white traders and settlers, setting in motion a spiral of violence. It made recruitment of labour a dangerous affair, resulting in the killing of settlers, traders, crews of ships; or, as happened to one unfortunate trader, Berthold, who was shipwrecked on the shore of New Ireland, being stripped naked and forced to work in the Islanders' own coconut gardens (his freedom was bought by Friedrich Schulle, a former employee of Robertson \& Hernsheim, for steel strips worth a few pennies) (Finsch 1888: 35-6).

\section{Commerce and politics}

On the Pacific island groups the adventurous Europeans, Australians or Americans could win no rajaships, which not so long before had been an additional bonus for people venturing out to the Pacific, but some were able to wield considerable political power (Van Dijk 2008). Indeed, by mingling in the internal affairs of the native states, supporting one of the various factions contesting for power, some even succeeded in becoming Prime Minister, as happened in Samoa, Tonga and Fiji, and to the north in Hawaii. In the end, if they were unlucky, financial ruin or banishment faced them when economic or political tides turned. 
Much of it was a game for new arrivals on the colonial scene. Citizens from Germany, the United States, Australia and New Zealand were at the forefront. Some of the companies involved in fact were so new - the most important of them, J.C. Godeffroy \& Sohn, actually was not, it was a respectable and politically well-connected firm (Staley 1935:5) - that in the German Reichstag one of the members could ask Bismarck where those Hamburg 'trade lords' had suddenly come from; those Handelsköninge, who were active in the Pacific but of whom he had never heard before (Koschitzky 1887-88 I: 197). Pioneers became financiers, who could cash in on the exploits of others who had come over to strike it rich but lacked the necessary funds and needed loans and working capital. Wealthy planters assumed a pivotal role in the white community. They had their shops, acted as middlemen, provided labour and bought up the crops, and served as a source of credit for starting or less affluent planters, also lending them money to buy daily necessities (Forbes 1875: 100, 116-7).

The pioneers, acting independently or as agents of firms in their fatherland, profited from a booming market for copra or cotton, two products that were in high demand. Copra, or rather coconut oil extracted from it, was used as an ingredient in candles and in a commodity that became increasingly popular in the second half of the nineteenth century: mass-produced soap. Coconut palms were 'the glory and the wealth of the South Sea islands' (Forbes 1875:52). Cotton growers could profit from a steep drop in American production during the Civil War (1861-65), but for exactly this reason their luck did not last. By the end of the 1870 s the Pacific cotton boom had passed.

German traders took a more than fair share. In 1877 their activities accounted for 87 per cent of the export from and 79 per cent of the import into Samoa and Tonga (Graichen \& Gründer 2005: 69). The trailblazers in Germany's economic venture in the Pacific were representatives of the Hamburg trading house Johann Cesar Godeffroy \& Sohn. With its trading post in Samoa, set up in 1857, as its base the company expanded its activities to other Pacific islands and purchased land for its own plantations for the cultivation of copra, cotton and other tropical products. Business went well for Godeffroy. Within a few years his company became the 'biggest of the early Pacific firms' (Scarr 1990: 150). In fact, it was almost single-handedly responsible for the growth of German trade in the South Pacific (Brookes 1941: 258). The position the company carved out for itself in the Pacific trade was such that the British started to refer to Godeffroy as the 'South Sea King' (Townsend 1930: 73).

Locally, Godeffroy's agent Theodore Weber, a German national, would play a key role in Samoan politics in the 1870 s and 1880 . Weber, described 
by one author as 'built on Bismarck's lines' - and he would indeed act in that way - used political as well as economic means to advance his own interests, those of the company he represented, and those of his fatherland (Staley 1935:2). He was also an inventive man. In 1864 he decided that it was more efficient not to produce coconut oil in Samoa, but to ship its dried meat and copra to Europe for further processing (Nuhn 2002: 68).

In Fiji, the German firm F \& W Hennings of Friedrich Wilhelm, Gustavus and Wilhelm Hennings acquired prominence. The three brothers were 'the boldest and most successful merchants of Fiji ... who had made cottongrowing ... a recognised and profitable industry' (Forbes 1875: 23). The first of the three Hennings brothers, Friedrich, had arrived in $185^{8}$ at a time when, as a minute presented by the German ambassador in London, G.H. Count von Münster, phrased it, pleading their cause with the British government in 1882, 'the Fijians were yet in their most savage state'. Soon Friedrich Hennings acquired the nickname 'Father of Fijian commerce', and, as the minute was to continue, he and his brothers were always prepared to extend a helping hand to new settlers: 'Neither personal assistance by either of the brothers, nor pecuniary aid by the firm, was refused when needed to any worthy of help'? It sounded noble, and almost all older plantations had been started by advances provided by the Hennings firm (Forbes 1875:24), but for the loan land had to be put up as collateral security. ${ }^{8}$

In this early stage, Berlin contended itself with treaties with local rulers signed by its naval officers to support the trade of German firms. The first one, a pact of friendship and most favoured nation with King George I of Tonga, an island group in which Godeffroy \& Sohn had considerable interests, was concluded by Naval Captain Eduard von Knorr of the corvette Hertha in 1876. The treaty between 'His Majesty the German Emperor, King of Prussia ... and the King of Tonga' secured Germany a coaling station on the island of Vava'u (Koschitzky 1887-1888 II: 3; Bennion 2004: 14). Two years later, by the end of 1878 and the beginning of 1879 , the Commander of the German naval corvette Ariadne, Bartholomäus von Werner, entered into treaties with local leaders on a number of islands located in the New Britain Archipelago. There Godeffroy \& Sohn had set up its first trading post in 1874 . A year later Robertson \& Hernsheim would follow. It had its headquarters on the Island of Matupi. All these pacts, 'taking as their base the fact that Germany had the same rights as other countries', emphasised free trade

$7 \quad$ Minute on the land question in the colony of Fiji to advance the claim of F. and W. Hennings 1-7-1882 (PRO FO 534 22).

8 Sahl to Bismarck 18-5-1882 (PRO FO 534 22). 
and dealt with the buying of land by foreigners (Koschitzky 1887-88 II: 12, 234; Nuhn 2002: 34). They allowed Germany to acquire tracts of land to satisfy Germany's need for harbour facilities. One of these, concluded with the chiefs of Topulu and Nerakua, King Dick and King Billy, gave Germany a port and a coaling station in the Makada or Fergusson harbour. Another one established Germany's presence in Mioko, a tiny island in the Duke of York group, but with an excellent harbour. Within years, Mioko would become the base for German operations when the decision had been taken to occupy the New Britain Archipelago and the north coast of the eastern portion of New Guinea. When he concluded his treaties Werner was not yet sure how his superiors in Berlin would react to the purchase of land. To be on the safe side, he asked and got a commitment from the firms of Godeffroy and Robertson \& Hernsheim that they would step in and take over the land he had bought to build harbour facilities in case the German government or the Reichstag withheld its approval (Koschitzky 1887-88 II: 234). Yet another of Werner's treaties lay at the basis of the Jaluit coaling station, more to the northeast, in the Marshall Islands.

German business interests spread in the Western Pacific from Samoa, Tonga and Fiji, to the New Britain Archipelago and the Caroline and Marshall Islands. In these places the German companies, which drew money not only from Germany but also from Australia and New Zealand, had to compete with companies of other nationalities. Among the British firms, many of them involving people and capital from New Zealand and Australia, were the Sydney-based but German-owned company of Rathbone, Féez, and Co., the Polynesia Company of Melbourne, and McArthur \& Co. from New Zealand. Somewhat later, in 1883 , they were joined by the mighty Sydneybased Burns, Philp \&Co. Of the American firms, the Central Polynesian Land and Commercial Company (CPLCC) deserves mentioning. Californiabased, it held extensive land claims in Fiji and Samoa. The Société française de l'Océanie, the Société française des Nouvelles-Hebrides and other French companies also played a role, albeit a lesser one.

\section{Conflicts over land}

When representatives of such companies felt threatened by unfriendly Islanders or by their business rivals, or when they got caught up in the internecine civil wars rampant on some of the island groups, the white planters and traders turned to their governments at home for protection and diplomatic or naval support. In this way, competition between business communities 
turned into rivalries between nations. It was not just trade that made the firms run by people from different nationalities collide in the Pacific and set in motion a course of violence in the South Pacific. An even more important factor was control over agricultural land on which plantations could be laid out. Wherever foreigners settled, conflicts occasioned in part by different perceptions of ownership of land and of what selling land implied were almost endemic. Against the Western concept of individual ownership stood that of the Islanders of communally owned land. A frequently encountered problem was that Islanders sold land without consulting or informing others who, according to customary law, shared ownership. Settlers, ignorant of the indigenous concept of landownership, entered into contracts with lower or higher chiefs only, or did not understand that according to the customs of the Islanders they had only bought the usufruct, not the land itself (see also Legge 1958: 50-5). But there was more. Most Islanders selling land did not realise that this meant that they were barred from it. In Fiji, for instance, 'they do not understand what they have done until they begin to feel pinched by hunger or cramped for room; but as soon as the land has been fenced in, the cocoa-nut trees cut down, and the bananas and yams cleared away to make room for cotton or sugar, they begin to perceive the effect of their rashness, and of course to regret it' (Forbes 1875: 200-1).

The result was not only conflicts and violence among the Islanders themselves, contesting each other's rights of ownership and alienation, or between settlers and Islanders, but also between settlers, who disputed each other's claims to titles of land. It was not uncommon for various Islanders to sell and resell the same piece of ground to different foreigners. In Fiji, 'infinite confusion' was the result (ibid.: 97). In Samoa, the outcome was 'an unusually complicated state of property', as a German diplomat would describe the situation in $1887 .{ }^{9}$ In 1889 , the total area of land claimed by British, Germans and Americans in Samoa was '1,700,000 acres - some 1,000,000 acres more than the total estimated area of land on all the islands!' (Masterman 1934:134). Protecting the ownership rights of one's own nationals against accusations by other foreigners or by Islanders that land had not been acquired in accordance with prevailing law, became one of the prime incentives for foreign communities in the Pacific to intervene in the administration and jurisdiction of those island groups where they had extensive landed property, or to ask the home government to intervene.

Suspecting the other of foul play and territorial ambitions, settlers called upon London, Berlin and Washington to protect the interests of 
their enterprising countrymen abroad and to annex the regions these estate owners or traders considered vital to their business. Both the German government in Berlin and the British one in London were inundated with petitions. Afraid of losing the possibility of exploiting agricultural land or of being cut off from their supply of labour, German and British businessmen or consuls pointed at the evil intentions of the other. Arguing that if the other side got its way, this would seriously damage, if not ruin, their own companies, they asked London or Berlin to prevent a territorial expansion of the other nation or to take the lead and act first.

\section{Policing the Pacific}

Since the late 1820 s British warships patrolled the Pacific. The aim was to protect compatriots, punish Islanders who assaulted Britons, act upon the abuses of white settlers and traders, and back up the arguments of the home government when conflicts over control over islands arose. Around the same time, the American navy took on a similar role, and the French were soon to follow. Warships were part of the diplomatic rivalries that emerged over the Pacific Islands, with their captains at times acting more rashly than their governments back home when matters of protection and annexation came up.

In keeping planters and labour recruiters in line, the British fleet was hardly effective if only because their captains could only act against British subjects, and cases had to be brought against perpetrators in courts in Australia. The police role of British warships did not make the British navy popular among British settlers in the Pacific. It also made others reject in advance a British annexation. Forbes, voicing the view of British settlers, complained that when an American was threatened by violent Fijians he could use a revolver, but that a Briton had to react in a different way:

for should he shoot or wound a native even in self-defence, he will most probably be 'deported' to Sydney by the next ship-of-war and tried for his life. Even if acquitted he will be a broken man, ruined in purse and in credit, his plantation overgrown with weeds, his cotton crop lost, and his soul embittered by what he feels to have been a cruel injustice (Forbes 1875: 82).

At more places in Forbes' book we find denunciations of the British navy's policy. He claims that in disputes with Fijians over land titles captains 
of British warships tended to side with the chiefs, putting planters with another nationality at an advantage. Not restricted by British naval supervision, they could take matters in their own hands and defend their claims by force of arms. At one point Forbes (1875:156-7) even writes that the Islanders respect Frenchmen and Americans because French and American gunboats struck 'terror into the hearts of native wrong-doers', while the Islanders knew 'by experience the dislike which the English have to help their own countrymen or to punish an adversary apparently weak', firing shells 'over the natives instead of at them'. Such an attitude would have given some Britons more faith in other navies. The prospect of the American navy coming to their aid would have motivated at least some British planters in Fiji to become American citizens (ibid.: 110, 157).

Among the abuses the British navy had to act upon were those of the recruitment of labour, a trade described by its opponents as a disgrace to civilisation; and this was probably also the public image labour trafficking had in those days. Recruitment and employment of labour became synonymous with slavery and kidnapping, words often used by contemporary critics when attacking their abuses. Moreover, in the tradition of the older slave trade, in Australian slang Pacific Islanders were 'blackbirds' and Islanders were captured in labour raids and transported in ships significantly called by Islanders 'snatch-snatch' vessels (Brookes 1941: 299). From early on, when Pacific labour was also needed for sheep and cattle farming in northern Australia, treatment of Pacific labourers was harsh. In March 1869 one local resident wrote in the Brisbane Courier: 'I have seen slavery in the British West India Islands in 1832-33, and until it was abolished ... I never saw or heard of a white man striking a negro with the fist, using a rope's end, or galloping and flogging them with a horsewhip, as has been witnessed on this island' (Hopkins-Weise 2002: 10). The Scottish poet and author Robert Louis Stevenson (1892: 31) noted of Samoa, where he lived in the early 189os, that it 'is said that the whip is very busy on some plantations'.

Only a few defended the recruitment of Islanders as contract labourers. They tried to convince the outside world that, in general, such labourers were treated well; blaming the bad name the trade had on a small number of excesses. Among them, in 1869, were the American and British consuls in Fiji and the Fijian planters themselves, and a British commission sent to the island group to investigate a possible annexation (Brookes 1941: 300-2; Forbes $1875: 269)$. Forbes $(1875: 41,246,268)$, himself a member of the settlers' community, calls the recruitment process 'fair and honest' with 'neither deception, nor coercion'. According to him, the labour-vessels - which others had described as overcrowded - were 'roomy enough and well-ventilated', 
and he was also content with the way labourers were housed in Fiji: "They are well-fed, not overworked, fairly paid, are protected in the enjoyment of their gains, and are relieved from a daily and hourly fear of being killed and eaten'. ${ }^{10}$

Voices like that of Forbes were ignored. In Great Britain the anti-labour recruitment campaign found support among politicians in the Houses of Parliament and the government, proud of the leading role their country had played in the abolition of slavery. As early as 1869, the British Foreign Secretary, George Villiers, $4^{\text {th }}$ Earl of Clarendon, had called the recruitment of labour 'a systematic slave trade breaking out in a new quarter' (Legge 1956: 10). Many would phrase the problem in a similar way. Five years later, the British Colonial Secretary, Carnarvon, commenting on the labour trade in Fiji described it as 'utter iniquity and barbarity'. ${ }^{11}$ In July 1883, Lord Lamington in the House of Lords spoke about 'labourers, whose condition, if not slavery, would certainly amount to servitude' and 'acts of piratical violence which have excited such just and general reprobation throughout the civilised world'. ${ }^{12}$ The British Admiralty was also against unrestrained labour trade but for different reasons. It blamed its excesses on attacks on ships by Islanders (Brookes 1941: 297). Even the German Chargé d'Affaires in London, arguing the importance of the New Britain Archipelago for the German estates in Samoa, informed the British government that 'there are few, if any voluntary recruits ... some men, too poor to marry, may leave in order to save money to obtain wives; but the bulk of the recruits are slaves sold by the chiefs, or prisoners of war, who are sold for arms, and who will not willingly remain on board' (The Argus 27-10-1884).

Great Britain did have its rules for the treatment of Pacific labour, the Queensland Act to Regulate and Control the Introduction and Treatment of Polynesian Labourers of 1868 and the two Pacific Islanders' Protection Acts, enacted in London in 1872 and 1875 . The wish to root out the abuses of labour traffic was one of the motives behind the creation of the office of the High Commission for the Western Pacific, headed by a High Commissioner and established in 1877 on the basis of the 1875 Pacific Islanders Protection Act, which it had to enforce. Its jurisdiction expanded to those British nationals living and working on Pacific islands where Western rule had not yet been

10 In a recent study about the contacts between Islanders and Europeans, Thomas (2010: 225) asserts that some Islanders 'found indenture an ordeal', but that because of the goods the labourers could buy and bring home, overall 'the balance of opinion was in favour'.

11 Carnarvon in House of Lords 17-7-1874 (hansard.millbanksystem.com/lords/1874/jul/17/ the-fiji-islands-cession-to-the-british).

12 Lamington in House of Lords 2-7-1883 (hansard.millbanksystems.com.lords/1883/july/02/ motion-for-papers). 
established, or, as it was phrased, on islands 'not within the jurisdiction of any civilised Power'. The High Commissioner had no authority to act upon non-British nationals or the local population, and some Britons evaded its jurisdiction by taking on another nationality, or sailing under a foreign flag, including the Fijian one (Legge 1958: 112; Ward 1976: 212). As they had also done in the past with respect to the British navy, British estate owners and labour traffickers would complain about the High Commission, stressing that it gave their foreign competitors, against whom it could not act, a definite advantage. The other side of the coin was that the High Commissioner did provide the British with legal and physical protection. A French author (Pelleray 1922: 81), in discussing the fate in the 1880 s and 1890 of of French settlers and traders who had to hold their ground in the then still not annexed New Hebrides, praised the law and order established by the High Commission, which these Frenchmen were lacking. In view of the difficult situation such people found themselves in, the French Governor of New Caledonia was given the additional position of Commissaire général de la République dans l'Océan Pacifique in 1901.

Perhaps such evaluations mirrored images rather than actual practice. The High Commission was hardly effective. It lacked funding, personnel and physical back up by the British navy, which up to then had performed the task of protecting the British nationals in the Pacific and controlling their activities. In 1883 a report from an enquiry into its performance concluded that 'as regards the greatest part of the vast area' it had to cover the High Commission had been 'almost inoperative' (Legge 1956: 12). A commission was instituted to enquire into its future. In spite of its poor performance, international relations were considered a factor in favour of the High Commission. Without such an institution things might become worse. The conclusion of the commission of enquiry was that 'the abandonment of control over the acts of British subjects would not be tolerated by foreign Powers having large interests there' (Ward 1976: 290).

The High Commission could not prevent the continued problem of Islanders being pressed by force to become estate workers, while the conditions under which they had to live and work remained bad. On some of the islands, the chances of surviving for any length of time on the estates were small. In Fiji, for instance, at that time already British, between 1880 and 189o, '27 per cent died in the course of their 3-year indenture to the sugar estates, mostly in the first year, with dysentery and influenza-pneumonia adding to physical exhaustion' (Scarr 1990:178). This percentage was probably already an improvement. One figure from the previous decade mentioned a death rate of $5^{\circ}$ per cent (Gravelle 1983: 111). 
In view of such facts, pleas for an annexation or arguments to support such a step were given a humanitarian twist. Extension of German or British rule was presented as an effort to end the abuses by labour agents, captains of ships who sailed to islands to recruit labour, and estate managers. Western domination, in particular and of course by one's own nation, was presented as an advance of civilisation and Christianity and their values. It was the other who was to blame for the maltreatment of Pacific Islanders. Germans made the accusation that the labour agents and estate owners in Queensland were engaged in something that was not much different from slave trade and suggested that Islanders preferred German estates near their home islands over those in distant Queensland (Koschitzky 1878-88 II: 219).

In Great Britain and Australia it was maintained that only British rule could be beneficial. Or, as the Premier of Victoria, James Service, phrased it in 1883 , 'politics, religion, commerce, civilisation and humanity all suggest the desirability of placing under British control as many of the Western Pacific islands as remain unappropriated' (The Argus 9-6-1883). In London one member of the House of Lords called for the annexation of Fiji because this provided Great Britain with 'a vantage ground, from which, by establishing a strong Crown Colony in the centre of Polynesia, a watchful eye may be kept to check the abuses in the labour traffic of the Islands'. ${ }^{13}$ British humanitarian societies, such as the Anti-Slavery Society and the Aborigines Protection Society, and a number of missionary organisations joined in, presenting fair treatment of Pacific labourers as an argument in favour of a British annexation of Fiji and New Guinea. Expanding British rule was a sacred duty. To urge London to take control of Fiji it was stated at meeting of the Aborigines Protection Society that if this was not done the British people would 'be unworthy of the great destiny which Providence has thrown open to their country ... to protect the interests of civilisation, and of the native tribes in that distant and interesting region' (Legge 1958: 143).

13 Dutch Consul General in Melbourne to Minister of Foreign Affairs 10-7-1979 (ARA FO A-dos. 111). 


\section{$4 \quad$ Fiji: The Start of Anglo-German Rivalry in the Pacific}

By the 1870 an explosive situation had emerged in a number of places in the Western Pacific. In some island groups, Fiji, Samoa and the New Hebrides, a combination of incessant factional strife amongst the Islanders and ruthless competition within the foreign community had created a situation hardly conducive to estate agriculture and trade. As was not uncommon, also elsewhere in the Pacific, a weaker party in a domestic war or threatened by outside forces might, of its own free will or urged by foreigners to do so, turn to European nations and the United States, offering sovereignty in return for armed support or protection. On some island groups in the South Pacific, where violence reigned and such requests were frequent, the matter was complicated by a sizeable minority of white settlers who had to protect their lives and property. Such merchants and planters, backed by the might of their weapons and the warships sent by their navies, took the side of those whom they believed could further their business interests most. As titles of land were a much sought-after commodity, this usually meant that they supported the faction that recognised their land titles and would allow them or their company to enlarge their landed property.

Figure 4 The South Pacific. Author: Kahuroa

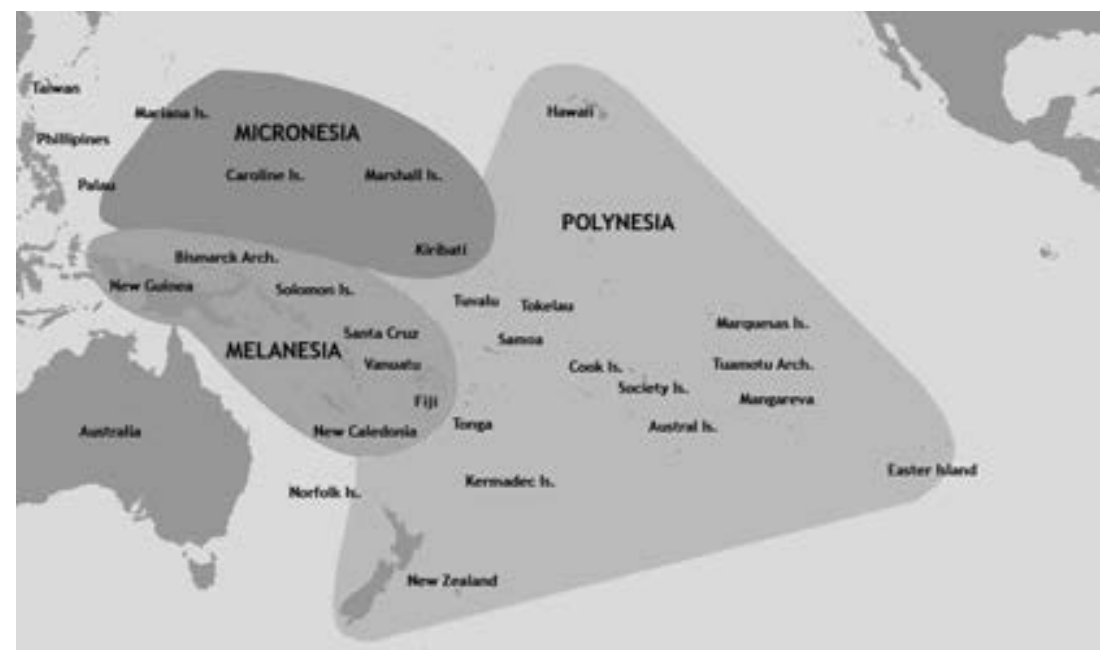

Source: en.wikipedia.org/wiki/File:Pacific_Culture_Areas.jpg 
Instrumental in what happened were the foreign consuls. Often, they were appointed by their governments to protect the interests of their nationals living on the Pacific islands. They were sometimes also sent, as some of the British consuls were, to curb the abuses of the labour trade and the estate economy, despite the fact that their power over the British residents was actually quite limited. Their authority was only backed up by the occasional visits of warships, making them, to a great extent, dependent on the goodwill of the settlers. British consuls who played an active part in the domestic affairs of Fiji hardly had any means to enforce their authority, also amongst British residents, but as the Foreign Office assured one of them in 1869 , they could always count on the occasional visit of British warships (Legge 1958: 100). Yet a third reason was to forestall annexation by rival powers; an intention that could result in serious international complications, especially when there was internal strife in the island groups.

After 1871 German Imperial consuls also played their role. They did so as members of what the German author Koschitzky (1887-88 I: 134), betraying the lines drawn in German domestic politics, proudly called 'the new consular system', which 'from the start functioned on a solid Prussian-North German base'.

In the earlier competition in the South Pacific, Great Britain and France had been the main contestants. The United States, where people like Commodore Matthew Calbraith Perry, the man who opened up Japan to foreign trade, for reasons of commercial and naval competition with Great Britain pleaded for taking possession of Pacific islands, had occasionally showed its flag in the South Pacific, but had not frequently sailed its waters. After a first visit to Samoa in 1839, it took some thirty years before an American warship visited the islands again (Dulles 1938: 103).

Franco-British rivalry in the Pacific dated from the late 1830s, when France under King Louis-Philippe had embarked on a colonial policy to regain some of the grandeur the country had lost after the Napoleonic Wars and, much as Germany was to do later, to show Great Britain that France was a nation that should be reckoned with as a power that counted on the international scene. The policy of showing what France was worth had in 1842 won Paris, by exploiting domestic strife in the kingdom, a protectorate over Tahiti (Taïti) in the Society Islands (Îles de la Societé) where British commercial interests had been dominant (Brookes 1941: 107). The person responsible was the French Rear Admiral Abel Aubert Dupetit-Thouars, who briefly annexed Tahiti in 1843, a decision the French government was forced to reverse after protests from London. The protectorate incidentally 
also gave the Tahitian kingdom a new flag in which the French Tricolore was shown in the upper right corner. As in other such cases, Tahiti and rumours of other French annexations aroused nationalist public sentiments in France as well as in Great Britain. In December 1844 the British Foreign Office noted that 'the public feeling in England' had been 'deeply wounded by the French proceedings in Tahiti' and 'might be again intensely excited by any further operations of the French in the immediate vicinity of Islands where our missionaries are successfully using their uttermost exertions to bring the inhabitants within the pale of Christianity and Civilisation' (ibid.: 152).

The missionaries were mentioned with good reason. The competition in the South Pacific between France and Great Britain was partly religiously inspired; also because from the outset French colonial ambitions and the spread of Roman Catholicism had been intimately linked (ibid.: 78 ). Missionaries and others dreaded that the islands on which they were active would fall into the hands of a country where another denomination was adhered to. The British position was well-expressed by Herman Merivale, Permanent Under-Secretary of State for the Colonies from 1854 until 1859: '[T]he South Sea Islands, Christianised and partly colonised by Englishmen, longed for British protection against the advance of a different nationality and religion' (Ward 1976: 187-8). Religious and racial sentiments had the upper hand but British fears may also have been inspired by what happened in Tahiti after the French takeover, when all land belonging to the London Missionary Society was confiscated (Brookes 1941: 157).

In the middle of the nineteenth century, France had made a steady advance in the South Pacific. In 1842 it had established a protectorate over Tahiti, some of the other Society Islands (Îles de la Société), the Marquesas Islands (Îles Marquises), Wallis Island (Uvea) and Tubuaï and Raivavae, two of the Austral Islands (Îles Australes). The Gambier Islands became a French protectorate in 1844. New Caledonia (Nouvelle-Calédonie), in the perception of the Australians uncomfortably close to their coast, followed in 1853 , while the Tuamotou (Tuamotu) Islands became a protectorate in 1859. In the 186os France would also add the Loyalty Islands (Îles Loyauté), adjacent to New Caledonia, to its overseas territory. In the Loyalty Islands, the scene of Anglo-French, Protestant-Roman Catholic conflicts, the French briefly tried to put an end to Protestant missionary activities, but had to give up after protests from London. In subsequent years, British, or rather Australian, anxiety would focus on a possible French takeover of the New Hebrides, and a Member of the House of Commons would state in 1886 that them becoming French would imply 'abandonment of the valuable 
work of civilisation among its independent native population of the British Presbyterian Church'. ${ }^{1}$

In 1854 the French penal system was changed, granting New Caledonia a special function and adding to British, or rather Australasian, dread. Guyana was being considered too unhealthy to serve as a penal colony and the South Pacific was thought to be a good alternative (Lorin 1906: 33). In 1864 a convict colony was instituted in New Caledonia, making French rule even more abject to the Australians. Despite New Caledonia being 1,200 kilometres away from Australia, Australians were daunted and upset by the unlikely prospect that some of the convicts - amongst whom soon would be, in fact, many supporters of the Paris Commune - might escape and reach their shores. The British were also unhappy with France establishing a protectorate over the tiny Austral island of Rapa (Rapa Iti, Oparo) in the Bass Islands (Îles de Bass) in 1867. Its harbour was said to be a perfect midway station between Australia and New Zealand and the Panama Canal once the latter would have been dug.

\section{Germany's ambitions}

Nobody in Great Britain or its Australian colonies had yet given a thought to a German threat in the Pacific. On the contrary, a German presence was welcomed. As early as 1848 some Australians considered a German colonisation of New Caledonia a good alternative to a French annexation (Ward 1976: 148). Similarly, in 1870 , when the possibility of a protectorate over Fiji was discussed, London preferred that Belgium or 'North Germany', that is, the Prussia-dominated Norddeutscher Bund of 1866, should be persuaded to take on this obligation (Legge 1958: 26, 72). The United States formed no option. It was too close and too big, and when William H. Seward had been Secretary of State between 1861 and 1869 , it had acquired itself a reputation as a nation not averse to expansionism. In 1867 the United States had bought Alaska from Russia and had taken possession of Midway. It had also tried, for the moment still in vain, to bring Hawaii within its orbit, and in 1872 , it would gain a foothold in Samoa. Allowing the Germans in would keep the Americans out.

Not much later Germany became Great Britain's main adversary in the contest over colonial possessions in the South Pacific. The regions Germany cast covetous eyes on were almost all on the doorsteps of some of Great

1 Howard Vincent in House of Commons 14-5-1886 (hansard.millbanksystems.com/ commons/1886/may/14/the-western-pacific-the-new-hebrides). 
Britain's own colonies or were islands or island groups that the people living there wanted to annex. Some had a significant number of British settlers and traders. Consequently, London had to take into account the opinions of the Australians and New Zealanders who tended to view the whole of the South Pacific as potential British territory and, since the 1870 s, 'had sent a constant stream of annexation requests' to the Colonial Office in London (Hiery 1995: 17). Germany and Great Britain had acted in unison against the Spanish claims over the Sulu Archipelago, but before the end of 1874, when negotiations with Spain were still going on, they fell out over another piece of the Pacific: Fiji. The consequences were great. The conflict over the Fiji islands would shape much of the perception in Germany of Great Britain as a nation that recklessly, rücksichtslos, pursued its own colonial interests, irrespective of the consequences for other nations and their citizens. A distrust of the intentions of the British (a feeling that would soon be reciprocal) became one of the major arguments for the German Empire to aspire after colonial territory. It gave Bismarck the arguments he needed to demonstrate that Germany needed more than just a few coaling stations or consular representations in Africa and Asia to protect the commercial interests of its countrymen overseas.

In the popular image of those days Fiji - also known as the Cannibal Islands - was populated by people who, not so long before, had been ferocious cannibals and, indeed, 'the most horrible cannibals that existed on the face of the whole earth'. ${ }^{2}$ Figures from those days had it that there were some 160,000 Fijians, of whom 140,000 were 'in a state of comparative civilisation'; that is, they had converted to Christianity, while the rest (mainly living in the interior) were 'utterly barbarous'.3 Among the white settlers, some 2,000 in total, the British were still the preponderant party, in numbers and in economic clout. Friedrich Hennings had arrived in 1858 and two years later Godeffroy \& Sohn had opened a branch in Fiji, but British, or rather Australian, settlers, many drawn to the island to grow cotton, were still dominant. According to a contemporary estimate, they accounted for five-sixths of the foreign community in 1873 (Ward 1976: 254). Furthermore, export was still largely in British hands (ibid.: 239) and British consuls did most of the mingling in indigenous political affairs and had a lion's share in creating a rudimentary form of administration in the foreign community.

2 Wilfrid Lawson in House of Commons 4-8-1874 (hansard.milbanksystems.com/ commons/1874/aug/04/resolution).

3 Carnarvon in House of Lords 17-7-1874 (hansard.millbanksystem.com/lords/1874/jul/17/ the-fiji-islands-cession-to-the-british). 
Among the tasks these British consuls had taken upon themselves was the vital and highly sensitive job of registering the titles of land acquired by settlers. The Germans played a secondary role in Fijian politics.

In Fiji two main rivals contested each other's power. One was Cakobau, the paramount chief of Bau, a small island east of the much larger Island of Viti Levu, who had been converted by Wesleyan Methodists in 1854. The other was Ma'afu, a Tongan, who had succeeded in establishing power in most of the eastern part of Fiji, the Lau Islands. Ma'afu was also a Christian, and it was he who was favoured by the missionaries of the Wesleyan Methodist Missionary Society. Although the missionaries did not go along with this, he 'posed as a Christian crusader engaged simply in opposing the enemies of the Gospel' (Legge 1958: 40-1).

In part, the Americans had been responsible for Cakobau's prominent position in Fiji. In 1855 the captain of the USS John Adams, E.B. Boutwell, had imposed a large fine on him as 'King of Fiji' to compensate for attacks on American ships and their crews and other transgressions. This included the plundering on Nukulau Island of the house of the man who had bought the island, John Brown Williams, a former American consul in New Zealand and the American Commercial Agent to Fiji. The incident happened after Williams had fired a canon bomb to celebrate the Fourth of July, accidentally setting his house ablaze. Cakobau had protested that he was not the chief of the perpetrators. His objection was ignored, and, as Forbes (1875: 294) writes, " $[\mathrm{t}]$ he Americans recognised him as King of Fiji, saluted him with a royal salute, and mulcted him in the sum of nine thousand pounds'. The New York Times reported proudly of Boutwell's punitive expedition and his 'important treaty' with 'the King of Fejee'; that is, Cakobau's signed debt obligation:

During the cruising of the John Adams in the Fejee group of islands, five sharp engagements took place between her crew and the cannibals of Polynesia, in which American valour was always victorious. Five of their largest towns were burnt, and all the houses therein reduced to ashes (New York Times, 15-2-1856).

His debts induced Cakobau to offer Fiji to Great Britain and left him in fear that he would one day have to pay. It took some ten years before Cakobau was reminded of the fact that he owed the United States money. This was in 1867 when the American warship Tuscarora visited Fiji. This time Cakobau tried to get out of his predicament by accepting the following year an offer by the Melbourne-based Polynesia Company to take over the debt in return 
for 200,000 acres of land (Legge 1958: 53). The debt, however, also made the United States side with him in his struggle for power with Ma'afu (Forbes 1875: 294). Such acts in 1869 accounted for the unwarranted suspicion in London, nourished by, amongst others, the future Foreign Secretary Granville, that Washington wanted to take possession of Fiji (Dulles 1938: 101).

\section{The reign of King Cakobau}

In June 1871 , with the support of a group of settlers, Cakobau was proclaimed king of the whole island group; according to Forbes (1875: 275), the result of a 'daring and successful coup d'état ... effected by a few white men ... almost unknown in the general community'. He was crowned in Levuka, the settlers' town and port on Ovalau Island. Ma'afu was assigned the subordinate position of Viceroy of Eastern Fiji. In ruling over Fiji, Cakobau was assisted by a Western-style government, controlled by and largely made up of foreigners; copying the political system of Hawaii, which been established earlier in Honolulu. Most of the members of Cakobau's cabinet were British, but among them were also Gustavus Hennings and his brother Friedrich, who became Minister of Finance. The government also had the blessing of the American consul.

In 1872 Cakobau tried to regulate and humanise the recruitment and employment of labourers and announced an enquiry into titles to land. He was too ineffective to accomplish much. Unpopular as the first was among foreigners, not to speak of the complications the second might give rise to, from the outset the Cakobau government had to deal with an impressive group of opponents: the government of New South Wales, the then British consul, E.B. March (who only recognised Cakobau as chief of Bau), and a pressure group of British planters styling themselves the Ku Klux Klan. The latter, soon to be renamed the British Subjects' Mutual Protection Society and Volunteer Corps, seemed to aim at an armed confrontation with Cakobau's government, but had to refrain from action when a British warship, the HMS Cossack arrived (Forbes 1875: 324; Gravelle 1983: 123-7). In 1873 Gustavus Hennings, the acting German consul, also turned against the administration. By that time, the Fiji government had lost most of its authority and had almost bankrupted the islands. It also did not help that all settlers were now considered Fijian citizens. Those resisting claimed that they were defending the liberties of the white community, comparing their actions with the rebellions in Great Britain against Charles I and II (Forbes 1875:333-4). A British naval presence in Levuka and elsewhere in 
Fiji was needed to keep some of them and Ma'afu in check and to prevent them from rebelling (Ward 1976: 249, 252; Forbes 1875: 325, 330).

The straw that broke the camel's back was probably the intention of the Cakobau government to organise elections in which the Fijians were also to participate in 1873: 'Every white man felt himself personally aggrieved, and determined to resist to the utmost', Forbes $(1875: 336)$ wrote.

By that time, the domestic political situation in Fiji had already become so chaotic that the Colonial Office in London concluded that a considerable armed presence would be needed to restore order (Brookes 1941: 371). Even without civil war the planters lived in a hostile environment. In spite of the tropical heat the richer planters roofed their wooden houses with galvanised iron. They did so to prevent angry Fijians and also workers (Forbes notes that the Solomon Islanders are 'a treacherous lot of men, both feared and disliked by their employers') from setting fire to their houses. Their white employees and the much more numerous small planters were not protected in this way and had to make do with walls made of reeds and thatched roofs (Forbes 1875: 70).

The settlers' community also became divided. Forbes (1875:33), longing for the old spirit of 'camaraderie', observed that he 'remained long enough in Fiji to see this kindly feeling among the settlers sadly change; to see it give place to mutual contempt and distrust, which threatened even to end in anarchy and bloodshed'. By 1873 civil war and collapse of law and order loomed. Or, in the words of Carnarvon, there was 'disorder and confusion all around, and a war of the most bloody character seemed imminent'. ${ }^{4}$ By the end of January of that year, John Bates Thurston, a cotton planter and former British consul as well as Chief Secretary of the Cakobau government, turned to the Foreign Secretary, Granville, enquiring whether London was prepared to accept a decision of the Fiji government to cede the kingdom to Great Britain. In the past London had always refused such requests. Apart from it being unwilling to add new territory to its empire, foreign relations had been an additional argument. Annexation of Fiji, it was argued in 1870, or, as was feared in 1873, might irritate the French or might induce Washington to take possession of Hawaii (Ward 1976: 241; Brookes 1941: 352).

This time the answer was affirmative, but London took the step to annex Fiji reluctantly. The annexation of Fiji, as the then Colonial Secretary, Carnarvon, characterised it nine years later in the House of Lords, had been

4 Carnarvon in House of Commons 17-7-1874 (hansard.millbanksystem.com/lords/1874/jul/17/ the-fiji-islands-cession-to-the-british). 
pressed on London by the Australian colonies. ${ }^{5}$ What London did was to appoint a Commission of Enquiry. Its members, Commodore James Graham Goodenough, the freshly appointed commander of the Australian Naval Station, and E.L. Layard, who was to take up his position as the new British consul in Fiji, were sent to the island group to investigate on the spot what action had to be taken.

There were four alternatives. One was to recognise the government formed by King Cakobau (himself a former cannibal, it was maliciously remarked in the House of Commons) in June $1871 .{ }^{6}$ In view of its poor performance and the widespread opposition against it, the likelihood that the Commission of Enquiry would come out in support for him was slight. A second possibility was to give the British consul the powers of a magistrate over British subjects. This could hardly be effective and would, Carnarvon explained in the House of Lords in July 1874 , be a temporary solution, 'a stopgap at best'? Y Yet another alternative was a British protectorate, leaving Fiji's own government more or less intact. The final option was annexation, the ceding of the kingdom by the king and the major chiefs, and the establishment of what Carnarvon called 'a Crown Colony of a rather severe type'.

Goodenough and Layard's brief was clear. London was 'far from desiring any increase in British territory' (Brookes 1941: 384). Annexation was out of the question 'unless it proved to be the only means of escape from evils for which this country might be justly held to be bound to provide an adequate remedy' (ibid.: 384). Yet this was the course of action to be taken. In the opinion of Goodenough and Layard the Cakobau government lacked authority and support and was not the institution to maintain law and order. There were, they wrote in their report, 'no prospects for these islands should Her Majesty's Government decline the offer of cession, but ruin to the English planters and confusion to the native government' (Gravelle 1983: 137).

When London made its final decision, dependent on the advice of the Governor of New South Wales, the outcome could no longer be doubted. In the House of Lords, Carnarvon spoke of 'protecting a place into which English capital has overflowed' and 'English lawlessness is going on'. ${ }^{9} \mathrm{He}$

5 Carnarvon in House of Lords 20-4-1883 (hansard.millbanksystem.com/lords/1883/apr/20/ question-observations).

6 Alexander Baillie-Cochrane in House of Commons 4-8-1874 (hansard.milbanksystems. com/commons/1874/aug/04/resolution).

7 Carnarvon in House of Lords 17-7-1874 (hansard.millbanksystem.com/lords/1874/jul/17/ the-fiji-islands-cession-to-the-british).

8 Ibid.

9 Ibid. 
now depicted the acquisition of Fiji as an excellent catch. Its islands were lovely with a nice climate ('No frost ever comes there'), located 'in the track of all ships passing between the new World of America and the still newer World of Australia'. They had 'unquestionably fine harbours'. One could also not complain about the economic prospects: 'The internal resources of the Islands are considerable, for the soil is very productive. The cotton plant, the sugar cane, the palm, the banana, all grow there'. Morally, the annexation was also a blessing:

Those Islands, though they do not cover the whole area of the kidnapping trade, rise, as it were, in the centre of it, and are a convenient post from which it may be watched and brought within those wholesome and legitimate limits within which it becomes a blessing instead of a curse. ${ }^{10}$

As the British Admiralty had done in 1859, proponents of annexation again pointed out that between Australia and Vancouver Great Britain 'had not an islet or rock on the 7,000 miles that separated those territories'. What was needed was an 'advanced position in the Pacific', an island 'on which to build a coaling station'. Great Britain's 'interests in the Pacific imperatively demanded such a port as the Fiji Islands' would give it, 'not only because of its strategic importance, but in connection with the trade which was likely to be developed'."

What aggravated the situation was that in the previous years the foreign community in Fiji had not fared that well, politically or economically. Politically, in the previous years Fiji had been the scene of rampant internal war and disorder, also affecting the life and property of the foreign settlers, especially those in remote areas, where the violence was greatest. Economically, the cotton market, which had been the motor of Fiji's prosperity, had collapsed in the early 1870 . 'Cotton-planting had not paid as men had expected it would pay. Since 1868 there had been a great fall of prices, and in 1873-4 the planting community in Fiji was to all intents bankrupt' (Forbes 1875: 335). Planters now tried their luck at growing sugar cane. One of the firms that felt the consequences of the economic downturn was that of the Hennings brothers, who owned shops and a number of large plantations on the islands. The Hennings had taken possession of land that had served as collateral security from cotton farmers who had become bankrupt, but

10 Ibid.

11 William M'Arthur in House of Commons 4-8-1874 (hansard.milbanksystems.com/ commons/1874/aug/04/resolution). 
this had not saved them. In 1874 their debts, partly arising from the loans they had previously advanced, ran to $£ 80,000$. Faced with the prospect of financial ruin, the Hennings had to borrow a considerable sum of money from another company, Rathbone, Féez, and Co., with Karl L. Sahl, the German consul in Sydney, as director and co-owner, pledging their landed property as security.

\section{The aftermath of annexation}

On 10 October 1874, in a deed of cession, Cakobau transferred Fiji to Great Britain. He did so, the text said, to secure 'the promotion of civilisation and Christianity and of increasing trade and industry.' ${ }^{12}$ The deed being signed, Hercules George Robert Robinson, Governor of New South Wales and temporary Governor of Fiji, said in a speech that he was sure that British rule would 'tend to develop the great natural capabilities of these beautiful islands, and at the same time, conduce largely to the contentment and happiness of all classes of the population' (Daily Southern Cross 9-11-1874). Thereafter, the flag of Fiji was lowered and that of Great Britain raised. A band played the British national anthem, HMS Pearl fired its salutes and there were three cheers for the Queen. Cakobau, no longer king, was rewarded with a lavish trip to Sydney, where he got measles. Cakobau survived, but many Fijians who contracted the disease after he had returned home in January did not.

It is difficult to reconstruct with hindsight, but it appears that before the British annexation it was access to economic opportunities and not nationality that provided the fault lines in the foreign community. Legge (1958), in his study of these critical years in Fiji, hardly mentions any Germans at all. Forbes $(1875: 118)$ praises the Hennings brothers and the contacts they had with the business community of Australia and New Zealand for contributing to the Anglo-Saxon predisposition of the Fijian settlers' society. Hedemann and a number of other German merchants were against the new government, urging Ma'afu to rebel. Hedemann even boasted about several thousand armed man being on stand-by in Samoa, but this did not set these Germans apart. British nationals also opposed the Cakobau government, and had testified of their readiness to take up arms (Gravelle 1983: 134; Legge 1958: 87, 96).

12 Deed of Cession of Fiji to Great Britain (www.vanuatu.usp.ac.fj/library/Paclzaw/Fiji/ DEED\%2oOF\%2oCession\%20\%2oFIJI.htm, accessed 10-7-2011). 
It was the annexation and its consequences for land ownership for foreigners and the recruitment of labour that would make the difference, not only in Fiji itself, but even more so for the relationship between Great Britain and Germany. The German resentments brought about by the annexation would deeply influence future developments in the South Pacific. The way the new British administration proceeded convinced the Germans, or at least allowed them to use this as a political argument, that a British takeover of islands where Germans had settled in significant numbers could only be to the detriment of German economic interests. The so-called Fiji Crisis was also a reason stated to plead for a German naval presence in the Pacific; and because this in itself would not suffice, given the strength of the British navy, actual colonisation. Or, as a contemporary German historian and apologist of Bismarck's colonial policy, Koschitzky (1887-88 I: 139-40), put it, because of Fiji, Germany became aware that the German trading and estate companies needed better protection 'than that by a friendly, but an otherwise unscrupulous England behaving selfishly towards foreign interest'. In the background of such observations feelings of aggrievement could be discerned: 'Germany did not want to have colonies or monopolies, just good and equal rights for its shipping and its trade', Koschitzky (1887-88 II: 13) writes elsewhere. A much more important person, Admiral Tirpitz, already observed in 1879 that the way Great Britain treated Germany resembled 'Society's response to a social climber' (Berghahn 1993: 49). What he wanted from London, he wrote thirty years later, was 'fair play' (ibid.: 49).

For Great Britain there were lessons as well, not least an even greater reluctance to take on new colonies unless political reasons absolutely necessitated it. After Fiji had become a Crown Colony, London asked the Australian colonies to contribute to the costs of its administration. The response was negative, at best evasive. To Australian politicians Fiji was an imperial question, and thus the responsibility of the home government, not that of the Australian colonies. The Australian reaction resulted in cost-sharing featuring prominently in future discussions with Australia and New Zealand about British expansion in the Western Pacific. Another lesson was that buying land from Islanders by foreigners was a tricky matter. Was there to be any British annexation in the future, land should remain under the control of the British administration. Fiji probably also added to the awareness in London that trouble between British nationals and settlers of other nationalities could have international implications, and that one of the ways to prevent such tricky situations from arising was to extend control over British settlers on the islands, another reason why the office of the High Commissioner was created (Ward 1976: 264, 266). 
Initially, German settlers in Fiji, in the words of Koschitzky (1887-88 I: 138-9), 'trusting in the justice and protection they expected from the British flag', had greeted the annexation 'with delight'. This assessment was not entirely true, but those who had held such expectations were also in for a big disappointment. Within days the new British administration announced that commercial debt claims dating from before June 1871 - when, as the Colonial Office in London maintained, 'there was no attempt at settled government' in Fiji ${ }^{13}$ - could not be taken to the courts it was setting up. In a time of economic downturn this was a highly touchy matter, made all the more sensitive because in the past, in the absence of banks, providing loans had been a private affair. Wealthier merchants and planters, acting on trust, had been the only source of credit (Legge 1958: 77; Forbes 1875: 100). Reclamations dating from before 1871 , for instance for compensation for property damaged during the violence of the previous years, would also not be taken into consideration.

One such case concerned the plundering in 1868 of German property by Fijians, in revenge for a military operation by the crew of the British corvette HMS Challenger, whose help had been called in by the British consul on the islands. Berlin would demand compensation but London refused, pointing out that what had happened was the Germans' own fault. They had tried to acquire land on the cheap in a region that was in the midst of civil war. When, in 1866-67, King Cakobau had subjugated the region, German and British settlers, in spite of warnings by the British consul not to do so, had 'followed up the retreating and beaten enemies of King Cakobau, and with muskets, powder, and lead purchased the land from which they were driven'. When fortunes of war turned against the king and the people he had chased from their land returned, the situation for the settlers, who 'in many cases with their wives had unwisely ventured among a heathen and cannibal people', had become extremely precarious. ${ }^{14}$ As they themselves wrote at the time, the mind of the Islanders was such that they feared for their lives, and were 'subject to all manners of threatening, thefts, violence, and annoyance. ${ }^{15}$

Land claims were an even more vexatious matter. Land, the initial feeling had been, could only increase in value after Great Britain had restored law and order. In the House of Lords Carnarvon even speculated that prices 
might quadruple or even quintuple. ${ }^{16}$ The planters had also expected that an annexation would solve land disputes with the local population in their favour (Forbes 1875: 200). Such expectations did not become a reality. Land claims could not be brought before court. Instead, an investigation was started into the land titles acquired by foreigners before 1871 . For the moment, all land owned or leased by foreigners was considered to have reverted to the Crown. It was only to be returned to them after a Land Commission had decided on the validity of the titles. Titles were to be refused for uncultivated land, for land that in the past had been bought for too low a price, or for which no positive proof of ownership could be produced.

Judging from the remarks of the Earl of Kimberley, politicians in London, aware of the weak basis of many of the land titles in Fiji, had expected fierce protests by settlers who were denied their claims, or who insisted that the new Fijian administration disregarded their interests and sided with the Fijians. ${ }^{17}$ What London politicians were preparing for were remonstrations in Australia, maybe even by the premiers of the Australian colonies. They were not aware that they were on the threshold of an intense diplomatic row. Trouble did not come from Australia, but rather from Berlin where the German government seized upon the opportunity to put pressure on London. Germans asserted that the British land policy in Fiji especially hurt their compatriots who had bought large tracts of land and, 'with much money, effort and time', had turned part of these into cotton and other estates or had got hold of them when debtors failed to pay off their loans (Koschitzky 1887-88 I: 138). Especially the demand for positive proof of purchase and ownership, they argued, was almost impossible to submit for land bought years before 'in the customary form of the country', in a manner that, until the annexation, had been considered lawful. ${ }^{18}$

To make matters worse, the evaluation of the land titles by the Land Commission proceeded slowly, if only because there were not enough surveyors to assist in the task of evaluation and measuring the plots, which even after a title had been acknowledged delayed the issuing of land grants. ${ }^{19} \mathrm{Among}$ the companies that suffered were Godeffroy \& Sohn and F \& W Hennings. Another victim was Rathbone, Féez, and Co. Germans were also to complain

\footnotetext{
16 Carnarvon in House of Lords 17-7-1874 (hansard.millbanksystem.com/lords/1874/jul/17/ the-fiji-islands-cession-to-the-british).

17 Kimberley in House of Lords 17-7-1874 (hansard.millbanksystem.com/lords/1874/jul/17/ the-fiji-islands-cession-to-the-british).

18 Aide-mémoire communicated by Münster 27-6-1882, Münster to Granville 1-7-1882 (PRO FO 534 22).

19 Gordon to Herbert 3-6-1879 (PRO FO 534 22).
} 
that when, in 1880, at the request of its chiefs Rotuma was annexed and became part of Fiji, German ships were no longer allowed to sail directly to the island, causing the ruin of all German firms on the island. This was presented as being all the more vexatious because all foreign economic activity in Rotuma was said to have been in German hands (Koschitzky 1887-88 II: 30).

On 13 October 1874 the new authorities had announced that no new transactions of land would be recognised before an investigation of ownership of land acquired before the annexation had been completed. In the meantime nothing was done, awaiting the arrival of the new Governor, Arthur Hamilton Gordon, and his instructions from London. Gordon did not arrive in Fiji before the end of June 1875, and once he got there he did not make haste. The delay did not exactly help to appease the planters who, Legge (1958: 163) writes, 'largely because of the sudden change in fortunes, were a particularly vehement pressure group'. To make matters worse for the foreign community, in matters regarding land, labour recruitment and labour conditions, Gordon tended to side with the Fijians, giving their welfare much more consideration than the interests of the planters. As much land as possible should remain in Fijian hands, and where foreigners had acquired large tracts of land, he only intended to allow them part of it (Legge 1958: 167, 181). Nevertheless, Fiji needed labourers. To solve this problem, Gordon turned to an equally discomforting new source of recruitment: India, later giving rise to severe ethnic tension (Thomas 2010: 267).

To rescue their investments, and unable to convince the new colonial administration of Fiji of their rights, Germans, via their consul, sought mediation by their government against what they considered to be a blatant violation of justice; hoping that Berlin could persuade London to give them what they thought was theirs, or at least have Great Britain compensate their losses. One of them was Karl Sahl, whose firm had been forced into liquidation, but in the end would survive. Something, Karl Sahl pointed out as late as May 1882 in a letter to Bismarck, had to be done to 'prevent the complete annihilation of German interests' in Fiji. ${ }^{20} \mathrm{His} \mathrm{firm}$, Sahl explained to Bismarck in May 1882, had been granted title for about 10,000 acres, but a land title had been refused for the circa 14,000 acres it acquired from its debtors, while with respect to the roughly 70,000 acres it had leased for ninety-nine years no decision had yet been taken. Sahl's company, it was explained to London, had not been able to cultivate their plantations as no official title deed had been granted for many of their plots and, in 
consequence, had not been able to pay off the loan they had had to arrange to survive. ${ }^{21}$

In London Münster, the German ambassador from 1873 to 1885 , indeed throughout these years, drew the attention of the British government to the problem, pleading that the 'well-founded claims of German subjects may reckon not only upon a higher degree of legal security, but also upon a more favourable consideration' than the new rules set in Fiji provided. ${ }^{22}$ At another instance, asking for the 'kind intervention' of Foreign Secretary Granville, he pointed out that 'it cannot be desired by the English Government that the hopes excited among the Germans at the annexation of the country by England (in regard to the increased security for property which it was expected to bring) should through the action of the Colonial authorities, be destroyed, ${ }^{23}$ The land issue had caused the German settlers 'great commercial troubles and serious losses'. ${ }^{24}$

London, in turn, tried in vain to convince Berlin that the Germans in Fiji were in no way treated differently from other Europeans who had settled there, including the British. Indeed, the latter suffered as much and protested as vehemently as their German colleagues did. Where the German government stressed the legality of some of these individual claims, London posed the opposite. It pointed out that the plots concerned had been acquired in a doubtful manner, that there was something wrong with the papers of ownership, or that the circumstances under which property had been damaged were exceptional. Gordon did not agree with the critics. During one and a half years - between January 1876 and June 1878 - over 800 claims, 'many of which were very difficult, complicated, and open to dispute' had been investigated, and this could by no means be called 'an inconsiderable piece of work', he wrote to London. ${ }^{25}$ German settlers were of a different opinion. Besides disputing the outcome of the investigations they were enraged by the fact that almost 18 months had elapsed between the formal annexation in October 1874 and the start of the investigation of land titles. Land, the planters complained, lay waste for years.

Whatever argument London put forward to the German government it only bore out the opinion that the British policy was unfair and implied a discrimination against German nationals. In Germany the impression

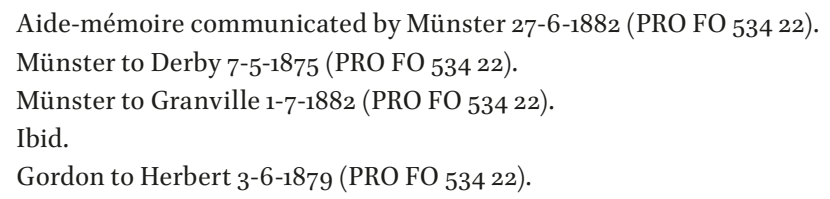


stuck, and was there to remain. In a recent German publication the birth of the German colonial empire is directly linked to the Fiji question and the fact that Great Britain 'without compensation compulsorily acquired more than half of the land and territory of all the estate companies with the exception of the British ones' (Nuhn 2002: 32).

As it did at other moments, British politics worked slowly. The conclusion Germans drew from this was that London 'apparently paid little attention' to the requests of Germany to have the matter solved (Koschitzky 1887-88 I: 138). They also stressed that the work of the Land Commission had 'an extremely long drawn-out course' and was 'highly protracted', resulting in an equally protracted diplomatic correspondence (ibid.: 127, 132). The fact that London seemed to put off offering a solution that satisfied the Germans was to disturb Anglo-German diplomatic relations for a decade. Anxiety on the side of the Germans even grew at the end of 1883 when fuel was given to their suspicion that Fiji was not just an incident but a portent of a consistent British policy. The occasion was the Australasian Intercolonial Convention in Sydney, where from 28 November until 8 December representatives from the British colonies in the Pacific, including Fiji, met. Urging for a British occupation of East New Guinea, the conference spoke out against acquiring landed property before a British takeover. In one of the resolutions the participants stressed that

in the opinion of this convention all purchases or pretended purchases of land made before the establishment of British jurisdiction or dominion in New Guinea or other islands in the Pacific not having recognised government, should not be acknowledged excepting in respect to small areas of land actually occupied for missionary or trading purposes, and further that after the establishment of such jurisdiction or dominion no acquisition of land should be permitted except through the Crown; and that only for like purposes (The Argus 10-12-1883).

This was much to the dismay of German South Sea companies and German planters, who recalled what had happened in Fiji ten years earlier.

The conflict would drag on for ten years. In 1884 Berlin and London agreed that the disputed land claims would be investigated by a joint commission. In 1885, when Germany and Great Britain also hammered out their other differences of opinion with respect to the Western Pacific, the Fiji case was finally solved. 



\section{The Samoa Conflict}

Shortly after the problems over land titles and loans on Fiji had arisen, the German and British Empires fell out over control over Samoa, an island group much smaller than Fiji, and which in those days was about three days' steaming away. In Samoa missionaries had already done their work. Since the 1830 s two Protestant missionary societies had been active on the islands: the London Missionary Society and the Methodist Wesleyan Missionary Society. In the mid-1840s, the French Roman Catholic Marist Brothers had joined the fray, but Protestantism remained the dominant religion among the Samoans. By 1850 almost all Samoans had become Christians (Göbel 2008: 193-4).

On these Navigators' Islands, as Samoa was also called, the Pacific adventure of the Godeffroy Company had taken off and the archipelago had remained the centre of its Pacific trade. Apia, on the Island of Upolu, Samoa's main port, a nucleus of trans-Pacific shipping, served as the firm's entrepôt harbour, where the cargo of smaller vessels sailing the Pacific was loaded into larger freighters bound for Europe and Australia. Initially, the foreign community in Samoa - some 150 persons strong in 1860 and about 400 in 1895 (Gilson 1970: 367, 403) - had been dominated by British and American citizens, but the presence of Godeffroy \& Sohn had changed this (ibid.: 178). Citizens of other states still had their share in the commerce of the island group, but Germans and their mercantile interests had become predominant among the tiny but articulate foreign community. Second came the British and third the Americans, but for most of the time it was political and strategic considerations that involved the United States in the Samoan Question. In 1887 the American Secretary of State, Thomas F. Bayard, called the American interests in Samoa 'unimportant'.' By the end of the century, when international tension over Samoa climaxed, the British would outnumber the Americans 'ten to one' and British trade with Samoa was 'vastly greater' than that of the United States, an American government official wrote in $1899 .{ }^{2}$ And yet it was the Americans, and not the British, who would become major players in the domestic and international complications that were to arise regarding Samoa.

The German success was due to the already mentioned Theodore Weber, local manager of Godeffroy \& Sohn, and during his first years in Samoa also

1 Memorandum by W.A Cockerell 1-4-1887 (PRO FO 534 35).

2 Chambers in The New York Times 16-2-1899. 
representative of the German government. His position nicely mirrored the change in political structure in Germany. Appointed consul of Hamburg in 1865 , he became consul of the Norddeutscher Bund in 1868 , and finally German Imperial consul in 1872. According to some of his contemporaries, Weber was one of the most remarkable personalities of his era. Stevenson (1892: 34), who lived in Samoa from 1890 until his death in 1894, describes him as being 'of an artful and commanding character; in the smallest thing or the greatest, without fear or scruple'. Unscrupulous was an image that stuck. In the American movie released in 1954, His Majesty O'Keefe (after the book published two years earlier by Laurence Klingman and Gerald Green), Weber figures among what a plot summary on Wikipedia describes as the 'evil German empire-builders' whom the hero (Burt Lancaster) encounters. ${ }^{3}$

Weber was also successful. As early as 1869 a French sea captain, Théophile Aube, observed that all the imposing buildings in Apia carried the flag of the Norddeutscher Bund, and that the local warehouses and estates were mostly Weber's (Brookes 1941: 291). Samoans were aware of this. One local song relates 'how all things, land and food and property, passed progressively, as by a law of nature, into the hands of Misi Ueba,' or Mr Weber (Stevenson 1892: 35).

Since the late 1860 s, Weber, alert to the prospects of the cultivation of coconut palms and cotton, had started buying up land from Samoans, first modestly and then on a large scale. Before that time, Samoans had been reluctant to sell their land (and their labour) but a long drought had upset their economy (Gilson 1970: 256-8, 276). Due to Weber's actions, Godeffroy \& Sohn would own vast tracts of land in Samoa, amassing claims of, in total, about 150,000 acres (ibid.: 340). Briefly, the Samoans' eagerness to sell land, also because internal warfare made them desperate for money to buy arms, made the American Central Polynesian Land and Commercial Company (CPLCC), which had begun to speculate in land in Samoa in the early 1870 s, a major competitor. Within years it acquired titles of 300,000 acres of land. The company had started modestly but had expanded its activities when the sale of land reached, what Gilson (1970: 281) calls, a 'suicidal rate'. In particular, agents of the CPLCC tried to make use of this new situation to acquire land, but the crooked way in which they proceeded saw to it that, already by 1873 , the company had run into serious problems, soon to go bankrupt (ibid.: 295-6). Weber and the other European settlers acted with more reserve than the CPLCC in acquiring land; though some of their deals also could not meet strict legal standards (ibid.: 282, 285). The matter was 
still complicated by the fact that many Samoans who sold land in the early 1870s had no right to do so. Gilson (1970: 288) estimates that 'perhaps a few thousand ... of some two hundred thousand acres' were sold in a correct way.

CPLCC's land purchases far outshone those of Weber, but to the Samoans they were less vexatious. The company was primarily engaged in land speculation and did not put the land to use; neither did New Zealanders and other British nationals who were also involved in such activities. Weber did. He turned the land he bought for his company into plantations, growing mainly coconut palms, and initially also cotton and coffee, actually evicting the Samoans from the land (ibid.: 377).

The dealings of these foreigners, among them some from Fiji, who had 'fled' the strict Gordon regime, their competition over land and over control of the administration of the island group and above all their intrigues, would, coupled with the civil wars among the Samoans themselves, for years put Samoa high on the agenda of the governments of Germany, Great Britain and the United States. For a couple of years the tiny island group would even be a focal point of international tension. In that period, 'Samoa played a part in world affairs quite out of proportion to its size and intrinsic importance', a historian put it in 1934 (Masterman 1934:15). Contemporaries held a different view, awed as they were by the dreams of the islands' economic prospects. Perhaps, there are some who are of the opinion that 'the game is not worth a candle', it was written in a journal in the Netherlands East Indies in 1886, but one should not forget that the Samoa group is 'one of the richest and most fertile in the Pacific, and after the opening of the Panama canal is located in the centre of one of the biggest trade routes of the world' (Australië's 1886: 56). Germany, accenting its preponderance in the island group, wanted to have a major say in Samoan affairs; London, in order not to disturb relations with New Zealand and Australia, could hardly assent to such a course of action. The annexation by Great Britain of Fiji brought into force an element of security as well, the prospect of an uncontested enemy naval base near to a British possession.

Samoa's domestic politics was dominated by rival lineages who contested each other's right to rule, of which the chiefs wore the title of Malietoa (Chief or Great Warrior), Tupua Tamasese and Mata'afa. Weber had purchased part of the land owned by Godeffroy \& Sohn from Tupua Tamasese Titimaea, but it was a disputed deal. In 1872 Malietoa Laupepa made it clear to Weber that only he, and not Tupua Tamasese Titimaea, had the authority to sell land to foreigners. Weber threatened Laupepa with the might of German guns. He succeeded in persuading the captain of the first German warship to call at Apia, the Nymphe, Louis von Blanc, to intervene on his behalf 
and force the Malietoa to recognise the Titimaea land deals; but Blanc had second thoughts and shrank back from the military force Laupepa could muster (Nuhn 2002: 68-9). Over time the situation would only deteriorate. Samoa, in the words of Stevenson (1892: 8), would become a land 'full of war and rumours of war'.

\section{An American takes control}

Samoa in the 1870 s was rife with internal, often violent, strife. The foreign community, their consuls leading the way, interfered, trying to protect - physically as well as legally - their landed property and expand it. The aim was to secure land with a clear title, at least with a title recognised by the local ally they supported, and in general an advancement of their own commercial interests and those of their compatriots. It was not only the British and Germans - and to a lesser extent the French - who acted in this way. During the administration of President Ulysses S. Grant, himself an 'expansionist', Americans had shown the way. In 1871 William H. Webb, a New York shipbuilder, dreamt of a shipping line between San Francisco and Australia served by 'magnificent side-wheel steamships' (Gilson 1970: 277). San Francisco was the port to be. The American transcontinental railway had just been completed and hopes were high. Such a rail link, Secretary of State Seward had prophesied, would make the city 'the Constantinople of the American Empire' (Immerman 2010: 115). Webb insisted that the railway could offer a faster connection between Great Britain and New Zealand and East Australia than transporting passengers and goods all the way by ship. Using this argument, he sought financial support not only from his own government but also from those of Great Britain, Australia, New Zealand and even Hawaii to realise his plans (Gilson 1970: 276).

In search of an intermediate harbour between San Francisco and Australia, Webb sent Captain E. Wakeman to Samoa. Wakeman's eye fell on the village of Pago Pago, on the island of Tutuila, which he called 'the most perfectly land-locked harbour that exists in the Pacific', and bought land there for Webb's company (Brookes 1941: 318). In his report, which was published to whet the appetite of investors and to elicit a favourable response in Washington, Wakeman described Samoa as one of 'the richest tropical territories in the world' (Gilson 1970: 278). Webb, in fact, had a double aim. He was also involved in the CPLCC and its scheme to buy up land, while the CPLCC, in turn, had incorporated Webb's plan for a coaling 
station in Samoa, and envisaged a 'central Polynesian depôt' serving as a hub in the trade in the South Pacific (Masterman 1934: 114).

At Webb's request an American corvette, USS Narragansett, commanded by Commodore Richard W. Meade, was ordered to inspect Pago Pago the following year. Reflecting the suspicion of Weber's intentions, among Meade's brief was to conclude a treaty with the local ruler 'to frustrate foreign influence which is at present very active in this matter, seeking to secure the harbor' (Dulles 1938: 104; Gilson 1970: 279). On her way to Samoa, the Narragansett called in at Honolulu, where Meade met the American envoy in Hawaii, Henry Pierce. Pierce put it to him that bringing Samoa within the American sphere of influence was essential for 'the future domination of the U. States in the N. \& S. Pacific Oceans' and that Washington would not object to a treaty with the local leaders to accomplish this (Brookes 1941: 321). In February 1872, Meade indeed obtained Pago Pago as a coaling station for the Americans. During his stay on Tutuila he also succeeded in getting a number of its chiefs cooperate in a new confederation, in return for an offer of protection. He presented them with a flag, 'a hastily-designed parody of the Stars and Stripes' (Gilson 1970: 279). Thus, having secured Pago Pago as a coaling station for the United States, Meade sailed home. A few weeks later the CPLCC, which clearly had a vested interest in American backing for maintaining law and order in view of the massive claims to land it had, succeeded in having a number of chiefs in Western Samoa sign a petition for annexation by the United States. In Washington these steps did not get a follow-up. Though the American navy had expressed its support for Webb's proposal and for the Pago Pago treaty, Congress refused to discuss it (Brookes 1941:323). It made Meade's treaty, which had the support of President Grant, void, but for the Godeffroy Company the episode - and the prospect of an American annexation - was reason enough to ask Berlin to act (Staley 1935: 1-2). Sensitive as Australians and New Zealanders were about the prospect of others taking possession of islands in the South Pacific, there also was some uproar in Australasia. In New Zealand the treaty was presented as a sign of Washington's imperialist intentions and as a danger to New Zealand's security (Ward 1876: 203, Sewall 1900: 14).

After Congress had spoken out against any action in Samoa Washington did not completely discard its plans. The visit of the Narragansett was followed by the sending of a special commissioner, an 'intelligent special agent', as he was called, to Samoa to investigate the commercial prospects of the islands and the merits of Pago Pago as a coaling station and harbour (Stathis 1982: 88). In the instructions drawn up by Secretary of State Hamilton Fish it was called 'not unlikely that perhaps in the not distant future the interests 
Figure 5 Albert B. Steinberger

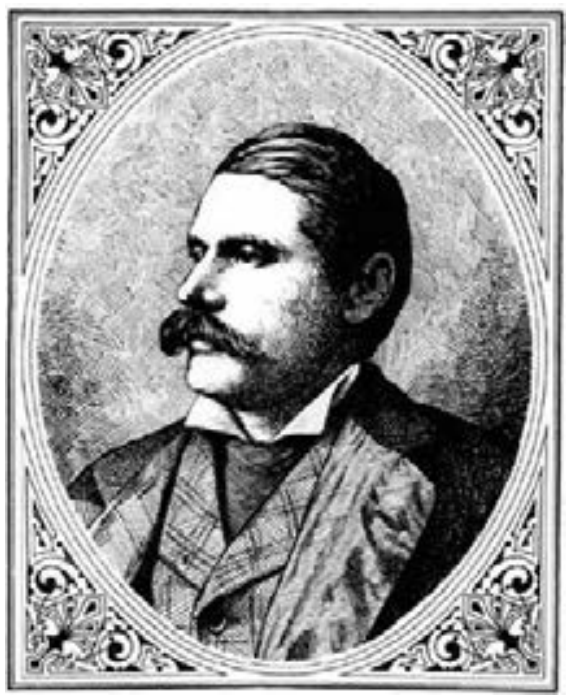

Source: Daily Graphic, 4-8-1875 (en.wikipedia.org/wiki/File:Albert_Barnes_Steinberger.jpg)

of the United States may require not only a naval station in the Samoan group, but a harbor where steam and other vessels may freely and securely frequent' (Dulles 1938: 105).

The special commissioner in question was Colonel Albert B. Steinberger, a personal friend of Webb and Grant. Briefly, Steinberger was to play a crucial role in Samoa's history. He was 'a man of medium height, and with nothing to distinguish him from any ordinary well-dressed gentleman to be met with in the street', an Australian journalist described him later, rather disappointed that a person who would dominate Samoan politics for some two years did not have a more commanding posture (The Age 3-7-1876).

When Steinberger was sent to the islands it was well known in the United States how shady the Samoa land deals were and apart from assessing Pago Pago, Steinberger was tasked by Fish to convince the Samoans not to sell any more land to foreigners, and to make clear that many of the sales concluded could not stand legal scrutiny (Brookes 1941: 324-5; Gilson 1970: 295). Steinberger arrived in Samoa on 7 August 1873. Just a few months earlier, in May, years of civil war, occasioned by a conflict between Laupepa and Talavou over the Malietoa title, had come to an end and he immediately took an active part in the discussions surrounding the drafting of a constitution, which was proclaimed on 21 August (Stathis 1982: 90). Two central political councils were established: one, the Ta'imua, made up of Samoa's 
most important chiefs; and the other, the Faipule, consisting of representatives of the Samoan districts, for which a general election was to be held every five years. Steinberger stayed two months in Samoa, campaigning for an American annexation and, stressing the defects of the land deals of the CPLCC, by now already in trouble, holding out special tribunals to investigate the land deals. These were not to convene immediately, but only after a year, and they were not to alienate other landowners (Gilson 1970: 300-2). In October, he sailed back to the United States to report to his government. He took with him a request from Samoan chiefs to turn their island group into an American protectorate. However, the two main Samoan contestants for power of that moment, Malietoa Laupepa and Mata'afa Iosefo (also spelled Iosefa and Josefo) had not been involved in the drafting of the request; the first, as Stevenson $(1892: 48,157)$ notes, was 'educated for the ministry', the second was 'a devout Catholic'. Laupepa, a former student of the seminary that the London Missionary Society had set up in 1844, the Malua Theological College, could count on the support of its missionaries, though their sympathies fluctuated (Gilson 1970: 261-7).

At this stage, it seemed that most of the German, British and other foreign settlers and missionaries could live with an American takeover, longing as they were for peace and orderly government. Weber probably would have objected, but he was on leave. Great Britain, reluctant to provoke the United States, was prepared to let the Americans have Samoa. London took the position that Great Britain could hardly deny others, having done precisely the same elsewhere. Colonial Secretary Kimberley considered this no more than fair: 'Considering the number of points in the world we have annexed, we cannot object to other maritime Powers seeking to obtain some stations of their own' (Brookes 1941: 330). As could be expected, London's attitude was much to the dismay of the government of New Zealand. As elsewhere in the South Pacific, the home government had to take public opinion in its Australasian colonies into account, but in this case it was New Zealanders in particular, supported by the Australians, who urged the home government to assume control over Samoa; or were actually scheming to reach this aim. Samoa should become a British protectorate. If necessary, New Zealand made it known, it would take the lead in realising British rule, not only in Samoa but also in Fiji. However, history would show that it could not and would not do this (Brookes 1941: 328-32).

No further steps were taken in Washington. Fish had his doubts that he could count on enough support in Congress and also did not see how the American people could be convinced that an annexation of Samoa was in the interest of America's safety and prosperity (Brookes 1941: 337). The Pago 
Pago coaling station also did not materialise for the time being. Webb's own ambitious plans had already come to nought a few months earlier, in March 1873, when he failed to get the financial support for the shipping line he had intended to establish (Gilson 1970: 295-6).

In August 1874 Grant wrote to Fish that Steinberger should once again be sent to Samoa with 'such powers as may be consistent with law and the best interest of the country' (Stathis 1982: 92). In April 1875 Steinberger returned to Samoa for a second visit, this time travelling aboard an American warship. He claimed that he represented the United States government, though again he was sent out only as a 'special agent of the United States' (Stathis 1982: 93). Steinberger may have had the tacit support of Grant and the more cautious Fish, but, as the latter was well aware, Congress would not agree to anything that resembled an American protectorate of Samoa. Hence Fish impressed upon Steinberger the need to limit his activities 'to observing and reporting upon Samoan affairs' (Stathis 1982: 93). Steinberger also had to convey to the Samoan leaders a message of thanks from President Grant, which, as Gilson (1970:307) points out, was so 'flowery and imprecise' that everything could be read into it, including an American annexation. Steinberger himself had bigger plans - to be in command of Samoan politics. The gifts he brought along on his second trip were indicative of what he intended to accomplish. They included three American flags, guns and ammunition, and one hundred sailors' uniforms to kit out a militia to be drilled by another American, Major J.H. Latrobe (Dulles 1938: 106; Gilson 1970: 313).

Once back in Samoa, Steinberger, a charismatic person and skilful negotiator, set out to restructure Samoan politics and to transform Samoa into constitutional monarchy along Western lines. To accomplish this, he first reconciled the Malietoa and Tupua Tamasese lineages. Alternatively, the heads of the two would serve as king for four years. The first to assume royal status on 22 May 1875 was Laupepa. Four days earlier a new Constitution had been promulgated. Its preamble, a 'declaration of rights', spoke of 'man's inalienable right to life, liberty and the pursuit of happiness' (Gilson 1970: 318). Steinberger himself was asked by Laupepa to become his Prime Minister. Duly, Steinberger informed Fish, asking him to have Congress allow him to hold such a position, and, having received no reply from Washington, he resigned as American commissioner (Stathis 1982: 95-6). Steinberger had wide support. Gilson (1970: 318), writing about a welcome ceremony three weeks after he had arrived, concluded that never 'had the political leadership or guidance of a European been so enthusiastically, so generally or so blindly accepted in Samoa as on this occasion'. 
Peace was short-lived. Steinberger quickly alienated the settlers; opposed as they were to his suggestion to submit their land claims to arbitrage. A number of them, and rightfully so, also suspected Steinberger of special dealings with Godeffroy \& Sohn, agreed upon during a visit he had paid to Hamburg ostensibly made to get the company's support for submitting its land claims to arbitrage (Stathis 1982: 93; Gilson 1970: 308). ${ }^{4}$ In return for financial compensation - and a schooner, the Peerless - Steinberger promised the firm preferential treatment by the Samoan government. The titles of land Godeffroy \& Sohn had bought would be authorised, while, among other prerogatives, Godeffroy \& Sohn would get the first right to buy the products that Samoans had to pay as taxes and fines. Equally important was that Steinberger pledged to allow the recruitment of labourers of other island groups; a measure that put British planters, who had to take into account London's policy in this regard (and who knew what had happened in Fiji), in a disadvantaged position (Staley 1935: 4; Brookes 1941: 337; Gilson 1970: 309, 321).

Before the year was over, the American consul, S.S. Foster, a former agent of the CPLCC and intent on rescuing as much as he could from its operations, and his British colleague, S.F. Williams with the backup of Captain R.N. Stevens, captain of the H.M.S Barracouta, decided to act; in the process restoring the extraterritorial rights of the Europeans and Americans they had lost because of Steinberger. They were also motivated by the fact that Steinberger, honouring his agreement with Godeffroy, tended only to discuss policy with Weber, the German consul (Gilson 1970:323-4). The plotters, The New York Times (7-5-1876) wrote, got the support of 'beachcombers, grog-shop keepers, and other lawless foreigners who had hitherto been under no restraint'. In fact, Steinberger had lost the support of many in the foreign community, including the missionaries (Gilson 1970:328). By the end of December 1875 a number of settlers - Britons, Germans, Americans, and people of other nationalities - issued a statement and accused Steinberger of 'acting as an absolute dictator of these islands'. He was also said to have instigated the Islanders against the settlers and threatened a number of the latter with 'summary vengeance' once the Barracouta left (New York Times 15-6-1876).

To get rid of Steinberger, Laupepa was invited on board the Barracouta in February 1876. There, 'harangued, cajoled and intimidated' as he was by residents of the foreign community, who feared that the new government

4 Later Steinberger would claim that his understanding with the Godeffroy company had been abrogated a few days after his arrival in Samoa (Stathis 1982: 101-2). 
would harm their business interests, he ordered the arrest and deportation of his Prime Minister, Steinberger (Gilson 1970: 330). In Steinberger's own version of the event, on board the Barracouta, Laupepa 'became intoxicated and was got to sign the paper deposing [him]' (New York Times 15-6-1876). Subsequently, Steinberger, who continued to claim that he was the American commissioner for Samoa, was arrested by the American consul and, on Foster's order, deported to Levuka on Fiji on board the Barracouta in March. In Levula, after Gordon had castigated Stevens for his actions Steinberger was released. Washington and London were not pleased. The affair cost Foster, Williams and Stevens their position.

It also meant the end of Laupepa's kingship. Enraged by the deportation of Steinberger and the unhappy role Laupepa had played in it, the Ta'imua and Faipule dethroned him but did not appoint a new king. The prime ministership was also left vacant. In the civil war that followed between the Ta'imua and Faipule and Laupepa, who set up a government of his own, the former could count on American support and sympathy and also on that of the Roman Catholic missionaries. The Germans and Britons, including a number of missionaries from the London Missionary Society, tended to side with the deposed king. British support for Laupepa became evident as early as March when a small British force from the Barracouta, commanded by Stevens, set out to the town of Mulinu'u, near Apia, the seat of the Samoan government, in an effort to reinstate him. The expedition was ill-fated. The marines retreated after clashing with a newly established militia and other Samoans. Three marines were killed and eight seriously injured.

\section{Weber goes on the offensive}

With a divided foreign community, meddling consuls who did not shun gunboat diplomacy and actually spurred each other on, and an intense rivalry amongst the Samoan elite, alliances were far from balanced. These could easily change when settlers and Samoans thought that a re-alignment served their aims better. For the Germans in Samoa the civil strife, and especially the prospect that the islands might become an American or British protectorate, held several dangers. Weber and other Germans virtually monopolised the plantation sector, but the way in which they managed the estates and the manner in which they had acquired their lands also made them very unpopular among the foreign communities (Masterman 1934: 74). Internal unrest, besides forming a direct threat to German life and property, could herald a repetition of the problems German planters 
and traders had experienced in Fiji. A foreign protectorate, which Samoans never offered to Germany, might imply an investigation into land titles held by Germans, or could force British rules concerning the recruitment and treatment of labour upon them.

Initially, the Germans in Samoa had only the economic power of Godeffroy \& Sohn to guard their interests. At that time, they lacked the threat of warships calling at Samoa that the Americans and British on the islands could deploy. When, as of 1874 , the German consul was also able to count on naval support, the Germans became an equal partner in the tripartite strife for control over the Samoan islands. Almost immediately, they demonstrated their new might by shelling a couple of villages into submission in an effort to enforce recognition of the land claims held by the Godeffroy Company (Gilson 1970: 308).

Weber, who, as a British official phrased it, was to acquire a position of 'unequalled influence' on the islands, was not averse to threats of violence. ${ }^{5}$ In 1876 and 1877 he asked Berlin a number of times to dispatch a warship to lend additional force to his effort to have the Samoans sign treaties in which they agreed to pay compensation for the damage done to the property of his company and promised to stay clear of the land it owned. Twice the German corvette Hertha, commanded by Eduard von Knorr, paid a brief visit to Apia, but the Samoans resisted German pressure. Fearing that Germany intended to take control over the islands, the Ta'imua and Faipule turned to Gordon, who besides being Governor of Fiji had just been appointed as the High Commissioner for the Western Pacific, and offered Great Britain a protectorate over the islands in April 1877. They were encouraged to do so by American residents, obviously blind to Gordon's policy in Fiji, who had a stake in the CPLCC land titles and feared that the claims would become null and void might Germany annex Samoa and should Godeffroy's interests prevail (Gilson 1970: 347).

After the British had declined the offer-Gordon was only interested in the incorporation of Samoa into Fiji, not in a protectorate, also aiming at an annexation of Tonga, while the government feared a countermove by France in the New Hebrides (Masterman 1934: 167; Gilson 1970: 346; Thomas 2010: 269) - the Ta'imua and Faipule set their hopes on the new American consul, Gilderoy W. Griffin, a person not averse to such an option and who, within weeks of his appointment in October 1876, had already travelled back to the United States to plead in Washington in favour of American support. 
By that time Weber had already accomplished what he wanted. In July 1877, in his capacity as German consul, he entered into treaties with the two factions in the Samoan civil war: Laupepa and the Ta'imua and Faipule. Weber secured a promise from both to regard the German settlements as neutral territory. German property, houses, estates and land were to be respected and any damage inflicted by their followers had to be compensated. They also vowed not to give other foreigners special prerogatives denied to Germans (Koschitzky 1887-88 II: 7-10). In persuading the Samoans to comply to the German demands, this time Weber could count on the backing of the German corvette Augusta, which had arrived in March 1877, and her captain Ludwig Hassenpflug (Nuhn 2002: 70-1).

Not much later - and Gordon's reaction to their request of accepting a British protectorate had added to this belief - the Samoans began to suspect that Great Britain also had the intention of incorporating their islands. To blame was the British consul. After the futile expedition to reinstate Laupepa as king a monetary penalty had been imposed to compensate for the slaying of the British marines of the Barracouta. When payment was not forthcoming in September 1877 the English consul demanded from the Ta'imua and Faipule that any land in Samoa that had not yet been sold to a third party should be bequeathed to the British crown to serve as a security for the fine. In an effort to thwart a possible British annexation of the islands, and facilitated by Griffin, a deputation set off for Washington to ask for protection by the United States.

In Europe, the German government was clearly annoyed by the approaches made by the Islanders to offer Great Britain and the United States a protectorate over the islands and the role their respective consuls had played in this. Berlin protested in London and Washington. In German eyes, the requests to become a protectorate had been brought about by intrigues of the American and British consular agents. Indeed, they were convinced that the British consular agents would have made Samoans believe that Germany was intent on occupying the islands (Koschitzky 1887-88 II: 8). Both London and Washington disavowed the steps of their consular representatives in Samoa. The American government contented itself with a Treaty of Friendship and Commerce concluded with the Samoan delegation, which had travelled to Washington with the help of Griffin. Signed in January 1878 , the treaty, amongst other things, reiterated the right of the United States to build a naval station in Pago Pago and waved the levying of custom duties in Samoa to Americans. This time Congress ratified the treaty. The treaty made for a sudden but short-lived renewal of American interests in Pago Pago. The warship the Adams, on which the delegation 
sailed home, called in at Pago Pago in July. The following year a second warship, the Lackawanna, was sent to Samoa. She had, in the words of President Rutherford B. Hayes to 'make surveys and take possession of the privileges ceded to the United States. ${ }^{6}$ The land on which the naval station was to be built was purchased. In order to save time and trouble the American government decided to pay all the Samoans who contested ownership title of the plots (New York Herald 5-1-1892). The first real arrangements would only be made in 1892, after rumours had begun to circulate that the British navy wanted to establish their own coaling station at Pago Pago.

Shortly after the Americans had concluded their treaty the British tried to do the same. In February 1878, a British warship with Gordon on board arrived in Samoa to conclude a treaty which, amongst other things, would have protected land purchased by British nationals in a 'normal and regular' way (Gilson 1970: 352). Heartened by Griffin, the Ta'imua and Faipule refused to comply. Gordon had to content himself with the seizure of a Ta'imua and Faipule ship, as payment of the penalty imposed after the ill-fated Barracouta expedition of March 1876. In response, Griffin, who with his consulate had moved to Mulinu'u, raised the American flag on the government flagpole in town. It was a dramatic gesture that could be interpreted as American support for the Ta'imua and Faipule. Some ten years later, Koschitzky (1887-88 II: 6-8) wrote that once again the Samoans had turned to the American consul and with his consent had raised the American flag. ${ }^{7}$ Not much later Griffin would be transferred to Fiji. Washington could not agree with him championing the cause of a protectorate.

When the news of the American treaty reached Samoa, Weber accused the Ta'imua and Faipule government of having broken its promise to the Germans that it would not grant any other foreign nation special privileges. He informed Berlin and again asked for a warship to be sent to Samoa. The German government decided that the time had come to show that Germany was at least as apt in gunboat diplomacy as the other Western powers and ordered the Ariadne to Samoa. There, to make matters worse, a special envoy of the American government, Gustavus Goward, after his arrival in Samoa in July 1878 to see to the execution of the Treaty of Friendship and Commerce, had upset the German community by suggesting to the Samoans that the treaty they had concluded the previous year with Weber was void,

6 Hayes' Third Annual Message 1-12-1879 (presidency.ucsb.edu/ws/index.php?pid=29520).

7 In May 1877, when Griffin was in the United States, the American vice-consul J.G. Colmesnil, disquieted by the appearance of the German corvette Augusta, had made a similar gesture to warn off the Germans from seizing control over Samoa (Masterman 1934: 141). 
and that they had every right to grant the United States special prerogatives. Still, in January 1879 the corvette Ariadne, with Weber on board, steamed to the small ports of Saluafata and Falealili on the east coast of Upolu, and 'with the customary ceremony in the presence of the gathered chiefs' occupied them in the name of the German Empire (Koschitzky 1887-88 II: 10). The reason to do so, it was explained in a statement, was the 'doubt as to the evil schemes and desires on the part of the chiefs of the Taimua and Faipule to transfer the whole of Samoa to some great Government'. Denying that Berlin had any intention of annexing the islands, it was stated that 'it is due to us that we should obtain some security for German rights' (Masterman 1934: 144).

After the Ta'imua and Faipule, bowing to the pressure of two German warships moored at Apia (and a third on its way), had once again acknowledged the stipulations of the 1877 treaty Saluafata and Falealili were returned to the Samoans in January of the following year. This new treaty of January 1879 implied some additional advantages. It gave Germany the right to establish a naval and coaling station in the port of Saluafata, which Germans boasted was the only place in the archipelago deserving the name of a harbour (Nuhn 2002: 73). Further, it acknowledged the titles and even 'peaceful possession' of land that German citizens had 'bought from Samoans in a regular manner and in accordance with the custom at the time'. ${ }^{8}$ Also reflecting the dangers of having to live on islands where war was the rule rather than the exception, it was further agreed that the Germans in Samoa would 'be exempt from occupation of their houses, lands, and plantations by war parties.' ${ }^{9}$ Satisfied by this, German soldiers in the two ports 'saluted the flag of the Ta'imua as the recognised government of the land' (Koschitzky 1887-88 II: 11). Weber, as the Melbourne newspaper The Argus (18-3-1879) described it, deploying the 'moral influence of two gun boats', also tried to get the deposed king Laupepa to sign a similar treaty in return for a promise to restore him to the throne, but failed.

The internal situation by now had deteriorated to such an extent that, in the words of Gordon, there was 'no Government whatever' in Samoa (Ward 1976: 268). Even Steinberger tried to intervene from a distance. He persuaded his friend General J.J. Bartlett to travel to Samoa, to take on the premiership. Bartlett arrived in August 1878, but the Ta'imua and Faipule were reluctant to comply, giving him the title of Teacher of Laws instead (Gilson 1970: $355^{-6}$ ). The Ta'imua and Faipule, discredited by their dealings 
with the United States and Germany, lost much of their popular support and had to give way to the Malietoa faction. In May 1879 Talavou, a Roman Catholic and, since 1860, contending with Laupepa for the Malietoa title, became the new king of Samoa, with Talavou's nephew Laupepa, as deputy king. The Ta'imua and Faipule were disbanded. Talavou, as a clerk of the British consulate would write maliciously about him some twenty years later, 'like all natives, loved the man who could keep him supplied with tinned salmon and sardines. ${ }^{10}$ For the Germans the new situation looked all the more promising as Talavou recognised the treaty Weber had concluded with the Ta'imua and Faipule. This happened after the German navy had come to his rescue in July 1879 , when, on board a German schooner rented by Talavou, he had been taken prisoner by his old enemies trying to regain their lost position (Koschitzky 1887-88 II: 15).

Now Great Britain again rushed in to make a treaty. It was concluded in August 1879 by Gordon and also secured Great Britain a naval and coaling station in the island group (and the assurance that houses and lands of British settlers would not be occupied by war parties). The treaty between the Samoan government and Great Britain completed diplomatic manoeuvring, with Samoa now having a 'Treaty of friendship' with the three major powers present on the islands; all three containing phrases such as 'peace and perpetual friendship' and 'perpetual peace and friendship'." Each was assigned the status of 'most favoured nation'. The treaties meant a victory for foreign economic interest. 'Full liberty for the free pursuit of commerce, trade and agriculture' was guaranteed, and land titles were recognised when they had been obtained in 'a customary and regular manner'. ${ }^{12}$

The new king, Talavou, became a party in the negotiations with the foreign consuls; negotiations in which Weber took the lead. It was a good moment for the three powers to join forces to end civil strife, 'this state of affairs so exceptional and so injurious to the interests of foreign commerce and industry', as their representatives called it in a joint statement (The Argus 4-11-1879). In September 1879 Great Britain, the United States and Germany finally decided to act in concert and jointly support the Malietoa faction. The three foreign consuls agreed to recognise Talavou as the rightful king and to lend him the necessary support in the struggle against

\footnotetext{
10 Johnston to acting British Consul 20-3-1900 (PRO FO 534 90).

11 Treaty of Friendship between Germany and Samoa 24-1-1879, Art. 1, Treaty of Friendship and Commerce between the United States and the Samoan Islands 17-1-1878, Art. 1 (Masterman 1934: 214, 216).

12 Treaty of Friendship between Great Britain and the King and Government (Malo) of Samoa 28-8-1879, Art. 3 (Masterman 1934: 218).
} 
his remaining enemies. The task to enforce this was delegated to the new German consul, Naval Captain O. von Zembsch, who had been appointed in November, and to the commander of the German corvette Bismarck, Captain August Deinhard. It was also on board the Bismarck that peace was finally concluded in December 1879, confirming Talavou's status as the ruler of Samoa and that of Laupepa as his deputy. Mata'afa Iosefo was also given a place in the new constellation. He became chairman of a newly established council, without whose agreement no policy could be executed (Gilson 1970: 364). The Ta'imua and Faipule were reconstituted. In return, Talavou had to accept that much of the executive authority of his government was in foreign hands. Plans were worked out according to which the Minister of Justice would be an American, the German community was to provide the Minister of Finance, while the position of Minister of Public Works was to be filled by a Briton. All three were to be paid by the Samoan government but selected by their respective consul.

The system, worked out by the these consuls, was soon disbanded again as neither Washington nor London could assent to the deep involvement in Samoa's administration that their consuls had come up with (Koschitzky 1887-88 II: 17-8; Gilson 1970: 365-6). Nevertheless, a few months earlier, in September, the three foreign communities had gained control over the city of Apia, the major foreign settlement in Samoa. In times of civil war it had to be recognised as neutral territory (a vow that in practice would not amount to much). Apia and its hinterland became a foreign settlement under joint British, American and German administration. The three consuls were to form a municipal board, whose tasks included appointing a magistrate. As a token gesture, to show that the agreement would 'in no way prejudice the territorial integrity of Samoa', it was magnanimously promised that in Apia the Samoan flag would be hoisted at such place of meeting of the Municipal Board as may be permanently adopted.' ${ }^{13}$

13 Convention between Great Britain (Germany, the United States), and the King and Government of Samoa, for the government of the town and district of Apia, 2-9-1879, Art. 8 (Masterman 1934: 221). 


\section{Germany Enters the Colonial Race}

In November 1882, a Bremen merchant and tobacco trader, F.A.E. Lüderitz, informed the German Foreign Office of his intention to purchase land and establish a trading post in South West Africa. By selecting a spot just outside British territory he could circumvent British import duties on his merchandise, which he stressed would all be of German make. Eventually, he might even exploit the copper and silver fields in the interior. Lüderitz foresaw one problem: if he carried through his plans the British would not hesitate - as they had done at the Gold Coast - to take possession of any land he bought. In this way, a potentially substantial market for German industry would be lost. To prevent this from happening, he asked for Schutz, protection, of the German flag. ${ }^{1}$ In April of the following year, Lüderitz' agent, Heinrich Vogelsang, landed at Angra Pequena, now Lüderitz Bay in Namibia, north of the Oranje River, the frontier of the British Cape Colony. From there, he travelled into the interior to buy land from the local chief, 'King Josef Frederick'. In April 1884 Lüderitz got what he wanted. South West Africa, by then larger than Germany itself, was placed under the protection of His Majesty Emperor Wilhelm I (Graichen and Gründer 2005: 74).

Initially, the new German Empire had had no colonial aspirations. Like the British government being inundated with requests for the annexation of Pacific islands, so the 1860 s and 1870 s saw a plethora of German citizens pleading for overseas possessions. All were ignored. Such dreams of overseas German settlements were not yet shared by the government of Prussia and the German Empire. To Bismarck, shaping the new Empire and solving domestic problems came first (Baranowski 2011: 14). Invariably, he turned down the pleas from German businessmen, among them also owners of German firms in Australia, and consuls abroad asking for a German annexation of spots in the Pacific and elsewhere. Had he acceded to such suggestions, Germany would have become the master of parts of Fiji, Samoa and New Guinea, taken possession of Hokkaido in Japan, driven the defeated French out of Cochin China (Bismarck preferred Alsace-Lorraine instead as war booty (Knopp 2011: 19)) and would have acquired Taiwan (Formosa) in China. Germany would also have established itself in Borneo, Sumatra, Timor and the Philippines, and would have administered colonies in Africa 
Figure 6 Bismarck 1880

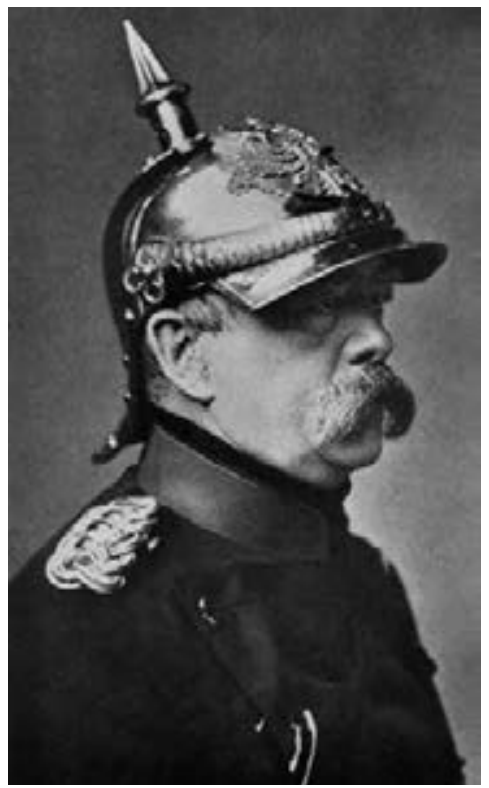

Source: nl.wikipedia.org/wiki/Otto_von_Bismarck

and Latin America. ${ }^{2}$ Sulu, though in this case the request came from its Sultan, would have become a German protectorate.

For more than a decade after the establishment of the German Empire, and in fact almost up to the moment he embarked on a determined colonial policy, Bismarck nourished a public image of a person opposed to the acquisition of colonies and protectorates. Not everybody in those years believed that Germany was not aspiring to overseas possessions. In April 1875 the Royal Colonial Institute, the British pressure group in favour of further expansion of the Empire, sent a deputation to the Colonial Secretary, Carnarvon, pleading for the annexation of East New Guinea (the western part was Dutch). The reason for concern was Germany. One of its influential members, A. Kinnaird, warned the British government that that country 'was determined to be a great naval Power, and would look to colonisation as the principal means to that end, and if she looked to New Guinea we may lose a very important colony'. ${ }^{3}$

2 For the early German plans see, for instance, Gründer 1999: 54-63.

3 Young to Granville 9-12-1882 (PRO FO 534 22). 
In the 188 os Bismarck changed his mind. In those years the groundwork for the transformation of Germany into a colonial empire had already been laid. The mid-1870s had marked the entrance of the German navy into the Pacific and developments in Samoa had already proven how effective such naval support was for the enforcement of German claims. Germany now had its own, albeit still modest, network of coaling stations and a navy that could lend military support to its overseas business communities and could be used to formally annex parts of Africa and Asia. A surplus population also became an argument in favour. It would be better for the country when those who were forced to seek a new livelihood elsewhere in the world would settle in a German colony, instead of the United States or any other foreign country. There they would lose their Germanness; and, as Carl Peters, one of the leading proponents of colonial expansion, argued, would only add to the strength of Germany's rivals (Gründer 1999: 89). Partly to show Germany's own might, and ostensibly out of chagrin over the behaviour of the British Empire and the way in which German nationals had been treated, especially in Fiji, Bismarck briefly embarked upon an active and aggressive colonial policy in Africa and the Pacific. What his motives were has been much discussed and power relations in Europe have been mentioned as well as domestic political considerations (Conrad 2012: 21). Bismarck blamed Great Britain for his change of mind. Britain's betrayal of German settlers in Fiji had forced him to act. The German nation was 'strong enough to protect the enterprises of its nationals and to demand justice' (Koschitzky 1887-88 I: 158).

Bismarck might have blamed London, but his ideas about colonialism were inspired by the British. He was certainly in agreement with their mercantile colonialism. He favoured the English system of chartered companies (in May 1882 the British North Borneo Chartered Company was founded after years of negotiations over the colonisation of Sabah, which, in fact, was the only one of its kind in those days). No occupation by the state. Private companies had to take the lead. Bismarck emphatically rejected 'artificial' colonisation and a colonial administration paid for by the government or the establishment of military garrisons in regions that did not yield a profit. When German citizens, of their own accord, settled in parts of the world not yet controlled by other colonial empires - when it involved 'constructions which grew naturally from the surplus fluids of the collective German body' - then it was 'the duty of the Empire to follow them with the shield of national protection' (Koschitzky 1887-1888 I: 157,163$)$. And to counter voices that doubted the commercial potential of some of the coastal regions where German companies wanted to establish 
themselves, Bismarck also underlined the importance of the opening up of new markets for German industry. Such, at first glance, useless places, where no estate agriculture was possible, should not be neglected and had to be considered as vanguard points for the opening up of trade with the hinterland (Koschitzky 1887-88 I: 189). The 'Hanseatic merchants' who were to undertake such endeavours could be assured that they were equipped with a Frei-und Schutzbrief, a Charter and Letter of Protection (Koschitzky 1887-88 I: 158).

Bismarck gave the impression that Germany would acquire its colonies for a pittance. The state did not have to spend money to buy land, to pay a colonial civil administration or to station a military garrison in faraway regions. The threat of a German fleet and the occasional deployment of warships could suffice (Koschitzky 1887-88 I: 157). The commercial firms to which the colonisation was to be delegated were expected to bear the costs involved in administering a colony themselves, with, at most, an initial financial incentive from the government. In view of the profits that lay in store, the optimistic view was that having been awarded control over the economic exploitation of the new possessions they would certainly be able to finance the undertaking themselves. In Bismarck's words, and he had New Guinea in mind when he spoke in March 1885, these were large, fertile and easily cultivatable regions, which now are overgrown with steppe grass as high as a man's head, located below the equator, and as such excellently suitable to the cultivation of coffee, cotton and similar tropical products' (Koschitzky 1887-88 I: 274). Avoiding costs was also foremost in mind of the British government, but, unlike Bismarck, British politicians used it as an argument to plead against colonisation or the establishment of protectorates, not in favour of it.

Bismarck encountered much opposition in the Reichstag, at times also ridicule, in particular from the left. Opponents called for caution, arguing that the German fleet was still no match for those of Great Britain and France, and they dreaded the additional financial burden a colonial adventure implied for a population already heavily taxed due to plans for a strong army and navy. It was also recalled that earlier German adventures in the tropics 'had ended in bankruptcy and at the roasting spit of savage cannibals', as one avowed opponent of any German colonial adventure, Ludwig Bamberger, phrased it (Koschitzky 1887-88 I: 159). Still others were sure that the climate in Africa and the Pacific did not suit Germans and that in Africa, German settlers only had two options, 'an honourable grave or to be eaten by the darkies' (Koschitzky $1887-88$ I: 289). Or, as the Allgemeine Zeitung in Munich wrote on 27 November 1882 with regard to a German 
annexation of New Guinea, the island was dreaded and avoided as the 'natural burial place of the white'.

In 1878 , when Werner, the commander of the Ariadne, had established a German presence in the New Britain Archipelago, he was still not sure that Berlin would sanction the act. In fact, Werner need not have worried. The German Empire had not yet publicly expressed colonial ambitions, but for Bismarck it had already become a main objective to see that German trade with faraway quarters of the world could develop free from any dependence on Great Britain. This, too, was part of the rise of Germany as a great power. A network of coaling stations to serve the German merchant and naval fleets was essential if this aim was to be achieved. German ships en route to remote destinations should be able to call at German coaling and repair stations, and should not be dependent upon harbour facilities controlled by other European powers.

The year 1884 was decisive to German colonial policy. After Berlin had enquired, in February (that is, even before Vogelsang had landed at Angra Pequena), November and again in December 1883, whether Great Britain was prepared to protect a German settlement north of the Oranje River - and the only British reaction had been a communication in February of the following year that it was impossible to respond because it was not known where the new German settlement was to be located - Bismarck gave orders for the first German protectorates to be proclaimed. He still rejected the notion of colonies, but it was an 'imperial duty' to protect German overseas settlements, he would tell the Reichstag in June 1884 (Knoll and Hiery 2010: 15). The German Consul General in Tunis, Gustav Nachtigal, was appointed Commissioner of the Empire for the West Coast of Africa and was ordered by Bismarck to conclude treaties of friendship, trade and protection with local rulers. In July 1884 Nachtigal proclaimed Togo and Cameroon German protectorates. The status of South West Africa, which on 24 April had already acquired protection, was confirmed in August. On 7 August, during a ceremony at Angra Pequena attended by a landing party from two German corvettes, the Leipzig and the Elisabeth, the whole region (with the exception of Whale Bay) was formally placed under the protection of the Emperor. Subsequently, a German gunboat, the Wolf, was dispatched along the coast of South West Africa. At various points along the coast the German flag was hoisted with due ceremony and a proclamation declaring South West Africa a protectorate was read out. ${ }^{4}$ London was left no other option

4 In April 1885 Lüderitz was forced to sell the land he had purchased to the Deutsche KolonialGeschellschaft für Südwest-Afrika, the German Colonial Society for South West Africa. Among 
than to inform Berlin that Great Britain 'friendly welcomed Germany as its neighbour' (Koschitzky 1887-88 II: 87).

In the Pacific attention went to East New Guinea and the New Britain Archipelago. It was there that the territorial ambitions of Germany and Great Britain, or rather of its colonies - in this case Australia - clashed, only adding to the bitterness that had arisen from the disputes over Fiji and Samoa.

\section{Australian claims and fears}

In Australia, especially in its most northern colony, Queensland, merchants and estate owners desired New Guinea to be British; though, as Fiji had already indicated, they were less enthusiastic about sharing the costs. British control would secure them land and labour for their business ventures. Supported by politicians and probably a large part of the public, they were adamant that the eastern, non-Dutch portion of New Guinea fell within the Australian sphere of influence. No other country should acquire a colony or protectorate there, and certainly not in those parts nearest to the Australian coast, the southeast of the island. The British administration in London tended to concur, fearing that if it reacted differently political complications with the Australian colonies and New Zealand would be the result. A non-British settlement in those quarters, Colonial Secretary Carnarvon realised, would 'involve the very serious risk of an almost irremediable collision with the Australian Governments'. ${ }^{5}$

Each time real or imaginary rivals appeared on the scene London stressed that Great Britain held special prerogatives. In 1876, after rumours about a French scientific expedition to New Guinea, which might as a sideline hoist the French flag, London, still shrinking from an actual annexation, tried to persuade other European governments to leave the eastern portion of New Guinea alone. France, in earlier decades the principal potential culprit in British eyes regarding annexations in the Pacific, should be made to understand that the British delay 'in taking actual steps with regard to the settlement of New Guinea is not to be regarded as waiving any portion of the claim, which discovery, the proximity of Australia, and the recent operations of British subjects may have established'. ${ }^{6}$

its financial backers were Hansemann and Bleichröder. In $188_{5}$ East Africa would also become a German protectorate.

5 Herbert to Tenterden 31-7-1876 (PRO FO 534 22).

6 Derby to Lyons 3-7-1876 (PRO FO 534 22). 
Consequently, the British ambassador in Paris, Viscount Lyons, was instructed to inform the French government that Great Britain's claim to New Guinea was 'prior to that of any other European Power'. 'What London wanted was out of reach. Lyons had to report that the French would never acknowledge an unsubstantiated claim that was not backed up by concrete evidence; but, from what the French Minister of Foreign Affairs Louis Decazes had told him, he concluded that it was very unlikely that France would try to appropriate a portion of New Guinea. For the moment Lyons was satisfied, even when, a month later, Decazes informed him that two months previously a French natural history expedition, led by Achille Raffray and Maurice Maindron, had left for the Sunda Islands in the Netherlands Indies and New Guinea. France would think twice before risking 'the inconvenience of raising a painful question with England'. Other European countries would do the same: '[A] power which desired to be on cordial terms with the British Government would hardly disregard the closer interest which England has in the question, and the priority of her claim to the island'. ${ }^{8}$

Back home, in London, Carnarvon had his doubts. It would only be a matter of time before others would try to establish themselves on the island. ${ }^{9}$ Annexation could not be postponed much longer. Lyons, having read Carnarvon's assessment, now tended to agree with him. At that moment there were no indications that others had any intention of occupying New Guinea, but as he wrote with a prophetic eye to Foreign Secretary Derby, 'if circumstances should arise which should make any country covet the possession of it, the first notice of the change which we should receive would very probably be the intelligence that a foreign flag has been hoisted there'. ${ }^{10}$

France and Germany were not the only potential intruders. In March 1879 articles appeared first in Italian and British newspapers, and later on also elsewhere in the world, reporting that Domenico Menotti Garibaldi, the eldest son of the famous Giuseppe Garibaldi, was to head an expedition to establish a colony complete with a town, Italia, on the south coast of New Guinea. Four ships with about three thousand well-armed emigrants were said to be fitted out. The object, The Times (18-3-1879) wrote, was 'to find an outlet for that spirit of adventure and enterprise which the making of Italy aroused in many who are still young men'. The Russian Empire was another possibility. Russia, it was speculated, might want to obtain a coaling

7 Lyons to Derby 14-7-1876 (PRO FO 534 22).

8 Lyons to Derby 25-7-1876 (PRO FO 534 22).

9 Herbert to Tenterden 31-7-1876 (PRO FO 534 22).

Lyons to Derby 15-8-1876 (PRO FO 534 22). 
station on the coast of New Guinea, a suspicion fortified by the exploits of N.N. Miklouho-Maclay, a famous Russian explorer. Miklouho-Maclay twice stayed in New Guinea, first in the 1871 and then again in 1883. Both times he travelled to and from his destinations aboard a Russian warship, charting the waters (the route along New Guinea was one of the ways a fleet on its way from Europe to Asia not sailing the Suez Canal could take).

For the Australian public and their politicians a foreign occupation of East New Guinea was a sensitive issue, evoking apprehension and jingoist bravado. In London Arthur Gordon told the Dutch envoy, C.M.E.G. Graaf van Bijlandt, during a formal dinner that if Italy attempted to acquire its colony in New Guinea 'the whole British population of Australia would move to New Guinea to prevent such a venture and to beat the Italians to it.."

A foreign presence in the Western Pacific was seen as a direct threat to the peace and security of Australia. Part of this derived from speculation that a foreign government might look at New Guinea as an ideal location for a penal colony. Such a possibility had indeed come up in relation to the Italian plans - when such an institution had been presented as a more humanitarian alternative to capital punishment - and would remain one of the concerns of Australians and New Zealanders when they discussed foreign settlements in the Western Pacific. A penal colony in New Guinea, as Derby, now Colonial Secretary, put it in the House of Lords in April 1883, would 'cause great annoyance to the Australian Colonies'. ${ }^{12}$ Convicts might well succeed in escaping to Australia. The concern about a convict colony was not confined to New Guinea. It stretched to other island groups in the Pacific - New Caledonia and the New Hebrides - and as such contributed to the wider territorial ambitions in Australia. Feelings were such that as late as 1883 , when protests against a possible annexation by Germany of New Guinea swelled, the Sydney Morning Post could still write that if Great Britain would not take possession of it, the island should go to Germany, and certainly not to France, convinced as Australians were that France would send its criminals there (Ward 1976: 316).

Even more threatening was the thought that a foreign occupation, especially of the south coast of New Guinea, would bring Australia within close range of a foreign navy, a concern entertained since the close of the eighteenth century (Hoffman 1990:4). In 1883 The Argus predicted that such

11 Van Bijlandt to Van Heeckeren 8-4-1879 (ARA FO A-dos. 110 box 218).

12 Derby in House of Lords 20-4-1883 (hansard.millbanksystem.com/lords/1883/apr/20/ question-observations). 
a naval base would fundamentally change life in Australia. With foreign naval establishments far away,

we live free from the apprehension of any serious danger even in time of war. At worst we would only be exposed to the flying visit of a few hostile cruisers, and competent naval officers have even questioned whether a modern ship of war would run the risk of so long a trip, and incur the chances of being left without coal before it was finished (The Argus 11-4-1883).

It was an apprehension that was shared in London. Carnarvon, by then a former Colonial Secretary, called attention in the House of Lords to the consequences of a foreign 'armed fort' in New Guinea. It was 'a monstrous thing' and a 'menace' to the Australians. Torres Strait, where Queensland and New Guinea come closest, 'would cease to be English territory' and the result would be 'an enormous military burden on the Australian Colonies.. ${ }^{13}$

\section{The Moresby annexation}

Despite such Australian anxieties, the British government did not look forward to claiming New Guinea. In 1873, feeling 'that the occupation of this island by any foreign maritime power ... would be a standing menace to Queensland', and 'also impressed by the richness and beauty' of the place, John Moresby, Captain of the HMS Basilisk, had hoisted the British flag on the southeastern New Guinea shore and had taken possession of the region 'in the name and on behalf of the most gracious Majesty Queen Victoria' (Moresby 1876: 207-8). He named the place Port Moresby, after his father Admiral Sir Fairfax Moresby. The ceremony, complete with a feu de joie, the shots frightening the natives, gave the coast its name: Possession Bay. The affair had not been without incident, however. Moresby and the crew of the Basilisk had been confronted by hostile Papuans.

The act had found no favour in the eyes of then Colonial Secretary Carnarvon. Costs had been a major consideration. Contrary to some of the advocates of colonisation, the British government took the position that the economic prospects of New Guinea and other spots in the Western Pacific

13 Carnarvon in House of Lords 2-7-1883 (hansard.millbanksystems.com.lords/1883/july2/ motion-for-papers). 
on the list of annexation were poor. With no prospect of economic gain, Australia, the main if not only beneficiary of such annexations, should share in the costs of occupying and administering such regions. Carnarvon deemed such a contribution essential to persuade the British public and Parliament to consent to taking hold of new possessions. This meant the end of the Port Moresby project. London refused to recognise the annexation. Without London's support for colonisation plans, the administration of Queensland had to restrict itself, for the time being, to claiming all islands within sixty miles of its coast in 1877 . This meant that almost the whole of Torres Strait became British.

Other initiatives that could herald British rule in New Guinea were also discouraged. Among these was a plan in 1876 for the newly established and London-based New Guinea Colonising Association to buy a ship from the British Admiralty and send a small expeditionary force of some two hundred men and fifty officers, commanded by its founder Lieutenant R.H. Armit, to New Guinea. The participants, all volunteers, would receive no pay. They would be rewarded with a plot of land. The greatest damper for the Association must have been that the British government, having learned its lesson in Fiji, left no doubt that any land title acquired from the Papuans would not be recognised should a British jurisdiction over New Guinea become a fact.

In those years nobody had an inkling of what to expect in New Guinea. It was still a largely unexplored island and the same stories circulated about it as about other islands in the Pacific prior to their colonisation. New Guinea was said to be strategically located - the Dutch envoy in Rome called New Guinea an Indies Cyprus, connecting Australia with British India and Japan $^{14}$ - and to hold great wealth; the sight of coconut palms along its shores greatly contributing to such images. Or, as the Premier of New South Wales Henry Parkes put it in 1874 , 'There probably is no country in the world which offers so fair and certain a field for successful colonisation as this great island, as there certainly is none so rich and attractive, and at the same time so close to British rule' (Ward 1976:312). People caught up in a Pacific fantasy imagined that New Guinea could be put on a par with the success stories that Samoa, Hawaii and Fiji seemed to be, or that the prospects it offered resembled those of Australia. In Melbourne, The Argus presented New Guinea as one of the richest islands in the world:

It possesses every natural advantage for the formation of a great colony. The climate, though of course purely tropical, is not unhealthy; there are 
great tracts of exceedingly fertile soil, abundantly watered with large rivers; and there is reason to believe that minerals abound, with, for ought we know, coal among them' (The Argus, 11-4-1883).

Such a vast track of land, not yet claimed by any other nation, could not but titillate the imagination, not only of politicians and merchants looking for new land and new opportunities, but also of crooks. A prospectus of the Australasian Colonisation Society issued around the same time spoke about the prospect of 'a favourable site being discovered in a healthy climate'. It was very clear about what might eventually be offered:

[A] [f]irst-class harbour, at the mouth of a Navigable River, in the immediate vicinity of a large area of soil for Cotton, Tobacco, or Sugar growing, backed by Mineral bearings and Auriferous Ranges similar to what may be observed in Victoria, New South Wales, or New Zealand.

To whet the appetite of potential investors yet further, the brochure mentioned trade in bêche-de-mer, tortoise shells, copra and coconut oil, ebony and sandalwood, pearl shell, gold and silver, not to mention copper, lead, diamonds and coal mines; all of this was designed to make people part with their money. The prospectus even laid out the plan of a city to be built, complete with the width of the streets and the size of the plots that a certain number of shares entitled holders to.

Enthusiasm was not tempered by occasional stories about an unhealthy climate or ferocious inhabitants. Among the voices of caution was that of one Reverend MacFarlane, a clergyman who had founded the first permanent mission station in New Guinea, in Port Moresby, and had lived there for five years. In May 1879, in an effort to dissuade others from travelling to New Guinea, The Sydney Morning Herald warned that Europeans could not live on the island 'because fever and ague abounded' (The Argus 15-5-1879). And then there were the natives, who might slay people who set foot on their shores. This, The Age (20-3-1879) concluded, made the situation along the coast 'very unsettled'. To demonstrate this the newspaper called attention to the fate of two men, Mr Irons and MrWillis, who had ignored warnings by a missionary not to go ashore. Seven days later they were both dead, killed by Papuans: 'They admitted that they had found Mr Willis sick of fever laying on the beach, and they had speared him. Soon after that, they had found Mr Irons walking about looking for cedar, and they killed him and cut his head off'. A group of 'native teachers and their families', employed as missionaries, did not fare much better, readers of The Age were made to 
understand. Nine had died of fever and seven had been poisoned by natives out for their possessions. According to the newspaper, they had 'proceeded about the poisoning of the teachers with the most diabolic cunning'.

\section{Bismarck's Reichstag debacle}

In 1878 , in an effort to attract new money, Godeffroy converted his private firm into a limited company, at the same time giving it a new name: the German Trading and Estate Company of the South Sea Islands in Hamburg, the Deutsche Handels- und Plantagen-Gesellschaft der Südsee-Inseln zu Hamburg, or DHPG for short. The issuance of shares was not a success. As yet, there was little faith in Germany's commercial circles in the profitability of the economic exploitation of the Pacific islands, and the economic and political problems in Fiji and Samoa may well have contributed to this feeling. Most of its shares were owned by Godeffroy, but due to speculation in the mining industry in Europe, which fell through, he almost went bankrupt the following year and had to pledge his shares and his South Sea estates as a security to his creditors, the British Baring Brothers and Co. and John H. Schroeder, both, it was pointed out in the Reichstag, of German origin (Koschitzky 1887-88 II: 22-25; Staley 1935: 5-6). DHPG was unable to settle Godeffroy's debts and secure the shares and estates for Germany.

The German interests in the Pacific, now represented by DHPG, had to be saved for nationalistic reasons. DHPG and its South Sea estates falling into foreign hands was presented as a blow to the prestige of the nation. All over the world, and as far away as Japan, it would be seen as a German defeat (Koschitzky 1887-88 II: 26). Closer to home, in Great Britain, the news of Godeffroy's downfall would have been greeted with malicious pleasure, and any plans to save the company with anxiety. In German minds the reason for such a reaction was clear. Because of their diligence and thoroughness, German merchants were far superior to their British counterparts in the not-yet-colonised parts of the world. The only option left to the British to beat German trade was to annex the regions where German settlers were active (as they had done in Fiji). London only refrained from such annexations out of awe for the German Empire, Heinrich von Kusserow - a senior civil servant at the Foreign Office and son-in-law of the influential banker and Geheime Kommerzienrat Adolph von Hansemann (Staley 1935:6) - explained in the Reichstag.

Afraid of an English or American takeover, and in view of the vital position of DHPG in the German commercial activities in the Pacific, Bismarck 
suggested to the Reichstag that the government should provide financial support to the firm; thus, going beyond an occasional show of force by German naval vessels to protect the German economic interests in the South Pacific. Bankruptcy might leave the door wide open for an advance of 'the British and Americans who already for a long time were scheming against the preponderance of the Germans' in Samoa (Koschitzky 1887-88 I: 143). For the first time, and it may have helped that one of the Godeffroys was a personal friend of his, Bismarck tried to involve the German Empire directly in the business interests of German nationals and firms in Asia and Africa (Masterman 1934: 67). A rescue plan was developed. In return for financial backing by the government, a number of German financiers set up a consortium to save DHPG. The initiative was taken by Adolph von Hansemann, 'one of the richest bankers of the Bismarck era', and Bismarck's private banker Gerson von Bleichröder, another successful German tycoon, who was also involved by Bismarck in the financial dealings connected with the political plans he made (One Man - One Bank 2003; Steinberg 2011: 227). A Seehandels-Gesellschaft (Maritime Trading Company) was to buy up the Godeffroy estates. In turn, the German government would provide a dividend guarantee. It would reserve money - a maximum of ten million Marks was agreed upon - to assure the investors a net profit of 4.5 per cent on the invested initial capital, and this for a period of ten years. Those in favour of government support played a fiercely nationalist, anti-British card, hinting at the territorial greed of Great Britain and its Pacific colonies. Others should not reap the harvest of German labour.

The efforts were in vain. Doubts about the feasibility of the Pacific endeavour prevailed. If the estates in Samoa did indeed form a profitable prospect financially, strong firms would certainly have been eager to step in without the promise of a financial guarantee by the state. Similar questions were raised about the prospects of trade. Bamberger made disparaging remarks about German trade with Samoa consisting of 'shotguns, gunpowder, brandy, beer and some cotton, which fitted the sartorial needs of the Samoans, because they wrap a piece of it around the loins' (Gründer 1999: 77). On 27 April 1880 Bismarck failed to get the support of the Reichstag for his Samoan Subsidy Bill. He suffered an embarrassing defeat: 128 representatives voted against, 112 in favour (Koschitzky 1887-88 II: 22-9). In the Bundesrat opposition also prevailed.

Nevertheless, for those in favour of German imperialism something good came out of the Samoa debate. Defeated in the Reichstag, proponents of colonisation started a campaign to mobilise public opinion in support of DHPG and the German presence in the Pacific. Wanting to outdo 'the 
jealously admired Englishmen', made them long for a German India in Africa and a German Hong Kong in the Far East (Graichen and Gründer 2005: 82). In December 1882 the Deutscher Kolonialverein, German Colonial League, with its journal the Kolonialzeitung (first published in January 1884) was founded in Frankfurt; a fact which was immediately reported by the British ambassador in Berlin to the Foreign Office in London. ${ }^{15}$ Influenced by the swelling campaign in Germany for the acquisition of colonies, people - according to the British, mostly ordinary citizens and clergymen ${ }^{16}$ - parted with their money to support DHPG (Nuhn 2002: 37).

The Deutscher Kolonialverein stressed that colonies would provide Germany with new markets and new investment opportunities. Similar to the opponents of a colonial policy, it showed itself not to be in favour of large agricultural colonies - arguing that all the land in the temperate zones was already occupied by others - leaving to Germany regions not fit for Europeans to employ in the agricultural sector. What it pleaded for was mercantile stations in the tropics. ${ }^{17}$ As an additional argument, also advanced by other German nationalists, the Colonial League pointed out that colonies would provide Germans who, out of economic necessity, had to consider migration an alternative to the United States or South America. Emigrants should not settle in countries like the United States and Australia, which were Germany's economic rivals. Just as Russia had Siberia, and Great Britain and the Netherlands had their colonies for their excess population, Germany should have its own colonial possessions where such people could go and find employment (Hardy and Dumke 1949: 386; De Indische Gids 1887, p.1388).

For Bismarck, the defeat in the Reichstag in April 1880 was difficult to swallow. In the following years he would repeatedly stress that the opposition against his colonial policy was directed against him personally and not against his plans. According to him, such an attitude played into the hands of Great Britain and did not represent public opinion in Germany: 'It is probably that had the country been consulted, the verdict would have been very different' (Townsend 1930: 74). And in 1883, still chagrined over the opposition he encountered in the Reichstag, he would say that colonies 'only belong to a mother country in which national feeling is stronger than

15 Ampthill to Granville 8-12-1882 (PRO FO 534 22). In 1884 a Gesellschaft für Deutsche Kolonisation (Society for German Colonization) would follow. In 1887 the two merged in the Deutsche Kolonialgesellschaft (German Colonial Society) (Gründer 1999: 64-5, Graichen und Gründer 2005: 85).

16 Powell to Salisbury 25-2-1887 (PRO FO 534 35).

17 Ampthill to Granville 14-2-1883 (PRO FO 534 22). 
party spirit'. What could be done, he continued, was 'only support of trading companies; but even for that it would be necessary to have a Reichstag which would have other and higher objectives than constant discussions and the creation of difficulties for the administration' (ibid.: 77). The following year he would even, observing enthusiastic popular support for his colonial policy, speak of a Völkerfrühling, a dawn of the nation. The nationalistic feelings that had spread were, as Bismarck worded it, a sure sign of 'God's blessing of German policy since 1866', the year the Norddeutscher Bund was established, which had continued after the 'big victory' of 1870 (Koschitzky 1887-88 I: 271, 276).

\section{The New Guinea expedition}

Bismarck's defeat in the Reichstag meant that the Seehandels-Gesellschaft had to be liquidated. What rested was to save and reorganise the ailing DHPG. To achieve this the bank consortium of Hansemann and Bleichröder stepped in. Hansemann and Bleichröder had great plans: Still, in the autumn of 1880 in a memorandum to the Ministry of Foreign Affairs and written at the request of Bismarck himself, Hansemann suggested that Germany should take possession of the northeastern part of New Guinea, and the islands of New Britain and New Ireland. There was still much 'vacant' territory in the Pacific. For various reasons Germany was entitled to part of it. This right rested, Hansemann wrote, on 'the numerous German settlements and trading posts scattered over many islands, on the considerable share of its merchant flag in the shipping of the South Sea, on the high esteem its sea power enjoys in the Pacific, and on the ports which its sea power has secured'. German trade had to 'emancipate' itself from the dominant role the British claimed for the ports of Sydney and Auckland in Pacific sea trade. The whole of the non-Dutch portion of New Guinea should also be prevented from becoming British. German explorers had to find the 'best harbours' along the north coast of New Guinea. His consortium would establish trading posts at all suitable places along the north coast, which concurrently could serve as coaling stations for the German navy. Hansemann, after whom a mountain and a coastal region in New Guinea were to be named, praised the island's fertility, which would make the development of an estate economy possible. Nor did he fail to mention that the climate along the north coast of New Guinea would not pose the same problems as it did in the south. Equally, the warlike tribes living in the north would pose no problem: Germany's 'military organisational skills' could 'discipline' them 
and use their warlike mentality for the defence of the colony. Hansemann was confident that New Guinea had a large potential for the development of a plantation culture, and that its harbours could become the centre of Pacific shipping. In so many words, he also hinted that New Guinea might be a stepping stone from which to acquire part of the Malay Archipelago. The Dutch had only transformed Java into a prime example of colonisation, but the rest of the Archipelago, equally richly endowed with natural resources, had remained underdeveloped. ${ }^{18}$

The Samoan Subsidy Bill debate had clearly shown that a majority of the Reichstag members opposed an active German colonial policy. In February 1881, aware that the Reichstag would never consent to such plans, the Ministry of Foreign Affairs, on behalf of Bismarck, had to inform Hansemann that he could not count on any government support, apart from naval and consular protection (Koschitzky 1887-88 II: 202). The bankers had to postpone their plans. The consortium continued to work in secret in order to avoid attention abroad and steer clear of the complications plans for the colonisation of New Guinea might have for Germany's relations with Great Britain and its Australian colonies. DHPG, with Mioko as its main settlement in the New Britain Archipelago, was to be its vehicle. The Robertson \& Hernsheim Company was also contacted, but refused to cooperate with DHPG.

In 1882, true to their words, Hansemann and Bleichröder founded the Neuguinea-Konsortium. Rumours about the consortium's activities began to circulate in 1883. In March the Antwerp newspaper Le Précurseur carried a report of a company to be formed in Germany to colonise New Guinea. One of its first steps on the way to achieving its ambition was the intention to equip a scientific expedition for the exploration of the island. The Précurseur revealed that the company, which was to take the same form as the North Borneo Company, wanted to establish a 'first-class colony', fashioned after the Dutch model. No problems were expected, it was added, as that part of the island belonged to no European power. ${ }^{19}$ In papers submitted to the British Parliament, there was also a note by the British ambassador in Berlin dated May 1883 about a company that had been recently founded in Germany, and which was designed to facilitate the colonisation of New Guinea. $^{20}$

18 Hansemann to Ministry of Foreign Affairs 9-9-188o (in Gründer 1999: 78-80), Koschitzky 1887-1888 II: 202.

19 Lumley to Granville 31-3-1883 (PRO FO 534 22).

20 De Willebois to envoy in Berlin 28-7-1883 (ARA A-Dos. 110 box 218). 


\section{The Queensland annexation}

In Australia in the meanwhile, in February 1883, The Sydney Morning Herald published a translation of an article in the Augsburger Allgemeine Zeitung of November 1882 in favour of a German occupation of the north coast of New Guinea. The ensuing discussions in the Australian press contributed to an atmosphere of 'widespread fears and rumours as to an impending occupation of New Guinea by Germany' (Legge 1956: 20). Alarmed, the Premier of Queensland, Sir Thomas McIlwraith, contacted London. Through the Agent-General for Queensland in London, Thomas Archer, he informed Derby of 'the strong feeling which prevailed in the Colony in favour of the annexation of New Guinea or at least of that portion of it which most nearly adjoins the Australian coast'. ${ }^{21}$

On 26 February McIlwraith reported to London that Queensland was prepared to bear the cost of the annexation. The commitment did not satisfy Derby, who wrote back that he needed firm assurances that money was indeed forthcoming, also in the future. McIlwraith did not await the results of the deliberations and instructed Henry Marjoribanks Chester, the police magistrate on Thursday Island in Torres Strait, to sail to Port Moresby and take possession of eastern New Guinea. On 4 April 1883 Chester hoisted the British flag at Port Moresby. It did not go completely peacefully: '[A]s befitted an old naval officer, [Chester] took the opportunity of shelling a warlike party of Motu who were thought to threaten the security of the port'. ${ }^{22}$

The annexation took many in Europe by surprise, including Colonial Secretary Derby himself. A few days later when the annexation was discussed in the House of Lords, Derby had little to tell, except that he had been 'quite unprepared' and that the government did not yet want to commit itself before it had received more news from Australia. Derby explained that after meeting Archer, he had written to Mcllwraith, avoiding any wording that might be construed either as a positive or negative response. Before a reply by mail could reach London, he had learned about the annexation from a 'Reuter telegram' in the London newspapers. Immediately, he had sent a telegram to McIlwraith. McIlwraith also replied by wire. In his telegram he confirmed that Queensland had taken possession of New Guinea (in the Netherlands there was some fear that the broad wording included the

21 Derby in House of Lords 20-4-1883 (hansard.millbanksystems.com.lords/1883/apr-20/ question-observations).

22 Chester, Henry Marjoribanks (1832-1914) (adbonline.anu.edu.au/bioghs/Ao30365b.htm). 
Dutch part of the island as well, or might be interpreted in this way) 'in Her Majesty's name' and explained that this step had been taken to prevent any other power from annexing the island. Derby concluded that this was all that had passed and thought it better not to comment on the annexation until Queensland had provided him, by mail, with more detailed information. ${ }^{23}$

From the beginning it was clear that the British government was not happy with the self-willed attitude of Queensland. As Derby was to explain in the House of Lords, 'the annexation even of an island in the Pacific may raise a question of foreign policy in which the Imperial Government is very deeply concerned'. ${ }^{24}$ That McIlwraith had not asked for permission and had not informed London beforehand was a source of irritation. A wire to London would only have caused a delay of 24 hours, Derby stated in the House of Lords, suggesting that the Queensland authorities had been well aware that the government's answer would have been a 'No' and had tried to force their hand. ${ }^{25}$ Derby himself, moreover, was no advocate of adding new territories to the British Empire. The British responsibilities with 'Possessions scattered ... over every part of the world' were already heavy enough. ${ }^{26}$ Derby did not look forward to the annexation of a virtually unknown and vast region inhabited, it was thought in those days, by three to four million people. Besides the costs involved in administering the population, there was the problem of policing them, not to speak of the not unlikely prospect that force had to be used to have the Papuans accept British rule. Great Britain could not take on the administration of New Guinea, because of the 'enormous extent of territory, the absolute unknown character of the interior, the certainty that the large Native population, numbering several millions, would object to foreign annexation, and the enormous expense.. ${ }^{27}$

There was also the taxpayer to consider. Ten years earlier it had made a bad impression in London that the Australian colonies had refused to share in the costs of the annexation of Fiji. The same issue emerged with regard to New Guinea. Could the British government justify that the people of the home country bore all the immediate and future costs of the annexation of a region in the world that would hardly bring it any profit? Would Parliament consent? The Queensland commitment that it was prepared to bear

23 Derby in House of Lords 20-4-1883 (hansard.millbanksystems.com.lords/1883/apr/20/ question-observations).

24 Derby in House of Lords 2-7-1883 (hansard.millbanksystems.com.lords/1883/july/2/ motion-for-papers).

25 Ibid.

26 Ibid.

27 Ibid. 
the costs of the annexation did not make a great impression. In London it was felt that Queensland, with its small population, would not be able to keep up its promise, neither financially nor in providing the manpower needed for such a venture. Or, as former Colonial Secretary Carnarvon said, Queensland would not be able to bear the costs of an annexation, 'because Queensland, though a prosperous and thriving Colony, had not more than 250,000 of population, and £2,000,000 of income'. ${ }^{28}$

It also did not help the Queensland cause that one of the first acts after the annexation was sending a labour recruitment ship to New Guinea. In Germany, as well as in Great Britain, the move was detested. In Germany it added to the impression that Australia aimed at undermining German commerce in the Pacific by preventing it from getting the labour its estates needed (Nuhn 2002: 59). In Great Britain the fact that the annexation had brought New Guinea under the Queensland labour regulations, which were less strict than those of the High Commissioner for the Western Pacific, made an unfavourable impression. It gave rise to the suspicion that the desire to secure an influx of Islanders for labour on the estates had been the main reason for the annexation. It signified, as a correspondent of The Times (15-5-1883) put it, 'the perversion of New Guinea into a miserable preserve of forced labour for the Queensland sugar plantations under the disgraced authority of the British flag'. For some the labour recruiting issue formed an argument for turning New Guinea into a Crown Colony, placing it under the jurisdiction of London and not that of the Australian colonies.

It took the British government, which had just become entangled in Egypt, about three months to decide, not least because consultation with Queensland - because of the nature of the matter at stake, and maybe also because of the costs involved - had to be conducted by mail and not by wire. In early July, reproving the Queensland administration for having exceeded its powers, the home government cancelled the annexation. London could not agree to the 'singular and unusual proceeding.'. ${ }^{29}$ On 2 July Derby defended the decision during a debate in the House of Lords. He explained that the additional information he had received from Australia had not been satisfactory. It spoke, he said, avoiding any mention of Germany, of 'strong reports throughout Australia of intentions of some Power - nobody knew what Power - to seize upon some part - nobody knew what part - of

28 Carnarvon in House of Lords 2-7-1883 (hansard.millbanksystems.com.lords/1883/july2/ motion-for-papers).

29 Derby in House of Lords 2-7-1883 (hansard.millbanksystems.com.lords/1883/july2/ motion-for-papers). 
New Guinea'. ${ }^{30}$ Derby claimed, and he would do so a number of times, that there was not the least bit of proof to substantiate the rumours about an impending foreign occupation:

They were simply a creation of the anxiety of the Colonists in this subject; and, as a matter of fact - and, of course, I have taken all possible pains to inquire - we are tolerably well assured that, as regards the leading European Powers, - that is to say, the only Powers that are at all likely to interfere in such a matter - no such intention is entertained. ${ }^{31}$

He assured the House of Lords, or rather the Australian people, that London would 'not view it as a friendly act' when a foreign nation attempted to establish a settlement in New Guinea. ${ }^{32}$ The Australian colonies were made to understand that in important matters such as an annexation London had to be informed in advance by wire. ${ }^{33}$

In spite of its reservations, the British government was prepared to make some concessions, provided that the political and economic costs would not be substantial. Derby shared the view that Queensland could not take on the costs of the administration of New Guinea alone. Queensland itself still had vast unsettled territories, a small population, and its capital, Brisbane, was far away from New Guinea, some 1,00o miles. 'If, therefore, anything is to be done in the way of conquering and administering New Guinea, one thing is clear - that it must be done by the Imperial Government, or the Australian Colonies acting together, or by those two agencies combined'.34

On 11 July 1883 Derby informed the Governor of Queensland, Arthur Hunter Palmer, of this possibility. London showed itself sensitive to the fear of a foreign penal colony or military station in New Guinea; though Derby left no doubt that he himself did not share such anxieties. As he had stated a few days earlier, the Australian colonies underrated 'their own powers and their own importance'. ${ }^{35}$ There was no need of British control over the millions of Papuans in the interior about whom little or nothing was known. Carefully, any impression was avoided that the British government condoned an extension of labour trade. Responding to the argument that an

33 Service to Lord Loch 20-12-1884 (home.vicnet.net.au/ centfed/defence/def_e3.htm).

34 Derby in House of Lords 2-7-1883 (hansard.millbanksystems.com.lords/1883/july2/ motion-for-papers).

35 Ibid. 
annexation of New Guinea would provide Queensland with a new reservoir from which to recruit labour, it was pointed out that the Papuans certainly would not be willing to work on the estates of their own free will. It was an additional reason to reject an annexation of the island.

What London might be prepared to do, it was hinted, was to establish control over the coast of New Guinea. One of the ways this might be accomplished was by strengthening the presence of the British High Commissioner for the Western Pacific in New Guinea. When Queensland, if it had to be in cooperation with the other Australian colonies, would finance the stationing of one or more Deputy Commissioners in New Guinea, London might expand the British naval station in Australia. When he proposed this, Derby was well aware that the jurisdiction of the High Commissioner only extended to British subjects. His suggestion was a response to the outcries in Great Britain and Australia about the excesses of labour trade and the other abuses committed by white settlers. He ventured that London could enter into negotiations on this point with other countries. Derby did not worry about the local population: 'As to the Natives, I believe it would be seldom necessary to exercise jurisdiction over them, if their rights or their lands were not interfered with' ${ }^{36}$

In May 1884 Derby became more specific. In a circular dispatch to the Australian colonies and New Zealand he wrote that the British government was prepared to station a High Commissioner 'on or near the eastern coasts of New Guinea', providing that the Australian colonies contributed $£ 15,000$ to furnish this functionary with a steamship and a staff; expenditures would be accounted for by the British government. ${ }^{37} \mathrm{He}$ forgot to mention whether an annual or once-only contribution was meant, which would later lead to some complications (Legge 1956: 36); his Under-Secretary Evelyn Ashley would correct this in July in the House of Commons; it was annually. ${ }^{38}$ Derby spoke of a precautionary measure, a step to provide government protection to British citizens in case a threat to their safety arose. He again gave the impression that he considered foreign annexation unlikely, or, as he wrote, 'Her Majesty's Government are confident that no Foreign Power contemplates interference with New Guinea'. ${ }^{39}$ Nevertheless, Derby now also

36 Ibid.

37 Evelyn Ashley in House of Commons 7-7-1884 (hansard.millbanksystems.com./ commons,1884/jul/o7/western-pacific-the-australian-colonies).

38 Ibid.

39 Service to Lord Loch 20-12-1884 (home.vicnet.net.au/ centfed/defence/def_e3.htm). 
felt some urgency. As explained in his dispatch, the Australian colonies had not yet replied to his suggestion of sharing the costs, while it was

always possible that the subjects of a Foreign Power might require the protection or intervention of their Government; and British subjects, also, by coming into collision with the Natives, or by setting up claims to land, might cause complications which would give much trouble hereafter. ${ }^{40}$

This was as far as the British government wanted to go. Any expansion should remain confined to the coast of New Guinea. Already reluctant to take this step, London had no desire to add still more islands in the Western Pacific to the British Empire. Derby could not agree to the larger territorial ambitions of Australia and New Zealand. Probably also fearing international complications, British nationals in the Pacific were reminded of the fact that there were international agreements on the independence of a number of the island groups, such as Samoa and the New Hebrides; while islands like New Britain and New Ireland, where Germans had their trading posts, were 'for the most part, of great size, and inhabited by warlike and cannibal tribes'. ${ }^{4}$

In Australia such reluctance did not go down well. There was, Legge (1956: 29) concludes, an 'extraordinary unanimity of Australian opinion' about the incorporation of New Guinea. The government in London was viewed as being characterised by, as the newspaper The Argus put it on 11 April 1883, 'an extreme reluctance to accept fresh responsibilities'. If it had not been for that hesitation, The Argus (11-10-1884) wrote on another occasion, testifying to a rather idyllic view of the conditions in New Guinea, Australians 'would have had herds grazing in the grass lands before now, and possibly sugar mills at work on some of the rivers' there.

Strictly speaking, Derby's words in the House of Lords about Germany not aspiring to a colony in New Guinea were within the bounds of truth, but this did not mean that, as the founding of the Neuguinea-Konsortium indicated, no German plans were made to gain control over part of New Guinea. German traders were well-established in the New Britain Archipelago. In September 1883 Baron von Plessen, the German Chargé d'Affaires in London, could inform the British government that DHPG, by now simply

40 Ashley in House of Commons 7-7-1884 (hansard.millbanksystems.com./commons,1884/ jul/o7/western-pacific-the-australian-colonies).

41 The Colonial Office to the Agents General of New South Wales, New Zealand, Queensland and Victoria $31-8-1883$. 
referred to by insiders as the German Firm or just The Firm, had taken over the last Australian trading post in that region, and that there were, in total, eighteen German stations in the islands. These stations, it was maliciously noted in The Argus (27-10-1884) a few months later, probably consisted of huts of traders who sell arms and stores to the natives in return for copra, bêche-de-mer, pearl-shell, and tortoise-shell, and who act as recruiting agents for Samoa'. How large or how small these posts were did not matter much; more important was that German commercial circles wanted to expand their business to the opposite north coast of East New Guinea. 



\section{The New Guinea Protectorates}

Detecting a new mood in Berlin the New Guinea Consortium - which had been renamed Neu-Guinea-Compagnie in May 1884 and which, setting earlier reservations aside, Robertson \& Hernsheim had joined - renewed its contacts with the German government. On 27 June 1884 Hansemann and Bleichröder informed Bismarck by letter that the preparations to establish themselves in New Guinea, which had been temporarily shelved because of the Queensland annexation of April 1883, had been resumed. Dr Otto Finsch, an explorer, zoologist and ethnographer, had been taken into the company's employ. Finsch was an old friend of the Godeffroy firm. In 1880 he had provided the proponents of a government subsidy to the company with the arguments that the Samoa business was worth its while. ${ }^{1}$

The consortium had bought a British passenger steamship, the Samoa, which like many steamers in those days was also still equipped with sails, which Finsch was to board. Under the pretext of a scientific expedition, the Samoa had to sail along the north coast of New Guinea and into the New Britain Archipelago. In reality, Finsch, who was to lend his name to Finschhafen on the Huon Peninsula, and the captain of the Samoa, Eduard Dallmann, a former whaler who was to be honoured with a port and a strait named after him, had to look for suitable harbours along the coast and set up trading posts to be manned by DHPG. Another one of their tasks was to enter into friendly relations with the population and purchase as much land as possible. Together with DHPG's existing settlements and their future expansion, the acreage acquired should be large enough to create a healthy colony. The scope of the expedition was limited to the New Britain Archipelago and the north coast of New Guinea. Finsch and Dallmann were not to sail to the south coast of New Guinea, where a German presence in such close proximity could create even greater furore in Australia. In their letter the two bankers asked Bismarck to protect the undertaking. The government should provide consular officials and commanders of warships equipped with the necessary mandates and instructions to place the new territories under the protection of the Empire (Koschitzky 1887-88 II: 205-8; Finsch 1888: 7).

1 Otto Finsch lived in New Guinea and the New Britain Archipelago for years and, in 1865, published Neu-Guinea und seine Bewohner. In 1888 he would report on his exploits in: Samoafahrten: Reisen in Kaiser Wilhelms-Land und Englisch-Neu-Guinea in den Jahren 1884 und 1885 an Bord des deutschen Dampfers 'Samoa'. For Dallmann see Pawlik 1996. 
Figure 7 The Samoa

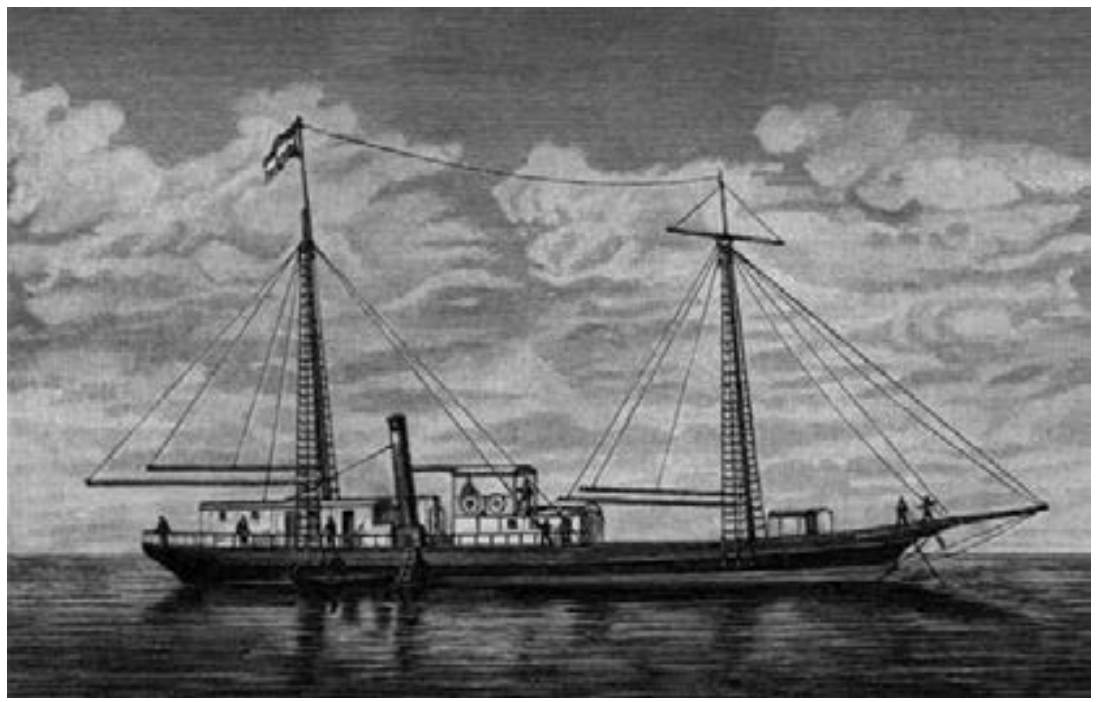

Source: Finsch 1888

On 20 August 1884, at a moment when the matter of a German settlement in South West Africa had not yet been settled, Berlin gave the go-ahead. Bismarck wrote to the Neu-Guinea-Compagnie that its exploits would be given the same support and protection from the Empire as those in South West Africa; providing that the regions where the company wanted to establish itself were 'independent' and not claimed by others (Koschitzky 1887-88 II: 212). The previous day Bismarck had informed the person who was to oversee the obligatory flag-hoisting ceremonies, Gustav von Oertzen, the German Consul General in Sydney and now also given the title of Imperial Commissioner of New Guinea and the New Britain Archipelago, about the expedition and had ordered the navy to send a squadron of no less than five warships to the region (Nuhn 2002: 59).

\section{The hoisting of German flags}

In September 1884 the Samoa, which turned out not to be anywhere near as fast as the previous owner had promised, left Sydney for Mioko. From there she made several trips along the north coast of New Guinea and in and around the New Britain Archipelago. First to be visited was Astrolabe Bay. There, at Konstantinhafen, Finsch bought some land, had the Papuans 
build a shed where coals could be stored, and had the German merchant flag hoisted in a tall tree. It was the first German flag raised in New Guinea. Thus, Finsch (1888: 65) wrote, 'the $17^{\text {th }}$ of October 1884 will for always remain a memorable day in the colonial history of Germany'. Two days later he and Dallmann discovered a more suitable location for a naval port, which they christened Friedrich-Wilhelms-Hafen, after the Crown Prince. The place was marked so that later a German warship could hoist the German war flag, in the words of the patriotic Finsch, 'this mighty tricolour', there (which would happen one month later) (Finsch 1888: 110). Again Finsch (1888: 92) was delighted. The omens were favourable: 19 October was the birthday of the Crown Prince and the anniversary of the Battle of Leipzig of 1813. The only disadvantage was - as Finsch and his crew would personally experience - that Friedrich-Wilhelms-Hafen was malaria-infested. Finsch (1888: 117) named a nearby mountain range, 'the highest along the whole northeast coast', after Bismarck, 'our great Chancellor'.

In Hihiaura Bay on the north coast of the East Cape, Finsch established a trading post, Blumenthal, named after Dallmann's place of residence. Blumenthal was manned by Karl Hunstein, who had sailed along especially for this purpose. Cows, which by their sheer size frightened the Papuans, and sheep were disembarked. Finsch, though not an expert himself, lectured the village chief, who did not understand much of what was said, about cattle breeding. Again he wrote that it was a first, this time the introduction of useful animals (Nutztiere) in that part of New Guinea (Finsch 1888: 254).

In October the Samoa rendezvoused in Mioko with the gunboat Hyäne and the corvette Elisabeth, two of the five warships directed to the region by Berlin to provide military support and the necessary ceremonial backup for a German occupation of coastal areas in eastern north New Guinea and the nearby islands. The Hyäne had already made herself useful. After arriving in Mioko she had embarked on a punitive expedition against Islanders who had killed the crew of a German schooner. Her captain meted out punishment in a way that was customary in those days for foreign warships, hanging the culprits and burning villages and crops. In this case the perpetrators were not found. 'So, powder and lead this time were saved, matches sufficed to burn down the houses, which together with the canoes and plantations that were destroyed should serve the natives as the usual warning' (ibid.: 138). The captain of the Elisabeth was Rudolf Schering. He was a man of experience. In August 1884 he had supervised similar annexation ceremonies to initiate German South West Africa.

The first island in the New Britain Archipelago which gained German Schutz was Matupi. On 3 November Captain Schering declared it to be under 
German protection. Reading out a proclamation, Schering explained that 'His Majesty the German Emperor, Wilhelm I, King of Prussia', had sent him to Matupi to hoist the flag as 'a sign that the German settlements of the Deutsche Handels- und Plantagengeschellschaft der Südsee and the land it owned were to be placed under the direct protection of the Imperial German State' (Nuhn 2002: 6o). Thereupon, 'with a toast to His Majesty Emperor Wilhelm, a cannon salute, and the strains of the national anthem, ${ }^{2}$ the first German war flag (the German flag with a two-headed eagle in its upper right corner) was hoisted in the South Seas' (Koschitsky 1887-88 II: 240). The next day the same honour fell to Mioko and its harbour. This was followed by similar acts at other spots in the New Britain Archipelago and along the coast of New Guinea; all being declared Schutzgebiet. In New Guinea, DHPG was not mentioned in the proclamations. Instead, it was spoken of in terms of Imperial protection of 'existing and future German land acquisitions and property on the north coast from the 141 eastern longitude eastwards as far as and including the Huon Gulf' (Nuhn 2002: 61).

The German flags, as Finsch (1888: 371) himself experienced when he revisited 'Flag Peninsula' (Flaggenhalbinsel) in Finschhafen, could easily disappear within a short span of time. In this case, the local population had taken the flag down and turned it into a sacred object. Finsch was proud of the role he played in acquiring German territory. He was pleased with what had been accomplished during the nine months of reconnoitring:

Extensive strips of fertile land were discovered, and partly obtained immediately, which in every respect were well suited for cultivation, cattle breeding and settlement, and everywhere friendly and peaceful relations were established with the natives (ibid.: 7).

Finsch proposed (1888:115-6), and luckily the Australians were not aware of his suggestion, that part of the land could be cleared by German prisoners, who certainly would prefer working in the open air over having to do so in their cells.

\section{The hoisting of British flags}

Crucial in defining British policy was what Derby had had in mind in May 1884 when he promised to station a High Commissioner on 'the eastern

2 As the German Empire had no official national anthem it was probably Heil dir im Siegerkranz that was played. 
coasts'. In Australia, it was understood to mean the whole non-Dutch eastern half of the island. The way London tackled this problem would infuriate Bismarck. The crux of the matter in the diplomatic negotiations in the months to come was whether Great Britain would settle for the south coast or wanted to extend its control over that part of the north that was opposite the New Britain Archipelago; the region between the Huon Gulf and the East Cape, geographically most of the eastern north coast. Politics and appeals of a humanitarian nature had resulted in a confusing state of affairs. This portion of the north coast had figured prominently in the Australian annexation plans. It was said that it was there and not in the south that Papuans needed protection. ${ }^{3}$

Germany did not contest the British the south. Leaving that part of New Guinea to the British was even an essential element in the arguments put forward by Bismarck himself or conveyed through his ambassador in London, Münster. In their correspondence and talks with representatives of the British government, they invariably posed the question why Great Britain would deny Germany the right in the north that London aimed to exercise in the south. Bismarck was even more persistent about the New Britain Archipelago, where - as Plessen had already told London in September 1883 - German trading posts had replaced those of the Australians. He regarded the New Britain Archipelago potential German territory, a position presented as non-negotiable.

London sent out conflicting signals. In early August 1884 British Foreign Secretary Granville, regretting the distrust his country encountered in Germany, assured Berlin that London was prepared to discuss the delineation of a British and a German sphere of influence in the Pacific. He also pledged that British action in New Guinea would be confined to the south of the island, the region closest to Australia. A few days later he made a statement to the same purport in the House of Commons. To the surprise and annoyance of the German government a different message reached Berlin the following month, when the British ambassador in Berlin, C. Scott, informed the German government that, after consultation with its Australasian colonies, Great Britain also intended to extend its protectorate in the most eastern part of the north coast, east of the $145^{\text {th }}$ meridian east. Thus, it was explained, the British territory would include the Maclay coast where the inhabitants had asked for British protection. Berlin protested. The north of New Guinea was potentially German territory. Great Britain,

3 Carnarvon in House of Lords 23-10-1884 (hansard.millbanksystems.com/lords/1884/oct/23/ the-queens-speech-address-in-answer-to). 
needing all the support it could muster in its conflict with France over Egypt, of which the British had taken control just two years earlier, backed down. In early October Scott suggested to the German government that for the time being a British annexation would remain confined to the south coast. A special commission should try to find a solution for the north (Koschitzky 1887-88 II: 211-3).

In October 1884, after Victoria and Queensland had committed the $£_{15,000}$ asked for by London, the Commodore of the Australian Station, Captain James Elphinstone Erskine, was ordered to proclaim a protectorate over the southeast coast of New Guinea, from the border of the Dutch half to East Cape; a region where, apart from some missionaries and one or two traders and bêche-de-mer or pearl fishers, no Europeans had yet settled. London did not have an annexation in mind. The move was intended to forestall the Germans. By the end of the month, Derby explained in the House of Lords that Great Britain had been forced to act. He pointed out that there seemed to be 'a scramble going on among European Governments for Colonies in different parts of the world' and that the British government was bound to act 'in those localities in which this country is interested'. He went on to spell out that a refusal to act in the south 'would have been deeply resented by all the Australian Colonies'. In view of this, it had been 'thought better to run the risk of some jealousy on the part of Foreign Powers, than to quarrel with our Colonists in a matter in which they are so deeply interested, and on which they feel so strongly'. ${ }^{4}$ But there was one problem with London's resolution. It concerned the wrong coast. Or as Carnarvon, who was not against a protectorate, observed in the House of Lords, it seemed 'rather strange that when you are annexing a large territory, that you should annex that which was never asked for, and omit that which was the origin of the question of annexation'. ${ }^{5}$

To put the south coast under British protection, two warships, HMS Nelson and HMS Espiegle, left Sydney in the middle of October. They were bound for Port Moresby, the site of a small missionary post. On 2 November the Nelson and Espiegle arrived at their destination, where three other warships, HMS Raven, HMS Swinger and HMS Harrier, had already anchored. ${ }^{6}$ On board the Harrier was Deputy Commissioner of the Western Pacific High

4 Derby in House of Lords 23-10-1884 (hansard.millbanksystems.com/lords/1884/oct/23/ the-queens-speech-address-in-answer-to).

5 Carnarvon in House of Lords 23-10-1884 (hansard.millbanksystems.com/lords/1884/oct/23/ the-queens-speech-address-in-answer-to).

6 The story of the proclamations is based on Lyne 1885: 1-28, 116-20. 
Commission, Hugh Hastings Romilly, also a man of some experience. In 1880 he had addressed the chiefs of Rotuma, telling them that Queen Victoria had assented to their request for a British annexation of their island. At Port Moresby, Romilly startled the newcomers by informing them that he had already proclaimed Southeast New Guinea a British protectorate on 21 October. He had misconstrued as an order to proclaim a protectorate a telegram he had received from Derby in Cooktown informing him about the establishment of the protectorate and about a ban on the purchase of land or settling in the region. His enterprising act, complete with a feu de joie and the hoisting of the British flag, threatened to ruin a grand ceremony planned for 6 November.

What were the Papuans who had attended the earlier proclamation to be told? After some deliberation 'it was decided that it should be explained to the natives as only preliminary to the duly authorised and proper ceremony' (Lyne 1885: 3). This settled, with the assistance of the local missionaries as many chiefs as could be found were to be assembled. They did not seem to know or mind the fact that the authority of the latter, as the ethnographer Finsch $(1888: 265,360)$ tells us, was not great anywhere on the island. The warships were dispatched along the coast to collect the chiefs. On 5 November, on the Nelson, 'a grand assembly took place with a feast for the chiefs and an address from the commodore, a presentation of gifts attractive to

Figure 8 The proclamation of the British Protectorate of New Guinea, Port Moresby 1884

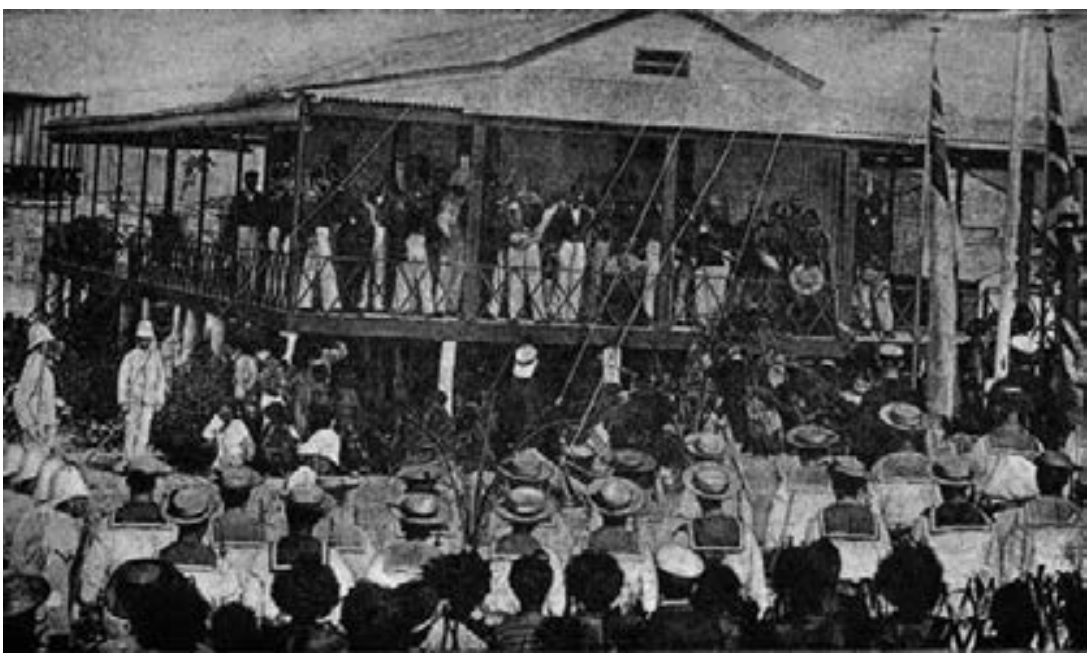

Source: Lyne 1885 
Figure 9 Hoisting the British flag along the coast of New Guinea

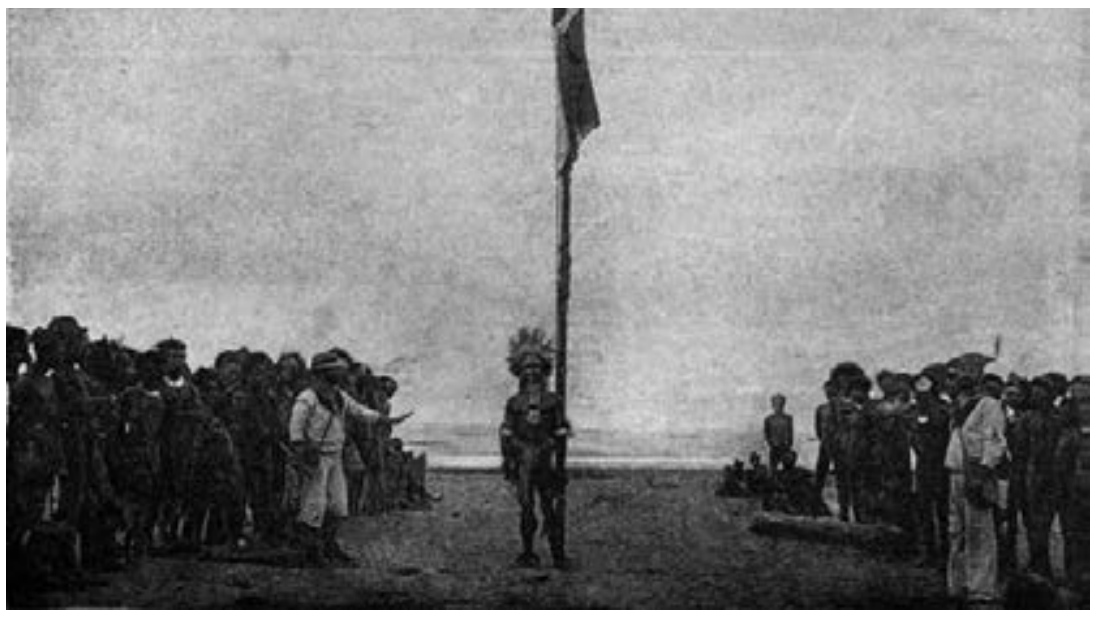

Source: Lyne 1885

the native eye, and the furing of the ship's guns' (Lyne 1885: 5 ). To add to the pomp, the naval officers wore frock-coats and swords. In contrast, most of the chiefs, about fifty in total, were 'destitute of clothing', but there was one reminder of the earlier Queensland proclamation, a Papuan 'dressed in a shirt, with a handkerchief round his loins, a red felt hat on his head (the hat given to him when the British flag had been hoisted in 1883 to mark the annexation by Queensland), and some green leaves through the lobe of his left ear' (ibid.: 5-6). The guests were fed - 'boiled rice, sweetened with brown sugar' (ibid.: 6) - and presented with a printed English text of the proclamation to be read; a text in their own language, it was promised, would be distributed later.

After they had 'devoured the rice with evident satisfaction', the Commodore explained to the chiefs in English what it was all about, a translation by one of the missionaries came next (ibid.: 6). Those present were told that the protectorate meant that in future 'evil-disposed men will not be able to occupy your country, seize your lands, or take your homes. ... Your lands will be secured to you, and your wives and children will be protected' (ibid.: 9). In return for such protection, the Papuans should 'under no circumstances inflict punishment upon any white person' and had to report to the British 'bad men' who mistreated them or tried to sell them arms, ammunition or liquor so that 'such men may be punished' (ibid.: 9-10). To facilitate communication - it would be difficult to consult with all the chiefs individually - one of them was appointed head-chief. As a token of 
his dignity, he received 'an ebony stick with a florin let in at the top, the Queen's head being uppermost, and encircled by a band of silver'. Rather enigmatically, it was explained that the stick 'represents the Queen's head' (ibid.: 12).

The festivities aboard the Harrier were only the prelude. The next day yet another impressive ceremony took place during which Southeast New Guinea was officially declared a British protectorate. Once again, it was explained that everything was being done in the interests of the population. The British, it was stressed in a language the absent Germans would have understood better than the Papuans present, had acted to protect the Papuans against brutal exploitation by white settlers:

Whereas it has become essential, for the protection of the lives and properties of the native inhabitants of New Guinea, and for the purpose of preventing the occupation of portions of that country by persons whose proceedings, unsanctioned by any lawful authority might tend to injustice, strife and bloodshed, and who, under the pretence of legitimate trade and intercourse, might endanger the liberties and possess themselves of the land of such native inhabitants, that a British Protectorate should be established over a certain portion of such country and the islands adjacent thereto (ibid.: 22).

After the Port Moresby proclamation the British warships, sometimes individually, sometimes in different combinations, sailed to eight other points along the coast to repeat the ceremony. Along with them went the missionaries stationed in Port Moresby and a number of native religious teachers and their wives. Everywhere the British flag was hoisted staffs of office were handed over to local chiefs. The ceremonies were complete with the firing of guns from the warships, which at times made the Papuans run away with fright, the singing of the national anthem, salvos of feux de joie, and not to forget 'the final British cheers ... for the Queen' (ibid.: 120). The naval officers - with blue jackets, epaulettes and cocked hats - and the marines - in white with straw hats - who lined up as guards of honour were impeccably dressed. The missionaries and native teachers (the latter not allowed to share a platform with the officers) and the local population in their traditional costume formed the public. On 26 November, during the final flag raising on Teste Island, Commodore Erskine had a special message. He asked those present to join him

in the fervent hope that the establishment of this Protectorate may conduce to the happiness, the peace, and the welfare of these people; that it may be a security to the Australian Colonies, and to the best interest of their people; 
and that it may redound to the honour of her Most Gracious Majesty Queen Victoria, for whom I ask you now to give three hearty cheers (ibid.: 220).

For the time being, the newly acquired territory was placed under the authority of the High Commission for the Western Pacific. The jurisdiction of the Special Commissioner for New Guinea appointed to administer the area only extended to British citizens, and not to those with another nationality. The British government might have, perhaps deliberately, overlooked this initially. On 24 October the Under-Secretary of State for the Colonies, Evelyn Ashley, explained in the House of Commons that the British would 'have jurisdiction over the subjects of Foreign Powers as well as over Natives' ${ }^{7}$ For a moment the protectorate was even closed to foreigners. A request from DHPG to be allowed to trade was refused (Legge 1956: 33).

In November 1884 General Peter Henry Scratchley was appointed Special Commissioner of the newly proclaimed protectorate, with powers extending outside it. (He would arrive in Port Moresby in August 1885, only to die within four months.) How far inland, and how far along the coast, the protectorate stretched was not clear. The British government had no answer to the question. Ashley pointed out that the interior was still 'unexplored and unknown', but that the protectorate would extend 'as far as local circumstances may demand'. ${ }^{8}$ Scratchley's successor John Douglas, constrained by the money at his disposal, but not by a lack of optimism, thought that with 'a force of twelve men, Europeans, six on the shore and six afloat, the Administrator should be able to guarantee perfect order and inter-tribal peace for thirty miles inland and for fifty miles east and west of Port Moresby' (Legge 1956:36). Douglas' assessment was highly unrealistic. As it turned out, the Special Commissioner would hardly have any staff and would lack sufficient funds, to exercise much power; he and his office becoming 'little more than symbols of a British authority not yet fully established' (ibid.: 37 ).

One of the few things they actually could do was to make the threat that titles of land bought from the local population might not be recognised after a formal annexation (ibid.: 38). Fiji and Samoa had shown just what a thorny matter land titles were. As Ashley remarked on 24 October, touching upon a familiar theme, 'there would be collisions and outrages if land were taken over from the Natives of New Guinea without the control of a British

7 Ashley in House of Commons 24-10-1884 (hansard.millbanksystems.com/commons/1884/ oct/24/western-islands-of-the-pacific-new).

8 Ibid. 
Officer. ${ }^{9}$ The protectorate had only one boat, and before the end of Douglas' term in office people began to worry about hostile natives and violence among the Papuans near Port Moresby. Warships were sent on punitive expeditions (Legge 1956: 42).

\section{Australian astonishment and indignation}

Most Australians, including its politicians, only learned of the German annexation through the press. The news was broken by The Age on 19 and 20 December 1884. The reaction, the Dutch Consul General reported to The Hague, was one of astonishment and indignation..$^{10}$ In particular, the fact that the Germans had claimed land as far south as East Cape came as a shock. The Prime Minister of Victoria, James Service, in a memorandum to the British Governor of the colony, used words like consternation, indignation and disappointment, and expressed his 'strong protest, on behalf of the Colony of Victoria, against the [British] inaction which gives an open invitation to Foreign Powers to come and take possession of lands in which no Power can be so much interested as the neighbouring and important communities of Australasia." ${ }^{11}$ New Zealand had its own agenda. It could live with a German New Guinea, but only when Samoa and Tonga became British (Ward 1976:305).

In the Australian press disappointment found its expression in attacks on the spinelessness of the home government, which had been bullied by Germany. In Australian eyes, Bismarck's resolve compared favourably to the policy of restraint exercised by London and the humanitarian stand it took by giving priority to the protection of the Islanders:

We have Prince Bismarck honouring and petting the adventurous Teuton, and insisting that if he establishes a plantation, no Western Pacific Commission shall eject him from his land; and, on the other hand, we have the British or Australian colonist warned that, whether he pays a fair price for the land or not, no claim on his part will ever be recognised (The Argus 11-10-1884).

Finsch experienced some of the anger himself when the Samoa called in at Cooktown in Queensland in January 1885. In protest to the German protectorate an 'Indignation-Meeting' was held in the town hall, where the

10 Dutch Consul General in Australia to De Willebois 24-12-1884 (ARA FO A-dos. 110 box 218).

Service to Lord Loch 20-12-1884 (home.vicnet.net.au/ centfed/defence/def_e3.htm). 
imperial government's dawdling was also deplored. People became hostile and one local newspaper suggested to blow Finsch, 'the fellow who stol [sic] us New Guinea', and the Samoa to smithereens. Finsch wrote that he had not been afraid, counting on the 'mighty protection of the German flag and the respect for our great Chancellor' (Finsch 1888: 286-7).

In London, in coping with the new German initiative, the British government was caught between keeping good relations with Berlin and satisfying demands from Australia, where also outside Queensland the April proclamation had been welcomed with much acclaim. By the end of 1883 , on McIlwraith's initiative an Intercolonial Convention had been held in Sydney to discuss the annexation of 'neighbouring islands' and closer cooperation between the Australian colonies. Attended by representatives of the six Australian colonies, New Zealand and Fiji, the meeting served its aims. Any non-British control over hitherto unoccupied quarters of the South Pacific was strongly denounced. A 'further acquisition of dominion in the Pacific, south of the Equator, by any Foreign Power, would be highly detrimental to the safety and well-being of the British possessions in Australasia' (The Times 6-12-1883). Touching upon the moral obligation to protect Papuans against ruthless Europeans, the convention called for an immediate annexation of the non-Dutch portion of New Guinea and adjacent islands; vowing that the Australian administrations were willing to share in the costs. Only the state should acquire land, and then only for missionary and trading purposes. ${ }^{12}$ The decisions of the Intercolonial Convention disquieted Bismarck, who could not believe that London had no hand in drafting them. London had to reassure Berlin that it had no colonial ambitions in the Pacific (Ward 1976: 318).

British statesmen were also not yet accustomed to having Germany as a new and, as it turned out, determined colonial rival. Earlier, German South West Africa had taken the British government by surprise. It had not realised that Germany was aspiring to colonial possessions (Massie 1993: 86). A similar situation arose in relation to German ambitions with regard to New Guinea. The establishment of a German protectorate had come 'to the great surprise of the Foreign Office and the Colonial Office' (Legge 1956: 28). London believed that it had gained a commitment from Berlin to refrain from any action and had left it at that. In January 1885 the British government protested, explaining that the move had come as a surprise; bearing in mind that in earlier consultations between London and Berlin it was agreed to maintain a status quo in the Pacific until a

12 Ashley in House of Commons 24-10-1884 (hansard.millbanksystems.com./commons,1884/ oct/24/western-islands-of-the-pacific-new). 
special commission had begun discussing the urgent problems of those days between the two countries in the South Pacific, Fiji and Samoa. From his side, Bismarck put forward that had London been more attentive the British government would certainly have been aware of the German intent to claim part of New Guinea (Koschitzky 1887-88 I: 183).

\section{New negotiations and hoisting of flags}

By the end of 1884 the British Assistant Under-Secretary for the Colonies, R.H. Meade, who was in Berlin to attend the Congo-conference, had discussed the dividing up of New Guinea and adjacent islands with German officials and with Bismarck. The deal he proposed greatly irritated Bismarck: in return for British recognition of Germany's right to New Britain, New Ireland and the Duke of York Island, Germany should leave the whole non-Dutch half of New Guinea and the Louisiade Islands to Great Britain. At home Meade's diplomacy also raised some eyebrows, as somehow he gave the impression that he had suggested a dividing up of the South Pacific between Great Britain, Germany and France, also bringing up the New Hebrides case.

The proposal was unacceptable to Bismarck. He took the position that earlier communications by British government officials had given the impression that Great Britain only aspired to the south coast of New Guinea. According to him, Germany had as much right to annex regions in the north as the British had in the south. As Meade would report back to London, Bismarck called it unworthy of Great Britain, 'which had such extensive still uncolonised possessions in that region' to begrudge Germany a part of the north of New Guinea, where it had few interests (Koschitzky 1887-88 I: 179). Bismarck also pointed out - and according to the report Bismarck sent to his ambassador in London, Meade had had to agree with this observation - that the British did not have settlements of any significance in New Guinea or the New Britain Archipelago. Their plans for a protectorate had only come up after Germany had shown an interest in the region. Particularly with respect to the New Britain Archipelago Bismarck stood his grounds. Only Germans had commercial interests in these islands and he had no intention of relinquishing German claims. Bismarck also saw no reason why Germany should make concessions elsewhere for a British recognition of a German protectorate of the New Britain Archipelago and abandon its claim to the north coast (Koschitzky 1887-88 I: 177).

After Bismarck had rejected Meade's plan Great Britain wanted to make sure that there would be no further territorial expansion of Germany in New 
Guinea. In January 1885, when the British government formally protested the establishment of the German protectorate, Berlin was informed that the British navy in Australia had been instructed to occupy the north coast of New Guinea, east of the Huon Gulf, and including the islands adjacent to it (Koschitzky 1887-88 I: 182; II: 222). London disregarded Bismarck'srequest to cancel the annexation order. The British flag was hoisted in the Louisiade and Woodlark Islands, east of New Guinea in the Solomon Sea. Rook Island and Long Island in the New Britain Archipelago were also declared British.

Germany and Great Britain seemed to be on a collision course. Both were aiming to establish a protectorate in a region where their immediate interests were small, and which, at least on the part of the British government, had not so long before been dismissed as not worth the costs of an occupation. Neither country could boast that it acted in the direct interests of its citizens. Hardly any Germans or British had settled in New Guinea. In January 1885 Granville could point out to the German ambassador in London that there was not yet a single German settlement along the north coast. A few days later Bismarck riposted that this might be the case but that the same was true of any British presence (Koschitzky 1887-88 I: 182-4). Germans could also ridicule the activities of the British High Commissioner in New Guinea. Referring to a report by Romilly about his first dealings in November 1884 with tribes in the south, they could point out that in the region concerned there were hardly any British citizens to protect. Living in the south were four bêche-de-mer fishermen, two missionaries and one land speculator, who claimed to have bought 7,000 acres of land for one penny (Koschitzky 1887-88 II: 214).

For Bismarck, the British efforts to establish itself along the north coast of New Guinea were a clear violation of earlier promises. On 20 January he sent a telegram to his ambassador Münster. Münster was to warn the British government that if the British plans were carried through, a collision of German and British interests lay in store. At home people were being prepared for what might come. To mobilise public opinion and to show how foully the British government had acted in Africa and the Pacific, Bismarck had a White Book published about the Anglo-German negotiations.

In response to the German remonstrations, London persisted in its claim that it had been unaware of any German plans to proclaim a protectorate along the north coast. The only reason why it had acted had been the desire to prevent adventurers from taking advantage of the situation and settling in regions not yet under British, German or Dutch jurisdiction (Koschitzky 1887-88 II: 222-3). The reply infuriated Bismarck even more. He vented his anger in a letter to Münster: 
When it had not been known to the Government of Great Britain that Germany wanted to carry out further annexations also east of the Huon Gulf, then that can only be imputed to that fact that our communications about these matters have not received the level of attention from the side of the Government of Great Britain which we expected in view of the friendly relations between the two countries (Koschitzky 1887-88 II: 223).

Münster should remind the British government that less than two weeks earlier, the note presented by British ambassador Malet protesting the German annexation and announcing the British intention with regard to New Guinea, had referred to mutual consultation before claiming new territory. It would have been in accordance with this position, Bismarck stressed, for the British government to consult Germany first, before sending out instructions to Australia. Finally, Münster had to convey Bismarck's hope that 'now that the supposed uncertainty about the intentions of Germany has been cleared', London would refrain from a follow-up and would not carry its intention through (Koschitzky 1887-88 II: 223). In a note that accompanied Bismarck's telegram to Münster, London was accused of trying to prevent a further German overseas expansion. Referring to what had happened in Africa, it was said that Great Britain and its colonies only came into action and claimed new territories after they had learned of new German overseas possessions. To prevent this from happening again in the New Britain Archipelago and, Bismarck indicated, more or less expecting that any day news could reach Berlin that the British flag had been hoisted there, Germany had placed the islands under its protection (Koschitzky 1887-88 I: 185-6).

\section{A different style of diplomacy}

What added to Bismarck's annoyance was the difference in political style between him and the British policymakers. He might well have considered the latter inefficient. Sometimes, also for reasons of tactics, a response from the London government was slow and evasive, as had been the case in the Fiji dispute over land titles and the German incursion in South West Africa. At other instances the British response had been inconsistent. Bismarck attributed the different views expressed by London with respect to New Guinea to differences of opinion between the Colonial Secretary, Derby, and the Foreign Secretary, Granville; suspecting the first of being more uncompromising than the latter (Koschitzky 1887-88 I: 178). 
But there was more. As the Dutch Minister in London also observed a number of times in his correspondence with the Dutch Foreign Office, the British government attached great value to the written word. Bismarck, as he explained in early March 1885 in the Reichstag, preferred verbal diplomacy. Direct talks between policymakers or between policymakers and ambassadors or special envoys were much more practical. The British preference for written communication annoyed him:

I may suppose it is known that the diplomatic traffic from the English side of late is conducted mainly or exclusively in the form of written notes, that is in the shape of notes, which are drafted in London, of which the text is sent over here, signed by the English ambassador here, and ... depending on the content of the note is read out, handed over to me, or left in transcription (ibid.: 208).

To Bismarck such a way of communication was inflexible. Letters and notes were definite and neither their content nor the impression they made could be changed. The ambassador only acted as an intermediary and such letters could well be sent by mail. It required no expensive diplomatic corps. It was also very time consuming, and Bismarck complained - he had them counted, he explained, because it had struck him that there were so many, and he had to answer all of them himself - that since the previous summer he had received 820 written notes from London, together some 700 to 800 pages. He had never before received so much correspondence in all the 23 years he had had held public office, not even from all foreign governments together (ibid.: 209).

In the course of the conflict Bismarck took a more belligerent, nationalist tone. In June 1884 he left no doubt in the Reichstag that he did not fear a naval confrontation with another power resulting from the German effort to gain overseas possessions. It was an appropriate moment in view of the bitter conflict in those days about the treatment of Germans on the Fiji Islands and the looming confrontation over New Guinea. The debate not only gave him the platform to publicly call for fair dealings, it also offered him the opportunity to refute the fear that establishing German colonies could lead to conflicts in faraway regions with nations with a stronger fleet; conflicts that Germany could not win. Bismarck hinted that he was prepared to fight out the conflicts arising over a colonial expansion not in Africa or the Pacific, but in Europe; the arena where, according to him, they were to be decided 'in a diplomatic or another way' (ibid.: 285). 
Bismarck said this after members of the Reichstag had pointed out, and not for the first time, that Germany's colonial adventure might push the nation in a naval entanglement along the coast of Africa or in the Pacific that it was bound to lose. Reacting to the possibility of such a Nasenstüber, such a punch on the nose, as the main critic of his colonial policy, Bamberger, phrased it, Bismarck replied that the German Empire would certainly be able to defend its overseas settlements. A colonial conflict with France, for instance, would be fought out before the gates of Metz where the French themselves would promptly suffer a Nasenstüber. Against Great Britain it might be more difficult to retaliate on land, but that country too, he promised, would feel the consequences if it tried to interfere with Germany's colonial plans. There were enough political means to make London understand that it should leave new German settlements untouched. Great Britain had to respect Germany. If not, London would feel the consequences. Such bellicose remarks were interchanged with assurances that the differences between the two countries were not yet serious enough to threaten peace. Bismarck hastened to assure the Reichstag that the relations with France and Great Britain were still good; putting much of the blame on the Australians and New Zealanders. Great Britain had not tried to obstruct German trade. As Fiji had shown, it was its Pacific British colonies, acting on their own, that did ( ibid.: 159-6o).

For a brief moment, and not withstanding Bismarck's reference to the gates of Metz, the deepening of the rift between London and Berlin made a rapprochement between Germany and France one of the options. In the autumn of 1883 Bismarck had already approached Paris to come to closer cooperation. One of the cards he could play was support for the French in their conflict with Great Britain over the occupation of Egypt, where some German property had also been damaged during the British bombardment of Alexandria. A few months later - and at that time an Anglo-French confrontation in continental Southeast Asia was not precluded - Bismarck went as far as proposing a Franco-German naval coalition against Great Britain (Taylor 1971: 296).

London was officially notified about such feelers in January 1885 when Bismarck communicated to Malet the content of a message sent to Münster in May 1884. Malet reported to London that it was a highly peculiar document. In it Bismarck offered Great Britain political support if London would assist Germany in realising its colonial aspirations. Bismarck hinted that he much preferred cooperation with London, but that as a last resort he might be forced to come to a reconciliation with France (Koschitzky 1887-88 I: 186). In London the prospect of a German-Franco alliance was viewed with 
some alarm. It came at a time when there was a growing awareness that the British Empire was far from invincible when it had to take on more than one enemy at a time. Towards the close of 1884 Great Britain experienced one of its naval scares after the Pall Mall Gazette had reported how vulnerable the British fleet was in such an instance (Kennedy 1985: 93). Talk about changing the relations between the homeland and the colonies, and the demands by the home government that the Australian colonies participated in the costs of the annexation of New Guinea, also made outsiders aware that, as Van Bijlandt reported to The Hague, Great Britain no longer felt strong enough to defend its overseas possessions and colonies on its own at times of war, without the latter sharing in the burden, financially and otherwise. ${ }^{13}$ The prospect of an anti-British pact between Berlin and Paris also came at a very inconvenient moment. Not only because of the conflict with France over Egypt, and the use Bismarck could make of this, and worries about a French naval presence in Southeast Asia, but also because of the fear that Russia might move against Afghanistan, reviving anxieties about India's safety and an Anglo-Russian confrontation.

\section{The Anglo-German colonial honeymoon}

Confronted with a gloomy national and international situation, Granville tried to appease Bismarck in early February 1885. He informed Berlin that he would regret a deterioration of Anglo-German relations because of New Guinea, when the reason for this was a misinterpretation of British intentions. As he had done before, Granville denied that Great Britain begrudged Germany its colonial ambitions. Stressing that the changing attitude of Germany to Great Britain was not the fault of the British government he admitted that there had been misunderstandings on the British side. But these, he explained, had been caused by the abrupt way London had learned of the change in Germany's traditional attitude towards the acquisition of overseas possessions (Koschitzky 1887-88 II: 225).

Nothing came of the German diplomatic offensive against Great Britain. In the course of 1885 , instead of a further drifting apart, Great Britain and Germany succeeded in solving the disputes that had arisen over the demarcation of their spheres of influence in the Pacific. In early March, and in accordance with the verbal style of diplomacy he preferred, Bismarck sent his son Herbert to London as a special envoy. Herbert von 
Figure 10 German and British New Guinea and the Bismarck Archipelago

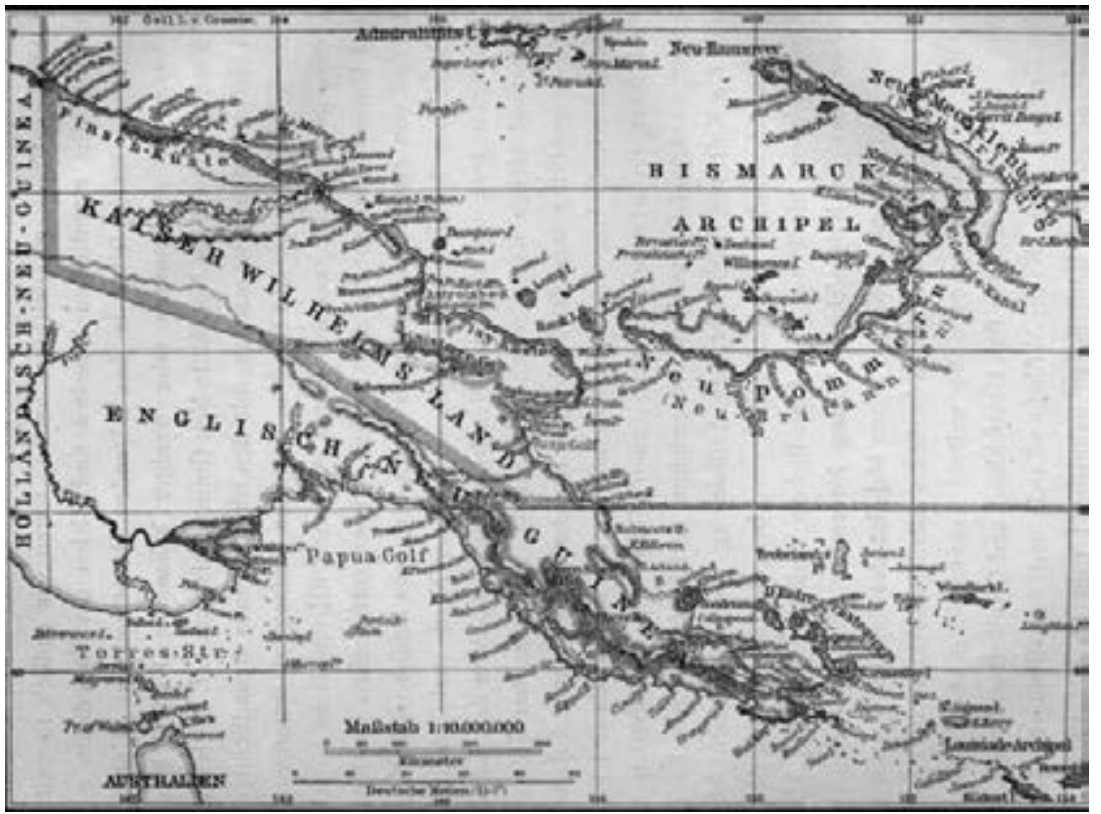

Source: Finsch 1888

Bismarck and ambassador Münster had to pressure the British into accepting Germany's role as a colonial empire. If Germany gave in, Bismarck wrote to Münster, the consequences might be that the country ran the risk of 'falling into a position inferior to England's and strengthening the unbounded arrogance shown by England and its colonies in opposition to us' (Massie 1993: 87).

In spite of the aggressive tone of the letter, the outcome of the talks was more to the advantage of Great Britain than Germany; though from a wider perspective it may have been Germany who was the winner, with people talking and writing about the prestige Great Britain had 'lost owing to the German policy of annexation in the Pacific'. This was an observation that would become more frequent in the 189os (Inagaki 1890: 60). Germany accepted a British protectorate over the eastern part of the north coast. On 25 April, in a note to Münster, Granville suggested an equal division of the non-Dutch part of the island, giving Germany an area of about 67,000 square miles and Great Britain one of some 63,000 square miles. Great Britain had to give up Rook and Long Island and recognise Germany's right to the Huon Gulf, but would retain the protectorate over the eastern part of the north 
coast. ${ }^{14}$ Granville did so, Ward (1976: 321) asserts 'for the sake of German goodwill in Egypt'. Before the end of the month Berlin agreed to the deal.

The accord, which indirectly also whetted colonial appetite in France, ushered in what Herbert von Bismarck dubbed the 'colonial honeymoon' between Germany and Great Britain (Townsend 1930: 112). ${ }^{15}$ In May a joint Anglo-German commission succeeded in hammering out the other disputes regarding the respective spheres of influence in the South Pacific. A line was drawn delineating a German and a British zone. Samoa and Tonga, both located in the British zone, would have a neutral status. According to the Demarcation Agreement, signed in Berlin the following year on 6 April 1886 by Herbert von Bismarck and Malet, the Caroline, Palau, Marshall and northern Solomon Islands fell within the German sphere of influence; the Gilbert (Kiribati), Ellice (Tuvalu) and Fiji Islands (and the New Hebrides) in that of Great Britain. The agreement meant that Finsch had to sail to the Hihiaura Bay to dismantle the Blumenthal trading post. Hunstein had withstood the Papuans who had wanted to lay their hands on the goods in his station, but the cows had gone wild and the sheep had died, probably, Finsch ventured, having eaten poisonous plants. In spite of having to give up Blumenthal, Finsch (1888: 5) was impressed by what Germany had achieved: 'Due to the excellent position of power it could lay its hand on certain regions where German trade had long since gained a firm foothold and had obtained an in part domineering position'.

Having reached an agreement, Emperor Wilhelm I could formally put the German territories in New Guinea, which had already been christened Kaiser-Wilhelms-Land in March, and the New Britain Archipelago under protection of the Empire. In his Schutzbrief of 17 May 1885 - in which he also stressed the task of civilising the local population - sovereignty over the region was delegated to the Neu-Guinea-Compagnie (Knoll and Hiery 2010: 70-1). It had to bear the cost of the administration. In return, the company was given the exclusive right to conclude contracts with the population

14 Arrangement between Great Britain and Germany relative to their respective spheres of action in portions of New Guinea presented to the House of Parliament in June 1885 (ARA CO V 30-6-1885-40).

15 The colonial honeymoon was not perfect, also not in the Pacific. On 24 December 1885 Herbert von Bismarck and the French ambassador in Berlin, Baron Alphonse Chodron de Courcel, signed a protocol on the boundaries between French and German territory on the west coast of Africa. In one of its clauses Germany recognised the French position in the Leeward Islands (Îles sous le Vent) of Tahiti (disputed by the British) and pledged not to protest France taking possession of the New Hebrides. In return, France promised not to obstruct German recruitment of labour when the latter became a reality. In the British view the clause displayed an 'apparent unfriendly attitude of Germany' (Thurston to Stanhope 8-10-1886, PRO FO 534 35). 
to buy up land in the new protectorate. At the same time, measures were taken to protect the right of the Papuans to their land and prevent New Guinea from becoming the plaything of white settlers; resulting in a policy that contrasted with the more violent exploitation of Germany's African colonies. On the suggestion of Oertzen, the New Britain Archipelago was renamed the Bismarck Archipelago. At the end of November New Ireland became Neu-Mecklenburg, New Britain Neu-Pommern and the Duke of York Islands the Neu-Lauenburg group. These names were selected, the Dutch ambassador in Berlin informed his government, because most of the crew of the ships that had sailed to these islands originated from these regions. ${ }^{16}$

The German administration over Kaiser-Wilhelms-Land and the Bismarck Archipelago did not have a fortunate start. The first ship the Neu-Guinea-Compagnie had commissioned to build, the Papua, was wrecked in the Torres Strait on her maiden trip from Hamburg to the Pacific (Koschitzky 1887-88 II: 230). Moreover, Oertzen, now the German Imperial Commissioner for the Pacific, under whose jurisdiction the new possessions came, was almost immediately confronted with problems with the local population. He had to cope without the support of any warship. The German navy had overstretched itself. Its warships had sustained damage or were directed to Samoa, where new violence had erupted, and to other island groups in the South Pacific where the German flag had to be raised. Oertzen could do nothing when an American adventurer with his ship, the Golden Gate, called at one of the islands of the Bismarck Archipelago and, by force, took over the trading station of the Robertson \& Hernsheim firm and chased away its German staff (Koschitzky 1887-88 II: 242).

The Germans hardly knew what they had acquired. The Neu-GuineaCompagnie had to kit out expeditions to explore the newly gained colony. One of these early expeditions headed by Richard Mentzler and the explorer Fritz Grabowsky, first went to the Netherlands Indies. The visit served two purposes. It was hoped that on Java or elsewhere in the Archipelago bearers could be recruited for a scientific expedition into the interior and labourers to build an administrative station; bearers that they were not so sure they could find in New Guinea itself. And, not realising that the natural habitat of New Guinea was not like that of Java, the leaders of the expedition expected that studying agriculture in Java might provide them with ideas on how to proceed in Guinea. ${ }^{17}$

16 Graichen and Gründer 2005: 171, Dutch ambassador in Berlin to Van Karnebeek 5-12-1885 (ARA CO V 16-12-1885).

17 Sprenger van Eyck to Van Rees 29-6-1885 (ARA CO V 29-6-1885). 


\section{The wider South Pacific}

To cash in on its agreement with Great Britain, Germany turned its attention to the Caroline and Marshall Islands. Declaring the Marshall Islands a German protectorate went smoothly. On 13 October 1885 the local German consul invited King Kabau of Jaluit and his chiefs on board the gunboat Nautilus, where they were honoured with twenty-one salutes. Without much ado they agreed to a German protectorate. Two days later LieutenantCaptain Fritz Rötger of the Nautilus and a small naval detachment went ashore. With the usual music by the navy band, salutes and toasts to the Emperor the German war flag was hoisted in front of the German consulate (Koschitzky 1887-88 II: 319-20).

Acquiring the Caroline Islands, where the German firm Robertson \& Hernsheim dominated trade, was less easy (Graichen and Gründer 2005: 172). Spain also laid claim to the island group, though neither Germany nor Great Britain recognised any such rights. In January 1885 Robertson \& Hernsheim asked Berlin to place the island groups under protection (Gründer 1999: 97). Having first gained assurance from London that Britain would not object, Berlin proceeded to put ideas into action stating the reason that the German traders who had settled there - diligent men who had made considerable financial sacrifices and whose work was not devoid of danger, Madrid was told - had repeatedly petitioned for German protection. ${ }^{18}$ In early August 1885 Berlin informed Madrid of its intention. For a brief moment one of its islands, Yap, took centre stage in world affairs. Yap, as The New York Times (6-9-1885) noted, was only 'ten miles long', while its economic prospects could hardly 'appear very attractive to the most ardent advocate of German colonization'. Its asset was that it had an 'excellent harbor'. Spain directed two of its warships, the San Quintin and Manila, to Yap. At the end of the month the two Spanish ships landed a Spanish governor, soldiers and priests on Yap to formally take possession of the island. Waiting for an altar to be shipped from the Philippines to allow a Roman Catholic service, the hoisting of a Spanish flag was delayed. Four days later the German gunboat Iltis arrived on the scene. Without losing any time its commander, LieutenantCaptain Paul Hofmeyer, went straight to the trading station of the Robertson \& Hernsheim firm, raised the German war banner and declared a German protection over Yap and the other Caroline islands.

The captains of the San Quintin and Manila were informed that they were now guests in a German port (Nuhn 2002: 64). In response, the commander 
of the Spanish ships raised the Spanish flag on the island. His gesture was futile. German marines forced him to lower it again. For a brief moment a fight threatened. The Spanish governor instructed the captain of the San Quintin to open fire on the Iltis. The latter refused. His orders had been to avoid an armed confrontation. Instead, the San Quintin sailed to Manila to ask for further instructions. The Iltis also left. In September and October she sailed to adjacent islands and occupied them in the name of the German Empire. On board, serving as an interpreter, was a German ethnographer, Johann Stanislaus Kubary, who in the past had been in the employ of Godeffroy to collect ethnographica for the Godeffroy Museum in Hamburg, and who later on would become station master of the Neu-Guinea-Compagnie in Konstantinhafen. ${ }^{19}$

For Spain the dispute over the Caroline Islands was one of the last convulsions of its colonial empire. Emotions ran high. Hearing about Yap an angry mob attacked the German embassy in Madrid and, shouting 'Down with Germany! War with Germany', they burnt the German coat-of-arms. The Spanish government acted with more caution. Its strategy to forestall the German intention without becoming involved in a war with Germany was successful. Bismarck, not prepared to sacrifice the much more important economic relations with Spain, agreed to mediation by the Pope (Gründer 1999: 97). Nevertheless, Bismarck did not fail to inform the Spanish government that Germany acted rightfully and that the Spanish claim to the Carolines was not justified, especially not when the principle of effective occupation agreed upon at the Berlin Congo Conference a few months earlier, was taken into account..$^{20}$ The Iltis and another German warship, the Nautilus, were ordered to the Caroline Islands to lower the German flags hoisted there. In December Germany and Spain agreed to the suggestion by the Pope to accept Spanish sovereignty over the Caroline and Palau Islands in return for full freedom of trade, shipping and fishery for other nations.

To round off its acquisitions in the South Pacific, Germany put the Brown, Providence and northern Solomon Islands (with Bougainville, Buka, Choiseul and Santa Isabella as its main islands) under German protection in 1885 and $1886 .{ }^{21}$ On one of the islands at least - Shortland Island in the Solomons - the Germans erected a proclamation in German in front of the

19 De.wikipedia.org/wiki/Johann_Stanislaus_Kubary. In the same year Kubary published Ethnographische Beiträge zur Kenntnis der Karolinischen Inselgruppe und Nachbarschaft in Berlin.

20 Bismarck to German Ambassador in Spain 31-8-1885 (In: Gründer 1999: 116-8).

21 In 1899 Germany handed over two of the Solomon islands, Santa Isabel and Choiseul, to Great Britain. 
house of the local chief - the king, as such dignitaries were often called. The proclamation was painted on tin and adorned with the Imperial Crown as a memento (Knoll and Hiery 2010: 51). In January 1888 the German Ministry of Foreign Affairs, that is Herbert von Bismarck, entered into an agreement with the Jaluit-Gesellschaft which had been established in Hamburg the previous month. In the spirit of Bismarck's views of colonialism, the firm was to perform the same function in the Brown, Providence and Marshall Islands as had been assigned to the Neu-Guinea-Compagnie in New Guinea and the Bismarck Archipelago. In return for bearing the cost of the administration of the islands the Jaluit Company was given the right to their economic exploitation.

By that time, Bismarck had lost any interest in a colonial venture, giving priority again to power relations and conflicts in Europe (Mommsen 1995: 80; Knopp 2011: 21). He may have wanted to get rid of what had turned out to be costly possessions, offering them to Hamburg (Knopp 2011: 21), but the impression left in Germany with Tirpitz and others was that Great Britain still reigned supreme and decided where Germany could hoist its flag and where not (Berghahn 1993: 49). Just how difficult life was on the spot for the new German administrators, the traders and estate managers who settled there, may be surmised from the fact that the German expansion in the Pacific and in Africa enriched the German language (and Dutch) with a new word, Tropenkoller, tropical madness, after the novel Tropenkoller: Episode aus dem deutschen Kolonialleben by Frieda Baroness von Bülow, published in 1896.

Germany taking control of the islands was much to the dismay of people in New Zealand and Australia. ${ }^{22}$ London, entangled in negotiations with its colonies on how to proceed, waited somewhat longer before taking its final steps. After London and the governments of Queensland, New South Wales and Victoria had reached agreement on the sharing of the costs of the administration of British New Guinea, the territory was formally put under British rule on 4 September 1888 . The three Australian colonies would jointly furnish $£_{15}, 000$ annually to pay for the administration; London would provide the New Guinea administration with a steamer (worth at least $£ 18,000$ ) and pay for its maintenance. Buying up land from the local population by individuals and companies was forbidden. Recruitment for the Queensland estates had already been declared illegal when the British protectorate had been established. Subsequently, annexation rules were

22 German ambassador to Van Karnebeek 7-12-1886, 18-12-1886, Thurston to Stanhope 8-10-1886 (ARA FO A-dos. 110 box 218, PRO FO 534 35). 
tightened. Papuans were not allowed to enter European employ when they had to leave their district (Legge 1956: 75-7). The British Empire now had a new colony, but nobody seemed happy. British colonists saw New Guinea as their resort, resenting any large-scale British investments on the island (ibid.: 95-6). In 1901 the Colonial Office in London complained that each year it was 'becoming more difficult ... to induce the House of Commons to vote money for the administration of a Possession in which the taxpayer of the United Kingdom has so little direct commercial interest' (ibid.: 103). In 1906 Australia took full control, renaming the island Papua.

Gradually, the British also established themselves elsewhere in the region assigned to them by the agreement with Germany. In 1892 the Gilbert Islands and Ellice Islands were placed under British rule. In 1893 part of the Southern Solomon Islands (New Georgia, Guadalcanal, Malaita and San Cristobal) followed. 



\section{Great Britain, Russia and the Central Asian Question}

In early 1885 , when London and Berlin were negotiating a solution for their dispute over New Guinea, Great Britain experienced one of its many political scares. The panic was occasioned by developments in Central Asia, a part of the world where Russia and Great Britain were engaged in an almost century-old imperialist rivalry. Though a fair distance away from the Pacific, the real and imagined conflicts in Central Asia would weigh heavily on the relations between the powers in the Pacific and in Europe. Russia and Great Britain were the main actors, but the proximity to Afghanistan, and thus to India, would also have its implications for British relations with and views of China and France. The first was important to keep Russia out of India, the second an additional threat to the British position there. What upset the British in 1885 was that in March of that year a detachment of Russian troops entered the small oasis of Penjdeh (Panjdeh, Panjeh), in present-day Turkmenistan, which according to the British was Afghan territory, giving rise to what contemporaries called the Central Asian Question.

The resulting commotion revealed a nagging, ever-present feeling of insecurity in the British colonial mindset. Great Britain's position in India was strong, but at the same time rivals were supposed to lust after Great Britain's major overseas asset. In a sense, India was a beleaguered colony, with enemies encroaching from all sides and, Great Britain being a naval power, aiming at its weak side, its land borders. Such fears - present at least since 1828, when an army officer, George de Lacy Evans, published his pamphlet On the Designs of Russia (Figes 2010: 49) - had a bearing on global strategic thinking and also affected the way the British reacted to and influenced developments in China and Southeast Asia. Aware of such apprehensions, which to some contemporaries looked completely unfounded - not least because of the difficult terrain a Russian army out to invade India would have to traverse -, one author wrote that one could never be certain of Russia's intentions. The question was whether Russia's advances aimed at India or were only intended to 'set up standing menace ... with a view of ulterior policy in other quarters of the East or Far East' (Temple 1902: 44).

During most of the nineteenth century, Anglo-Russian relations in Central Asia were coloured by commercial competition and reciprocal fears and suspicions about the other's territorial ambitions. Both suspected the 
other of wanting to move forward to the detriment of their own position. By the end of the 1850 s, after Great Britain had emerged victorious from the Anglo-Persian War of 1856-57 and had driven the Persians from Herat, Tsar Alexander feared a British advance towards the Caspian Sea (Figes 2010: 453). In British scenarios Russia did not just attempt to expand its Empire overland in Central Asia and China, its ultimate aim was India. Lord Curzon, portrayed by Hopkirk (1994: 504) as an 'arch-Russophobe', was one of the people who frequently called attention to the Russian danger and to Russia's 'passion for territorial expansion' and the 'Muscovite earth-hunger'. In his words, and many of his compatriots may have thought the same, Russia was in a stage Great Britain had already passed, 'in which the lust for new possessions is in excess of every other sentiment' (Curzon: 1892 I: 216, 238). Curzon (1892 I: 171), who had travelled through Persia as a correspondent of The Times, wrote, in an effort to sketch the Russian threat to Persia, that the Russian Empire was a 'great Power whose movements and intentions form the subject of conversation in every Oriental bazaar, and whose ever swelling shadow, witnessed with a sort of paralysed quiescence by the native people, looms like a thunder-cloud over the land'.

Defeat in the Crimean War of $1853^{-56}$ had frustrated Russian plans to march towards Constantinople and the Turkish Straits, connecting the Black Sea and the Mediterranean Sea. Consequently, Russia turned its attention in that part of the world to the Caucasus and Central Asia, viewing their conquest as a preliminary step for incursions into the Ottoman Empire and Persia, and also moving in the direction of Afghanistan. The end of the Crimean War had come as a disappointment to the British Prime Minister Lord Palmerston. He had wanted to fight on. Since at least 1840 some British had worried about a Russian conquest of Khiva (Buckley 1902 I: 347). But a prolonged war would have brought Russia to its knees and would certainly have prevented a Russian advance (Figes 2010: 497). Russia did advance. In the 186os, it could call itself master of Chechnya, Dagestan, Azerbaijan and the rest of the Caucasus. Around the same time, in the name of civilisation, it moved onwards, east of the Caspian Sea, turning into protectorates the Uzbekistan Khanates, Bukhara (Bokhara, Bukhoro) in 1868 and Khiva in 1873, and annexing a third one, the Kokand (Khokand) Khanete, in 1876. Moving to the south, towards Persia, it also entered into Turkmenistan.

To the east lay China, another object of Russian commercial and territorial expansion. The groundwork for this had been laid in 1851. In the Treaty of Kulja (Ili, present-day Yining), Kulja and Tacheng (Tarbagatai, Chuguchak) in north Xinjiang (Sinkiang, also known as Chinese Turkistan or Uyghuristan) were opened to Russian trade, and Russian consuls were 
allowed to take up residence there. These were prerogatives in inland China that remained denied to other powers for a long time. Nine years later, as part of a treaty concluded between St Petersburg and Beijing in 1860, Russia gained the same rights in Kashi (Kashgar), much further to the south, and thus more menacing in the British mind. A decade later, the instability created by an Islamic rebellion in Xinjiang and Yunnan, and the establishment of an independent Kashgaria Khanate by Yakub Bey in the mid-186os, offered Russia the opportunity to enter the Chinese part of the Ili (Yili) River Basin. Ostensibly to restore law and order, Russian troops crossed the border in 1871 . When in 1877 the Chinese army succeeded in suppressing the rebellion, Russia tried to hold on to much of its territorial gains. For a moment it seemed that it was going to succeed in doing so. Under the Livadia Treaty of 1879 , Russia was only obliged to return part of the territory it had conquered. The treaty signed by the Chinese negotiator was immediately repudiated by Beijing. In what went down in history as the Ili Crisis, China succeeded in resisting Russia, assisted in doing so by Great Britain, Germany and the United States, which issued a joint warning to Russia - which had sent a fleet to the Chinese coast - not to attack any treaty port; thus preventing any aggressive intention St Petersburg might have had on the Pacific coast. It took until 1881 before the border between China and Russia was agreed upon. Under the Treaty of Ili, or Treaty of St Petersburg, of 24 (12 according to the Russian calendar) February of that year Russia gave up most of the territory it had seized. In return, St Petersburg gained the right to establish new consulates in Xinjiang, was promised that even more might be opened later, won additional trading concessions in the region, exceeding those other powers had elsewhere in China, and received an indemnity to compensate the military expeditions in the previous years and for the loss of Russian lives and property during the Yakub Bey rebellion. China came to regret the concessions, but proved too weak to undo them (Williams 1916: 801).

\section{Persia and Afghanistan and the threat to India}

By 1890 Russia controlled the Caucasus, the Caspian Sea and Turkmenistan, and had gained commercial preponderance in the north of Persia. Competition was fierce. Curzon (1892 I: 137), not given to moderate views, observed that 'acute commercial warfare' was being waged there 'between Russian and Anglo-Indian merchandize'. He complained that Russia had shut 'the northern gates to every other power' and foresaw that, in the long 
run, Anglo-Indian commerce would disappear from the north of country (Curzon 1892 I: 137; II: 558). Russian politicians may even have considered themselves the masters of all of Persia. In his memoirs, the architect of Russia's economic expansion into Central and north Asia, Count Sergei Witte, recalled that in 1896 'it was perfectly natural for us to look at Persia as totally under our influence and protection, a country with which we could do anything we thought useful for us' (Harcave 1990: 202). Witte, out to demonstrate how disastrous the Russo-Japanese War of 1904-05 had been for his country, exaggerated. Great Britain claimed the south. In the words of Curzon (1892 II: 41), though he probably exaggerated as well, Great Britain had 'undisputed ... commercial predominance' up to Isfahan. The obstacles British trade experienced in the north were more than compensated by the control Great Britain exercised over the Persian Gulf, where sea traffic with the homeland had greatly benefited from the opening of the Suez Canal and from intensified communication with Bombay (Mumbai) and other British ports in India.

Russia's penetration into Persia posed a double threat. Russian troops could march straight south to the Persian Gulf to gain a port and a naval station there, as well as direct access to the Indian Ocean. An equally daunting thought was that halfway on its journey south to the Persian coast a Russian army could turn east, entering Afghanistan through a more accessible terrain than in the north; a possibility that was to haunt the British well into the twentieth century. Afghanistan played a crucial role in the British strategic scenarios of those days. Already for decades, and wary, if not downright alarmed by, Russia's aggrandisements in Central Asia, London considered Afghanistan to be vital to the defence of India and to fall within the British sphere of influence. Afghanistan should remain a buffer, protecting India against a Russian invasion. With regard to Afghanistan, Lord George Hamilton, Secretary of State for India, pointed out in 1898 that Great Britain had 'a large and long Frontier to protect, with a limited force'.'

Russia approaching India via northern Afghanistan, via Kabul and the Khyber Pass would mean 'hard fighting' and a march of some 500 miles through wild territory inhabited by 'wild tribes', which would fiercely fight any invader, including the Russians (Curzon 1892 I: 236). Entering Persia would make the Russian task a little easier. It would bring Russia significantly closer to the boundary of India, with better access into and through Afghanistan via its western border, allowing a Russian army to

1 Hamilton in House of Commons 14-2-1898 (hansard.millbanksystem.com/commons/1898/ feb/14/address-in-answer to-her-majesty's-most-gracious speech). 
march from Mashhad (Meshed) in north Persia, via Herat and Kandahar in Afghanistan, to the Bolan Pass in Baluchistan in present-day Pakistan, near the garrison town of Quetta; though sceptics still wondered whether the Russians really could accomplish this (Temple 1902: 45). In the same vein, as some saw Chinese armies commanded by Russians marching southwards from Manchuria, it was feared that the Russians on their way to India might co-opt local tribesman, luring them with the loot they might amass in India and aiming at fomenting unrest in Afghanistan and India; a scenario of old that was familiar to Russian dreams, as was, by the way, the fear that Great Britain might act in a similar way and arm Afghans to take on the Russians in Central Asia. Yet another possibility was that Russia might eye for the southeastern Persian regions directly bordering with British India. Such considerations made Persia matter to Great Britain. For some, among them former Governor of Bombay Richard Temple (1902: 46), the fact that Persia 'might become a highway between Russia and India' was the overriding reason why.

In 1878 , when in the last stages of the Russo-Turkish War of 1877-78 British threats had stopped Russian troops from closing in on Istanbul, London decided to act. Kabul, more or less forced by Russia, had received a Russian mission that, as such missions often were, was protected by a strong military guard, and had concluded a treaty of friendship with St Petersburg. The Russian approach was described by Temple (1902: 40) as a 'collateral result' of Russia planning for the Russo-Turkish War. The Amir of Afghanistan, who might, as Hopkirk (1994: 382) wrote, have feared 'the might of Russia more than that of Britain', denied the British a similar prerogative. A British mission was stopped at the border. In reaction, troops were sent into Afghanistan. The Second Anglo-Afghan War of 1878-80 was a fact. The outcome was that, to all intents and purposes, Afghanistan came within the British sphere of influence. In May 1879 the Treaty of Gandamak was concluded. In return for a pledge of British support against 'any foreign aggression', the Amir promised to 'conduct his relations with Foreign States in accordance with the advice and wishes of the British Government'. The treaty did not end the war. In September mutinous Afghan troops massacred the newly established British Mission in Kabul. The Treaty of Gandamak had given Great Britain what it wanted, but the British remained highly suspicious of Russia's intention; an apprehension manifesting itself in the desire to move westwards to be better able to meet a Russian confrontation. Also, after the war had ended, the British government would make it plain a number of times that a Russian invasion in Afghanistan would be viewed as a hostile act and a cause for war. 
Fears of further Russian territorial aggrandisements in Central Asia, and the consequences of such expansion for British political and economic interests in the region, were strengthened by the construction in the 1880 os of the Trans-Caspian Railway, also known as the (General Michael Nicolaivitch) Annenkoff Railway and the Central Asian Railway. The railway, running parallel to the north Persian border, could not only be used by Russia to expand its influence in Persia, it was also an encroachment on China's and Afghanistan's borders. The new Trans-Caspian Railway, one contemporary author was sure, placed the northern frontier of Persia 'completely at the mercy of Russia' and allowed for the transportation of Russian troops to 'the Afghan frontier at a very short notice from all parts of Russia' (Inagaki 1890: 252).

Great Britain guarded its interests in the south of Persia zealously. London was adamant that Russia, having established its influence in the north, should not move further southwards; threatening British commercial interest in central and south Persia and, ultimately, reaching what many

\section{Figure 11 British India in 1909}

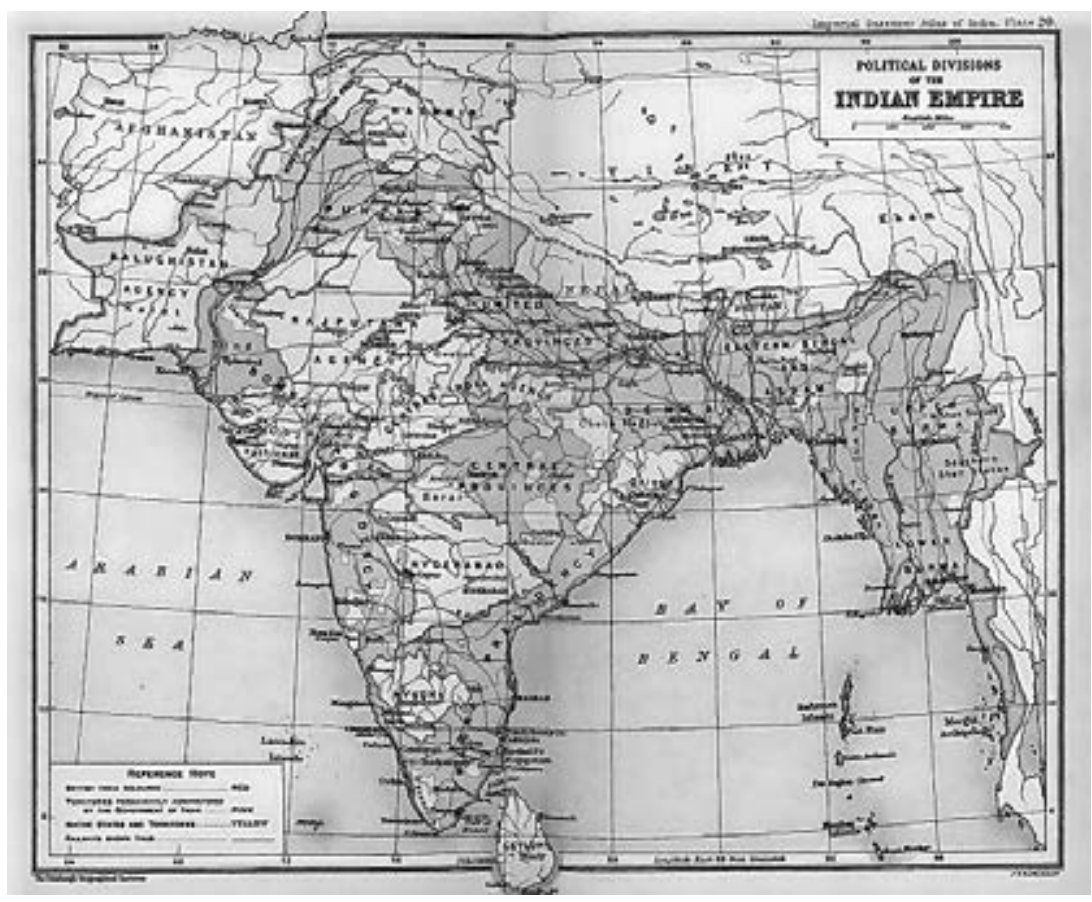

Source: Imperial Gazetteer of India (en.wikipedia.org/wiki/File:British_Indian_Empire_1909_Imperial_Gazetteer_of_India.jpg) 
thought was Russia's ultimate aim: the Persian Gulf. A Russian naval base in the Persian Gulf, would, as the most renowned expert of naval strategy of those days, Mahan (1900: 119) warned, form a 'perpetual menace' to a British fleet and that of its allies 'in case of complications in the farther East'. It would 'involve an exhausting effort, and a naval abandonment of the Black Sea, or of the China Sea, or of both'; of which especially the latter, with Great Britain still dominating China trade, the country could ill afford.

The British had no intention of letting this happen. 'A Russian port upon the Persian Gulf would no more be tolerated by any English minister or government than would an English port on the Caspian by any Czar', Curzon (1892 I: 236) wrote. He even portrayed the Persian Gulf as a 'British Protectorate'. Law and order there was exclusively due to British effort and the British pacification of the Persian Gulf had been tenfold more strenuous than that of the Caspian Sea by the Russians. If the latter had only 'scared a few penniless buccaneers', then the British in the Persian Gulf had 'effectively destroyed a pirate combination and fleet' (Curzon 1892 II: 464-5). Curzon's discussion of a Russian foothold in the Persian Gulf was one passionate appeal against it:

I would regard the concession of a port upon the Persian Gulf to Russia by any power as a deliberate insult to Great Britain, as a wanton rupture of the status quo, and as an intentional provocation to war; and I should impeach the British minister, who was guilty of acquiescing in such a surrender, as a traitor to his country (ibid.: 465).

His words carried weight, also at the British embassy in Russia. There, in July 1899, the British ambassador Charles Scott, referring to Curzon's assessment in a letter home to Salisbury, now Foreign Secretary and Prime Minister, wrote that 'the Persian Gulf [was] as much a British interest as the Caspian was Russian'.

From a Russian perspective it was exactly the opposite. The Russian expansionist policy was an effort to prevent British influence extending northwards into Persia and northwestwards onto the Indian subcontinent. In the early 1870s, St Petersburg had successfully thrown a spanner in the plans of Baron Paul Julius von Reuter, a German-born British citizen, to become the prime mover in the economic exploitation of Persia. In July 1872, in return for a loan to the Shah, Reuter had succeeded in getting permission to build a railroad from the Caspian Sea via Tehran to the Persian Gulf, and 
had received the exclusive rights to the exploitation of coal, iron and other minerals in the country. He had also been promised preferential treatment for the construction of public works. Reuter had turned to London to ask for British assistance should problems arise with the Persian government. But subsequent Russian protests and domestic opposition resulted in the Shah cancelling the deal in November 1873 (Staley 1935: 8-9). Even an expansion of British economic and political interests less ambitious than Reuter aimed at, would have been unacceptable to St Petersburg. Curzon (1892 I: 237), a strong believer in the strategic considerations presented in those days, admitted that even by occupying only the most southeastern provinces of Persia, Great Britain 'would be in a position very seriously to menace the Asiatic status of her rival'.

\section{Russian moves and British countermoves}

In March 1885 Russian troops, 'actively aggressive', as Temple (1902: 43) would later write, capturing the mood of such front troops, defeated a small Afghan army detachment and moved into the Penjdeh Oasis, and it soon became clear that they had no intention of leaving. The Russian Foreign Secretary, Nicholas de Giers, defended the move by talking of acquiring 'a defensive position against the hostility displayed by the English government towards us since the Crimean war'. ${ }^{3}$ London regarded Penjdeh as being part of Afghanistan. St Petersburg claimed that the oasis belonged to the Khanate of Merv, which Russian troops - in spite of earlier assurances by St Petersburg to the contrary - had annexed some three years before. After St Petersburg had refused to withdraw its troops war seemed likely. Russia had advanced uncomfortably close to the northwestern frontier of Afghanistan and Herat. Queen Victoria even sent a telegram to Tsar Alexander III urging him to prevent the 'calamity of war' (Hopkirk 1994: 427). At the German Court the mood was more cheerful. An Anglo-Russian confrontation over Penjdeh appealed to the future Wilhelm II. 'It would be such a pity if there was not war', he wrote to Bismarck. ${ }^{4}$

In Great Britain and India there was much public anger over the Russian incursion into a region 'of only a few miles of territory 500 miles from their Indian Possessions', as one less hot-headed contemporary described 
the Russian move. ${ }^{5}$ There was also talk of the negative consequences for the British image among the Afghans of a British retreat and a Russian army marching to Herat (New York Times 17-4-1885). Having been 'slapped violently in the face', the New York Times correspondent (12-4-1885) wrote, the British were 'all tingling with passion for an immediate fight'. Disquieted also by the appearance of a Russian cruiser in the Andaman Sea, which was seen as a Russian move to disrupt British shipping in the Gulf of Bengal, the imperial government in London and the colonial government in India prepared for war. In India troops were moved to the border and the possibility of sending them into Afghanistan was considered. This was easier said than done. Military Command did not yet fully realise the consequences of such a marching order. On their way to Afghanistan the soldiers had to pass through 'almost inaccessible regions, and the fearful difficulties of sending a large body of troops with transport were then recognised for the first time. ${ }^{6}$ In London the Board of the Admiralty, one of its members would recall later, was ordered 'to make hasty preparation for war'? One of the measures taken was that the Chinese and Australian stations of the British fleet converted merchantmen into warships. The conversion had caused the Admiralty 'grave anxiety and wasteful expenditure. ${ }^{8}$ The ships were too slow.

Great Britain was prevented by the other European powers from moving against Russia in the Black Sea, the most obvious target of retaliation, but hit back in East Asia. In May 1885, on the instructions of the Admiralty, British warships occupied Port Hamilton, a number of small islands off the southern coast of Korea, which a year earlier the American Secretary of the Navy had identified as a suitable place for an American naval station (Field 2001: 4). The aim was to check the Russian Pacific Fleet in Vladivostok and to frustrate any Russian hope of turning Port Hamilton into an ice-free Pacific port for the Russian navy. For Britons expecting war it was 'vital' to 'have a coaling station and base of operation within reach of Vladivostok and the Amoor at the beginning of a war' (Inagaki 1890: 30).

Within months, and before the Penjdeh crisis could escalate, London and St Petersburg agreed to respect the territorial integrity of Afghanistan. St

5 The Duke of Marlborough in House of Lords (hansard.millbanksystems.com/lords/1885/ aug/o4/questions-observations).

6 J. Dickson Poynder in House of Commons 14-2-1898 (hansard.millbanksystem.com/commons/1898/feb/14/address-in-answer- to-her-majesty's-most-gracious speech).

7 Lord Brassey in House of Lords 8-7-1902 (hansard.millbanksystems.com/lords/1902/jul/o8/ merchant-cruisers-in-the-navy).

8 Ibid. 
Petersburg, in the words of Curzon, made 'the honourable concession ... of certain territory on the border of Afghanistan, important to the Ameer'. ${ }^{9}$ In 1887 an Anglo-Russian Joint Afghan Boundary Commission, which had been set up three years earlier, a few months before the Penjdeh incident, reached agreement on the delineation. Penjdeh remained in Russian hands. In return, Russia acknowledged Afghanistan's rights to the Zulfikar Pass. A Russian advance was halted, but, to the disappointment and even alarm of some in Great Britain, Russia had gained a position 'inconveniently near to Herat' (Temple 1902: 43). Shocked by the Penjdeh incident, Great Britain decided upon a more aggressive 'forward policy' or 'advanced frontier policy' aimed at preventing Russian agitation along the Indian border and meeting a Russian military threat right on India's border with Afghanistan; or, better still, in 'Kabul', and not as the previous doctrine was along the Indus. Effective control was expanded westwards, with high costs and, at times, with disastrous results.

To realise this policy, the Durand Line was agreed on with Afghanistan in November 1893. The line defined their respective spheres of influence over the independent frontier tribes living along the infamous present-day border of Pakistan and Afghanistan. ${ }^{10}$ The British never tired of emphasising that these tribes, among them those living in the Valleys of Swat and Bajaur in the northwest, were savage people who coupled fierce feelings of independence with religious fanaticism. There was 'an almost inexhaustible supply of fanaticism' in that corner of India, as Lord George Hamilton put it to the House of Commons in $1898 .{ }^{11}$

With the Penjdeh crisis solved, Port Hamilton was returned to Korea in January 1887. This happened after London had solicited a written guarantee from Beijing that China - which, on its part, had received a promise from St Petersburg that Russia would not interfere in Korea if the British did not either - would not allow any another power to acquire a part of Korea. The fate of the naval base had been decided by a change of government and a change of mind. Naval experts, among them three Naval Commanders-inChief on the China Station, had spoken out in favour of abandoning Port Hamilton. In times of peace the base was too expensive to maintain, in times of war defending the unfortified port would tie down warships that

9 Curzon in House of Commons 21-1-1886 (hansard.millbanksystem.com/commons/1886/ jan/21/first-eight).

10 After Pakistan had become independent in 1947, Kabul made it clear that it did not recognise the British-imposed Durand Line.

11 J. Lawson Walton in House of Commons 14-2-1898 (hansard.millbanksystem.com/commons/1898/feb/14/address-in-answer- to-her-majesty's-most-gracious speech). 
could be better deployed elsewhere. To some, leaving Port Hamilton was yet another indication of the weakness of Great Britain. They assumed that Russian pressure was the real reason for Great Britain's withdrawal (Krahmer 1899: 187).

After the Penjdeh crisis the focus of Anglo-British rivalry shifted to the extreme northeast of Afghanistan, to the Pamir mountains in present-day Tajikistan, an isolated and in those days still mostly uncharted region, which had its own passes into northern Kashmir (which a century later would be among the main supply routes of Russian troops into Afghanistan). In 1891 Russia moved in to occupy part of the mountains, 'empty land' that did not belong to Afghan, British Indian or Chinese territory. In doing so, they evicted from the area Captain Francis Edward Younghusband and another British officer gathering intelligence there. Their treatment and the stories they brought back about the Russian intentions caused anxiety about the defence of India. The Russian advance was seen as a threat to the towns of Chitral and Gilgit, both located on the British side of the Durand Line; though not everybody was that worried. The supply line that invading Russian troops would have to depend upon was too long. What followed resembled the Penjdeh scare. There was much speculation about an Anglo-Russian war and in India troops were mobilised.

Russia backed down, but this time the British did move. Still in 1891, in a pre-emptive strike, a military expedition brought Hunza and Nagar in Gilgit-Baltisan under British control. Chitral would acquire a special place in British history. In early 1895 , fearing for the life of the British political agent who had been stationed there a few years earlier at the request of the local ruler, troops were directed to Chitral. The expedition resulted in the famous, almost disastrous, siege of a British garrison in the Chitral Fort. In the background loomed the suspicion that St Petersburg might take advantage of the dynastic strife in the Princely State; a threat not deemed unrealistic as Russian troops had already advanced within some 20 miles of Chitral. As so often was the case, people in India were more alarmed than the home government. In London Prime Minister Rosebery considered it very unlikely that India could be invaded via Chitral. Sarcastically, he wrote to the Indian Viceroy, the Earl of Elgin, that India seemed to be 'guarding against Russia on every peak of the Hindu Kush.12

In March 1895, under the 'Pamir Agreement', Great Britain and Russia decided that the contested spot of 'empty land' the Russians had marched into in 1891 would be added to the territory of Afghanistan, which now 
effectively formed a buffer between Russian and British territory. The Russian benefit was clear. One author, Dodwell (1932: 464), concluded in 1932 that the 1895 agreement 'brought Russia a great extension of military and political prestige'. Later, Hopkirk (1994: 501) also concluded that the Russians had not only 'secured their long southern frontier, but they had also placed themselves advantageously if ever it came to a war with Britain'. Russia controlled most of the Pamir region (Hopkirk 1994: 499). In Great Britain people worried about the consequences of the agreement for the Indian state of Kashmir (Temple 1902: 44).

The settlement more or less fixed the Russian and British positions in the region, but did not put an end to British anxiety regarding India. In 1900 the Minister of War, General Aleksey N. Kuropatkin, told the British ambassador, Scott, that Afghanistan remained Great Britain's 'sensitive point', and pressuring the British there 'could always be turned to Russia's political advantage elsewhere'. ${ }^{13}$ The conversation took place after Great Britain was still in shock over its reverses in the first phase of the Boer War and the Russian military saw the British engagement in South Africa as a good opportunity for some offensive action along the Persian and Afghan borders; there aspirations were kept in check by Nicholas II who wanted to stay clear of a conflict with Great Britain. ${ }^{14}$ Persia would indeed give the British a lot to worry about. At the end of the century, Calcutta rather alarmingly concluded that Persia, in view of Russia 'closely pressing upon Persia and upon Afghanistan', had become 'a matter of vital concern' to India. The reason was that Persia shared a frontier with Afghanistan 'for many hundreds of miles' and was 'conterminous for hundreds of miles' with Baluchistan in present-day Pakistan, while the Persian Gulf was uncomfortably close to the Indian Ocean, where Indian influence was 'supreme'. ${ }^{15}$

British military presence in Chitral also continued to be a source of concern for Calcutta and London, leading to heated debates about its purpose. Chitral became 'a post of observation' and a road was built between Chitral and Peshawar. Not everybody was convinced of its usefulness. In a letter to The Times it was posed that Chitral was 'a post of defense and observation which defends and observes nothing', while the road was 'a road which leads

13 Scott to Salisbury 22-2-19oo (PRO FO 539 81).

14 Scott to Salisbury 11-1-1900 (PRO FO 539 81). Speculations about an Anglo-Russian confrontation in Central Asia also circulated in South Africa, where it was used to boast the morale of the Boers (Pakenham 1992: 338).

15 Government of India to Secretary of State for India 21-9-1899 (cited in Shuster 1912: 231). 
nowhere. ${ }^{16}$ It may have led to nowhere, but it also traversed a region where, Secretary of State for India Lord George Hamilton observed in August 1897, the inhabitants could 'be subject to sudden outbreaks of fanatical zeal', ${ }^{17}$ At that moment Hamilton was still full of optimism, presenting the British presence in the region and the economic progress it would bring as a successful implementation of the 'forward policy' of meeting the Russian threat by extending the territory under British control. What he did not yet know was that in the previous month local tribesmen, led by someone the British called 'Mad Mullah', had attacked and laid siege to British outposts along the Chitral road at Malakand and Chakdara. It was, as one Member of the House of Commons, Henry Fowler, claimed, 'the greatest outbreak since the Mutiny'. ${ }^{\prime 8}$

16 Cited by Lawson Walton in House of Commons 14-2-1898 (hansard.millbanksystem.com/ commons/1898/feb/14/address-in-answer-to-her-majesty's-most-gracious speech).

17 Hamilton in House of Commons 5-8-1897 (hansard.millbanksystem.com/commons/1897/ aug/05/army-in-India).

18 Fowler in House of Commons 14-2-1898 (hansard.millbanksystem.com/commons/1898/ feb/14/address-in-answer- to-her-majesty's-most-gracious speech). 



\section{Samoa Remains a Source of International Tension}

With the proclamation of the protectorate over Kaiser-Wilhelms-Land and adjacent island groups, the German territorial expansion in the South Pacific had almost come to a halt. Only Germany's position in Samoa remained unsettled. There the relationship between the three main foreign competitors, Germany, Great Britain and the United States, continued to be an uneasy one. Economic rivalry, political strife and nationalist emotions, all played a role. About the German community Robert Louis Stevenson (1892: 34) noted, 'Patriotism flies in arms about a hen; and if you comment upon the colour of a Dutch umbrella, you have cast a stone against the German Emperor'. Elsewhere he spoke of 'national touchiness and the intemperate speech of German clerks', which saw to it that a 'scramble among dollar-hunters assumed the appearance of an inter-racial war' (ibid.: 37-8). The culprit was the DHPG, 'the true centre of trouble, the head of the boil on which Samoa languishes' (ibid.: 28).

Though Great Britain and Germany had agreed in Berlin upon the neutrality of Samoa, the islands not falling within the sphere of influence of either country, Germany continued to strive for a dominant position in Samoa, which its statesmen considered was warranted because of Germany's preponderance on the islands. In Samoa itself, Weber, by now a man of political importance, continued to be haunted by a Fiji scenario and kept warning Berlin that should the British take possession of the islands, this would be the end of the DHPG, because he would no longer be able to recruit labour for its estates (Koschitzky 1887-88 II: 30).

The position of the Samoan king, recognised by the three powers, was precarious. To stay in power he had to be responsive to the demands of the foreign residents. Talavou had been in this position and after his death in 1880 so was his successor, Laupepa, whose authority had been confirmed in July 1881 aboard an American warship, the Lackawanna, and not on a German one. On the Lackawanna it had also been decided that Tamasese Titimaea and not Mata'afa Iosefo would be deputy king. It was the foreign consuls, senior naval officers of German, American and British warships visiting the islands and, of course, Weber who called the cards. The king owed his position more to their backing and scheming than to his own popular acclaim and had to deal with rebellions by fellow Samoans contesting his right to rule. 


\section{Germany presses on}

Laupepa's position became all the more insecure after December 1883 when Weber, whose company by now had its own jail for Samoans who had committed offences against the German community, fittingly called 'Weber's prison' (Stevenson 1892: 44), acquired ownership of the land of Mulinu'u where the Samoan seat of government was located. Grand the place was not. Stevenson (1892: 21) described Mulinu'u as a flat, windswept cliff, 'planted with palms. Backed against a swamp of mangroves and occupied by a rather miserable village'.

Owning the Mulinu'u land gave Weber and the German consul in Samoa extra leverage: the opportunity to evict the Samoan government should the king or his officials and followers displease them. On 5 November 1884, in a desperate attempt to counter increasing German pressure, King Laupepa and the chiefs supporting him turned to Queen Victoria and offered her a protectorate over Samoa. The Governor of New Zealand, William Francis Drummond Jervois, was petitioned in the same manner. ${ }^{1}$ To the Germans, such requests for protection could only be the result of British intrigue. With what had happened in Fiji in mind, they were sure that New Zealanders, scheming for an annexation, had convinced Laupepa that he would get back the land he had sold the Germans once Samoa had become a British protectorate (Koschitzky 1887-88 II: 39). Land was not the only issue. The German consul of those days, Otto Wilhelm Stübel, as Weber did, informed his government at home of the dangers that British labour legislation posed to the German estates on the islands. London refused to place Samoa under its protection, but such was the mood in New Zealand that Jervois informed London that New Zealand was prepared to finance the annexation not only of Samoa but also of Tonga, and that the colony was also willing to take on the administration of Fiji (Ward 1976: 304).

On 10 November 1884 Stübel, who had learned about Laupepa's annexation offer to Queen Victoria, backed up by the might of a German warship, the SMS Albatross, which had just arrived in Samoa, forced Laupepa and Titimaea to sign a new agreement. Reiterating the stipulations of 1879 , it expanded the German intervention in internal affairs even further. The new pact called for the establishment of a Samoan police force manned by the Samoans to protect German estates and it held the king fully responsible for the damage inflicted upon German property and for attacks on German residents and people in German employ; thus also the armed guards used 
to protect the plantations who were recruited from among their workforce. Furthermore, Laupepa had to accept German say over government affairs. A new legislative body was established, the German-Samoan Council of State, made up of the German consul or his representative and two Samoans, one selected by Laupepa, the other by Titimaea. The Council had to decide on all matters that, as stipulated in one of articles of the November agreement, were of 'joint interest to the Samoa government and the Germans living in Samoa'. ${ }^{2}$ German land claims were recognised.

In January 1885 London told Berlin that the new German-Samoan agreement was a clear breach of Samoan independence. Laupepa had, as Thurston, now the British High Commissioner for the Western Pacific, would phrase it, granted Germany 'concessions of an exceptional nature which the other Powers could not regard with indifference'. ${ }^{3}$ Bismarck thought differently. The new agreement only aimed at the restoration of law and order in Samoa. As it had done before, Berlin accused the British of inciting the Samoan population against Germany. They did so, it was alleged, by spreading false rumours about German desires to annex Samoa; hence, the requests to Queen Victoria and the Governor of New Zealand.

When, as the German version goes, the Samoan government - on the instigation of the British - delayed the execution of the 1884 agreement with Germany, action was taken. On 23January 1885 an Albatross landing party occupied Mulinu'u and hoisted the German war pennant. The act, Stübel was quick to assure in a special proclamation, did not imply an annexation. It was just intended to force the Samoan government to comply with the 1884 treaty. Stübel ended his proclamation with an appeal to the Samoans to remain calm: '[T]rust the Imperial German government and also me, then everything will turn to the best for Samoa' (Koschitzky 1887-88 II: 36). Laupepa, who wrote to Stübel that he intended to hoist his flag again in Mulinu'u, was told that he had better not. If he did, arrest by the marines of the Albatross would follow. A distressed Malietoa Laupepa now even turned to the German Emperor for help. He sent Wilhelm I a letter - a letter from 'a so-called King ... I believe his name is Malietoa or something like that', Bismarck was to refer to it in the Reichstag - begging the Emperor to forbid any further agitation in Samoa by Stübel and Weber (Koschitzky 1887-88 I: 283). Laupepa's plea was counterproductive, the more so because the letter

2 For the text of the agreement, see Koschitzky 1887-1888 II: 31.

3 Thurston to Stanhope 8-10-1886 (PRO FO 534 35). 
held 'several passages and forms of address which were contrary to German feelings and etiquette'. ${ }^{4}$

Stübel and Weber now backed the deputy king, Titimaea, providing him with arms, and they did all they could to make the life of Laupepa as miserable as possible. Paramount was that German life and property was protected, also outside Apia. Laupepa was not the right man to accomplish this. He no longer exercised sufficient authority over his subjects and, worse, he had not honoured the treaty arrangements with Germany. The British argued the opposite. Titimaea was no match for Laupepa. The fact that Laupepa had not yet shown this was only because the British consul, wanting to avoid bloodshed, had persuaded him not to wage war on his rival. ${ }^{5}$

Yet in January 1885 Weber and Stübel encouraged Titimaea to rise in rebellion and set up his own government in Leulumoega in the province of Aana, his home base. At the end of the same month between three and four hundred German marines, for the second time, marched into Mulinu'u, where Laupepa had indeed hoisted the Samoa flag again. Once again they replaced it with the German war pennant. Stübel had gone too far. In Berlin Bismarck reminded the German navy in the middle of February that it was not in Samoa to establish a German protectorate (Nuhn 2002: 75). He also took care to assure London that he had never ordered the raising of the war banner and that Germany still recognised Laupepa's government until the powers had come to an understanding (Ward 1976: 306). Berlin's intervention did not help Laupepa much. In desperation, he turned to New Zealand for help and, because of London's opposition, pleaded in vain for annexation by Great Britain or New Zealand. He even lost his seat in government. On the pretext that for years they had not paid the rent of the land owned by the DHPG, he and his supporters were evicted from Mulinu'u. They withdrew to Apia where the flag they raised was lowered by Stübel and his sailors at the end of December.

When, in January 1886, Laupepa, having moved lower down the bay of Apia, flew his flag there, Stübel acted once more. Stübel, in the estimation of Thurston, a man who had shown 'great want of discretion, and an amount of temper incompatible with the dignity of his office', boarded the Albatross, sailed to the new seat of Laupepa's government and there hoisted the German war pennant. Using 'abusive language' he ordered the king to take down the Samoan flag. ${ }^{6}$ When Laupepa refused, Stübel called in the help 
of an armed party from the Albatross. Under the protests of the American and British consuls, who by now had also arrived on the scene, Stübel ordered a sailor of the Albatross to climb into the tree where the flag had been hoisted and remove it. In London the German ambassador, Hatzfeldt, took up the incident, asking the British government to restrain its 'strong anti-German' consul, Wilfred Powell. Salisbury was not impressed, replying that 'the German Consul was quite as much in need of recommendation of a peaceful character from home'.?

German support for Titimaea, in what by now was a fully-fledged civil war, culminated in April when the German East Asia Squadron, four warships in total, called at Samoa and its commander, Knorr, now a rear admiral, left no doubt that in his view Titimaea was the rightful ruler. To add to the confusion, after the German squadron had sailed away the American consul raised the American flag and declared Samoa an American protectorate on 14 May 1886. As Berlin had done, Washington renounced the act of its consul, but in the United States among proponents of a more active American Pacific policy there was support for this 'timely and courageous action of an American representative at a distant post', as his successor as consul, Herald Marsh Sewall (1900: 11), would later phrase it. In view of such complications, Bismarck now thought it wise that, for the time being, no German warships would be directed to Samoa (Nuhn 2002: 76). The incidents were illustrative of, as it was called in a report by Friedrich Richard Krauel of the German Foreign Office on the visit to London in October 1886, 'the recurrence of past jealousies and recriminations between the foreign Consuls which rendered good government and its results, the security of life and property, and the maintenance of peace and order almost impossible in Samoa. ${ }^{8}$

At that moment the powers were already working on a solution. In June 1886 Great Britain, Germany and the United States each sent a special Commissioner to the islands for an on-the-spot investigation into the causes of disorder. London assigned Thurston with the task, Berlin appointed G. Travers, the German Consul General in Sydney, and Washington sent George H. Bates. On the basis of their reports, the three powers were to meet in Washington, where Bayard played the card that as the United States had so few real economic interests in Samoa, it could act as a perfect mediator between Germany and Great Britain. ${ }^{9}$ Furthermore, in August London

7 Ibid.

8 Memorandum Hervey 3-11-1886 (PRO FO 534 35).

9 Memorandum W.A Cockerell 1-4-1887 (PRO FO 534 35). 
agreed to a suggestion from Berlin, made as early as March, to recall their quarrelling consuls in Samoa, Stübel and Powell.

The German position was clear. Emphasising the 'absolute preponderance of German interests', Berlin wanted such dominance to be reflected in the agreement reached. If the preference was for an international trusteeship, with Germany, Great Britain and the United States successively being entrusted with heading the administration, then it should be a German who took the first turn. Were Samoa to remain independent, then 'native affairs should be left to the natives', but a government composed of foreigners, in which Germany should have 'the absolute majority', should be established to look after their specific interests. ${ }^{10}$ For this, Berlin was even prepared to withdraw its support for Titimaea.

Still, as Herbert von Bismarck had phrased it, in their colonial honeymoon, though love was disappearing quickly, Germany and Great Britain tried to find a mutual understanding before the start of the Washington conference, also with respect to the complicated and sensitive issue of land titles. Yet there were obstacles. Thurston was sure that a majority of German representatives in a Samoan government, or even in Apia's municipal board, which was Berlin's aim, would only add to the discord between the foreign communities in the island group: "The rivalry and ill-feeling, so long existing, would not be allayed, but highly aggravated'." The final result could well be that Great Britain and the United States would make one front against Germany. The German government wanted to avoid such an outcome, discussing a possible solution with the British first, before submitting their plans to the Americans. London responded well to the German overture. It even drafted a proposal about the desired political structure of Samoa. Taking up the suggestion of the German ambassador in London about a foreign adviser to assist a newly elected king, the British suggested that a German should be the first to take up such a function.

At that time, Samoa losing its independence almost seemed to be a foregone conclusion. The only questions that remained were when and who would get what. On the German side there was a strong tendency in favour of replacing indigenous with foreign rule. Initially, Thurston even suspected the Germans in Samoa, in particular Weber, of deliberately trying to bring this about by creating a situation of perpetual disorder through their support of Titimaea..$^{12}$ In the end he came to the same conclusion as

Memorandum Krauel 3-11-1886, Hatzfeldt to Iddesleigh 10-11-1886 (PRO FO 534 35).

Confidential dispatch Thurston to Stanhope 8-1-1886 (PRO FO 534 35).

Thurston to Stanhope 8-10-1886 (PRO FO 534 35). 
the Germans that indigenous rule was to the detriment of law and order. In his report to the British government he concluded that 'the Samoan natives are incapable of forming, independently, a stable and efficient administration'. The only satisfactory way, he suggested - and London was to agree - 'of preventing the peace of the islands from being disturbed by conflicting native claimants to the throne, and of securing the interests of the three civilised nations' was foreign supervision. ${ }^{13}$

\section{The Tonga Islands}

Yet another source of discord between Great Britain and Germany influencing negotiations loomed - the status of the Tonga island group, or the Friendly Islands as Captain James Cook had baptised them. In Tonga, Germany had acquired a coaling station at the Vava'u Islands in the north as a consequence of the treaty with King George Tupou I in 1876, and Anglo-German business competition intensified after the New Zealand firm McArthur \& Co. had taken over the estates of Ruge, Hedemann and Co. in 1880 (Koschitzky 1887-88 II: 30). In December 1884 the status of Tonga had already been discussed in the margins of the Congo Conference. The British representative, Meade, had suggested that, as compensation for German concessions elsewhere, Great Britain could agree to a neutral status for Samoa and Tonga. Bismarck dismissed the proposal and told Meade that (as in the Bismarck Archipelago) German economic interests and settlements were predominant, which would make agreeing to their neutral status a German and not a British concession. In April 1886 the joint Anglo-German commission delineating the British and German sphere of influence in the South Pacific had agreed upon the neutral status of Samoa and Tonga, but this had not stopped Germany and Great Britain from quarrelling and worrying about the two island groups.

Already during a meeting with Travers in October 1886 Thurston alluded to his fears that Germany, after taking hold of Samoa, might turn its attention to Tonga. He left no doubt that Germany expanding its influence in these islands was even more unacceptable to the British. Tonga was within one day's sailing from Fiji, and might even be considered 'Eastern Fiji'. Travers was quick to react, asking how Great Britain would respond with regard to Samoa when Germany gave it a free hand in the Tonga Islands. Thurston did not take up the suggestion of Great Britain abandoning its 
interests in Samoa in return for Germany doing the same in Tonga. Yet he did not fail to point out that, should law and order collapse in Tonga, which at that moment was not the case, Great Britain might well claim the islands 'on behalf of the Colonies generally, and of Fiji in particular'. ${ }^{14}$ Privately, the scheme appealed to him. Regarding Samoa 'in all but name ... a German dependency' and pointing out that the British position in Samoa was 'not sufficient to make it worth being on unfriendly terms in respect of them with a neighbouring Power having such intimate relations with us as Germany', he suggested accepting Travers' suggestion. In view of the 'unstable character of the Samoans' and the 'present disposition of Germans', any solution in which Samoa remained independent would only 'lead to new complications and further unprofitable entanglements'. It would be much better to try to reach 'amicable and favourable settlements to our convenience in other places' and, for instance, ask Germany to 'withdraw her political interests, acquisitions, and influences in Tonga'. To strengthen his argument, Thurston added that the British navy did not need a Samoan coaling station. Fiji served that purpose as well. It would be even better for the navy to establish an additional coaling station not in Samoa, which was relatively close to Fiji, but somewhere further to the east. ${ }^{15}$

The idea appealed to London and in January 1887 the British ambassador, Edward Malet, was instructed to suggest this possibility when Samoa came up in his conversation with representatives of the German government. ${ }^{16} \mathrm{~A}$ new diplomatic tug of war was born. The German and the British governments both began to emphasise how important Tonga was to their own Empire, each trying to demonstrate that their country's share in Tongan trade and commerce far exceeded that of the other. In his conversation with Thuston, Travers had mentioned that German trade in Tonga was 'slipping away', but when a few months later, Baron von Plessen, the German Chargé d'Affaires in London, visited Salisbury the opposite case was argued. Plessen told Salisbury that the Tonga Islands 'were most important to Germany and that German interests there in regard to shipping and the export trade were considerably larger than those of Great Britain'. Moreover, as law and order prevailed in Tonga there was no urgency to intervene in its internal affairs. Consequently, the island group could not be viewed in the same way as Samoa. ${ }^{17}$ Salisbury struck back though. Henry Francis Symonds, the former 
British consul in Tonga who had just been transferred to Samoa, provided him with the ammunition. The German commercial interests, Symonds had reported, were falling rapidly below those of Great Britain. There were forty-two British merchants in the islands and only thirty-four German ones; against the sixty-three German nationals living in the islands stood $15^{0}$ British subjects. Shipping tonnage confirmed the British preponderance. Also, to turn to the field of religion, Christianisation of the Tongans was largely due to the efforts of the British Wesleyen Church. Salisbury submitted the information to Count Paul von Hatzfeldt, the German ambassador, stressing that German control over Samoa would not go down well in Australia and New Zealand either. London required something in return to demonstrate that an agreement with Berlin about Samoa was 'reasonable and harmless to Colonial interests'. In short, Tonga - whose Prime Minister was already a British national, but this fact should not enter negotiations to avoid London overstating its case - should be brought within the British sphere of influence. The matter, Salisbury added, was all the more pressing since the king was old and civil disorder might follow if he died or become incapable of governing. Such complications had to be prevented on an island group located so close to British held Fiji. ${ }^{18}$

Germany could not agree, also not with the figures provided by Symonds. It was an error, Plessen told the British government in April, to suppose that German commercial interests in Tonga had fallen below those of Great Britain. The British figures gave a highly distorted picture. There were forty-two Germans in Tonga engaged in trade, of whom only three worked for a British firm. Of the British living in the islands, on the other hand, twenty-one were in German employ. Apart from that there were ten German firms represented in Tonga, the biggest one employing thirty-four people. The number of British firms was seven, while they had, at the most, fifteen employees. Symonds, Plessen pointed out, had moreover only been able to show a larger tonnage of British shipping by including 'two visits of a steamer on a pleasure trip'. No other conclusion could be drawn: German trade and shipping exceeded those of the British. ${ }^{19}$ But Great Britain was not yet defeated. Plessen had boasted of a German monthly shipping line that had been recently established and which called at Tonga; one of the lines Bismarck had championed. Its existence, he had said, 'made the superiority of the German flag still more considerable'. ${ }^{20}$ His words gave Great Britain

Memorandum Plessen 15-4-1887 (PRO FO 534 35).

Thurston to Colonial Office 13-9-1887 (PRO FO 534 35). 
the opportunity to retaliate. 'The steamer', Thurston wrote, 'one of a large tonnage, carries little or no cargo, and but for the heavy State subvention the line receives, could not be maintained there'. There was, he argued, nothing amiss with mentioning the pleasure trips. They carried many passengers, and even some cargo, while the freight of the German liner 'does not, it is believed, pay her wages bill. ${ }^{21}$

\section{Civil war in Samoa}

When London instructed Malet to investigate the Tonga solution, in Samoa Weber and the new German consul Eduard Becker put their full force behind Titimaea. On their instruction, Eugen Brandeis, a former Bavarian officer and now in the employ of the DHPG, became Prime Minister of Titimaea's government in January 1887. Among his tasks was the drilling of Samoan troops and the routing out of any resistance remaining against Titimaea. On the diplomatic front matters had not improved, with Germans viewing the British and Americans with much suspicion, and vice versa.

What followed put a strain on the relations between the United States and Germany in particular. In June and July 1887 the Washington Conference took place to discuss the future of Samoa. Bismarck entrusted the negotiations to his son, Herbert. Weber attended as member of the German delegation. The atmosphere was far from friendly. Herbert von Bismarck refused to shake hands with one of the American negotiators who had written an article in favour of the United States taking control of Samoa because the islands were the 'key of maritime dominion in the Pacific' (LaFeber 1998: 139). The conference came to nought. Great Britain did acknowledge Germany's economic preponderance and, consequently, was prepared to allow Germany to play a leading political role in the island group. London could do so not only because the British stakes were much smaller than those of Germany and the United States, but also because the British government considered the Samoa dispute irrelevant compared to the other international complications the country was involved in. As Salisbury was to write a few months later to Malet: 'Samoa matters very little to us' (Ward 1976: 308).

The United States, though equally convinced that the commercial value of Samoa was not that great and might remain small (Sewall 1900: 13), refused to follow the British, and demanded a joint three-power administration. 
Washington, declining to annex Samoa itself, presented itself a champion of Samoa's independence and was determined that Samoa should not come under the control of another power (Dulles 1938: 111). It also did not want to part with Pago Pago. As its commissioner to Samoa, George Bates, suggested, now that the United States had acquired a foothold in Samoa 'it would be shortsighted indeed if we were to permit the advantage of this action to slip away from us by leaving the way open to European domination in this group' (Dulles 1938:113). It was a foothold Bates valued very much, convinced as he was that after the construction of the Panama Canal the importance for inter-Pacific shipping of Samoa would outshine that of Hawaii. Pago Pago was destined to become 'the key of maritime dominion of the Pacific' (Dulles 1938: 126). Washington agreed. Increased Pacific passenger and freight trade made the islands too valuable to retreat. As Secretary of State Bayard explained during the conference, the transcontinental railway and the prospects offered by the Panama Canal gave Samoa a highly strategic position (LaFeber 1998: 55). Those Americans who were in favour of annexing Hawaii argued the opposite, stressing the advantages of Pearl Harbor over Pago Pago.

In August, just after the Washington Conference and at a moment when there were no American or British warships moored at Apia, the Germans in Samoa acted against Laupepa; apart from his impolite letter to the Kaiser, among his other sins was his refusal to offer his apologies - and pay damages - for the maltreatment of German nationals celebrating the Kaiser's birthday in May in a bar in Apia, and for the theft from German plantations during the previous four years. Using the insult to the Kaiser as an excuse, Bismarck decided that the time had come to act and ordered the German East Asia Squadron to Samoa. Care was taken that it would arrive when there were no British and American warships in Samoan waters, and also after the Australian mail boat had left Apia on 23 August. This would give the German warships a couple of weeks to act in which no news from Samoa could reach the outside world; or as Stevenson (1892: 68) wrote, 'when the eyes of the world were withdrawn, and Samoa plunged again for a period of weeks into her original island absurdity'. Backed by the presence of the Bismarck and four other German warships, Becker declared war on Laupepa on 24 August 1887. The German flag was raised over Government House in Apia and German troops raided Apia and searched houses in the hope of arresting Laupepa. With German backing, Titimaea was now formally declared king and moved from Leulumoega to Mulinu'u. German warships, flying his flag, sailed to different parts of Samoa, spreading the news of him being king. In one of the villages they sailed to the proclamation was torn 
up: 'For this offence the village was ultimately burned by German sailors, in a very decent and orderly style' (Stevenson 1892: 73). In Washington Bayard dismissed Titimaea's government in a note to Berlin as a 'government of the islands by the local German commercial and landed interests' (Dulles 1938: 113). One of Brandeis' deeds was to do away with the special status of Apia and its municipal board in October 1887, bringing the city under the jurisdiction of the Samoan government, a decision ignored by its nonGerman residents (Gilson 1970 391-2).

Laupepa surrendered in September and was first deported to Cameroon, and subsequently, for reasons of health, to Jaluit. Weber tried to make use of the German moves to acquire a monopoly over the copra trade. Britons, Americans and other non-German nationals feared that their land titles were at stake (Staley 1935: 7). Samoans themselves did not take kindly to the new government and the repression to which the German navy resorted to enforce its acknowledgement. They were, as Gilson (1970: 393) wrote, 'whipped into a revolutionary fury' by the 'reign of terror'. Civil war once again erupted in September 1888 when Mata'afa Iosefo, who had declared himself king, turned against Titimaea. The German consul, confronted with a large popular rebellion, and finding the presence of one German warship insufficient, had to ask for and received the backing of two additional ones (Nuhn 2002: 82). Prospects for the Germans looked bleak. Titimaea could not stand his ground against Iosefo's soldiers, who Brandeis to his surprise discovered 'were well-trained and commanded', forcing his Samoan troops to retreat to Mulinu'u, where they had to seek the protection of German marines (Nuhn 2002:83). The rebels were also well-armed, for which the commander of the only German warship present, Captain Ernst Fitze, blamed the British and the Americans. Fitze did not fail to inform the German Admiralty about his suspicion, adding that the Iosefo's rebel force were gaining the upper hand. In Berlin the reaction was one of 'rage and indignation' (Nuhn 2002: 82-3). Bismarck decided that stern action was in order.

The decision to end the rebellion by engaging German soldiers misfired. In December 1888, German troops suffered a humiliating defeat. A navy detachment of 140 men sent ashore at Fangalii to engage the followers of Iosefo was ambushed and suffered heavy losses. According to Stevenson (1892: 213), and later authors often copy this figure, fifty-six of them were killed or wounded; the actual number of dead was probably 16 , while 30 Germans were seriously injured (Nuhn 2002: 85). Fritze asked Berlin for an additional thousand soldiers.

The German action was ruthless. They applied excessive force. As the American consul reported: 'Shelling and burning indiscriminately, 
regardless of American property. Protests unheeded. Natives exasperated. Foreigners' lives and property in greatest danger. Germans respect no neutral territory' (Dulles 1938:115). On top of this, the new German consul, Wilhelm Knappe, having taken up his post in November, informed the British consul that martial law apply to non-German nationals as well and that non-German ships could also be searched, as indeed they were. This was a mistake. Bismarck, telling Knappe that he had no authority over non-German settlers and that Germany did not want to put Samoa under German administration, ordered him to back down immediately. He blamed Knappe's behaviour on morbus consularis. Nevertheless, after consultation with the new Emperor, Wilhelm II, only about half a year in office, German Naval Command prepared for large operations in Samoa. Bismarck, also after discussing the matter with the Kaiser and fearing international complications, especially with the United States, did not want to hear of it, and disavowed Knappe and Brandeis (Nuhn 2002: 87-8; Gilson 1970: 396).

In Washington Congress earmarked extra money for the protection of American interests in Samoa and for the development of Pago Pago. President Cleveland furthermore decided to send two additional warships to Samoa, where one American warship was already stationed, as 'a gesture of protest against the amoral actions of the Germans' (Nuhn 2002: 88). Matters might have developed into a serious international conflict between the United States and Germany. Germans and Americans in the city 'were on the brink of war, viewed each other with looks of hatred, and scarce observed the letter of civility', Stevenson (1892: 247) noted. In the United States, public opinion was aroused. People demanded action. There was 'a growing popular demand for an aggressive foreign policy' (Dulles 1938: 120). The mood had definitely become anti-German: 'Germans in America publicly disavowed the country of their birth. In Honolulu, so near the scene of action, German and American young men fell to blows in the street' (Stevenson 1892: 247). American politicians were not immune to voicing such nationalist sentiments; though there were also those who questioned whether Samoa was worth all the trouble and all the money. They presented Europe as a threat to the American presence in the South Pacific and called for decisive action by the American government. Losing Pago Pago would be a disaster (Dulles 1938: 119-0).

In March 1889 disaster struck. At that moment three American, three German and one British warships were moored in Apia to protect the interests of their nationals and the Samoan faction they backed. All were 'ready for battle' (Nuhn 2002: 89). The American warships included the USS Trenton. On board was the commander of the American Pacific Station, 
L.A. Kimberley. A confrontation was avoided because on the $16^{\text {th }}$ a hurricane destroyed six of the warships. Only the British HMS Calliope was not shipwrecked. Ninety-three Germans and 117 American perished. To Stevenson (1892: 245), the loss of 'any modern war-ship with the power of steam' in Apia belonged 'not so much to nautical as to political history'. Their captains had ignored the warning signals of an impending hurricane and, entangled in the show of power in Samoa, had not left the bay.

The loss of the warships brought about a new round of talks. On the invitation of Bismarck the three powers involved in the Samoan conflict met in Berlin in April. Again Washington came out in favour of Samoa's independence. In the words of the American Secretary of State James G. Blaine the United States refused 'to subordinate the right of this amiable and dependent people to the exigencies of a grasping commerce, or to the political ambition of a territorial extension on the part of any one of the treaty powers' (Dulles 1938:124). In June a compromise was reached. Samoa was to become a 'Condominium', a joint protectorate. In the Final Act of the Conference on the Affairs of Samoa (sometimes referred to as the Samoa Convention or the Berlin General Act of 1889) Germany, Great Britain and the United States agreed to respect 'the Independence and Neutrality of the Islands of Samoa'. ${ }^{22}$ The powers recognised Laupepa as king; also because Berlin was adamant against Iosefo holding that position. The Germans could not forgive him the defeat he had brought upon them. Because of the 'disordered condition of government' in Samoa Laupepa becoming king would not be subject to an election. That of his successor would. He would 'be duly elected according to the laws and customs of Samoa.. ${ }^{23}$

Iosefo detested the selection of Laupepa by the powers and insisted on an election. That he was a popular leader became evident in October when the Samoans, disregarding the powers, proclaimed him king (with Laupepa as deputy king). The following month in November, Laupepa returned to Samoa on board the German gunboat Wolfafter two years in exile. He was received with 'royal salute' (Nuhn 2002: 92). Among those to greet him was Stübel, now the German Consul General in Samoa (Knappe had, as other German officials before and after him, been recalled for incompetent, headstrong behaviour, and getting in the way of Berlin's diplomatic strategy). Laupepa, reluctant to take the throne, and even speaking out in favour of Iosefo, was crowned in December, with the foreign warships once more firing their salutes. Iosefo resigned as king, but soon turned against the 
new government. In 1891 he was branded a rebel by the powers. Two years later, he was exiled to Jaluit for rebelling against Laupepa.

The three powers also forbade the import of fire arms and alcohol and, more importantly, agreed on the setting up of a Municipal Council of Apia and a Supreme Court. If they could not agree on the people to head these institutions, the king of Sweden and Norway would decide. The Head of the Supreme Court, the Chief Justice, who could be removed at the joint request of two of the three powers involved, would act as adviser to the Samoan government. The first to hold the position was a Swede, Otto Conrad Waldemar Cedercrantz. He assumed office in 1891. It was decided in Berlin that the President of the Municipal Council of Apia should 'be a man of mature years, and of good reputation for honour, justice and impartiality'. ${ }^{24}$ If the powers were unable to agree on a candidate he should come from a neutral country (mentioned were Sweden, The Netherlands, Switzerland, Mexico and Brazil). The first President of the Municipal Council was a German, Arnold Freiherr Senfft von Pilsach. He was not selected from among the residents. Instead, following the position being the outcome of diplomatic bickering, the decision was made to give the post to a German civil servant appointed by Berlin. Accused of mismanagement Senfft von Pilsach had to resign in 1893 . His successors were also Germans.

An agreement on the problem of land titles also was reached. There should be no new alienation of land to foreigners, who in future would only be allowed to lease land, not to buy it; and this only with the agreement of the king and the Chief Justice. Existing land titles were to be investigated by a commission made up of representatives of the three powers to be assisted by a 'Native Advocate', who had to enlighten the commission about local customary law. Final responsibility lay with the Chief Justice. Inspired by what had happened in Fiji, where the Land Commission had proceeded slowly, the Samoan commission had to finish its task in two years, later expanded to three and a half years (Gilson 1970: 407). Valid claims should be properly registered. All land obtained before 28 August 1879, the date of the Anglo-Samoan Treaty, moreover, had to be regarded as validly acquired, providing it had been purchased 'in good faith, for a valuable consideration, in a regular and customary manner. ${ }^{25}$ The land claims were settled by a fact finding commission and the Supreme Court. Among the criteria to decide whether they were valid was that the land had to be occupied and cultivated for ten years. This highly favoured those land titles Weber held 
for the DHPG, and was a blow to those who had been involved in land speculation. Hence, $5^{6}$ per cent of the German titles were acknowledged, seven per cent of the American ones, and three per cent of the British ones (Gilson 1970: 411). Proof of payment was also necessary. Titles of land paid for by providing firearms and liquor were not recognised. ${ }^{26}$ Claims to a total of 1.7 million acres were investigated; only the titles of 135,000 acres, or about one-fifth of Samoa's total acreage, were deemed legal (ibid.: 411, 415).

American opinion about acquiring territory had been and remained ambiguous and divided along party lines. Not everybody in the United States was happy with what had been agreed in Berlin. Some did not see why the country needed a naval station in faraway Pago Pago or did not understand why, as The Nation wrote, it should worry about 'a group of islands in the South Pacific Ocean more distant from our shores than Berlin itself' (Dulles 1938: 120). The most powerful opponent was President Cleveland, who assumed office in March 1885. While under his successor, Benjamin Harrison, London would be warned that it should keep away from Pago Pago, Cleveland suggested, in vain, to the American Congress that the United States should withdraw from Samoa. Pago Pago - though still not much of a coaling station - was too dear to the Americans (Dulles 1938: 128-9; LaFeber 1998: 140). Similar misgivings about staying in Samoa were expressed in London and Berlin, in the latter case inspired by the adverse effects of years of turmoil on the financial results of the DHPG (Nuhn 2002: 94). 


\section{The Emerging Economic World Powers}

A frequent lament in Great Britain in the 189os was that, in the past, the British had virtually monopolised China trade and that now others were demanding their share. British business circles bewailed the progress other nations were making and were inclined to accuse the British government of apathy, of not doing enough to promote and protect British commerce in the Far East. Sometimes such observations went hand in hand with complaints about trade protectionism by other powers in their colonies and protectorates and the subsidies that foreign governments, those of France, Germany and Japan, gave to railways, shipbuilding and shipping lines. Another practice foreign competitors were accused of was undercutting prices, and offering products inferior to those produced by the British, which sold well precisely because they were cheaper.

At that time, Great Britain was still by far the dominant commercial force in China trade, at the close of the century still responsible for two-thirds of China trade; but new rivals had appeared (Curzon 1896: 281; Chambre 1898a). The United States and Germany were looking for markets for their surplus industrial products (and in the case of the United States also agricultural ones, cotton being among the most important), their politicians and economists - and likewise their British colleagues - reflecting on what winning or losing markets meant for domestic employment and prosperity. In both countries, however agitated some of their businessmen and politicians might become about China's commercial prospects and its Open Door, from a general perspective trade with China only played a minor role, amounting to a tiny percentage of total foreign trade (LaFeber 1998: xxvii, 301; Wertheimer 1913: 71; Conrad 2008). Both the United States and Germany, and also Great Britain, had to deal with increasing economic and political competition in China from yet another newcomer, Japan, which had the obvious advantage of proximity.

\section{Germany's world politics}

The first new economic power to make its mark was Germany, making the transition from an agricultural to an industrial nation in the last decades of the nineteenth century. The change was accompanied by a desire to manifest itself, not only in Europe but also in the wider world. One of the champions of such a new German role was Wilhelm II, who since he had 
ascended the thrown in 1888 had enthusiastically endorsed the transformation of the country from a continental inland power into a nation with world ambitions. The prestige of Germany and its Emperor had to be enhanced. Germany should become a world power. In 1897 Weltpolitik, world policy, became the aim, giving the acquisition of overseas possessions and the delineation of spheres of influence a new impetus; not only contributing to international complications in Samoa, but also in China and the Philippines. As in Bismarck's days, conflicts over colonial affairs with other powers were the result. And, again as in Bismarck's days, Wilhelm II tried to exploit Great Britain's tense relation with Russia and France to further German interests. Or, as it was phrased in a memorandum from the German Foreign Office in 1895 , he wanted Germany to react in such a way that 'when the moment arrives when England absolutely needs us and begs for help, we can exact proper payment, and if a conflict takes place without our being involved in it, we can take what we want ourselves'.

Wilhelm II might have had great plans. When he saw off troops on their way to China in December 1897 he impressed upon them that their expedition was just the first step of the tasks Germany had set itself overseas, and that the stunning development of German trade made it his duty to give Germans abroad the protection they wanted him and the Empire to give them (Weicker 1908: 39). Weltpolitik was fully supported by Prince Bernhard Heinrich Karl Martin von Bülow, between 1897 and 1900 Minister of Foreign Affairs and Chancellor from 1900 to 1909. Bülow wanted to do away with the country's 'tepid and vacillating policy in the Far East'. ' Germany, he would explain in the Reichstag in December 1899, had been drawn into world politics by the 'rapid growth of its population, the unprecedented flourishing of its industry, the thoroughness of its merchants and the enormous vitality of the German nation'. To some British alarmists at that moment, and there were many, Germany had already grown into an enemy to count with, also in Asia. One of them, Pickering (1898: 267), was even sure that Germany, motivated by what he described in a letter to the London and China Telegraph in 1897 as its 'insane jealousy of England', would eventually annex the Netherlands in Europe and its colony, the Netherlands Indies, in Asia. Should this happen, then the British in Asia would be encircled by

1 Memorandum German Foreign Office 20-2-1895 (www.mtholyoke.edu/acad/intrel/gerchin. htm).

2 Wilhelm II to Bülow 7-11-1897 (E.T.S. Dugdale, German Diplomatic Documents, Vol III, The Growing Antagonism, 1898-1910; www.mtholyoke.edu/acad/intrel/dugdale/Kiao-Chou.htm).

3 Germanhistorydocs.ghi-dc.org/pdf/deu/6o8_Ungeleicher\%2oVertrag (accessed 3-1-2011). 
Russia on the north and west, by France on the east, and by Germany on the south, east, and south-west' (Pickering 1898: 261).

Even in the spiritual sphere there was a special role to play, providing powers and their governments with a prestige they might be in want of in other fields and sometimes also with a motive to act. Not only did commerce follow in the wake of missionaries, so, at times, did the flag. One of the additional responsibilities Russia and France had taken upon themselves, and at times used as a justification to interfere in internal affairs of weaker nations, was that of protector of Christians living amidst Muslims and heathens. As early as 1853 , and only months after Napoleon III had been crowned Emperor of France, a conflict between France, Russia and Turkey over the protectorship of Christians and the Christian holy places in Palestine had been at the root of the Crimean War. Among the other regions where France claimed such a role was China and its vassal states, a country to which foreign missionaries, Protestants and Roman Catholics, of many nations, among them Britons, Frenchmen, Americans and Germans, had flocked to spread the Gospel. Germany could hardly accept such a French role for its own Roman Catholic citizens, and in 1875 the German government made it clear that 'it recognised no exclusive rights of any protection of any power' of German Roman Catholics in the East. If necessary, Germany would take on such an obligation itself. ${ }^{4}$ In 1890 actions matched deeds. This happened after the German minister in Beijing, Max von Brandt, had suggested that one way to counter a growing French influence in China and Southeast Asia was to take on a more active role in the religious field. Brandt's idea appealed to Wilhelm II. He reacted positively to a request by Johann Baptist von Anzer, the German bishop of the southern Shandong (Shantung) vicariate in north eastern China, the region where German missionary activities were concentrated (Chambre 1898a: 440). Anzer was an ideal partner for a more forceful German stand in China. He was, as one German author described him, a man with a 'warlike mind', a person it was easy to imagine with 'a cross in the one hand and a naked sword in the other, of whom it would not have come as a surprise when below his bishop's garb all of a sudden a shining cuirass would have become visible' (Weicker 1908: 58). Opting for Germany suited Anzer and the other Steyl missionaries, 'aggressive nationalists' and 'aggressive proselytisers' as they were, to use the words of Esherick (1987: 80). After lengthy negotiations with Rome, Wilhelm II took on the protectorship of the German Roman Catholic

4 en.wikisource.org/wiki/catholic_encyclopedia (1913)/ protectorate_of_missions (accessed 14-7-2010). 
Steyl Mission of the Society of the Divine Word (SVD). He valued his newly found status greatly. Bishop Anzer was presented with a royal honour once the protectorship was a fact.

Germany's ambitions were made possible by a rapid economic and industrial growth, which allowed Germany to emerge as one of the leading economic nations in the world, overshadowing Great Britain in a number of sectors of the economy, and reducing the gap in others. In the mid-188os, when coal mining and the iron and steel industry experienced a boom, Germany became one of the major coal and steel producers in the world. It would also take the lead in the chemical and electrical industries and in the production of precision instruments and optics. By 1914, Germany would be 'the European frontrunner in chemicals, the world leader in electrical goods' (Blackbourn 1997: 331). All this made Germany's share in world trade increase markedly; its advance only being surpassed by that of the United States (Blackbourn 1997:330). It also meant, however, that China remained insignificant when aggregate Germany export figures are considered, its market - an exception being armaments - not yet ready for the high-tech products the Germany producers excelled in (Wertheimer 1913: 71).

The growth of merchant shipping and shipbuilding made the German Empire a seafaring nation of importance. Not just increase in trade had contributed to this. Berlin's colonial policy and its suspicion of Great Britain were equally important factors. The German overseas possessions and business enclaves should have their own sea connections with the motherland. To become independent of Great Britain at sea, and eventually to rival it, the creation of shipping lines to Africa and the Pacific to take care of the country's intercontinental freight and passengers traffic were crucial. Granting financial support to establish such lines became one of the cornerstones of Bismarck's colonial policy in the middle of the 188 os. Once he had turned in favour of acquiring colonies in Africa and the Pacific, Bismarck submitted to the Reichstag a plan to create new German steamship lines. At that moment, in 1884 , the Hamburg-Amerikanische Paketfahrt Aktien-Gesellschaft, better known as the Hamburg-Amerika Linie (founded in 1847) and the Norddeutscher Lloyd (founded in 1857), sailed from Hamburg and Bremen to the United States, but there were no regular German lines to the Far East, Australia and Africa. In view of the growing commercial interests in those parts of the world, and in anticipation of the opening up of China to foreign investment and trade, Bismarck aimed to fill the gap. The new lines should provide Germany with its own freight and passenger connections with distant parts of the world, competing with existing ones, in particular those British-owned. Bismarck asked permission 
from the Reichstag to subsidise three such lines. One to Singapore as the main port of destination with onward connections to Hong Kong, Shanghai, Korea and Japan; one to Australia with a sideline to call at Tonga and Samoa; and one to Africa. With these shipping lines, German mail, freight and passenger traffic no longer had to use foreign mail steamers and freighters. An additional argument in favour was that German shipping lines would allow for communication independent of the goodwill of other countries between Navy Command in Berlin and the German warships sailing the Pacific or the coast of Africa, where such warships had become an indispensable tool in backing up German presence (Koschitzky 1887-88 I: 256).

Bismarck expected that his proposal would fail to gain a majority in the Reichstag. There was too much opposition by members who were said not to understand what was wrong with sending German freight along with British vessels or who recoiled from the financial risk of a subsidy (Koschitzky 1887-88 I: 258-60). Those in favour stressed trading prospects. Among them was H.H. Meijer, founder and director of the Norddeutscher Lloyd, who expected that the opening up of China would result in a rising demand for railway materials and other industrial products. He also suggested that the liners should be constructed in such a way that, with some adjustments, they could serve as auxiliary warships (as some would later in World War One) (Koschitzky 1887-88 I: 260). To get what he wanted Bismarck indicated that he was prepared to settle for a compromise, and that of the three lines proposed, that to Africa was the least important. Vital were those to East Asia and Australia, the second one especially in view of the German interests in Samoa. Two lines it would be. In April 1885 the Reichstag agreed to those to the Far East and Australia.

The subsidy to create the new lines went to the Norddeutscher Lloyd. One of the conditions demanded by the government in return for its money was that, when necessary, the mail boats should be available for the transportation of troops. The first steamer of its East Asia line to sail was the SS Oder. In June 1886, its departure from Bremerhaven was 'marked by a patriotic demonstration, attended by representatives from the highest Imperial and Bremen governing bodies, the Chinese Minister in Berlin, and numerous members of the Federal Council and the Reichstag' (Taylor 1908: 201). The following year the Australia line was initiated. From Sydney there were connections to Japan via Hong Kong and to New Guinea. In addition, there was 'an excellent service of small steamers plying among the lovely islands of the South Pacific' (Taylor 1908: 201).

The German liners became an object of pride. They earned admiration at home and abroad. Colquhoun (1902: 226) wrote that the (British) Peninsular 
and Oriental Steam Navigation Company ( $\mathrm{P} \& \mathrm{O})$ with its 'high prices, limited accommodation and ... scant courtesy' could not stand comparison. Also, the British Commander, Basil Taylor (1908: 201), praised the 'excellent service' maintained by the Norddeutscher Lloyd 'between Europe and all the chief ports east of Suez'. He noted that the growth of the company had 'been due to the care exercised in seeing that passengers lacked no comforts' and that by the mid-189os the vessels designed were of 'the best type of steamer for the tropics'. The Hamburg-Amerika Linie, which opened a service to the Far East as well, earned similar praise. In 1908 one British author wrote how the Hamburg-Amerika Linie, 'by careful navigation, strict discipline, efficient organisation, and constant effort to promote the comfort and convenience of their patrons ... grew and prospered year by year', becoming 'one of the greatest steamship companies in the world' (Wright and Cartwright 1908: 466). German ocean-going steamships were also faster than other commercial vessels in the world; between 1898 and 1907, holding the Blue Riband, the award for the passenger liner crossing the Atlantic in record speed. To the alarm of the British Admiralty, such German liners sailed faster than the British cruisers (Massie 1993: 493). It was not only a matter of speed and comfort, but also of prestige. As one member of the House of Lords exclaimed: 'Our mail steamers show the flag in distant harbours. They create an influence similar in kind and scarcely inferior in degree to the visits of warships. ${ }^{5}$

By 1886 the German community in the Far East was already large enough to warrant the publication of a German newspaper, Der Ostasiatische Lloyd. Its first edition appeared in October of that year in Shanghai; a port city in which, according to a travel guide from 1905, the German position in the foreign settlement was 'influential' (Darwent 1905: 166). A similar remark can be made about the second centre of China trade, Hong Kong. In Hong Kong the German community, Bickers (2012: 310) notes, was 'socially and commercially prominent'.

The German accomplishments impressed many, whether they were British, French, Americans or Chinese; all praised the entrepreneurial spirit of the Germans and their work ethic. In Great Britain there was some soul-searching about what the Germans did right and the British did wrong. The answer was inspired by a mix of awe, fear of losing out on a competitive market, popular perceptions and actual observations. As early as 1875 , the Brisbane Courier (6-8-1875) noted that German products

5 Lord Brassey in House of Lords 8-7-1902 (hansard.millbanksystems.com/lords/1902/jul/o8/ merchant-cruisers-in-the-navy). 
were cheaper than British ones and that German merchants accepted lower salaries than their British counterparts. Competence was mentioned as another distinctive trait of German trade. The Germans who came to the Far East were said to be able to speak one or two foreign languages, this in contrast with the 'sturdy antipathy to speak any language but their own' of the British and the Americans (Colquhoun 1902: 377). Also praised was the fact that Germans who came to China were well-trained for their job. They could 'compete successfully with men from England, who however accomplished in a classical sense, may not have been designed and prepared for commerce from their youth, as their German rivals have'. At the turn of the century, members of a British trade mission to China were impressed by the German firms in Hong Kong and Shanghai, which were often small and lacked capital, but took away business from the British by assiduous attention to business, by never neglecting the smallest opening, by working long hours for less money and commissions than Englishmen in the East are willing to do' (Neville and Bell 1898: 209). Other British qualifications included 'Teutonic thoroughness' and 'plodding perseverance' (Cartwright 1908b; Colquhoun 1902: 376). Around the same time, a former American commissioner to China, William W. Rockhill, praised the aggressiveness of German commerce. They had their agents look for markets everywhere. It was an example Americans should follow in China (Lawton 1912: 1261). In Korea, where the German trading interests were small, it was similarly noted that the Germans working there were 'throughout familiar with the Korean language', which seemed to 'illustrate very admirably the methodical system upon which German commerce in the Far East is built up' (Hamilton 1904: 166). The French also wrote with admiration and probably also with a bit of envy about the German spirit of enterprise and perseverance (Chambre 1898a: 189; Grupp 1980: 68).

Incompetent British consuls, insensitive to mercantile interests, got part of the blame, as did the dexterity of the competition. Going into matters of international politics as well as trade, Pickering (1898: 258), in a letter to The Times in April 1895 tried to impress upon its readers that 'France will coquet with Russia to spite us, and Germany can do nothing but act as a cuckoo, and place her young ones in the nest of the other powers, so that they may make money out of our markets and undersell us'.

Germans themselves would mention 'hard work and nerve' to explain the success of their overseas business ventures (Weicker 1906: 171); but over time they also had to come to terms with the facts that not all went as smoothly as they had hoped. In 1913 the German author Wertheimer (1913: 73) observed that British and American products in China were cheaper 
than the German ones, and better geared to local demands. Wertheimer (1913: 76-7) does praise the 'fresh energy' and zest for work of the German merchants in the Far East, but criticises them for not being innovative, for just copying what others also already did.

The German commercial advance commented upon was unmistakable. In various ports in China contemporaries noted a spectacular growth of the German business community. In Hong Kong, the first German company, Siemssen \& Co., had set up an office in 1846. In 1898 the number of German trading firms in Hong Kong had increased to 21 (Taylor 1908: 216; Zimmermann 1901: 299). In the Chinese treaty ports a similar pattern was visible. In Tianjin (Tientsin), where in 1882 only two German merchants had been active, there were 24 German firms in 1898 (Zimmermann 1901: 299). In that year $107 \mathrm{German}$ companies had an office in the treaty ports of China compared to 398 British, 114 Japanese, 43 American, 37 French, and 16 Russian ones. ${ }^{6}$ And, of course, among the German companies active in Asia was also Krupp, but that company was everywhere. Also, the British navy used its steel for the protection of its battleships. After having sold its first cannons to that country in 1871 China became an important market for Krupp. Its purchases made Germany the leading arms exporter to China. Krupp sold some 78 pieces of ordinance annually; amounting to almost 14 per cent of Krupp's exports and 8 per cent of its production (Graichen and Gründer 2005: 223; Steinmetz 2007: 426).

To the north, in Russian Vladivostok, the firm of Kunst und Albers was founded in 1864. It was to grow into an important German mercantile house in the region, also active elsewhere in Asia. Its department store in Vladivostok was the biggest in town. One could buy there 'absolutely everything, from a pound of butter to a piano,' (Norman 1900: 146). The company had, the British author Putnam Weale (B.L. Simpson) wrote in 1908 , a 'practical monopoly in every species of dealing', in that part of the Far East. It had accomplished this 'by merit, by industry, and by a thorough knowledge of local conditions and needs'. He also attributed the fact that, contrary to the Germans, the British had failed in Siberia to their companies employing interpreters and not 'men well-trained in the language of their patrons' (Putnam Weale: 1908: 17, 249).

Similar observations can be made about Southeast Asia. In the mid-188os, Germans played a prominent role in the foreign commercial community

6 These figures are from the 1898 annual report of the Dutch consul in Shanghai (Onze handel 1899:44). In other reports slightly different figures can be found. A French one puts the number of French companies in China as low as eight to ten (Chambre 1898a: 448). 
of Saigon (Scott 1885: 310, 312). In 1914, in British Straits Settlements, Singapore, Malacca and Penang, among the foreign residents only the British were more numerous (Nasution 2006: 43). The start had been modest. In Singapore a British resident remembered in 1874 that the first German merchant who had settled there - he must have been talking about the important trading and shipping company Behn, Meyer \& Co., which had set up business in the city in 1840 - only had a simple desk in the office of a British firm. Since then, 'German houses have sprung up in the settlement, until ... they [are] almost equal, if they do not outnumber, the English' (Bogaars 1955: 111). Shipping was one of the sectors in which the Germans excelled, hitting especially the $\mathrm{P} \& \mathrm{O}$ hard. By the early twentieth century, shipping in the Straits and British Borneo had become predominantly German (Taylor 1908: 201; Shennan 2000: 78). Among the connections controlled by German companies were those to the Philippines and Thailand. For some British it was an unpleasant surprise, and an additional reason to bemoan British decline, to have to board a German ship in a British port in Southeast Asia (Colquhoun 1902: 226). In 1904 one traveller noted (with some exaggeration) that, in the past, the shipping at Bangkok 'was practically British, now 95\% is German and 5\% British' (Shennan 2000: 78). In Thailand as a whole, contested between Great Britain and France, Germany had become the second foreign investor, after the British (Taylor 1908: 201; Chew 1969: 290). Around 1890 the Germans also were said to be a 'very strong element' in the European society of Rangoon (Yangon) in Burma (Browne 1888: 114).

In Asia, the Germans participated with gusto in the social and cultural activities organised in the foreign enclaves to brighten life far away from home. Buildings reflected the status of the German community in the Far East, also in Anglo-Saxon eyes. In all the important treaty ports in China Germany had 'impressive and commodious consulates' (Millard 1906: 212) and imposing commercial buildings. In Guangzhou (Canton), the office of the German-Swiss Arnhold, Karberg \& Co. company was 'the most conspicuous commercial building' in the city (Cartwright 1908b: 788). In Shanghai, the office of the Deutsch-Asiatische Bank (established in 1889 by a consortium of German banks to promote trade in Asia and one of the biggest banks in Asia) was among the grandest buildings on the Bund. The German consulate was located on 'the most desirable site' the European settlement, and the German club, Club Concordia, was rated as one of the most handsome structures on the Bund, perhaps even its 'most striking building' (Darwent 1905: 64; Millard 1906: 213, Cartwright 1908: 372). 


\section{America's large policy}

America's commercial contacts with China were as old as those of Great Britain and France, but for a long time did not really take off. After the First Opium War (1839-42), the United States was among the first nations to sign a treaty with China. In Washington President John Tyler evoked American mercantile interests as the rationale behind the Sino-American treaty of 1844. Imports from China were 'large' and exports to China constituted an 'interesting and growing part' of American commerce, statements that were, in fact, untrue (Tyler 1842). Ten years later, in 1853, Commodore Perry forced Japan to open up to foreign trade and shipping. Commanding a small fleet and carrying a letter by President Millard Fillmore he sailed to Japan and invited Japan to enter into a treaty of peace and amity. The treaty signed during Perry's second visit the following year gave America the coaling and anchorage stations it was looking for, for its whalers and its ships sailing between China and the United States. Perry also suggested turning Taiwan and Hawaii into forward stations for America's China trade, but Washington was not receptive.

Having reached the Pacific Coast, a strong American presence in the Pacific was a logical extension of the overland migration. It was a proposition wholeheartedly supported by William H. Seward, US Secretary of State in the 186os, who urged his countrymen to 'continue to move on westward' (Immerman 2010: 114). Seward, a firm believer in the expansion over the globe of American economic and political influence, was also not averse to some territorial aggrandisements, but the American Civil War forced him and other American expansionist to temper their ambitions. After the war ended, efforts were resumed. When the United States bought Alaska from Russia in March 1867, China was mentioned as one of the considerations to do so. Seward, responsible for the deal, explained that the purchase would open up new trade with China. America could not but benefit from such an American 'entrepot in the Northwest' (Immerman 2010: 124). Coaling and repair stations were also on the agenda. In August of the same year, Captain William Reynolds of the USS Lackawanna took possession of Midway Island, as its name indicates located halfway the route between North America and Japan and China, which had to serve as the coaling station of the Pacific Mail Company (Brookes 1941: 264). It was no success story. In 1870 government efforts to turn Midway into a real port were halted. The expenditures necessary far exceeded the sum allocated by Congress (Brookes 1941: 344) The island anyway was too small to become a hub in Pacific shipping (Immerman 2010: 125). 
The next step came in 1871 when five American warships sailed to Korea, a Chinese vassal, to seek redress for the sinking of an American merchantman and the killing of its crew five years before. The squadron bombarded the forts at the mouth of the Han River on Korea's west coast, the entrance to Seoul, but the resistance put up forced the squadron to sail home without having accomplished its mission. It took more than a decade, until 1882, for Commodore Robert W. Shufeldt to succeed in concluding a Treaty of Peace, Amity, Commerce, and Navigation with Korea, also allowing missionaries in. The treaty had been made possible by the Chinese government, in need of international support against Japan and seeking international acknowledgement that Korea was a Chinese vassal. Washington rewarded Beijing by sending American advisers to modernise the Chinese fleet (Field 2001: 3). Japan had preceded the United States by six years in getting trade concessions in Korea, but this did not prevent Shufeldt from stating that he had succeeded in bringing 'the last of the exclusive countries within the pale of western civilisation' (Field 2001: 3).

Throughout most of the nineteenth century, and influenced by an Anglophobe mood, American business circles and politicians tended to see the British as the main political and economic adversary. In the 1860 , beating Great Britain in the race for economic and political dominance had already been among Seward's aims (Immerman 2010:126). Asia was one of the arenas of such Anglo-American commercial competition. Seward was convinced that the 'battle between Britain and America is to be fought if not in at least for Asia!' (Immerman 2010: 106-7).

By the 189os, Americans politicians could boast, as one would do in 1893, that their country produced 'of manufactures more than any two nations of Europe; of agriculture more than any three, and of minerals more than all together' (LaFeber 1998: 147). Others wrote about America's 'future manufacturing supremacy over Europe', even about its 'commercial supremacy of the world' (LaFeber 1998: 183, 377). Europe had to come to terms with America's growing role in international trade. In France some even warned against the American peril and worried about the consequences for the economic position of France and the other European nations in the Pacific once the Panama Canal had been dug (Grupp 1980: 58, 66). Globally, in 1893, American foreign trade was second only to that of Great Britain (LaFeber 1998: 18). The United States had grown strong enough to be mentioned by contemporaries as 'England's great commercial rival' in the Pacific (Inagaki 1890: 47). Some foresaw that changing alliances might be the result. In 1900 the Russian Ambassador in Washington, Count Cassini, was sure that commercial rivalry would drive the United States and Great 
Britain apart. He told his German colleague in St Petersburg that 'England could not look on at America's enormous advance in shipbuilding without anxiety', and that American investments in the part of China that London regarded as its preserve - the Yangtze (Yang-Tsze-Kiang) Valley - could only lead to tension between the two. ${ }^{7}$ In St Petersburg, in 1902, the Foreign Secretary, Vladimir N. Lamsdorff, thought along similar lines, predicting that its economic rivalry with the United States and Germany might bring Great Britain closer to Russia (Soroka 2011: $5^{8}$ ).

The close of the nineteenth century saw Washington embark on its own version of world politics. Henry Cabot Lodge, Theodore Roosevelt and other leading Republican politicians advocated a more aggressive course of action, captured in 1898 under the term 'large policy' (Immerman 2010: 141). Up to then, American government policy had resembled that of the British. There was talk of Empire, but, with some exceptions, it was essentially a commercial one Americans had in mind. Seward, for instance, had aimed first and foremost at economic expansion, shrinking away from the cost and effort of ruling over subjugated peoples (Immerman 2010:122).

The Far East was in the American picture but for years gaining markets and political influence in Latin America had had priority. Interests in Asia lagged behind. Around 1900, however, the United States redirected part of its energy - both mercantile and with regard to spreading the Faith - to Asia. Confronted with an economic depression and overproduction at home and the social upheaval that went with it, business circles and politicians felt that American trade needed a new outlet. Steel was one of the products seeking new markets, machineries, cotton and wheat were others. In the 189os, American cotton exports to China increased in value by some 60 per cent (while that of Great Britain shrank by about 8 per cent) (Beresford 1899: 102).

Though American trade with China was still small, it was growing and large enough to have any barrier put in its way upset the mercantile community, with the newly established Committee on American Interests in China and the American Asiatic Association in front (LaFeber 1998: 355-7; Beresford 1899: 426-7). One periodical, the Journal of Commerce, in 1897 even depicted China as 'the greatest market which awaits exploitation' (LaFeber 1998: 356). It was such expectations of growing export - and obstacles perceived - that made the United States an avowed proponent

7 Prince Von Radolin to Imperial Chancellor 2-9-1900 1897 (E.T.S. Dugdale, German Diplomatic Documents, VIII, The Boxer rebellion, June, 1900 to March 1901. The Yang-Tsze Agreement; www. mtholyoke.edu/acad/intrel/dugdale/boxer.htm). 
of an Open Door in China, as adamant on this point as Great Britain, if not more so. The efforts to find new markets abroad, and with respect to China the concomitant pleas for free trade, took place against a patriotic background. When Beresford attended a banquet of the American Asiatic Association during his visit to the United States he was praised in The New York Times (24-2-1899) for joining 'with animation in the frequent outburst of enthusiasm that followed the utterance of patriotic American sentiments'. The newspaper also observed that 'while his hosts laid aside not a jot or title of their Yankee patriotism, they evinced the most unselfish cordiality in cheering Lord Beresford, his country, his Queen, and his country's fame'.

\section{Asia for the Asians}

Japan's rise was at least as spectacular as that of Germany and the United States. Within years after the Meiji Restoration of 1868 Japan made its first aggressive move, acting as a power should. In 1874 Tokyo sent a punitive expedition to Hengchung in Taiwan to avenge the murder, three years earlier, of 54 shipwrecked sailors from the Ryukyu islands, which Japan asserted were Japanese territory a claim Beijing denied. According to an agreement brokered by Thomas Francis Wade, the British envoy in Beijing, in return for Japan withdrawing its troops from Taiwan China had to pay a 'a certain sum to compensate the families of the shipwrecked Japanese' and for 'the roads made and the buildings erected by the Japanese. ${ }^{8}$ It was also forced to extend its de facto control over the island and, as the agreement demanded, 'take steps for the due control of the savage tribes' in Taiwan, to show that the island was really Chinese territory and not free for the Japanese to take. ${ }^{9}$ Korea came next. In 1876 a Japanese fleet forced Korea to open up Busan (Fusan, Pusan) and two other ports to Japanese trade in the Treaty of Kanghwa (Ganghwa) and gained extraterritorial rights for its nationals. In the conventional way Japan would also try to expand its influence in Korea by having a Japanese officer appointed adviser to its army. In 1895 Japan defeated China in a conflict over control over Korea. By that time 'Japanese boasted loudly of the fact that they were leaders of civilisation in the East, and were thus entitled to undertake the reform of Korea' (Lawton 1912: 174).

8 Engagement between Japan and China respecting Formosa 31-10-1874, Art. 2 (www.taiwandocuments.org/1874treaty.htm).

9 Ibid. 
By the end of the century, Japan had firmly acquired the status of a world power. The other nations had to treat it as an equal; also because Japan could be a valuable ally in their struggle over China. Between 1894 and 1897 Tokyo succeeded in revising the unequal treaties it had been forced to conclude earlier with the European nations and the United States (and in the 1870 s also with Hawaii and Peru), which among other regulations had granted extraterritorial rights to foreigners. In 1899 Japanese residents were legally included in the population group of 'Europeans' in the Netherlands Indies. Another indication of Japan's growing importance was that Japan was mentioned as a possible rival to the United States for the takeover of Hawaii and the Philippines.

Japan had become an assertive power in its own right, strong enough to compete with the western nations, politically and economically. Japan did produce (and export) coal but needed iron ore and other raw materials the country itself lacked. Also, it could no longer do without the import of food to feed its people, and had to find an outlet for a growing population. The United States and the British colonies in the Pacific (including Canada) were discouraging the immigration of Japanese, if not being downright hostile to it. Japan had to look west, at Asia, notably at Korea and Manchuria, though as early as 1893 Southeast Asia also came into the picture (Goto 2003: 7). Or, as the Japanese Prime Minister Ito Hirobumi said after Japan had taken hold over Korea: 'The population of our country ... shows a very rapid rate of increase, and it is natural that its increment should overflow in Korea' (Lawton 1912: 1064). Commercially, Japan became a serious competitor in China, also in those regions where other powers had acquired a strong mercantile position, such as the Yangtze Valley, adding to the doom scenarios in Great Britain about the country's future position in China, and what was to become German Jiaozhou about his prospects. Like the other powers, Japan had its commercial representatives abroad doubling as political agents. The whole of China was 'flooded with Japanese agents who collected information about commercial opportunities, and who with the political ideas they present to the Chinese ... also sell their goods', the German navy pastor Weicker (1908: 170) observed.

Japan's political offensive went hand in hand with the slogan 'Asia for the Asians' and the promotion of pan-Asianism. For reformers and nationalists in Asia, Japan became a model of reform and development, of dealing with the colonial powers on an equal footing. Japan was hailed as the herald of Asia's Awakening and as an example of an Eastern nation that had forced the European states to treat it as an equal. Economically, Japan in its trade with China increasingly came to be seen as a serious competitor. By 1905 , 
after the Russo-Japanese War, people in Great Britain began to observe that Japan was 'rapidly becoming the predominant commercial Power in the Far East' (Lawton 1912: 265). Japan also acquired a name as producer of cheap consumer goods. It earned the Japanese some admiration, such as from a trade mission from Blackburn investigating Lancashire's decreasing share in textile imports, which praised the Japanese knowledge of and approach to the Chinese market (Neville and Bell 1898: 190). At the same time, European and American commercial circles (the latter being equally accused by Beresford (1899: 102) of exporting to China 'a considerably lower standard of goods ... to meet the Chinese requirement of cheapness') had difficulty in coming to terms with Japanese competition. It was claimed that Japanese products were often of inferior quality, that the Japanese were not afraid of copying others' design, producing 'most shameless imitations' for the Chinese and Korean markets (Hamilton 1904: 167) and flooding China with 'goods which bore pirated trademarks belonging to well-known foreign firms' (Lawton 1912: 974).

The development of banking and shipping accompanied Japan's economic growth. The Yokohama Specie Bank, established in 1880, became one of the biggest banks in Asia. Japanese international shipping lines, the Nippon Yusen Kaisha and Osaka Shosen Kaisha, both subsidised by the government, prospered and, as the German lines did, took away part of the British passenger and freight transport (Colquhoun 1902:227). As in the German case, price, comfort and service made the difference (Colquhoun 1902: 3355). Lawton (1912: 934) was full of praise for the 'commodious steamers, with excellent accommodation for passengers'. Shipping to and from China increased spectacularly. Between 1897 and 1907 in Shanghai, where more than half of Chinese foreign trade took place, the tonnage of British shipping had increased from 4,498,278 to $6,848,400$ tons, that of Japanese shipping from 575,833 to 3,102,070 (Cartwright 1908a: 368-9). The Japanese also settled in increasing numbers in the treaty ports. In Tianjin, in the north, they made up more than half of the foreign population, and mirroring the custom of the other powers, had their own club there (Wright and Cartwright 1908: 726).

\section{Building strong navies}

In 1890, Mahan stated in his book The Influence of Sea Power upon History that naval power was an essential element in the rise and fall of commercial or political empires (Immerman 2010: 142-3). It was a message that was 
understood by Theodore Roosevelt and other Republican politicians in the United States, with whom Mahan was well-acquainted, by Wilhelm II and the architect of the German navy, Alfred Tirpitz, and by the British. By the turn of the century, almost all nations, strong and weak, with colonial or mercantile interests were strengthening their fleets.

One of the countries that took Mahan's lesson to heart was Germany. The initial aims of the German Imperial navy, which grew out of the navies of Prussia and the Norddeutscher Bund, had been modest. The Flottengründungsplan of 1873 did not provide for the acquisition of coaling stations or naval bases in distant waters, relying for coaling on British facilities (Sieg 2005: 174). Lieutenant-General Albrecht von Stosch, the first German Chief of the Admiralty and an early protagonist of German colonialism, had wanted otherwise, but political opposition had been too strong. The navy of the early German Empire was geared to Germany's commercial ambitions; relying on small cruisers and gunboats equipped with steam and sails. It had to protect and promote overseas trade; including the backing up of the authority of German consuls and the punishment of local communities which had assaulted Germans or destroyed German property.

Defending colonies was not an option. Consequently, in Bismarck's days, the weakness of the German fleet was seen as an impediment to Germany's overseas expansion and a reason why Germany had not yet become the mighty colonial empire some Germans dreamt of (Berghahn 1993: 33). It was also considered a serious handicap in some of the conflicts in the Pacific with Great Britain in which Germany became involved. The 'Fiji crisis' of 1874 had made for persistent calls for a strengthening of the navy, especially in the cities that had the greatest stake in Pacific trade, Hamburg and Bremen. Six years later, the absence of a strong navy in the Pacific provided an additional argument to those opposing government support to the Godeffroy company. Bismarck tended to concur. In 1881 he still spoke of 'a fleet that cannot sail', using this observation to demonstrate why Germany should not seek colonies; fearing that when it came to war with France, the French would easily take any foothold Germany had acquired in Africa or Asia (Graichen and Gründer 2005: 90). When he changed his mind and came out in favour of acquiring colonies, Bismarck showed himself confident that the might of the German army in Europe, not on a German navy in Africa or Asia could secure their existence.

Under Wilhelm II, enlargement of the German navy, modestly embraced under Bismarck (who fell from power in 189o), became one of the country's priorities. Even before he had ascended the throne in 1888, Wilhelm II, who since his youth had been impressed by the British fleet, had shown himself 
a proponent of a strong navy. In the early years of his reign, the German navy that was envisaged no longer just had protection of German maritime trade as its main aim. It was planned for a defensive war in Europe, with a more aggressive role in Africa and Asia (Nuhn 2002: 128).

The man behind the German fleet plans was Alfred Tirpitz (in 1900 he became Alfred von Tirpitz), State Secretary of the Imperial Navy since 1897. His dream was an offensive German navy aiming at a confrontation with Great Britain in the North Sea. For such a purpose battleships were essential, not cruisers and gunboats. Raiding British ships elsewhere in the world, Tirpitz wrote in a memorandum to Wilhelm II, was 'so hopeless because the shortage of bases on our side and the great number on England's side; (Massie 1993:172). Aiming at a confrontation in Europe, Tirpitz sacrificed German naval presence in the Pacific. In his view, the German possessions in Africa and the Pacific were too wide and far apart and also unable to withstand a hostile attack without support from home. Tirpitz did not think much about the coaling stations Germany had acquired in the South Pacific, refuting any argument others had presented in their favour. They provided insufficient protection against the forces of nature, were located too close to a strong British base, or were too far away from the main shipping routes to act as a base of operation to prey on enemy merchantmen (Nuhn 2002: 129-30, 232). The German overseas possessions had to be protected in another, indirect way. Their fate would be decided not as Bismarck had envisaged by the deterrent of the German army in Europe, but by the fighting strength of the German fleet in European waters; also turning into a German advantage the fact that Great Britain had to station part of its fleet in Asia and Germany did not. A strong German navy in Europe could also serve as a political instrument; or, in Tirpitz' words, a maritimer Hebelarm, a maritime leverage, to have other powers accept any further German colonial expansion (Nuhn 2002: 232-3).

In 1898 , the Reichstag accepted the first Navy Law. Its aim was ambitious. Ultimately, Germany was to rival Great Britain as the paramount power. A strong and modern navy should be able to protect an expanding German merchant fleet and German settlers all over the world without having to rely on British goodwill. It had to serve as a deterrent to prevent other powers, in casu Great Britain, from blocking the sea routes connecting Germany with its overseas possessions (though some argued that it was the other way around, that Berlin only aspired after colonial possessions to justify a naval build-up). Or, as it was stated in the preamble to Germany's Second Navy Law of 1900: 'To protect Germany's sea trade and colonies ... Germany must have a battle fleet so strong that even for the adversary with the greatest 
sea power, a war against it would involve such dangers as to imperil his own position in the world' (Massie 1993: 181). The German navy did not have to be as powerful as the British one. It would suffice when it could inflict such damage that what remained of the British fleet would be in a weak position in a confrontation with a navy of a third power.

Germany's ambitions set a naval race in motion. All over the world increasingly heavy battleships came to be built. International tensions, perceived threats, and rivalries between the powers saw to it that worldwide strong navies with huge battleships became the focus of patriotic drives. In 1898 Germany got its Deutscher Flottenverein (Navy League), which would also have a branch in Shanghai, founded and heavily subsidised by Krupp. By the end of the following year, membership already had reached 240,000 and over time would swell to two million (Halpern 1994: 3; Graichen and Gründer 2005: 85). The Alldeutscher Verband, established in 1891, and the Deutsche Kolonialgesellschaft, set up in 1887 , joined the campaign of the Deutscher Flottenverein to turn Germany into a naval power (Nuhn 2002: 231). Such a campaign went hand in hand with overviews of the position of Germany in Africa, Asia and the Pacific in which the perfidy of Great Britain, and, to a lesser extent, of France was highlighted. The bitter experiences in Fiji and Samoa had their role to play in the propaganda, but also other German setbacks. Reflecting such sentiments, Zimmermann (1901: 297-8), for instance, made much of the problems Count Friedrich zu Eulenburg encountered in 1860-1861 in entering into diplomatic relations with China and Japan; blaming British and French intrigues for the obstacles encountered.

In Great Britain (where a Navy League would be founded in 1894), calls to strengthen the navy were initially inspired by the country's strained relations with Russia and France and the conflicts over territorial expansion in the Far East. As early as 1884, at a time France tried to gain new territory in Southeast Asia, Norman (1884: 286) noted that many 'distinguished British admirals' had 'been at some trouble to prove that the French fleet is the equal, if not the superior', of the British one. Penjdeh only made anxiety increase. At what The New York Times (17-4-1885) called 'a large meeting of citizens of London', among them Members of Parliament and the Lord Mayor, 'immediate steps to secure the supremacy of the English Navy over all the other navies of the world' were demanded. The result of all urging was the Naval Defence Act of 1889 and the formalisation of the Two-Power Standard, the principle that a British navy had to equal the combined strength of the two next largest fleets; those of France and Russia. Ten years later, the shock of Russia occupying Port Arthur prompted the First Lord of the Admiralty to announce the building of four additional warships. 
Not much later the build-up of the American, German and Japanese navies made for questions whether the Two-Power Standard of 1889 still sufficed. In the end the German naval plans became a main incentive to prompt Great Britain to expand its fleet. One response was the development of a new type of battleship, that of the dreadnought class. The first one made its maiden trip in October 1906. It was equipped with heavy guns; firing power, the Russo-Japanese War had demonstrated being a decisive factor in a naval battle, and outshone anything the Germans were building (Massie: 1993: 486 Lawton 1912: 322).

\section{The American-Japanese naval race}

The United States had to come from far. By the 1880s, America did not yet have much of a maritime power. Its navy had 'decayed into a flotilla of deathtraps and defenseless antiques', while its merchant fleet, due to 'American reluctance to recognise the usefulness of the steamship' was also not up to date (LaFeber 1998: 58,19 ). The first concrete plans for modernisation of the fleet were made in 1883 when the American Congress appropriated funds for the building of steel cruisers. Stress was laid on disturbing trade and trading routes of other powers and the protection of American foreign trade. The real change set in in 1889 when Benjamin Harrison became President and James G. Blaine, also known as Jingo Jim, Secretary of State. As in Germany, events in Samoa played a role. One of the factors swaying the American government and public in favour of a strong fleet was the naval confrontation that had threatened in Samoa just before the hurricane struck in March 1889; another was the fact that two years later the American navy could not be relied upon to seek a naval confrontation with Chile. Patriotic feeling ran high. Since 1888 LaFeber (1993: 125) wrote, Congress had 'grown amazingly offensive-minded', with bellicose speculations of war with Great Britain. The danger of war passed, but prospects of, and dreams about, growing exports, also to the Pacific and Asia made for new pleas to strengthen the navy in the 189os. The United States had to take into account, Secretary of the Navy Hilary A. Herbert wrote to Mahan in October 1894, the protection of its 'close interests with China and Japan'; its 'geographical and political relations with the islands of the Pacific'; and its 'multifarious interests along the whole South and Central American coasts (LaFeber 1998: 231).

The American fleet underwent the same transformation as the German one; from fast 'commerce destroyers' to heavy battleships, thus preparing 
for full-scale naval battles; but unlike in Germany, the American plans were presented as having a defensive purpose (LaFeber 1998: 123). Terminology reflected this. The warships to be built were described as 'shields of commerce', 'coast defense battleships', and 'sea-going coast defense battleships' (Coffman 2009: 260). At the end of the century, a strong modern American fleet became, as Richard Olney, Secretary of State between 1895 and 1897, put it, 'an essential element both of national security and national greatness' (LaFeber 1998: 240-1).

An additional reason for people in the United States to plead for a stronger navy was Japan. Japan emerged as a threat to American interests in the closing years of the nineteenth century, at a moment when the United States itself was transformed into a colonial empire by adding Hawaii and the Philippines to its territory (though some would argue that a Japanese bogey was created to make that empire possible). The personification of the call to strengthen the navy was Theodore Roosevelt, a bellicose expansionist, appointed Assistant Secretary of the Navy by William McKinley in April 1897. Within weeks after his appointment, Roosevelt wrote to his friend Mahan about the danger Japan posed and the need to have a dozen new battleships built. ${ }^{10}$ Anxiety over Japan's role as a naval power in the north Pacific would increase, and by 1905-1906 Americans would seriously considered the possibility of war, complete with the accompanying war scare.

Identifying Japan as a possibly aggressive nation meant that the American navy had to show its presence on two oceans, and thus had to have more warships. As Roosevelt explained, after he had become President, to Congress, to underline the urgency of the Panama Canal, the American battle fleet was still by no means big enough to allow part of it to be stationed in the Pacific and part in the Atlantic (Lawton 1912: 372). In saying so, he was in all probability inspired by Mahan (1911: 25-6) who warned that a dividing up of the American fleet was 'forbidden by military considerations, in that it is too small; the half is weaker than any probable enemy'. At the same time, Mahan stressed that the American fleet should remain stationed in the Atlantic. His words illustrate the American dilemma of that moment. For commercial and political reasons Asia and Japan had grown in importance, but strengthening the American naval presence in the Pacific would seriously weaken that in the Atlantic. It might, in the view of some contemporaries, even mean 'abandoning' the latter (Putnam Weale 1908: 617). Concentrating on the Atlantic coast left the west coast vulnerable. It - and Hawaii and the Philippines - lay wide open to an invasion fleet, 
and the land defences were insufficient; somehow it had to be protected. Or, as a report of the General Staff of the American army put it at a time of mounting American-Japanese tension, in 'the absence of effective naval opposition a certain Oriental Power, within a month of the time its hostile intentions began to be even suspected, could land 100,000 men on our Pacific Coast, which could be increased at the end of the second month to 300,000' (Lawton 1912: 381). It was a doom scenario: 'It would be practically impossible for the United States to regain possession of the country after its occupation by the enemy'. San Francisco would become and remain Japanese.

In reality, Japan had other things to worry about: its own security at home and its position on the coast of China. Its army and navy had to defend the country against a foreign enemy, with Russia as the most likely candidate. In the south, Russia could use the Isle of Tsushima located between Japan and Korea as a base from which to advance. In the north, there was Hokkaido, where, in 186o, the Russians had established the naval station Vladivostok on the opposite coast and, in 1875 had gained the island of Sakhalin. Korea and Manchuria could also provide that stepping stone.

Japan had its own history urging it on on the path of armament. A first confrontation with Beijing over Korea in 1882, and the realisation that Japan was still too weak to confront China gave an impetus to Japan's plans to strengthen its army and navy, as would, a decade later, the construction of the Trans-Siberian Railway connecting European Russia with Vladivostok. Even before work had commenced on that line in 1891, the Japanese Prime Minister, Yamagata Aritomo, already pointed at the danger the railway posed to Japanese interests in Korea and the defence of Japan itself, and the military response this would require (Drea 2009: 74-5). The Sino-Japanese War also left its mark. The Japanese Parliament still refused to furnish money for the further development of the Japanese fleet in December 1890, but the performance of the Japanese navy during that conflict removed any doubts about its significance as an instrument of war (Jukichi 1895b: ii-iii). After having been forced out of the Liaodong Peninsula by Russia in 1895 a strong army and navy became even more imperative. Frustration over the indignation Japan had suffered was one reason for this. Another was that a Russo-Japanese confrontation was building. The contemporary impression was that in preparing for war Russia not only could count on a large army, but was also assembling 'the most imposing fleet of any nation represented in Pacific waters' (Lawton 1912: 227).

Naval plans evoked in Japan the same nationalist sentiments as elsewhere in the world. 'About their Navy the patriotism of the Japanese is as easily 
aroused as is our own in Great Britain', Curzon (1896: 38) wrote. By the beginning of the twentieth century, the strength of the Japanese fleet was observed with awe in the Netherlands proper and in the Netherlands Indies, where the Dutch were often prey to a vague foreboding that a more powerful rival would take away the Dutch colony, Japan in the twentieth century being the most likely candidate. Japan's 'formidable navy' with its 'fighting machines', the 'floating citadels', which had a far greater battle capacity than any of the warships of the Dutch navy, inspired simultaneously admiration and anxiety (De Locomotief 6-1-1900, 8-3-1900).

Its fleet became a great asset for Japan in the international power struggle and the carving out of spheres of influence in Asia, closely located as the country was to the main areas of contestation there. The European powers had to station the main bodies of their navies in Europe to be prepared for a European confrontation. Japan could bring to bear its whole navy in Asia. In Great Britain, the strength of Japan as a naval power was the reason to seek an alliance, taking much of the weight off its own navy in Asia. Japan was, in the words of Foreign Secretary Lansdowne, 'a Power of great commercial and political influence' with 'a strong Army and even stronger Navy'. ${ }^{11}$ In the year he spoke these words, 1902, Japan launched its third naval plan. Four more were to follow within a decade. For some, this could only mean that Japan's aim was 'the ultimate command of the Pacific' (Lawton 1912: 604). To play such a role, Japan built its own shipbuilding yards capable of turning out state-of-the art warships and ocean liners. In early 1905, Japan took naval warfare a step further by laying down the keel of the Satsuma, a heavily-armed battleship, preceding by a few months the building of HMS Dreadnought by the British (Lawton 1912: 322, Massie 1993: 469). The Satsuma was launched in November 1906, a second Japanese battleship of the same class, the Aki followed in 1907. The new Japanese warships made an impression. Putnam Weale (1908: 491-2) wrote about 'the two biggest vessels in the world', adding that to some experts they were more powerful than the British dreadnoughts.

Just as Germany and Great Britain in Europe, America and Japan became entangled in a naval race in the Pacific, expanding their fleets with an eye on the danger the other might pose. America was disquieted over the dominant position Japan had seemingly acquired in the Pacific Ocean;Japan was anticipating the consequence of an American naval presence there once the Panama Canal could be sailed and American warships no longer have to

11 Lansdowne in House of Lords 13-2-1902 citing a speech by John Spencer in 1901 (hansard. millbanksystems.com/lords/1902/feb/13/anglo-japanese agreement). 
round Cape Horn (Lawton 1912: 586). If the naval race between Germany and Great Britain was inspired by real threats, the one between the United States and Japan was less so. In Japan, the image of the United States as the enemy was needed to justify the further expansion of the fleet (Drea 2009:127). In the United States, the spectre of Japan as a possible aggressor developed at a moment when, weakened by the Russo-Japanese war of 1904-05, the Japanese armed forces could not live up to that image. In the United States, and also in the rest of the world, the unexpected victory of Japan over a European power, gave Japan an aura of strength, blinding people to how hard hit, military and financially, Japan was by the war and also to the fact that the Japanese army and navy were not the efficient war machine people supposed them to be. Still, as time passed, an American-Japanese confrontation became a real factor in people's mind, and in diplomacy. In 1912 one author, Lawton (1912: vi), observed that to the United States 'Japan has become what in Europe Germany has so long been to Great Britain'. 



\section{Great Britain, France and Southeast Asia}

To the north, in continental Southeast Asia, lay another area of conflict between the European powers, in this case between France and Great Britain. France had acquired its first foothold in Indochina, or Further India as the British preferred to call it, in 1859. This happened after France, in a joint expedition with Spain, had ordered a fleet to Annam to punish that kingdom for the persecution of Roman Catholics converted by French and Spanish missionaries. In February 1859 Saigon (present-day Ho Chi Min City), according to the British author Norman (1884: 158) the 'finest harbour' in Annam, was occupied, resulting in what one French author described as 'diatribes' in the British press (Garnier 1864: 40). In those years, the position of France in Cochin China or South Vietnam was still far from secure. During the Second Opium War (1856-6o), troops were needed in China, leaving the French in Cochin China vulnerable and delaying the movement of the French inland. When, in 186o, Saigon was besieged the French were forced into a defensive position, having to leave the city to the enemy. Fortunes changed after the Opium War had ended. In the Treaty of Saigon of 5 June 1862 Annam (Central Vietnam) ceded Cochin China to France. The treaty also secured freedom of religion for French citizens (and for Spanish ones; the Queen of Spain was the third party in the treaty) and Vietnamese converts. Popular resistance in the newly acquired regions forced the French to get Annam to confirm the treaty in the Treaty of Hué of 14 April 1863.

Cambodia, to which both Bangkok and Saigon (following in the footsteps of Annam) laid claim, came next, making France the master of the Middle and Lower Mekong. When the naval officer Pierre-Paul de La Grandière, a man with colonial ambitions, had become Governor of Cochin China in May 1863 one of his first acts was to send Ernest-Marc-Louis Doudart de Lagrée to Cambodia. In August of that year, in what was called a Treaty of Friendship and Trade, Doudart de Lagrée succeeded in having King Norodom of Cambodia accept a French protectorate. Thailand responded immediately by concluding a similar treaty with Cambodia in December. Four years later Bangkok gave way. Thailand and France agreed on the frontier of Cambodia in the Franco-Siamese treaty of 1867 . It was an agreement that the French were later to regret. Two important provinces, Angkor (Siemreap, Siem-Réap) and Battambang (Batdambang, Patabang, Battanbang), were assigned to Thailand and not to Cambodia. 
France also looked north. In 1866 Doudart de Lagrée and another naval officer, Francis Garnier, surveyed the Upper Mekong River in search of a trade connection with Yunnan and the other southern provinces of China. They also had to investigate the commercial prospects for Cambodia and Cochin China of the regions they would traverse, especially northern Laos. The aim was not only to allow for the sale of French products and exploitation of their natural resources by French companies, but also to cut out Chinese traders, in whose hands lay trade in such valuable Chinese export products as tea and silk. For the occasion Doudart de Lagrée was promoted to the rank of grand mandarin by La Grandière, from whom the idea of the expedition had originated. Permission for the expedition was sought and granted in the capitals of the countries the expedition was to pass through: Bangkok, where the Thai permission spoke of Napoleon III as 'the Sovereign of a friendly nation', Hué (Annam), Mandalay (Ava or Upper Burma) and Beijing. In the old tradition of voyages of discovery members of the expedition were instructed to pay ample attention to the flora and fauna of the regions they were to enter and to the customs and history of the people who lived there (Garnier 1873:15-21).

Doudart de Lagrée and Garnier found the Upper Mekong almost unnavigable for steamers and another entry into China had to be found. The most promising was the Tonkin or Red River, which linked Hanoi and the Gulf of Tonkin with Yunnan. Garnier (1873: 549) - Doudart de Lagrée had died during their Mekong expedition - had high hopes. As he wrote, 'the opening of commercial relations with the south of China through the Valley of Tonkin is one of the most important results French politics could seek to obtain in Indochina'. A second explorer, the adventurer Jean Dupuis, who in 1871 and $1872-73$ sailed the river twice, agreed. He even predicted that within a couple of years trade along the Red River might amount to half of that along the Yangtze, the river which played such an important role in British China commerce (Sentupéry 1890: 231). The coal fields of Tonkin formed an additional attraction. Both the French and the British in those days were well aware that should it come to an Anglo-French confrontation, the French would be seriously handicapped in Southeast Asia without a source of coal of their own. Its trade prospects - according to Dupuis, the local population was eager to trade and keen to buy European products (Sentupéryibid.: 81, 283) - and its mineral wealth made Tonkin a desirable object; one Frenchman even ventured that it might well be 'one of the richest countries in the world' 
Inspired by such considerations, Rear Admiral Marie-Jules Dupré, Governor and Commander-in-Chief of Cochin China, tried to convince his superior in Paris, the Minister of the Navy (France did not have a Ministry of the Colonies yet), in the middle of 1873 that for the future of French domination in the Far East the occupation of Tonkin was 'a matter of life and death' (Sentupéry 1890: 85). The supposed richness of Tonkin's natural resources was one of the reasons for him to advance his plea. Another was to secure a safe and profitable trade route to Yunnan, but paramount probably was his desire to keep the British out. Since Dupuis had sailed the river it had become general knowledge that the Red River was navigable; though - as would only be fully realised later - rapids, seasonally changing water levels and its silting up posed formidable obstacles (Scott 1885: 222-3; Doumer 1905: 117). With others also aware of the accessibility of the Red River, Dupré feared that France might have to face the rivalry of British, German and American commerce. He and his confidant Garnier did not even preclude an invasion by another European power or China. They may even have considered China the most likely aggressor, impressed as both were by the strength of the Chinese army in Yunnan fighting Islamic insurgents, equipped as it was with quick-firers and having been trained by European instructors. The government troops were clearly winning and after having suppressed the rebellion and with no enemy anymore to fight in Yunnan, Beijing might well decide to direct them to Tonkin to restore order in a what was a very volatile vassal of Annam.

In the opinion of Dupré and Garnier, a Chinese Tonkin could only benefit Great Britain. Their judgement seems to have been clouded by an intense distrust of the British. Essential in their line of reasoning was the belief that London's influence in Beijing was considerable. They saw proof in the fact that a Briton, Robert Hart, had become Inspector General of the Chinese Imperial Maritime Customs Service in 1863. Garnier, and probably also Dupré, was sure that the British envoy in Beijing was actually trying to talk the Chinese government into invading Tonkin. ${ }^{2}$ A Chinese Tonkin would increase the commercial significance of Hong Kong to the detriment of Saigon, Garnier wrote to the French minister in Beijing and others. ${ }^{3}$ He also saw a British hand in what had happened in Yunnan. To draw the province into its own orbit Great Britain would have encouraged its Muslim population to rise and gain independence from China, in which 
case, Garnier's reasoning was, Yunnan would have become closed to French trade (Norman 1884: 114).

\section{The French military expeditions to Tonkin}

Annam's hold over its vassal Tonkin was weak. Without the assistance of Chinese troops Annam/Hué could not cope. Its inability to maintain law and order made Tonkin seem an easy prey for any foreign power out to take control over it. Part of the trouble was caused by the fact that piracy, a term used by Annamese authorities as well as the French, was rampant on land and on sea. Collectively known as the Pavillons Noirs or Black Flags and branded as pirates and smugglers, they formed a serious obstacle to any commerce Europeans had in mind and thus a reason to act for the powers intent on expanding their trade in the Far East.

To stay ahead of the British; or, as the British author Norman (1884: 157) wrote, to wrest from Great Britain its 'China trade - by fair means, if possible; if not by foul' -in November 1873 French forces briefly occupied Hanoi, the capital of Tonkin. Taking the city had not been among the original French plans. Dupré and Garnier were well aware that the French in Cochin China lacked the necessary manpower for an annexation of Tonkin. What they wanted to accomplish by applying military pressure was freedom of French trade, suppression of piracy and, inspired by Hart's position in China, a Frenchman to head the customs service of Tonkin (Norman 1884:112).

The immediate cause for the French, or rather Dupré, to act was Dupuis' second Red River voyage of 1872-73, undertaken to provide the Chinese army in Yunnan with arms and ammunition. In April 1873 Dupuis returned to Hanoi and immediately ran into trouble with the Annamese and Tonkinese authorities. He was accused of conducting illegal trade, ignoring a ban on foreigners trading along the Red River and evading Tonkin customs duties. Dupuis, who could count on a small flotilla of junks and a force of about 350 well-armed men, including a contingent of soldiers from Yunnan, established himself firmly in the city of Hanoi. Annam, reluctant to offend France by using force against a French citizen, turned to Dupré to mediate. About the follow-up Paris and Saigon differed in opinion. In France the government was not looking forward to a Tonkin adventure. Foreign Secretary Jacques-Victor-Albert Duc de Broglie cautioned Dupré not to engage France in Tonkin. In Saigon Dupré decided otherwise, afraid that non-French adventurers, especially British ones, alerted to the weakness of Annam by Dupuis' obstinacy, might follow the Dupuis example, with 
ultimately a British intervention as the result. What also motivated Dupré to act were reports that Hué had contacted the Governor of Hong Kong. Convinced that the British were only waiting for an excuse to gain control over Tonkin, Dupré informed the king of Annam, Tu Duc, that he could not tolerate the interference of other powers in a matter that only concerned France and Annam (Norman 1884: 94-5).

Dupré was full of confidence that for what he had in mind the French troops already in Cochin China sufficed. No reinforcements from France would be needed. Success was assured, he wired to the Minister of the Navy a few days after he had received De Broglie's call for restraint (Sentupéry 1890: 85). To have his superiors in Paris agree to the venture, Dupré presented the expedition he wanted to send to Tonkin as a reply to the request by Hué to act upon Dupuis; conveniently forgetting to report that Hué had rejected his suggestion to send a gunboat to Hanoi, but had agreed to the visit of a French officer to make Dupuis see reason. Dupré's stratagem worked. Paris gave the go-ahead (Norman 1884: 90-5). Put in command of the expedition was Garnier, according to Norman (1884: 98), not an author to hide his dislike of the main French actors, 'a man well versed in Oriental character, well skilled in Eastern languages and ways; but, hot-headed by nature, ... little inclined to study their diplomatic finesse, and too ready ... to resort to force'. Obviously Dupré's interests went beyond Tonkin. Garnier wrote to friends in Paris that with the rebellion in Yunnan suppressed, he also had to acquire mining concessions in Yunnan and this before the British did. That mission also had some urgency. Garnier was worried by a British advance in Yunnan from the other side, from Burma, where they had just stationed a political and trade agent, Thomas Thornville Cooper, on the Upper Irrawaddy River, in Bhamo, where the river ceased to be navigable. The French had some reason to be anxious. Cooper was an exponent of British mercantile and political expansionism. He had played a role in efforts by the India Office to befriend the Yunnan rebels and in $1868 \mathrm{had}$ travelled deep into the interior of China to find an overland trade route between India and Burma and the Chinese coast. ${ }^{4}$ He published Travels of a pioneer of commerce in pigtail and petticoats, an account of this last adventure, in which he claimed to have had the backing of 'several of the most influential merchants of Shanghai'. In the same breath, however, he bemoaned the lack of support from the city's mercantile community, where, his expedition, if Cooper is to be believed, was considered to be a threat to

4 Bickers 2011: 255-7; en.wikisource.org/wiki/ Cooper,_Thomas_Thornville_(DNBoo), (DNB biographies) accessed 3-1-2013. 
Figure 12 A street in Bhamo, Burma, circa 1885

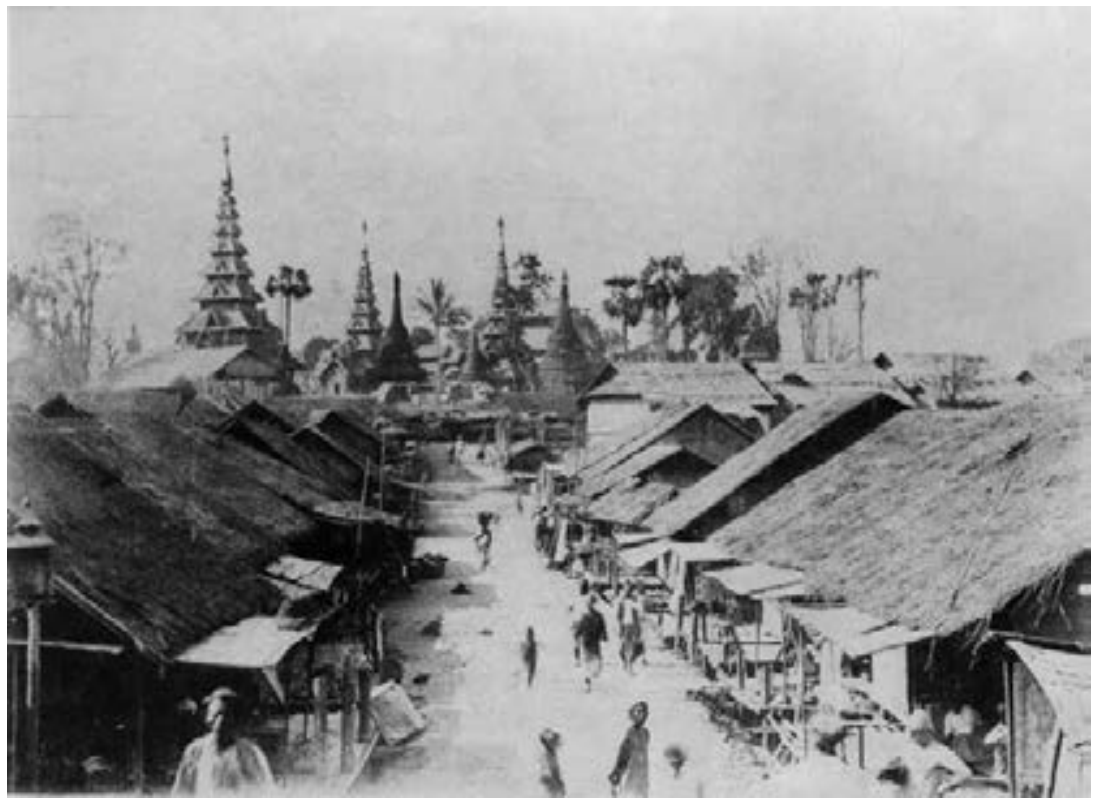

Source: Browne 1888

existing trade (Cooper 1871: 8). Adding fuel to the French suspicion were reports in newspapers in India linking Cooper's appointment in Bhamo with the desire to outmanoeuvre the French in Yunnan (Norman 1884: 109-11).

Garnier, as Dupré and other Frenchmen, full of praise for Dupuis' exploration of the Red River, arrived in Hanoi on 5 November. In his negotiations with the local authorities and envoys from the Court of Hué he emphasised trade and the opening of the Red River (and the treatment of Christians), not how to deal with Dupuis. For the Tonkin authorities it was the other way around. Dupuis' menace was the issue, not the trade treaty Garnier was set to conclude. Such a matter had to be decided upon by Hué. Garnier threatened to resort to violence. When the Tonkin authorities persisted that they needed instructions from Hué he took the citadel of Hanoi with a force of only a few hundred men, among them Dupuis' Yunnan soldiers, and raised the French flag on 20 November. It was an easy victory. Norman (1884: 132) observed that the defenders, said to be some 7,000 men strong, were 'unaccustomed to artillery fire and hitherto ignorant of the terrible effect of shells'. After having captured Hanoi and still on the $20^{\text {th }}$, Garnier, in his capacity as 'grand mandarin' and 'envoy of the noble French Kingdom', issued a proclamation in which he informed the people of Tonkin that he had come to their country to 
open a trade route, that he had no intention to take possession of the region, but that the obstruction by the Tonkin authorities had forced him to act. The Tonkinese were assured that they could continue to live in peace, that customs would be respected, and that the Tonkin officials who accepted French rule would retain their position (Norman 1884: 132-3). Other towns and forts in the Red River delta were also occupied, but the French expedition ended in disaster. Everybody - except the Christians - united against the French. At the end of December, a large force of Annamese, Chinese and Black Flags besieged the French in Hanoi. During a sortie Garnier fell in battle.

In Saigon, Dupré could not condone Garnier's vigorous action. He had Paris to consider. When in early December he heard of the occupation of the Red River delta, he dispatched another of his naval officers and colonial administrators, Paul-Louis-Felix Philastre, to Hué and Tonkin to undo the damage. Philastre had to end the military occupation and to negotiate the opening of the Red River for commerce by foreigners. His negotiations would result in a treaty concluded in Saigon on 15 March 1874, the beginning, as it was stated in the furst article, of an 'eternal' alliance between France and Annam. ${ }^{5}$ France acknowledged Annam's sovereignty and its 'complete independence vis-à-vis all foreign powers' (a stipulation China and Annam preferred to ignore). ${ }^{6}$ Still, Annam - on paper at least, practice would be different - was firmly drawn into the French sphere of influence. In return for a French promise to support Annam in maintaining order and peace and to protect it against foreign aggression, Hué had to conform to French foreign policy and had to promise not to enter into commercial arrangements with other nations without consulting the French first. France also offered instructors to train Annam's army and navy, and experts to manage the country's tax and customs service. Annam in turn had to allow trade by foreigners on the Red River and to open three ports, Hanoi and Haiphong on the Red River and Qui Nhon in south Annam, to commerce and industry by foreigners. ${ }^{7}$ In each of them France was allowed to station a consul or agent, complete with a consular guard of up to a hundred men 'to guarantee his safety and to have his authority respected'. ${ }^{8}$ These consuls had

5 Franco-Annamese treaty $15-3-1874$, Art. 1. (The text is among other places to be found in Norman 1884: 148-155).

6 Franco-Annamese treaty 15-3-1874, Art. 2.

7 Haiphong had been selected to serve as a port without much prior study and soon discussions would start in France about the selection of another, more suitable place in Tonkin, the millions spent in developing Haiphong, and even about abandoning the place (Doumer 1905: 111).

8 Franco-Annamese treaty 15-3-1874, Art. 13. In return, France agreeing to commerce by people from Annam in France and it colonies allowed Annam to station agents in cities of its 
to act as judge in conflicts in the foreign community; foreigners (including Frenchmen) who wanted to take up residence in the three ports had to register with them, while a French passport provided by them was needed to travel into the interior. Freedom of religion of Roman Catholics was also part of the treaty. Dupuis must have been pleased that in one of its other stipulations a 'full and complete' general amnesty was proclaimed. A commercial treaty concluded on 31 August dealt with preferential customs duties for merchantmen from French ports. It also confirmed the French hold over the Annamese customs service, stipulating that only Frenchmen and no other foreigners could be employed in it (Norman 1884: 145-6, 155-6).

The treaty did not bring the French what they had hoped for. The consuls in Tonkin, living in stockaded settlements, would have 'an unpleasant time', as Scott (1885:12) noted. Commercially, Dupré's fears became a reality. Hong Kong and not Saigon dominated Tonkin trade. In 1880 imports in Haiphong almost exclusively came from Hong Kong. Saigon's share was a mere 0.5 per cent. Of Haiphong's exports 79 per cent was shipped to Hong Kong, compared to 16 per cent to Saigon. To make matters more embarrassing for the French, Hong Kong also dominated Yunnan's export trade (Scott 1885: 215-7).

As Dupré had experienced, obtaining new colonial possessions was not easy to justify in France. This was especially so in the late 186os and 1870s, when France first had to deal with war with Prussia and later had to come to terms with its consequences, military and otherwise; though for imperialists like Garnier expanding the French presence in Indochina was exactly one of the ways to have France recover from the economic downturn occasioned by the Franco-Prussian War and its aftermath (Sentupéry 1890: 232 ). In the early 1880 s the mood changed. France embarked on an active colonial policy and went in search of new territory and national glory; enough reason for a British author like Scott (1885: 329, 368-9) to write about 'French earth-hunger' and the 'great Indo-Chinese Empire' France wanted to create, leaving the British at the most Burma. One of the targets was Annam, which had hurt French pride by not treating the French representative in Hué with the respect the French deemed due to such an official, and, more importantly, by preferring relations with China over those with France (Doumer 1905: 155). Annam also refused the French a concession to win coal, while French ships still did not have unrestricted access to the Red River. 
The train was set in motion during the first prime ministership of Charles de Freycinet. As he wrote in July 1880 to his Minister of the Navy, Admiral Jean Bernard Jauréguiberry, Freycinet did not expect any trouble from China should France occupy the Red River. He was also sure that such an occupation would be a money-maker and that the costs of the expedition would be offset by future customs revenues. ${ }^{9}$ On finding out what France intended to do Beijing protested, but Freycinet's successors, Jules Ferry and Léon Gambetta, continued on his course. In 1881 the Governor of Cochin China, Charles le Myre de Vilers, was instructed to stage a show of force impressive enough to convince the King of Annam that he had to abide to the 1874 Saigon Treaty and to show him that France had the means to enforce its demands (Norman 1884: 181). An occasion presented itself when the consul in Hanoi asked for reinforcement of his escort. In response, Le Myre de Vilers ordered the Commander of the French naval station in Cochin China, Captain Henri Laurent Rivière, to proceed to Tonkin in January 1882, impressing upon him that he had to proceed with prudence. In March, before he sailed to Tonkin, Rivière's task was extended. Rivière, who, Norman (1884:191) maliciously wrote, lacked experience in the East but 'had written several excellent novels', was to command a military expedition. What followed was a repeat of the Garnier invasion: a commander who overstepped his brief, the taking of the citadel of Hanoi without much trouble (in April 1882), followed by massive popular resistance and guerrilla warfare, and Rivière being killed during a sortie (on 19 May 1883), only a few miles from Hanoi and not far from the place where Garnier had died.

Just a few days before it had come to that, the Ferry government, supported by Parliament, had already agreed to step up the French military effort in Tonkin. As an additional step, Paris appointed François-Jules Harmand, a former consul in Bangkok who had also taken part in the Garner expedition, as Civil Commissioner-General of France to Tonkin. He had to arrange the political aspects of the expedition. When Harmand arrived in Hanoi in June 1883 he almost immediately issued a proclamation stating that France was 'a great and powerful kingdom ... feared and respected all over the world', that its patience had run out and that France had to show that a treaty concluded with it was a serious matter (Norman 1884: 222-3). France, he also stressed, did not intend to conquer Tonkin. Its only aim was to restore law and order. Officials who accepted this had nothing to fear, but those who resisted would be shown no mercy. They would not be able to escape the wrath of France, not even when they sought the protection of 
the citadel of Hué, which, Harmand boasted, the French forces could take as easily as they had done other forts.

By this time Paris no longer ruled out a protectorate. During Ferry's first premiership from September 1880 to November 1881 France had already proclaimed a protectorate over Tunisia. His Tunisia policy had been Ferry's downfall, but during his second term in office, from February 1883 to April 1885, Annam and its dependency Tonkin - the latter considered to be economically the more important of the two - came into view.

Later, Ferry would be hailed by one of the protagonists of French colonialism, Lorin (1906: 35), as 'the visionary patriot to whom France owes Tunisia and Tonkin', but his expansionist policy did reap as much resistance in France as that of Bismarck would do in Germany. Opposition was not just a matter of the profitability of colonies and protectorates. Franco-German antagonism loomed large. Part of the criticism was aimed at the fact that France should concentrate its money and effort on a confrontation with Germany to regain Alsace-Lorraine, which France had lost to Germany in 1871. Some also reasoned that because of Indochina France lagged behind Germany in the building of fast cruisers and battleships, or blamed colonial ventures for the weakness of French defences along the frontier with Germany. In line with this, it was further argued (as also later historians would do), that Germany looked favourably upon and even stimulated the French colonial ambitions, to direct part of the French energy away from Europe (Norman 1884: 308-9; Geiss 1990: 137). From his side, Ferry (1890: 46) would complain that each time France tried to regain its place amongst the powers, there were those in opposition to such plans who exaggerated the dangers which loomed in Europe.

Ferry himself was an ardent protagonist of French colonial expansion. Economic reasons formed part of his arguments. France, he stressed in March 1884, had to find new outlets for its export in a period in which Germany was erecting trade barriers, the United States had become 'extremely protectionist' and foreign products were flooding the French market. But he also mentioned the greatly changed 'conditions of naval war' to impress upon the French public how important it was to have overseas possessions. A ship could carry 'no more than two weeks' supply of coal' and without it was 'a wreck on the high seas, abandoned to the first occupier'. That was why France needed 'Saigon and Indochina' and other places of 'defence and provisioning ${ }^{10}$ What France aimed at, Eugène Tenot (1904: 49) wrote

10 Speech before the French Chamber of Deputies 28-3-1884 (web.viu.ca/davies/H479B. Imperialism.Nationalism/Ferry.Fr.imperialism.1884.htm, accessed 3-10-2011). 
around the same time on behalf of a Parliamentary commission, was 'a vast colonial empire, industrial and commercial development, accumulation of wealth and power, [and] radiation of civilisation'. Still others mentioned overpopulation as a reason for colonial aggrandisement. International developments formed an additional incentive. Annam provided the French who just months before had been forced to accept the bitter fact of British preponderance in Egypt with an opportunity to restore some of their national pride. As Ferry (1890: 36$)$ would write, Tonkin was a 'revenge' for Egypt.

In line with the new mood in Paris, Harmand first demanded from Hué to accept a French protectorate over Tonkin. In the end the whole of Annam would suffer this fate. ${ }^{11}$ In August 1883, French troops, allowed to do so by Paris, took the coastal forts guarding access to Hué. The way to the capital of Annam lay open. Still in the same month, on the $25^{\text {th }}$, Harmand forced Annam (its court being in disarray after the death of its king, Tu Duc, in July) under the provisional Treaty of Hué to accept a French protectorate; including the French running the customs service. He also gave Annam a new king, a boy of about 15 years of age (Tu Duc's successor, who had resisted the French, had fled Hué). The treaty reflected the importance attached by France to Tonkin. It allowed for the opening up of Tonkin to foreign trade, industry and mining, for a strong French administrative presence, and for a good road and a telegraph line between Saigon and Hanoi. Annam also had to part with the province of Binh Thuan, which was added to Cochin China territory. On the morning of 5 January 1884 the Treaty was ratified in the Royal Palace in Hue with much display of splendour by the Annamese Court (see Scott 1885: 301-4; The Straits Times 26-1-1884). The court showed what it was worth, but could not, as hard as it tried, mollify the French into making concessions. During the ceremony in the palace the young king had already tried to do so and afterwards during a breakfast offered by the French his regent pleaded in vain for less French officials to be stationed in Annam than the French intended. In Hué the answer was that the 'railroads, telegraphs, \&c.', which the residents were to introduce would 'only contribute to the wealth and prosperity of Annam' (The Straits Times 26-1-1884). In Paris a different mood prevailed. Politicians shrank from the impact of the treaty and refused to ratify it. A 'lighter' protectorate was in order, something like France had established in Cambodia. As the French

11 In 1888 the French would take the port of Danang (Da Nang, which they called Tourane or Turon), south of Hué, from Annam, to turn it into a real 'concession' administered by the French and under French jurisdiction. 
had not yet accomplished much in Cambodia, and pleased with the way matters were turning out in North Africa, Tunisia should be the example to follow (Neton 1904: 48).

To acknowledge the new political relationship, an Annamese delegation, escorted by its own soldiers, with their 'inlaid mother-of-pearl scabbards to their swords', visited Saigon. In the city they were received in March by a guard of honour, salutes, and a military band playing 'the Marseillaise and some opera-bouffe airs', and could watch 'the ascent of field-balloons' (Scott 1885:306). Nice words were spoken, but, the suspicion was that on the way back to Hué the delegation incited the population against the French and the local Roman Catholics, the start of years of unrest, even 'anarchy', especially in the southern part of Annam (Scott 1885: 306; Doumer 1905: 60, 299).

In Great Britain, the French advance was perceived as a threat to its China trade. It would, a member of the House of Commons stated in August 1883, place a 'French Naval Station right in the track of our trading fleets'. ${ }^{12}$ Or, as Norman (1884: 8), a former officer of the Indian Army, would write: 'French cruisers supplied with coals from its mines in Tonkin would lie in the fairway of our China trade, Burma and Calcutta would be effectively blockaded, and our outlying Oriental possessions grievously threatened'. For the British, always insecure about the security of their Empire, there was an additional hazard to worry about. Alarmed, Norman (1884: 1-2) pointed out that foreign colonies in the vicinity of British possessions would not only mean 'the divergence of trade to other markets', but would also 'necessitate the further dislocation of our forces, none too large for the efficient protection of the British Empire'. There were also the indirect consequences for trade to be considered. The French did not adhere to the principle of free trade in their colonies. Where they could, the French government gave preferential treatment to French trade, to, from and in the colony. As in the days of Doudart de Lagrée, the aim was not only to strike at Western commercial rivals, but also at Chinese ones (Chambre 1898a: 23-4). Norman was sure that British commerce would suffer the consequences, also when it did not come to an Anglo-French confrontation. 'In times of peace', he lamented, France did its 'utmost to ruin our trade by the imposition of heavy duties and of equally onerous bounties'. New French colonies without such impediments would be a blessing for European trade but, every 'fresh conquest made by France, every new Custom-house over

12 Ashmead-Bartlett in House of Commons 9-8-1883 (hansard.millbanksystem.com/ commons/1883/aug/og/supply-civil-service-estimates). 
which the Tricolour flies, is an injury to the trade of the world' (Norman 1884: 307, 331-2).

As a French author, Prince Henri d'Orléans would observe, the French 'had not been masters of Tonkin for two years' before they 'surrounded it with a thick wall of Customs dues' (Cunningham 1902: 46). The way the French colonial authorities proceeded in Indochina fortified the image of a protectionist France. It seems certain, the British author Browne (1888: 445) wrote about Indochina, that 'the French by their usual policy of imposing heavy import duties are doing their best to strangle the commercial prosperity of the country in its infancy'. His compatriot Scott (1885: 241), was equally sure that in view of 'the present temper of France', new French colonies would not 'be thrown open ... to the commerce of the world'. To leave no doubt about France's protection of its own trade and industry, in 1893 Paris instructed the colonial authorities, not only in Indochina but also elsewhere in the world, to order the goods they needed in France, even mentioning the towns where they should do so (tiles in Marseilles and Bordeaux, salted pork in Le Havre, etc.) (Lanessan 1895:346). Such a policy also drew criticism from part of the French business community, making a strong plea for free trade, by pointing out that the discriminatory import and export duties levied hurt trade, also that of the French, and made some products too expensive for the local population to buy (Chambre 1898a: $23-4,44-5,84)$.

Norman published his book at a moment when Great Britain and France were engaged in a naval race and the fighting capacity of the British navy had become a topic of public debate in Great Britain. Among the topics discussed were also the strength of the British fleet in the Far East and the defence of Hong Kong and Singapore (which would actually be improved because of the tension in Southeast Asia). The French showed themselves full of confidence. Newspapers optimistically predicted that the French navy was strong enough to take on the British fleet (Norman 1884: 8). In Great Britain, such a spirit seemed wanting; with naval officers and others, whether really concerned or for less altruistic motives, stressing the urgency of a build-up of the navy to counter the French threat.

The country most directly involved, China - which as France was more interested in Tonkin than in Annam (Scott 1885:305) -, had more real issues to complain about. It could not condone any treaty Hué made without its approval. Annam was a Chinese vassal and to add insult to injury, in the treaty Harmand had enforced upon Annam China was mentioned by name as one of the powers Annam was not allowed to conduct foreign relations with without the consent of France. Beijing protested when Rivière had 
taken Hanoi. Paris was not quick to respond and when it did it only insulted the Chinese government by informing it that the conflict only concerned France and Annam, not China.

Both sides prepared for war; strengthening their armed forces by purchases from abroad and mobilising extra troops for a coming confrontation, those of France including 'fanatical men of Algeria' (Norman 1884: 243). A setback for China was that it had three cruisers under construction at the Vulcan yard at Stettin (Szczecin), but in December 1883, when Chinese sailors were already on their way to Germany to sail them home, Berlin delayed delivery at the request of Paris.

For a moment it seemed that war could be avoided. In the Preliminary Treaty of Tianjin (Tientsin) of 11 May 1884 - signed by the Governor of Zhili and François-Ernest Fournier, commander of the French warship Volta-China promised to withdraw its troops from Tonkin and to recognise the treaties concluded between France and Annam. The agreement paved the way for an adjusted Franco-Annamese treaty, signed in Hué on 6 June 1884. France remained responsible for Annam's foreign relations but any reference to foreign powers had been dropped from the text of the relevant article. A cessation of Binh Thuan was not mentioned and neither was the road between Saigon and Hanoi. In a combination of seeking economic advantages and a belief in a Western modernisation mission, it was stated (as it had been in the Harmand treaty) that Annamese civil servants could continue to work as they always had, but an exception was made for the customs service, public works and 'in general, all that required unique management and know-how of European technicians' (Lanessan 1895: 18).

Within weeks hostilities were resumed in Tonkin, and in August these spilled over (there was no declaration of war) into the Sino-French War of 1884-85; presented by Paris as a punishment of China for not honouring the Tianjin treaty. A French fleet defeated a Chinese one at Fuzhou (Foochow) in Fujian; French soldiers briefly occupied the Penghu (Pescadores) Islands and the city of Jilong (Chilung, Keelung) on the northeastern coast of Taiwan. In Tonkin itself, at the end of March a Chinese army defeated the French at Lang-Son. In Hanoi, hearing of the news the commander of the French army in Tonkin, Brigade General Louis Alexandre Esprit Gaston Brière de l'Isle, panicked and sent a telegram to Paris conveying his doubts about the French army being able to hold its position in Tonkin and asked for extra troops. When his telegram and other private ones about a chaotic French retreat from Lang-Son reached Paris, alarm spread there as well. Frustration and anger focused on Ferry, who was widely blamed for the 'Tonkin disasters'. He should resign and did so on 30 March 1885 . Five years later, in an effort 
to show that he had been right, Ferry (1890: 1) would write about the 'violent prejudices, the furious ill feelings', his policy had encountered, in equal terms complaining about a hostile press and a public opinion averse to the Tonkin expedition. Clearly, he was still angry over what had happened: 'The real enemies of the French flag ... are in France', Ferry (1980:19) wrote.

In spite of the panic and the military setbacks on land the French emerged victorious. A few days after Ferry had resigned A. Billot of the French Ministry of Foreign Affairs and James Duncan Campbell of the Chinese Imperial Maritime Customs Service, who acted on behalf of the Chinese government, signed a protocol in Paris for the suspension of hostilities, the withdrawal of Chinese troops from Tonkin and an end to the French military operations in Taiwan. A definitive treaty was signed on 9 June 1885 in Tianjin. China agreed to all French demands. Mentioned in the new treaty was a promise that were railways to be constructed in south China, cooperation with France had to be sought. The treaty further noted the French intention to build a railway in Tonkin. In April 1886 and June 1887 Beijing and Paris agreed on commercial links and the demarcation of the frontier between China and Tonkin.

During the Franco-Chinese War there had been calls for mediation by London, Berlin and Washington, coupled with criticism of London for not doing so out of fear for complications in Britain's relations with France. The British once again had their trade in mind. Commercial circles (and the government) expressed their apprehension over the damage that the war had done to British China trade, in this case also hampered by a French blockade of Taiwan. Another cause of concern had been the territorial concessions France might gain, ranging from the fear that France and Russia would divide up China between themselves, to the less unrealistic suspicion that France was aspiring to a piece of China. ${ }^{13}$ Among the rumours circulating was that France would demand Zhoushan (Chusan) near Shanghai as a security for the payment of a war indemnity. To show that they would not allow the island to fall into French hands, the British government sent an expert to Zhoushan, who had to advise the Chinese on the improvement of its fortifications.

When peace was concluded, the British anxiously considered the gains and trading benefits it might bring France. There were cries demanding compensation from China, including the opening up of Nanning to British trade (Browne 1888: 449). In France the feeling was that by gaining hold of Tonkin the French had outwitted Germany and Great Britain, where

13 Ashmead-Bartlett in House of Commons 21-11-1884 (hansard.millbanksystem.com/ commons/1884/nov/21/france-and-china-the-hostilities). 
its commercial circles were supposed to be equally eager to exploit the possibilities Tonkin offered (Sentupéry 1890: 96). The reality was that once again all threatened to go terribly wrong for the French. Almost immediately after the Tianjin Treaty they were confronted with a fully-fledged rebellion and the massacre of Christians in Annam and Tonkin.

Tonkin not being a success story (even its coals were initially supposed to be entirely unsuitable for steamers), the French lost interest in their new possession (Chambre 1898a: 62; Lorin 1906: 32). Algeria was more important. Indochina, formally constituted in October 1887 and encompassing Cochin China, Annam, Tonkin and Cambodia, cost the French more than it yielded. The region, Neton (1904: xix) complained, was only viewed as a 'military colony' without any real commercial or industrial value of its own, its significance being that it served as a springboard for economic penetration into a much more promising China. No efforts were made for its development. Apart from a small track in the South, from Saigon to the port of My Tho, built between 1881 and 1885, railway construction did not take off. Railways were even considered useless. The idea was that in the lowlands, rivers sufficed, and in the thinly populated mountains there was nothing to transport (Lorin 1906: 345). Another illustration of the relative insignificance of French Indochina in those days was that until at least 1895 the mail boats connecting France with Saigon and from there with China and Japan were much slower than those sailing to and from Australia (Lanessan 1895: 208). Parliament refused to furnish additional money allowing for faster communication.

For the French in Indochina the neglect was difficult to swallow. In 1891 Acting Governor-General of Indochina, E.A.G.R.J.G.P. Bideau, complained about the sorry state of affairs in Tonkin, the region that for decades had figured so prominently in the French effort to expand its territory in continental Southeast Asia. There was a huge financial deficit and for years no public works had been carried out. Soon, Bideau feared, there might even be no money to pay for civil servants' salaries or to purchase essential goods, such as food. Politically the situation was equally disastrous. The border with China was still far from secure, along the coast piracy was still rife, and the Tonkin Delta and its mountainous hinterland were in the hands of insurgents and so-called Chinese rebels (ibid.: 1-3; Norman 1900: 98). In Cambodia it was not much different, Lanessan (1895:5) observed. Since 1863 the French had remained strangers, without much contact with the local population or leaders. The result of it all, Lanessan (1895: 279) lamented, was that French colonists had 'lost all confidence in the future'. Still, not everything was so bad. Within a few years of France becoming master 
of Tonkin, travellers praised the way the French had turned the swamp of Haiphong, at the mouth of the Red River, into a seaport town, which, initially, some French optimistically thought might become a commercial rival to Shanghai (Browne 1888: 445; Cunningham 1902: 43, 48-9).

\section{The end of the Kingdom of Ava}

In the west of continental Southeast Asia, Great Britain had established itself earlier than the French had done in the east. In 1852, after the Second AngloBurmese War, Great Britain had gained Lower Burma, an achievement the British were quite happy with. Some thirty years later Secretary of State for India Kimberley could state with satisfaction that '[no] other portion of Her Majesty's Dominions has made greater progress than Lower Burmah'. ${ }^{14}$ Burma, his Under-Secretary Ughtred Kay-Shuttleworth also stated, 'had been a source of very considerable Revenue to India' for many years. ${ }^{15}$

The central and northern portion of the country, the Kingdom of Ava or Upper Burma, had survived as an independent state. It had the misfortune of becoming a pawn in Anglo-French rivalry, with Frenchmen at least since the early 186os pleading for greater influence in the kingdom to prevent further British expansion, and the British set to avoid this (Garnier 1864:35). For the British there were two additional considerations. Trade in British Lower Burma depended for about one-eighth on Ava, which, because of its geographical location, lay in the way for establishing trade with southwest China, a goal that many had high hopes for. A breakdown of law and order or misrule in Ava would seriously affect commerce; or, as it was worded in a note from the India Office, 'anarchy and disturbance on one side of the border makes it felt on the other, and paralyses every effort in the direction of friendship, civilisation, or trade ${ }^{\prime}{ }^{6}$ Furthermore, the foreign-drilled native troops syndrome had to be contended with. The armies of Ava and Thailand would be no match for French-trained and -led soldiers from Annam. 'Without being alarmist', Scott (1885: 241), referring to this, alerted his countrymen to the fact that 'every Frenchman who writes about Cochin

14 Kimberley in House of Lords 22-2-1886 (hansard.millbanksystem.com/lords/1886/feb/22/ kingdom -of-ava-resolution).

15 Ughtred Kay-Shuttleworth in House of Commons 22-2-1886 (hansard.millbanksystem.com/ commons/1886/feb/22/resolution).

16 Note on the Relations between the Government of India and Upper Burmah during the present King's Reign (www.nectec.or.th/thai-yunnan/22.html). 
China draws attention to the ease with which troubles may be created for England on the Siamese and Burmese frontiers'.

In 1867 a treaty had guaranteed British free trade in Ava. Having concluded the treaty, 'measures were taken for the opening of old trade routes with Western China, by which in former days a considerable trade had been carried on' (Browne 1888: 83). One was the appointment in 1873 of Cooper, in his day a famous explorer who had traversed eastern Tibet and Yunnan, in Bhamo, which had so alarmed Garnier. At that time there was already a feeling on the British side that war might be unavoidable. In 1871 Edward Charles Browne, one of those who propagated the annexation of Ava from an early juncture, and other British soldiers reconnoitred the Upper Irrawaddy River to prepare for an invasion (Browne 1888: 84). Geopolitical motives also played a role. Conquering Ava, the reasoning went, would place British troops along part of China's southern frontier, which would give London an additional leverage in respect of getting Beijing to resist any demands made by Russia and France. In the mid-1870s the North China Herald, published in Shanghai, wrote that expanding British rule over Ava and the 'contiguity of the British Indian Frontier with that of Yunnan would mean a pressure on China that could hardly fail to be felt at Pekin'. ${ }^{17}$

Relations reached a low when, first, in 1878 , Cooper was murdered and, subsequently, in the autumn of 1879 the British Resident in Mandalay, 'insulted daily' and with his life in 'imminent danger', had to be recalled (Browne 1888: 95). Burmese trade also experienced a setback (Scott 1885: 313). War threatened but the British already had the Second Anglo-Afghan War (1878-80) on their hands, besides the risk of an Anglo-Russian confrontation (Browne 1888: 94). The Afghan War had another consequence as well. The Viceroy of India, the $1^{\text {st }}$ Earl of Lytton, unnerved by the killing of the British mission in Kabul in September, withdrew the whole mission in Mandalay in October. ${ }^{18}$

The confrontation came six years later, at a time when France was consolidating its position in Southeast Asia and Ava made overtures to France. In May 1883 there had already been some trepidation among the British when the King of Ava, Thibaw (Theebaw) Min, had sent a delegation to Italy and France; countries to which he had looked since the beginning of his reign in 1878 for modernising his country and his army. Ava informed

17 North China Herald cited by Richard in House of Commons 22-2-1886 (hansard.millbanksystem.com/commons/1886/feb/22/resolution).

18 Note on the Relations between the Government of India and Upper Burmah during the present King's Reign (www.nectec.or.th/thai-yunnan/22.html). 
London that its objectives were 'purely scientific and industrial', but his assurances did not make a great impression. ${ }^{19}$ The influential Indian officer, Colonel Edward Bosc Sladen, warned of a number of dangers. He accused Ava of 'forming alliances with European States which have no interests in Burma' and whose presence would form a threat to the British position in British Burma. France in particular had no right to be there. Unlike Great Britain it had no political or commercial interests whatsoever in Ava, except 'of a very remote or clandestine character'. Moreover, Ava's scheming might land Great Britain 'at any moment in serious complications with European foreign Powers' (Browne 1888: 106).

British anxiety mounted in 1885 , both in Rangoon, where a French advance was primarily seen as a danger to British interests in Ava, and in London, where the fate of India was uppermost in mind. In January Paris informed London that France and Ava had signed a treaty, dealing with commercial matters. The news made the India Office in London conclude in November that 'King Theebaw was now anxious, according to reliable report, to throw himself in the arms of France in order to escape from English control'. ${ }^{20}$ In particular, the right that Paris had won to station a consul in Mandalay worried the British. The new Viceroy of India, Lord Dufferin, informed London that this was likely to increase British 'difficulties in dealing with the Court of Ava, and to prove antagonistic to British interests'. ${ }^{21}$ In London the India Office saw the new French consulate as a 'central point for intrigue'. ${ }^{22}$

Frederick Haas, appointed as French Chargé d'Affaires and Political Resident in Mandalay, almost immediately overplayed his hand by trying to conclude a secret treaty with Thibaw, according to which a Frenchman would become head of Ava's customs service and a French bank would be set up in Mandalay. Even more alarming to the security-obsessed British was that a French company was said to have received a concession to construct a railway running from Mandalay right up to the border of Lower Burma. The treaty, an Australian - who would meet Haas later on in China, and describe him as the 'most gentle-mannered of men ... with strange rancour against the perfidious designs of Britain in the East', - wrote, would have made Ava 'virtually a colony of France ... with France to support her in any difficulty

19 Cross in House of Commons 30-7-1883 (hansard.millbanksystem.com/commons/1883/ jul/3o/burmah-burmese-embassy-in-paris).

20 Note on the Relations between the Government of India and Upper Burmah during the present King's Reign (www.nectec.or.th/thai-yunnan/22.html).

21 Ibid.

22 Ibid. 
with British Burma' (Morrison 1895: 42-3). In London the India Office voiced a similar concern: 'French Agents would dominate all trade and chief sources of revenue in Ava, and ... the consequences for British interests and trade would be fatal. ${ }^{23}$ The India Office also suspected Haas of being behind the sanctions of the Kingdom against the Bombay-Burmah Trading Corporation, which held large forest concessions in Ava and whose Burmese and Indian workforce formed the bulk of the British subjects who had to be protected against mistreatment. A large fine was imposed on the company for illegal logging, and it was feared that it might lose its large timber concessions in Ava.

The treaty was bilingual. Haas spoke no Burmese and Thibaw no French and, both being distrustful of one another, they needed somebody to check the text in the language they did not master. Both turned to the same person, the Italian Chargé d'Affaires in Mandalay, Giuseppe Andreino, who also happened to be the local representative of the Bombay-Burmah Trading Corporation, the Irrawaddy Flotilla Company (on whose ships the British army would sail to Mandalay a few months later) and a number of other British firms.

The 'French Question' was born, with people being sure that France wanted to turn Ava 'into a second Ton-King' (Browne 1888: 102). The news of the treaty occasioned a sudden change in British policy, always susceptible to possible threats to India's flanks. As late as March 1885, though this might have been too rosy a picture, Calcutta was still assuring London that there were hardly any problems in Anglo-Ava relations, nor had the British Chief Commissioner in Burma been in favour of annexation. ${ }^{24}$ Nevertheless, before the year was over, British troops were to march into Ava, with Edward Bosc Sladen as Political Officer of the invasion army. They did so in spite of the fact that the French government, after a strong British protest, had disavowed Haas' action and recalled him. In September French Foreign Secretary Charles de Freycinet even assured London that no treaty had been signed and that France did not aim at a position of preponderance in Ava. The British had difficulty believing him. 'The French Government disclaimed what was going on', one British Member of Parliament, voicing British distrust, stated, 'but European Governments generally disclaim intrigues until they were successful'. ${ }^{25}$

23 Ibid.

24 Hunter in House of Commons 22-2-1886 (hansard.millbanksystem.com/commons/1886/ feb/22/resolution).

25 MacLean in House of Commons 22-2-1886 (hansard.millbanksystem.com/commons/1886/ feb/22/resolution). 
There was a certain eagerness on the side of the British government in London, and the Indian administration in Calcutta, to act. What the King of Ava had had in mind, Kimberley explained afterwards, would have caused Great Britain 'great embarrassment' and might have had 'an injurious effect upon the peace and security of Her Majesty's Indian Dominions'. ${ }^{26}$ Apparently, one of Thibaw's faults was that he had established diplomatic relations with France and Italy, where an ambassador was stationed. Perhaps Ava was even seen as having no right at all to establish diplomatic relations on an equal footing with any country. In 1882 negotiations initiated by Ava to come to a commercial treaty had broken down, among other things because Great Britain refused to allow Ava an ambassador in London.

In October 1885, after Thibaw had refused to submit his sanctions against the Bombay-Burmah Trading Corporation to arbitrage, Lord Dufferin sent him an ultimatum. As the Amir of Afghanistan had earlier, so should Thibaw follow the advice of the British in all matters concerning foreign relations. Ava also had to accept a British consul, facilitate 'the opening up of British trade with China', and should leave the Bombay-Burmah Trading Corporation in peace. Thibaw was not, as he had wanted, allowed time to think things over and consult France, Germany and Russia (Browne 1888: 165-6). In response, he 'issued a hostile proclamation threatening to efface the heretic Christian barbarians, and to conquer and annex their country', as the British Under-Secretary of State for India, Ughtred Kay-Shuttleworth, phrased it in retrospect. Consequently, Great Britain declared war on Ava in November. ${ }^{27}$ At that moment the British Parliament was in its six-month recess and could only withhold its consent and reverse matters after it had assembled again. Momentum had shifted to British India, where Calcutta was most eager to act. The military campaign was financed and executed by India, which made it possible to go to war without consulting the British Parliament. The Third Anglo-Burmese War (1885) did not pose many problems to the British. Within six weeks British troops entered Mandalay and imprisoned Thibaw. He was first taken to Rangoon and subsequently exiled to India.

On 1 January 1886 Great Britain annexed Ava on the advice of the Viceroy of India, Lord Dufferin, who had dismissed a protectorate as 'inexpedient

26 Kimberley in House of Lords 22-2-1886 (hansard.millbanksystem.com/lords/1886/feb/22/ kingdom -of-ava-resolution).

27 Ughtred Kay-Shuttleworth in House of Commons 22-2-1886 (hansard.millbanksystem.com/ commons/1886/feb/22/resolution). 
and impracticable'. ${ }^{28}$ Contrary to the French, the British did not opt for a protectorate. A month before the war Edward Bosc Sladen, 'one of the best living authorities on Upper Burma', had already pleaded in favour of incorporation. A protectorate was 'complex'. The Burmese would never accept it. Keeping a King on the throne and appointing a Resident 'would be proof of political imbecility'. The 'temperament of its people would result sooner or later in the usual fiasco', while, because of the 'almost superstitious veneration for the royal family', a protectorate would force the British to deport 'all surplus members of the royal family'. Annexation was simpler, 'nothing more than a quiet military parade' (Browne 1888: 107-11).

All that remained was to seal the annexation. Lord Dufferin and his wife visited Mandalay in February. In preparation, the streets leading from the river bank to the Palace, soon to be renamed Fort Dufferin, were improved. At the landing place a 'sort of young Crystal Palace was getting taller and taller, day by day', while 'some hundreds of Chinese carpenters hammered away night and day to metamorphise Theebaw's barbarously splendid palace into modern reception rooms for Lady Dufferin and suite' (ibid.: 236). After his arrival Lord Dufferin - who, Browne (1888: 237) wrote, 'talked a great deal, and said very little' - and his wife 'rode in a handsome carriage drawn by four magnificent English horses, and all his bodyguards, tall, stalwart Sikhs, clad in long scarlet coats and jack-boots, bestrode a like breed of animal'. These horses would have been much taller than any horse the Burmese would ever have seen, Browne explained to his readers. The carriage, outshining anything the Burmese knew, had to convey a similar message of British superiority. The climax came at Lord Dufferin's departure. In the presence of the 'city magnates' he thanked the audience for their 'friendly feelings', informing them that they had 'become British subjects under the rule of Her Most Gracious Majesty the Queen-Empress'. Showing himself confident that the Burmese would 'serve Her with loyalty and fidelity', Lord Dufferin assured them that the British officers who had taken over the administration of Ava would do all they could to

promote the happiness and well-being of Her Majesty's Burmese subjects, to restore tranquillity amongst them, to develop the resources of the country; to respect the customs; to place its religious property and establishment under protection of the law; and to advance the well-being of all classes as good citizens (ibid.: 239). 
The annexation of Ava, which came within months of the Penjdeh crisis in Central Asia, the Franco-Chinese Treaty relating to Indochina and the partition of New Guinea, had the odour of being engineered, with incidents of previous years being raked up. In the reconvened British Parliament the war met with passionate opposition. One of the bones of contention was the annexation itself. Annexation went against accepted British policy. Such a step should only be taken as a last resort and might not have had the approval of a significant portion of the British politicians and public in those days. The 'great British public' found annexation 'an ugly word', Browne (1888: 228) - himself in favour of it - wrote with some regret. From his words, it can be surmised that, until Dufferin's visit to Mandalay, there was doubt in Calcutta and Rangoon about whether the British government would allow an annexation. 'Great anxiety prevailed', Browne (1888: 238) - himself an eyewitness - wrote, "lest the word "annexation" should choke the Cabinet at the last moment'. In London the Secretary of State for India, Randolph Churchill, came out in support of annexation and convinced the cabinet to take up this cause. Churchill was said to be proud of the course of action taken. It had added territory to the British Empire, given stimulus to British commerce, and had 'added to the area of civilisation and of progress so vast and so valuable a possession'. ${ }^{29}$ To justify the step his successor, Kimberley - also full of hope of that the incorporation would result in an increase in trade with China, which he said might 'ultimately become very great' - would insinuate that among Thibaw's 70 children no-one could be found with the right character to succeed him..$^{30}$ In London doubt was also expressed about the reasons presented by Salisbury's Conservative government to justify a military expedition. Great Britain had acted, it was explained a few months later in the Queen's Speech of January 1886, because 'the protection of British life and property, and the cessation of dangerous anarchy in Upper Burmah, could only be effected by force of arms'. ${ }^{11}$

The prestige of Great Britain was also at stake. As a young Curzon, who just a few days before had become a Member of Parliament, stated: '[L]ives and property of British subjects and the honour and credit of the Empire' were at stake..$^{32}$ One month before the war started, Bosc Sladen

29 Churchill in House of Commons 25-1-1886 (hansard.millbanksystem.com/commons/1886/ jan/burmah-military-operations-incidence-of).

30 Kimberley in House of Lords 22-2-1886 (hansard.millbanksystem.com/lords/1886/feb/22/ kingdom -of-ava-resolution).

31 Hansard.millbanksystems.com/lords/1886/jan/21/the-queens-speech.

32 Curzon in House of Commons 21-1-1886 (hansard.millbanksystem.com/commons/1886/ jan/21/first-eight). 
had expressed himself in a similar vein: circumstances in Ava were 'so barbarous and insecure and the attitude of the Government so intractable, that we cannot consent on the one hand to countenance massacre and misrule, or on the other to invite insult and risk the lives of our political officers' (Browne 1888: 104). There had indeed been insults. Apart from King Thibaw's 'hostile proclamation', there was the 'shoe question', the treatment of the British Resident at Court. When he ascended the throne Thibaw had insisted that court etiquette should be honoured. During an audience the British Resident also had to take off his shoes, remove his sword and to sit on the floor. While some made fun of this, Roper Lethbridge, a Member of the House of Commons, pointed out that the Resident 'was ordered to sit on the floor with his feet behind him', and that any Member of the House of Commons who tried to sit in such a position for any length of time would find it 'most disastrous to him'. ${ }^{33}$ To the British it was no trivial matter. One of their demands of the King of Ava had been for an envoy to the court 'with free access to the King upon the same terms as are usual at other Courts, and without submitting to any humiliating ceremony'. ${ }^{34}$

Members of the Liberal opposition opposed the war and after Gladstone's new cabinet had taken office on 1 February 1886 and hesitantly supported the stand taken by his predecessor, many stuck to this position. Those against the invasion suggested that the economic and political arguments presented to justify the invasion had been trumped up. British merchants in Rangoon had already spent years pleading for annexation; and amongst those who cried foul, that they were treated unfairly by the Ava administration, was the Bombay-Burmah Trading Corporation. W.A. Hunter, a Liberal Member of the House of Commons, who was sure that the 'Chambers of Commerce' were behind the invasion, spoke of 'a war to open up new markets for British trade'. ${ }^{35}$ Another Member remarked that Salisbury's government had 'given an exaggerated importance to the interests of commerce as represented by the Chambers of Commerce, and had appealed to the worst instincts of a nation of shopkeepers' $3^{6}$ Yet a third blamed the 'modern freebooters, the commercial Jingoes, who believe that they are entitled to do anything in

33 Roper Lethbridge in House of Commons 22-2-1886 (hansard.millbanksystem.com/ commons/1886/feb/22/resolution).

34 Note on the Relations between the Government of India and Upper Burmah during the present King's Reign (www.nectec.or.th/thai-yunnan/22.html).

35 Hunter in House of Commons 22-2-1886 (hansard.millbanksystem.com/commons/1886/ feb/22/resolution).

36 McIver in House of Commons 22-2-1886 (hansard.millbanksystem.com/commons/1886/ feb/22/resolution). 
the name of British trade'. ${ }^{37}$ Hunter was also not impressed by the alleged insult to the British Agent:

taking off the shoes in a hot climate was not worse than taking off the hat in a cold; leaving one's sword outside the Palace was not more absurd than a civilian wearing a sword, to which he was in no way accustomed ... and as for sitting on the floor, that was, no doubt, an attitude to which they were not much accustomed, but neither were they walking backwards, like a crab'. ${ }^{8}$

Another issue was the ruthlessness of Thibaw's rule. Some of the facts to substantiate Thibaw's offences against Great Britain dated from the early years of his rule and Burmese 'atrocities' loomed large in the debate. In the House of Lords Salisbury, during a debate on the Macedonian massacres, even stated that in Burma there was 'constant perpetration of horrors on a scale and characterised by an atrocity before which anything which can be related with regard to Macedonia would pale'. ${ }^{39}$ There was also scepticism about the fear of the French gaining a footing in Upper Burma, which had been a main reason to act. French goods could only reach Ava through the Irrawaddy and the Pegu rivers, both running through Lower Burma; allowing the British to keep control of armaments and other goods imported into Ava. For some, like Lord Napier of Magdala, such control could only result in 'serious complications' with France..$^{40}$ For others this was a reason why the invasion had been pointless.

Upper Burma was to be administered from Calcutta. The British government was pleased. The war had cost relatively little money, and Dufferin was also sure that its administration would be conducted 'cheaply'. ${ }^{41}$ In the not so long run Upper Burma might become a profitable possession. In 1888, at the end of his Governor-Generalship, the Earl of Dufferin was made Marquess of Dufferin and Ava. By annexing Ava, Great Britain had

37 Clark in House of Commons 22-2-1886 (hansard.millbanksystem.com/commons/1886/ feb/22/resolution).

38 Hunter in House of Commons 22-2-1886 (hansard.millbanksystem.com/commons/1886/ feb/22/resolution).

39 Salisbury in House of Commons 17-11-1884 (hansard.millbanksystem.com/lords/1884/nov/17/ question-observations).

40 Lord Napier of Magdala in House of Lords (hansard.millbanksystem.com/lords/1886/feb/22/ kingdom -of-ava-resolution).

41 Kimberley in House of Lords 22-2-1886 (hansard.millbanksystem.com/lords/1886/feb/22/ kingdom -of-ava-resolution). 
secured part of the trade route to Yunnan, and from there it was hoped further into Central China. But by controlling Tonkin and its access to the Red River, France was in a better position than Great Britain to establish a trade connection with that province; one which was much faster and where the terrain offered fewer obstacles.

Among those who opposed the annexation of Ava there had been some who feared complications with China. China considered the Kingdom of Ava one of its vassals. Within months a solution was reached in the Anglo-Chinese Convention relating to Burma and Thibet of July 1886; though rumours that Chinese troops might invade Upper Burma did not cease. Beijing recognised British rule in return for the continuation of 'the customary ten-yearly Missions' of the Burmese authorities to the Viceroy of Yunnan..$^{42}$ China also undertook to promote trade between China and Burma. A Delimitation Commission and Frontier Trade Commission were established. Because British troops had some difficulty in bringing Upper Burma under control; the Delimitation Commission, tasked with determining the border between China and Burma, could not start its work for some time.

42 Parliamentary Under-Secretary of State for Foreign Affairs, James Fergusson, in House of Commons 26-8-1886 (hansard.millbanksystem.com/commons/1886/aug/26/england-and-china/ treaty-regarding-burmah). In 1894 a French missionary told Morrison (1895:146) that the Chinese in Yunnan were sure that the 'English had determined to renew the payment of the tribute which China formally exacted by right of suzerainty from Burma. The Chinese were daily expecting the arrival of two white elephants from Burma ... the official recognition by England that Burma is still a tributary of the Middle Kingdom'. According to the story told, the procession went complete with 'yellow flags floating from the howdahs [carriages on the back of the elephants] announcing, as did the flags of Lord Macartney's Mission to Peking, "Tribute from the English to the Emperor of China"...' 


\section{The French Expansion Westwards into Southeast Asia}

Later, proponents of an active French policy in Southeast Asia and China would deplore the fact that after establishing a protectorate over Tonkin France had lost interest in colonial expansion. Étienne (1897: 20) wrote about France having become 'indifferent if not hostile for such a long time' towards colonial adventures. Ferry (1890: 5), in his effort to defend his past policy, detected an 'anticolonial monomania' in France, while a Lyon trade mission to the south of China would deplore the almost complete lack of interest in and enthusiasm for French endeavours abroad (Chambre 1898a: 443).

The reality was a little different. After Annam had become a French protectorate and Great Britain had annexed Ava, Thailand, or Siam as it was called in those days, became the arena of Anglo-French rivalry. Newspapers in Saigon urging for the annexation of Thailand or turning that country into a protectorate fed British misgivings (Scott 1885: 376). Thailand, considered an easy prey by both the French and British, was so terrified of France that Bangkok would avoid anything that might cause the French offence and provide Paris with an excuse to invade the country. Scott (1885: 376) would even write of 'the terror of irritating the French'. Initially, attention focused on Laos and the Upper Mekong. Having established itself in Vietnam and Cambodia, France aimed at an expansion westwards into Laos. Gaining Laos would bring the French right up to the eastern border of Upper Burma, a gateway to India as the fearful British would stress.

Laos was disputed territory. According to the British, it formed part of Thailand 'by right of conquest for nearly a century'. ${ }^{1}$ France disputed this. Laos, the French had to admit, was economically dependent on Thailand, but it had been a tributary of Hué and was usurped by Thailand, making use of years of civil war in Annam. The French based their position, it was stressed, 'on the incontestable rights of Annam which had been exercised for several centuries'. ${ }^{2}$ In October 1891 France publicly staked its claim to Laos and alerted the British when its Minister of Foreign Affairs,

1 Lord Lamington in House of Lords 15-6-1893 (hansard.millbanksystem.com/lords/1893/ jun/15/questions-observations).

2 Dufferin to Rosebery 7-2-1893 (cited in Norman 1900: 470). 
Figure 13 Continental Southeast Asia after the annexation of Ava in 1886

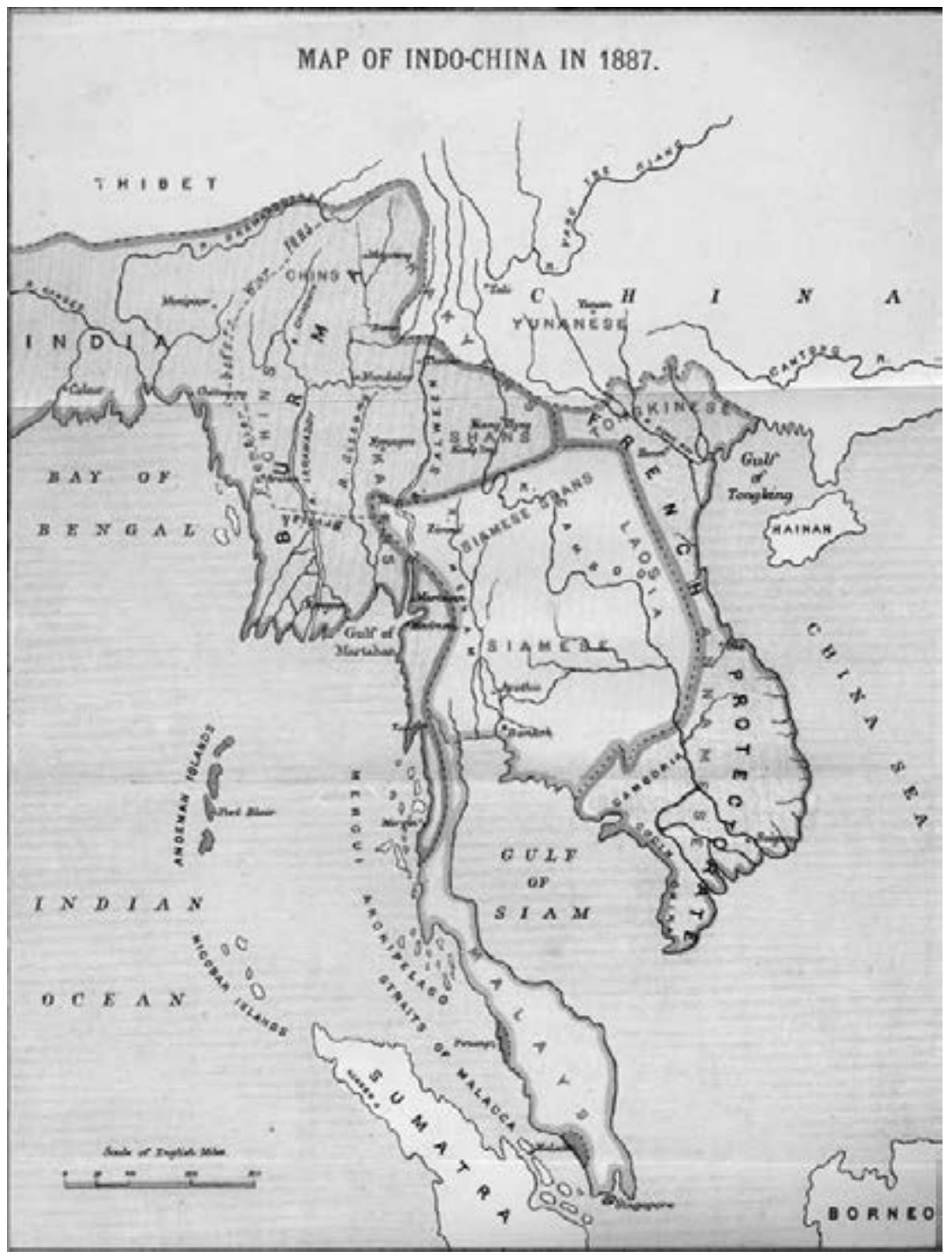

Source: Browne 1888

Alexandre Ribot, announced in Parliament that the Upper Mekong should be the boundary between the French and British spheres of influence (Chandran 1977: 13). In case London might have missed the signal, Paris informed London of its intention in May 1892; suggesting that the river 'should be a boundary across which neither the French westward nor the 
British southwards [from India through Burma] will expand their sphere of influence'.

Its designs would bring France on a collision course with Great Britain. It gave the British the impression that besides Russia yet another enemy was encroaching on its colonial possessions. The persistence France showed in its efforts to have Bangkok yield to its territorial demands at one point made Salisbury and other British politicians ponder that a partition of Thailand might be near, and even that when Great Britain did not stand its ground France might take the whole of Thailand within a decade. ${ }^{4}$

The consequences of such a French advancement would be great. In Thailand British economic interests were paramount; or, as the then Foreign Secretary Rosebery expressed it in August 1893, Great Britain possessed 'practically a monopoly of Siamese commerce'..$^{5}$ Again according to Rosebery, British shipping in Bangkok accounted for 87 per cent in tonnage and 93 per cent in value of the whole shipping. ${ }^{6}$ Great Britain, as Lord Lamington observed, 'could not for one moment allow any other European supremacy in Siam proper than her own'? For France it was exactly this British economic preponderance in Thailand that was an additional reason not to accept Thai control over Laos and the Mekong, "because "Siamese property" was tantamount to "British property" in view of the predominant British influence at Bangkok' (Thio 1969: 286).

Diplomacy would concentrate on the east bank of the Mekong, but the region France claimed was not that far away from Bangkok and the fertile Menam (Chao Phraya) Valley, making the prospect of a French forward move all the more alarming, because, as Lamington pointed out in the House of Lords, there was 'no natural frontier between the Mekong and the Menam' that could prevent the French from moving on. ${ }^{8}$ The terrain was flat and there were no mountains to cross. British policy in countering French intentions hinged on three principles. Firstly, the territorial integrity of Thailand, as a whole or at least the territory located west of the Upper

3 Minute by Salisbury 10-5-1892 (cited in Chandran 1977: 21).

4 Kimberley to Rosebery 25-7-1893 (cited in Chandran 1977: 64), Salisbury to Chamberlain 21-9-1895 (cited in Chandran 1977:184), Salisbury to Curzon 3-12-1895 (cited in Chandran 1977:214).

5 Rosebery to Gladstone 26-8-1893 (cited in Chandran 1977: 79).

6 Rosebery in House of Lords 27-7-1893 (hansard.millbanksystem.com/lords/1893/jul/27/ questions).

7 Lord Lamington in House of Lords 15-6-1893 (hansard.millbanksystem.com/lords/1893/ jun/15/questions-observations).

8 Ibid. 
Mekong (opinions about this differed), should be maintained to allow the country to serve as a buffer between the French and British territories in Southeast Asia. A French Thailand would, in the words of Rosebery, mean 'another great military power' on India's border. ${ }^{9}$ Rosebery, portrayed by the historian Chandran (1971a:108) as a man 'who possessed a morbid suspicion of French intentions', even appears to have judged this to be a more realistic threat than a Russian invasion of India, though there were others who thought the fear of French troops marching towards India through Thailand to be 'the most foolish of all the bugbears that the panic-mongers' had come up with. ${ }^{10}$ Secondly, in the south of Thailand, in the Kra Isthmus, no other power should receive special concessions.

Thirdly, the land between the northern boundary of Thailand and the southern one of China should also not fall into French hands. There a kind of Thai-Chinese buffer had to be created between Upper Burma and the approaching French, necessary, Britons argued, because of 'the French aggression in Siam' (Morrison 1895: 241). The 'empty land' located there comprised a number of small Shan states. Two of these, Meung Lem (Munglem) and Keng Hung (Kiang Hung), should go to China on the condition that China would not cede them at any later date to France; as, in fact, they would under the Convention between Great Britain and China relative to Burmah and China, 1 March 1894. ${ }^{11}$ A third state, Keng Cheng (Kyaing Chaing, Kyaing Cheng, Kaing Khen), should be added to the territory of Thailand. Edward Grey, at that moment Parliamentary Under-Secretary for Foreign Affairs, explained that Great Britain had 'feudal rights' over it because of the incorporation of Ava; but, as Salisbury would state two years later, in China and 'to some extent in France' there was 'a tendency to underrate the claims and rights of her Majesty's Government'. Much more Salisbury could not say, except that Keng Cheng, which was indeed claimed by China, was 'a country of which we know so little.. ${ }^{12}$ Thailand accepted Keng Cheng in mid-1892, but in May 1894 London cancelled the transfer.

9 Rosebery to Gladstone 26-8-1893 (cited in Chandran 1977: 79). See also Rosebery to Elgin 18-6-1895 (cited in Chandran 1977: 151).

10 Sir William Harcourt, Chancellor of the Exchequer, to Kimberley 25-3-1895 (cited in Chandran 1977: 134).

11 At least of Keng Hung some British initially were of the opinion that it belonged to Burma; but, as Grey phrased it, 'found' that it was 'under Chinese administration' (Grey in House of Commons 2-4-1894, hansard.millbanksystem.com/commons/1894/apr/o2/kiang-hung).

12 Grey in House of Commons 19-6-1893 (hansard.millbanksystem.com/commons/1893/jun/19/ the-french-in-siam), Salisbury in House of Lords 30-8-1895 (hansard.millbanksystem.com/ lords/1895/aug/30/the-franco-chinese -treaty). 
In April 1893 London, in the name of 'the national independence of Siam', declined the French proposal that the Upper Mekong River should form the boundary between the French and British spheres of influence in that part of the world. ${ }^{13}$ Disregarding what London thought about such aggrandisement of French colonial territory, and at the same time suspicious that in the north Great Britain wanted to expand its control east of the Burmese border - and thus also east of the Mekong, moving in the direction of south China (Chandran 1971a: 6, 1977:20-1) -, France was prepared to go to war to enforce its claim. It was, as Taylor (1971: 344) asserted, France's 'substitute for a great war in Europe'. On the British side, then and later, there was the suspicion that the French lusted after the whole of Thailand, with the added complication that should they succeed, France and Great Britain would share the large Burmese-Thai border, something the British wanted to avoid at all costs (Temple 1902: 46). Thailand should remain a buffer.

\section{The Franco-Thai war}

By 1893, due to heightened tension with Great Britain over territorial expansion in Africa - and a desire to outdo the British and the Germans - the mood in France had become different from the one which Lanessan and other French colonialists had so criticised. Illustrative of this was that Ferry's self-vindication, which at the same time was an attack on those opposing an active colonial policy, published in 1890, became an instant bestseller with at least fourteen editions before the year was over. An organised colonial lobby had also come into existence. First, the Comité de l'Afrique française was formed in 1890, followed by the establishment of the Groupe Coloniale de la Chambre (Colonial Group in Parliament) in 1892 and the Union Coloniale française in 1893. Together with a variety of other similar but less influential groups, some in fact having more in common with learned societies than pressure groups, collectively known as the 'parti colonial', a deceptive name that created the impression of more unity of purpose than there actually was. Though the Germans acquiring their Pacific Islands and the Italian exploits in the Horn of Africa were mentioned as reasons why Paris should embark upon an active policy of colonial expansion, Great Britain was the main adversary but also the example to follow. The call was for chartered companies, which the British again were establishing - the Royal Niger Company of 1886, the (Imperial) British East Africa Company of 1888, and the 
British South Africa Company of 1889 - called into being through a government decree. Or, as the leading figure of the movement, the chairman of the Groupe Coloniale, Eugène Étienne, Under-Secretary of State of the Colonies ${ }^{14}$ in 1887 and again from 1890 to 1892 , argued - and even more forcefully so after the cabinet of Charles de Freycinet, of which he was a member, fell in February 1892 -, France should support its commercial companies, which wanted to exploit foreign territory in the same way Great Britain, Germany, Italy, Belgium and the Netherlands had done so successfully (Étienne 1897: 18). Everywhere European powers were expanding their overseas territory. France could not lag behind. It should regain the status of the mighty colonial power it had once been and seek compensation for past reverses. Frenchmen stressing this latter point could and did point to many examples: the Peace of Paris of 1763 after the Seven Years' War, which had robbed France of its colonial possessions in North America and would make Great Britain the dominant foreign power in India; the lost Franco-German War of 1870-71; the Suez Canal and Great Britain taking control of Egypt in 1882. More generally, it was argued that where it concerned colonial expansion Great Britain had always tried to frustrate French plans. Newspapers, still optimistically writing about the strength of the French navy, joined in in creating a bellicose patriotic spirit. At the end of 1893 Le Stéphanois (22-121893) would gloat over the alarm in the British press over the strength of a combined Franco-Russian fleet, boasting that the French warships were more numerous, better armed and faster than the British ones.

Étienne and his political friends did not get what they wanted. The Freycinet government decided against them, not wanting to bypass Parliament, which might not be in favour of such chartered companies and could refuse to pass a law to call them into being. The hesitance shown by the French government was indicative of the weakness of the leading protagonists of French colonial expansion. They might have excellent connections with the ministry in charge of the colonies, but less so with that of Foreign Affairs (which was against their idea of creating chartered companies by decree). Acting primarily as lobbyists, they also do not seem to have aimed at influencing the press or the larger public (Grupp 1980: 19, 43). If colonial sentiments did flare up, it was in response to international developments, not to a campaign by protagonists of colonial expansion.

Though Africa was the immediate cause, the colonisation of mainland Southeast Asia also received renewed attention. A bellicose press campaign demanded the occupation of Laos and pressure on the government to act 
firmly gathered steam. At the Foreign Office in London, Permanent UnderSecretary Philip Currie observed in March 1893 that in France people were 'working themselves up into a state of excitement against Siam with the view of plundering her'.5 In March 1893 the French minister resident in Bangkok, Auguste Pavie, a war horse, demanded that Thailand should withdraw the troops from Laos it had sent there to call to order restless refugees from Yunnan. ${ }^{16}$ To add force to the ultimatum, the French gunboat Le Lutin was directed to Bangkok. There she anchored 'with her decks cleared for action and her guns trained on to the place ${ }^{17}$ The Thai government was warned that a French fleet had been dispatched to Saigon, from where it could sail on to Bangkok if necessary. ${ }^{18}$ To avert a French attack, Bangkok, as it had done before in the previous months, tried to gain British diplomatic support by alerting London to the danger of Thailand becoming a French protectorate, but London did not commit itself. The following month, in April, troops from Indochina marched into Laos.

Great Britain did take its precautions. In mid-April the gunboat HMS Swift was dispatched to Bangkok on the suggestion of the Commander of the China Squadron. The British navy also went in search of a suitable place for a coaling station in the Gulf of Thailand; a decision which may have been taken with both Germany, suspected of wanting to acquire a coaling station in Thailand, and France in mind. In June London directed a second warship from Singapore to Thailand; a third one was soon to follow. In French eyes, these ship movements were meant to encourage Thailand to resist. Consequently, Paris warned Bangkok not to turn to other powers for help.

On 13 July hostilities started with the so-called Paknam Crisis or Paknam Incident, or to quote a patriotic French contemporary, Fournereau (1998: 7), with the 'glorious Paknam affair'. Two gunboats, the Comète and the Inconstant, forced their way up the Menam River to Bangkok, 'the weak point of the Siamese Empire'. ${ }^{19}$ When these French warships disregarded a warning not to sail the Menam and crossed the Paknam bar, guns located at the local fort, guarding the entrance to Bangkok, opened fire. The FrancoThai War of 1893 had begun. Still the same day, the two warships anchored

15 Currie to Rosebery 7-3-1893 (cited in Chandran 1977: 45).

16 www.paknam.com/history/paknam-incident-1893.html (accessed 8-8-2012).

17 Gibson Bowles in House of Commons 29-6-1893 (hansard.millbanksystems.com/ commons/1893/jun/29/the-french-in-siam).

18 Grey in House of Commons 29-6-1893 (hansard.millbanksystems.com/commons/1893/ jun/29/the-french-in-siam).

19 Rosebery to Jones 18-11-1892 (cited in Chandran 1977: 33). 
off the French Legation in Bangkok. The next day, 14July, the Thai Minister of Foreign Affairs congratulated the commander of the French gunboats upon their sailing on to the city and 'all the Siamese vessels in the river were dressed with flags, the tricolour at the peak, in honour of the French national fête' (Norman 1900: 467).

London did not even protest. ${ }^{20}$ In view of their disputes over Africa, the British government did not want to disrupt Anglo-France relations by coming to the support of Thailand. In Africa there was a danger of British control over Egypt being destabilised, in particular after the death in January 1892 of the Khedive, Tewfik Pasha, the son of Ismail, and a British ally. In identical statements in both Houses, Rosebery and Grey clarified that it was government policy to do nothing that would 'aggravate the situation in any way' and to 'consider justly and dispassionately the present position of affairs between France and Siam'. Further, they explained that Thailand's independence and integrity was 'a subject of grave importance to the British, and more especially to the British Indian Empire. ${ }^{21}$ Ten days later Rosebery left no doubt that London did 'not feel called upon to pronounce an opinion' and had 'scrupulously avoided giving any advice to the Siamese Government, beyond, when they have asked for it, urging them to come to terms as quickly as possible with their powerful neighbour. ${ }^{22}$ Bangkok could do worse than follow such suggestions, because, as Kimberley, at that time Foreign Secretary, later wrote to the British minister to Bangkok, Maurice de Bunsen, otherwise the outcome might be 'the more or less complete extinction of Siamese national existence. ${ }^{23}$ This was the rationale behind London's advice, afraid as British politicians were that if Bangkok resisted, Thailand might cease to exist or be forced to hand over some of its more important provinces to France; both eventualities Great Britain wanted to avoid.

On 19 July Paris issued an ultimatum to Bangkok. Among other things, Paris demanded that Thailand should recognise 'the rights of Annam and Cambodia on the left bank of the Mekong and over the islands in that river' (Chandran 1977: 57). To the French, the Mekong was a French river, and not just for geographical reasons. As a leading French colonialist and

20 Grey in House of Commons 19-6-1893 (hansard.millbanksystems.com/commons/1893/ jun/19/the-french-in-siam).

21 Rosebery in House of Lords and Grey in House of Commons 17-7-1893 (hansard.millbanksystem.com/lords/1893/jul/17/question-observations, hansard.millbanksystem.com/ commons/1893/jul/17/france-and-siam).

22 Rosebery in House of Lords 27-7-1893 (hansard.millbanksystem.com/lords/1893/jul/27/ questions).

23 Kimberley to De Bunsen 27-10-1894 (cited in Chandran 1977: 118-9). 
former Governor-General of Indochina, Doumer (1905: 30), would write, the Mekong was also French from a historical point of view. It was the French who had explored the river and had presented the outcome of their famous work to the world.

When Thailand refused to comply, a French naval blockade, which even before it became effective drew protests from Foreign Secretary Rosebery and created an uproar in Great Britain. This was particularly true after 30 July, when news reached London that the British warships anchored at Bangkok had been ordered to leave the blockade area. The Siam Crisis of 1893 was born. Rosebery feared that war could erupt at any moment. He even went as far as to inform the German Emperor, who at that moment was visiting Great Britain, via Queen Victoria, about the seriousness of the situation. The news made Wilhelm II agonise over the possibility of a European war with Russia siding with France, and how Germany - which, he thought, if it really was a world power had to join - would perform in it (Carter 2010: 164). ${ }^{24}$ German support, diplomatically or otherwise, turned out not to be necessary. The crisis was defused within a day when Paris attributed the order to leave the blockade area to a misunderstanding of instructions (Chandran 1977: 68-9).

Urged to do so by both France and Great Britain, Bangkok yielded to the French demands. A Franco-Siamese Treaty and Convention was signed on 3 October. Bangkok had to pay an indemnity. Laos, about one third of Thailand's territory, became a French protectorate. As a token of its might, a French gunship was stationed permanently in Bangkok. Lorin (1906:356) observed that the French naval expedition had made the Thai court panic, and a decade later boasted that it could well have turned Thailand into a French protectorate, but had settled for less. France might have won, but the war did not make it win friends in Thailand. Lorin (1906:356) concluded that their lenience cost the French dearly. French nationals were molested, the French minister was jeered and, more importantly, functions in the public administration went to other foreigners, not to Frenchmen. Great Britain, for instance, provided a police force for Bangkok made up of Sikh soldiers from India, commanded by British officers.

24 His Chancellor, Count Leo von Caprivi, had other considerations. He hoped that if it came to an Anglo-French War Germany could be 'certain of expanding the triple into a quadruple alliance'; that is with Great Britain joining the Triple Alliance or Dreibund of Germany, AustriaHungary and Italy which had been formed in 1882, among other reasons, as a defensive pact against France (Taylor 1971: 343). 


\section{Continued British-French rivalry}

After Thailand had yielded to the French ultimatum tension was far from over. London remained suspicious of a joint Franco-Russian offensive. It was even deemed possible that a Russian naval squadron would sail to the French naval base of Toulon, protecting France in Europe and giving the French freedom to act in Thailand. Both sides prepared for the worst. With possible French actions in Southeast Asia in mind, Rosebery urged, a number of times, for an increase of the British naval presence in Singapore. Thailand could still 'be eaten like an artichoke, leaf by leaf', he observed in October $1894 .{ }^{25}$ In October 1895 (when Salisbury had become Prime Minister and Foreign Secretary) London indicated that it was prepared to have its Indian Army march into Thailand should France resort to gunboat diplomacy, and sent its warships to Bangkok; though privately Salisbury doubted whether the British were prepared to take such a step (Chandran 1971a: 44). In the same months, the French government discussed a military response should Great Britain somehow succeed in extending its sphere of influence over the heartland of Thailand, i.e. Bangkok and the Menam Valley (Chandran 1977: 192-3).

A bone of contention remained the Anglo-French border in the north. On 31 July 1893, London and Paris had seemingly come to an understanding. Nowhere along the Upper Mekong should there be a joint frontier. This was agreed, an Anglo-French Protocol of that date stated, 'with a view to obviating the difficulties which might arise from a direct contact' and required 'mutual sacrifices and concessions' (ibid.: 71). A few months later, at the end of November, London and Paris agreed on the conditions of mapping out the frontiers of the buffer to be; these, a young Edward Grey, Parliamentary Under-Secretary of State for Foreign Affairs, explained in the House of Commons in December, could not yet be fixed in absence of 'further geographical and ethnographical information'. ${ }^{26}$

The French almost immediately backtracked. Complicated negotiations between London and Paris and much bickering were the result. The French preference for a mutual frontier gave rise to the suspicion in London that the French intended to move on and might try to incite the population on the British side of such a border. The French, from their side, still hoping that the Mekong might be made navigable, regarded the British insistence 
on a buffer state as an effort to obstruct any future French trade route into Yunnan (Chandran 1971a: 105).

The issue briefly brought the Shan states along the Mekong, almost as remote and uncharted as the Pamirs, to the centre of world attention. London was adamant that they should form part of a buffer; preferring this above a 'neutral zone', which would provide less of a safeguard. A conterminous French-British border in mainland Southeast Asia 'would involve both States in great military expenditure and cause constant liability to panic'. ${ }^{27}$

A buffer, a status quo region between the Nam Hou (Nam U) and Mekong rivers, the exact frontiers of which still had to be determined, was to be created. To Rosebery it did not matter much whether the newly created buffer was to be governed by China or Thailand, as long as it came into being. Discussions centred on Keng Cheng ('as much ours as the Channel Islands', a British diplomat would state ${ }^{28}$ ) and Keng Hung to its northeast, with the complicating factor that the territory of both extended eastwards over the Mekong river - land France aimed at. Keng Tung was also caught up to the west. London and Paris differed in opinion about whether its territory transgressed the Mekong or not. London wanted to keep Keng Tung out of the buffer. It 'was in feudatory relations with the Indian Government'. ${ }^{29}$ The proposed buffer made little impression in Great Britain. In the House of Commons Balfour spoke about 'a small, powerless buffer'. ${ }^{30}$

Both sides took steps, military and otherwise, to assert their presence in the Upper Mekong region, especially in the eastern, trans-Mekong part of Keng Cheng. In January 1894, when the new French government of Jean Casimir-Perier indicated that it did not feel bound to the buffer agreement, London, in an effort to assert that Keng Cheng was British, reacted by sending an army officer and a small detachment of soldiers to its capital, Mong Sing (Muong-Sing), located on the left bank of the Mekong, to collect tribute from its ruler (Chandran 1977: 99). Mong Sing also had the attention of the French. At the end of 1894, when J.G. Scott, the chief British representative in the joint committee to decide on the border, reached Mong Sing, he was greeted with a view of the French flag flying over the palace of its ruler,

27 Rosebery in House of Lords 27-7-1893 (hansard.millbanksystem.com/lords/1893/jul/27/ questions).

28 Phipps to Sanderson 27-9-1894 (cited in Chandran 1977: 123).

29 Grey in House of Commons 19-6-1893 (hansard.millbanksystem.com/commons/1893/jun/19/ the-french-in-siam).

30 Balfour in House of Commons 2-8-1893 (hansard.millbanksystem.com/commons/1893/ aug/o2/civil-services-and-revenue-departments). 
whom the British suspected of French sympathies anyway, or at least of being anti-British. The flag was immediately lowered (ibid.: 129, 156, 187).

The situation deteriorated to such an extent that London ordered Calcutta to prepare for a military expedition to Keng Cheng in February 1895. This posed some problems. The disputed part of Keng Cheng was 14 to 21 days' distance from the nearest British military post, and seven weeks from the nearest point on the railway; and 'cut off from communication with Burmah and India during the rains', Curzon would later explain. ${ }^{31}$ Such conditions already made the Indian government hesitant to comply. An additional reason for its reluctance was that it was the time of the Chitral crisis, and Calcutta considered a Russian aggression on India's northwest frontier to be a much more realistic threat. The reaction prompted Rosebery (now Prime Minister) to lament that the British in India did not realise the dangers posed by France, 'a great military power at least as unscrupulous and aggressive as Russia is represented to be'. ${ }^{2}$ Others went even further. At the India Office in London, George Hamilton, the new Secretary of State for India, wrote that the French were 'more hostile' and 'more likely to come into active hostilities' with Great Britain than Russia. ${ }^{33}$

Mong Sing was occupied on 5 May 1895. The crossing of the Mekong by British troops created an uproar in France. The French government protested. The British occupation held the danger that Great Britain would block one of France's chief objectives - using the Mekong as a commercial waterway into south China. Paris reacted by ordering a gunboat, the Grandière (named after the former Governor of Indochina), up the Mekong some months later. In response, London took the decision to station a military garrison in Mong Lin in Keng Tung, which at that moment appeared to be the target of a French military expedition (Chandran 1977: 199-200).

Another conflict area lay to the south. Politicians in London were suspicious of France demanding additional concessions from Thailand to make Bangkok stick to the peace conditions. The possibility of a further French encroachment was considered very likely. France might even aim at the Southern Thai provinces, bordering the British sphere of influence in the Malay Peninsula. Soon, as it was phrased some ten years later, Luang Prabang (Louangphrabang), Battambang, Angkor and Chantaboon (Chantabun, Chantaburi, Chantaboum) would become as familiar to British

31 Curzon in House of Commons 27-3-1896 (hansard.millbanksystems.com/commons/1896/ $\mathrm{mar} / 27 /$ france-and-siam).

32 Rosebery to Steward 13-6-1895 (cited in Chandran 1977: 147).

33 Hamilton to Elgin 23-8-1895 (cited in Chandran 1977: 179). 
'mouths as household words' ${ }^{34}$ One of the first new requirements France had made was that Bangkok would allow, much to the dismay of the British, a temporary French occupation of the port and river of Chantaboon in the province of the same name. Other provinces might well follow. Part of the province of Luang Prabang, which the French claimed was under their protection, had, in fact, already been acquired by France, despite protests from London. But Paris wanted more, and intended to claim its west bank portion as well. Angkor and Battambang, originally Cambodian regions, might also be swallowed by France. Though in the Franco-Siamese Treaty of ${ }_{186}$ Paris had recognised Thai suzerainty over these two provinces, they were claimed by Cambodia, and thus, by extension, could also be claimed by France. London left no doubt that for economic and political reasons they should remain Thai. Them becoming French, Rosebery was sure, would 'produce a deplorable effect' in Great Britain. ${ }^{35}$ The Singapore Chamber of Commerce had warned Rosebery that Thailand surrendering Angkor and Battambang would be a serious blow to British trade. In the familiar pattern of British distrust of foreign annexations the Singapore Chamber of Commerce highlighted the high tariffs the French would impose. Both provinces, moreover, were located not far away from Bangkok, which in the eyes of the British added an additional threat to them becoming French. Annexing them, Paris was made to understand, would not only be an invasion of the integrity of Thailand, but would in view of the proximity of these provinces to Bangkok put an end to Thailand's independence. ${ }^{36}$ London attached so much value to the two provinces that at the end of July 1893 the prospect of France acquiring them had been behind London's suggestion to Bangkok to yield to French demands; otherwise, Thailand might lose Angkor and Battambang (Chandran 1977: 65). Having Bangkok meet the French conditions was the only way, Rosebery had thought at that moment, in which Great Britain could strike a 'fatal blow' to French territorial ambitions in Thailand. ${ }^{37}$ Whatever his motivation might have been, the impression in Great Britain and abroad was that Bangkok had yielded to France following the advice of London.

In its 1893 ultimatum France had not asked for Angkor and Battambang, but it had insisted that France should receive the tax farming rights in 
the two provinces in case Thailand could not pay the indemnity agreed upon. As an additional condition, France also demanded that Thailand should withdraw its army from Angkor, Battambang and a 25-kilometre zone west from the Mekong, expanding French influence still further. The zone became a serious point of contention between London and Paris, London eventually hoping to use it as leverage to get France to meet some of the British demands.

In France the government was spurred on by public opinion demanding further expansion. In London the government was confronted with an equally belligerent mood; with complaints about sacrificing Thailand and the British commercial interests there, and the damage done to British prestige in the wider world, including Southeast Asia. One member of the opposition in the House of Commons, evoking the fear of Russia approaching India from one side and France from the other, pointed out that 'large sections' of the public 'felt considerable anxiety' and spoke about the 'grave apprehension' that the British had about France absorbing the whole of Thailand..$^{8}$

Another bargaining chip London had was the buffer in the north. In his last months as Foreign Secretary, Kimberley, impressed by the determination of France, had begun to doubt the feasibility of such a buffer hoping that concessions on this point, especially parting with East Keng Cheng, would lead to a more general understanding with France, which would extend to the Anglo-French disputes in Africa (Chandran 1977: 143). The new government of Salisbury was not disinclined. Assuming that control over the whole left bank of the Mekong was an overriding French desire, handing over Keng Cheng might, for instance, induce the French to abandon the 25-kilometre demilitarized zone west of the Mekong and a pleased Bangkok might consent to the British getting hold of Kelantan and Terengganu on the Malay Peninsula (Thio 1965: 295). Prepared to abandon the buffer idea, British politicians and senior civil servants suddenly began to belittle the importance of the Shan states concerned. In Calcutta the new Viceroy of India, Lord Elgin, wrote to Rosebery about the 'remote and unpleasant region on the banks of the Mekong' and the 'unhealthy and difficult districts' one had to traverse to reach it. ${ }^{39}$ In London the India Office agreed. These states, in the words of one of its officials, Steuart

$3^{8}$ R. Temple in House of Commons 30-3-1894 (hansard.millbanksystem.com/commons/1894/ mar/3o/france-and-siam).

39 Elgin to Rosebery 7-7-1895 (cited in Chandran 1977: 160). 
Bayley, were 'distant, worthless and inaccessible bits of territory'. ${ }^{40}$ The qualifications were taken over by politicians. A few months later Prime Minister Salisbury wrote about Keng Cheng: 'It is distant, it is unhealthy, the access to it is roadless, the governor is in the jungle.. ${ }^{41}$

An additional reason for British politicians to change their minds was that the Sino-Japanese War (1894-95) had shown that China might not be strong enough to defend a buffer. The Far Eastern Triple Alliance that had been formed in the wake of it made China seem an unreliable partner of the British. France had outwitted Great Britain by coming to the rescue of China in its effort to deny Japan territorial gains on Chinese soil; something London had refused to do.

\section{The Anglo-French Declaration}

Within a month of Salisbury becoming Prime Minister and Foreign Secretary in June 1895, he indicated that he could agree with the Mekong forming the boundary between Burma and French Indochina. Six months later an agreement was reached. In the Anglo-French Declaration of London regarding Siam, the Niger and Tunis (15 January 1896), Great Britain and France pledged 'not to advance their armed forces' into most of Thailand as we know it nowadays. ${ }^{42}$ The Mekong became the border between Upper Burma and Laos (Art. 3). Not included in the deal, and thus open to future diplomatic and armed manoeuvres, though both the British and French government denied that they harboured any such intentions, were some of the French and British immediate desiderata. On the French side these were Angkor, Battambang, Chantaboon, Luang Prabang and the 25-kilometre zone on the right bank of the Mekong. The British had their eyes on the Kra Isthmus and the Malay Peninsula.

London accepted reality. British troops left Mong Sing and the section of Keng Cheng situated on the left bank of the Mekong was transferred to France. The British government soothed itself with the idea that it had rescued that part of Thailand that was most vital to the country's own prosperity and to British commercial interests. What remained of Thailand, as Curzon, co-responsible for the deal, was to stress in 1896, was 'that part of the kingdom which was most important to British interests, and ... most 
essential to the security, prosperity, and development' of Thailand. ${ }^{43} \mathrm{An}$ additional argument, Curzon asserted, mirroring the generally held belief in those days, was that up north the Mekong was unnavigable for steamers; though the French, of course, would make every effort to improve its navigability. ${ }^{44}$

Neither in France nor in Great Britain was the Declaration greeted with much enthusiasm. For expansionists in France it was not easy to come to terms with the fact that France could not proceed further into Thailand (Thio 1969: 302). To some, like Darcy (1904: 202), Thailand also became a case to demonstrate how selfish the British were and that Great Britain would never allow France the expansion of its Empire it was not only entitled to, but even needed in order to survive on the world scene; also complaining about the British who never had any qualms about presenting themselves as victims of French ambitions. In Great Britain, the 1893 Franco-Thai agreement had already been received with little enthusiasm because of the territory France had gained. Then and in subsequent years, the press had lashed out at Rosebery for not being firm enough. He and his cabinet had made 'very grave blunders'. ${ }^{45}$ Salisbury was well aware that the AngloFrench Declaration would receive similar treatment in the press and in Parliament. It did not help that there had been a change in government in London. The Declaration provided the Liberal politicians, now in opposition and themselves accused of having saddled Great Britain with numerous diplomatic defeats, the chance to hit back. Curzon, now Under-Secretary of State for Foreign Affairs, mockingly spoke of 'Lord Rosebery going up and down the country talking of the surrender of Siamese territory and the sacrifice of British interests. ${ }^{46}$ By surrendering part of Keng Cheng, the new Conservative government had seriously blundered, Rosebery and other Liberal politicians argued. Curzon said he did not understand such a line of reasoning. Only a trivial concession had been made. It concerned a 'small slice of territory', a 'small physical protuberance on the frontier of India'. 47 The area handed over to France was just ' 1,250 square miles ... inhabited by about 3,000 people'; so there was no 'great sacrifice' that the opposition

43 Curzon in House of Commons 27-3-1896 (hansard.millbanksystems.com/commons/1896/ mar/27/france-and-siam).

44 Ibid.

45 Ashmead-Bartlett in House of Commons 27-3-1896 (hansard.millbanksystems.com/ commons/1896/mar/27/france-and-siam).

46 Curzon in House of Commons 27-3-1896 (hansard.millbanksystems.com/commons/1896/ $\mathrm{mar} / 27$ france-and-siam).

47 Ibid. 
was talking about. ${ }^{48}$ Similarly, Salisbury, in a letter to Chamberlain, wrote about a 'worthless territory'.49

The provinces of Angkor and Battambang, not included in the Declaration and thus still exposed to any plans France might have, and the city of Chantaboon, still occupied by French troops, also figured prominently in the discussion. Critics could point out that in 1893 Curzon had still considered Angkor and Battambang essential to Thailand, and had insisted that Chantaboon was important to British trade. Apart from all this, there were doubts that by concluding the Declaration Great Britain had gained much elsewhere for the concession it had made regarding Thailand. 



\section{Russia, Japan and the Chinese Empire}

In the closing years of the nineteenth century, the Chinese Empire became one of the prized targets in the race to carve out spheres of influence and expand colonial empires. China had, in practice, long been closed to maritime foreign trade, which between 1757 and 1842 had been confined to Guangzhou. In that year the treaty of Nanjing (Nanking), signed after Great Britain had defeated China in the First Opium War (1839-42), had forced China to open five treaty ports to British ships and traders and to cede Hong Kong to Great Britain; the latter much to the dismay of Foreign Secretary Lord Palmerston, who would have preferred to gain Zhoushan and not just a barren rock, as he said Hong Kong was, with almost nobody living there. In 1844 France - simply as an imitation of the British, one French historian wrote (Lorin 1906: 27) - and the United States concluded similar treaties; the French succeeding in having China revoke a ban on Christianity. Due to over-optimistic expectations about the prospects of trade with China too many ports had been opened at the same time, with the existing ones, Macau and Guangzhou, suffering from the new competition. Hong Kong and the treaty ports had a slow start, as did later ones.

China was forced to make even more concessions in the Second Opium War (1856/7-60), fought by France and Great Britain together - with Great Britain initially somewhat weakened by the Mutiny in India, and having to redirect troops that were already assembled in Singapore to fight in China back to India. These Chinese concessions appeared in the Treaties of Tianjin (Tientsin) concluded with Great Britain, France, the United States and Russia in June 1858 . China was reluctant to comply but at the end of the war when British and French troops had entered Beijing the Chinese government was forced to ratify the Tianjin treaties in the Conventions of Beijing of October $1860 .{ }^{1}$ China had to open an additional number of treaty ports and cede part of the Kowloon Peninsula opposite Hong Kong to Great Britain. Beijing also had to allow British, and thus also other foreign ships, to sail the Yangtze or Blue River flowing from Tibet in the west to

1 In 1849 Portugal annexed Macau, which up to then had still been Chinese territory, for the use of which Portugal had paid rent. The islands of Taipa and Coloane were added to Macau in 1847 and 1864 , respectively. In the Treaty of Beijing of 1 December 1887 China recognised Portugal's position in Macau. In return Lisbon promised not to alienate Macau without China's consent and to allow Hart's Chinese Imperial Maritime Customs Service to control the import of opium into China. The latter, it would turn out, would be a serious blow to the smuggling of opium from Macau, one of the pillars on which the economy of the city rested (Norman 1900: 186-7). 
Figure 14 China at the end of the nineteenth century

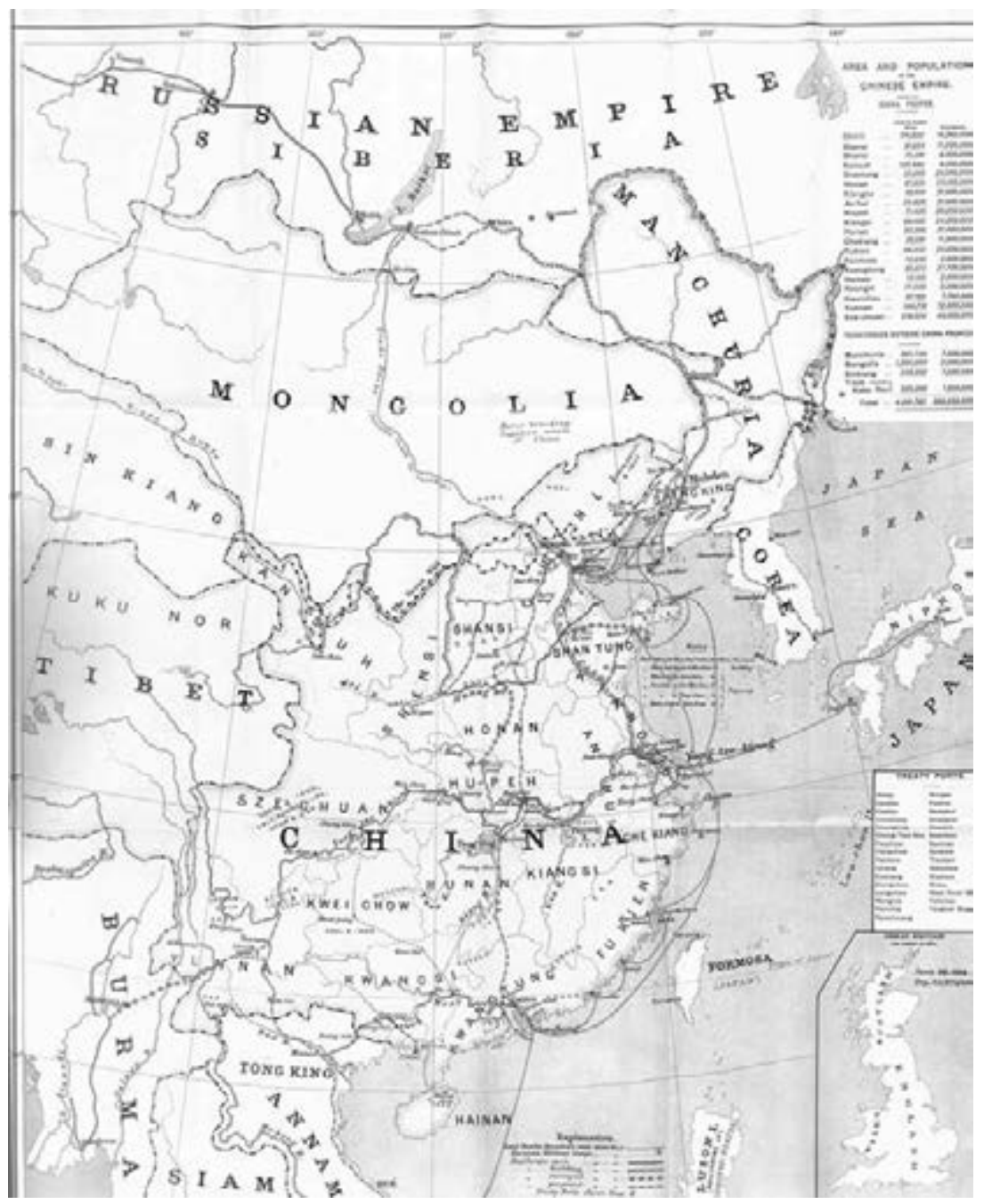

Source: Beresford 1899

Shanghai on the east coast, which would soon become a main artery for British commerce in China. Along the Yangtze foreigners could trade at three river ports. Which ones these should be was still to be decided upon, but the provision was made that foreign merchant ships should not sail further inland than Hankou (Hankow).

In the Convention concluded with France, China not only guaranteed the safety of Christian missionaries in China, but also committed itself to 
allowing them to settle in China wherever they wanted. Such a permission had not been mentioned in the French text of the treaty. It was only included in the Chinese text, inserted there by a French missionary acting as translator. From then on, missionaries were allowed to live in the interior of China; a privilege denied to foreign traders, who, though allowed to travel in the country, had to take up residence in an increasing number of so-called treaty ports. France also used its position of power to have the cathedral in Beijing reopened.

Soon Germany would join in. Germany's interest in China dated from around 1860, when, in an effort to gain the same protection for its Asia trade that the British and French had, a Prussian naval expedition was dispatched to Asia under the command of Count Friedrich zu Eulenburg to enter into diplomatic relations with China, Japan and Thailand. This resulted in treaties with Japan and China in 1861 and with Thailand in 1862 .

For years Germany would play a minor role in China, as would France. Great Britain's greatest European rival in China became Russia, approaching China from the north. During the Crimean War, Russia had still not been secure about its position along the upper north coast of the Pacific. A combined Anglo-French fleet had gone in search of Russian warships in the north Pacific and had tried to dislodge Russian stations along the Siberian coast; in doing so it hit at one of Russia's weak spots, poorly defended by the Russian navy as the region was (Soroka 2011: 2). ${ }^{2}$ In 1854 there was a failed attempt to besiege the port of Petropavlovsk on the Kamchatka Peninsula, north of the Kuril Islands. The next year Great Britain and France tried again, only to find, as a British Member of Parliament would phrase it half a century later, 'the forts dismantled, the [Russian] ships gone, and the inhabitants selling trophies of our defeat'. ${ }^{3}$ During the Second Opium War, coming so shortly after the Crimean War, Russia again did not preclude that Great Britain would use the occasion to undo some of the advances Russia had already made along the north Asian Pacific coast (Soroka 2011: 2).

This concern proved groundless. In fact, Russia gained even more than the other powers. When British (and French) soldiers 'in the most brutal

2 British and French residents in Shanghai, Hong Kong and Singapore worried about raids by Russian warships. In Singapore British residents founded a Volunteer Riffle Corps 'to resist the invasion of a foreign foe' (Bickers 2011: 134; Buckley 1902 II: 6o6).

3 Colomb in House of Commons 2-4-1901 (hansard.millbanksystems.com/commons/1901/ apr/o2/china-crisis-russia-and-manchuria). 
manner were sacking the Summer Palace', a British Member of Parliament would later observe, Russia, presenting itself as a friend of China and offering arms and advisers, was intently engaged in securing advantages by means of commercial treaties with the Chinese Empire. ${ }^{4}$ If Great Britain, as a naval power, had to be content with Hong Kong, Russia, as a land power, gained a considerable slice of Chinese territory. In the 1858 Treaty of Aigun and the 1860 Convention of Beijing, China, weakened by having to fight the Second Opium War, ceded Outer Manchuria to Russia; that is, the territory on the left bank of the Amur River. China remained in control of Inner Manchuria, the land in between the right bank of the Amur and its tributary the Ussuri river. The Amur and Ussuri rivers, as well as the Songhua (Sungari) River, were opened to Russian ships, but not to vessels of other nations. China and Russia agreed to exercise joint control over the land between the Ussuri River and the Sea of Japan. Another advantage the Russians gained was that its merchants were now allowed to trade in Ulan Bator in Mongolia and in Zhangjiakou (Kalgan) northwest of Beijing, a stipulation said to be included in recognition of the existing Russian trading route from Kiakhta (Kyakhta, Kiakta) on the Mongolian border to Beijing. In Ulan Bator, Russia was permitted to station a consul. Later, the Russian mercantile advance into Mongolia would become even more pronounced, as in the Ili or St Petersburg Treaty of 1881 China made additional trading concessions in Mongolia, similar to those Russia had been offered in Xinjiang.

By gaining Outer Manchuria Russia had finally gained a strong position along the Pacific coast, with Japan on the other side of the Sea of Japan. Russia had also become a neighbour of Korea, the 'Hermit Kingdom' as it was called at the end of the nineteenth century, a country even more xenophobic than China and Japan had ever been (Seth 2006: 211-2). In 186o Russia established the naval station Vladivostok - which had the disadvantage that it was icebound for four months of the year - thus adding a new dimension to naval relations in the Pacific.

If Great Britain had been the main adversary of Russian expansion in Central Asia, then in the northeast it was Japan. Initially, in the decades after the opening up of Japan, Russia was still the strongest party. The Treaty of Commerce, Navigation and Delimitation of 1855, also known as the Treaty of Shimoda, divided the Kuril Islands into Russian and Japanese portions, with Sakhalin, opposite the coast of Manchuria, coming under joint control. Twenty years later, in the 1875 Treaty of St Petersburg, Russia annexed

4 Bickers 2011: 147-8; Butler-Johnstone in House of Commons 6-7-1875 (hansard.millbanksystems.com/commons/1875/jul/o6/motion-for- papers). 
Sakhalin, using what one author later called 'coercive diplomacy' (Lawton 1912: 257). In return, Russia ceded its part of the Kuril Islands to Japan. For those in the closing decades of the nineteenth century, and apparently there were many, who saw behind every territorial expansion a strategic motive, the benefits of Sakhalin to Russia were clear. The island provided additional protection of the mouth of the Amur River, gave Russia control of the narrow northern entrance to the Sea of Japan, and might serve as a base of operation for an invasion of the northern Japanese island of Hokkaido. ${ }^{5}$

Initially, Japan's politicians and military men depicted Russia as the aggressive enemy, the reason why the country needed its army and navy (Drea 2009: 1, 24). When Japan grew stronger both Russia and Japan began to aspire to a slice of Manchuria and control over or occupation of Korea. Korea could offer Russia the proverbial ice-free port along the Pacific coast it still lacked. First in mind were Wonsan (Gensan) and Port Lazareff at Broughton Bay on the northeast coast, initially also mentioned as the terminus of the Trans-Siberian Railway (in Russian terminology also the Great Siberian Railway, the construction of which had started in 1891 in Vladivostok when Nicholas II, then still crown prince, cut the first sod). Port Hamilton was another possibility before Great Britain occupied it in 1885 at the height of the Penjdeh Crisis. Busan (on the southeast coast) and other Korean ports could serve the purpose as well. Strategically, there was much at stake according to contemporary evaluations. 'Permanent Russian squadrons at Port Lazareff and Fusan' would make Russia 'the greatest naval Power in the Pacific', Curzon (1896: 213) wrote in 1896.

The first moves turning Russia and Japan into archrivals in north Asia were made in Korea, in those days still a Chinese vassal state, and which for decades, to use the description given by Curzon in the House of Commons in 1911, would be 'one of the most unhappy of all nations in the world' and 'a sort of football kicked about by the Powers of the East'. ${ }^{6}$ Japanese efforts to gain control over Korea dated right back to the start of the Meiji Restoration. In 1868 a Japanese envoy had urged Korea in vain to acknowledge that the Japanese Emperor was of superior status to the Korean King (Curzon 1896: 191). The following year an invasion of Korea was contemplated for the first time, while in 1873 the decision by the Japanese government not to send a fleet to Korea to enforce upon it trade relations with Japan led to passionate protests among the military

5 Inagaki (1890: 28) citing John Geddy, The Russian Empire (1882, s.l. T. Nelson and Sons) p.28.

6 Curzon in House of Lords 27-3-1911 (hansard.millbanksystems.com/lords/1911/mar/27/ british-interests-in-japan-and-korea). 
(Drea 2009: 20, 35-6). Three years later, in 1876, Japan showed its military muscles for the first time by sending warships to the Han River. Where in 1871 the United States had failed Japan now succeeded. It forced Korea to open its first treaty ports, granting the Japanese extraterritorial rights there. To embarrass China the first article of the Treaty of Kanghwa read that Korea, 'being an independent state, enjoys the same sovereign rights as does Japan' (Curzon 1896: 192). In 1879 Japan again moved against China and annexed Okinawa and the other Ryukyu islands in between Japan and Taiwan, which in the past had paid tribute to Japan as well as China. In Washington President Hayes said that the United States was prepared to mediate, but when Beijing turned to him to protest the annexation, he decided in favour of Japan. In 1880 Japan gained access to the port of Wonsan opposite Port Lazareff. Wonsan was opened to other nations in 1883, the same year Chemulpo (Incheon), the harbour of Seoul on the west coast, also became a treaty port. Over time, as in China, the number of ports Korea had to open to foreign trade increased.

The next to enforce concessions were the Americans with Commodore Shufeldt's Treaty of Peace, Amity, Commerce, and Navigation of May 1882. Included in the Treaty were the American promise to come to the assistance of Korea in case the country was attacked, and the Korean promise to open up the country to missionaries. Great Britain and Germany followed suit in 1883. Russia concluded its Treaty of Amity and Commerce with Korea in 1884. France did so in 1886. The following year, when Great Britain had decided to return Port Hamilton to Korea, London, more worried about the port becoming Russian than a Japanese advance in Korea, got China to vow that it would protect Korea's territorial integrity.

The competition over political influence in Korea between China, Russia and Japan could link up with domestic unrest, a struggle at court between rival factions, accompanied at times by outbursts of xenophobia. One such instance took place in July 1882 when a mob attacked the Japanese legation and the Japanese ambassador and his staff had to flee to Chemulpo, where they took refuge on a British ship. The Japanese adviser to the Korean army was not that lucky. He was killed. Tokyo retaliated. It sent a naval squadron to Korea. Seoul turned to Beijing for help.Japan was still too weak for a military confrontation with China (Drea 2009: 53). In the Treaty of Chemulpo of August 1882 Korea had to assent to the stationing of Japanese troops on its soil for the protection of Japanese nationals. The presence of Japanese soldiers in Korea made for an explosive situation, domestically as well as internationally, the more so as China also established a military garrison near Seoul in 1882 . 
The next confrontation came in December 1884 when members of a pro-Japanese political group, the Korean Independence Party, backed by Japanese soldiers, occupied the Royal Palace. Three days later Chinese soldiers drove them away. Seoul became the scene of fierce rioting against the presence of Japanese and other foreigners in the country; inducing Tokyo to send additional troops to Korea. In 1885, when China was engaged in war with France, Japan moved again and compromise was reached. In the Treaty of Tianjin of April of that year, also known as the Li (Hongzhang) -Ito (Hirobumi) Treaty, Tokyo forced China to withdraw its garrison from Seoul. Japan did the same. The Korean king, assisted by foreign advisers, should build up his own army.

At Tianjin, China and Japan also agreed that in times of unrest in Korea both could send in troops, but only after they had informed the other of their intention. The moment to do so came a decade later. In 1894 King Kojong (Gojong) turned to China for help to suppress a religiously inspired peasant revolt, the Tonghak rebellion, in southern Korea; a revolt partly inspired by xenophobic and anti-Japanese sentiments. China duly informed Japan that it was to send troops to Asan, along the south coast, near Seoul. Tokyo did not to object to this, but it did protest the reason presented by Beijing for its intervention. It could not accept the phrase that China acted 'for the sake of a tributary State'. 7 Japan also informed Beijing that the situation in Korea 'seemed to be a very serious one' and that it also intended to dispatch troops. ${ }^{8}$ The reason stated was to protect its diplomatic staff and other Japanese citizens in Korea, and, as the Japanese commander was to be instructed, if necessary also other foreigners and even the king of Korea. China, clinging to its sovereign rights, impressed upon Tokyo that it should only land a small military force, one which sufficed for the protection of the Japanese, and that the Japanese soldiers should not march into the interior; demands turned down by Japan. Beijing, in turn, still considering Korea a Chinese tributary, rejected a Japanese proposal for a joint effort to reform Korea's finances, civil service and army. Such reforms were necessary, the Japanese government would maintain, for domestic law and order and for the functioning of Korea as an independent state. ${ }^{9}$ In early June, after having sent an officer to Korea for an on-the-spot assessment, Tokyo decided that Japan had to go to war in order to maintain its position in Korea. On 12 June the first Japanese soldiers disembarked at Chemulpo. In line with

7 Statement of the Japanese Imperial General Staff (translation in Lawton 1912: 168-71).

8 Ibid.

9 Japanese declaration of war 1-8-1894 (Manchuria 1921: 8). 
existing tradition they had strict orders that they had been sent to Korea for the protection of Japanese life and property only and should not engage Chinese troops in combat (Drea 2009: 80). In July Tokyo informed Beijing that it would regard the sending of additional Chinese troops to Korea as 'a menace. ${ }^{10}$

Another culprit in Japanese eyes was the Korean government, which, Tokyo maintained - ignoring the widespread anti-Japanese sentiments in Korea - tended to side with China because of 'blind feelings of veneration which they, in their ignorance, cherished for China'. ${ }^{11}$ When the Korean government hesitated to side with Japan, the Japanese envoy in Korea, Keisuke Otori, ordered the Japanese troops to march to Seoul on 23 July. The Koreans should be shown that Japan was strong enough to guarantee the independence of their country and carry through the reforms which were needed in the country. In Seoul (only after they had been fired upon, the Japanese would claim) Japanese soldiers occupied the Royal Palace and confined the King to its premises. On the instigation of Keisuke Otori a pro-Japanese government was formed, which issued a declaration of independence and charged Keisuke Otori with the task of having the Chinese army withdraw its soldiers from Asan. China, in turn, decided to send fresh troops to Korea, claiming that the Japanese troops frightened the population and the Chinese traders living in Korea (Lawton 1912: 172).

\section{The Sino-Japanese War}

With war looming China turned to the powers to have Japan retreat from Korea. Great Britain, fearing the adverse consequences of war for its trade in China; and, as Under-Secretary of State for Foreign Affairs Grey put it, 'the large moral grounds' of maintaining peace, succeeded in having the powers give the 'friendly advice' to Tokyo and Beijing not to engage in war. ${ }^{12}$ It was in vain. On 1 August 1894, after Japanese and Chinese army and navy units had already clashed, Japan declared war on China. The stated issue was China's ill-will with regard to Korea, a country which the Japanese declaration of war stated had been 'first introduced in the family of nations by the advice and under the guidance of Japan' (Manchuria 1921: 7). Referring

\footnotetext{
10 Statement of the Japanese Imperial General Staff (translation in Lawton 1912: 168-71).

11 Ibid.

12 Grey in House of Commons 30-7-1894 (hansard.millbanksystems.com/commons/1894/ jul/3o/revenue-departments).
} 
to the authority Keisuke Otori had been given, Japan and Korea concluded an agreement on 26 August, which would be in force for the duration of the war. The treaty stipulated that Japan would do the fighting in Korea, while Korea would provide the Japanese soldiers with 'every possible facility ... regarding their movements and supply of provisions'. ${ }^{13}$

That Japan won the war, and even more so the ease with which it did so, surprised many (Bickers 2011: 324-5). The Japanese campaign was highly successful, also because already years earlier Japanese spies had mapped the battlefields (Jukichi 1895a: 4). In September a Chinese fleet was defeated near the Korean-Manchurian border. As with so many acts of war, and both sides deploying modern warships, it gave military experts abroad an opportunity to see how modern war technology performed when put to the test (Jukichi 1895b: i). In October troops landed on the Liaodong (Liaotung, Kwantung) Peninsula where Port Arthur, its fortifications and armament meeting contemporary, modern standards, was taken in November. More to the northeast, other troops had crossed the Yalu river, the border between Korea and Manchuria, while in February the Chinese naval base Wei-haiwei (Weihai) along the coast of the Shandong was seized, eliminating what was still left of the Chinese navy. Japan controlled the Bohai Sea, or as it was called in those days the Gulf of Pechili (Zhili, Chihli), and the Japanese troops might march on Beijing itself; but Tokyo abandoned any such plans, shrinking from the prospects of intervention by the European powers (Drea 2009: 90).

In desperation China again turned to the powers for help. In London Rosebery responded, once more appealing to a 'concert of Europe' (which domestically would earn him some scorn, because if anything seemed impossible in Europe it was to bring about such a concert). In October the British government suggested that the European powers and the United States should jointly guarantee the independence of Korea and ask Japan - not happy with the British initiative - to accept peace in return for a Chinese war indemnity. The initiative failed. Germany dismissed the plan as 'scarcely opportune', considering that the chance was slight that Tokyo would accept such a recommendation. Its refusal earned Berlin the praise from Japan for the 'loyal German attitude'. ${ }^{14}$ An outright rejection also came from the United States. Washington, as Secretary of State Walter Quintin Gresham informed London, did 'prefer to act alone' (LaFeber 1998: 308).

13 Treaty of Alliance between Korea and Japan 26-8-1894 Art. II (Manchuria 1921: 8).

14 Baron von Marschall to German ministers in Beijing and Tokyo 14-10-1894 (www.mtholyoko. edu/acad/intrel/gerehin.htm). 
Figure 15 Bird's eye view of Port Arthur

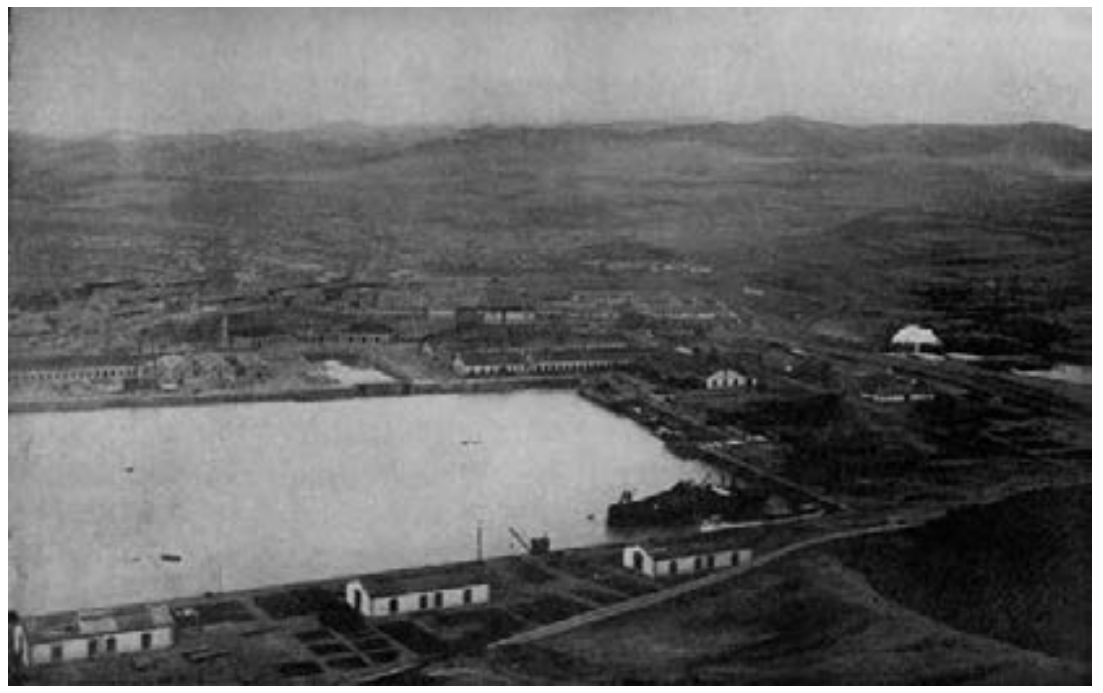

Source: Jukichi Inouye 1895

Only St Petersburg and Paris showed some interest. Russia, not wanting Japan to usurp Korea, made a definite answer dependent on the consent of the Tsar. France reacted in a similar non-committal way.

On 17 April 1895, at the Treaty of Shimonoseki, China was forced to make a number of far-reaching concessions. One was that it had to recognise the independence of Korea and that, 'in consequence, the payment of tribute and the performance of ceremonies and formalities by Korea in China, in derogation of such independence and autonomy' should end. ${ }^{15}$ Another was that China had to part 'in perpetuity' with Taiwan, the nearby Penghu Islands to the west of it, and the eastern part of the Liaodong Peninsula in South Manchuria. In addition, China had to open four additional treaty ports to foreign trade; an indication of Japan's increasing commercial interest in Central China and a cause of lamentation to the British, a sentiment which would only become stronger over time. All four ports could be considered an encroachment on the British position in Central China. Two of them, Shashi in Hubei on the Yangtze and Chongqing (Chungking, Tchoung-king) in Sichuan where the Yangtze and the Jialing river met, were far inland. The other two, Suzhou (Suchow) and Hangzhou, were located in the Yangtze

15 Treaty of Shimonoseki, Art. 1 (www.taiwandocuments.org/shimonosekio1.htm, accessed $15-3-2013)$. 
river delta. In Chongqing, according to some French businessmen the commercial capital of the rich province of Sichuan (Szechuan, Se-Tchouan), the Japanese saw to it that they got the best plot of land to build a concession (Chambre 1898:136; Neville and Bell 1898:355). They had also not forgotten to force China to accept that steamships - and not just sailing vessels - should be permitted to sail to the new treaty ports, thus allowing for a deeper and more intense economic penetration of China's interior. Wei-hai-wei was to serve as a security for the war indemnity Japan had imposed. Tokyo promised that it would withdraw from Wei-hai-wei a year after China had paid the first two instalments. Japan's victory gave Japan, and thus also the other powers, the right to build factories in treaty ports, changing the nature of Shanghai and other foreign enclaves and increasing still further the foreign economic onslaught on China (Esherick 1987: 74; Neville and Bell 1898: 3).

The Japanese victory made a great impression worldwide; all the more so as such a devastating defeat of the Chinese forces had not been expected. It gave Japan, a British author would write a few years later, 'a place among the nations that she could hardly have attained, and certainly not in the present generation, by any degree of cultivation of the arts of peace' (Temple 1902: 287). It also led to the first alarm among Europeans about their colonies in the Far East. In Indochina Governor-General Doumer (1905: 383) worried in a report in 1897 about the danger Japan, with its recently acquired land hunger, might pose to the European colonies in Asia. A year later Curzon, soon to become Viceroy of India, observed that the "whole face of the East was changed by the results of that war. It exercised a most profound and disturbing effect upon the balance of power, and upon the position and destinies of all the Powers who either are situated or have interests around the China Seas ${ }^{\prime}{ }^{16}$ Business circles were also alerted, but in a different way. A strong Japan was worrying, but a weak China meant new economic and political prospects. The outcome of the war induced the Chamber of Commerce of Lyon to take the initiative for a 'commercial exploration' mission to south China. It left France amazingly quickly, in September, five months after the Treaty of Shimonoseki, and when it entered China was suspected of being the advance party of a French invasion army (Chambre 1898: 49). There were to be more such missions, taking stock of opportunities and activities by rival nations - the Chamber of Commerce of Blackburn sent one

16 Cited by J. Walson in House of Commons 8-2-1904 (hansard.millbanksystem.com/ commons/1904/feb/kings-speech-motion-for-an-address). 
in 1896 - culminating in Beresford's tour in 1898 , by which time domestic insecurity had become a main concern.

The Liaodong Peninsula and its ice-free harbour, Port Arthur, commanded the entrance to the Bohai Sea. Its possession might give Japan control over a portion of China's foreign trade, to the detriment of the commercial interests of other powers. Even more important was that the Bohai Sea was the gateway to Beijing. It was feared that the populous Zhili province and Beijing itself could come under Japanese control. It took an invading force twenty-four hours to sail from Port Arthur to the Dagu (Taku) Forts, which were built on both sides of the mouth of the Pei-ho River on the coast of the Bohai Sea. Once the forts had been taken an army could march inland; first to Tianjin with its foreign settlements and then to Beijing about eighty miles further inland. However, as the Boxer Rebellion would show, such an expedition might not proceed as easily as contemporaries thought.

At Shimonoseki Japan had demanded too much. The Liaodong Peninsula and Port Arthur were, as Taylor (1971: 356) and other historians have observed, 'the keys to Manchuria and indeed all of northern China'. Contemporaries were of the same opinion. Possession of Port Arthur, with its fortifications built by German and British engineers and its British Armstrong and German Krupp artillery, would make Japan the 'unrivalled master of North-China' (Krahmer 1899: 18). St Petersburg informed Tokyo that an occupation of Port Arthur was not only 'a constant menace to the capital of China', but would also 'render illusory' the independence of Korea, and thus would 'jeopardise the permanent peace in the Far East'. ${ }^{17}$ Russia, not yet having enough troops in the area to stop (even in a joint effort with China) a further Japanese advance, turned to Germany, Great Britain and France even before the treaty was signed. The aim was to deny Japan its newly acquired foothold on the mainland, which Russia was also vying for, the Liaodong Peninsula; a convenient stepping stone for Russia to Korea and for Japan to Manchuria. Germany, which less than a year before had rejected Rosebery's peace effort, came out in support of Russia. For the British it was an unpleasant surprise (Temple 1902: 263, 428). Besides strategic considerations, race also played a role in Berlin's decision. Wilhelm II did all he could to warn the world of 'the yellow peril', die gelbe Gefahr. On his instructions, and based on a sketch drawn by Wilhelm II, Hermann Knackfuss drafted the political cartoon Völker Europas, wahret eure heiligsten Güter! ('Peoples of Europe, defend your most sacred possessions!') depicting the danger

17 Balfour in House of Commons 5-4-1898 (hansard.millbanksystem.com/commons/1898/ apr/05/far-east). 
Figure 16 Völker Europas wahret eure heiligsten Güter, by Hermann Knackfuss

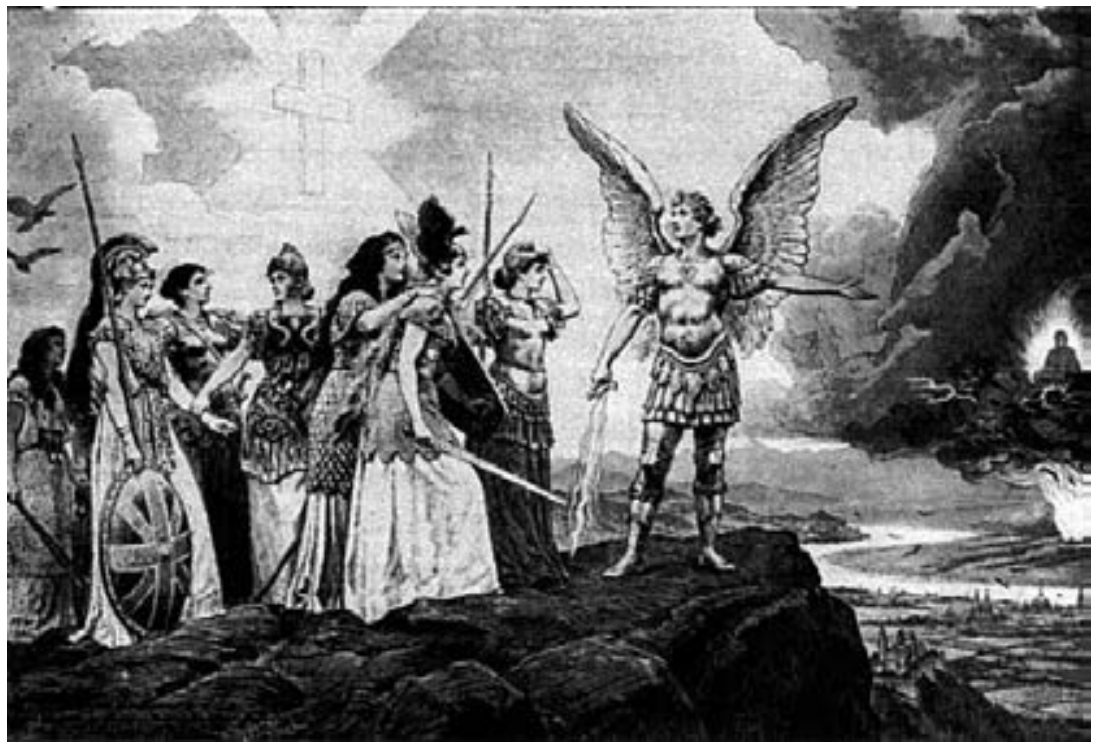

Source: commons.wikimedia.org/wiki/File:Voelker_Europas.jpg

Japan posed; with Germany in the shape of Archangel Michael - more often used by Wilhelm II as a symbol for the German empire - in the role of the valiant guardian of Europe. Copies were sent to European statesmen, to the Hamburg-Amerika Linie and the Norddeutscher Lloyd, and, to impress on him what was at stake, to Nicholas II (Cecil 1998: 333). France, Russia's partner in the recently concluded Dual Alliance, responded positively; though the idea of France acting in concert with Germany was not received well by sections of the French public (Grupp 1980: 118). It would also earn France a 'very visible hostility' on the part of Japan (Doumer 1905: 383).

At the time that St Petersburg sought the support of Berlin, Germany was seriously considering the establishment of a coaling station in China for its warships sailing in the region, which up to then had had to bunker in Nagasaki or Hong Kong. During the Sino-Japanese War Wilhelm II had become convinced that London would use the war to take possession of Shanghai and 'several other strategically important positions' in China and that Russia and France would follow Great Britain's example. ${ }^{18}$ In line with this, the Foreign Office had alerted the Imperial Navy Office to the possibility that other European powers might use the Sino-Japanese War to 
occupy parts of China, and that such an eventuality might provide Germany with the opportunity to acquire its own coaling station in China, by force or by negotiation. As late as March, Chancellor Prince Chlodwig Karl Viktor zu Hohenlohe-Schillingsfürst had still advised against Germany joining Great Britain and Russia in mediating peace. Showing himself quite satisfied with the profits that shipping and selling arms had brought German firms, he wrote to Wilhelm II that only Great Britain and Russia had to lose from a Japanese victory. Joining the two could only be to the detriment of Germany. Matters, however, would be different when there was some compensation, and Germany could 'expect to acquire certain points on the coast of China'. ${ }^{19}$ Wilhelm II was not unfavourably inclined. In a letter to the Tsar he not only tried to convince Nicholas II that Russia's role was crucial in defending 'Europe from the inroads of the Great Yellow Race', he also asked for Nicholas II's help in Germany's endeavour to 'acquire a port somewhere where it does not "géne" you'. ${ }^{20}$ In retrospect, the German Foreign Office would blame the navy for Germany not having a coaling station already. Naval officers tended to think big, turning the idea of a simple coaling station into a progressively more elaborate one; first a naval base, subsequently a point of support for trade, and finally even a nucleus of a colony. By doing so they only had delayed action. ${ }^{21}$

In April the Far Eastern Triple Alliance - or in German the ostasiatische Dreibund - of Russia, Germany and France, presenting itself as a guardian of China's territorial integrity insisted that Japan should evacuate the peninsula. The joint démarche took the form of 'friendly advice', which of course was not seen in this way in Japan; but, as the new Russian Minister of Foreign Affairs, Prince Aleksei Lobanov-Rostovsky, told the German ambassador, should Japan not comply then Russia would contemplate 'joint warlike operations of the three Powers by sea against Japan, the first aim being to isolate the Japanese forces on the mainland'. ${ }^{22}$ The French and Russian envoys in Tokyo did not mention such a possibility when they protested about Japan holding on to Port Arthur. Only the German representative, a man of 'violent character' who 'enjoyed the opportunity for humiliating Japan', spoke of war. ${ }^{23}$ htm).

23 Schwartzenstein to Bülow 19-6-1907 (www.mtholyoke.edu/acad/intrel/gerchin.htm). 
Like Berlin, London had a surprise in store. Great Britain was also approached but had refused to join. The government of Rosebery, and indeed that of his successor Salisbury, valued good relations with Japan too much. One factor to consider was the challenges to the British fleet. Later Rosebery's Foreign Secretary Kimberley explained that looking at the great change impending in the Far East, ... there was nothing more important to this country than to establish a friendly relation with the growing naval Power of Japan'. In view of the fact that the British commercial presence in China could only be shielded against the malintent of others by naval protection, he, not without reason, added that a naval power would 'always be of more consequence as a friend to this country in that quarter of the world than any other Power'. ${ }^{24}$ Yet Great Britain did not emerge unscathed. In Russia and Japan its position met with hostility. The reaction in the Russian press made Queen Victoria complain to Tsar Nicholas II about the 'most violent and offensive articles against England' (Carter 2010: 179). In Japan, where the British effort in October to mediate peace had already not been taken kindly, resentment had only grown because London had failed to come to the assistance of Japan in dealing with the Far Eastern Triple Alliance; thus, being indirectly co-responsible for a political defeat that was, and would continue to be, considered a great humiliation in Japan (Silbey 2012:19). In retrospect, some British politicians even spoke about 'Rosebery's mistake'. In their view, London had 'abandoned Japan to Franco-Russian coercion'. ${ }^{25}$

Another country that stayed aloof, but for different reasons, was the United States. It had other worries. Fearing a partition of China and the harm this would do to American contemporary and (especially) future commercial interests in China, Washington had already urged Tokyo to show restraint during the war. It hoped that a grateful China would grant concessions to American companies, first and foremost in Korea (LaFeber 1998: 310). Gresham impressed upon the Japanese ambassador that if Japan continued 'to knock China to pieces, the powers, England, France, Germany and Russia, under the guise of preserving order' would partition China (ibid.: 308). Washington's refusal to side with the Far Eastern Triple Alliance was one of the first indications of a growing rift between the United States and Russia, ending 'a century of friendship' (ibid.: 318).

24 Kimberley in House of Lords 17-5-1898 (hansard.millbanksystems.com/lords/1898/may/17/ occupation-of-wei-hai-wei).

25 Ashmead-Bartlett in House of Commons 27 March 1896 (hansard.millbanksystems.com/ commons/1896/mar/27/france-and-siam). 
The combined pressure of Russia, France and Germany was too much for Japan. As early as May, in an Imperial message, Tokyo pointed out that Japan had 'taken up arms against China for no other reason than our desire to secure for the Orient an enduring peace'. Japan would follow the 'friendly recommendation of the three Powers [which] was equally prompted by the same desire'. Face was saved. By signing the Treaty of Shimonoseki, China had 'shown her sincerity in regret for the violation of her engagements', which meant that the justice of the Japanese cause had 'been proclaimed to the world'. ${ }^{26}$ The price was still more war reparations. In November Japanese troops withdrew from the Liaodong Peninsula. The retreating troops took along artillery, machinery and every thing else worth taking and demolished everything else that could not be transported back to Japan (Krahmer 1899: 112). Abandoning Liaodong greatly upset the Japanese. As Drea (2009: 90) wrote, it created a 'sense of national humiliation' and 'a determination, encouraged by the government, to avenge this wrong', aimed in the first place at Russia.

Japan could keep Taiwan, where it was almost immediately confronted with a rebellious local population resisting Japanese rule (as they had done to Chinese rule before), lasting at least until 1907, which for the moment put a stop to any Japanese plans to turn the island into a colony for its surplus population. Nevertheless, Taiwan, which had also figured in earlier German and French plans and in Perry's plan for a naval base, was a valuable prize. The Taiwan Strait was a busy shipping lane, vital to China trade. The island itself formed a bridgehead to China. It could serve as a base for economic expansion and, if needed, a military incursion into the opposite Chinese province of Fujian (Fukien), of which it had been part of in the past (Colquhoun 1902:368; Drea 2009: 91; Bickers 2011: 273). Abroad, Taiwan also soon came to figure in scenarios about a Japanese expansion southwards, towards the Philippines, and after that - the Dutch feared - towards the Netherlands Indies. Even in faraway Australia people began to worry about such a move and the prospect of a Japanese invasion (Hiery 1995: 14).

Almost immediately, after Japan had evacuated Liaodong, speculation arose about Russia itself occupying Port Arthur. Responding to such suppositions, A.J. Balfour, First Lord of the Treasury, true to the spirit of free trade, suggested in February 1896 that Russia should be allowed to acquire an ice-free commercial port on the Pacific north coast. To explain his remark, which was not well understood in Great Britain, he pointed out that such a Russian port could only benefit British commerce; taking the position 
that the more Chinese ports were opened (and the more railways built) the better it would be for international trade and thus also for Great Britain.

China was hardly capable of paying the indemnity Japan had forced upon it. The loans Beijing had to arrange to raise the money gave rise to national and international complications. Nationally, on top of the usual financial consequences of war for a population came the new obligation of the indemnity, burdening the people even more, with all the feelings of discontent that this would entail. China, almost broke, also had to redirect the appropriation of the tax proceeds. Such money could no longer be used for the upkeep or improvement of local security. Beresford (1899: 149, 158, 163) identifies this as one of the reasons why local Chinese officials and the Chinese army could not guarantee law and order in the country, so desperately needed by foreign traders and investors at that time. The troops needed for this also had to be deployed to guard the coast of the Bohai Sea against a foreign invasion. Beresford also notes that the impression the Chinese people had gained, that they were no longer paying taxes for the good of the country or their province, but that the money went to foreigners, 'kindled the latent hostile feeling' against people from abroad (ibid.: 164).

Internationally, the competition and animosity between the powers was augmented by the question of which power was to arrange the loan (and thus could expect something in return) and which banks would put up the money; resulting, among other things, in additional complications in the Anglo-French negotiations over Thailand. Initially, London had suggested that Great Britain, Germany, Russia and France should jointly arrange the first loan to China. However, due to Russian manoeuvring, and in spite of Great Britain urging Beijing not to accept such an offer, the loan provided in 1895 was a Russo-French one, with Tsar Nicholas II complaining about the delay the 'intriguing of the British and Germans' in Beijing had caused (Carter 2010: 188). For this purpose, the Russian Ministry of Finance in December 1895 established the Russo-Chinese Bank, which would play a crucial role in Russia's advance in northeast China. The outcome also added to American frustrations about Russian policy in the Far East. An American company had also been interested in the loan and its failure to subscribe was attributed to Russian scheming (LaFeber 1998: 303, 321).

In 1896, when China again needed foreign money to finance its indemnity payments to Japan, it again approached the French government. France was given the right to construct a railway from Tonkin to Lungchow in Guangxi, but the loan was provided by the Hong Kong and Shanghai Bank and the Deutsch-Asiatische Bank. In January 1898 Beijing, not happy with the conditions St Petersburg wanted to attach to a new Russian loan, turned 
to London to guarantee a third loan to pay the final instalment of the reparations. London had already protested in Beijing against one of the Russian conditions, the replacement of Hart as inspector general of the Chinese Imperial Maritime Customs Service. ${ }^{27}$ The Chinese request was received well in British financial circles, but Salisbury himself had 'the greatest hesitation'. He did not look forward to the task of 'finding money for Governments that might want money'. ${ }^{28}$ Nevertheless, and to the displeasure of Russia and France, the British government was prepared to arrange the loan. In return, London initially asked, among other concessions, that Dalianwan (Talienwan), the bay on the east side on the Liaodong Peninsula, and Nanning in Guangxi on the West River in the south should become open ports. This was not a smart move, and could only rub up Russia and France the wrong way, who had set their sights on Dalianwan and Nanning, respectively. Both powers protested.

Beijing, fearing additional bullying by St Petersburg and Paris, could not meet the British conditions. A day after the Chinese had indicated on 16 January that the opening up of Dalianwan 'would embarrass them very much', the British envoy in Beijing was instructed by telegraph not to insist. London did so, Salisbury said, with reluctance. ${ }^{29}$ Nevertheless, on 19 January the British government was still made to understand by Russia that a demand to turn Dalianwan into an open port 'could not be regarded as a friendly action'. $3^{\circ 0}$ Salisbury suggested that the matter be left alone until a railway had reached the port. He defended his decision by pointing out that the hinterland of Dalianwan was 'practically worthless in itself, and that no trade could arise there until the railway reaches the port'. ${ }^{13}$ Salisbury kept silent about Nanning, which remained equally closed. An Anglo-German loan, again by the Hong Kong and Shanghai Bank and the Deutsch-Asiatische Bank (and not an exclusively British one, which both Russia and France had protested against), was issued in March 1898.

27 His jurisdiction was limited to the treaty ports. Hart, a generally respected person in Great Britain (he would get his own statue in Shanghai), would hold that position between 1863 and 1907. His bureau and the local stations employed many non-British foreigners.

28 Salisbury in House of Lords 8-2-1898 (hansard.millbanksystem.com/lords/1898/feb/o8/ the-queens-speech-reported-by-the-lord-chancellor).

29 Balfour in House of Commons 29-4-1898 (hansard.millbanksystem.com/1898/apr/29/ class-ii).

30 Cited by Harcourt in House of Commons 29-4-1898 (yourdemocracy.newstatesman.com. parliament/order-of-the-day/HAN1455362).

31 Salisbury in House of Lords 8-2-1898 (hansard.millbanksystem.com/lords/1898/feb/o8/ the-queens-speech-reported-by-the-lord-chancellor). 


\section{Russo-Japanese strife over Korea}

After the Sino-Japanese War the struggle for control over Korea became one between Russia and Japan; China being too weak to enforce any claims. Korea had the misfortune of being the terminus of the Russian advance in north Asia, while a Japanese occupation of the country would threaten Russia's move into Manchuria. Having practically no army and navy itself, Korea became, in the words of Hamilton (1904: xxxix), 'the helpless, hapless sport of Japanese caprice and Russian lust'. Having few investments in Korea, Russia's intentions were primarily strategic. Economically far outshone by Japan, Russia presented itself as the champion of Korean national integrity. Japan, in justifying its policy, stressed its dominance in trade with and investments in Korea and the many Japanese who had settled there. Indeed, Japanese trade far exceeded that of other nations; Russian trade coming second, but only at a far distance. In 1902 almost 299 Japanese steamers, with a total tonnage of 186,050 tons, entered Chemulpo, the main port of Korea, compared to only 42 Russian with a total tonnage of 58,332 tons (and only three from Great Britain, one from Germany and the United States each, and none from France) (ibid.: 302-3). In the same year both Japanese and Russian liners called at Korean ports. Those from Russia, plying between Vladivostok and Shanghai, would call in at Busan and Wonsan. Curzon (1896: 178) suspected that the venture was far from profitable and that the main reason to set up the Russian line in 1891 had been political. To him it was yet another example of how Russia made 'an experimental and even expensive commerce subserve larger political ends'. He was sure that (as other powers did) Russia was preparing for the deployment of auxiliary warships in war; that merchantmen and ocean liners could be transformed into warships when the moment was there. The real reason behind the Russian line was 'the avowed object of providing a useful auxiliary marine, with well-organised complement, in time of war'.

Japan, in the aggressive tradition it had already established, continued to try to gain direct political control. On the instigation of the recently appointed Japanese ambassador, Miura Goro, Korean and Japanese assassins forced their way into the Palace in October 1895. They murdered Queen Min Myongsong, who, contemporary observers agreed, held more power than her husband and was seen as the main obstacle to growing Japanese influence in Korea. King Kojong, an American journalist wrote a decade later, 'never recovered from the shock caused by the murder of his wife' and was in 'constant fear' of being assassinated himself (Millard 1906: 119, 89). Miura denied any Japanese involvement, but after foreign protests was 
recalled by Tokyo, where Prime Minister Ito Hirobumi claimed that Miura had acted on his own (Drea 2009: 92).

Kojong turned to Russia for help (ibid.: 92). On 10 February 1896 between 100 and 150 Russian sailors landed at Chemulpo and marched to Seoul. The following day the king escaped from his palace and took refuge in the Russian embassy. In May the Russian and Japanese envoys in Seoul came to an agreement over his safety. This was followed in June by an agreement on the independence of Korea between the Russian Minister of Foreign Affairs, Lobanov-Rostovsky, and general Yamagata Aritomo, the Japanese Minister of War and Inspector General of the Japanese army, who was in Russia for the coronation ceremony of Tsar Nicholas II. Lobanov-Rostovsky rejected Yamagata's offer to institute a Russian sphere of influence in the north of Korea and a Japanese one in the south (Caraway n.d.: Ch.29, p.1) It took until February 1897 before Kojong could return to his Palace and a few months later, in August, almost two years after the Treaty of Shimonoseki, he officially proclaimed the Empire of Korea and assumed the title of Emperor. Part of the June 1896 agreement was that Lobanov-Rostovsky consented to Japanese troops guarding the telegraph line between Busan and Seoul and Japanese settlements in Seoul, Busan and Wonsan. From his side, Yamagata did not object to Russian troops protecting the Russian embassy and the Russian consulates. The sending of additional troops became subject to prior consultation.

Russia continued to try to expand its military and economic influence in Korea. On the explicit request of Kojong, St Petersburg stressed, it sent military instructors to Korea in 1897 . Russia also tried to remove the one important asset the British had in Korea: John McLeavy Brown, who had come to the country in 1893 when Hart had tasked him with running the Korean customs. In 1894 McLeavy Brown was appointed head of the Imperial Korean Maritime Customs, newly instituted on the instigation of Japan. He was one of the most influential foreigners in Korea. McLeavy Brown had a hand in the modernisation of the city of Seoul, and besides running the customs service he also became financial adviser to the Korean government in 1893; an unhappy task as Kojong was not known for his thrift. The British held McLeavy Brown in high esteem. He was 'the man who has held the Korean State together', Hamilton (1904: 81) wrote. Russia and its ally France detested the key positions held in the Chinese and Korean customs service by Hart and McLeavy Brown. To the Russians, McLeavy Brown was the man who could thwart their economic and political schemes in Korea. At the end of 1897 the Russian Consul General, Alexis de Speyer, acting in concert with the French envoy, tried to get rid of him. They partly succeeded. McLeavy 
Brown lost his position as financial adviser but remained Head of Customs, where a Russian official was appointed alongside him.

Such Russian intrigues convinced Salisbury that Russia was set on occupying Korea, and that any protest in St Petersburg would be a futile action (Berryman 2002: 7). British commercial interests in Korea were, in the words of Curzon, 'not assessable at a very high figure' and initially the British remained on the sidelines, only acting when the safety of British nationals was at stake or prestige had to be upheld..$^{22}$ In July 1894 British troops had landed in Korea after the British Consul General, Walter Hillier, had been beaten up by Japanese soldiers; after his wife had protested 'vehemently', the same soldiers had 'scattered the chair bearers and pushed the chair, with Mrs. Hillier in it, into a ditch' (New York Times 19-7-1894). In October 1895, during the turmoil in Seoul, British troops once again landed in Korea, this time in Chemulpo. The following year, in response to the Russian troop movement in February, and at the request of the British Consul General, British marines entered Korean territory for the third time; officially to protect the British legation.

In 1897 Great Britain again decided to act. In July Curzon, in his capacity as Under-Secretary of State for Foreign Affairs, had already made clear the British position that 'Corean territory and Corean harbours' should not be 'made the base of schemes for territorial or political aggrandisement, so as to disturb the balance of power in the Far East and give to any one Power a maritime supremacy in the Eastern seas'. ${ }^{33}$ When, in December 1897, news reached London that a Russian squadron of nine warships had sailed to Chemulpo to bully Korea into allowing a Russian coaling station at Deer Island off Busan, the British Admiralty ordered the Commander of the China Station, Admiral Sir Alexander Buller, to have a British fleet of about the same strength sail to Chemulpo (Berryman 2002: 7). The show of force had the desired result. Russia was forced to back down, while as a side effect the position of McLeavy Brown as head of the Korean maritime customs was secured.

In a more general sense, the Russian adventure in Korea was also not a great success. Early 1898 was a time of intense anti-Russian demonstrations and protests in Seoul against the influence and concessions foreigners had gained. St Petersburg, as it revealed in March, felt compelled to complain to the Korean government about the xenophobic circumstances under

32 Curzon in House of Commons 19-7-1897 (hansard.millbanksystem.com/commons/1897/ jul/19/foreign-office-vote).

33 Ibid. 
which the military officers and the Russian Head of Customs had to work. Referring also to 'parties' in Korea which publicly vented the opinion that the country could well do without foreign assistance, Kojong and the Korean government were asked whether the services of these persons and the 'protection of the Court' were still needed. The answer was: many thanks, but no we do not need them anymore. Consequently, the Russian Head of Customs went home. The Russian officers were discharged from the Korean army, but stayed in Korea. In view of the tense domestic situation, they were attached to the Russian embassy (Krahmer 1899: 183-4).

Next, the Russian Minister of Foreign Affairs, Baron Roman Romanovich Rosen, and his Japanese colleague, Baron Nishi Tokujiro, met in Japan to try to hammer out a division of Japan's and Russia's spheres of influence in northeast Asia. Instead, in Tokyo the Nishi-Rosen Protocol was signed on 25 April 1898. In it Japan and Russia 'definitely' recognised Korea's independence. ${ }^{34}$ They also promised not to interfere in Korean domestic affairs and not to send military or financial advisers to Korea without consulting each other first. Russia refused to give Japan a free hand in Korea in return for its own preponderance in Manchuria (Caraway n.d.: Ch.29, p.4). What the Russians had to admit was that economically Japan had a far greater presence in Korea and that much more Japanese than Russians had taken up residence there. Hence, the Protocol mentioned that Russia would not 'impede the development of commercial and industrial relations between Japan and Korea'. ${ }^{35}$ Satisfied, Balfour, the British First Lord of the Treasury, spoke in the House of Commons of Russia's 'great retreat in Korea' ${ }^{6}{ }^{6}$ Russia also failed to get a coaling station on Korean soil. In fact, it was not such a disaster for Russia, having just leased nearby Port Arthur from China in March; though the navy's preference was for a base in Wonsan Korea (Putnam Weale 1908: 26; Caraway n.d.: Ch.29, p.3).

34 Nishi-Rosen Protocol Art. 1 (as cited in Brown 1919: 135).

35 Ibid.

36 Balfour in House of Commons 28-4-1898 (yourdemocracy.newstatesman.com.parliament/ order-of-the-day/HAN1455362). 


\section{Thailand and Beyond}

Just as today, around 1900 China's immense population was looked upon in the West as a huge potential consumer market; making China a promising destination for exports and for money to invest; especially, some reasoned, after economic development would give rise to a large group of Chinese having money to spend (Chambre 1898a: 450-1). It was thought that building up an infrastructure, in particular the promised construction of railways, would produce big profits and would greatly facilitate trade. Foreigners were also eager to exploit China's natural resources. One of the regions where competition between the powers became intense was southern China. Having reached a stalemate in Thailand, the Anglo-French rivalry came to focus on Guangxi (Kwangsi), Guangdong (Kwantung) and Yunnan; three Chinese provinces, Lanessan (1895:109) concluded in 1895, with which French trade was still very small. A fourth commercial target lay more to the north, in Sichuan, thought to be one of the richest provinces of China. ${ }^{1}$ Access to Sichuan was easier from the east along the Yangtze River than from the south, though it took until 1898 when a small British steamer succeeded in sailing upriver as far as Chongqing. Nevertheless, the French were still hoping that they might beat the British there. One of the aims of the Lyon mission was to investigate whether the province could be incorporated into the 'direct commercial or political sphere of influence' of France (Chambre 1898: vii; Morrison 1895: 72, 149; Colquhoun 1902: 389). At that moment much still had to be done. French China trade was still predominantly characterised by imports from and not exports to that country, and the number of people on the spot who could introduce French products was still small; indeed, according to the Lyon mission, 'very small' (Chambre 1898a: 444-8).

The British felt that due to their position in Hong Kong Guangxi, Guangdong and Yunnan, or as it was sometimes also phrased the West River valley, should be theirs when spheres of influence had to be delineated. As Beresford (1899: 477) exclaimed on one of the last pages of his book, if any nation had 'any reasonable claim to exclusive influence' there, it was Great Britain. Beresford (1899: 323) also claimed Sichuan for the British by including it in the Yangtze provinces. What drove him to do so was an encounter with French railway surveyors in Sichuan who had told him that should a

1 Yet another province occasionally popping up in the Anglo-French rivalry in the south was Guizhou (Kweichow), in between Guangxi and Sichuan. 
Figure 17 French Indochina at the turn of the century

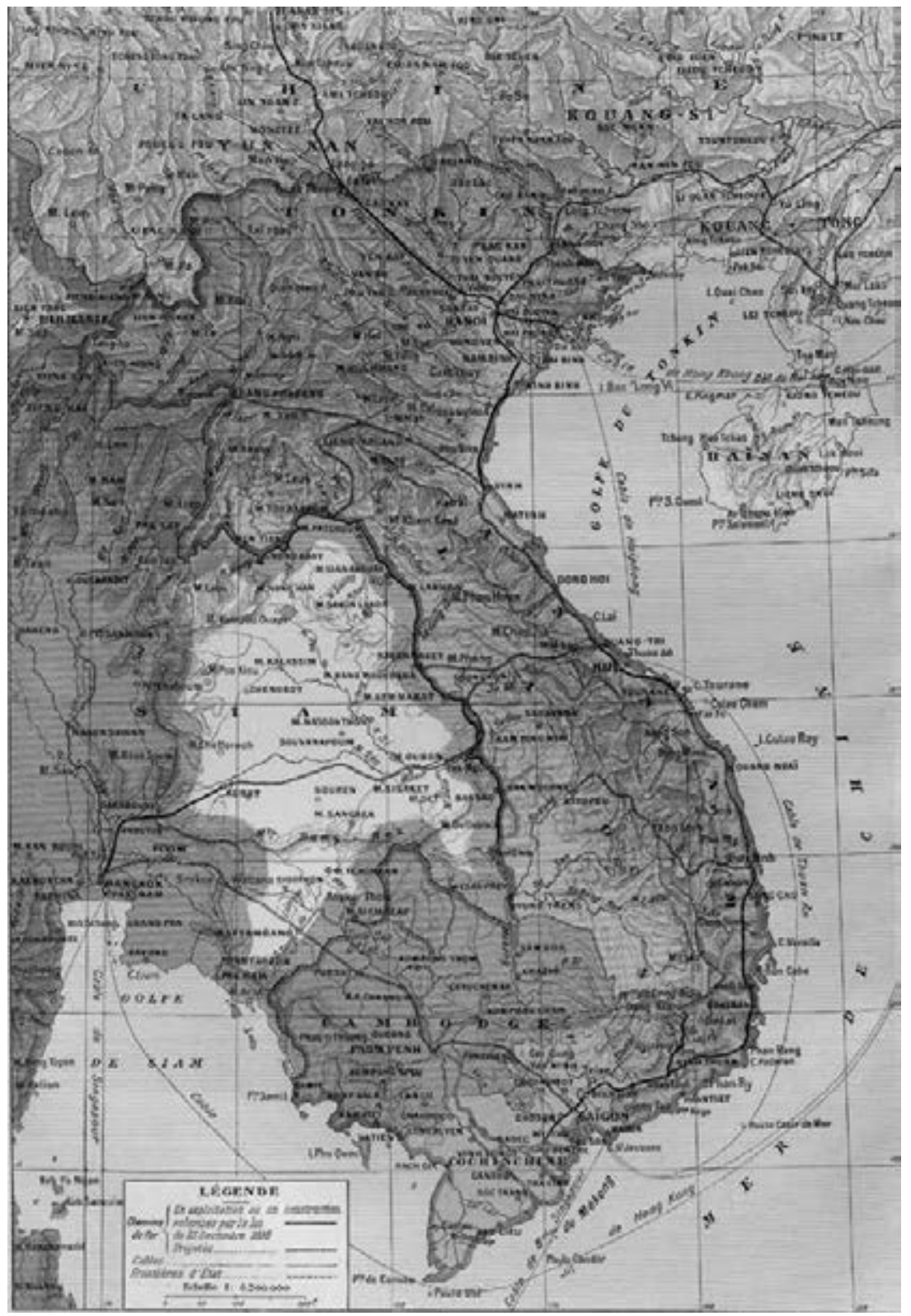

Source: Doumer 1905 
division in spheres of influence in China become a reality Sichuan would fall within that of France. Rivalry, or rather British suspicion, extended to Portuguese Macau, close to Hong Kong, where the British tried to prevent Frenchmen from acquiring property (Cunningham 1902: 32-3).

Figuring prominently in Franco-British rivalry over trade with south China was Yunnan, bordering in the south with French Indochina and in the west with British Burma. In the 1890 s Yunnan was still impoverished after the Islamic rebellion of years before and its ruthless suppression by Beijing. Westerners could only guess at the size of its population with estimates ranging from four to twelve million (Chambre 1898a:129). This did not deter those pleading enthusiastically for the opening up of the province. They were sure that recovery had set in, and that potentially Yunnan was among the richest regions in China with good trading prospects and abundant natural resources. There was also fierce competition regarding access to the Xi or West River (Sikiang, Si Kiang, Xi Jiang), which with its tributaries was the pre-eminent waterway of south China. Rising in Yunnan and running through Guangxi and Guangdong, it empties into the South China Sea near Chinese Guangzhou, British Hong Kong, Portuguese Macau and Taiwan (Japanese since 1895). What struck contemporary observers was that the Treaty of Shimonoseki of April 1895 had not mentioned allowing trade by foreigners in the cities along the West River. Opening up the West River had been one of Tokyo's demands, but had not been included in the peace treaty. The culprit, people were sure, was France, with its own plans for gaining preponderance in southern China. The French wanted the West River to remain closed to trade by foreigners, not looking forward to challenges to their own gateways into south China.

Trade with Yunnan and the rest of south China had been on the British and French agenda for decades; that is trade by European merchants and preferably in larger quantities; goods already found their way to and from China by local trading networks. And, when he steamed up the Red River in 1877, the French consul in Hanoi must have been unpleasantly surprised to see that 'Manchester goods from Burmah ... were being freely exchanged for the produce of the local mines' (Norman 1884:186). Commercial ambitions had inspired the Mekong expedition by Doudart de Lagrée and Francis Garnier in 1866; while trade with southern China had been a main reason - if not the only one - for the occupation of Tonkin, and was presented as such in the negotiations with the British government to persuade the latter not to deny France that trade (Chandran 1971a: 21).

The British had not stayed behind. A British expedition headed by Edward Bosc Sladen traversed Yunnan in 1868. In 1874 the combined pressure 
of the advance of France in continental Southeast Asia and a lobby of British commercial interest seeking to promote trade between Lower Burma and China resulted in a second expedition, this time headed by Colonel Horace A. Browne (Bugrava n.d.: 3). It had, the Under-Secretary of State for India, George Hamilton, explained, 'to report upon the trades, routes, and prospects of trade between Burmah and Western China'. ${ }^{2}$ The expedition had the approval of Beijing but took place at an unfortunate moment when China had just re-established its authority over Yunnan. Consisting of some fifty men and guarded by Burmese soldiers, the expedition experienced a sorry fate. In February 1875, just after Browne had crossed the Burmese-Chinese border, his interpreter-to-be Augustus Raymond Margary and five other members of his staff on their way from Shanghai to join the expedition were murdered in south Yunnan. Margary would be honoured with a monument in Shanghai. When the main body was also attacked the expedition was discontinued and its members returned to Burma. The prospect of London demanding redress from Beijing rekindled French efforts to have China allow foreign traffic on the Chinese part of the Red River. ${ }^{3}$ Great Britain would use the incident to enforce the Yantai (Chefoo) Convention of 1876 upon China. The convention was negotiated in Tianjin with gunboats at the ready nearby along the coast of the Bohai Sea in order to strengthen the British position. The outcome was like other treaties before and after. Beijing was forced to pay an indemnity, send an official delegation to London to apologise for what had happened in Yunnan, and open yet more ports to trade by foreigners.

\section{The Race for Yunnan}

The Anglo-French Declaration accelerated what was dubbed the 'Race for Yunnan' (Chandran 1971a: 37). Inspired by political motives and overoptimistic expectations about trading prospects, Great Britain and France tried to extend their commercial presence in Yunnan and the rest of south China. In their quest they had to face a reluctant Chinese government, refusing to throw open the country to trade by foreigners, at times a hostile, if not xenophobic, population and local officials equally opposed to Western penetration. For Great Britain the security of India was an additional

2 Hamilton in House of Commons 12-7-1875 (hansard.millbanksystems.com/commons/1875/ jul/12/india-burmah-and-western-china-question).

3 Decazes to Rochechouart 3-7-1875 (cited in Norman 1884: 164). 
motive. For the French the intention to keep the British out of most of southern China and to gain special privileges for itself there were just as important incentives. Even Haas, the former French Chargé d'Affaires in Mandalay, had a role to play. In 1894 he re-emerged in British sight as French consul in Chongqing in China, assigned with the task of redirecting trade from Sichuan via Yunnan to Tonkin, away from the Yangtze River. Being an Australian, Morrison (1895: 42, 149), who met him in Chongqing, did not give Haas much chance of success. He noted that 'no man can venture to assert that any other trade route [to Sichuan] can exist, than the River Yangtse; and all the French commissioners in the world can no more alter the natural course of this trade than they can change the channel of the Yangtse itself'.

In March 1894 Great Britain and China had concluded the Convention relative to Burmah and China. Meung Lem and Keng Hung had gone to China as part of the negotiations and London 'wishing to encourage and develop land trade of China with Burmah as much as possible' and Beijing had forged an agreement on duty-free trade between China and Burma. ${ }^{4}$ Despite this, the British were at a disadvantage, a fact the French were well aware of and relished; all the more so as they believed that the Red River ran through the richest and most populous part of Yunnan (Chambre 1898a:114). As the traveller Morrison (1895:148) observed: Yunnan City was 'within easy access at all seasons of the year of the French colony of Tonquin, whereas the trade route from here to Burma is long, arduous, and mountainous, and in its Western portion is closed to traffic during rains'. Another asset for the French - but this was a recent one - were their local representatives. Cunningham (1902:27-9) wrote about 'ambitious and clever consular agents', the kind of officials that many a merchant complained the British were lacking in the Far East. British consular staff in south China were 'often inexperienced and weak', or, a more general evaluation suggests, were not good at bullying Chinese officials (ibid.: 191; Neville and Bell 1898: 337-8).

Another setback for the British was that just a few months before the Anglo-French Declaration of January 1896 was signed the French had scored two important diplomatic successes. Following the agreements of April 1886 and June 1887 with China, two complementary conventions were agreed on in June 1895, only months after the Treaty of Shimonoseki had been concluded; one on the frontier between Tonkin and China and one on commercial relations. They were a reward for - or were at least facilitated

4 The Convention between Great Britain and China relative to Burmah and China of March 1894, Art. VIII. An exception was made for the export of salt to Burma and of rice to China. 
by - the French support to China in its conflict with Japan. In the first convention China, in contravention of what Beijing had promised London little more than a year before, handed over a portion of Keng Hung - the districts of Muang U and U Tai - to France..$^{5}$ In London it was speculated that China had not wanted to, but had yielded to joint Franco-Russian pressure, and perhaps also to that of Germany. ${ }^{6}$ London protested in Beijing and Paris, where the treaty was defended at that time as a countermove to the British occupation of Mong Sing in May (Chandran 1977: 149-50).

Equally unfavourable to British interests was the new Franco-Chinese commercial agreement signed on the same day. ${ }^{7}$ In it France gained a number of important concessions. One was that it would be allowed to extend its still non-existent Indochina rail network into south China providing that China would indeed decide to build railways there. ${ }^{8}$ China also promised to turn to French engineers first for the exploitation of mines in Yunnan, Guangxi and Guangdong. Furthermore, it caused an outcry in Great Britain when a number of places in these provinces were opened to French trade and that in two towns France could station a representative: a consular agent in Tong-hing in Guangdong and a consul in Szemao (Simao, Se-mao) in Yunnan, a city that also figured in British plans to expand China trade. The right of France to station a consul in a third city, Mengtze, near the Tonkin border, in Yunnan, was reconfirmed. The convention was a real coup. It not only offered France special economic prospects at the cost of the British, but the treaty also raised British fear that Yunnan might end up within the French sphere of influence. Should this happen, some feared, France could well cut the communication, difficult as this in reality might have been, between British Burma and the Yangtze Valley (Chandran 1977: 176).

The trade convention called for a British reaction. Its railway concession prompted the British to speed up plans advanced by the Indian government to extend the railroad between Rangoon and Mandalay to the Yunnan frontier. The commercial and military advantages were thought to be evident. The line would 'attract a large part of the trade from south China'

5 Complementary Convention to the Convention Delimiting the Frontier between Tonkin and China of 26 June 1887 signed in Beijing, 20-6-1895 (www.chinaforeignrelations.net/node/169). 6 Dilke in House of Commons 8-2-1898 (hansard.millbanksystems.com/commons/1898/ feb/o8/address-in-answer-to-her-majestys-most-gracious-speech).

7 Complementary Convention to the Supplementary Convention of 26 June 1887 signed in Beijing 20-6-1895 (www.chinaforeignrelations.net/node/168).

8 In June 1897, Beijing would even promise the French that they might go as far as Kunming, the capital of Yunnan. In December 1898 the French Government would officially endorse plans for such a line; at that moment still awaiting an official Chinese concession. 
and would allow the Indian Army 'to place troops on the Upper Mekong more quickly than the French'. ${ }^{9}$ The terminus selected was Kunlong Ferry. Having decided on this earlier, China had been forced to formally accept that the city was on Burmese territory in the Convention between Great Britain and China relative to Burmah and China of March 1894 (Chandran 1971a: 11). In November 1895, the decision was taken to build a line between Mandalay and Kunlong Ferry. For the business community it was only the beginning. They wanted a line into Yunnan (and the idea was, running from there to Sichuan, and to the Yangtze Valley and Shanghai), but met with a reluctant government, in London as well as in India.

In the political sphere, London demanded from the French government that it accept that Great Britain should be allowed the same concession in south China that France had acquired. Paris could agree but only where it concerned Yunnan and only when the province of Sichuan was included in the deal of equal commercial rights and privileges, and certainly not in Guangxi. In January 1896, London and Paris came to an understanding. In the Anglo-French Declaration in which London and Paris settled their dispute over Thailand an article was included stating that 'all commercial and other privileges and advantages conceded in the two Chinese provinces of Yunnan and Sichuan either to France or Great Britain ... shall, as far as rests with them, be extended and rendered common to both Powers'. London and Paris promised that they would 'engage their influence and good offices with the Chinese Government for this purpose'. ${ }^{10}$ The French had won the day. Their concession had been trivial. People in Great Britain were not satisfied. The cities in Yunnan where France had given up its exclusive trading rights were close to the Tonkin frontier, and thus within easier reach of French than of British commerce. ${ }^{11}$

The 1896 accord regarding Thailand did little to improve Anglo-French relations, which remained delicate as a similar rapprochement could not be reached regarding Africa, where three of the trouble spots were Egypt, Niger and the Sudan. In particular, Sudan - culminating in the Fashoda (present-day Kodok) crisis of 1898 - made, as Grupp (1980: 115) phrases it, for a 'wave of nationalism' in France when, after months of an intensified patriotic, even bellicose, mood on both sides of the Channel, Great Britain

9 Elgin to Hamilton 30-7-1895 (cited in Chandran 1971a: 18), Government of India to Hamilton 30-7-1895 (cited in Chandran 1977: 177).

10 Anglo-French Declaration 15January 1896, Art. IV (see, for instance, Chandran 1977:350-1).

11 Reginald McKenna in House of Commons 27-3-1896 (hansard.millbanksystems.com/ commons/1896/mar/27/france-and-siam). 
showed its teeth and France had to back down. These conflicts over Africa intensified anti-British feelings in France. Since 1815 it was asserted by one author, Great Britain had never failed to oppose any effort by France to expand its overseas territories. The British had done so by showing their displeasure, with polemics in the press or criticism in Parliament, and with diplomatic protests. At times, they had also given the impression that they would not shy away from war to restrain the French (Darcy 1904: 1). It was Great Britain's destiny to 'fight all powers which wanted to have ports, big ships and colonies' (Darcy 1904:19). Such sentiments made expansionists of the parti colonial plead for a kind of 'colonial entente' (Grupp 1980:120), a French, Russian, German cooperation. Other reactions included expressions of schadenfreude when Germany got the better of Great Britain (Grupp 1980: 70, 102-7).

China was caught in-between. It was 'being bullied whilst she is down', having to suffer the 'bullying expedient of claims and counter-claims', Beresford (1899: 438-9) wrote. A chain reaction was set in motion. London demanded additional concessions from China for the promises it had made to France (and occasionally also to Russia in the north), and once these were given - or were going to be granted - it was the turn of Paris to lean on the Chinese government to gain some advantages. Confronted with British and French pressure, it seemed that Beijing was more afraid of France, which could always bring into play its Dual Alliance partner, Russia (where plans for a railway line connecting the Trans-Siberian Railway with Yunnan and Tibet were considered) (Snow 1994: 363).

London also had to settle a score with China. The Franco-Chinese agreement of June 1895 about the frontier between Indochina and China had whetted the territorial appetite of the British, seeing in the supplementary convention a good opportunity for a favourable adjustment of the border between Burma and China. Indignant British politicians decided that China had to pay for breaching the Convention between Great Britain and China relative to Burmah and China of March 1894. Salisbury even suggested a 'large-scale' modification of the frontier (Chandran 1977: 183).

At the end of January 1896, shortly after the Anglo-French Declaration, Great Britain succeeded in soliciting a promise from Beijing that the West River would be opened up to trade by foreigners. How far inland this would be would play a part in the negotiations over the Burmese-Chinese frontier, and the adjustments London wanted to make to the Convention of 1894 . Great Britain was prepared to abate its territorial demands in return for the West River being opened up. China tried to make the best of the importance attached by the British to the river, suggesting that London should abandon 
any territorial claim it had along the Burmese border (Chandran 1977: 233-4). At the same time, fearing what Curzon dubbed 'French susceptibilities', China was determined to make the final agreement with Great Britain the least offensive as possible to Paris. It did so by keeping a number of cities along the river, and especially the important port of Nanning, closed to foreign trade. ${ }^{12}$

Another British target was Kokang, yet another Shan state, considered by London to be a tributary of Burma and of special importance, located as it was just beyond Kunlong Ferry, the terminus of the railway planned for the Yunnan frontier. With railways and railway stations considered strategic assets and prime objects of foreign aggression, Kokang was seen by the British India Office as being of great value as a forward defence against a Chinese attack, should it come to an armed conflict between the two. ${ }^{13}$ Indeed, such importance was attached to Kokang that Salisbury was even prepared to send in troops to underscore that it was British territory; though he deemed an opening up of the West River even more urgent, overriding any claim to Kokang (Chandran 1977: 241, 244).

In February 1897 the Anglo-Chinese Agreement modifying the 1894 Convention was signed. In the preamble, London stated that it wanted 'to waive its objections' to part of Keng Hung becoming French (Agreement 1897: 1). China had to pay a price. Kokang - which in 1894 London and Beijing had still agreed belonged to China - became British, Great Britain was allowed to station a consul in Szemao, while Beijing also pledged to investigate whether 'conditions of trade' warranted the construction of railways in Yunnan and, if so, connect them with the Burmese railway system (ibid.: 4). In addition, Great Britain leased perpetually a small, triangle-shaped piece of land, about half-way between Bhamo and Kunlong Ferry, protruding into Burma. In this so-called Namwan Assigned Tract, China would 'not exercise any jurisdiction or authority whatsoever' (ibid.: 2). The rent was to be fixed at a later date. China, Curzon was to state a year later defending the decision to allow China to hand over part of Keng Hung to France, had paid 'liberally' for its mistake. Great Britain had 'secured a very substantial increase' of its interests and 'the opening up of great waterways'. ${ }^{14}$ In spite of these words, the treaty did not bring London what it might have expected. Some, like Morrison (1895: 239), were sure that Great Britain could easily

\footnotetext{
12 Memorandum by Curzon 8-12-1896 (cited in Chandran 1977: 247).

13 Hamilton to Salisbury 28-4-1896 (Chandran 1977: 240).

14 Curzon in House of Commons 8-2-1898 (hansard.millbanksystems.com/commons/1898/ feb/address-in-answer-to-her-majestys-most-gracious-speech).
} 
Figure 18 French railway plans and the projected British Mandalay-Kunlong Ferry line

\section{THE FRENCH RAILWAYS}

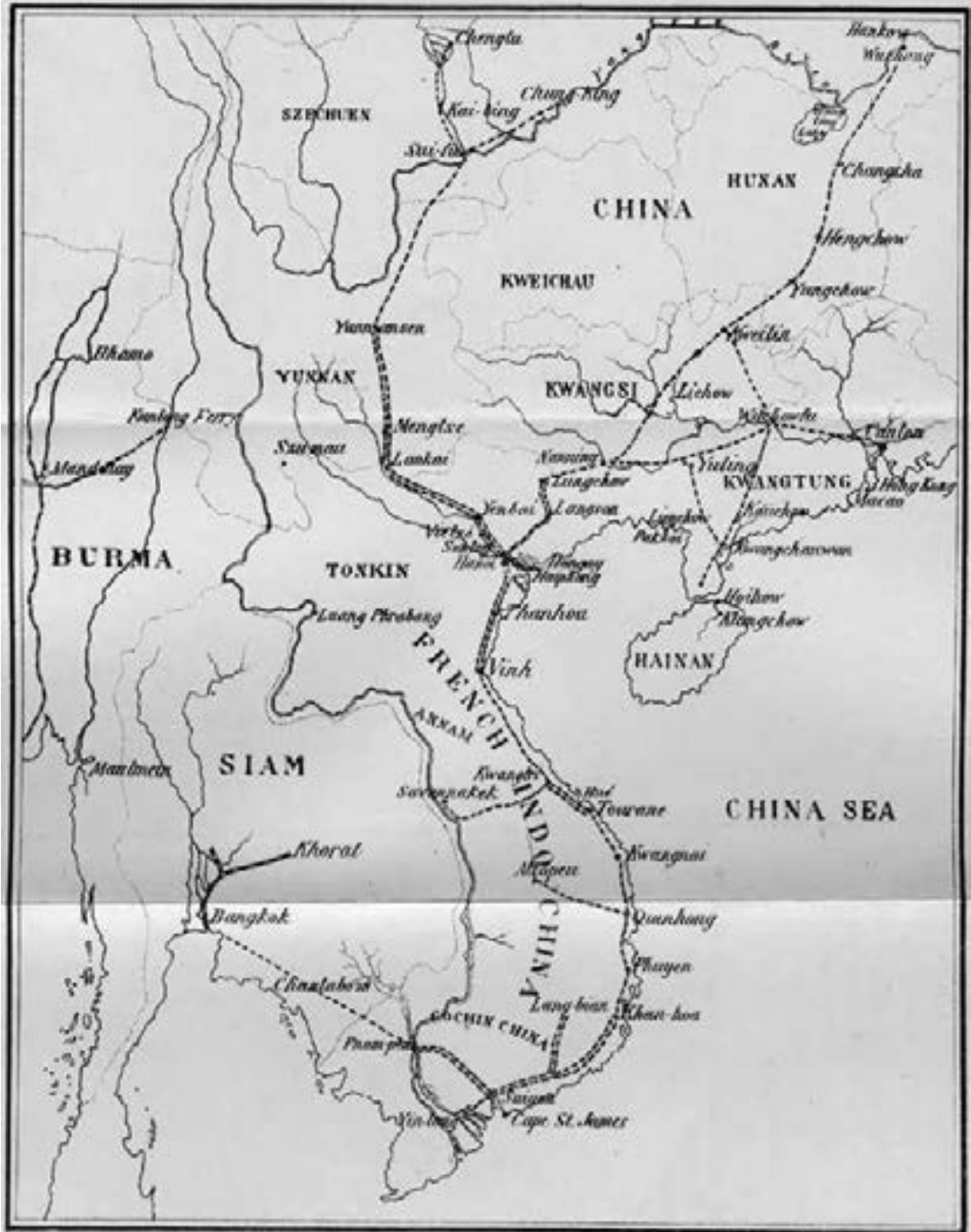

- I.jnen notrally worleingr.

Lets, at Be Mosylow Frindiog Trase

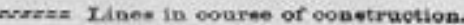

t.t.n- Lioen proponed.

Source: Cunningham 1902 
have gained more, weakened as China was by its war with Japan. The new agreement mentioned the opening of the West River, but only up to Wuchou in eastern Guangxi, which left Nanning, one of London's main objectives, closed to trade by the British. ${ }^{15}$ Allowing trade by foreigners would also not bring what the British might have expected. A report by the Chamber of Commerce of Blackburn of 1898 noted that since 1885 import trade to Yunnan had 'almost entirely shifted' from the West River to the 'Tonkin route'. The Blackburn Chamber of Commerce attributed this 'revolution' to 'the energy of the French in vigorously enforcing on the Chinese Government their right to transit passes', an achievement that also benefitted British trade imported via the Red River (Bourne 1898: 87). Such transit passes made imports and exports, for which duties had been paid at the Chinese Imperial Maritime Customs, exempt from the many additional local taxes or likin levied inland. Trade from and to Burma could not compete with this. The British had not succeeded in getting rid of such additional taxes imposed along the way, in spite of the fact that transit passes made these illegal.

Beijing also promised that if the Chinese were to construct railways in Yunnan the network would be linked with a Burmese line (a gesture presented as fitting compensation for the railway concessions Beijing had made in the north to Russia). Nanning remained high on the British agenda and was raised each time when new talks were started, whether this concerned conditions for loans to China, such as in March 1898, or concessions for China ceding territory to Russia and France; Beijing, fearing the French reaction if it consented, dragged its feet.

Keng Hung and Meung Lem continued to be Chinese, but once again China had to promise not to cede any of its territory without prior British consent. The British would not build their railway into China. The costs were too high, the terrain too difficult, and doubts were voiced about the trading prospects of Yunnan and Sichuan. Now, it was stressed that Yunnan was 'thinly populated and very malarious' and that Szemao was 'of no commercial value' (Chandran 1971a: 61, 67, 82). Responsible for the decision to stop work was Curzon, Viceroy of India since January 1899. Initially, he had been prepared to give railway plans the go-ahead, mainly to avoid rubbing up the British Chambers of Commerce the wrong way. Later he became more resolute, preferring the money required to be invested in Burma and India and speaking out against a railway into China (Chandran 1977: 282, 285; Cunningham 1902:105). Work was discontinued about two years after

15 As compensation for the opening up of the West River, France gained permission to extend the railway connection to Lungchow to Nanning. 
Curzon became Indian Viceroy. The projected line would not even reach Kunlong Ferry and would only run to Lashio. Should some still hope that construction would be resumed, Curzon made crystal clear what he thought about the project when he addressed the Chamber of Commerce in Rangoon in December 1901. He called it 'midsummer madness' to assume that 'the wealth of Szechuan would stream down a single metre-gauge line, many miles of which would lie over mountains, to Rangoon, while great arterial rivers flow through the heart of Szechuan itself, which are quite competent to convey its trade to and from the sea' (Chandran 1971a: 96).

\section{An ambitious Governor-General}

A year after the signing of the Anglo-French Declaration a person entered the scene who could upset the delicate balance in continental Southeast Asia and the adjacent part of China. It was J.A.P. Doumer, Governor-General of Indochina from 1897 to 1902 (and future President of France). His ambitions went further than those of most politicians in France. In his efforts to strengthen the French position in the Far East, Paul Doumer could count on the support of fellow expansionists (and towards the end of his term as Governor-General also on that of the Comité de l'Asie française, founded in 1901 by Étienne and of which Ferry was one of leading members). However, as he himself would sketch out a few years later, at the time he left for Indochina their lobby had not succeeded in turning around the hostile attitude of 'politicians' and the press towards pressing on in Asia (Doumer 1905:3). It did not put him off. Almost immediately after his arrival Doumer embarked upon what one contemporary British author, Cunningham (1902: 104, 184), a journalist from Hong Kong - and who in his travel account called upon the British not to underestimate the French doings in southern China - characterised as an 'ambitious programme ... for commercial and political conquest' of southern China. Doumer was depicted as an 'ambitious, clever and energetic official'.

Doumer was certainly energetic. Being a former Minister of Finance, money and the budget of Indochina were his key concerns. Realising that the light protectorates of Cambodia and Annam had brought the French almost no economic gains and little real influence in the interior, and that an unruly Tonkin cost the French much more than it yielded, he immediately carried out reforms (Doumer 1905: 154, 234, 286). In June 1897 an administrative reorganisation was implemented in Tonkin. Subsequently, on 11 July, Doumer concluded a new treaty with Cambodia, greatly increasing France's 
Figure 19 Doumer arrives at the inauguration of the International Trade Exhibition organized by him, Hanoi 1902

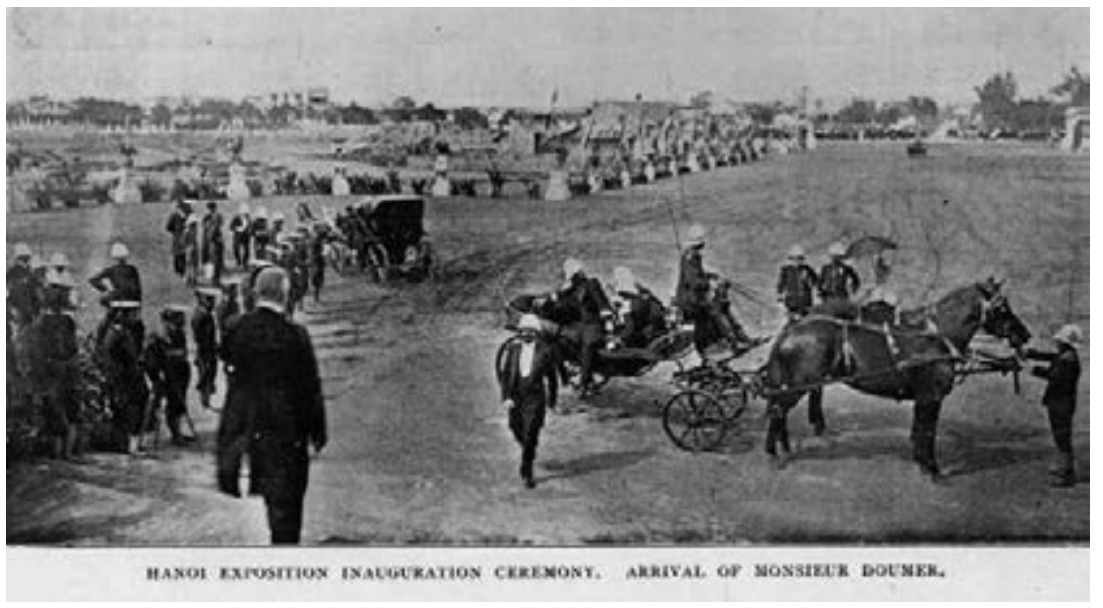

Source: Cunningham 1902

direct control over Cambodian affairs and allowing French citizens and companies to buy land. His instructions to French colonial civil servants in Cambodia captured what he had in mind for the whole of Indochina: 'Build roads, dig canals ... plan and construct railways, [improve] the great arteries of navigation' (ibid.: 244). His resolution must have been infectious. In 1902 the French Chief Resident of Cambodia wrote about its agricultural products being among the best of Indochina, and the excellent prospects for forestry and mining (ibid.: 245). Finally, in September 1897, Annam had to accept a greater French say in the running of the protectorate and its income, and the right of Frenchmen to own land.

With the same vigour as he had tackled the reorganisation of the administration of Indochina, Doumer set out to advance French influence in Thailand and south China, finding ways to circumvent Paris' reluctance to act. It was due to his efforts, he was convinced, that the impression gained ground that French consuls and agents in south China acted more resolutely and were better equipped for their job than their British counterparts. Money provided from the Indochina budget had seen to it that French representatives, receiving insufficient funds from the mother country, 'could cut a better figure and work more fruitfully' than the British, Doumer (1905: 377-8) wrote. After Indochina had started to earn money, that is after 1898, Doumer took steps to improve the French presence in Thailand and south China by supporting and expanding the activities of the representatives 
of the French government there, also in the scholarly field. Moreover, he saw to it that the French living and working there presented a friendly face; instructing those he sent to Yunnan to establish cordial relations with the population and the local officials. To reach out to the population in south China and Thailand, French hospitals and medical posts were set up providing free medical care. Chinese children received free education at schools where, among other subjects, they were taught French ${ }^{16}$ (ibid.: $378-81$ ).

Doumer was also a railwayman, emphasising that French products and French influence travelled along the railways (ibid.: 378). When he arrived in Indochina it had already become clear, also to Doumer, that the Red River was not such an easy waterway to navigate with steamers as had been assumed in the days of Dupuis and Dupré. On its own it could not serve the aim of opening up south China to commerce from Vietnam and outdo the Yangtze route. Doumer revived plans that had been dormant for some years and had already been mulled over by Garnier, at least since 1873, for reaching Yunnan by rail; a venture that Doumer considered to be as politically important as it was economically significant (Norman 1884: 101; Doumer 1905: 330). In December 1897, within a year of taking up his post, Doumer had a proposal ready for a railway network in Indochina and for what he invariably called railways or lines of penetration into China (and via Phnom Phen and Battambang into Thailand, to stimulate trade that up to then had been almost absent) (ibid.: 346). The aim was to connect Tonkin with Kunming (Yunnanfu, Yunnan-Sen), though Doumer aimed at more, at links with Sichuan and the treaty port of Hankou (Hankow, part of present-day Wuhan) on the Yangtze (Cunningham 1902: 125, 133; Chandran 1977: 289). In the long run, these railways should turn Haiphong into a big seaport, which some dreamt - but they were exceptions - would surpass Hong Kong (Neton 1904: 239). In presenting his plans Doumer made much of the railway in Burma that the British were building in their effort to open up Yunnan and Sichuan, provinces which he stressed should be 'reserved for our commercial penetration'. If France wanted to emerge victorious from the 'peaceful contest' with Great Britain it should start by constructing a railway network in Indochina that could serve as the starting point for 'the penetration of China' (Doumer 1905: 326). What Doumer had in mind did

16 Doumer was also responsible for what Cunningham (1902:28) described as 'a very aggressive post-office' in Canton and for two shipping lines, one from Guangzhou to Hong Kong and one from Guangzhou up the West River, both established also with the intention to show the French flag in regions where it had hardly been seen before (Doumer 1905: 378). 
not stop at trade and political influence. Sparsely populated and with a climate that suited Europeans much more than that of Indochina, Yunnan was a region where 'our race' could establish itself. French settlers, farmers, planters, cattlemen - all could go there. French civilisation in Indochina, and its place in that part of the Far East, would be secure (ibid.: 339).

As had been the case elsewhere, some assessments were hyper-optimistic. French officers surveying Yunnan would report a 'salubrious' region with 'an enormous plateau yielding three harvests of rice annually', and a laborious and peaceful' population. It also had minerals and coal and promised 'a great market ... for European goods' (Cunningham 1902: 132). Others, among them the well-known economist and student of colonialism P.P. Leroy-Beaulieu, questioned the feasibility of the rail line; disqualifying the markets it was to serve as poor (ibid.: 148). Optimism - and Doumer's persistence - won the day. In France a convention to allow for a railway to Kunming was signed in April 1898, explicitly keeping open the possibility of an extension. Doumer's only disappointment must have been that Paris did not allow Indochina itself to take on construction and exploitation of the line, but wanted a special company to be in charge. In September 1898 Doumer, who wanted his railway scheme executed as soon as possible, travelled to France to convince the government of its urgency and to attract investors. The commotion caused by Fashoda, the Dreyfus Affair and a change in government made for some complications. Doumer (1905: 328) hints that it made people in France uninterested in Indochina, but he nevertheless succeeded in having a special act in favour of his railway proposals promulgated in December 1898 .

The turmoil in China at the turn of the century resulted in a delay in the building of the line and also put a damper on French geological research in the south, preceding an exploitation of its natural resources (Lorin 1906: 361). The Boxer Rebellion made Paris order all French officials to leave Yunnan. The wheels were set in motion in mid-1901, when the Banque de l'Indochine, other major French banks and French railway companies formed the Compagnie française des chemins de fer de l'Indochine et du Yunnan (the French Company of Railroads in Indochina and Yunnan). It was a moment of glory for Doumer. He was sure that the decision to go ahead with the French line into Yunnan had made the British decide not to continue with theirs from Burma, and that it was up to Indochina to open up Yunnan, not the British (Doumer 1905: 344). Construction of the French railway to Yunnan, which had to surmount fewer natural obstacles in the landscape than the British railway would have, started in 1904 and despite the turmoil that would culminate in the Chinese Revolution it 
was completed in 1910. The stock and most of the material needed for the construction came from France.

In improving relations with Thailand and Yunnan, Doumer also assumed an active, personal role, and in doing so he disquieted the home government. In Paris Théophile Delcassé, Minister of Foreign Affairs since June 1898, feared that Doumer might complicate relations with Great Britain by going his own way in Yunnan; a suspicion fanned by a report from the, we may assume scheming, French consul in Mengtze indicating that Doumer was looking for an excuse to order troops into south China. In early 1899 Doumer was made to understand that he had to act with caution (Chandran 1977: 292-3). It does not seem to have bothered him much. In April 1899, and well-briefed in advance by Paris, which probably did not fully realise that this was an equally sensitive undertaking, Doumer paid an official visit to Bangkok. He judged it a great success. His arrival alone almost moved him to tears. On entering the city the carillon of the church in the French settlement had played the Marseillaise. Hearing the national anthem played in a country, a neighbour of Indochina, which 'rivals were trying to close to French influence', had touched him (Doumer 1905: 262). The rest of his visit was equally pleasant. Doumer was fêted, was greeted warmly by King Chulalongkorn (Rama V) and had amiable conversations with the king and some of his ministers. Failing to notice any animosity, he was sure that it would not be difficult for France to assume 'the place in Siam to which its strong position in Indochina entitled it' (ibid.: 262).

Doumer (1905: 340), as he later wrote, was also eager to see the route of the Yunnan railway for himself. With permission from Paris, in June 1899 he travelled to Yunnan's capital Kunming without an official escort. Indeed, Doumer travelled 'almost alone' (a French interpreter accompanied him). Riding horseback he was quite proud of his horsemanship and the distance he could cover in a day. His aim was also to establish relations with the authorities of Yunnan and to assess the mood of the population - their 'real sentiments' - and, one gets the impression, to stake France's claim in Yunnan. He wrote of assuring 'the legitimate authority of France over the province' (ibid.: 340-1). Yunnan at that moment was 'a little agitated'; but, he wrote, remaining strikingly silent about this controversial trip, he had experienced no problems at all and was well received everywhere. The members of the Lyon trade mission had an altogether different experience, writing about ill-mannered mandarins, people calling them Devils from the West, and stones being thrown at them (Chambre 1898: 108-9, 339). As in Bangkok, Doumer may have misjudged reality. Shortly after he had returned to Indochina in July, anti-French riots erupted in Mengtze. Doumer (1905: 
379-81) was perplexed, in no doubt about the good rapport the French had established with the population. He considered sending troops to Mengtze, but, as could be expected, was restrained from doing so by Delcassé (The Straits Times 27-7-1899). It was the Chinese troops that restored order.

After he had been recalled to Paris in 1902, Doumer (1905: vii, 245, 262), singing his own praises and trying to counter views in France that Indochina was not worth the money, showed himself well pleased with what he had achieved as Governor-General. He foresaw great prospects for Indochina, not even excluding that at a certain point in the future the colony and not the home government would bear the expenses for the military necessitated by the French presence in Indochina (ibid.: 308). What had been accomplished in Indochina 'did credit to French civilisation' (ibid.: 286). Thanks to him, Indochina had experienced an extraordinary development. Revenues had increased, Phnom Phen had become a real city, as had Hanoi and Hué, and Tonkin and Annam had been pacified without much bloodshed (ibid.: 289, 299). Most important of all, France had become a player to reckon with in the competition over influence and interests in the Far East. It had failed to befriend Thailand, but for this Paris was to blame (ibid.: 262).

\section{The Malay Peninsula}

London not only looked to the north, to Yunnan and the rest of south China. It also directed its attention to the south, to the Malay Peninsula; a region that Great Britain had not been very interested in for a long time (Tregonning 1964: 180). In the same period that Great Britain and France tried to include Yunnan in their trading networks, London proceeded to consolidate its position in the Malay Peninsula. A week after the signing of the Anglo-French Declaration of London regarding Siam, the Niger and Tunis in January 1896, Great Britain started negotiations with Thailand to thwart any German penetration. Thailand should be prevented from granting special concessions to any other power in the south western coastal region not yet under British supervision, the Isthmus of Kra and the Thai Malay, Muslim states. An occupation of any part of the Peninsula or the many islands along its shore by another power was seen as a potential threat to British shipping in the Bay of Bengal, the Andaman Sea and the Straits of Malacca, thus affecting the important trading routes between the east coast of India and the west coast of Burma with China, with Singapore as its intermediate port. The power that was in control of the Malay Peninsula 'must, to a great extent, command the route to the Far East', a memo of the 
British Colonial Office asserted in 1896 (cited in Thio 1969: 282). Singapore would suffer, 'half of the value of Singapore would be gone if to the north of it a neck of the Peninsula were held by some other Power', the memo continued.

Great Britain had gained its first foothold on the Malay Peninsula in 1786 when the Sultan of Kedah had ceded the Island of Penang to the East India Company in return for protection against the threat to his sultanate posed by Thailand and Burma. In the early nineteenth century the founding of Singapore in 1819 and the taking over of Malacca from the Dutch in 1824 gave Great Britain its three ports, its 'Straits Settlements', along the Malay coast. For the moment London was satisfied. It ignored persistent demands in Singapore (since the 1840s) to penetrate deeper into the Malay Peninsula. A source of inspiration for such calls must have been the venture of James Brooke, Rajah of Sarawak, who had acquired a large tract of land in Borneo in return for helping to suppress a rebellion in 1841. Those in favour of territorial expansion on the Malay Peninsula cherished the same inflated economic expectations of profits to be gained as would later be expressed about the islands in the South Sea. The Malay population and the British would both profit. An appeal from 1844 predicted a transformation of the Malays, made indolent because the incompetence of their rulers and 'insecure in their possessions, and without a motive to exertion'. Instead of peasants only cultivating 'scanty fields of paddy' and harvesting 'a few cocoanuts, which surround their villages' they would become people happily and energetically toiling the soil, yielding 'those rich and abundant crops for which nature intended it'. Their growing prosperity would create 'a large demand for the manufactures of England', and Great Britain would also 'receive those supplies of sugar which she so much requires, besides an abundance of other tropical productions' (Buckley 1902 II: 421-2).

Before the early 1870 s London had invariably reined in ambitious local officials by impressing upon them that it did not want to hear of any interference in the affairs of the Malay States in the Peninsula (Tregonning 1964: 181). This policy was ignored when, in 1873 , news reached the British that the Sultan of Selangor and other local rulers were looking for assistance by other powers to maintain domestic order, cut out local rivals to their position and control warring Chinese factions, drawn to the Peninsula by the prospects offered by tin mining. Uppermost in their minds was Germany, an indication that the German victory over France must have made a great impression, also in this part of the world. Bismarck would have rejected such a request, but London did not know that. Consequently, Kimberley, at that moment Colonial Secretary, maintained that it would be 
'impossible’ for Great Britain ‘ to consent to any European power assuming the protectorate of any state in the Malay Peninsula' (ibid.: 183).

The task of restoring order in the States on the Peninsula should be taken on by the British. In line with this, in September 1873 Kimberley instructed the new Governor of Singapore, Andrew Clarke, to 'consider whether it would be advisable to appoint a British Officer to reside in any of the States ... of course, only ... with the full consent of the Native Government'; not failing to mention that the Straits administration had to bear the costs. Kimberley did not allude to any German threat. Instead, he stressed the need to 'rescue, if possible, those fertile and productive countries from ruin' and the importance 'to secure protection to trade and commerce with the native territories' ${ }^{17}$

Clarke, who arrived in Singapore in November 1873, took Kimberley's hint to heart. He grabbed the opportunity provided by the request of Raja Abdullah in Perak to his predecessor, Harry St. George Ord, to recognise him as the Sultan of the State in return for sending a British officer 'to teach him how to rule', not awaiting advance approval by London to act (Swettenham 1907: 175). In January 1874, in the Pangkor Engagement, Raja Abdulah, Sultan of Perak, had to accept a British Resident, who practically came to rule his state, except in matters of religion and Malay customs (this would also become the rule in the other Malay States). According to James Alexander Swettenham (1907: 177), though he is not a detached observer as he took an active part in placing Perak under indirect British rule and would move on to become the most important British official in the region, Clarke's action was 'received with high approval by all classes and nationalities' in the Straits Settlements. Selangor followed in February of the same year. These steps assigned Great Britain with command of much of the west coast of what now is Malaysia, where it also interfered in parts of Negeri Sembilan. In the following decade Pahang had to allow a British Resident, while Johor became a protected state, for the time being not having to accept the presence of a Resident. In this way, Great Britain also secured a great part of the Peninsula's east coast. Some British may have convinced themselves that their moving in was an act of altruism. In retrospect, Swettenham (1948: vi-vii) would write that the British role was 'due to the simple fact that 70 years ago the British Government was invited, pushed, and persuaded into helping the Rulers of certain States to introduce order into their disorderly, penniless, and distracted households'. 
To the north of them lay the equally small states of Kelantan, Terengganu, Perlis, Kedah and Patani (Pattani). Culturally, these statelets were akin to their southern neighbours, having a Malay Muslim population. Politically, they were vassal states of Thailand, but for long this link had not amounted to much. In 1888 Browne (1888: 443) could still write that Thailand's power in the south was 'almost nil'. Partly in an effort to create a modern state, partly to forestall foreign intrusions, Bangkok started to try to assert its sovereign rights in the southern states. Its claim did not go uncontested in Great Britain and its colonies, and in the states themselves, some of which resisted effective Bangkok rule in the habitual fashion of states fearing for their existence, they would look for support from abroad. In 1826, in the (Henry) Burney Treaty of that year, the East India Company had recognised their Thai vassal status, but British expansionists, well-represented in the business community and the colonial administration of Singapore, could point to a loophole in the text. They had their doubts about its validity with regard to the two states bordering those under British dominion, Kelantan and Terengganu, where, according to Article 12 of the treaty, Great Britain and Thailand had 'equal rights' (Thio 1969: 281).

Internationally, London sought assurances that no other power would be able to arrange a coaling station or naval base there or gain important economic concessions. Their coast, Chamberlain wrote in September 1895, was 'a most dangerous vantage ground for France or Germany'. ${ }^{18}$ The fear that the latter might gain a foothold in the Malay Peninsula was a major reason for London to expand British hold over the southern Thai tributaries. Such strategic considerations linked up with economic expectations - some unrealistic - of profits to be gained (Thio 1969: 283). Economic hopes were focused on tin and other mining products. Rubber, the export product of the Malay Peninsula, of which production only took off after 1900, seems to have hardly entered British considerations, and was barely mentioned at all.

To the British, control over the states had become all the more imperative ever since France had annexed Annam in the early 1880s. It was not precluded that France, after having conquered Thailand, would also claim its Malay vassal states; much in the same way as it had justified its annexation of Laos. In London the British government bore such a scenario in mind, but for much of the 188 os and 1890 s it had to show more restraint than seemed proper to British expansionists in the Straits Settlements. For one, the British cabinets of those years did not want to antagonise the Thai government. It was 'not for the interest of India that Siam should be 
made unfriendly and thrown into the arms of France and Germany', it was observed at the Foreign Office in $1891 .{ }^{19}$ A more pressing consideration was that should Britain act in south Thailand, France might use such a British move as an excuse to reciprocate on Thailand's eastern border, annexing the provinces of Angkor and Battambang (and, before 1893, also Laos) it had set its sights on.

An equally pressing problem was control over the Kra Isthmus. It was a contentious area. Though there were doubts about the feasibility of such a project, constructing a canal across the Kra Isthmus, linking the Indian Ocean and the China Sea, when completed might be a serious blow to Singapore; a reason why Thai consent to its digging could not help but create a severe conflict with Great Britain. For years already there had been talk about French plans for such a passage. Ferdinand de Lesseps had visited Thailand in 1882, but had failed to get the cooperation of the Thai government. A French survey mission early the following year, undertaken with the permission of the Thai king, also had no follow-up. Nevertheless, some ten years later, at the height of the conflict over Thailand the Permanent Under-Secretary at the Foreign Office, Philip Currie, still portrayed the Kra Canal as 'a favourite French scheme' (Chandran 1977: 77). Conversely, France used all the diplomatic pressure it could muster to prevent the British from digging the canal; in 1886 thwarting plans by a British dominated Anglo-French company (Thio 1969: 287).

All the time British politicians were in no doubt that would it come to a partition of Siam the states to the north of Perak and Pahang had to come under British control. In July 1893 the Colonial Secretary, the Marquess of Ripon, suggested to Prime Minister Rosebery that if Thailand 'were to fall under French influence in the future we might find it necessary to take under our Protection or into our own hands the whole of the Malay Peninsula'. ${ }^{20}$ The peninsula he had in mind was larger than present-day Malaysia and included the Kra Isthmus. After reports had been published in the British press that during the 1893 Franco-Thai negotiations France might ask for permission to dig the Kra Canal, London wasted neither time nor effort to impress upon Bangkok that such a concession would be highly undesirable, and that if granted London would not hesitate to act to protect its interests. Bangkok was told that should France be allowed to dig the Kra Canal, the British government 'would reserve their entire freedom to take any action which they might consider expedient for the protection of the 
important British interests which would be affected'. ${ }^{21}$ France was equally made to understand that such a French scheme was out of the question (Thio 1969: 292-3). In London Foreign Secretary Rosebery called for alertness against Thai concessions 'affecting the Malay Peninsula whether a canal or otherwise'. ${ }^{22}$ His successor, Kimberley, was to stress that Great Britain

could not, from considerations of safety to their Indian and Colonial possessions, allow any other European Power to establish a footing in that Peninsula either by annexation, protectorate or by concessions for a maritime canal or railways and other public works of first rate ${\text { importance. }{ }^{23}}^{23}$

In a letter to Rosebery (now Prime Minister) he also alluded to 'the Siamese States in the Malay Peninsula, which some day we may want to take. ${ }^{24}$

First in mind seem to have been Kelantan and Terengganu. Both sultanates were mentioned in a memorandum of August 1895 by the then Under-Secretary of State for Foreign Affairs, Curzon, as compensation for Great Britain yielding to France by giving up the idea of an upper Mekong buffer state; and again in October, in a letter by Thomas Sanderson, the Permanent Under-Secretary at the Foreign Office, to Curzon. In his own memorandum, Curzon wrote about 'long desired concessions' (Chandran 1977:172, 188). Chamberlain, in his capacity as Colonial Secretary, in a letter to Prime Minister Salisbury in September 1895, showed himself equally prepared to swap gaining control over the west coast of the peninsula with British concessions to the French in the north of Thailand (Chandran 1971: 154-5). Salisbury himself observed in a memorandum about a Franco-British agreement on Thailand that any delimitation of influence should 'cover Tringanu and the other territories that are in the same condition, which are claimed at the present moment by Great Britain, though apparently they belong to Siam. ${ }^{25}$

The perceived threat came from Germany and to a lesser extent from France, but not from Russia. Russia was seen by Thailand and the Malay States as a possible counterbalance to British or French expansion, but stayed aloof (Snow 1994). That said, a change in Russian policy could be

22 Rosebery to Currie 27-8-1893 (cited in Chandran 1977: 80).

23 Kimberley to De Bunsen 27-10-1894 (cited in Chandran 1977: 118).

24 Kimberly to Rosebery 12-6-1895 (cited in Chandran 1977: 146).

25 Memorandum Salisbury, October 1895 (included in Chandran 1977:340-2). 
perceived. At the beginning of the 1890 s St Petersburg was still rejecting an active Russian role. The reason was that 'there were only three Russian residents in Siam and no trade' (Thio 1969: 293). By the end of the decade Russia assumed some political presence in Thailand. Cordial ties developed between the courts of Russia and Thailand and in 1897 formal diplomatic relations were established. As elsewhere, the French and Russian envoys seemed to work in concert. Doumer (1905: 260) was full of praise for the assistance of the first Russian Consul General in Bangkok, Alexander Olarovsky, in improving Franco-Thai relationships (ibid.: 26o-2).

Russia looked for expansion of its sphere of influence in China and Persia, not for a foothold in the Malay Peninsula. When an official of the Russian consulate in Singapore was contacted by a dissatisfied member of the Selangor elite, probably also an associate of the Sultan of Kelantan, he ruled out any support because Russia did 'not have interests in these countries' (Snow 1994: 364; Reid 1965: 44). In 1903 the Sultan of the South Malayan State of Johor also contemplated travelling to Berlin and St Petersburg, to ward off a full British annexation of his state (Snow 1994: 360 ).

With Germany it was a different matter. Its real and imagined threats played such a prominent role in British policy in the Peninsula that one Malaysian historian, Tregonning (1964), would entitle one of his articles How Germany Made Malaya British. Because Germany had stayed out of the Anglo-French rivalry over Thailand it had a much better image there than France or Great Britain. Through its business community in Penang and the other Straits Settlements, Germany had succeeded in expanding its economic presence in Thailand (Nasution 2006: 70-1). The way it had forced Great Britain out of the shipping sector had not gone unnoticed and, in general, Germany had, as Tregonning (1964:185) observed, 'secured a good trade and diplomatic footing' in the country.

For Germany Southeast Asia was a not a region to look for territorial aggrandisement, but one for the expansion of its trade and investment. It also formed a good location for a naval and coaling station for its ships en route to the Far East; preferably to be established near the Straits. There were two possibilities. One was along the coast of Sumatra, which, to the dismay of people in the Netherlands Indies, was indeed suggested in the German press (De Locomotief 21-2-1898). The other one was along the coast of the Malay Peninsula. London was made aware of these plans in 1890 when, much to the alarm of Prime Minister Salisbury and other British politicians, news reached the British that German diplomats had entered into negotiations with Bangkok to allow Germany to build a coaling station north of Penang. 
To keep rival powers out and to block the digging of the Kra Isthmus channel, the king of Thailand was made to promise in the Anglo-Siamese Secret Convention of April 1897 'not to grant, cede, or let any special privilege or advantage, whether as regards land or trade ... either to the Government or to subjects of a third Power, without the written consent of the British Government' in the south. ${ }^{26}$ London had had to proceed with care in order to get such a guarantee. The negotiations should not alert the German or French governments who themselves were looking for concessions in the region. It was also important to avoid another power exploiting feelings of discontent in the Malay states that might be occasioned by British recognition of Thailand's rule in the south. At the same time, London should steer clear of obstructing possible future steps to establish British control in the northern Malay states. The problem was solved partly by keeping the agreement secret - not even the colonial authorities in Singapore were informed about its content - and by speaking in the first article about the rights of the Thai king in the region, avoiding words such as suzerainty and sovereignty (Chandran 1971: 158-9; Thio 1969: 301-2).

One of the places the Germans had in mind as a suitable location for a coaling station was the Langkawi Islands, located just below the present-day border of Thailand and Malaysia and not far from British Penang. In 1899 the important German plantation firm and shipping agent Behn, Meyer and Company tried to lease the islands from Kedah and place them under German Schutz. A report that the lease had successfully been concluded even appeared in the London and China Express in February 1900 (Nasution 2006: 71). Swettenham, now Resident-General of those States that were already under British protection and soon to be Governor of the Straits Settlements (and never hesitant to provide his superiors with news that might persuade them to act), informed London about the German intention, also alerting it to plans Germany might have for arranging a coaling station on Terengganu's Redang Island along the east coast (Tregonning 1964: 186; see also Reid 1965: 44). London reacted immediately. A remonstration in Bangkok, reminding Thailand of the Anglo-Siamese Secret Convention of April 1897, made the German Langkawi plan come to nought, which in turn led to protest by the German ambassador to Thailand (Tregonning 1964: 186). Langkawi was too close for comfort for the British. The German move, moreover, came at a time when Bangkok tried to improve its relations with St Petersburg and Berlin. 
In March 1896, defending the Anglo-French Declaration of that year regarding Thailand, Curzon still stressed that it was a misconception to assume that Thailand had been divided into a central neutral zone and 'two spheres of influence, possibly at some future day of possession, on either side, by the French on the east and the British on the south-west'. ${ }^{27}$ In a similar vein, Salisbury informed the governments of Thailand and France that London had no intention of infringing upon Thai rights in the south (Thio 1969: 297). The reality was different, and at least on the French side the Declaration had been linked to the establishing of a French and a British sphere of influence, the British on the Malay Peninsula and the French on the right bank of the Mekong (Lorin 1906: 354). In the south Germany caused the British to act in a way similar to the French. On top of the reports about a German lease of Langkawi came rumours in 1901 that Malays in Patani and Kelantan, who were experiencing a political, cultural and religious encroachment by the Buddhist Thai state, were looking for German assistance to gain independence (Turnbull 1981: 182). In response, London forced a new agreement upon Bangkok in 1902. In it Great Britain was given the right to appoint advisers in Terengganu (where the Sultan refused to accept such a political agent) and Kelantan (where one was appointed in 1903). In 1905 Kedah, including the Langkawi Islands, followed (ibid.: 182).

Two years later London learned of the intention to have the Germans construct and finance a railway from Kedah to Bangkok, to be built with a different gauge from the British system in the southern part of the Peninsula. The British could not let such an insult pass (Nabijan 1979: 124). In 1909, in accordance with the Anglo-Siamese Treaty or 'Bangkok Treaty' of July of that year, Kelantan, Kedah, Terengganu and Perlis came under full British control after Thailand handed over suzerainty. 'There has been no action of the British Government in Malaya during the present century so notable', Swettenham (1948:353) wrote, remaining silent about any threat by other powers, mentioning instead the menace Bangkok would have posed to these four statelets (ibid.: vii). In return, Great Britain provided Thailand with a loan to build a railway between Bangkok and Alor Star in Kedah. It was not much of a sacrifice, as German plans to build a line from Bangkok to the south had been among London's reasons to act (Turnbull 1981: 181-2; Snow 1994: 361). The Malay-Muslim state of Patani, which had turned in vain to the British for help in resisting tighter

27 Curzon in House of Commons 27-3-1896 (hansard.millbanksystems.com/commons/1896/ mar/27/france-and-siam). 
central control and modernisation efforts by Bangkok, also remained outside the deal. To this day it remains a restless part of Thailand, and has been from time to time, most recently since January 2004, the scene of a vicious war between government forces and Malay Muslims fighting for independence.

The gradual expansion of British control in the region was matched by that of France in the east. In accomplishing this, Paris could point at the British effort for a justification (Lorin 1906: 42, 357). New negotiations, presented in France as an effort to reach an Entente Cordiale with Thailand, were started in 1902. After an earlier attempt in 1902 had failed because of opposition in the French Parliament, the French could realise much of their colonial ambitions in agreements concluded on 13 February 1904 and 23 March 1907. In 1904 France left Chantaboon but gained territory in the north, in Luang Prabang, and in the south in the region bordering Angkor. The 1904 agreement, acknowledging French predominance in the Mekong Basin, was typical of those days. Among its stipulations were a commitment to build a railway between Battambang and Phnom Penh and a Thai promise that if it wanted to build railways, canals and ports in the Mekong Basin but lacked the necessary capital or qualified personnel it would contact France. In place of the 25 -kilometre demilitarized zone it was now agreed that only Thai troops commanded by Thai officers could enter the Mekong Basin; an exception was made for the Gendarmerie, at that time commanded by Danish officers. In 1907 Battambang and Angkor were added to Cambodia. People like Doumer (1905: 201) had argued that such a transfer would fulfil a long-nursed wish of the Cambodians. Moreover, it returned the Angkor monuments to the country that historically was entitled to them. Thailand only received a small territorial compensation in return. Bangkok had realised, as Lorin (1906: 357-8) had already written regarding the 1904 negotiations, that it could not provoke French patience to the very end and could not count on any assistance from London in resisting justified French claims. The latter was true, not because of a lack of British resolve in terms of coming to the support of Thailand, but because France and Great Britain were able to straighten out their colonial differences in Asia and Africa and had reached their Entente Cordiale in April 1904. Though Taylor (1971: 413) ranks Thailand among the lesser disputes to be settled, as does most other Entente Cordiale literature, Frenchmen in those days thought differently. In terms of gains, Thailand was one of the prizes, and not a small one, for accepting a British de facto protectorate over Egypt. The territorial expansion in Thailand flattered French self-esteem. It was good for its international standing. 
As Lorin (1906: 358-9) wrote, a few token French advisers to the Bangkok government would not have sufficed to give France a place comparable to that of Great Britain in continental Southeast Asia. Such appointments would not have counted for much in a country where the British acted as advisers in the fields of finance and justice, the Germans were building railways and the Danes were reorganising the army. The territory France had gained did. 



\section{The Scramble for China: The Bay of Jiaozhou and Port Arthur}

In 1880 one of Japan's senior military officers, if not the most important one, Yamagata Aritomo, called attention to the danger that the modernisation of the Chinese army and navy posed to Japan's safety. At the same time, the fortifications built to defend Japan's coast were not only intended as a deterrent against a Russian attack from the sea, but also against a Chinese invasion, should Japan and China become involved in a military conflict over Korea (Drea 2009: $5^{2}, 55$ ). The might of China, which as Norman (1884: $259,287-8$ ) wrote, had 'made great strides' since 1860 'in what we call Western civilisation', was also still a factor taken into account by politicians and diplomats in France and Great Britain. In 1883 the French ambassador in Beijing warned his government that the Chinese soldiers were well-trained, well-armed and had foreign officers (who in the eyes of Western observers made the difference) (ibid.: 107, 262). The performance of Chinese soldiers in the Sino-French War of 1884-85 impressed the British and, some ten years later, the then British Secretary for India, Lord Kimberley, mentioned their 'serious power of annoyance' as an argument not to provoke China too much in the Burmese-Chinese frontier negotiations that were being conducted. ${ }^{1}$ The Chinese fleet had German- and British-built state-of-the art warships, and the Chinese army and navy used European armaments manufactured by Krupp, Mauser, Armstrong and other companies; a reality that in 1900, at the time of the Boxer Rebellion, made the military operations to relieve the besieged legations in Beijing far from easy for the powers. China also produced such weaponry, with varying success, in local arms factories.

At that time, London still looked to China as a balancing force in solving the British disputes with Russia over the Pamirs and with France over Thailand. London tried to convince Beijing that Great Britain and China should be 'working in close accord' in both issues. ${ }^{2}$ To some contemporaries it even appeared that China made good use of the opportunity the British predicaments presented. Morrison (1895: 241), who had the negotiations over the frontiers of Burma and the buffer London wanted to create there between French and British territory in mind, complained that with its

1 Kimberley to Lansdowne 23-8-1892 (cited in Chandran 1977: 27).

2 Rosebery to O'Conor 17-10-1893 (cited in Chandran 1977: 87). 
overtures Great Britain was willing to suffer 'indignities and humilities' by 'a hypothetically powerful neighbour'.

By the end of the century such caution and praise had disappeared. The 'China Question' became a source of concern for politicians and a topic of public debate. In analogy to the Ottoman Empire, China came to be referred to as 'the sick man of the Far East' (Wright and Cartwright 1908: 773). It had become too weak to resist demands by foreign nations and its government was no longer able to enforce its authority all over the country. Treaty ports no longer sufficed. Wider concessions were sought. In contrast to the South Pacific, where individual settlers played a leading role in the expansion of Western political influence, in China governments were in the vanguard. A partition of China, or as it was sometimes phrased a dividing up of the country into separate watertight compartments, seemed imminent. As Hart recollected: 'the powers were to partition China ... each year - nay, every month, the press or local rumour, Cassandra-like, foretold woe' (Silbey 2012: 51). The poor image of China in the West and in Japan, the idea that the country could collapse at any moment, and racial prejudices all contributed to such prophesies. In the Western world anti-Chinese sentiments were widespread. Morrison (1895: 2), an Australian and correspondent for The Times in China, wrote of the 'strong racial antipathy to the Chinese common to my countrymen'. This certainly held for the self-governing British colonies in the Pacific, Australia, New Zealand and Canada (or rather British Columbia), where, as in the United States, racial feelings were enhanced by a strong aversion to the immigration of cheap Chinese and Japanese labourers; against what some called the influx of pagan races from Asia, which in reality only concerned relatively small numbers. ${ }^{3}$ In Germany Kaiser Wilhelm II was rabidly anti-Chinese and would, from time to time, deliver rambling, even to his countrymen embarrassing, speeches about how to deal with China. German missionaries in China displayed similar prejudices (Esherick 1987:125). In Japan a decisive anti-Chinese bias became manifest almost from the day Japan had opened up, fuelled by China's inability to resist the Western powers and the backward conditions many Chinese lived in. The Chinese were downgraded as half-barbarians, a qualification that was extended to the Koreans (Keene 1998: 49, 79; Goto 2003: 4).

As the eagerness of Europeans and Americans, and later also Japanese, to trade with and invest in the country indicates, China continued to be a country that businessmen and politicians looked to for the advancements of

3 In Australia most of the Pacific Islanders who had taken up residence there were forcefully repatriated in the beginning of the twentieth century (Thomas 2010: 238). 
their economic interests. The Chinese market was developing. The rare traveller who in the closing decades of the nineteenth century traversed China could confirm this, reporting about the European products for sale in local shops and markets and, as Dikötter (2007:1) concludes, 'the material culture of broad sections of the population was already inextricable intertwined with global trends by the end of the nineteenth century, whether by the yarn of their clothes, iron of their tools, or their lamps and the oil in them'.

A modern infrastructure was also developing, detested as elsewhere in the non-Western world by those who because of it had lost their livelihood. Here, too, it was to become a source of discontent an unrest. In the $1870 \mathrm{~s}$ Chinese shipping companies had embraced steam, and by the end of the century Chinese ships, sailing boats as well as steamers, would have a large share in transporting goods to and from China. Railways were built and, once constructed, the Chinese made frequent use of them. Electric street lights spread from the Western settlements and, by 1900, had also been installed in Changsha, the capital of Hunan, described by one Frenchman as 'the province the most hostile to foreigners' (Chambre 1898a: 450; Dikötter 2007: 134-5). China also had a banking network covering much more of the country than foreign banks did and a telegraph network, essential for trade and for military and political communication. Initially, the telegraph was an affair of the foreign settlements and foreign and Chinese commerce. The first land line of the Chinese Telegraph Administration dated from 1881, linking the commercial centre of Shanghai and the politically important city of Tianjin, reaching Beijing in 1884 (Eitel 1895: 505-6; Morrison 1895: 156; Darwent 1905: viii; Bickers 2011: 297).

As elsewhere in the non-western world, local products had to give way to imports, with the same devastating consequences for local traditional production as the introduction of trains and steamships had, but China was not without an industrial and commercial sector of its own, and the opposite was also possible. As a Blackburn trade mission to China at the end of the century noted, in the marketing of coarse cotton yarn the British had been 'beaten by India, Japan, and China' (Bourne 1898: 5). The report also praised the Chinese trading networks and bewailed the fact that the moment goods entered the country the British (and other foreigners) no longer had any role to play, locked up in the treaty ports as they were. And even there, with the exception of Shanghai and Hong Kong, 'the whole distributive trade' of imports was 'in the hands of Chinese', with British merchants in the foreign settlements only functioning as 'outpost stations for the collection of exports' (Neville and Bell 1898: 217, 339). Some Frenchmen, more realistic than their earlier compatriots in Indochina in the late 186os, took a different 
approach, pleading to make use of these Chinese traders and their networks and knowledge of the local markets, instead of trying to cut them out. It was impossible to beat them (Chambre 1898a: 25-6; d'Orléans 1894: 485). Also in Southeast Asia it was impossible for Westerners not to notice the prominent role Chinese traders played. As one contemporary study about French Cochin China noted: 'They married all the prettiest women, and got all the commerce' (Scott 1885: 247). In another study the Chinese in Singapore were praised for being 'public-spirited' (Colquhoun 1902: 225).

\section{The consequences of military defeat}

China's defeat in the Sino-Japanese War set in motion a development that many in those days were sure could not help but lead to a dividing up of China among the powers. The chance that this would not happen, Colquhoun (1902: 45) wrote, was ‘slender'. In London Grey agreed. In 1903 he would quote with approval the Shanghai correspondent of The Times who had written that 'the future maintenance of the integrity of China is, humanly speaking, impossible'. 'The break-up of an Empire of four hundred millions of people', as the opening sentence of Beresford's plea not to let it happen read, would have 'no parallel in history' (Beresford 1899:1). Anticipating such a chain of events, Curzon had viewed with some favour the construction of a railway from Burma to the Yangtze Valley. Troops from India could be transported quickly along the route to Central China, should a situation arise in which 'anything like a Protectorate or even actual possession' of the Valley had to be considered. ${ }^{5}$ A drawback, as one British Member of Parliament expressed it, was, 'You cannot have a railway in China without protecting it' (with troops). ${ }^{6}$

Fearing that other powers might push Beijing to cede territory to them or grant them exclusive commercial privileges, much diplomatic effort and scheming went into soliciting promises from Beijing that China would not make concessions to another power in certain parts of the country, and especially not in those regions where one considered one's own existing or future economic interests paramount. For Great Britain this was the

4 Grey in House of Commons 23-7-1903 (hansard.millbanksystems.com/commons/1903/ $\mathrm{jul} / 23 /$ civil-service-and revenues-departments).

5 Memorandum by Curzon 12-6-1898 (cited in Chandran 1977: 280).

6 Caldwell in House of Commons 20-3-1902 (hansard.millbanksystems.com/commons/1902/ mar/2o/situation-in china-general observations). 
Yangtze Valley, consisting, according to a definition drawn up by London, of the provinces bordering the river and the Henan (Honan) and Zhejiang (Chekiang) provinces, or roughly the whole of Central China. ${ }^{7}$ Having established itself in Indochina, France aimed north, at southern Chinese provinces. Russia was safe and secure in the north and keen to expand its influence there still further. The staking out of spheres of influence and the hunt for commercial and territorial concessions, which characterised the closing years of the nineteenth century in China, were inspired by a mix of existing economic interests, ideas about profits to be gained in the future, political strife, and national pride and prestige. It got the better of all the participants. At a certain moment it was realised in Paris that while it aimed at control over southern China, French investments were in fact greater in the Yangtze Valley (Chandran 1977: 302, 307).

After defeating China, Tokyo had made it clear that it wanted Korea to fall within the Japanese sphere of influence. Japan, having acquired Taiwan, made the opposite coast of Fujian a likely object of a similar intention. As The New York Times (14-4-1901) reported, the Japanese seemed 'to feel that the province ought to be theirs' and that they regarded themselves as 'the protectors of Fukien'. An indication of Japan's increasing economic interest in the region would be reflected in the growing share of Japanese shipping, to the detriment of that of the British, to and from the treaty port of Xiamen (Amoy) (Bowra 1908: 820). Some were pretty sure that Fujian would be one of the regions in China where Japan would 'undoubtedly' act should it come to a partition of China (Colquhoun 1902: 375). As the opening of the ports along the Yangtze after the Sino-Japanese War indicated, Japan was also very interested in trade along that river, and a Japanese trading mission had at that time investigated its possibilities, travelling as far inland as Chongqing (Chambre 1898: v).

It would not take long before other countries made their move, aiming at the Bohai Sea to the north. The first to gain a concession on its coast was Germany, where Wilhelm II and its leading politicians had recently embarked on their Weltpolitik. Territorial expansion formed part of this. Or, as Bülow said in the Reichstag in December 1899: when the British speak about a 'Greater Britain', the French about a 'Nouvelle France' and the Russians are opening up Asia, the Germans are entitled to a 'Greater Germany' (Graichen and Gründer 2005: 83).

7 Brodrick in House of Commons 8-6-1899 (hansard.millbanksystems.com/commons/1899/ jun/o8/the-yang-tsze-valley). 
In 1894 Germany had disbanded its East Asia Squadron, but the course of the Sino-Japanese War and Wilhelm II's insistence that Germany should get its 'fair share' when Great Britain and other powers would seek territorial concessions in a weakened China, made for a reversion of this decision before the year was over. ${ }^{8}$ A German naval presence in the Far East was deemed necessary, also, it was argued, in view of expanding German-China trade. To accomplish this, Germany needed its own Stützpunkt, a bunkering and repair station for its warships, so that it no longer had to rely on the goodwill of Great Britain, Russia and Japan for such activities in north Asia. The first priority was to decide on the location of a 'German Hong Kong in China' (Graichen and Gründer 2005: 82). Several places were considered. In November 1894, at a time when war was still raging, Wilhelm II suggested to his Chancellor, Hohenlohe, a joint occupation of Taiwan with Japan. The German Foreign Office showed a preference for Zhoushan Island in the Hangzhou (Hangchow) Bay, at the estuary of the Qiantang River. Located not far to the south of Shanghai, a German annexation of Zhoushan would have met with strong opposition from Great Britain; the more so if the German Foreign Office had it right that Zhoushan 'would soon supersede the river port, Shanghai, which is difficult to access'. ${ }^{9}$ The German envoy in Beijing, Edmund Friedrich Gustav von Heyking, recommended the Penghu Islands (which in 1895 became Japanese) near Taiwan or the Bay of Jiaozhou and its harbour Qingdao (Tsingtao, Tsingtau). The latter was also the location that Tirpitz had in mind when he briefly served as Commander of the German East Asia Squadron in 1896. Among the points in its favour, he mentioned that its hinterland, Shandong, as others also were to point out, was rich in coals and iron ore, promising good economic prospects. Tirpitz had yet another motive: the presence of the German missionaries in the province and the good impression a German presence in their vicinity would make at home on the Roman Catholic Germans, whose votes Tirpitz sought for his plans to expand the German navy (Esherick 1987: 128).

In the discussion about where the Germans should settle, the assessments of the German explorer and geologist Ferdinand Freiherr von Richthofen figured prominently. Richthofen, who had sailed with the Prussian naval expedition of Count Eulenburg, made a detailed survey between 1868 and 1872 of the natural resources of China and recorded its geography. Richthofen, one of those people dreaming of the opening up of China to Western commerce and civilisation, the country criss-crossed with railways and its 
natural resources exploited by foreigners, evidently did want to contribute his might and did not shy away from suggesting places along the Chinese coast best suited for a German naval and coaling station. ${ }^{10}$ In 1869 he had drawn Bismarck's attention to the Island of Zhoushan as the ideal location for such a station. He praised the island for having the best harbour along the whole Chinese coast. Located in the Yangtze Delta, it formed 'the key to whole of central and northern China', and could dominate the entrance to northern China and Japan. ${ }^{11}$ With the same zeal, Richthofen, though he had never been there, recommended the Bay of Jiaozhou (Weicker 1908: 31). In the second volume of his extensive report about his travels through China, published in 1882, he described it as the biggest and best sheltered seaport in northern China.Jiaozhou Bay, he wrote, offered an anchorage completely sheltered from the winds (a British naval expert who visited the place in 1898 saw matters differently, pointing out that a breakwater would have to be built to protect it from the easterly seas). As the terminus of a railway network in north China, the Bay of Jiaozhou could serve as an excellent starting point for an economic incursion into China. Its connections with the hinterland were superb. Two mountain ranges hampered any transport inland from other nearby ports, while the Jiaozhou harbour was located at a lowland pass in between these mountains. An additional advantage, which he mentioned, were the nearby rich coalfields of Shandong, to which a railway could be built without any great trouble or costs (Richthofen 18821911 II: 262-6; Beresford 1899: 81). Politically, it was a plus that Jiaozhou Bay was located far away from the British sphere of influence, which Zhoushan was not. ${ }^{12}$ At the same time, this made it second-rate, the more so because the waters were too shallow for the biggest ships, and there were doubts about the possibility of defending a naval base effectively (Weicker 1908: 31).

Germany had expected - as had France and Russia - to gain some reward for its intervention on behalf of China after the Sino-Japanese War in relation to the right to issue a loan to China or another concession. The reward it suggested, permission to build a naval base along China's coast, was too great for China to grant. In October 1895 Beijing only agreed to allow Germany to have two foreign settlements of its own, one in Tianjin and one in Hankou. Berlin had not pressed the matter, Wilhelm II would write, out of

10 Richthofen to his parents (cited in Knopp 2011: 146).

11 Richthofen to Bismarck 2-1-1869 (cited in Gründer 1999:59-61).

12 Before making a final decision Tirpitz sent George Franzius, director of the port of Kiel and a hydraulic engineer, to China in early 1897 . Franzius also mentioned Zhoushan as the best location for a German base. Other places he recommended were Xiamen and nearby Samsa Bay, north of Fuzhou, both already treaty ports (Weicker 1908: 30). 
'excessive modesty'. ${ }^{13}$ Contrary to these words, Berlin had applying military force in mind. In the autumn of 1896 the Kaiser ordered naval command to plan, in secret, for the occupation of the Bay of Jiaozhou (Nuhn 2002: 132). The German legation in Beijing also received its instructions and, months in advance, had already drafted a proclamation in Chinese to be posted after a German landing (Matzat 1985: 6).

The bay was close to the Russian sphere of influence. Before he could proceed, Wilhelm II wanted to make sure that Russia, which used the waters in winter as an anchorage place for its warships, would not object. In August 1897 he visited St Petersburg. One of his aims was to sound out how Russia would react should Germany establish a coaling station in north China. He assured Nicholas II that German warships would not enter the Bay of Jiaozhou without prior approval by the Russian naval authorities, and gained the impression, or maybe convinced himself, that Russia would not raise objections. ${ }^{14}$

The opportunity to act presented itself in November 1897. Earlier, in October 1895, the German minister in Beijing had already warned the Chinese government that if Christians were not given better protection Berlin would take on this task itself (Esherick 1987: 113). Actions matched these words when, on 1 November 1897, All Saints' Day, two German Catholic missionaries from the vicariate that Wilhelm II had taken under his protectorship were hacked to death in West Shandong. For reasons of domestic as well as foreign politics the unrest in Shandong came at a convenient moment for Berlin. The murder of the two missionaries provided Wilhelm II with the justification needed and offered an opportunity to bully China into giving Germany the bunkering station it aspired to. Not only had two German citizens been killed but their slaying was an insult to the Emperor in his role as protector of the Shandong mission. At home the incident could be used as yet an additional argument for expanding Germany's naval strength. Incidents like that in China, and another one in Haiti that took place around the same time, in which two German warships had appeared before Port-au-Prince to demand the release of a German trader and an indemnity for his arrest, served to demonstrate that Germany needed a strong navy to protect its overseas commerce and its nationals living in faraway parts of the world. Wilhelm II had yet another reason to act. He

13 Wilhelm II to Bülow 7-11-1897 (E.T.S. Dugdale, German Diplomatic Documents, Ch. III, The Growing Antagonism, 1898-1910; www.mtholyoke.edu/acad/intrel/dugdale/Kiao-Chou.htm).

14 Bülow to the Ministry of Foreign Affairs, 11-8-1897 (E.T.S. Dugdale, German Diplomatic Documents, Ch. III, The Growing Antagonism, 1898-1910; www.mtholyoke.edu/acad/intrel/ dugdale/Kiao-Chou.htm). 
could show his Catholic subjects - who in Bismarck's days had suffered under the so-called Kulturkampfor Cultural Confrontation directed against them - 'once again' that he cared for them as much as he did for the rest of the nation. ${ }^{15}$ National pride was also evoked. Bülow told the Reichstag in December 1897 that it was imperative that 'German missionaries and German entrepreneurs, German products, the German flag and German ships should be respected in the same way those of other Powers were'. ${ }^{16}$

Wilhelm II, who was an admirer of Kipling (Mann 1992: 509) as well as a staunch supporter of Germany's Weltpolitik, which because the South Pacific had become divided up meant acquiring a foothold in the Far East, did not hesitate. He treated the killing of the two German missionaries as a personal affront. Haste was made. Germany, one author wrote some ten years later, acted without going 'to the trouble to stalk her pray through the usual processes of evasive diplomacy, but sprang abruptly upon it without warning and established possession by pure audacity almost before other powers realized what was happening' (Millard 1906: 210).

On 6 November, and within hours after he had read about the murders in the newspapers, Wilhelm II sent a wire to the Ministry of Foreign Affairs in which he emphasised that the Shandong mission was under his protection and that vengeance was in order, if not harsh retribution. The East Asia Squadron (now renamed the East Asia Cruisers Division) should steam to Jiaozhou Bay immediately, occupy the town there and threaten China with the most severe retaliation if it refused to pay a large sum in compensation and punish the people responsible. ${ }^{17}$ Following a reply from the Ministry the following day, Wilhelm II, with similar speed, that same day cabled the Commander of the German East Asia Cruiser Division in Shanghai, Rear Admiral Otto von Diederichs, with orders to steam north. Wilhelm II had made up his mind, and could only have been fortified in his opinion that he had taken the right decision by Anzer, who happened to be in Berlin. When he met the Kaiser a few days later, Anzer told him that occupying the Bay of Jiaozhou was 'the last chance for Germany to get a possession anywhere in Asia', adding that it was good for restoring German prestige and that Shandong had a future which would be 'greater and more meaningful than Shanghai is today' (Esherick 1987: 128).

In his enthusiasm, Wilhelm II had overlooked one possible obstacle: Russia. Reminded to do so by the German Chancellor, Hohenlohe, who 
preferred a political solution (Gottschall 2003: 156), he informed Nicholas II of the intention to send a squadron to the Bay of Jiaozhou; also stressing that he was 'under the obligation to [the] Catholic party in Germany to show that their missions are really safe under my protection' (Esherick 1987: 130). He contacted the Tsar reluctantly: 'However humiliating it may be for the German Empire to be obliged almost to obtain permission in St. Petersburg ... I did nevertheless not hesitate a moment in taking this step for the good of my country', he complained. ${ }^{18}$ When the response of Nicholas II was that he did not 'approve or disapprove', Wilhelm II thought he could proceed. ${ }^{19}$ On 7 November he instructed Diederichs (who would receive this order in Shanghai on 8 November) to sail to the bay and demand 'complete satisfaction'. ${ }^{20}$ It was also the day the Chinese government learned what had happened in Shandong from the German minister. They expected the worst, assuming that the killing of the missionaries was the pretext Germany was waiting for (Esherick 1987: 129).

As is evident from the haste he made, Wilhelm II wanted to show the world what Germany was worth:

I am determined to abandon our hyper prudent police, which all over East Asia is seen as weak, and with all rigour and when necessary with the most brute inconsideration to show the Chinese that the German Emperor does not stand for any nonsense and that it is a bad thing to have him as an enemy. ${ }^{21}$

He also had no doubts about how the expedition would be viewed and that the Germans were out to conquer territory:

Hundreds of German merchants will rejoice at the realisation that the German Empire has at last won a firm footing in Asia. Hundreds of thousands of Chinamen will tremble when they feel the iron fist of the German Empire heavy on their necks, and the whole German people will be glad that their Government has done a manly act. ${ }^{22}$

18 Wilhelm II to Bülow 7-11-1897 (E.T.S. Dugdale, German Diplomatic Documents, Ch. III, The Growing Antagonism, 1898-1910; www.mtholyoke.edu/acad/intrel/dugdale/Kiao-Chou.htm). 19 Ibid.

20 Wilhelm II to Diederichs 7-11-1897 (cited in Nuhn 2002: 132).

21 Wilhelm II to the Ministry of Foreign Affairs 6-11-1897 (See Gründer 166-7).

22 Wilhelm II to Bülow 7-11-1897 (E.T.S. Dugdale, German Diplomatic Documents, Ch. III, The Growing Antagonism, 1898-1910; www.mtholyoke.edu/acad/intrel/dugdale/Kiao-Chou.htm). 
Diederichs (who was to have a mountain in the bay named after him) must have been only too happy to comply. He himself, as he would write to his wife, pleaded with all his 'might' in favour of Jiaozhou Bay being a suitable place for a German base when he was Chief of Staff of the German navy ${ }^{23} \mathrm{He}$ was also among those naval officers with a firm belief in naval retaliation, and, being informed about the murder of the missionaries on the same day as Wilhelm II, had himself suggested to his superiors in Berlin that he be allowed to sail to the Bay of Jiaozhou (Gottschall 2003: 153-7). The three warships of the East Asia Cruiser Division left Shanghai on 10 November and arrived at the bay three days later. The following morning troops went ashore. Beijing, realising that its military was too weak, refused to put up a fight (Esherick 1987: 129). So, without meeting any resistance, the Germans marched through Qingdao to the Chinese military camp to the strains of Prussian marching music; there they discovered Krupp field guns (Nuhn 2002: 276). The Chinese commanding officer, Chang, was handed a proclamation written in Chinese informing him that Jiaozhou Bay had been occupied to serve as a guarantee that China would comply with the demands Germany was to make to avenge the killing of the two missionaries. The same proclamation was posted in Qingdao. In it the Triple Intervention of 1895 was mentioned to convince the Chinese that Germany had always been a good friend of China and that the occupation was not a hostile act against China. On the contrary, it would only make it easier to foster friendly relations between the two nations. The Chinese were further informed that the German authorities would protect peaceable Chinese, but would act with severity against anybody who broke the law or resisted German rule (Weicker 1908: 36). In his official report Diederichs described Chang as a 'helpless weakling'. He found it hard to treat him in a harsh manner, but, he wrote, remembering the fate of the two missionaries and the 'unscrupulous way other nations, namely the English for example in the opium question', had behaved made him set aside his reservations (Nuhn 2002: 275). In the afternoon, once the German troops had secured their position, Diederichs addressed his men, expressing the hope that 'German rule and culture' might be there to stay (ibid.: 276). Subsequently, the German flag was hoisted, with 'three hurrahs for his Majesty the Emperor' (Weicker 1908: 34).

Further action had to be delayed. Much to his dismay, Diederichs - who wanted to press on $^{24}$ - was informed by telegram that the occupation had 
Figure 20 German Qingdao

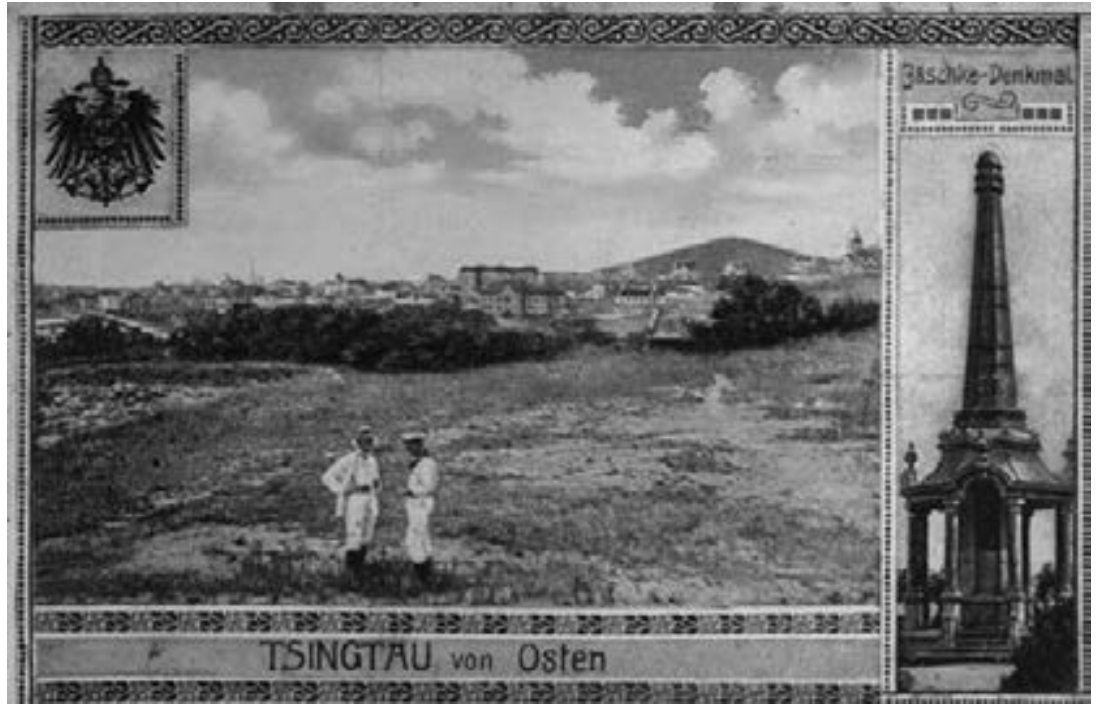

Source: KITLV 110376

to be postponed. To Wilhelm II's surprise Russia protested. The Kaiser had put too much faith in emperors' tête-à-têtes and private correspondence. Russia considered Jiaozhou Bay as falling within its sphere of influence. Within days after Wilhelm II had ordered the squadron to sail, the new Russian Minister of Foreign Affairs, Count M.N. Muraviev, informed the German Chargé d'Affaires in St Petersburg that Russia had a special claim to the Bay. In 1895 the Chinese government would have promised Russia that when Qingdao had to be turned over to a foreign nation, it would be offered to Russia first. St Petersburg threatened to direct Russian warships to the Bay of Jiaozhou 'the moment any German ship entered it'. To add yet more weight to the Russian protest Muraviev hinted that a situation might emerge in which both Great Britain and France would also send warships to the Bay. The Russian reaction was reason enough for Hohenlohe to suggest improving relations with Great Britain and gain a token of goodwill from London, 'if only in connection with Samoa'. He wanted Muraviev's belief in bad Anglo-German relations to be 'shaken a little'. The Russian message had clearly upset him. Hohenlohe feared the consequences should Wilhelm II persist. He did not preclude that the German squadron would have to leave the Bay of Jiaozhou, and might have to go in search of another 
spot along China's coast more to the south, closer to the British sphere of influence. ${ }^{25}$

Russia withdrew its reservations, for reasons that would soon become clear, and Germany could proceed. German troops occupied Qingdao and then moved further inland. In December Germany announced that it intended to turn Qingdao, at that moment no more than a small fishing village, into a fortified coaling station. To show that he meant business, Wilhelm II dispatched his brother Prince Heinrich of Prussia (who would soon have a mountain in Shandong named after him) as commander of a special navy squadron from Kiel to north China in December 1897. Accompanying the squadron were extra troops, about a thousand marines, and artillery units, plus a geologist charged with investigating the mining prospects on the Peninsula. Seeing them off, Wilhelm II impressed upon the marines that their task was a logical continuation of what his grandfather and Bismarck had started, and what his father 'had accomplished with the sword on the battlefield'. Trade abroad, he also said, could only prosper when one felt secure under the protection of the power of the state, and power of the state meant power at sea. Those who tried to deny Germany its rights should be confronted with an 'armoured fist' (Weicker 1908: 39-40). Heinrich, for his part, was also partial to rhetoric. In a toast to his brother he promised, as newspapers all over the world reported, to preach 'the gospel of Your Majesty's hallowed Person' to those who wanted to listen to it and also to those who refused to do so. The fact that he took the risk of sending his only brother, Wilhelm II stated in the Reichstag, showed how highly he valued the honour of the Empire. Unfortunately, the journey did not proceed as splendidly as the words promised. Shortly after sailing, Heinrich's flag-ship, the Deutschland, ran aground. She was refloated and eventually made it to Chinese waters, where her engines broke down. This time Heinrich had to change ships and board one of the accompanying battle cruisers. His arrival in Shanghai in April was seized upon by the German community in town as a way of demonstrating what they were worth. Years later years people would remember how Heinrich was fêted in the ballroom of Club Concordia (Darwent 1905: 166). He must have been less pleased, however, with the playing of the German and French national

25 Baron von Rotenham to Wilhelm II 10-11-1897; Hohenlohe to Hatzfeldt 13-11-1897, 16-111897; Muravieff to Ostensacken 13-11-1897, Bülow to Hatzfeldt 8-1-1898 (E.T.S. Dugdale, German Diplomatic Documents, Ch. III, The Growing Antagonism, 1898-1910; www.mtholyoke.edu/acad/ intrel/dugdale/Kiao-Chou.htm). 
anthems when he visited the Roman Catholic bishop in Beijing (Doumer 1905: 222).

The military intervention earned Wilhelm II the praise of the Pope and many other Westerners in China. Even the British minister in Beijing, Claude Maxwell MacDonald, hailed the extra protection that the German action would provide foreigners: 'It seems hopeless to expect the Chinese to do their duty in protecting missionaries and discouraging anti-foreign movements unless they are forced thereto by some measures as the Germans have taken'. ${ }^{26}$

China replaced the Governor of Shandong and other local officials and punished those said to be responsible for the murder of the missionaries; it paid an indemnity and promised to build a number of cathedrals (Esherick 1987: 131). However, it still lost the Bay of Jiaozhou. In view of the strategic location of the Bohai Sea, Berlin rejected an offer by Beijing to grant Germany a port more to the south, presenting the refusal as a friendly gesture towards Great Britain. ${ }^{27}$ On 6 March 1898 Germany leased the region for ninety-nine years; though leasing might not be the appropriate word as in the contract - in contrast to the Anglo-Chinese agreement relating to Burma of February the previous year - the word rent was not mentioned. In the introduction to the Lease Agreement it was stated that, after the mission incidents in Shandong had been resolved, the Chinese government considered it 'advisable to give a special proof of their appreciation of the friendship shown to them by Germany'. Article one mentioned the legitimate German desire to have a place in the East Asian waters where German ships could be repaired and fitted out, just as other powers had. ${ }^{28}$ London protested, fearing (not without reason) that Russia and France might act the same way Germany had done. Bülow, from his side, assured the British ambassador, Frank Lascelles, a number of times that Berlin had been careful to select a spot outside the British sphere of influence. Wilhelm II, pleased with the occupation of the Bay of Jiaozhou, commissioned the German painter Carl Wuttke to make a painting of the Bay and Qingdao for his City Palace in Berlin (Titus 2012: 132).

26 MacDonald to Salisbury 1-12-1897 (cited in Esherick 1987: 134).

27 Bülow to Heyking 17-12-1897, Hatzfeldt to German Foreign Office 29-3-1898 (E.T.S. Dugdale, German Diplomatic Documents, Ch. III, The Growing Antagonism, 1898-1910; www.mtholyoke. edu/acad/intrel/dugdale/Kiao-Chou.htm).

28 Convention between the German Empire and China respecting the lease of Kiai-chau (Pachtvertrag zwischen China und dem Deutschen Reich) of 6-3-1898. (www.jstor.org.stable/2212069, accessed 22-11-2010). 
The Bay of Jiaozhou, an area of some $55^{\circ}$ square miles, became a Pachtgebiet, though Germans continued to speak about a Schutzgebiet. In a wider area in Shandong, German troops were allowed to patrol a semi-circle of 50 kilometres inland from the coast (measured at high tide); an agreement, Weicker (1908: 98) suggests, that was intended to keep out 'robbers and other undesirable rabble'. China, though reserving its rights to sovereignty, would refrain from any measure or regulation regarding the zone without German approval. Its hinterland, the province of Shandong, became a German Interessengebiet (Gründer 1999: 109). Germany gained the right to construct two railways from Qingdao to Jinan (Tsinan), the capital of Shandong, only one of which - with a branch line to Poshan would actually be built. A naval officer became Governor. On the express request of Tirpitz the German concession was administered by his Imperial Navy Office, and not as was the case with the other German protectorates by the colonial department of the Ministry of Foreign Affairs (Germany would only establish a Colonial Office in 1907). This was a decision that, not unexpectedly, led to frictions with and obstructions by officials of that ministry. The reason was that Tirpitz had a poor opinion of the colonial administrators appointed by the Ministry of Foreign Affairs, and, as he wrote in his memoirs, the stakes of the navy were too high to leave matters in Jiaozhou Bay to such people (Gründer 1999: 173-5; Nuhn 2002: 135).

Jiaozhou also provided the Germans with a convenient base from which to organise punitive actions when their incursions inland to prepare for their railway and mining projects met with resistance by the population. Troops could also be deployed when the missionaries and their Chinese converts in other parts of the Peninsula needed or asked for military assistance. In Germany Tirpitz was well aware of what was happening and reined in the German action in Shandong. In June 1899 he warned the German Governor of Jiaozhou Bay, Captain Otto Jäschke, that the missionaries formed a 'serious danger' to the German economic interests and that he should beware of becoming a 'blind tool' of them. ${ }^{29}$ For Tirpitz and the German navy commercial considerations had priority. Unrest occasioned by the missionaries did not fit into their plans. They intended to turn the newly won territory into more than just a naval base. The Bay of Jiaozhou was to become a model colony and a centre of international trade (Graichen and Gründer 2005: 225; Steinmetz 2007: 473-8). In line with this, Qingdao was declared a Freihafen, a free port, on 2 September 1898. The navy - which decided on the matter - was sensitive to the commercial drawbacks an 
alternative policy might have. In August 1900 the Imperial Navy Office pointed out to Wilhelm II that other parts of China, and especially the Yangtze Valley, were of much greater importance to German commerce and that German trade would be best served by an Open Door policy in China. ${ }^{30}$

\section{Port Arthur}

When Germany invaded Shandong Russia had already moved forward in Manchuria. Russia's expansion being essentially one overland, railways played an important role. If the Trans-Caspian Railway had caused much anxiety among the British in Central Asia, the Trans-Siberian Railway, which was to connect European Russia with Vladivostok, did the same in north Asia. The line was both the symbol and the instrument of further Russian expansion eastwards at the end of the nineteenth century. Construction was zealously promoted by the influential statesman Count Sergei Witte, who had started his professional career as a railway manager. He saw railroads, as it was phrased in a document of his Ministry of Finance, as a means of 'expansion of the natural sphere of Russian political and commercial influence in the countries of the east' (Wcislo 2011:161).

During the Sino-Japanese War (1894-95) Russia had been too weak militarily to come to the assistance of China in repulsing the Japanese invasion. Aware of this, still in 1895 St Petersburg decided to speed up the construction of the Trans-Siberian Railway. Because of the difficulty of the terrain, the best way to proceed was to construct part of the railway in Chinese Inner Manchuria and not in Russian Outer Manchuria; an option Witte may well have considered earlier, not out of strategic considerations, but for reasons of economy (ibid.: 176-7). Such a route had as an additional advantage that this would reduce the track to be laid by half. Beijing agreed. China's approval was facilitated by St Petersburg holding out a defensive pact against Japan, arguing that it could only effectively take on such an obligation when there was a railway line along which it could move its army to the front. The Russian promise was put on paper during the visit to Moscow by the official representative of China, Li Hongzhang (Li Hung-chang), for the coronation of Nicholas II. During his stay in Moscow, he and the Russian Minister of Foreign Affairs, Prince Lobanov-Rostovsky, signed a secret Sino-Russian Treaty on 3 June (or 22 May according to the Russian calendar) 1896. However, the status of this treat, also in view of later developments, 
remained unclear. The agreement, also known as the Li-Lobanov Treaty, not only stipulated the engagement of Chinese military forces if Russian territory in East Asia was attacked (which China was hardly capable of doing), and the engagement of Russian troops in case China or Korea was invaded. It also stressed the importance of constructing a railway line to facilitate the Russian army reaching the theatre of war. ${ }^{31}$ In September 1896, in the Chinese Eastern Railway Convention (adjusted in July 1898), China gave an 80-year concession to the recently established Russo-Chinese Bank, which had to establish a Chinese Eastern Railway Company for this purpose in which only Chinese and Russian nationals could hold shares. In theory, the company would be under joint Russo-Chinese management, with the president being appointed by China. The railway line would not only allow for a much greater economic presence of Russia in Manchuria, but also for a military one. The transportation of troops, weaponry and ammunition along the line could be a threat to China, but it could also be to its advantage in facing Japanese aggression. In July 1897 construction of this Chinese Eastern Railway (and a telegraph line) by the company of the same name commenced. The project alarmed not only the Japanese (though the business community immediately recognised the opportunities for trade with Manchuria) but also the British. One British politician foresaw that completion of the railway would 'mark the turning point in the history of Central Asia'. ${ }^{2}$ The military significance of the Trans-Siberian Railway was not lost on Bülow either. In 1898 he speculated that maybe ten years from then, with the railway and 'Russian war preparations on the Indian frontier' completed, a war between the Dual Alliance and Great Britain might become a reality. ${ }^{33}$

At the end of 1897, with the presence of German soldiers on Chinese soil, the grabbing of land started. Events happened in quick succession. In December 1897, a few weeks after the German punitive expedition against Qingdao, a Russian naval squadron of five warships sailed from Vladivostok to Dalianwan on the east side of the Liaodong Peninsula in South Manchuria. They subsequently sailed on to Port Arthur (named by Captain William C. Arthur in 1856 during the Second Opium War), the harbour that in 1895 St Petersburg had denied Japan. Witte had been against

31 An English translation of the treaty is included in Manchuria 1921: 30-2.

32 Ashmead-Bartlett in House of Commons 1-3-1898 (hansard.millbanksystem.com/ commons/1898/mar/o1/independence-of-chinese-territory).

33 Bülow to Hatzfeldt 30-3-1898 (E.T.S. Dugdale, German Diplomatic Documents, Ch. III, The Growing Antagonism, 1898-1910; www.mtholyoke.edu/acad/intrel/dugdale/Kiao-Chou.htm). 
this action. He feared a confrontation with Japan and resistance by the local population when the Chinese Eastern Railway had to be connected with Port Arthur, but his objections were ignored (Wcislo 2011: 182). Witte, an advocate of a peaceful, economic advance into the Far East, was losing ground. For years after he had become Minister of Finance he had been a dominant force in domestic politics. His relations with Alexander III resembled those of Bismarck - whom he admired (ibid.: 171-2) - with Wilhelm I. After the Tsar's death in October 1894, however, he was unable to build a similar rapport with Nicholas II. A group of, what the British ambassador in St Petersburg called, 'military chauvinists' came to the fore, favouring territorial expansion. ${ }^{34}$ The seizure of Port Arthur also meant that Witte could no longer withhold money for plans developed earlier by Grand Duke Alexander Mikhailovich, a cousin of the Tsar, to strengthen the Russian fleet in the Pacific (Wcislo 2011: 181-2).

Ostensibly, the reason for the presence of the Russian squadron at Port Arthur was to look for an ice-free port where its warships - with permission of the Chinese government - could anchor during winter. Troops were landed and the Russian flag was run up. On 23 December St Petersburg assured Great Britain - the only power to protest (Temple 1902:435) - that the occupation was only temporary. A few days later, on 25 December, the squadron was sighted by chance by the British Admiral Buller. On his way to Incheon, he ordered two cruisers to keep a close watch over the Russian warships (Berryman 2002: 7-8).

Aiming at Port Arthur was a provocative gesture, one that led to anxiety in Great Britain on a similar scale to what the country had experienced at the time of the Pamir incident and during the conflict with France over Thailand. Not so long before, Curzon (1896: 213) had pointed out that a 'Russian port and fleet in the Gulf of Pechili would, in time of war, constitute as formidable a danger to British shipping in the Yellow Sea as they would to the metropolitan province and the capital of China'. By mid-January Anglo-Russian relations had reached a low. Great Britain, Russia and France were quarrelling over the third Chinese loan (with British politicians still angry over what had happened with the first loan in 1895), while the British Admiralty had directed warships to Korea to counter a Russian move to acquire a coaling station on Deer Island.

St Petersburg considered Port Arthur and Dalianwan to fall within the Russian sphere of influence. Muraviev, who had initiated the taking of Port Arthur, left no doubt about this (Wcislo 2011: 182). On 12 January 1898 he 
warned the British ambassador in St Petersburg, Nicolas Roderick O'Conor, that the presence of the British warships at Port Arthur was seen by St Petersburg 'as so unfriendly as to set afloat rumours of war with Great Britain'. ${ }^{35}$ Before the month was over, three more protests followed. When the last one was received on 26 January, the two warships - which, leaving aside the matter of spheres of influence, the British had every right to send there - had already sailed away. St Petersburg and London had different stories about the reason why. St Petersburg made good use of the incident. In Beijing and elsewhere, it presented what had happened as a victory: the British warships had left because of Russian objections. Newspapers published the Russian version. The story, O'Conor reported home, had had a 'most injurious effect' ${ }^{36}$ In London the British government tried in vain to convince its critics that the Russian version was incorrect. Nothing out of the ordinary had happened. The departure of the ships from Port Arthur had nothing to do with the Russian protests. It had already been decided upon by the navy well in advance. The Admiralty had given the orders, not the government, nor had it been asked by the government do so. The explanation did not prevent Beresford, not afraid of using big words, from calling the sailing away of the British warships 'one of the most humiliating things' that had ever happened to the British Empire. ${ }^{37}$ Later, British authors also wrote about the 'retreat of the British fleet' (Putnam Weale 1908: 251).

Russia's move to gain a naval base in Port Arthur was the beginning of what one Member of the British Parliament described as a 'great crisis'. ${ }^{8}$ In Europe many wars were thought possible; between Russia and Japan, between Russia and Great Britain, and, although less likely, between Russia and China. When matters had settled down, people in Great Britain debated whether skilful diplomacy by the government had prevented an armed confrontation with Russia, which the Conservative Leader in the House of Commons, Balfour, feared would have involved 'the whole globe in the horrors of war', or that London had bowed to Russian power politics. ${ }^{39}$

35 Letter by O'Conor cited by Harcourt in House of Commons 29-4-1898 (hansard.millbanksystems.com/commons/1898/apr/29/class-ii).

36 Quoted by Dilke and Beresford in House of Commons 29-4-1898 (hansard.millbanksystems. com/commons/1898/apr/29/class-ii).

37 Beresford in House of Commons 29-4-1898 (hansard.millbanksystems.com/commons/1898/ apr/29/class-ii).

38 George Wyndham in House of Commons 28-4-1898 (hansard.millbanksystems.com/ commons/1898/apr/29/class-ii).

39 Balfour in House of Commons 29-4-1898 (hansard.millbanksystems.com/commons/1898/ apr/29/class-ii). 
The Chinese government was powerless to resist Russia claiming Port Arthur, hoping in vain that London might be able to deter St Petersburg from pressing on; for instance, by pledging that Great Britain did not - contrary to what Nicholas II was thought to believe - have its own plans with Manchuria. $4^{0}$ London, trying to convince St Petersburg that taking Port Arthur would signify the beginning of the dismemberment of China, made some efforts, offering feeble alternatives to a Russian expansion on the Liaodong Peninsula; but St Petersburg was not responsive. On 27 (or 15) March 1898 Russia was granted a twenty-five-year lease on Port Arthur and the Bay and Port of Dalian, an area of about 220 square miles. In the lease Dalian was declared an open port but an exception was made for Port Arthur (and one inner bay of Dalian). Port Arthur was to be a naval base open only to Russian and Chinese ships and would be considered as a closed port to war-ships and merchant vessels of all other States. ${ }^{41}$ Russia made this exception for Port Arthur because, St Petersburg claimed, it needed a naval base to protect its commercial fleet in the Pacific.

The convention, as hypocritical as other international treaties enforced upon a weak country were and would be, spoke of the desire to strengthen still further the friendly relations between the two countries and mentioned as the rationale of the lease that Russia needed 'a secure base' for its navy in the northern Chinese waters; with enough land 'as is necessary to secure the proper defence of this area'. ${ }^{42}$ The rest of the Liaodong Peninsula to the north of the Guandong Leased Territory became a neutral zone, which Chinese soldiers were only allowed to enter with Russian permission. It was closed to concessions to other states. Japan did not protest, using the pretext that the occupation of Port Arthur was only 'of a qualified and temporary nature'. ${ }^{43}$ Russian troops took over the buildings and fortifications the Japanese had been forced to evacuate a few years earlier.

In a separate statement, St Petersburg, announcing the lease, spoke about the 'existing friendly relations' between China and Russia, and hailed Dalianwan (which, in February, Salisbury had called 'practically worthless ${ }^{44}$ ) as a new centre in the Pacific for Chinese and Russian commerce and industry. The Trans-Siberian Railway was presented as connecting the 'far borders of the two

40 Harcourt in House of Commons 29-4-1898 (hansard.millbanksystems.com/commons/1898/ apr/29/class-ii).

41 Convention for the lease of the Liaotung Peninsula, Art. VI (Manchuria 1921: 43).

42 Convention for the lease of the Liaotung Peninsula, Art. I, II (Manchuria 1921: 42).

43 Paper submitted by the Japanese Minister to the British Minister of Foreign Affairs 29-1-1901 (PRO FO 538).

44 Salisbury in House of Lords 8-2-1898 (hansard.millbanksystem.com/lords/1898/feb/o8/ the-queens-speech-reported-by-the-lord-chancellor). 
continents of the Old World'. The 'profound historic meaning' of the agreement for Russia was also noted in the statement (Krahmer 1899: 20). Finally, the Russian Empire had its long desired ice-free port on the shore of the northern Pacific. ${ }^{45}$ Nicholas II did it all over again. In a telegram to the Chinese Emperor, he called attention to the 'great historical meaning' of the agreement, which he saw as a 'confirmation of the friendly bond which had already existed for centuries' between Russia and China. In his reply, the Chinese Emperor showed himself to be extraordinarily pleased with the friendly telegram and also referred to the 'over 200 years of hearty friendship' between the two empires (Krahmer 1899: 21). Similarly soothing words were spoken by the Commander of the Russian Pacific Squadron at the end of March after the Russians had entered Port Arthur and Chinese troops had withdrawn. Russia's 'only' aim was to transform the Peninsula into a strong army and naval base for the protection of China (ibid.: 24). To show that China still held the sovereign rights over the territory, the Russian and Chinese flags were flown side by side.

The Guandong Leased Territory gave Russia command over the Bohai Sea and thus over the road to Beijing, but still much work had to be done to turn Port Arthur into a strong naval base. The deep water port was small, while the surrounding area was muddy and almost fell dry at low tide. Such conditions necessitated the building of a second port, Dalian (Dalny, Dairen, Tairen), for commercial shipping. Within a few years the Russians succeeded in transforming the little village of Dalian into 'one of the finest ports in the whole region of the Far East' (Lawton 1912:1274). Dalian had the advantage over the nearby treaty port of Yingkou (Yinkow, Newchwang, Niu-Chwang, Niuzhuang, Niuchuang) on the Liaodong Peninsula that it was ice-free, which Yingkou was not.

The taking of Port Arthur earned the Tsar the praise of the German Kaiser. In a letter to Nicholas II, dated 4 January 1898 , Wilhelm II enclosed a sketch that he had drawn 'under the blaze of the lights of the Xmas trees', 'showing the symbolising figures of Russia and Germany as sentinels at the Yellow Sea for the proclaiming of the Gospel of Truth and Light in the East'. Two months later, on $28 \mathrm{March}$, the Kaiser again referred to Germany and Russia as 'a good pair of sentinels ... who will be duly respected especially by the Yellow Ones', complementing the Tsar for having become 'morally speaking, the Master of Peking!' (Letters 1920: 41, 43-4).

45 In the winter of 1898-99 Russian warships had to divert to Nagasaki because the waters at Port Arthur were partly frozen over (Caraway n.d.: Ch.29, p.5). Within about ten years powerful icebreakers would solve the problem, also keeping open the port of Vladivostok in winter (Lawton 1912: 434). 



\section{The British Reaction: Wei-Hai-Wei}

On 9January 1898 the British Cabinet met to discuss the new, and as people did not fail to mention, novel, unanticipated situation in northeast Asia. It was decided that Great Britain would not seek territorial expansion, unless it was forced to do so by circumstances. The prospect of occupying part of China did not appeal to the British government. It carried with it, Balfour would say in the House of Commons repeating the familiar argument, the 'unmixed evil' of 'responsibility for populations not always very easy to deal with.' What London did was to suggest, still in January, a clear delineation of the British and Russian spheres of influence in China and in the Ottoman Empire (Salisbury's partition of preponderance) with the first right to important economic endeavours, such as the construction of railways and mining. Nicholas II would write to Wilhelm II that the British proposal, unique as it was, had been 'tempting' and 'quite amazing', adding that 'never before had England made such offers to Russia.. ${ }^{2}$ Nevertheless, Russia declined.

Satisfied with what Hong Kong and the treaty ports offered it, the British government 'desired neither territorial acquisitions in China, nor even the extension of British influence in the Chinese Government beyond such extensions and such influence as may be necessary for the protection and maintenance of our commercial position', as Spencer Compton Cavendish, $8^{\text {th }}$ Duke of Devonshire and Lord President of the Council, recapitulating government policy, explained in the House of Lords in April 1898. An exception in the British policy of restraint was made for an extension of the British territory on the Kowloon Peninsula, which was to be added to Hong Kong. Protection of both British commercial interests in China and free trade were to be the focus of British policy. On 17 January the Chancellor of the Exchequer, Michael Hicks-Beach, even said in a speech in Bristol that Great Britain would defend the Open Door in China, if necessary at the cost of war. ${ }^{4}$ Balfour chose less bellicose words. On 10 January 1898 he

\footnotetext{
1 Balfour in House of Commons 5-4-1898 (hansard.millbanksystem.com/commons/1898/ apr/05/far-east).

2 Nicholas II to Wilhelm II 3-6-1898 (E.T.S. Dugdale, German Diplomatic Documents, Ch. III, The Growing Antagonism, 1898-1910; www.mtholyoke.edu/acad/intrel/dugdale/Kiao-Chou.htm). 3 Cavendish in House of Lords 5-4-1898 (hansard.millbanksystems.com/lords/1898/apr/05/ far-east).

4 Later Hicks-Beach would deny that when he gave his speech he had the negotiations about the China loan and the discussion about the Bay of Dalian in mind (hansard.millbanksystems. com/commons/1898/feb/o8/address-in-answer-to-her-majestys-most-gracious-speech).
} 
Figure 21 Bohai Sea or Pechili Gulf

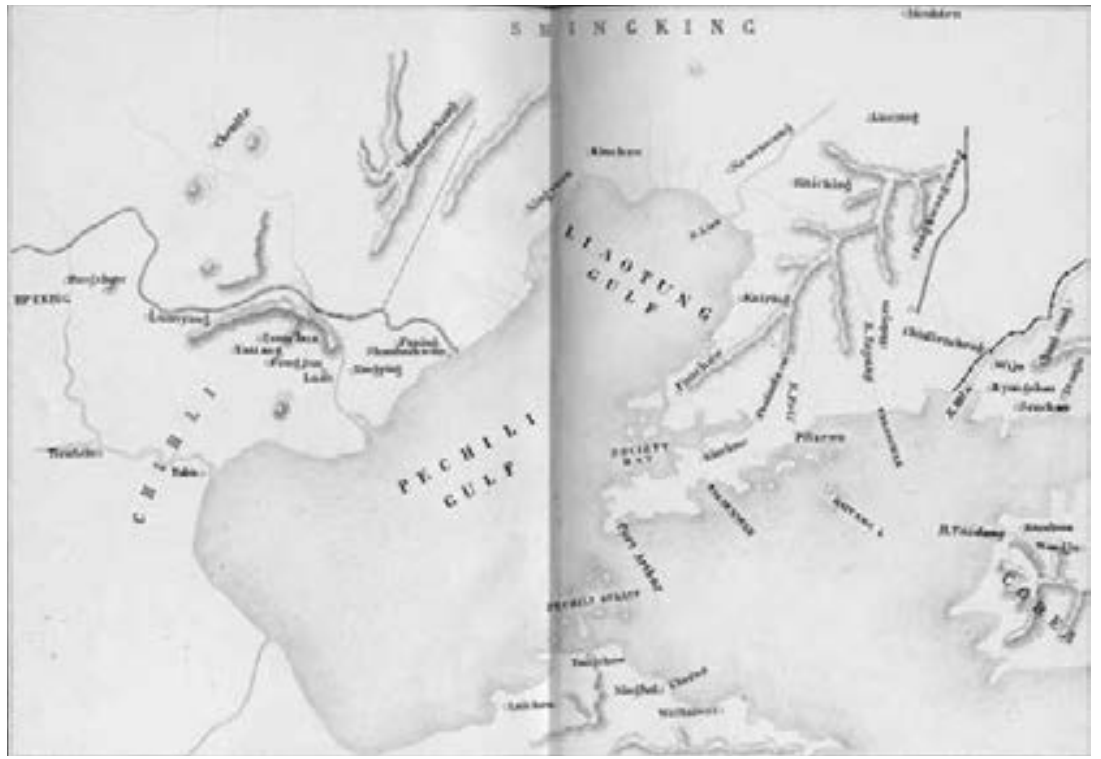

Source: Jukichi Inouye 1895

stated - as he had done in the past - that Great Britain did not object to a commercial winter port for Russia. His words were much misconstrued and presented as an invitation to St Petersburg to act. In April, after the lease had taken effect, Balfour would again state that he preferred foreign ports above Chinese ports remaining closed, as the first could only give a boost to trade and industry, including British. He extended his argument to railways, even with differential tariffs. ${ }^{5}$ Or, as Beresford (1899:384) would also argue, the taking of Port Arthur and the Bay of Jiaozhou and the railways to be built there could only increase trade. In the past there had been little trade in that part of China, and it had been exclusively Chinese.

In advance of concluding their leases, Berlin and St Petersburg assured London that Jiaozhou and Guandong would be open to commerce and merchant vessels of all nations. Salisbury had even found some solace in the words of the German ambassador, who had flattered him by saying that the German government 'had come to the conclusion that our manner of dealing with such things, at all events in the colonies, is better than theirs, and that in this instance, at any rate, they intended to imitate our 
methods'. ${ }^{6}$ Such pledges by Russia and Germany did little to ease concern. Other powers could still institute protective customs duties and gain a preferential treatment in parts of China. China was seen as a potential growth market and the British might be barred from large parts of it. Or, as Curzon (1896: 416) had written, and his words were later to be quoted by others: 'Every port, every town, and every village that passes into French or Russian hands, is an outlet lost to Manchester, Bradford, or Bombay'.

What London wanted to prevent, though Salisbury's partition of preponderance ran counter to this, was that other powers would enforce upon China special privileges to the detriment of British trade and investments, and that in regions wrestled from China by these countries British commercial interests would be discriminated against. There certainly existed a deep suspicion that this was exactly the aim of some, if not all, of Britain's rivals. Or, as Cavendish said: 'To some of them it appears that the value of political influence at Pekin consists rather in the possibility of the exclusion of foreign competition than in the extension of equal opportunities to all'?

The British concerns about Port Arthur were, primarily, political, not economic. British mercantile interests elsewhere in China were far greater. On 22 March 1898, when it had been formally informed by St Petersburg of the intention to lease Port Arthur and the Bay of Dalian, the British government protested against a Russian occupation of Port Arthur. Port Arthur could not be developed into a commercial port. It was, as Balfour pointed out in the House of Commons, of no importance commercially. Its significance was 'a purely naval and military one'. Russia only wanted to take hold of Port Arthur for political reasons, so that it could increase its hold over the Chinese government and add extra weight to the threat that already emanated from Russia's presence in Manchuria. ${ }^{8}$ Cavendish noted that a Port Arthur in Russian hands, which already had 'a frontier of 4,000 miles conterminous with that of China', formed a great threat to the future of that country. So close to Beijing, and with the Chinese navy not amounting to much, Port Arthur would give 'Russia powerful influence over the policy of the Government of China'. ${ }^{9}$ As menacing as such a Russian

6 Salisbury in House of Lords 8-2-1898 (hansard.millbanksystem.com/lords/1898/feb/ the-queens-speech-reported-by-the-lord-chancellor).

7 Cavendish in House of Lords 5-4-1898 (hansard.millbanksystems.com/lords/1898/apr/05/ far-east).

8 Balfour and Curzon in House of Commons 5-4-1898 (hansard.millbanksystem.com/ commons/1898/apr/05/far-east).

9 Cavendish in House of Lords 5-4-1898 (hansard.millbanksystems.com/lords/1898/apr/05/ far-east). 
position was considered to be, rumours began to circulate that the Chinese government intended to arrange for a new capital more to the south, out of easy reach of the Russian army.

What happened in northeast Asia, and especially Russia gaining control over Port Arthur and the Bay of Dalian, put Salisbury in a difficult position. Some directly blamed the British government for Russia also taking the Bay of Dalian. By mentioning the Bay in the discussions about a loan for China, Great Britain had been 'the first to introduce the name of Talienwan into the Chinese Question'. In doing so, it 'set Russia upon determining to occupy Talienwan' and not only Port Arthur. ${ }^{10}$ Developments were closely followed by the general public in Great Britain, among whom, as a number of Members of the House of Commons noted, there were feelings of 'considerable anxiety', 'alarm' and 'great apprehension'. Even the words 'scare' and 'panic fears' could be heard. The feeling of anxiety was partly caused by the impression that the government had not reacted resolutely enough; all the more so as London had abandoned its plan to turn Dalian and Nanning into open ports in return for the loan to China. The British government tried to give the impression that it had not suffered a diplomatic defeat. It had advanced the idea, Salisbury explained, 'on very liberal terms', with the only intention of 'increasing and freeing the trade with China'." Curzon also stressed that opening the Bay of Dalian and Nanning to foreign trade had just been mentioned as something one would like to see realised and not 'as a demand'. On top of this, there was much lamenting about Great Britain not coming to Japan's assistance in 1895. If Japan, with British support, had been able to hold on to Port Arthur, the place would never have become Russian.

Russia took centre stage in the British reactions. Germany, with its actual and aspired commercial activities in other parts of China, would think twice before proclaiming a protectionist trade policy in Shandong, it was thought. The German presence was seen as a commercial venture rather than a military threat, and received much less attention from the British public and government; an exception being those traders who had an immediate commercial interest in north China and feared unfair competition. After an initial protest, Great Britain did not persist. London, in search of allies to counter the Russian and French advance in China, and careful not to alienate Berlin, kept a low key regarding Germany's newly won territory

10 Harcourt in House of Commons 5-4-1898 (hansard.millbanksystem.com/commons/1898/ apr/05/far-east).

11 Salisbury in House of Lords 8-2-1898 (hansard.millbanksystem.com/lords/1898/feb/o8/ the-queens-speech-reported-by-the-lord-chancellor). 
in China; presenting a German Jiaozhou as beneficial to the commercial development of China. Some British politicians even contemplated a Dual Alliance, a defence treaty with Germany in an effort to find support against a further intrusion of Russia into Asia and to neutralise French claims in Asia and Africa. One of its advantages, Beresford explained in the House of Commons, would be to force Russia to relocate a considerable number of troops from Manchuria and the Caucasus to the German-Russian frontier. ${ }^{12}$

After it had become evident that neither Berlin nor Moscow was prepared to back down, the British public called for a demonstration of strength in Chinese waters, even for war against Russia. A feeling prevailed, Salisbury concluded in the House of Lords - also taking into consideration public opinion with respect to Afghanistan -, that it was a British duty to take possession of everything they could, 'to fight everybody, and to make a quarrel of every dispute'. ${ }^{13} \mathrm{He}$ called such sentiments 'a very dangerous doctrine' and warned against 'undue concessions to rashness which has, in more than one case in history, been the ruin of nations as great and powerful' as the British Empire. ${ }^{14}$

The conflict over Port Arthur made Great Britain appear even more isolated in Europe. It was the only country that protested; for obvious reasons Germany and France did not. The Colonial Secretary, Joseph Chamberlain, acting in those days as a kind of shadow Foreign Secretary, was convinced, as a Member of the House of Commons paraphrased it, that it was 'hopeless to talk of maintaining the policy of the open door in China ... without the assistance of military allies'. ${ }^{15}$ Consequently, he went in search of such partners to stop a further Russian advance in north Asia. Chamberlain tried to solicit American, German and Japanese support but failed (Taylor 1971: 376). Likewise, approaches to Washington and Berlin in February and March 1898 to join Great Britain in its struggle for an Open Door in China failed to produce concrete results.

Amidst calls for war and searches for allies, the opinion of the Salisbury government prevailed. Great Britain could not risk a war over Port Arthur or Qingdao. The Trans-Siberian Railway had cast its shadow. Balfour mentioned the line as a reason why the British government had never contemplated

12 Beresford in House of Commons 5-4-1898 (hansard.millbanksystem.com/commons/1898/ apr/05/far-east).

13 Salisbury in House of Lords 8-2-1898 (hansard.millbanksystem.com/lords/1898/feb/o8/ the-queens-speech-reported-by-the-lord-chancellor).

14 Ibid.

15 Robson in House of Commons 10-8-1898 (hansard.milbanksystem.com/commons/1898/ aug/10/appropriaton-bill). 
taking Port Arthur. The Russian military threat was too great. In anticipation of the transportation of Russian troops and weaponry along the line, a British Port Arthur would have needed strong fortifications and a large military garrison. The British army lacked the manpower and experience to fight such a war. 'Russia would have gone on making her railway ... and the railway would have crept down ... and would have come closer and closer'. ${ }^{16}$ At sea the British fleet in Asian waters might have to take on the combined naval force of Russian or German warships from the north and that of French from the south. Russia, according to the doom scenarios of those days, could also react by sending its army into Afghanistan, threatening the British position in India.

Until that moment many Britons had cherished the idea that if any foreign power had a say in China it was Great Britain. Commercially, the British were still preponderant, but Port Arthur and Jiaozhou had shattered the British belief that their interests in China were secure. British investors and merchants in China began to fear the consequences for their economic ventures of an aggressive Russia pushing southward in the direction of Beijing. The anxious Associated British Chambers of Commerce invited Beresford to report on the safety of British investments in China; also in the physical sense, unsafe as trade routes in China could be. Beresford, a Rear Admiral and Member of Parliament, who had participated in the occupation of Alexandria and was later to become commander of the British Channel Fleet, accepted. Starting his tour in October 1898, he traversed China. Convinced as he was that a strong Chinese army was the only means to prevent a break-up and restore the law and order in the country that trade and investment required, he took it upon himself to sound out $-\grave{a}$ titre personnel, he would stress - how the Chinese would react to the British training and reorganising the Chinese army. He was prepared to involve American, Japanese and German military officers in these plans, but not Russian ones. For him, it went without saying that Great Britain, economically still predominant amongst the powers in China, should take the lead in such an undertaking (Beresford 1899: 164-5, 169, 179-81, 439).

Afterwards, Beresford wrote a gloomy report about his visit to China. He observed, and he was not the only one, how detrimental the occupation of Port Arthur and the retreat of the British warships had been to British prestige. Russia was clearly seen as the winner, the stronger party. Chinese as well as foreigners, Beresford had experienced, had become inclined to

16 Balfour in House of Commons 29-4-1898 (hansard.millbanksystems.com/commons/1898/ apr/29/class-ii). 
think that Great Britain was afraid of Russia. They held Russia in higher esteem than Great Britain. Every time he had proposed something to Chinese authorities they had responded, Beresford (1899:21-2) wrote, by asking: 'But what would Russia say to that? or with similar remarks'. In short, 'British prestige was at a low ebb all through China at all the places I visited; not one, but every Chinese authority I spoke to continually referred to the fear with which Britain regarded Russia' (ibid.: 138). The poor performance of the British army in the initial phase of the Boer War would, as Hart noted, only enhance the British image among the Chinese of a nation that was no match for the Russians (Bickers 2011: 343).

Such developments made some go even further than Beresford had, concluding, as one Member of the House of Commons did in 1900, that British prestige and influence in China had become non-existent. It was 'almost hopelessly subordinated to the immense power' that Russia had gained. ${ }^{17}$ In retrospect, Ernest Mason Satow, British minister in Beijing since 1900, made a similar observation, noticing that in those days 'China feared only Russia'. ${ }^{18}$ For some the conclusion was clear. As Hamilton (1904: xix) would write, Salisbury had committed a 'monstrous blunder'. His 'drifting and vacuous policy ... made it impossible to avert the decay of our prestige and trade which has set in throughout the Far East' (ibid.: 144).

\section{Wei-hai-wei}

In March London suggested that if Russia did not take possession of Port Arthur, Great Britain would refrain from occupying a port along the Bohai Sea. When the answer was negative, London addressed 'grave representations' to Russia and, when these were unsuccessful, St Petersburg was told that Great Britain would not hesitate to take any steps necessary to protect British interests and 'to obviate, as far as possible, the evil consequences which ... might result from the step which had been taken by Russia'. ${ }^{19}$ Somehow the British government had to restore British prestige and show what Great Britain was worth, not only for international but also for domestic consumption. Public opinion, Chamberlain wrote to Salisbury,

\footnotetext{
17 Walton in House of Commons 30-3-1900 (hansard.millbanksystems.com/commons/19oo/ $\mathrm{mar} / 30 /$ british-commercial and political-interests-in-china).

18 Satow to Grey 31-3-19o6 (PRO FO 800 44).

19 Cavendish in House of Lords 5-4-1898 (hansard.millbanksystems.com/lords/1898/apr/05/ far-east).
} 
demanded 'some sensational action' (Massie 1993: 242). Salisbury agreed. He saw the acquisition of a piece of China merely as the 'territorial or cartographic consolation' the public wanted (ibid.: 242). Such was the mood that even Shanghai, or another place near the mouth of the Yangtze, was mentioned. Salisbury did not expect tangible benefits. As he concluded in March 1898: 'It will not be useful, and will be expensive; but as a matter of pure sentiment we will have to do it' (Taylor 1971: 241). Great Britain did not need an additional naval station on the Chinese coast. The one in Hong Kong served to protect British commercial interests in China perfectly. ${ }^{20}$ At the same time, the British government warned St Petersburg that Port Arthur was the limit. As Chamberlain wrote in a memorandum on 1 April 1898: 'We might say to Russia - "You have got all you say you want. We are ready to recognise your position, but you must go no further. The rest of China is under our joint protection"' (Taylor 1971: 376).

The territorial consolation Great Britain received was Wei-hai-wei, or Port Edward as it also came to be known, off the Shandong Peninsula, some eighty miles from Port Arthur. Wei-hai-wei, in the Bohai Sea, had already been considered by the British as a naval base at the end of the Second Opium War in 1860, but at that time one of the British officers in command, Lieutenant-Colonel Garnet Joseph Wolseley, had dismissed the idea (Wright and Cartwright 1908: 773). Wei-hai-wei had also been mentioned in 1895 when it was speculated abroad that this was the price London should ask for a loan to China.

On 3 April 1898 China assented to a British lease of Wei-hai-wei; though a formal agreement would only be signed on 1 July. The reason stated for Beijing's consent was 'to provide Great Britain with a suitable naval harbour in North China, and for the better protection of British commerce in the neighbouring seas'. Great Britain would be allowed to stay in Wei-hai-wei for the same length of time - twenty-five years - that Port Arthur would remain Russian..$^{21}$ The territory consisted of the islands in the bay, of which one, Liu-Kung, was to serve as a naval station, and a small strip of land along the coast ten miles wide. As in Jiaozhou and Port Arthur, there was a larger zone which only British and Chinese troops were allowed to enter and where Great Britain had the right to build fortifications, hospitals and the like, and to station troops. The British could only take possession of Wei-hai-wei after it had been vacated by Japanese troops at the end of May 1898. On 21 May, in a brief ceremony, Japan returned Wei-hai-wei 
Figure 22 Wei-hai-wei at the time of the Sino-Japanese War; shown is the landing of Chinese prisoners

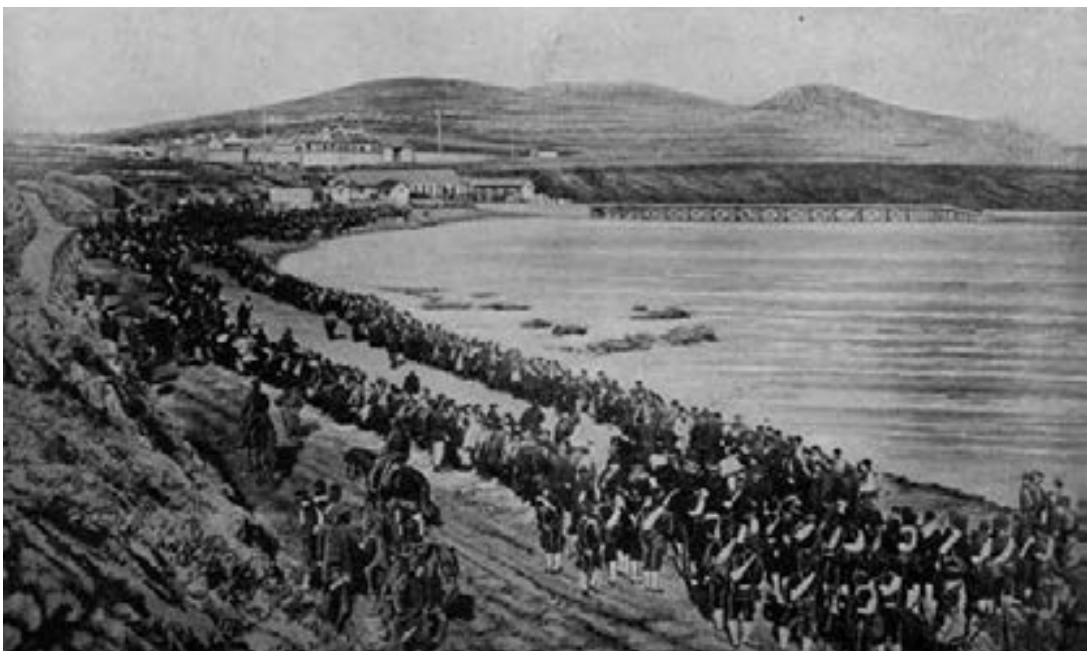

Source: Jukichi Inouye 1895

to China. After the Japanese had left (as they had done in Port Arthur in 1895, taking with them all the guns of the forts) the first British troops disembarked. On 24 May, the Queen's Birthday, the British flag was raised. It was not only British marines who attended the ceremony; a detachment of Chinese naval sailors marched to the fort, preceded by a British band playing 'A Life on the Ocean Wave', where the Chinese were to hand over the enclave. With the Chinese flag already flying from one flagstaff, the British flag was hoisted after the transfer had been concluded. This was accompanied by the playing of 'God Save the Queen'. To give due honour to Wei-hai-wei still being Chinese territory, something that was supposed to be the Chinese national anthem, which in fact China did not have yet, was also played. As the newspapers did not fail to mention, the British officers greeted the hoisting of the British flag with three cheers for the Queen and just one for the Chinese Emperor (Marlborough Express 28-7-1898; Thames Star 2-8-1898; Bickers 2011: 336).

To the dismay of some Britons, who saw it as an apology to Berlin for occupying part of Shandong, London was careful not to impinge on any sphere of influence that Germany had established in the Peninsula and so informed the German government hours in advance of Great Britain taking control. Worse, the British ambassador in Berlin had to communicate that Great Britain was not 'to interfere with the interests of Germany in that 
region'. ${ }^{22}$ This meant that the government had, 'unasked by Germany', forfeited the opportunity to join in the exploitation of the Peninsula. ${ }^{23}$

Keen to stress the military rather than the commercial value of Weihai-wei, the British government made much of the fact that access to the rest of the Peninsula was almost impossible; a condition it somehow presented as an advantage, and - as a Member of Parliament remarked, almost apologetically - also communicated to Berlin. ${ }^{24}$ Wei-hai-wei, Balfour said in Parliament, was not an island, but the government would 'have preferred it if it had been' and certainly treated it as such. ${ }^{25}$ On another occasion, he pointed out that Wei-hai-wei had no population (which it had, some 4,000 people) and thus 'no responsibility of government', and the enclave was 'incapable ... of being turned into a commercial port'. ${ }^{26}$ Stressing its isolation, Balfour remarked that it was impossible to construct a railway to the interior of Shandong. But not everybody agreed with him; certainly not Joseph Walton, a Member of Parliament who had visited China and had gone 'to the top' of Wei-hai-wei to survey the landscape. ${ }^{27}$

Precisely what the British had gained, contemporaries were not entirely sure. From a commercial point of view, Wei-hai-wei was not much of a concession compared to the Bay of Dalian and Jiaozhou, small as the concession was with the opposite coast on the mainland cut off from the hinterland by mountains. Wei-hai-wei had served as a base for the Chinese navy, it had been protected by a number of well-armed forts, and it had been important enough for the Japanese to occupy and subsequently to hold on to it as a security for war reparations; but opinions about Wei-hai-wei's potential as a naval base for the British varied. The judgements were being influenced by patriotic and political sentiments, one author even arguing that with Weihai-wei 'Britain, and not Russia, became the mistress of the Pechihlee Gulf and of the North Pacific' (Temple 1902: 436). Balfour, keeping quiet about the money needed to turn Wei-hai-wei into a well-fortified naval station, tried

22 Cited by Harcourt in House of Commons 29-4-1898 (hansard.millbanksystems.com/ commons/1898/apr/29/class-ii).

23 Walton in House of Commons 30-3-19oo (hansard.millbanksystems.com/commons/190o/ mar/3o/british-commercial and political-interests-in-china).

24 Harcourt in House of Commons 10-8-1898 (hansard.milbanksystem.com/commons/1898/ aug/10/appropriaton-bill).

25 Balfour in House of Commons 10-8-1898 (hansard.milbanksystem.com/commons/1898/ aug/10/appropriaton-bill).

26 Balfour in House of Commons 5-4-1898 (hansard.millbanksystem.com/commons/1898/ apr/05/far-east).

27 Walton in House of Commons 30-3-1900 (hansard.millbanksystem.com/commons/1900/ mar/3o/british-commercial-and-political-interests-in-china). 
to convince the House of Commons that it was 'by the confession of every competent judge the one port in the Gulf of Pechili which may be held to balance the possession of Port Arthur'. ${ }^{28}$ By establishing itself there, Great Britain had prevented 'the Gulf of Pechili from falling under the undisputed maritime control of any one Power'. In the same session, Curzon suggested that Wei-hai-wei had restored 'the equilibrium of power' in north China and gave the British fleet a naval base 'to vindicate that respect for our Treaty rights and privileges which we have claimed and received'.29

The Admiralty also stressed this strong point, omitting the fact that not having a connection with the interior or a nearby coalfield was clearly a disadvantage. Wei-hai-wei was 'a very valuable station in which a very considerable squadron can be harboured with safety'..$^{30}$ In 1902 ViceAdmiral Edmund Fremantle, Commander of the British China Station, was almost lyrical, even venturing Wei-hai-wei's potential as a commercial port. Wei-hai-wei was 'admirably situated' and for British purposes 'a far more valuable possession' than Jiaozhou and Port Arthur (Wright and Cartwright 1908: 773). When he visited Wei-hai-wei Beresford, himself a senior naval officer, also showed himself to be optimistic about its potential. Nowhere, he wrote, could warships anchor so close to the shore. Nevertheless, he had to admit that with no guns mounted yet it was dwarfed as a naval base in comparison to Port Arthur (Beresford 1899: 79-80). Some even doubted whether Wei-hai-wei was of any use in denying Russia control over the Bohai Sea (Krahmer 1899: 205).

Leasing Wei-hai-wei was intended to show China and the rest of the world that Great Britain still counted in the Far East. So the public was told an assertive story. Wei-hai-wei was leased to serve as a naval base and to balance the Russian presence in Port Arthur and the Bohai Sea. It would also make a quick response possible should Russia launch an attack on China, preceding a conquest of Beijing. Acquiring Wei-hai-wei was even presented as an altruistic move to prevent the dismemberment of China. As Prime Minister Salisbury said in the House of Lords in May 1898:

I should say that what China wants is courage, and one of the defences of the occupation of Wei-hai-wei is that it had a tendency to strengthen

\footnotetext{
28 Balfour in House of Commons 5-4-1898 (hansard.millbanksystem.com/commons/1898/ apr/05/far-east).

29 Curzon in House of Commons 5-4-1898 (hansard.millbanksystem.com/commons/1898/ apr/05/far-east).

30 Salisbury in House of Lords 17-5-1898 (hansard.millbanksystems.com/lords/1898/may/17/ occupation-of-wei-hai-wei).
} 
China against despair, and to give it courage, if the occasion should arrive, to stand up against her enemies. The danger of allowing the occupation of Port Arthur to take place without any corresponding movement on our side was that China, or, at all events, large classes of Chinamen, would give themselves up to despair, and believe that the domination of one foreign Power was the destiny from which it was impossible for them to escape..$^{31}$

(The moral courage that Salisbury spoke of, Grey concluded two years later, failed to emerge.) $)^{32}$ Presenting Wei-hai-wei as an effort to discourage the dismemberment of China, Salisbury stressed that the lease was only 'a political measure in order to balance and compensate that which had been done by another Power' ${ }^{33}$ Salisbury now also explained that with the growth of Japan and the building of the Trans-Siberian Railway, northern China and the Chinese Sea would become increasingly important commercially, warranting a British coaling and naval station there. Hong Kong had sufficed as long as Britain's main commercial interests had been in the south, in Guangzhou and Shanghai, but this was no longer the case with the development of distant northern China.

Wei-hai-wei did not make the impression London might have wanted it to. At home the opposition initially attacked the government for having abandoned the Open Door policy. ${ }^{34}$ In China British merchants reacted to the British government's policy 'with astonishment and dismay'. ${ }^{55}$ There and at home British commercial circles continued to hesitate to invest money in China, especially in its northern part. They pointed to the 'undue risk' brought about by the Russian advance in the north, the domination of Beijing by Russia that might be in store and their 'distinct feeling of unrest and apprehension regarding the safety of the capital already locked up'. They also continued to attack the 'neglect of the China Question' by London, 'the absolute absence of any definite policy [and] the complete apathy shown'. ${ }^{6}$

31 Ibid.

32 Grey in House of Commons 30-3-1900 (hansard.millbanksystems.com/commons/1900/ mar/3o/british-commercial and political-interests-in-china).

33 Salisbury in House of Lords 17-5-1898 (hansard.millbanksystems.com/lords/1898/may/17/ occupation-of-wei-hai-wei).

34 Curzon in House of Commons 5-4-1898 (hansard.millbanksystem.com/commons/1898/ apr/05/far-east).

35 Provand in House of Commons 28-4-1898 (yourdemocracy.newstatesman.com.parliament/ order-of-the-day/HAN1455362).

36 Memorandum of the China Association in Shanghai 6-10-1898 (Beresford 1899: 86,96), British section of Chamber of Commerce Tianjin (in Northeastern China) to Beresford (Beresford 1899: 26). 
Great Britain also tried to protect its wider interests in China. Others should not encroach on the large Yangtze Valley, the 'best part of China', as Millard (1906:188) called it, which to all intents and purposes Britain treated as a British sphere of influence. Among the advocates of such a view was Curzon, who as early as January 1896, in his capacity as Under-Secretary of State for Foreign Affairs, suggested that should Russia take 'the North of China and France the South', Great Britain 'ought to grab the whole intervening portion'. ${ }^{37}$ According to the Permanent Under-Secretary at the Foreign Office, Thomas Sanderson, such a bold step went too far. He pointed out that 'the burden would be enormous and the position politically and strategically most uncomfortable'. ${ }^{8}$ The matter had come up during the negotiations with France over Thailand and speculation about that country taking hold of southern China. Salisbury suggested that as compensation London could make a French 'abandonment of any rights over the middle a condition of our acquiescence'. ${ }^{39}$

In February 1898, during negotiations over the disputed Chinese war indemnity loans, in the so-called Yangtze Agreement, London gained a 'definite assurance' from Beijing that the Chinese government would not cede or lease any part of the Yangtze Valley to another power. ${ }^{40}$ The question, of course, was how to uphold the Chinese pledge. There were doubts about what China's word was worth to guarantee 'this great paper sphere of influence', as one member of the House of Commons called it. ${ }^{41}$ Again, some suggested an occupation of the Yangtze Valley; a move, others countered, for which Great Britain lacked the military strength. The February deal also foiled a Russian move to get rid of Hart as inspector general of the Chinese Imperial Maritime Customs Service. Beijing promised that as long as British commercial interests were predominant in China, that position should be held by a British official; a commitment London hailed as a big diplomatic success. China further gave the assurance that in any treaty it was to conclude in the future all nations would get the same commercial treatment. Also greeted as a British accomplishment was the Inland Steam Navigation Regulations concluded a few months later and in which China opened up all its rivers to foreign commercial steam shipping. The British

39 Salisbury to Sanderson 10-6-1896 (cited in Chandran 1977: 220).

40 Exchange of Notes between Great Britain and China respecting the non-alienation of the Yang-tsze Region, 9, 11 February 1898 (Hertslet 1908: 20).

41 Dilke in House of Commons on 5-4-1898 (hansard.millbanksystem.com/commons/1898/ apr/05/far-east). 
business community had had high hopes for what the implications would be. Just before the Regulations were issued in July and September 1898, in its report the mission of the Blackburn Chamber of Commerce to China had listed the advantages of unrestricted inland navigation. It would allow British ships to sail to Nanning on the West River, which would mean the end of the 'vaunted Red River route of our jealous friends', allowing British access to Yunnan and Sichuan via the Yangtze (another blow to the French), and at last making the approach from Burma to the Yangtze feasible. Strategically, a British foothold on the Upper Yangtze would, and Curzon advanced a similar argument at the time, allow for the transportation of troops from Burma to the Lower Yangtze should 'serious complications' arise there (Neville and Bell 1898:332-3). As so often, there was a gap between expectations and reality. It would not take long before The Times in frustration would dismiss the regulations for their 'complete worthlessness'. ${ }^{42}$ Additional rules were agreed upon in 1902. These testified to British impatience and Chinese reluctance. To see to it that 'the people living inland should be disturbed as little as possible by the advent of steam vessels to which they were not accustomed', the opening up would take place 'gradually'. 43

\section{Railway concessions}

Wei-hai-wei was only part of the strategic considerations in those days. Much attention went to the construction and control of railways. These were the days when the 'railway question' played, 'so important a part in the international relations of the Chinese Empire', one British politician observed. ${ }^{44}$ In China everybody - including Belgian companies - wanted to finance and construct railways; also because when railways were being built for the Chinese government and loans were provided to China for this purpose, lack of proper financial control could make for excessive profits and commissions (Putnam Weale 1908: 570-1). Up to World War One, competition over who was to finance a railway in China and the tenders that went with it would frequently lead to complications between the powers, initially usually involving Great Britain, France and Russia, later also Germany, the United States and Japan. Expectations, augmented by

42 The Times quoted in The Star 5-7-1900.

43 Additional rules inland waters steam navigation, Art. 7 (United States 1902: 564).

44 Dilke in House of Commons (hansard.millbanksystem.com/commons/1898/aug/10/ appropriation-bill). 
international rivalries, got the better of investors. Already in 1898 British companies had won the right to lay 2,800 miles of railways, of which in 1907 just a few hundred miles had actually been realised (Lowe 1988: 67). By 1900, concessions for some 5,000 miles of railway had been granted by China, with concessions for another 2,000 miles still being considered (Wright and Cartwright 1908: 95).

In north China, railways did not simply concern transport and the economic benefits which went with it. Article VI of the Chinese Eastern Railway Convention of September 1896 gave the company running the line the 'absolute and exclusive right of administration' of the land needed for the construction of the railway, including 'the lands in the vicinity of the line necessary for procuring sand, stone, lime, etc. ${ }^{45}$ No land taxes had to be paid and the Chinese Eastern Railway Company was free to construct 'buildings of all sorts, and likewise to construct and operate the telegraph necessary for the needs of the line'. ${ }^{6}$ The term 'railway zones' was born, which would allow Russia (and later Japan) to claim the right of administration over whole towns. The Chinese Eastern Railway Company took the text as a licence to engage in all kinds of economic activities, included mining; though mining had hardly been mentioned in the convention. It only stipulated that the income the Chinese Eastern Railway earned from the transportation of passengers and goods and from operating the telegraph line would be free from tax and duties but that mines formed an exception. For mines, the prospect of a special arrangement was held out.

After it had acquired the Guandong Leased Territory, Russia was also given the right to build a railway connecting the newly won territory with the Chinese Eastern Railway under the same conditions as those of the 1896 contract. Russia's occuption of Port Arthur had intimidated Beijing into complying. In 1897 China had still refused Russia to construct a railway in Manchuria to an ice-free port on its coast or in Korea (Paine 2010: 19). The South Manchuria Railway, running from Harbin to Dalian, gave the Trans-Siberian Railway an outlet to the Yellow Sea, as St Petersburg proudly proclaimed. ${ }^{47}$ It is an irony of history that among the passengers on the first

45 Contract for the construction and operation of the Chinese Eastern Railway 8 September (27 August) 1896 (Manchuria 1921: 15). It was a much disputed stipulation as a translation of the Chinese text of the contract read that the company was allowed to erect 'any buildings and carry out all kinds of work' after the land had come under its management (Lawton 1912:1303). 46 Contract for the construction and operation of the Chinese Eastern Railway 1896, Art. VI (Manchuria 1921: 15).

47 Russian Imperial Order regarding the establishment of Dalian as a free port on 11 August 1899 (Manchuria 1921: 44). 
train from St Petersburg, which arrived in Port Arthur in August 1902, was the Japanese crown prince (Wcislo 2011: 184). In the far south a branch line was built from Tashihchiao to Yingkou. It had a dubious basis. China and Russia had agreed that such branch lines could be built to facilitate the construction of the South Manchuria Railway, but once work had been completed they should be dismantled 'at the notice' of the Chinese government. ${ }^{4}$ Rolling stock, rails and much of the other equipment needed for the South Manchuria Railway would be American-made; a reflection, Beresford (1899: 58) suspected, of Russia's intention 'not to purchase anything in England unless it is unavoidable'. ${ }^{49}$ Politically, the railways meant an inroad into China. Russian troops (Cossacks) entered Chinese territory. They were needed to protect the Russian labourers and engineers against a hostile population, infuriated by the disregard the builders of the line showed for their material interests. The stationing of Russian troops was also a little bit dubious. The railway contract made China responsible for the safety of the line; while the Chinese Eastern Railway Company had to see to it that Russian troops and war material could 'be carried through directly from one Russian station to another, without, for any pretext, stopping on the way longer than ... necessary' ${ }^{\circ}$ The presence of these soldiers put Chinese Manchuria under factual Russian control. The flag flown over the Russian barracks in the city of Jilin (Kirin) at the end of the nineteenth century gave a hint of this: it was the Chinese flag with the Russian tricolour in the right upper corner (Krahmer 1899: 177).

Germany followed the example of Russia, except for the stationing of soldiers on Chinese territory. After having leased the Bay of Jiaozhou, Germany energetically undertook the economic penetration of the hinterland. In 1895 the German Minister of Foreign Affairs spoke out against an occupation of Jiaozhou because, without a railway, it had little value for German trade. Having acquired the lease, still in 1898, work was started on a railway line, while the first drilling operations also took place; almost immediately leading to trouble with the local population and the deployment of German troops. ${ }^{11}$ On 1 June 1899 the Shantung-Eisenbahn-Gesellschaft (Shantung

48 Agreement concerning the southern branch of the Chinese Eastern Railway 6-7-1898, Art. III (Manchuria 1921: 48).

49 Such products were also among those listed by Beresford as being of inferior quality to British ones, but at the same time he had to admit they were less expensive and could be delivered much faster that the British ones (Beresford 1899: 36-7).

50 Contract for the construction and operation of the Chinese Eastern Railway 1896, Art. VIII (Manchuria 1921: 15).

51 Marschall to Hatzfeldt 1-2-1895 (www.mtholyoke.edu/acad/intrel/gerchin.htm). 
Railway Company) was founded by a German syndicate represented by the Deutsch-Asiatische Bank to build a railway in Shandong. A few months later, on 23 September, Prince Heinrich of Prussia officially cut the first sod. In his speech he expressed the hope that the railroad would disseminate 'German culture and German conscientious devotion to duty' and strengthen Sino-German relations (Weicker 1908: 155).

In an effort to prevent future trouble, the railway company concluded a contract with the Governor of Shandong regarding how to proceed outside the German enclave in March 19oo. One of the aims of the contract was to 'prevent excitements and disturbances of any kind ... and to maintain friendly relations between the population ... and the Company'. ${ }^{2}$ The intentions were good: 'Houses, farmsteads and villages, temples, graves and above all high class graveyards belonging to the gentry' would be spared as much as possible and the purchase of land should take place 'peacefully'.53 Chinese officials were to be involved in the buying of the land required. They were made responsible for settling the conflicts arising. ${ }^{54}$ Outside the $5^{0}$-kilometre zone the rail line was to be guarded by Chinese and not German soldiers. ${ }^{55}$

Like the Russian railways in northeast China, the line was not just a railway track. Along with the railway came mining concessions. The March 1898 convention regarding the lease of Jiaozhou not only granted Germany the right to build railways, it also stipulated that German mining activities would be allowed in a 15-kilometre zone on both sides of the tracks. The company exploiting these, the Shantung-Bergbau-Gesellschaft, was a subsidiary of the company managing the railway, which in the contract with the Governor of Shandong had won the right to build branch lines to the mines without having to ask the Chinese authorities for permission..$^{5}$ A contract with the Governor of Shandong concerning German mining activities was signed on the same day as the railway contract, and for the same reason: avoiding complications with the population. ${ }^{57}$ Both the railway and the mining company were Sino-German joint ventures. By having Chinese shareholders, preferably holding key positions in the Chinese administration, and indeed the Governor of Shandong was one of them, the Germans hoped to minimise the risk of disturbances in the 
construction and exploitation of the mines and rail tracks; but their caution could not prevent Chinese miners from going on strike (Weicker 1908:144-5).

In Great Britain people were much dismayed that the Russian and German governments did not want British railways to be constructed in their concessions without their permission. Worse, the feeling was that St Petersburg and Berlin preferred the railways the Chinese authorities allowed them to construct in their spheres of influence and in the rest of China to be built with Russian and German expertise and with Russian and German material, which would be detrimental to the British steel industry.

The matter had come up even before Germany had formally leased the Bay of Jiaozhou in March 1898. A month earlier, the British minister in Beijing, MacDonald, had informed London that the German envoy had told the Chinese government that no railways should be constructed in Shandong 'without an arrangement with Germany'. Should China do otherwise, it might face 'serious consequences'.$^{8}$ London protested in Berlin and Beijing, warning the Chinese government that if German firms were given preferential treatment, Great Britain would demand compensation. In early August Curzon could tell the House of Commons that Bülow had assured him that all of this was a misunderstanding. The German ambassador had merely told the Chinese government that when a railway was to be constructed in Shandong German companies should be contacted first. This also held for other projects. China should turn to Germany first for the machinery, material and capital required. The following day Balfour tried to convince the British public and the opposition that not much was amiss with this: it was only the right of 'first offer' that was at stake; if others submitted a better tender, then the contract would go to them. ${ }^{59}$ Bülow would also reassure the American government that Germany would honour free trade in the concession it had won; but this did not prevent the suspicion from remaining. From time to time, London and Berlin had to deny that Germany acted in Shandong contrary to the principles of an Open Door policy.

Because railways were linked with the extension of political and economic influence Great Britain was also not averse to keeping the competition out where it considered its own interests to be predominant, be it in China or elsewhere in Asia. In April 1899 the Anglo-Russian Agreement

58 Curzon in House of Commons 9-8-1898 (hansard.millbanksystem.com/commons/1898/ aug/og/germany-and-the-shan-tung-concession).

59 Balfour in House of Commons 10-8-1898 (hansard.milbanksystem.com/commons/1898/ aug/10/appropriaton-bill). 
Respecting Spheres of Influence in China, also known as the Anglo-Russian Railway Agreement, was concluded. The agreement, an exchange of notes in St Petersburg between the British ambassador, Charles S. Scott, and the Russian Minister of Foreign Affairs, Mouravieff, on 28 April, was a weak reflection of the partition of preponderance Salisbury had previously suggested. Or, as Balfour, disliking the term 'spheres of influence', would phrase it, of spheres of interests; regions where no other power should control a port or railways. A transgression of this principle would be considered an 'unfriendly act'. ${ }^{6}$ Taking into account 'the economic and geographical gravitation' in China, Russia promised not to seek railway concessions for itself, its subjects or others in the Yangtze Valley, and Great Britain would not do so north of the Chinese Wall (Manchuria 1921: 53). The Anglo-Russian Railway Agreement was a feat for the Russians. It put an end to any hopes the Chinese government had that allowing the British to build a railway south from Jirin in Manchuria to the coast, to Shanhaiguan, where the Chinese Wall ended, could prevent Russia from gaining supremacy in Manchuria (Paine 2010: 19). Plans by British merchants in Yingkou to build a railway into Manchuria also came to nought. Such a line would also have served American mercantile interests, as much of the trade into and out of Yingkou was in American hands; and indeed, before Port Arthur had become Russian, American investors were looking for railway and mining concessions in Manchuria, hoping for Russian participation (LaFeber 1998: 353). In fact, Russia got even more. In 1899 China succeeded in turning down a Russian suggestion for a railway line connecting the South Manchuria Railway with Beijing. In return it had to promise - in a note dated 1 June 1899 - that China preserved the right to build a line from Beijing 'to the north or to the northeast towards the Russian border', but that except for Russia no other power would be allowed to do so. ${ }^{61}$

Earlier, the Anglo-German Financial Agreement of 1898 regarding plans by a joint Anglo-German business endeavour to have a British company construct a railway line in the Yangtze Valley, linking up with a German-built line in Shandong, had resulted in some misunderstanding. It was seen as a formal treaty between Great Britain and Germany about stressing exclusive rights to construct railways in their spheres of influence, and not, as it was, a commercial contract between two companies, countersigned by Berlin and London.

6 o Balfour in House of Commons 28-4-1898 (yourdemocracy.newstatesman.com.parliament/ order-of-the-day/HAN1455362).

61 Note of the Tsung-li-Yamen to the Russian Minister at Peking in regard to the construction of railways northward and northeastward from Peking 1-6-1899 (Manchuria 1921: 55). 



\section{The Scramble for China Continues: Guangzhouwan and Tibet}

France became a full partner in all of this, guarding and expanding its interest in southern China. In early 1897, when the Anglo-Chinese Agreement of February of that year was finalised, it gained a guarantee from China that the island of Hainan (which, some had speculated at the time of the Sino-French War of $1884-85$, the French would claim after victory) and its adjacent coast would not be ceded or leased to another power; a promise that was not put into writing, probably to prevent other powers from coming to similar arrangements (Scott 1885: 329; Chandran 1977: 260). The following year, this time in reaction to the loan Great Britain and Germany were to provide to China to pay its war indemnity to Japan, France sought a pledge from China that Keng Hung, and Yunnan, Guangxi and Guangdong would not be ceded or leased to another power. ${ }^{1}$ The Anglo-Russian Agreement Respecting Spheres of Influence in China of April 1899 also called for a reaction. The French Foreign Office drafted a proposal for a French sphere of influence in China to serve as a starting point for negotiations with London. The region France had in mind consisted of East and South Yunnan, Guangxi and East Guangdong. Guangdong's capital Guangzhou should have a neutral status (Chandran 1977: 303).

A foothold in China was also on the French agenda. This had taken concrete form at the beginning of 1896 when the French government adopted the suggestion by the Commander of the French Far Eastern Squadron, Admiral de la Bonnière de Beaumont, that in view of the distance between Saigon and Vladivostok France needed a coaling facility along the Chinese coast, preferably at the Bay of Guangzhou or Guangzhouwan (Kwangchowan, Kwang-chou-wan, or for the French Quang Tchéou Wan) in Guangdong, located roughly opposite Haiphong. After the ratification of the Anglo-German loan to China of March 1898, Paris pressed on and entered into negotiations with China over the lease of a coaling station on the same conditions Germany had acquired its station in Jiaozhou (ibid.: 271).

On 10 April 1898, a week after Great Britain had leased Wei-hai-wei, a ninety-nine-year lease of Guangzhouwan was agreed upon, becoming effective on 27 May. France also received, what Lorin (1906: 364-5) called,

1 This, in turn, would make London seek a pledge that China would not alienate to France Guangdong, Yunnan and the 'Yangtze' province of Guizhou (Chandran 1971: 63-4,1977: 271-2). 
vague preferential rights in a wider region, including the port city of Beihai (Pakhoi) on the north coast of the Gulf of Tonkin and the Island of Hainan. Included in the deal was a railway from Beihai to the West River; but, as the French historian Lorin (1906:364) significantly wrote, in view of the French desire to have Tonkin remain the main avenue of trade with south China this was, in reality, a matter of 'non-construction', mentioned in order to keep rivals out and prevent other powers from building the line. On top of this, the French right to build a railway from Tonkin to Kunming, already mentioned in the Franco-Chinese Complementary Commercial Convention of 1895, was reconfirmed; all in the name of 'closer bonds of friendship'. Soon the French came to regret that they had not leased Hainan as well. Apart from being a source of cheap labour, another power taking possession of the island was seen as a security risk for Indochina (Chambre 1898: xii). When, in 1902, German warships appeared in Hainan, the French, as Cunningham (1902: 26-7) observed, 'became curiously excited' by these ships in their 'zone', sending a cruiser to investigate. Cunningham could agree with such a course of action: 'Germany in possession of Hainan would indeed be, and rightly enough, an impossible situation to the French'.

Guangzhouwan, which came to be administered by the GovernorGeneral of Indochina, was intended, in the words of Lorin (1906: 43), as 'a naval station and point of economic penetration'. It was to serve, Doumer (1905:44) noted, as an advance position of a French move forwards into the northern waters of China and Japan. Doumer, as mentioned a passionate expansionist, was pleased with the new acquisition; though he was a little apprehensive about the turbulent disposition of the Chinese population. He was certain that Guangzhouwan would become one of France's 'great national naval establishments' and saw 'a brilliant future for it as a port of commerce'. Allowing France to penetrate deeply into south China, into Guangdong and Guangxi and the West River basin, Guangzhouwan would 'drain the products of an immense region' (Cunningham 1902: 7). Although a drawback was that it was difficult to defend, other French officials, among them Rear Admiral Édouard Pottier, Commander of the French Far Eastern Squadron, agreed that Guangzhouwan had been a good choice for the location of a naval base (ibid.: 8). As was the case with Jiaozhou, coal was nearby. One of its assets was that Guangzhouwan was located one day's sailing from the coalfields of Hongay in Tonkin. Convinced of

2 Agreement in regard to a concession to build a railway from Tongking to Yunnan, the lease of Kuang-chou-wan, and the organisation of the Chinese postal service, 10-4-1898 (www. chinaforeignrelations.net/node/170, accessed 20-6-2012). 
the future of the new possessions, France started to build a commercial seaport, Fort-Bayard (Zhanjiang). It did so even before trade had started. Unlike ports in Indochina, Guangzhouwan was to be a free port. This status added to Doumer's confidence. As he wrote initially, 'the absence of customs ... the entire liberty allowed to ships of commerce, which will have no duties whatever to pay nor formalities to fulfil, tend to make it soon one of the principal entrepôts of the Far East' (ibid.: 23). A few years later, Doumer (1905: 294) had to admit that after being in French possession for about five years, not much had yet been done to facilitate its development. Guangzhouwan's fate would be not dissimilar to that of Wei-hai-wei; an acquisition of almost no use.

In response to the French leasing Guangzhouwan, Great Britain expanded its territory in Hong Kong. Under the Convention respecting an Extension of Hong Kong Territory of 9 June 1898, also known as the Second Convention of Beijing, it acquired a ninety-nine-year lease of the so-called New Territories, a strip of land of some $35^{\circ}$ square miles adjacent to the territory the British already had on Kowloon Peninsula (Hong Kong Island was some 30 square miles). One reason was the desire to improve the defences of the colony, but the fear that it would become French also played a role (Eitel 1895:359). France, Curzon said in the House of Commons, was piqued that this addition to British territory in China had hardly received any attention at all, 'a concession which the British community in Hong Kong have been agitating, appealing, and praying for for years'. Had it gone to another European power, Members of Parliament 'would have cried out ... that British prestige had suffered an irreparable disaster'. ${ }^{3}$ The extension had been on the British agenda since June 1895 when it had been mentioned as compensation for China handing over part of Keng Hung to France (Chandran 1977:154). And, in January 1898 , when the British Cabinet in response to the German and Russian moves to occupy Jiaozhou and Port Arthur decided that it would not seek a territorial concession from China, an exception had been made for the Peninsula. It was not only said that the land was essential for the defence of Hong Kong, by claiming it Great Britain wanted to forestall France forcing China to declare it would not alienate the strip of land to any power (ibid.: 272-3). When, in April 1899, the British tried to take formal possession of the New Territories things did not go as smoothly as they might have hoped. Troops had to be deployed to suppress resistance by the local population against the extension of Hong Kong's territory.

3 Curzon in House of Commons 2-8-1898 (hansard.millbanksystem.com/commons/1898/ aug/o2/civil-service-estimates). 
The last country to join in the quest for Chinese soil was Italy; its international standing was stained by its military defeat by Ethiopia in 1896. In February 1899 Rome tried to lease Sanmen (San Mun) Bay near Shanghai, sending a squadron of cruisers to China to enforce its demand. Italy sought railway concessions as well. In a rare gesture of defiance, the Chinese government returned the note in which the request was made unopened. In Europe such a response was taken as a diplomatic affront. Salisbury was of the opinion that a reprimand was in order. China had the right to decide whether or not to lease territory to a foreign country, but returning a diplomatic letter unopened was not done. It was 'most discourteous' (Xiang 2003: 87-8). The Italian attempt was the only incursion China successfully resisted.

\section{The Boxer Rebellion}

It was in northwest Shandong, not in the German part of the peninsula, that just over a year after the German occupation of Jiaozhou the Boxer Rebellion started; spreading via Zhili to Beijing, spilling over into Manchuria, and also causing some trouble in Wei-hai-wei. ${ }^{4}$ As Esherick (1987: 271) has argued, the unrest initially was anti-Christian in nature with the anti-foreign element coming to the fore 'at a very late stage'. The Boxers also protested the recent land concessions Beijing had been forced to make. Initially, the powers underestimated the seriousness of what was happening. In March 1900 a suggestion by French Foreign Secretary Delcassé for a joint naval demonstration in the Bohai Sea was turned down by Great Britain, Germany and the United States; all preferring a wait-and-see attitude and with the United States reluctant to enter into any formal cooperation with another power. A joint protest, let alone the idea of joint military action, was contrary to American policy. As Secretary of State John Milton Hay informed the American envoy in China, even when the United States had 'to act on lines similar to those other treaty powers follow, it should do so singly and without the cooperation of other powers'. ${ }^{5}$ In Beijing the turmoil culminated in the fifty-five-day siege of the foreign legations, starting on 20 June 1900, just hours after the German minister, Klemens Baron von

4 Brodrick in House of Commons (hansard.millbanksystem.com/commons/11-5-1900/ wei-hai-wei- attack-on-the-british-demarcation-commission).

5 Silbey 2012: 60, 93-4; New York Times 10-11-1900 quoting from documents released by the French Government. 
Ketteler, on his way to the Chinese Foreign Affairs Board, was murdered by a Manchu Lance Corporal in full uniform.

An initial international relief force to Beijing, headed by British ViceAdmiral Sir Edward Hobart Seymour, which had left Tianjin ten days earlier, failed; confronted as it was by heavy resistance from Chinese troops, some well-armed with quick-firing Krupp rifles. For the Japanese to expand their participation London literally had to pay a price. Tokyo, still angry that it had been forced to retreat from the Liaodong Peninsula in 1895, and in need of funds, demanded and received a large sum of money - one million British pounds - from Great Britain in early July (Drea 2009: 98). A new eight-nation expedition force was constituted with Japan, Russia, Great Britain and Germany providing most of the troops. The United States also participated, albeit hesitantly, with Washington zealously guarding its right to develop a China policy independent of and different from that of other powers. Consequently, the commander of a small contingent of American troops in China had been instructed to 'avoid entering into any joint action or undertaking with other powers tending to commit or limit this Government as to its future course of conduct' (Silbey 2012: 129).

The city of Tianjin, where since the middle of June the foreign settlement and foreign troops stationed there had been besieged by a combined force of Chinese soldiers and Boxer rebels, was taken on 14 July. It took until 4 August when the expeditionary force departed from Tianjin. On 14 August the first troops entered the legation compound. During the final days of the march national sentiments flared up in the international force; as they already had during Seymour's failed expedition and during the attack on the Dagu forts in June. Anticipating that before forcing their way into the city the national anthems were to be played under Beijing's city walls, the French general ordered his troops to sing theirs as loudly as possible (Fleming 1989: 194). It also became a matter of pride and honour who would be the first to enter the city (the Russians) and the foreign compound (the British) and not to lose the race (as the French and the Germans did). For the Japanese, not very eager to join in with countries responsible for the Triple Intervention of 1895 , but swayed by the opportunity to gain international prestige and a handsome amount of British money, joining the expedition offered a theatre to show the world, as its commanders intended to, how well-disciplined and courageous Japanese soldiers could be (Fleming 1989: 133; Drea 2009: 98). The foreign soldiers wrought havoc, killing and destroying at will, and looting what they could, an activity in which missionaries also enthusiastically participated; creating even stronger xenophobic feelings (Esherick 1987: 310). 
Though the Boxer Rebellion was confined to the north of China there were also international complications in Shanghai where the rivalry between the powers in China was enacted in miniature. Using the prospect of disturbances as a justification, the British, spearheaded by the secretary of the local branch of the China Association, J.O.P. Bland, saw a chance to gain preponderance by having British troops land in Shanghai. The plan failed when French, German and Japanese soldiers also disembarked. The foreign troops withdrew after two years. Much to the chagrin of Great Britain, Germany used the occasion to obtain a promise from Beijing that no part of the Shanghai Valley would be ceded or leased to another power. ${ }^{6}$

Something similar happened in Xiamen, opposite Taiwan and a likely spot for a Japanese incursion into China. At the end of August, using a fire in a house occupied by a Japanese national as an excuse, Japanese marines from a squadron of four warships landed on the Islands of Xiamen and Gulangyu (the latter the site of the foreign settlement) at the mouth of the Jiulong River in south Fujian. The foreign consuls protested and within days Great Britain, the United States and Germany each directed two warships to Xiamen. France and Russia sent one ship. On the pretext of protecting British interests against possible local unrest British troops also went ashore. They and the Japanese marines only returned to their ships after the American consul had threatened that American marines would disembark as well.

In the meantime, preparations had been made in Europe, the United States and Japan to send reinforcements to China. The fitting out of an international expeditionary force provided Wilhelm II with the opportunity to show, once again, his more belligerent and racist side. What happened in China excited him; though it will have pleased him less that German troops would only play a minor role in the relief of the foreign legations. Calling for vengeance - and for Beijing to be levelled to the ground - he ordered the sending of a German expeditionary force of about thirty thousand soldiers and marines to teach the Chinese a lesson they would not forget (Massie 1993: 282). At the end of July 1900, when he saw off the first three troop ships sailing from Bremerhaven to the Far East, he held his infamous Hunnenrede (Hun speech), which attracted attention all over the world for its 'unchristian words', as a newspaper in the Netherlands Indies, De Locomotief (11-8-1900) put it. He begged the German soldiers to act without mercy when confronted with the enemy: 
Figure 23 Field Marshal von Waldersee reviewing troops in Beijing

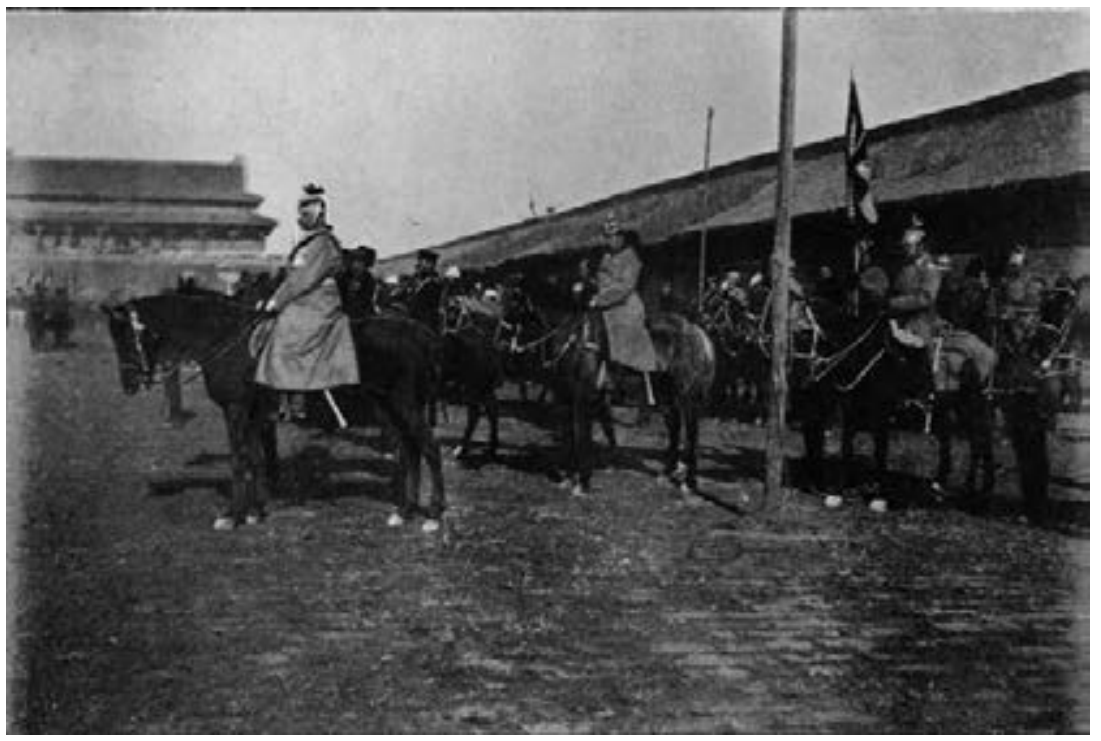

Source: Casserly 1903

Meet him and beat him! Give him no quarter! Take no prisoners! Kill him when he falls into your hands! Even as, a thousand years ago, the Huns under their King Attila made such a name for themselves as still resounds in legend and fable, so may the name of Germans resound through Chinese history a thousand years from now... (Massie 1993: 282). ${ }^{7}$

With this speech he gave the Germans, thirty years after the birth of the German Empire, a term of abuse by which their enemies could refer to them: the Huns. His soldiers were to behave accordingly.

Wilhelm II was determined to have his country play a prominent role in punishing China. Earlier, in June, when the initial relief force had to be organised, Great Britain had involved only Russia and Japan in the negotiations, leaving out Germany (Silbey 2012: 121). No doubt piqued by this and using the killing of Ketteler in Beijing as a supportive arguments, Wilhelm II set out to have a German officer take supreme command of the international force. His effort was bolstered by the animosity between Japan and Russia, contesting each other's influence in Manchuria and Korea, and adamant that the position should not go to a rival officer (Silbey 2012: 143). 
He succeeded in persuading the Russian Tsar to nominate Field Marshal Alfred Count von Waldersee for this position and the Japanese to second the proposal (Fleming 1989: 179). Reluctantly, Great Britain and France agreed, neither very keen to take command themselves, as did the United States. Wilhelm II sent a telegram to the American President, writing that he was pleased that German and American soldiers would 'fight together for the common cause of civilisation' and praising the American army 'which has shown of late [in Cuba and the Philippines] so many warlike qualities'. ${ }^{8}$ On 18 August 1900, presenting Waldersee with the Field-Marshal's baton, Wilhelm II again held, what Waldersee called, 'a somewhat vivacious address which unfortunately got into the newspapers' (Fleming 1989: 179).

The first reinforcements from Germany arrived in north China in late August, at a time when the foreign legations had already been relieved. Waldersee reached Beijing in October. His expedition was meant to make an impression; a show of soldiership worthy of a world power. Martially, his soldiers entered Beijing, goose-stepping as good German soldiers did. True to his Emperor's words, Waldersee set out to organise merciless punitive expeditions; worrying only about 'our slackness with the Chinese' (ibid.: 253). Germans were pleased with the result. The vigorous action of the German government had greatly contributed to the 'increase of prestige and the strengthening of the Germany's position of power in China', one contemporary German China expert wrote. The fact that 'the German Army and Navy in strength far outshone the other powers' and that Waldersee had been given overall command could not but have made a lasting impression on the Chinese (Zimmermann 1901: 303).

In June 1901 the Chinese Emperor ordered a special delegation headed by his brother Prince Chun to travel to Germany to convey his regrets to Wilhelm II for the killing of Ketteler. As an additional token of remorse, and as a visible sign of humiliation, the Chinese government promised to erect a Ketteler Memorial Arch, in Chinese style, on the spot where the German envoy had been assassinated, expressing the same regret and with the text in Chinese, German and Latin. Its dedication in January 1903 was a grand affair. The ceremony was, The New York Times (19-1-1903) reported, 'a brilliant assemblage of diplomats, Chinese officials, all the military officers, the entire foreign community of the city, as well as German officers from Tien-Tsin and other cities'. A similar expression of regret was conveyed to the Japanese government for the killing of Sugiyama Akira, chancellor of the Japanese legation in Beijing in June 1900. 
The defeated Chinese Empire was forced to sign the so-called Boxer protocol on 7 September 1901. In it a large indemnity was imposed, which the powers partly used to build grand new buildings for their envoys, giving them, as Lawton (1912: 1367) observed, 'far more imposing residences than any of their ambassadors in the chief European capitals'. The legation quarter in Beijing became a foreign enclave guarded by foreign soldiers, where no Chinese were allowed to reside. The Dagu forts guarding the mouth of the Hai (Bai, Pei-ho) River on the coast of the Bohai Sea were to be razed. Trade was not forgotten either. Beijing explicitly had to consent to the improvement of the navigability of the Hai River (on which work had already started in 1898) running from the coast to Beijing and, to the south, of the Huangpu (Whangpoo) River, a tributary of the Yangtze flowing through Shanghai.

Russia made optimal use of the chaos during the days of the Boxer Rebellion. The unrest provided St Petersburg with a good excuse to send troops to Manchuria, ignoring Witte's warning that this might lead to complications with Japan (Wcislo 2011: 184). In September Russian troops occupied Yingkou and other places in Manchuria. To prevent Russia from moving southwards into China proper British troops entered Shanhaiguan. Nevertheless, and in violation of the agreement of April 1899, Russian troops succeeded in gaining control over the railway between Shanhaiguan and Tianjin (Van de Ven 2006: 641). Russia's military penetration in Manchuria was to precede a political and economic one. As British merchants observed, around 1900 Russian trade with Manchuria was still almost non-existent (Beresford 1899: 44-5). In the nearby Chinese treaty port of Yingkou, Russian shipping was said to account for $1 / 500$ th of total tonnage, that of Great Britain for half (ibid.: 49-50, 56). In November 1900 the Governor of Russian Manchuria, Admiral E.I. Alexeiev, a staunch exponent of Russian expansion in north Asia, drew up a far-reaching agreement in Shenyang (Mukden) with the Chinese Commander in Manchuria. The treaty gave Russia virtual control of South Manchuria, including Shenyang and the only treaty port, Yingkou. Russia would be free to decide how many troops it wanted to station in South Manchuria and would under certain circumstances be allowed to dismiss Chinese government officials. It would also receive exclusive mining and railway concessions; thus, Japanese, British and American politicians argued, distracting from the equal rights the powers were entitled to in China by treaty. In Great Britain the agreement added to the conviction of those who saw Russia's recruitment of hardy local soldiers as a first step on the way to the conquest of China and India. 


\section{The British incursion into Tibet}

The Boxer Rebellion and the joint international expedition made the powers rein in their territorial ambitions. Partition became less likely. This did not prevent Great Britain, or rather the Indian government, from exploiting China's weakness to carve out a British sphere of influence in Tibet, a vassal state of China and already for decades striving to gain independence from directives from Beijing. Initially, in the 1870s, London's aim in Tibet had been to expand trade and keep the French out. Later, the concern became to prevent Russia from gaining influence in Tibet, a country characterised (incorrectly) by a Member of Parliament of those days as 'the only territory now left between India and the Russian sphere'.9

In negotiations leading to the Yantai (Chefoo) Convention of 1876, which had come in the wake of the disastrous Browne expedition to explore potential trade routes between Burma and southern China, Tibet trade had been introduced by Great Britain out of the blue. The British gained Beijing's permission to send a mission to explore the possibility of trade into Tibet; which, in fact, London was reluctant to undertake out of fear of a repeat of the disaster that had befallen Browne. In July 1886, at China's request, London traded the right to organise such an expedition for China's recognition of the annexation of the Kingdom of Ava. It appears that China in no way wanted such an expedition to take place. In retrospect, Rosebery would single out 'the anguish' with which the Chinese government had asked London to abandon the expedition, and the positive British response, as a main factor in securing the Anglo-Chinese Convention relating to Burma and Thibet of that year (Tibet being included in the convention at the request of China)..$^{10}$ Reflecting British focus on trade with Tibet, one of its articles read that it was 'the duty of the Chinese Government, after careful inquiry into the circumstances, to adopt measures to exhort and encourage the people [of Tibet] with a view to the promotion and development of trade'."1

At the beginning of the twentieth century, Great Britain took a more aggressive stand, afraid as its leading politicians were of the growing Russian influence in Tibet, which in fact might have been considerably less

9 Walton in House of Commons 30-3-1900 (hansard.millbanksystems.com/commons/190o/ mar/3o/british-commercial-and-political-interests-in-china).

10 Rosebery in House of Lords 26-2-1904 (hansard.millbanksystems.com/lords/1904/feb/26/ the-mission-to-tibet).

11 Anglo-Chinese Convention relating to Burma and Thibet of July 1886, Art. IV (www. chinaforeignrelations.net/node/148). 
Figure 24 Curzon 1904

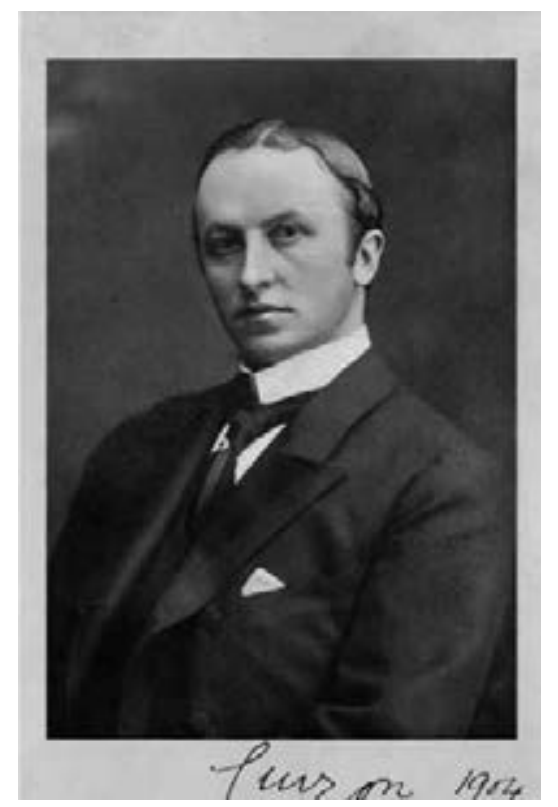

Source: Landon 1905

than Curzon and others assumed. Decisive action was deemed necessary. In February 1903 Secretary of State for India George Hamilton, who would refer to 'a monkish clique at Lhasa', informed Curzon, Viceroy of India since January 1899 , that something had to be done. ${ }^{12}$ The order may have come from London, but the British were spurred on by Curzon, a hawk and deeply suspicious of Russian intent for almost his whole life. Indeed, some would blame Curzon for how the Tibet Question would develop, wondering who had taken the lead, Curzon or the government in London.

As the Tibetans had ignored the arrangement between Great Britain and China about their country - their stubbornness attributed in Great Britain to stirring by Russia - Curzon came up with the idea of direct negotiations with the Tibetans on Tibetan soil, in which the Chinese should also participate. In July 1903, after Russia had duly been informed that the British had no intention of annexing or occupying Tibet, and China, equally reassured that the mission would withdraw after 'reparations' had been obtained, had given its permission, British troops marched into Tibet.

12 Hamilton in House of Commons 13-4-1904 (hansard.millbanksystems.com/commons/1904/ apr/13/east-indian revenues-tibet). 
The reasons put forward to justify the expedition - it was called a Political Mission with an armed escort, which implied that no consent from Parliament was necessary for the expedition, financed by the Indian government - were trivial and difficult to defend. This was the case domestically (where in fact the expedition had considerable public support) and abroad, especially in Russia. This time it was the Russians who had to worry about their prestige in Asia, and indignation about an English expedition marching into China was great (Soroka 1911: 81). Trade, especially the export of tea from India, was one reason stated, but not everybody was so convinced that such a trade held great prospects. Even Lansdowne, the Secretary of State for Foreign Affairs (and Governor-General of India from 1888 to 1894 ), had to admit that what Great Britain wanted to enforce was 'not a very extensive or valuable trade'. ${ }^{13}$ Rosebery, a critic, became derisive. People might conclude that Calcutta had embarked on the expedition 'to make people drink Indian tea who do not like Indian tea and do not want Indian tea', he said. ${ }^{14}$ Indeed, they preferred to drink tea from Sichuan, not from India.

Then there was the matter of frontiers. Tibetans had removed a number of boundary pillars along the frontier with Sikkim, a Chinese vassal that had become a British protectorate in 1890 . Tibetan herds had grazed on Indian soil, while herdsmen and other people from Sikkim had been barred access to the adjacent Chumbi valley. At the root of such acts was the annexation of the Chumbi Valley by Tibet in 1886. The Tibetan invasion in Sikkim in turn had led to a British expedition two years later, resulting in the AngloChinese Convention relating to Sikkim and Tibet of 1890. In December 1893, during negotiations in Calcutta, the Tibet Trade Regulations were annexed to the Convention, which called for, among other things, a trade market at Yatung - 'a sort of free port in the desert', one Member of Parliament would call it ${ }^{15}$ - and the abolishment of border duties for five years after the opening of Yatung to trade. ${ }^{16}$

13 Lansdowne in House of Lords 26-2-1904 (hansard.millbanksystems.com/lords/1904/feb/26/ the-mission-to-tibet).

14 Rosebery in House of Lords 26-2-1904 (hansard.millbanksystems.com/lords/1904/feb/26/ the-mission-to-tibet).

15 Lough in House of Commons 13-4-1904 (hansard.millbanksystems.com/commons/1904/ apr/13/east-indian revenues-tibet).

16 The Regulations of 1893 regarding trade, communication, and pasturage. Indian tea, it was agreed, could be imported into Tibet 'at a rate of duty not exceeding that at which Chinese tea is imported into England' but export from India would only start after five years (Art. IV). 
What irked advocates of the invasion most was that Tibet had not recognised the Anglo-Chinese arrangements regarding their country and that the anti-British and pro-Russian Dalai Lama - who protested that Tibet had not been involved in the negotiations in 1890 and 1893 - had ignored British diplomatic démarches three times, returning letters unopened. It was an insult that, as the Italian case of Sanmen Bay had shown, was not taken lightly. Prime Minister Balfour explained in the House of Commons that 'no cause of offence that ever could be given ... could be more than that letters written by the Indian Government to the Tibetan Government should be returned unanswered'. ${ }^{17}$

The affront could not be left to rest. Pride and national honour were at stake. As Landon (1905 I:v), the journalist who accompanied the mission, wrote: 'We who work in India know what prestige means. Throughout the expedition we felt that our national honour was at stake'. Considering this so self-evident that no further explanation was needed, Balfour presented a similar argument. Being belittled by Tibet was bad for British prestige in Nepal and Sikkim. ${ }^{18}$ Lhasa had to be taught a lesson. To defend the expedition, Lansdowne argued that he knew of no case in history 'in which a powerful and civilised Power has dealt more patiently or more indulgently with a barbarous or semi-barbarous neighbour'. ${ }^{19} \mathrm{He}$ and the Secretary of State for India, William St John Fremantle Brodrick, both stressed that British patience had come to an end.

Overriding all other reasons to act were rumours about secret contacts, if not a secret treaty, between Tibet and Russia, engineered by a Russian-born Tibetan monk known by the Russianised name of Agvan Dorjiev; the villain in the British story. He would have tried to convince Lhasa that Russia offered Tibet better protection than China, weak as the latter was (Landon 1905 I: 31). Any Russian influence in Tibet, Balfour explained, resounding the earlier British fear of a Russian-dominated Chinese government in Beijing, would 'be a serious misfortune to the Indian Government, and a danger to our northern frontier. ${ }^{20}$ Brodrick, who had replaced Hamilton as Secretary of State for India in October 1903, just after the start of the expedition, advanced a similar argument. He stressed that a Tibet under the control of

17 Balfour in House of Commons 13-4-1904 (hansard.millbanksystems.com/commons/1904/ apr/13/east-indian-revenues-tibet).

18 Ibid.

19 Lansdowne in House of Lords 26-2-1904 (hansard.millbanksystems.com/lords/1904/feb/26/ the-mission-to-tibet).

20 Balfour in House of Commons 13-4-1904 (hansard.millbanksystems.com/commons/1904/ apr/13/east-indian revenues-tibet). 
Russia was not only very detrimental to Anglo-Tibetan relations, it would also 'cause considerable unrest in Nepal, Bhutan, and Sikkim. ${ }^{21}$

Starting in 1898, Dorjiev visited Russia and St Petersburg a number of times, and in 1900 had even been received in an audience by the Tsar. His visits raised the suspicion of London; also because of reports that Russia had asked for a railway concession in Tibet and that 'camel loads' of Russian arms had entered the country (Landon 1905 I: 34). The mention of a railway hit a raw nerve. 'Concessions to construct railways must seem insignificant enough to a country which has not a wheel within its borders except a prayer-wheel', Landon (1905 I: 34) wrote, 'but to the eye of the uncharitable European diplomatists the very mention of railways in connection with Russia calls up a wide field of reminiscence and implication'. Equally unsettling were rumours reported in the Chinese press, also circulating in British India, that in return for a Russian pledge to protect China and to come to its assistance if the Chinese government could not quell domestic disturbances, China had handed over Tibet to Russia, or at least had agreed to exclusive Russian mining and railway concessions. The rumours were strong enough for London to issue a warning to Beijing that Great Britain 'would regard any alteration of the political Status quo in Tibet most seriously'. ${ }^{22}$

St Petersburg did its best to assure Great Britain that there was nothing to worry about. In July 1901 it had already communicated to London that the visits by Dorjiev could 'not be regarded as having any political or diplomatic character'. ${ }^{23}$ They were religious visits aimed at meeting Buddhists living in Russia. Later, in April 1903, Lansdowne informed the British envoy in St Petersburg that the Russian ambassador in London had 're-assured him that there was no convention about Tibet' and that the Russian government had no 'intention of sending Agents or missions' into Tibet. ${ }^{24}$ For British politicians and members of the public it was difficult to believe such words, suspicious as the British were of Russian intent, and convinced as they were that though one Russian government official might say one thing, another one or another state department might well act to the contrary of such words. And indeed, a Tibetan protectorate may well have been one of the desiderata of Nicholas II and a radical faction in the military, while in

21 Brodrick in House of Commons 13-4-1904 (hansard.millbanksystems.com/commons/1904/ apr/13/east-indian revenues-tibet).

22 Satow to Lansdowne 8-9-1902, China Times 18-7-1902 (PRO FO 539 81).

23 Lamsdorff to Scott cited by Lord Reay in House of Lords 26-2-1904 (hansard.millbanksystems.com/lords/1904/feb/26/the-mission-to-tibet).

24 Lansdowne to Scott 8-4-1903 cited by Lord Reay in House of Lords 26-2-1904 (hansard. millbanksystems.com/lords/1904/feb/26/the-mission-to-tibet). 
the press appeals to pester the British wherever possible, be it in Tibet or Afghanistan, continued to be voiced (Soroka 2011: 63). Even if the assurances were sincere it did not matter. In an effort to defend the invasion, the new Under-Secretary of State for India, the Earl of Hardwicke, gave the impression that psychological spheres of influence were as important as material ones. It was unimportant whether the Tibetan delegations to Russia had been of a commercial, political or religious nature. What mattered was that among Tibetans the impression had been created that they had the support of Russia and had 'said openly - "we do not fear England; we have Russia behind us". ${ }^{25}$

\section{How far to enter into Tibet}

Curzon, who was sure, or at least gave the impression of being sure, that Russia and Tibet had come to some sort of arrangement, was the driving force behind the expedition. Some even suspected that it was his personal revenge for the French occupation of Chantaboon in Thailand in $1893 .{ }^{26} \mathrm{His}$ opinions differed in two ways from that of the government at home. Curzon wanted to march on Lhasa, the capital of Tibet. London - which, according to Landon (1905 I: 36), was still 'far from understanding the urgency of the matter' when the invasion plans were developed in early 1903 - wanted to keep the intrusion into Tibetan territory as limited as possible, and instructed Curzon to retreat once negotiations had been concluded successfully. Curzon also pleaded for a British Resident in Lhasa or, if that was impossible, a British Agent in the city of Gyantse in the Nyang Chu Valley. London was forced to consider Russia, which viewed the expedition as an attempt to establish a British protectorate and was threatening to seek compensation elsewhere in Asia (Soroka 2011: 62-3, 69). Hamilton could agree with negotiations, also about trade, but not with a British Agent or Resident, which - and Afghanistan had shown what the implications might be - 'might entail difficulties and responsibilities incommensurate'. ${ }^{27}$ Step by step, Curzon would get his way. He convinced London that the obstinate Tibetans, who continued to ignore the British eagerness to negotiate, should

25 Hardwicke in House of Lords 26-2-1904 (hansard.millbanksystems.com/lords/1904/feb/26/ the-mission-to-tibet).

26 Gibson Bowles in House of Commons 1-6-1904 (hansard.millbanksystem.com/ commons/1904/jun/o1/the-anglo-french-convention-bill).

27 Hamilton to Curzon 28-5-1903 cited by Lord Reay in House of Lords 26-2-1904 (hansard. millbanksystems.com/lords/1904/feb/26/the-mission-to-tibet). 
be made aware of the might of the British army, and therefore a further advance of the expedition was in order. As he impressed on London when the expedition was already underway: 'His Majesty's Government should realise that the Lhasa Government have no conception of our power. ${ }^{28}$

On 27 February 1903 Hamilton informed Curzon that his 'proposal to send an armed mission to enter Lhasa, by force if necessary, and to establish there a Resident' might be the correct response were it only a matter of India and Tibet, but that the changed relations of China with the powers also had to be taken into account; and that London did not look forward to 'sanctioning a course which might be regarded as an attack on the integrity of the Chinese Empire'. ${ }^{29}$ Persisting in his view that stationing a British Resident in Lhasa was 'the best possible security for future observance of conditions', Curzon proposed a compromise in the form of a trade market and a British Agent in the city of Gyantse..$^{30}$

In April London made up its mind and opted for Khambajong, just across the border with Sikkim, as the place for the negotiations. The expedition should not move further into Tibet without consulting the home government. Khambajong was as far as the mission was allowed to advance. On 6 July 1903 the expedition, headed by Younghusband, now a Lieutenant Colonel who was given the title of British Commissioner for Thibet Frontier Matters, crossed the border; setting up camp in Khambajong the following day. ${ }^{31}$ In fact, Indians had already secretly surveyed the countryside in advance. Younghusband waited in vain in Khambajong for months for any Tibetan representative to appear; and, for that matter, for the representative of the Chinese government, the Amban, the Chinese Governor of Tibet. But the Tibetans were doing their best to prevent the latter from joining negotiations. Growing impatient, Younghusband suggested occupying the Chumbi Valley bordering Sikkim and pushing on to Gyantse, about halfway along the road to Lhasa. Curzon informed London that such an advance would probably not be enough for Lhasa to enter into negotiations and that, almost certainly, the mission would have to penetrate deeper into Tibetan

28 Curzon to Hamilton 16-9-1903 cited by Lord Reay in House of Lords 26-2-1904 (hansard. millbanksystems.com/lords/1904/feb/26/the-mission-to-tibet).

29 Hamilton to Curzon 27-2-1903 cited by Lord Reay in House of Lords 26-2-1904 (hansard. millbanksystems.com/lords/1904/feb/26/the-mission-to-tibet).

30 Curzon to Hamilton 7-5-1903 cited by Lord Reay in House of Lords 26-2-1904 (hansard. millbanksystems.com/lords/1904/feb/26/the-mission-to-tibet).

31 During the whole period of the expedition Curzon was on leave in Great Britain, his place as Viceroy taken by Oliver Russell, 2nd Baron Ampthill. 
territory..$^{32}$ Agreeing to the occupation of the Chumbi Valley (where the expedition was to arrive on 16 December), Hamilton wired to Curzon that the British government had 'grave misgivings' about going beyond that point..$^{33}$ By the end of September Hamilton began to waver. On 1 October, a little more than a week before he would step down, he informed Curzon that London could consider proceeding to Gyantse 'if complete rupture of negotiations proves inevitable'. ${ }^{34}$ On 5 November Curzon asked permission 'to transfer the scene of our negotiations to a locality in Tibet more suited for the purpose than Khambajong and better calculated to impress the Tibetan Government with a sense of our greatness and power'. ${ }^{35}$ The following day Brodrick, who had succeeded Hamilton on 9 October, sanctioned an advance to Gyantse. London later claimed that the decision was taken after the Tibetans had resorted to acts of hostility. ${ }^{36}$

On 31 March 1904, on its way to Gyantse, the expeditionary force clashed with Tibetan soldiers at Guru. What happened added to the opposition to the expedition at home. The poorly armed Tibetans troops were no match for the British soldiers, who, Brodrick told the House of Commons, had acted 'under great provocation', ${ }^{37}$ Brodrick lamented the loss of life. Others, both those against and those in favour of the expedition, spoke about 'a very great and unfortunate slaughter'; 'the slaughter of 600 to 700 practically unarmed men by disciplined soldiers armed with the most modern weapons of precision'; and the 'heavy slaughter of ... people ... not only ignorant of civilisation, but absolutely ignorant of the horrors and dangers of warfare'.$^{38}$ Those who had been present thought differently. Landon (1905 I: 154) praised the discipline of the 'native troops' involved, noting that 'when the word was given they naturally had no mercy upon an enemy whose attempt to

32 Curzon to Hamilton 16-9-1903 cited by Lord Reay in House of Lords 26-2-1904 (hansard. millbanksystems.com/lords/1904/feb/26/the-mission-to-tibet).

33 Hamilton to Curzon 20-9-1903 cited by Lord Reay in House of Lords 26-2-1904 (hansard. millbanksystems.com/lords/1904/feb/26/the-mission-to-tibet).

34 Hamilton to Curzon 1-10-1903 cited by Lord Reay in House of Lords 26-2-1904 (hansard. millbanksystems.com/lords/1904/feb/26/the-mission-to-tibet).

35 Curzon to Brodrick 5-11-1903 cited by Earl of Northbrook in House of Lords 19-4-1904 (hansard.millbanksystems.com/lords/1904/apr/19/tibet-east-indian revenues).

36 Brodrick in House of Commons 12-5-1904 (hansard.millbanksystems.com/commons/1904/ may/12/tibet-mission-advance-to-lhasa).

37 Brodrick in House of Commons 13-4-1904 (hansard.millbanksystems.com/commons/1904/ apr/13/east-indian revenues-tibet).

38 Lough in House of Commons 13-4-1904 (hansard.millbanksystems.com/commons/1904/ apr/13/east-indian revenues-tibet), Earl of Spencer in House of Lords 19-4-1904 (hansard.millbanksystems.com/lords/1904/apr/19/tibet-east-indian revenues). 
Figure 25 Negotiations between Younghusband and the Commander of the Tibetan army just before the battle at Guru

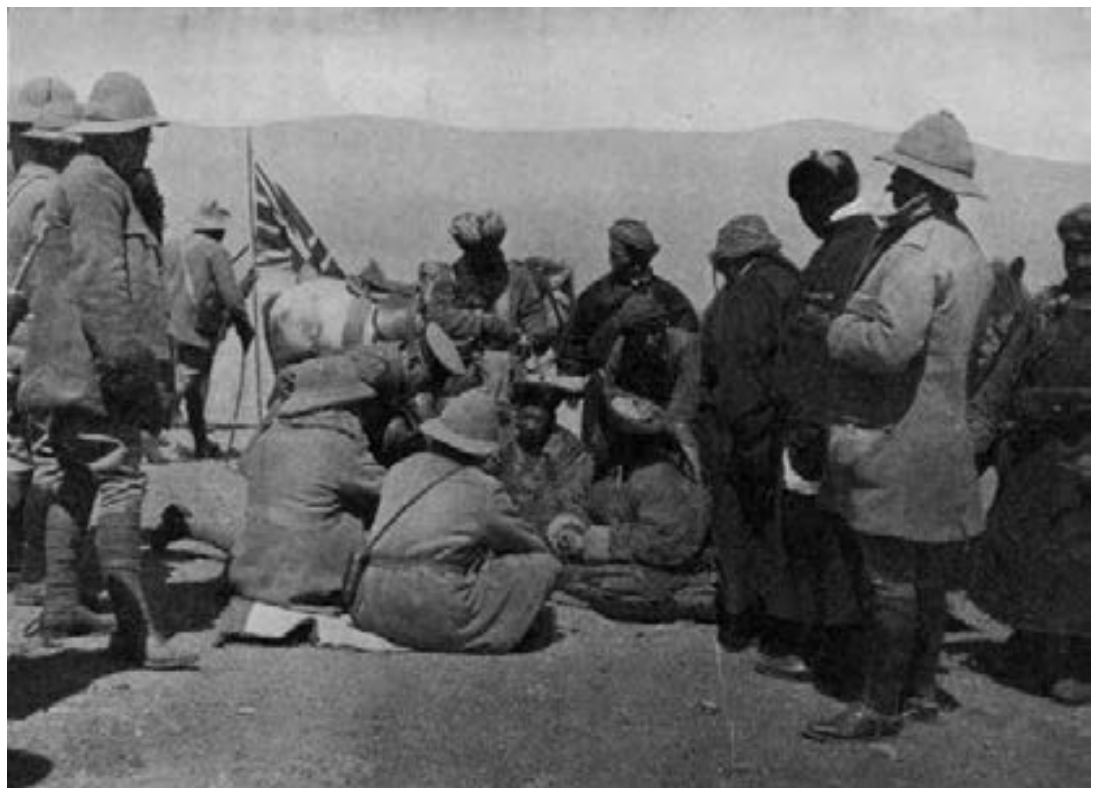

Source: Landon 1905

equalise matters by the hand-to-hand use of vastly superior numbers had been tried and failed'.

The incident forced the Balfour cabinet to abandon the pretext that the mission was a peaceful one and to secure the approval of Parliament for military operations in Tibet (still paid for by India). As the Earl of Hardwicke would state in the House of Lords, Great Britain was 'no longer in Tibet on a peaceful Mission'. ${ }^{39}$ The country was at war with Tibet.

On 12 April 1904 the British expedition reached Gyantse. Again, no Tibetan envoys made their appearance. On 12 May 1904, one week after the British position in Gyantse, where a fortress guarded the road to Lhasa, had come under attack (for which Dorjiev was blamed), Brodrick announced in Parliament that it had become imperative for the mission to march on to Lhasa unless representatives of the Tibetan government arrived in Gyantse within six weeks. A letter informing the Tibetan government was returned unopened. Some two weeks after the ultimatum had expired the British tibet). 
expedition marched to Lhasa. It reached the city in early August, only to withdraw again in late September. They returned to India with an AngloTibetan Convention signed on 7 September in their hands.

\section{The Anglo-Tibetan Convention}

In London the Secretary of State for India could not agree with the text of the Anglo-Tibetan Convention, all the more because Russia had protested. Younghusband had brought Great Britain new territory in Tibet. He had enforced upon Lhasa an indemnity, to be paid off in seventy-five annual instalments, giving Great Britain the right to hold the Chumbi Valley as a security until the total sum had been paid. London - having promised Russia it would not annex any Tibetan territory - 'as an act of grace', as it was to be stated in the modified convention ratified by the Indian government in November, reduced the indemnity to one-third, and promised to return the Chumbi Valley to Tibet after three annual instalments had been paid. Younghusband was aghast. To him, the Chumbi Valley was 'the key to Tibet', the 'most difficult part of the road to Lhasa'. Possession of the Valley would give Great Britain 'a clear run into Tibet'. ${ }^{40}$ Other critics also did not understand London's 'deference to the susceptibilities of Russia' (Landon 1905 II: 397).

In the Anglo-Tibetan Convention Tibet pledged that no portion of its territory would 'be ceded, sold, leased, mortgaged or otherwise given for occupation, to any foreign Power', and that it would not grant to foreigners 'concessions for railways, roads, telegraphs, mining or other rights'. In accordance with the British intention to block any political influence of Russia in Tibet Lhasa also agreed that no foreign power would be 'permitted to intervene in Thibetan affairs', and that no representatives of such a power would be allowed to enter the country. ${ }^{41}$ In London The Times was pleased with the result. Relations with Tibet were better than ever and the treaty had 'added to the security of our North-Eastern frontier and strengthened our position throughout Central Asia' (Landon 1905 II: 401-2).

Before the British troops had entered Lhasa the Dalai Lama had fled to Outer Mongolia. In September, when the mission was still in the city, the

40 Younghusband cited by Campbell-Bannerman in House of Commons 14-2-1905 (hansard. millbanksystems.com/commons/1905/feb/14/kings-speech-motion-for-an-address).

41 Convention between Great Britain and Thibet 1904, Art.9 (www.tibetjustice.org/materials) treaties/treaties1o.html, accessed 3-8-2010). 
Chinese governor of Tibet formally deposed him. It mattered a great deal to the British that China would not allow him to return to Tibet. They feared the influence of the Dalai Lama among the population, afraid, as Satow phrased it, that 'the return of that sacred functionary to Lhasa would be the signal for the punishment of all Tibetans who have been friendly to us'. ${ }^{42}$

The Lhasa Convention gave Great Britain two markets, one in Gyantse and one in Gartok (a third one, in Yatung, almost immediately disappeared from the British desiderata); but, as the convention made clear, no British Resident in Lhasa, as Curzon (and also Younghusband) had wanted. London was against a formal British representation in Lhasa not only in view of the complications in Tibet that might be the result, but also because it had promised Russia that it would not appoint such an official (Landon 1905 II: 20). A legation would only be opened in 1937. In Gyantse a British trade agent, the former secretary and interpreter to the mission, was stationed. He could count on a military escort of Indian soldiers. In Gartok, according to one author 'probably the most remote outpost of the British Empire' (McKay 1997:159), an Indian provincial officer became trade agent. He had to do without an escort.

Because Great Britain still recognised Chinese suzerainty over Tibet, the modified treaty was formalised in the Convention between Great Britain and China respecting Tibet, signed in Beijing on 27 April 1906. In one of its articles, China promised 'not to permit any other foreign State to interfere with the territory or internal administration of Tibet'. With respect to the concessions not allowed to be granted to foreigners in the Lhasa convention of 1904, an exception was made for telegraph lines connecting the two markets agreed upon in Tibet with India. ${ }^{43}$ As early as late 1904, within a month of the Younghusband expedition, the British government would consider it better that Tibet remain in a 'state of isolation'. ${ }^{44}$ When a new trade agreement, amending the one of 1893 , was signed in Calcutta on 20 April 1908 (this time Tibet was a treaty partner), 45 it was done at a time when there seemed to be a widely shared feeling in Great Britain that the less the country had to do with Tibet the better. Just before the signing of the agreement Chumbi had been evacuated in February 1908.

42 Satow to Grey 22-1-19o6 (PRO FO 800 44).

43 Convention between Great Britain and China respecting Tibet 1906, Art. 2, 3. (www. tibetjustice.org/materials/treaties/treaties11.html, accessed 3-8-2010).

44 Morley in House of Commons 5-7-1906 (hansard.millbanksystems.com/commons/19o6/ $\mathrm{jul} / 5 /$ tibet).

45 Agreement between Great Britain, China and Tibet Amending Trade Regulations of 1893 (www.tibetjustice.org/materials/treaties/treatiesı.html, accessed 3-8-2010). 
The following year Beijing ordered the army to enter Tibet to assert China's suzerainty and to prevent other nations from taking advantage of regional unrest in China's frontier provinces. British intervention was also not precluded. A situation might develop that could make Great Britain decide to send a military expedition into Tibet to act upon unruly Tibetans stirring up trouble against the British; a possibility that not so long before had been hinted at by British Members of Parliament speculating about China losing control over Tibet. ${ }^{6}$ The Dalai Lama (reinstated in November 1908) fled to British India. For Russia, the establishment of real Chinese authority in Tibet was a positive development. Since the Younghusband expedition, St Petersburg had urged Beijing to establish its authority there in order to forestall any chance of a growing British influence in Tibet (Soroka 1911: 6). For the British it was a moment of concern. At stake was Chinese interference in Bhutan, in between India and Tibet and considered by China to be its vassal. Great Britain reacted by putting the kingdom under a formal protectorate in the Treaty of Punakha of 8 January 1910.

In concluding its treaties, Great Britain had acknowledged China's suzerainty over Tibet. In July 1914, two years after the Chinese Republic had been founded, this had changed when the secret, to this day much disputed, Anglo-Tibetan Declaration was signed at Simla. China was no partner to it, its representative having withdrawn in protest from the negotiations. Appended to the Simla Accord was the treaty that China had refused to sign. In it China's suzerainty over Tibet was acknowledged but it was also stated that Great Britain and China recognised the autonomy of what was called 'Outer Tibet' and that in view of 'the special interest of Great Britain' and of 'the maintenance of peace and order in the neighbourhood of the frontiers of India', China promised 'not to send troops to Outer Tibet, nor to station civil or military officers, nor to establish Chinese colonies in the country'. Great Britain and Tibet also agreed on their frontier, the so-called McMahon Line. China never recognised it, claiming part of the Indian frontier region as Tibetan and thus Chinese territory. ${ }^{47}$

46 Earl of Ronaldshay and Balfour in House of Commons 17-2-19o8 (hansard.millbanksystems. com/commons/1908/feb/17/the-anglo-russion-convention).

47 Convention between Great Britain, China and Tibet, Simla (1914), attached to the AngloTibetan Declaration of 3 July 1914, Art.2, 3 (www.tibetjustice.org/materials/treaties/treatiesı. html, accessed 3-8-2010). 



\section{The Failed Annexation of Hawaii}

In 1842 the American President Tyler had cautioned his countrymen not to expect too much of the opening of China: '[T] he cheapness of labor among the Chinese, their ingenuity in its application, and the fixed character of their habits and pursuits may discourage the hope of the opening of any great and sudden demand for the fabrics of other countries'. But, he continued, Western products did 'find a market to some extent among the Chinese' (Tyler 1842). Americans had traded with China in Guangzhou, the country itself was among the first powers to enter into a treaty with China, and in the 1850 s the presence of Americans in Shanghai had been significant enough for people to speak of a separate American settlement (though in fact a formal treaty with China confirming a settlement status did not exist) (Darwent 1905: 207).

The American Civil War from 1861 to 1865 and the loss of its merchant ships at that time had an effect on American China trade. The role of American freighters was taken over by ships sailing under another flag, concealing America's share in the China trade (LaFeber 1998: 19). Goods exported to China could end up being recorded as British in the statistics while in fact they had been produced in the United States. Another consequence was a decrease in the number of Americans travelling as merchants or sailors to the Far East, one insignificant indication of this being that baseball was no longer played in Shanghai (Darwent 1905: 190). Competitors, basing their assessment on real facts or imagination, continued to be awed by American China trade. In the 1870 s an American advance figured prominently in pleas by Dupré and Garnier for a more active French colonial policy in Southeast Asia. The US was explicitly mentioned by Cooper (1871:2), along with Great Britain and France, as three countries having 'vast trade' with China. In the 188 os America's interest in China was expressed in its role in the Ili crisis and the Shufeldt expedition to Korea. Nevertheless, around the turn of the century American trade with China was still small, although growing steadily.

In two regions American firms were relatively successful: Manchuria and Korea. In Manchuria American commercial interests exceeded those of the other powers except Japan (Millard 1906: 115; LaFeber 1998: 301). It was estimated that around 1900 American products accounted for half of the imports in Yingkou, one of the gateways to Manchuria and northern China (Beresford 1899: 435). Successful American imports in Manchuria included cottons and piece goods; a market Japanese merchants wanted 
to conquer, and which they tried to do so, a former American Consul General in Manchuria complained, in an aggressive way. He even accused the Japanese of creating 'some hostility to American products' by imitating American trademarks, faithfully adding in English that the product, said to be inferior to the American equivalent, had been manufactured in Japan, a futile gesture as the Chinese did not read English (Lawton 1912: 1262). In Korea American investors had won a number of important contracts. They had constructed the first Korean railway, ran the electric tram in Seoul and managed the city's electricity, waterworks and telephone system. An American concern, the Oriental Consolidated Mining Company, owned a number of gold pits in Unsan; the only mining operation in Korea which was successful (Hamilton 1904:155; Putnam Weale 1908: 515). By 1904 Americans and Japanese were said to compete for the first place among concession holders in Korea, leaving others far behind (Hamilton 1904: 148).

Though the United States remained conspicuously absent in the race to divide China into spheres of influence, there was much concern among politicians and businessmen about Russia gaining a hold over Manchuria. The taking of Port Arthur and the Bay of Jiaozhou only intensified fears that north Asia might become 'closed' to American trade. As Beresford (1899: 424) noted when he visited San Francisco in February 1899, in the city '[a]ll the mercantile community were intensely interested in the Eastern question, pointing out that San Francisco would naturally be the port for the great output of American trade when China was opened up'. Elsewhere he had encountered a similar mood. China trade and the restraints it might encounter 'excited a considerable amount of interest throughout the United States' (ibid.: 427). Businessmen demanded 'fullest protection' by Washington, while newspapers hinted at action to be taken against 'European aggression'. Some speculated about war, if it had to be in cooperation with Great Britain (LaFeber 1998: 381-2). Diplomats were equally worried. The American ambassador to Great Britain, John Hay, who within months was to become Secretary of State, informed his superiors in Washington about rumours in Great Britain that the Far Eastern Triple Alliance might try 'to exclude, as far as possible, the trade of England and America from the Far East, and to divide and reduce China to a system of tributary provinces' (ibid.: 380). His colleague in Beijing, Colonel Charles Denby, shared Hay's pessimistic outlook. In January 1898 , he reported home that a partition of China 'would tend to destroy' America's China trade (ibid.: 354). Confronted with such opinions, Secretary of State John Sherman, himself an adversary of American territorial expansion, asked the German and Russian governments for guarantees that they would respect the Open Door principle in 
China. As had been the case with the British request the response was affirmative (ibid.: 380 ).

Washington did not react, as London and Paris had done, by claiming a concession in China. It confined itself to stressing free trade, becoming one of the advocates, if not the major one, of the Open Door in China. Nevertheless, the United States took its share, not in China but in the Pacific, annexing Hawaii and the Philippines. Hawaii had already for some time been on the American agenda; the Philippines would be an unexpected bonus.

\section{American interests in Hawaii}

Throughout most of the nineteenth century American shipping and commerce had been predominant in the Hawaiian or Sandwich Islands, located some 2,000 miles from America's west coast. American ships far outnumbered the other foreign whalers and merchantmen which called in at Honolulu on Oahu Island. It also served as an intermediate port of American trade with China, and, as a British navy captain had reported to the British Admiralty as early as 1815 , a British naval station in Hawaii could 'effectually annihilate that trade' (Thomas 2010: 78 ). In the past, merchants and sea captains from Great Britain, France and Russia had shown an interest in gaining a foothold, but already for over half a century the United States had claimed a special interest in the island group, ever since, in the 1840 s, Washington had left no doubt that Hawaii fell squarely within the American sphere of influence and that it would not tolerate a British of French annexation or a Russian incursion.

The American claim was couched in the 'Tyler Doctrine'. In December 1842 Tyler, in a special message to Congress, which was as much about Hawaii as about trade with China, had pointed out that owing to 'their locality and to the course of winds which prevail in this quarter of the world, the Sandwich Islands are the stopping place for almost all vessels passing from continent to continent across the Pacific Ocean'. Stressing that five-sixths of all ships that visited Hawaii annually were American, he continued by stating that, in view of this, 'it could not but create dissatisfaction on the part of the United States at any attempt by another power ... to take possession of the islands, colonize them, and subvert the native Government' (Tyler 1842).

The following year, urged to do so by a Hawaiian delegation visiting London, France and Great Britain, whose warships had shown the Hawaiians the might of the European powers, promised to respect Hawaii's 
independence. In November 1843 they issued a joint declaration signed by the British Foreign Secretary and the French ambassador vowing 'never to take possession, either directly or under the title of protectorate, or under any other form' of any part of Hawaii. The declaration also held an assessment of Hawaii, a kingdom too weak to put up a military defence against foreign aggression, but for the rest strong enough to function as an independent state: Hawaii had 'a government capable of providing for the regularity of its relations with foreign nations'.

Hawaii was not only important for American China trade. Though the archipelago was located much farther away than New Guinea was from Australia, people in the United Stated viewed a non-American acquisition of the islands much like the Australians did that of New Guinea. A foreign occupation was seen as a threat to America's security, transforming the islands into a base from which an enemy fleet could attack. At the same time, Hawaii figured as a forward station in the defence of California and the American Pacific coast. It was also a perfect place for an intermediate port. In 1853 Commodore Perry singled out Hawaii as a suitable place for a coaling station along the sea route to China. The islands were, as The New York Herald wrote in June 1854, the 'halfway point' between California and China (Dulles 1938:159). When these opinions were expressed, Hawaii seemed to be for the taking. In 1851, and at the request of the ruler of Hawaii, King Kamehameha III, unable as he was to resist surprise attacks by foreign warships, backed-up by their government or not, the first specific negotiations regarding American protection took place, disregarding protests from London and Paris. Washington was prepared to pay US $\$ 300,000$ for gaining control over Hawaii. Nothing came of it. Kamehameha died before the deal could be concluded and his successor, Kamehameha IV, was passionately anti-American. Equally decisive was that opposition in Congress (where since domestic turmoil over the purchase of Alaska in 1868, a two-thirds majority in the Senate was needed for annexations; or, when that failed, a majority in both houses) was too strong to allow for the acquisition of regions outside the North American continent.

Americans would continue to look at Hawaii, coupling their pleas for protection, annexation or special prerogatives and their warnings that the islands should not fall to France and especially to Great Britain, with the observation about how important the islands were to the United States, for its defence and for its shipping. Among them was William H. Seward, Secretary of State between 1861 and 1869, the man who had purchased Alaska, 
and a fierce promoter of American mercantile expansion; he had high hopes for the boost in ocean sailing that would result from the construction of the American transcontinental railway. In a letter to the American ambassador in London in August 1868, Seward claimed that many of his fellow Americans wanted annexation, adding that in no way the islands should become British or French (Brookes 1941: 280). At that moment opposition by France and Great Britain and an anti-American king were the stumbling blocks for any concrete American steps, but Pacific trade continued to be a compelling argument. In the second half of the 188os, during the first Cleveland administration, Hawaii came to be presented as a vital hub in America's commercial network in the Pacific; as a 'stepping-stone to the growing [American] trade in the Pacific', where other powers should stay clear of (LaFeber 1998: 54). And, as late as March 1893, one American admiral, George E. Belknap, warned in the Boston Herald that should Great Britain take possession of Hawaii 'Honolulu would soon become one of the most important strongholds of Great Britain's power' (Dulles 1938: 187).

Similar to Samoa and Fiji, Hawaii had experienced an influx of foreigners. White settlers, the most prominent among them Americans and other 'Americanized Europeans' (Musick 1898: 8) had the lion's share in the islands' main and almost sole export earner, the production of raw sugar for the American market. A smaller segment of the white community, but at least as influential, was formed by puritanical American clergymen. Missionaries and church leaders and their descendants played an important role in local politics and in the economy. To one contemporary author, Musick (1898:8), Hawaii was even 'the land of missionaries'. The first of them had arrived in 1820 and four years later Protestantism had been declared the religion of the state. Another foreign element making its mark was the Chinese and Japanese labour force needed in the sugar industry. Arriving in increasing numbers they would eventually turn the Hawaiians into a minority in their own country (Coffman 2009: 64). As a migrant group they also established themselves outside the plantation sector. After having served their contract, Japanese labourers would stay on and try to find other employment on the islands, competing for jobs with Hawaiians and poor whites.

In the 1870 os, the dominant position of the American community in Hawaii, and the close economic links between the archipelago and the United States, found their expression in the Convention for Commercial Reciprocity (that is of the reduction or doing away with tariffs, treaties also negotiated with other countries) concluded with King Kalakaua. The convention drew Hawaii even more into the American orbit. In 1866 Seward had already ventured that a reciprocity treaty would lead to a 'quiet absorption' of the 
islands (Coffman 2009: 6o). His successors took a similar view. A Reciprocity Treaty, Frederick Theodore Frelinghuysen, Secretary of State from 1881 to 1885 , would explain, had 'all the benefits which would result from annexation were that possible' (LaFeber 1998: 49). The treaty, already considered for more than a decade and initially opposed by American sugarcane producers and Congress, was finally signed in 1875 . It allowed for the duty-free import of a range of products in the United States and Hawaii, of which especially the growers of 'Sandwich Island sugar' and its refiners in the United States profited. Gaining free access to the American market, sugar production boomed, and with it also the immigration of Asian workers. From his side, Kalakaua pledged not to lease or cede any port or land to a third nation, or enter into a similar treaty. This time Congress consented. In doing so, it was partly guided by anti-British sentiments and a false perception of a British expansionist policy following the British annexation of Fiji, which had produced hints about an insatiable British appetite for new colonial possessions and remarks that America's history was 'but one history of difficulties' with Great Britain (Brookes 1941: 360 ).

That Kalakaua signed the Reciprocity Convention may well have had much to do with the events surrounding his accession to the throne in 1874 . His becoming king had not been undisputed and he had only succeeded because American marines had restored order and had occupied Honolulu for about a week. Starting his reign as someone who was on good terms with the Americans, within a decade Kalakaua distanced himself from the United States. Domestically, using the slogan 'Hawaii for the Hawaiians' he aimed at the restoration of a kingdom in which Hawaiians were firmly in control; and where the powers of the monarchy would again be as they had been in the past, before white settlers had made their influence felt. Internationally, he irked the Americans by visiting Japan on a trip around the world to solicit a treaty of mutual support in 1881, but did so without success. He tried, in vain, to interest Japan in the idea of a Pacific federation (Coffman 2009: 188).

Kalakaua's trip to Japan was part of a role he had taken upon himself, but could not deliver, to prevent further annexations by the powers in Polynesia. In 1881 he had also visited Thailand and, inspired by the position of the Thai king, he aimed at uniting Polynesia into one kingdom, under his own leadership (Krout 1898: 8). In pursuing these ends, Kalakaua found a close ally in 'an American renegade' Walter Murray Gibson, a former Mormon who, in $185^{2}$ had been arrested in Sumatra by the Dutch for holding out American assistance in the struggle of one of its sultanates, Jambi, against the Dutch. He was sentenced for high treason but escaped (Locher-Scholten 
2004: 101-14). Three decades later, in 1882, Gibson became Kalakaua's Prime Minister and Minister of Foreign Affairs; and he was as much opposed to any cession to the United States of a coaling or naval station as Kalakaua was (Hardy and Dumke 1949: 410-1; Sewall 1900: 20). Both had become enchanted by the ideals of the Australian journalist Charles James Herbert de Courcy St. Julian, who in the 1850 s, as Commissioner to the Polynesian islands of the Hawaii King, Kamehameha III, had already aimed at forming a Polynesian federation made up all islands groups in the region which were still formally independent (Day 1984: 45).

To forge closer ties with the latter, a British merchant vessel was purchased and turned into a warship in 1887. Renamed the Kaimiloa (Seeker of Knowledge) it was sent as 'a vessel of peace and not of war' to Samoa, manned with 'older boys from the Industrial Reformatory School', a school for children of the poor and juvenile delinquents, and some marines and white sailors (Allen 1988: 125). A band also went along. Captain of the Kaimiloa was George Jackson, a former British naval officer and head of the reformatory school (Thomas 2010: 274). On board was John E. Bush, the King's 'Envoy Extraordinary to the Courts of Samoa and Tonga and High Commissioner to the High Chiefs and peoples of Polynesia'. Among his tasks was discussing a Hawaiian-Samoan Alliance with Malietoa Laupepa, which, as his instructions read, would give Hawaii 'a right to speak authoritatively to foreign powers on behalf of the independence of Samoa' (Sewall 19oo: 21). As could be expected, nothing came out of Kalakaua's adventure, though a treaty with Laupepa was concluded in February 1887; if only because the latter had included the clause that the treaty was subject to the obligations Malietoa Laupepa had entered into with other countries (Sewall 1900: 23).

In Germany, the suspicion was that Washington was behind the Kaimiloa expedition in order to enhance America's own position in Samoa. German politicians also did not take kindly to Hawaiian interference in Samoan affairs. Consequently, Bismarck informed Washington that should Hawaii 'try to interfere in favour of Malietoa, the King of the Sandwich Islands would thereby enter into a state of war with us' (Sewall 1900: 19, 25).

\section{The white settlers take charge}

In Hawaii his conduct and ideals brought Kalakaua into conflict with the community of white settlers. In 1887 a rebellion by foreign residents threatened. InJanuary of that year, foreigners had formed an underground organisation, the Hawaiian League, headed by Lorrin Andrews Thurston, a 
lawyer, businessman-cum-newspaper owner, and the grandson of one of the first American missionaries who had come to Hawaii. It claimed some 400 members, all sworn to secrecy (Coffman 2009: 80). On 30 June a mass meeting took place, guarded by the Honolulu Rifle Company, popularly known as the Honolulu Rifles, a settlers' militia dating from 1846. On the instigation of Thurston a resolution was drawn up, in which it was observed that the Hawaiian government had 'ceased through incompetence and corruption to perform the functions and afford the protection to personal and property rights for which all governments exist' (Krout 1898:3). When, subsequently, a company of armed men marched to the Palace, Kalakaua had to give in; if he had not, a Republic would have been proclaimed (Coffman 2009: 82).

King Kalakaua had to allow for changes in the Hawaiian constitution, which curbed his powers and increased the say of the foreign residents in the running of the kingdom. The new 'Bayonet Constitution' that was proclaimed on 6 July shifted the balance of power to community of the white settlers. The right to vote, which had previously been denied to them, became dependent on property. To be eligible to vote, one should 'have paid his taxes' (Art. 62), while members of the House of Representatives had to own 'real estate within the Kingdom of a clear value' (Art. 61). Kalakaua also had to accept that Gibson and his cabinet had to go. Gibson, narrowly escaping being lynched, was forced to leave Hawaii. On 1 July, a new cabinet assumed office, headed by William Lowthian Green, a British businessman. Thurston became Minister of the Interior.

The new cabinet gave the United States its first concrete foothold in Hawaii, by agreeing to a drastically changed Reciprocity Treaty and having it ratified by Kalakaua, who was, in fact against it, in October 1887 . On the instigation of the leader of the Republican Party, James G. Blaine, and to remove domestic American opposition against its ratification, which demanded a clear compensation for the advantages the treaty offered to Hawaiian sugar producers, the American Senate had added a crucial clause (Coffman 2009: 92). It allowed the United States 'the exclusive right to enter the harbor of Pearl River, in the Island of Oahu, and to establish and maintain there a coaling and repair station for the use of vessels of the U.S.' (Department 2001). Pearl Harbor, not so far from Honolulu, was a price well worth paying. It had been on the American agenda since 1873, when an American military commission visiting the islands, had singled out Pearl Harbor as the only harbour in Hawaii that could be defended from the shore in times of war (Brookes 1941: 348).

Though both sides denied that the new clause distracted from the sovereignty of Hawaii, to many Hawaiians - to Kalakaua and certainly to 
his sister, Lydia Kamakaeha Kaolamalii Liliuokalani, who was to succeed him - the new amended reciprocity treaty formed the first step on the road towards annexation (Allen 1988:125). The reaction of the other powers was equally negative. Great Britain and France protested, calling into mind the joint Anglo-French Declaration of November 1843 about Hawaii's territorial integrity. In line with the suggestion of a joint three-power administration for Samoa made by the United States at the Washington Conference of 1887 , they called for a joint statement by the United States, Great Britain and France guaranteeing Hawaiian independence. Washington refused. Berlin used Pearl Harbor as an argument to justify German action in Samoa. Washington was made to understand that up to that moment Germany had not used its own position of preponderance in Samoa to demand special privileges there, as America had done in Hawaii (Dulles 1938: 117).

Queen Liliuokalani ascended the throne in January 1891 after the death of Kalakaua. In the United States, President Benjamin Harrison, a Republican, clearly was not pleased with her becoming queen. He feared that her reign would favour 'schemes of those who are seeking to bring the islands under the control of European powers' (LaFeber 1998: 143). From the outset, Liliuokalani ran into trouble with John Leavitt Stevens, Envoy Extraordinary and Minister Plenipotentiary of the United States in Hawaii since 1889 . He had arrived in Honolulu, shortly after his predecessor, George W. Merill, in July of that year had requested the protection of his legation by American marines of the USS Adams during an ill-fated one-day coup d'état against Kalakaua (whose own role was not clear) by dissatisfied Hawaiians, headed by Robert W. Wilcox, who wanted to restore the old constitution. The marines had also provided the Honolulu Rifles, with ammunition. ${ }^{2}$

Stevens was an appointee of Blaine, now Secretary of State; a close friend of his, and like Blaine an ardent promoter of expanding America's hold over Hawaii. 'Destiny and the vast future interests of the United States in the Pacific', he wrote to the new Secretary of State, John Watson Foster, in November 1892 (Blaine had resigned in June for reasons of health), 'clearly indicate who at no distant day must be responsible for the government of these islands'. There were two courses of action open. The first was 'bold and vigorous measures for annexation'. The other was a list of prerogatives: 'a "customs union", an ocean cable from the Californian coast to Honolulu, Pearl Harbor perpetually ceded to the United States with implied but not

2 Testimony of William Dewitt Alexander before the Morgan Committee (morganreport.org/ mediawiki/index.php?title=Summary_of_Alexander; accessed 25-2-2011). 


\section{Figure 26 Queen Liliuokalani}

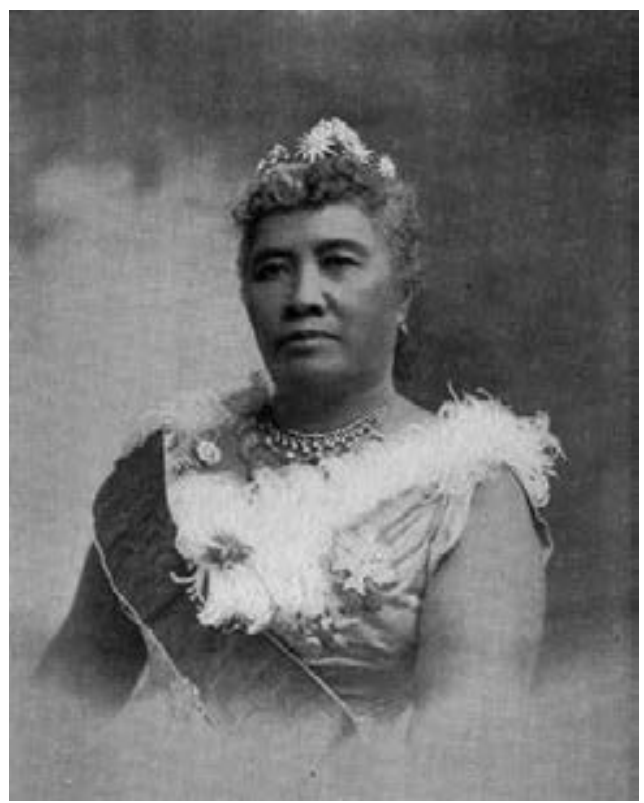

Source: Musick 1898

expressly stipulated American protectorate over the island'. Stevens himself preferred the first option. It would be better for Hawaii and 'the cheapest and least embarrassing in the end to the United States'. ${ }^{3}$

Queen Liliuokalani's intention to continue the Hawaii-centred policy of her late brother clashed with Stevens' conviction that Hawaii should become part of the United States. She recollected later how Stevens, who had been 'constantly unfriendly and quarrelsome', had given a 'most inconsiderable speech', on her accession to the throne, which 'would lead me to suppose that he considered an American protectorate established on that day'. 'Not one of the other representatives', she stressed, 'chose my coronation day as an occasion for threats and penalties'. ${ }^{4}$ Stevens made it his job to convince his government that should the United States not interfere, Great Britain could well take advantage of domestic strife in Hawaii and take possession of the islands (Dulles 1938: 171-2). He even tried to persuade Washington to allow him to take an active role in preparing an American

3 Message of President Cleveland to American Senate and House of Representatives, New York Herald 19-12-1893.

4 Dutch envoy in Washington to Minister of Foreign Affairs 12-3-1893 (ARA A-Dos box 223). 
annexation. In March 1892, he pleaded with Blaine to allow him and the senior naval commander of American warships present in Hawaii 'to deviate from established international rules and precedents' and go beyond a simple protection of American lives and property, should unrest erupt. The special relationship between the United States and Hawaii warranted such a course of action. ${ }^{5} \mathrm{~A}$ few months later he saw to it that Thurston, on a visit to the United States, could meet Blaine and other influential politicians. Harrison, wisely, refused to meet Thurston in person, but no doubt was left with Thurston that the American government would regard an annexation request with sympathy (Coffman 2009: 117).

The focus of the dispute between Liliuokalani and the foreign residents became the Bayonet Constitution, which Stevens had told her she should not try to do away with (Coffman 2009:124). She could draw strength from the fact that in 1890, still under her brother, Kalakaua, an anti-American and anti-white establishment political party, the National Reform Party, had won the elections and Thurston and the other members of the cabinet had been forced to resign. Her people, she used to stress, wanted the constitution to be changed. Petitions to that effect had poured in, she could rightfully claim. Worried by such intentions, American residents, with the backing of Stevens, became even more intent on taking full control of the government and on handing over Hawaii to the United States.

Annexation offered some settlers an additional advantage. In 189o, on the initiative of the Republican Congressman William McKinley, soon to be President, Washington had abolished all import duties on raw sugar to become effective in two years later, and simultaneously had granted local American producers a bounty. The new import regulations did away with the advantages that the sugar growers in Hawaii had derived from the Reciprocity Treaty. They now had to compete with sugar producers in Cuba and elsewhere in the Caribbean and Latin America. The consequences were immediately felt. The price of Hawaiian sugar plummeted, to fall below production costs in 1892 (Castle 1999: 77) A 'sense of panic' set in (Coffman 2009: 107). Dependent as it was on the export of sugar, the Hawaiian economy plunged into a depression. The prospects of becoming entitled to the subsidy made it all the more attractive for the producers of sugar for Hawaii to become part of the United States.

For Foster and Blaine the crisis was god-sent. In his November letter to Foster, Stevens mentioned the Hawaiian sugar crisis as one of the reasons

5 Message of President Cleveland to American Senate and House of Representatives, New York Herald 19-12-1893. 
for annexation. Blaine had also tried to make use of the bad prospects of the Hawaiian sugar industry. He held out a new reciprocity treaty; offering a subsidy on Hawaii's sugar similar to the one American producers were given in return for American control over Hawaiian foreign policy and the right to land troops on the islands in the case of domestic disturbances. Kalakaua, regarding the proposals as aiming at a virtual protectorate, and advised to do so by the British envoy (much more outspoken than his government in London), refused (Coffman 2009102). Liliuokalani, according to the Americans spurred on to do so by Canadian citizens with links to the Canadian transcontinental railroad and thus having a keen interest in an intermediate port for trans-Pacific shipping, took a similar position (LaFeber 1998: 143). She, moreover, found a new source of money, to ease Hawaii's financial problems: the Louisiana Lottery Company, the only surviving legal lottery in the United States. It was in need of a new outlet after anti-lottery legislation in the United States had gradually forced it to seek a new base of operation abroad. In 1884 the company had already tried to get a lottery bill accepted in Hawaii but had failed (Musick 1898 346). Liliuokalani, looking for ways to overcome a financial crisis in her country and ignoring domestic opposition by puritan Christians, saw to it that a lottery bill and an opium shop bill were promulgated in January 1893 .

Under these dire economic circumstances, yet another pressure group of foreigners was formed in 1892, the Annexation Club. Again, Thurston was one of its initiators. It claimed a membership of two thousand (Krout 1898: 151). In 1893, after a period rife with rumours about serious trouble brewing in Honolulu, and the Queen trying to undo the power the white settlers had gained, matters came to a head. On Saturday 14 January 1893, Liliuokalani, claiming that she was acting at the request of 'her dear people', made an attempt to revoke the constitutional reform of 1887 Hawaiian Gazette 17-1-1893). Later, in a statement widely cited in the American press, she would defend her actions by pointing out that the Bayonet Constitution had robbed the Hawaiians of 'their just and inalienable rights'. She also stated that it had not been her intention to 'deprive one white man of one legitimate right', but pointed out that under the Bayonet Constitution 'any newly arrived white man without interests or intention of residence' was 'placed as a voter over the heads of thousands of my subjects, to whom God had given these islands, and no other home. ${ }^{6}$ In the afternoon of 14 January, the Queen dressed in a 'magnificent morning costume, with a sparkling coronet of diamonds', presented her four cabinet ministers with 
a new constitution (Hawaiian Gazette 17-1-1893). They refused to sign and also would not step down. A crowd of Hawaiians had assembled outside. Scared, three Cabinet Ministers fled to the seat of government, Government Building. Having assured themselves of the support of leading members of the settlers community, they would later return and persuade Liliuokalani to postpone the promulgation of her new constitution. She did so 'with bitter reluctance' it was reported (Hawaiian Gazette 17-1-1893).

In a next step, still on 14 January, late in the afternoon, the Annexation Club, which at least had the sympathy of Foster and others in Washington if not their active support, called into being a Citizens' Committee of Public Safety, usually referred to as the Committee of Safety. During its first meeting, which took place behind closed doors, Thurston proposed forming a provisional government as a prelude to annexation by the United States. The conspirators turned to Stevens and asked for the assistance of American marines from the USS Boston, anchored in the harbour of Honolulu. Stevens, who well might have wanted to respond differently, refused, saying that he was prepared to disembark troops for the protection of American life and property only, not to support a rebellion.

On 16 January, the Committee staged a mass meeting, in which American, British and German residents, and what Krout (1898: 21), not a neutral observer, described as 'the best of the native element', participated. On that same day, Stevens acted, responding positively to a request 'by a respectable number of American citizens ... to protect their lives and property' (Musick 1898: 359) against, what one of them would later call, 'assaults and danger from the natives' (New York Times 15-4-1893). He ordered the Commander of the Boston, Captain G.C. Wiltse, to do all he could 'for the protection of the U.S. Legation and U.S. Consulate, and to secure the safety of American life and property' (Musick 1898: 359). Between four and five o'clock in the afternoon of 16 January, 160 American marines entered Honolulu and took control of the strategic buildings in the city. If we may believe one contemporary witness, when the troops passed the Palace, 'the Queen appeared upon the balcony and the troops respectfully saluted her by presenting arms and dipping the flag, and made no demonstration of any hostile intent'.

On 17 January 1893, Liliuokalani informed Stevens that she would leave the Bayonet Constitution intact. It was to no avail. Stevens, claiming that he could not take sides, refused to come to her assistance. Still on the same day, 
Liliuokalani was deposed. ${ }^{8}$ A Provisional Government was formed. This was done, a proclamation read out from the steps of Government Building stated, for 'the control and management of public affairs and the protection of the public peace'. ${ }^{9}$ The Provisional Government was to be in office until Hawaii had become part of the United States. An executive council of four was formed. It was chaired by Sanford Ballard Dole, a Hawaii-born lawyer and sugar planter and at the time a member of the Supreme Court. Dole, the son of a missionary, also assumed the posts of President and that of Minister of Foreign Affairs. His government had 'good support from the great majority of the better class of our foreign community', the Dutch consul in Hawaii, J.H. Paty, reported to his government. ${ }^{10}$

After the proclamation had been read, supporters of the new Republic marched to the Palace where they 'found no one save an indignant woman, once a queen but now deserted by her cabinet, and her soldiers safely housed in the police quarters making no effort to save her' (Musick 1898: 358). Liliuokalani blamed 'American capitalists' and those aiming at 'the restoration of the sugar bounty' for the coup d'état. ${ }^{11}$ In a statement she delivered to the Provisional Government, the queen stressed that she yielded 'to the superior force of the United States of America whose Minister Plenipotentiary, His Excellence John L. Stevens, had caused United States troops to be landed at Honolulu'. She had resigned, the statement continued, 'under protest ... until such time as the Government of the United States shall, upon facts being presented to it, undo the action of its representative'. ${ }^{12} \mathrm{On}$ 18 January, the new government proclaimed martial law. All liquor stores were closed and the lottery was forbidden. Power in Hawaii had been seized by the missionaries, a British Member of Parliament concluded, giving the impression that he regretted the end of betting in Hawaii and the blow to horseracing this had implied (as well as the obligation to attend church on Sunday he said that had been instituted). ${ }^{13}$

8 After she had been deposed agents of the Louisiana Lottery Company contacted Paul Newman (one of her confidants) and informed him that they wanted to buy the Island of Lanai for 'a syndicate of sporting men' to turn it into a gambling resort (Musick 1898: 230). In return, they were prepared to finance the Queen's return to power. Newman reported the conspirators to the new authorities and they ended up in jail.

9 Proclamation establishing a provisional government at the Hawaiian Islands Art 2.

10 Paty to G. van Tienhoven 18-1-1893 (ARA F.O. A-dos box 223).

11 Dutch envoy in Washington to Minister of Foreign Affairs 12-3-1893 (ARA A-Dos box 223).

12 Statement Liliuokalani cited in Gresham to Cleveland 18-10-1893 (New York Times 11-11-1893).

13 Beckett in House of Commons 19-7-1897 (hansard.millbanksystem.com/commons/1897/ jul/19/foreign-office-vote). 
Assessments of the state of affairs Honolulu was in at that moment by contemporaries, and in later reconstructions of the dethronement of Queen Liliuokalani, depend on sides taken. Opponents of annexation would maintain - as by the end of the year the new American President, Stephen Grover Cleveland, would do - that the American marines occupied a quiet town, where there were no signs of unrest or disorder. In Cleveland's words, Honolulu was 'in its customary orderly and peaceful condition'. ${ }^{14} \mathrm{His}$ Secretary of State, Walter Q. Gresham, was to give a similar assessment. He was to write that when the marines landed, the Provisional Government 'had little other than a paper existence' and that Liliuokalani's government was still in 'full possession and control of the palace, the barracks and the police station'. ${ }^{15}$ Those condoning the act pointed at a tense situation that had come about in the city. Stevens would later defend his action by stating that he had been motivated by 'the fear of incendiarism, tumult and robbery, and the danger of alarming panic in the night' (New York Times 30-11-1893).

\section{Annexation or not?}

On 1 February, Stevens, who later claimed that because there was no telegraph connection with the continent he had not been able to consult Washington, had his own proclamation read from the steps of Government Building by an officer of the Boston: 'To the Hawaiian people!' In the statement, he announced that for the protection of life and property and at the request of the Provisional Government he had assumed protection of the Hawaiian Islands in the name of the United States of America. As a kind of postscript, it was mentioned that the action had the approval of Wiltse, the Commander of the Boston. Subsequently, the American flag was hoisted on top of the tower of Government Building (and later also at the Palace; Liliuokalani would stay in her mansion, Washington Place). Marines of the Boston and volunteers of the Honolulu Rifles standing in line in front of the building saluted the flag and shots were fired by the Boston. Stevens' proclamation was also to be published in the press. At Government Building, the Hawaiian flag (still the same one as that used under the monarchy) continued to fly, albeit considerably lower, in the grounds. As Dole assured the Dutch consul in Honolulu, the 'Hawaiian

14 Message of President Cleveland to American Senate and House of Representatives, New York Herald 19-12-1893.

15 Gresham to Cleveland 18-10-1893 (New York Times 11-11-1893). 
flag still flies from the staff in front of Government Building and will be displayed in all the Government offices on customary occasions' ${ }^{16}$ Still on the same day, Stevens sent a letter to the State Department in Washington explaining his action. 'The Hawaiian pear is now fully ripe and this is the golden hour for the United States to pluck it', he wrote to try to convince his superiors of the wisdom of his action. ${ }^{17} \mathrm{He}$ must have been busy. Also on 1 February, letters went out to the foreign consuls, informing them that at 'the official request of the Provisional Government', he, 'aided by the United States Naval Force in the Harbor of Honolulu', had assumed 'temporary protectorate of the Hawaiian Islands' and that the status of Hawaii would be decided by negotiations in Washington. ${ }^{18}$

Stevens justified his move by pointing at the evil intention of other powers, claiming that had he not raised the American flag, the British or Japanese might have taken advantage of the situation (Dulles 1938: 176).

We have said in effect, if not in words, to other nations: "You may, if you will, take possession of many islands in the Pacific, subdue and improve them at your will, but in these islands, standing at our gates and fronting our coasts, American rights and interests are before all foreign claimants, the natives shall be protected and civilized, and American interests defended",

he would explain later in a speech. Hawaii had become American and 'all dangers of dual or tripartite arrangements' were avoided. At the same occasion, Stevens would use a similar argument to the one he had used to justify the landing of American marines. The Provisional Government had insufficient security forces to maintain order. 'Fear and panic began to make headway in the city. A riot was feared. Millions of American property and life and order were in peril' (New York Times 30-6-1893).

Stevens and Dole almost got their way. In Washington Harrison and Foster shared Stevens' fear that the British and the Japanese might advance their interests should the coup d'état fail. Great Britain took centre stage in such doom scenarios and, ostensibly to forestall any British action, Harrison had seen to it in 1891 that an American warship would frequent Honolulu (Coffman 2009:112, 123). Foster would write in retrospect that he was convinced

17 Message of President Cleveland to American Senate and House of Representatives, New York Herald 19-12-1893.

18 Stevens to Paty 1-2-1893 (ARA A-Dos box 223). 
that if the Hawaiian islands did 'not soon become American territory, they would inevitably pass under the control of Great Britain or Japan' (LaFeber 1998: 146). Such anxieties, if they were sincere, had little to do with reality. London had no intention of annexing Hawaii. Japan lacked the military capacity to contemplate such a step and was much more concerned with its conflict with China over Korea and the threat Russia might pose to its own security. In line with this, Tokyo had informed Washington that it had no intention at all of annexing Hawaii. As The New York Times (15-4-1893) wrote, there was reason to believe that rumours about Japan's evil intention originated from those in Hawaii (and in the United States) seeking annexation. Japan did send a warship, the Naniwa, to Hawaii to show - as other powers were also in the habit of doing - that it was not indifferent to the fate of its citizens abroad when local unrest threatened. Its arrival caused a brief panic. As Stevens was to relate, he feared a collaboration between the Japanese and the 'fallen queen, the lottery ring, and the palace gang' to restore Liliuokalani to the throne (New York Times 30-11-1893). In London the British government saw no reason to take a similar step. British lives and property were 'safe under American protection'. ${ }^{19}$ The presence of the Naniwa and the expected arrival of a British warship figured prominently in Stevens' defence of his action. He knew about London's position, but also knew, as he would state, that the British representative in Hawaii was of a different opinion (New York Times 30-6-1893). The consul's opposition to the Provisional Government, was probably shared by part of the British residents, according to one contemporary, who attributed this to their 'jealousy of the Americans', even by a majority of them. ${ }^{20}$

Washington instructed Stevens to cooperate with the new administration and on 15 February 1893, almost at the end of Harrison's term of office, a draft annexation treaty was transmitted to the Senate. Here, Republican members tended to be in favour, while the Democrats who opposed it were not inclined to make haste, awaiting Cleveland's inauguration. The Senate was given the impression that the Committee of Safety had acted independently of any American support. To underline this, a number of letters were supplemented to the draft of the treaty. One was from Harrison, who vowed that his government in no way had promoted the overthrow of the Hawaiian monarchy. Another was a copy of a message from Foster to Harrison, which incorrectly stated that the proclamation of

19 Grey in House of Commons (hansard.millbanksystem.com/commons/1893/feb/o2/thesandwich -islands-1).

20 Morganreport.org/mediawiki/index.php?title=Summary_of_Alexander(accessed 25-2-2011). 
the Provisional Government of Hawaii had been read before the American mariners had disembarked. The new government had been recognised, it claimed, only after the Queen had abdicated and after the rebels were 'in effective possession of the government buildings, the archives, the treasury, the barracks, the police station, and all the potential machinery of the government'. ${ }^{21}$ As an additional argument to convince the Senate, Harrison stressed the danger of other nations intervening: 'It is essential that none of the other great powers shall secure the islands. Such possession would not consist with our safety and the peace of the world' (Dulles 1938: 177).

It seemed that within less than a month after the reading of the proclamation, the plotters had achieved their aim. Change in government in Washington, and the anti-annexation mood strengthened by the developments in Hawaii, put a spoke in the wheels. The opposition against the United States becoming a colonial power drew upon an mixture of idealistic, economic and racial considerations. Some took their inspiration from American history. To them, acquiring territory outside the North American continent violated American democratic principles and was a betrayal of the own history as a former colony. Others preferred to make a cost-benefit analysis; coming out in favour of free trade as an alternative to colonial aggrandisement of which the financial burdens of conquest and rule might well exceed the profits. Yet a third objection was a racial one. The United States had closed its borders to Asians. Since 1882 a Chinese Exclusion Act was in force. Incorporation of Hawaii and the Philippines might open the door again to Asians. Or, as Henry Johnson, vice-president of the Anti-Imperialist League (founded in June 1899) rhetorically asked: 'Are you ready to grant citizenship to those your laws exclude from coming into this country?' (Miller 1982: 125). In the case of Hawaii, 'alien, inferior, and mongrel races' had to be kept out (Miller 1982:124). With respect to the Philippines, and with an evident lack of knowledge of the ethnic map of Asia, worry was expressed about the 'Malays, Chinese Mestizos' and people of 'other inferior race' brought into the American system (Miller 1982: 15). Even the spectre of Filipino Senators, who would 'destroy' the American Constitution, was held out (Miller 1982: 125).

On 4 March 1893, Cleveland, a Democrat, took office. In contrast to his predecessor, Cleveland - a man averse to Jingoism in all things, as The New York Times (15-4-1893) described him - was not convinced that annexation

21 Message of President Cleveland to American Senate and House of Representatives, New York Herald 19-12-1893. 
Figure 27 The proclamation of the Republic of Hawaii on 4-7-1894

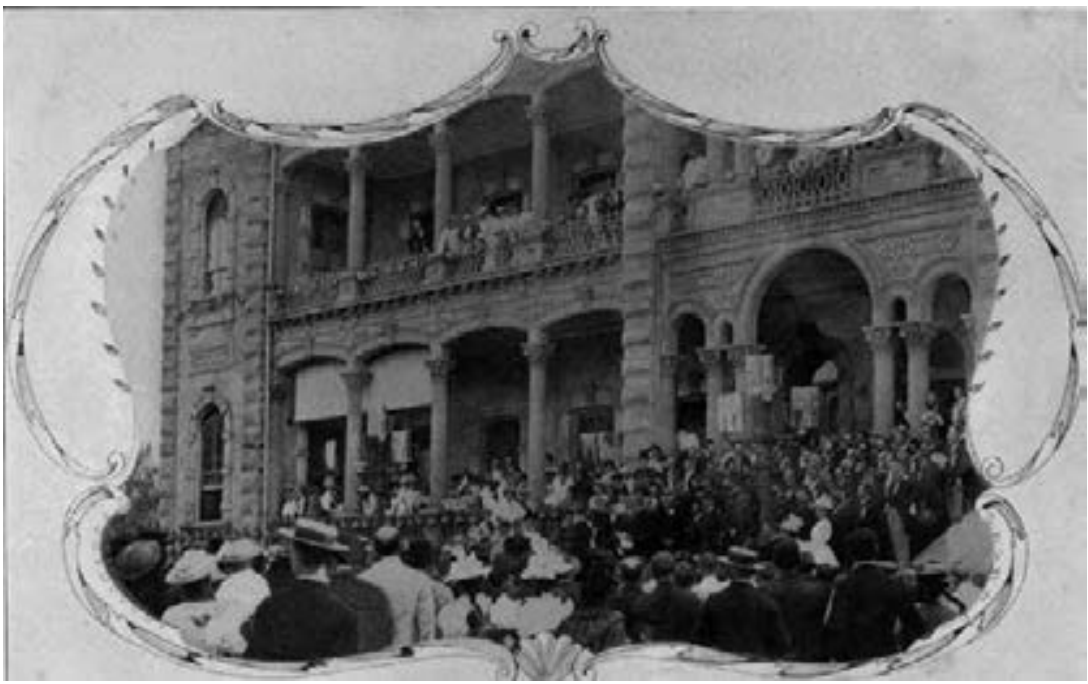

Source: Musick 1898

was the right way to proceed. Within days, Cleveland, stating that a reexamination was in order, withdrew the draft annexation treaty from consideration in Congress and sent James Henderson Blount, chairman of the House Committee on Foreign Affairs, as special commissioner to Hawaii with paramount powers to investigate.

From the outset Blount, who arrived in Hawaii on 29 March, may well have been averse to annexation. He was accused of having an open ear to the opinion of Hawaiians, but hardly making time for representatives of the Provisional Government and other white settlers (Krout 1898: 208). Stevens even criticised Blount's choice of hotel. It was owned by a former chamberlain of Kalakaua, and the owner of a firm that primarily wanted to do business with Great Britain; in short, a venue supporters of the Provisional Government were hesitant to enter (New York Times 30-11-1893). One of Blount's first deeds, on 1 April, was to order the withdrawal of the American marines from the city. On the same day, in the presence of a large crowd and a bugle sounding the notes of the retreat the American flags were lowered and replaced by the old Hawaiian flag; creating, The New York Times (14-4-1893) reported, 'among the American party a feeling of consternation not altogether unmixed with indignation'. At the Palace, the flag-lowering ceremony was witnessed by many. As elsewhere in the Pacific the scene was quite telling for racial relations. 'The native and Oriental 
population crowded the side-walk across the road in front of the Palace, the Americans and Europeans were collected in the grounds or upon the pavement adjoining' (Krout 1898: 159).

Stevens was dismissed. Blount reported to Cleveland that Stevens must have had prior knowledge of the coup d'état and that the majority of Hawaiians did not support the new government (which they indeed did not, as was well known at that time). As he wrote to Secretary of State Gresham:

The present Government can only rest on the use of military force, possessed of most of the arms in the islands, with a small white population to draw from to strengthen it. Ultimately it will fall without fail. It may preserve its existence a year of two, but no longer (Musick 1898: 369-70).

Naturally Stevens had no good word for Blount. He called Blount and those who backed him 'extremely un-American', 'unpatriotic', and acting 'in direct opposition to the civilizing and Christianizing influence on the Hawaiian Islands' and suggested that Blount 'was aiding ultra-British interests' (The New York Times 30-11-1893).

Blount's report, completed in July 1893 , made Cleveland order the restoration of Liliuokalani to the throne in November. Similar to the situation in Great Britain and London's reluctance to acquire new territory, American expansionists branded such restraint a big mistake. For the Republican Senator, Henry Cabot Lodge, typified in a recent study of American imperialism by Immerman (2010:130), as 'a pivotal force in driving America's rise to global dominance', the refusal to annex Hawaii was a reason to entitle one of his articles Our Blundering Foreign Policy. Among the reasons for him - and for Mahan - to do so was the importance Hawaii would acquire once ships could sail the Panama Canal. Hawaii was, as Lodge would put it, the Gibraltar of the Pacific (Immerman 2010: 140, LaFeber 1963: 409).

The person who had to guide the restoration to power of Liliuokalani was Albert Shelby Willis, the new American envoy to Hawaii. Willis arrived in Honolulu in November 1893. He needed all his powers of persuasion to accomplish his task. For one, he had to convince Liliuokalani that Dole and his associates should be pardoned. She should, as Willis said to her, 'show forgiveness and magnanimity' and show that she wished to be 'the queen of all the people, both native and foreign born' (Musick 1898: 376). He also asked her to include some of her opponents in her cabinet. Initially, Liliuokalani refused. Law demanded that traitors should be beheaded and that their property should fall to the state. Later, after Cleveland had impressed upon her that she should show lenience, she agreed to an amnesty. 
Dole, whom Cleveland addressed as his 'great and good friend', also stood his ground and refused to agree to a restoration of the monarchy; indeed, he threatened armed resistance. Cleveland was unable to force the Provisional Government to resign and decided to leave the matter to the American Congress. In defiance of all who had stressed the strategic importance of Hawaii, he left no doubt that, in his opinion, Harrison had been wrong. On 18 December, referring to the ideals of America's own history, Cleveland wrote a lengthy message to Congress, denouncing Stevens' action. The annexation of islands 'more than two thousand miles removed from our nearest coast' departed from an 'unbroken American tradition'. ${ }^{22}$ Explaining his position, he compared the statements of the previous administration about the non-involvement of American troops in the coup d'état with other information that ran counter to it. Cleveland concluded rather diplomatically that Harrison and Congress had been 'misled'. In strong words, he condemned what had happened in January in Hawaii. The occupation of Honolulu had been 'wholly without justification', while, according to him, it did not appear that the Provisional Government had 'the sanction of either popular revolution or suffrage'. Stevens was disavowed. Citing from Stevens' correspondence with the State Department, Cleveland depicted Stevens as a man who had 'zealously promoted' an annexation of Hawaii. Stevens had 'an ardent desire that it should become a fact accomplished by his agency and during his ministry, and was not inconveniently scrupulous as to the means employed to that end'.

Congress, for the time being, put an end to any annexation ambitions. On February 1894, the House of Representatives in a resolution denounced 'interference with the domestic affairs of an independent nation' as 'contrary to the spirit of American institutions' and spoke out against annexation or establishing a protectorate as being 'uncalled for and inexpedient'. ${ }^{23}$ The Senate followed. In the Turpie Resolution of 31 May 1894, it declared that domestic affairs in Hawaii were a matter of the Hawaiian people themselves and that the United States should in no way interfere (adding the warning that intervention by other powers would be 'regarded as an act unfriendly to the United States') ${ }^{24}$ Congress, having decided against American rule, also rejected American military assistance to restore Liliuokalani to the

22 Message of President Cleveland to American Senate and House of Representatives, New York Herald 19-12-1893.

23 Resolution as cited in en.wikipedia.org/wiki/Republic_of_Hawaii (accessed 25-2-2011).

24 Resolution as cited in morganreport.org/mediawiki/index.php?title=The_Rest_of_The_Rest (accessed 25-2-2011). 
throne; which, in view of opposition by the white settlers in Hawaii, might not have be an easy matter. ${ }^{25}$ With incorporation into the United States out of the question, in a show of pro-American feelings on 4 July 1894 (the Fourth of July was enthusiastically celebrated by the white community in Hawaii, as was Thanksgiving, complete with the consumption of turkeys), the Provisional Government proclaimed the Republic of Hawaii.

When, in 1894, under the provisions of the Wilson-Gorman Tariff Act a high import tariffs for sugar was instituted, Hawaii remained exempt due to its reciprocity treaty with the United States, a circumstance highly advantageous to the new Republic. To quell any doubt about America's position, Great Britain, Japan and Russia were warned for the umpteenth time not to interfere in domestic Hawaiian affairs. Just how much the United States cared about Hawaii became clear in January 1895 when royalists tried to stage a coup d'état and Washington directed a naval squadron to the islands. The event sealed the fate of Liliuokalani. After weapons had been found in her garden she was arrested on 16 January 1895 and abdicated on the 24January. Liliuokalani was imprisoned in Iolani Palace, now the seat of the republican administration, tried, found guilty of not informing the authorities about plans to stage an insurrection involved, and was pardoned a few months later.

25 In reaction to Cleveland's message the Senate Foreign Relation Committee chaired by John Tyler Morgan started an investigation into what had happened earlier that year in Hawaii. The Morgan report, which was completed in February 1894, questioned many of the conclusions Blount had drawn. It denounced the plans of Liliuokalani to change the Bayonet Constitution, condoned the landing of American troops, as, it concluded, at that moment there was no government in Honolulu capable of maintaining law and order, but rejected the proclamation of a protectorate by Stevens. 


\section{The United States Becomes a Colonial Empire}

The campaign for the annexation of Hawaii gained new momentum after McKinley's inauguration on 4 March 1897. One of his appointments (made at Lodge's request), making Roosevelt Assistant Secretary of the Navy, would have far-reaching consequences. Roosevelt, an early advocate of the annexation of Hawaii and much more resolute than his chief, Navy Secretary John D. Long, would make a significant contribution to the aggressive turn American foreign policy would take. In Hawaii circumstances had also changed. There, Harold M. Sewall, a 'Cleveland appointee', had taken the place of the deceased Willis as American ambassador. Sewall was as much an expansionist as Lodge and Roosevelt were and in retrospect would sing the praises of the person who had preceded him as consul in Apia and, in May 1886, on his own initiative had annexed the islands (Sewall 1900:11). With similar speed as Cleveland had blocked annexation,

Figure 28 Hawaii citizen guard 1895

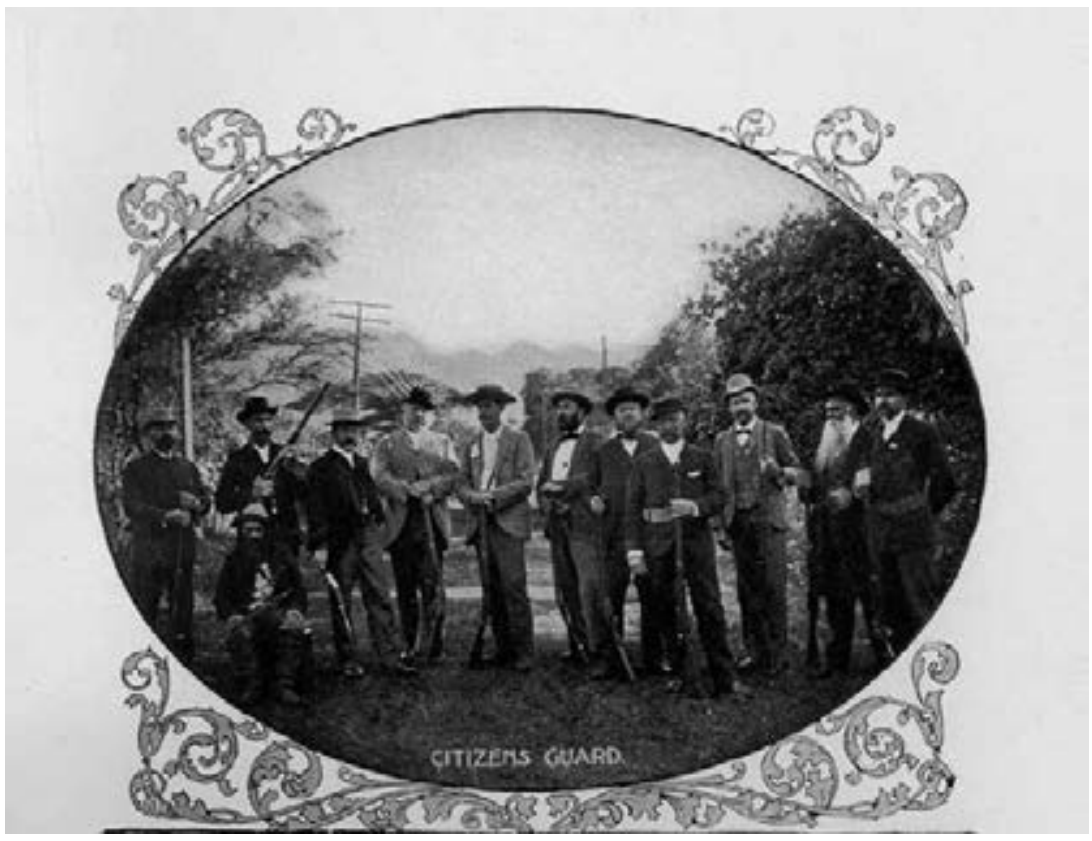

Source: Musick 1898 
McKinley proceeded to accomplish it. In June he asked Congress to agree to an annexation. As Dulles (1938: 189) would write, McKinley 'took up the Hawaiian question so promptly and so vigorously that within a little more than three months of his inauguration a new annexation treaty had been signed'.

These developments unnerved people in Great Britain, where there was also some unease about 'the persistent unfriendliness of America', and in its Australasian colonies. ${ }^{\prime}$ One of the reasons was that Hawaii was seen as a key coaling station for shipping between Australasia and Canada; which had only grown in significance with the construction of the Canadian transcontinental railway. London decided that, in view of the many international complications it was involved in, the best policy was to proceed with caution; but in New Zealand, Prime Minister Richard Seddon, a dedicated proponent of territorial expansion of the colony, suggested that Great Britain should join forces with Japan to prevent the United States from moving forward in Hawaii and other parts of the Pacific (Hiery 1995: 14).

Commerce also figured prominently in McKinley's considerations. For him, a decisive argument in favour of annexation was the strategic position of the archipelago for American trade with China and Japan, which was growing and would increase still further over time. To him annexation 'was "the inevitable consequence" of "three-quarters of a century" of American expansion into the Pacific' (LaFeber 1998: 5).

\section{The Japanese spectre}

New international factors had also come into play - Germany and Russia taking possession of the Bay of Jiaozhou and Port Arthur. In public opinion, trade with Asia, the territorial integrity of China and an American annexation of Hawaii became interlinked (LaFeber 1998: 365-7). Occasionally, the old spectre of a British annexation was also dusted off, but the new threat perceived to the American position in Hawaii was Japan. The fears Japan evoked in the United States were inspired more by the image the country was acquiring than by actual facts. Japan had just made its mark by defeating China, but its politicians and military still felt that Japan was not yet strong enough militarily to withstand the combined pressure of Russia, France and Germany.

1 Beckett in House of Commons 19-7-1897 (hansard.millbanksystem.com/commons/1897/ jul/19/foreign-office-vote). 
In April 1897 Japan fuelled American anxieties by directing the Naniwa for the second time to Honolulu, where she was to remain until the end of September, this time to protest the restrictions on Japanese immigration. Imaginary as a Japanese invasion may have been, the presence of the Naniwa, as a headline in The New York Times of 28 June 1897 read, caused a 'Japanese scare in Hawaii', with all kinds of rumours circulating among the 'English-speaking people' about Japanese hostile intent and landing parties. Ignoring counsel from the American embassy in Tokyo that Japan only had the interests of the Japanese immigrants at heart (Coffman 2009: 256), the McKinley administration also prepared for the worst. Secretary of State John Sherman instructed the American ambassador in Hawaii to 'land suitable force, and announce provisional assumption of protectorate by the United States over Hawaii pending consummation of annexation', should Japan try to enforce the admittance of its emigrants (Dulles 1938: 191).

Hawaii had upset Japan for two reasons, both inspired by anxiety over the consequences of a growing Japanese colony on the islands, and both fortified by a persistent belief, also manifest in Europe and the United States, that everything the Japanese did or said at home or abroad was orchestrated by Tokyo. Terms like peaceful invasion and colonisation were used. It was feared that by increasing the volume of Japanese immigrants, Japan might well aim at gaining control of Hawaii in an indirect way; that Hawaii would become, as one contemporary expressed it, 'a Mongolian colony.' Such reasoning lay at the root of the idea, genuinely felt or used as an argument to convince others, that if Congress did not approve annexation, Hawaii could well fall to the Japanese. Or, as McKinley was to state: the Japanese did not come to Hawaii 'voluntarily, as ordinary immigrants'. Japan was 'pressing them in there, in order to get possession' of the islands (Coffman 2009:308). To prevent the Japanese immigrants from influencing domestic politics, the Hawaiian Provisional Government, just after its coup d'état, refused a request - Stevens called it a demand (New York Times 30-11-1893) - by Tokyo to give the Japanese residents in Hawaii the right to vote. It had also - in February 1897 - tightened immigration rules, resulting in the refusal to allow over a thousand new Japanese labourers to disembark and enter the country. They had been temporarily detained before being sent back; a course of action leading to much commotion in Japan. Tokyo protested. It demanded an indemnity for the maltreatment of the immigrants detained and adherence to the Treaty of Amity and Commerce the two countries 
had concluded in 1871, which assigned the same rights to the Japanese as to other foreigners in Hawaii. Japan also made it clear, and Japanese politicians were not alone in this, that a Japanese threat 'existed only in the minds of the zealous advocates of annexation', and was used by them for a speedy realisation of their aim (New York Times 18-6-1897).

The Hawaiian government and the American politicians eager to annex Hawaii made much of the threat Japan posed; a line of reasoning which of course found its way to the press. For Dole, Thurston and like-minded white Hawaiians, the prospect of Japanese aggression had become an indispensable argument, aware as they were that their annexation movement lacked popular support; the suffrage Cleveland had mentioned in his message to Congress. Most indigenous Hawaiians did not want to be incorporated into the United States, thus blocking the possibility to back up an annexation request by a plebiscite; a procedure that would have made support in the United States greater. In the autumn of 1897 protests were staged on the islands and two Hawaiian petitions denouncing annexation, one with 21,000 and one with 17,000 signatures, were drawn up (Coffman 2009: 279). Planters also had their doubts. Fearing the consequences of the limitations in place in the United States on cheap contract labour for the recruitment of Asiatic workers, they wanted the establishment of a protectorate at the most.

On 16 June 1897 representatives of the United States and Hawaii agreed on an annexation treaty. After receiving the consent of the American Senate, the islands would become part of the United States as the "Territory of Hawaii'. However, this did not yet grant them the full rights of an American state and important appointments were still being decided on in Washington. Annexation was decided upon, the preamble read,

in view of the natural dependence of the Hawaiian Islands upon the United States, of their geographical proximity thereto, of the preponderant share acquired by the United States and its citizens in the industries and trade of said islands and of the expressed desire of the Government of Hawaii that those islands should be incorporated into the United States. ${ }^{3}$

In the treaty the issue of Asian immigration had to be tackled before Hawaii could become part of the United States. It was stipulated that the treaties Hawaii had concluded, such as with Japan in 1871, would 'forthwith cease' and would be 'replaced by such treaties as may exist, or as may be hereafter 
concluded between the United States and such foreign nations'. Japan still had to be treated with care, China did not. Consequently, one of the articles read that there should be 'no further immigration of Chinese into the Hawaiian Islands' and that no Chinese should be 'allowed to enter the United States from the Hawaiian Islands'. ${ }^{5}$

Japan rejected annexation, but as the Japanese Minister of Foreign Affairs, Count Okuma Shigenobu, wrote to his ambassador in Washington, opposition 'should be within limits of diplomacy' (Coffman 2009: 255). Even before the negotiators appointed by Washington and Honolulu had signed the Annexation Treaty, the Japanese ambassador had lodged a protest. The civil rights of the Japanese formed a major issue. In the note it was observed that there were '25,000 Japanese in the islands with large property rights' who, according to the treaty of 1871 , were allowed to become Hawaiian citizens. After annexation they would be subject to American legislation, which would imply that they 'would lose the right to become citizens and to vote'. It was also noted that 'large interests owned by Japanese citizens in the islands would be greatly jeopardised', all reasons that 'the Japanese Government must firmly protest'. ${ }^{6}$ It was, LaFeber (1998: 363 ) writes, 'probably the strongest protest Japan ever issued to another power up to that time'.

In Japanese newspapers, Okuma Shigenobu drew a parallel between France successfully opposing a British protectorate over Egypt and Japan resisting annexation of Hawaii, stressing that 'Japan must oppose to the utmost' (New York Times 26-7-1897). Great Britain, France and Germany were informed about Tokyo's objections. Berlin also had intended to protest, but retracted when London refused to issue a joint note (LaFeber 1998: 363 ). Japan withdrew its opposition to annexation in December 1897. It accepted an indemnity of $\$ 75,000$ to compensate for the sufferings the detained and repatriated labourers had had to endure (Coffman 2009: 257, 213). It did not matter. Japanophobia had become too strong. In March 1898 the Senate Foreign Relations Committee singled out the strategic position of Hawaii as 'the main argument in favor of the annexation' (LaFeber 1998: 410). Japan was the country to be kept out. It was the enemy the United States had to confront in the future (though for a brief moment the Russians taking Port Arthur in December 1897 complicated matters and made

4 Treaty of Annexation of Hawaii, Art. III.

5 Ibid., Art. V.

6 Report in The New York Times (25-6-1897) of the Japanese protest as read to the American Senate. The protest referred to decisions of the American Circuit Courts (Appeal Courts) that no Asian could become a citizen of the United States. 
for a rapprochement between Tokyo and Washington). As the Committee observed in its report: "The issue is whether, in that inevitable struggle, Asia or America shall have the vantage ground of the control of the naval "Key of the Pacific", the commercial "Cross-roads of the Pacific" (ibid.: 410).

\section{The Philippines, unexpected spoils of war}

When the annexation of Hawaii was still undecided, the United States found itself at war with Spain and having to fight in Cuba and the Philippines. As in the case of Hawaii, strategic considerations would provide the proponents of an annexation of the Philippines with their arguments. The rich natural resources of the islands were mentioned, but this was only a minor factor, if it played any significant role at all. Political and commercial considerations, and trade with China, were paramount. The 'Philippines were the key to the Orient and Manila the natural rival of Hong Kong', Frank A. Vanderlip, US Assistant Secretary to the Treasury, wrote in an article in August 1898 (Dulles 1938: 233). 'And just beyond the Philippines are China's illimitable markets. We shall not retreat from either', Albert Jeremiah Beveridge, a Republican Senator in favour of taking control of the Philippines and of America's 'mastery of the world', promised.7 Protagonists of an American Philippines saw these islands, more so than Hawaii, as compensation for the commercial opportunities they feared might be denied to them in China. LaFeber (1998: xxii) is even of the opinion that, given the threat to the Open Door policy in China, McKinley had 'no alternative but to go to war to extend the United States' control over both Cuba and at least the port of Manila'. Manila, he writes, was seen as 'a way station to the Orient' (LaFeber 1998: 411). What the American reaction was can also be surmised from the words of the historian Dulles (1938: 222): 'Our rivals were establishing footholds in Asia which threatened to shut us from the rich markets of China'. The Philippines provided the Americans with psychological and strategic compensation. It was, Dulles (1938: 222) posed, their Hong Kong, their Guandong, their Jiaozhou. After the United States had annexed the islands, yet another factor came into play: the threat or power that radiated from this act and from the presence of an American military force not so distant from China. As one Republican leader, Chauncey Depew, would phrase it, the American victory in the Philippines 'echoed through the

7 Beveridge in Senate, 9-1-1899 (Miller 1982: 250, marchand.ucdavis.edu/lessons/philippines/ philippines. html, accessed 25-9-2011). 
palace at Peking and brought to the Oriental mind a new and potent force among western nations ... striving to enter the limitless markets of the east. These people respect nothing but power' (Miller 1982: 147).

The Philippines, a colony of Spain, came into American view after a rebellion against Spanish rule had started in Cuba in February 1895, raising the prospect of intervention to protect American interests on the island. Preparing for such a confrontation, American Naval Intelligence also drafted plans for war against Spain and the Spanish fleet in the Philippines at least as early as the end of 1896 (LaFeber 1998: 360 ). At that moment the Philippines - like Cuba - was in a state of turmoil. In August 1896 Emilio Aguinaldo had risen in rebellion against Spanish rule. The revolt, which had wide popular support, was grist to the mill of those outside the Philippines looking for territorial expansion, as such disorder could be used as an excuse to land troops to protects compatriots' lives and property. Indeed, in Japan the army briefly contemplated interfering (Goto 2003: 8). Furthermore, rumours immediately began to circulate that Japan intended to purchase the islands from Spain (for which it did not have the money). Coupled with the voices of Japanese nationalists airing their views about the leading role Japan had to play in Asia, such stories also gave rise to the suspicion that Japan had masterminded the rebellion in the Philippines (Saniel 1962: 223; De Indische Gids 1896: 1719-22).

Assigned with the task of taking on the Spanish in the Philippines was Commodore George Dewey, one of the members of an inner circle of American 'imperialists' who met frequently in Washington (Immerman 2010: 134). In December 1897 he got his orders. Dewey was to take over command of the Asiatic Station in January 1898. In February he received more specific instructions on how to proceed should there be war. They were drafted by Roosevelt who, not much later, would eagerly join the fighting in Cuba. Dewey had to prevent the Spanish fleet in the Philippines from being redirected to the Caribbean. Engaging the Spanish in war in the Philippines was something of a journey into the unknown. At the end of 1898 the War Department published an over-three-hundred-page handbook for the invasion of the islands, compiled from consular notes, naval intelligence, some travel books, and even the Encyclopaedia Britannica and the National Geographic Magazine. It was full of detailed military maps and geographical information, but on one of its first pages could also be read that the Philippines had 'a great number of good harbours', although little was known about them because of the 'exclusive policy of the Spanish Government in closing them to foreign commerce' (Military Notes 1898:12). And, from what was to follow, it appears that neither the American government nor its navy 
and army had any inkling of Aguinaldo's popularity or the mood among the population and the resilience of guerrilla warfare. After his return to the United States in December 1898, Major General Wesley Merritt, a senior army officer who had been on the spot and who had been in charge of the army operations in the Philippines, said that 'the people of the Philippines ... do look forward to a colonial government' (New York Times 27-12-1898). He suggested that should trouble erupt, the United States could rely on an army of Filipinos commanded by American officers, just as the British did in India; a somewhat idle hope, also in view of the disdain with which American soldiers and officers treated the Filipino forces and the independence movement. Perhaps because of such misconceptions no plans were developed on how to proceed in the Philippines after Spain had been defeated. As Foreman (1906: 484) wrote, 'there was neither a Philippine policy nor any fixed programme regarding the future disposal of the Islands'. Only a few had warned from the beginning that a bitter and long battle with the local population striving after independence might lay ahead (Miller 1982: 27).

Matters between the United States and Spain came to a head after the blowing up of an American warship, the USS Maine, in Havana on 15 February 1898. On 21 April the American Congress issued a Joint Resolution in support of Cuba's independence, vowing that the United States had no intention of annexing the island. War was declared on 25 April. In response, London issued a declaration of neutrality, forcing Dewey's squadron to leave Hong Kong and move to Chinese waters (to Mirs Bay, which, with the extension of Kowloon, would become British within months). From Mirs Bay, Dewey steamed to the Philippines with a squadron of warships, which, Foreman (1906: 438) wrote, had been 'well supplied with coal from British vessels'. On 1 May he destroyed the Spanish fleets in the battle of Manila Bay. In the Caribbean the Spanish fleet suffered a similar fate on 3 July. On land, where in Cuba and the Philippines its troops had to fight insurgents as well as the American army, prospects were equally gloomy for Spain. In Hay's words, for the Americans it was a 'Splendid Little War' (Immerman 2010: 149).

As elsewhere in Asia, German commerce in the Philippines was expanding (Colquhoun 1902: 108). The American-Spanish War offered Wilhelm II a chance to consider expanding German territory in Asia even further by acquiring the Philippines or part of it (Mann 1992: 516). Public opinion seemed ripe for such an adventure. In 1897 the new American ambassador in Berlin observed a clearly anti-American mood in the German press and among German intellectuals. About the latter, he noted that 'some of their expressions seemed to point to eventual war' (LaFeber 1998: 325). 
Figure 29 Admiral Dewey in a Pears' Soap advertisement

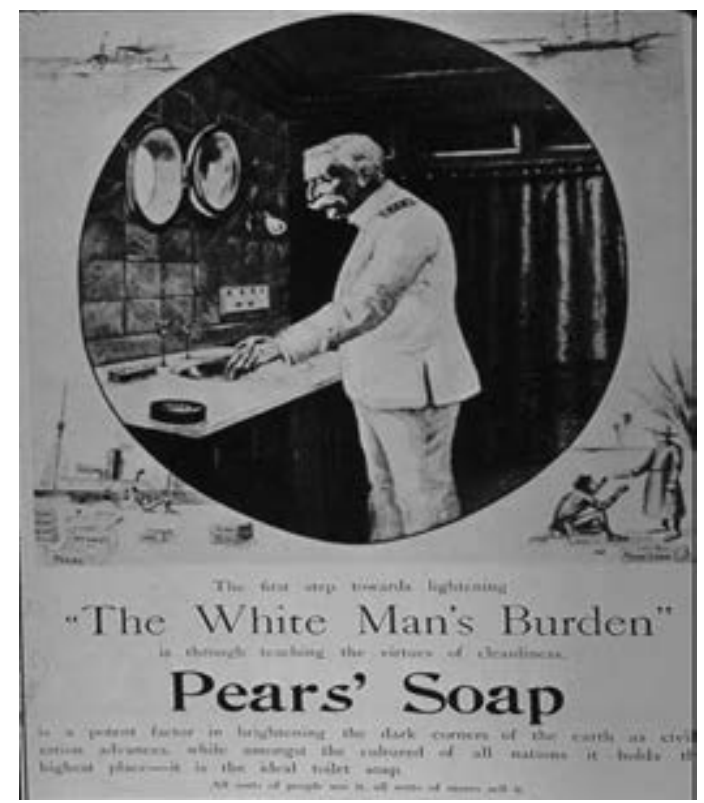

Source: en.wikipedia.org/wiki/The_White_Man's_Burden

The Philippines had already been on the agenda of the explorer Richthofen. In 1869 he had pointed at the strategic position of the archipelago for trade in the Far East. With Zhoushan Island near Shanghai and Manila on the island of Luzon, Germany would command the two best ports in East Asia, the future focuses of China trade. ${ }^{8}$ The Philippines was not an empty spot that the powers had been contesting each other elsewhere in the world for, but there might be a way in which a slice of it could be acquired relatively easily to satisfy German colonial ambitions in Asia and give even more substance to the country's world politics. Wilhelm II, as Berlin informed its ambassador in Washington, hoped that coming to the support of Spain could give Germany a part of the Philippines. To him it was 'a principal object of German policy to leave unused no opportunity which may arise from the Spanish-American war to obtain maritime fulcra [points of support] in East Asia' (Dulles 1938: 225).

Just a few days after Dewey had defeated the Spanish fleet a German squadron of five warships appeared on the scene. It had, as Knoll and Hiery (2010:26) phrased it, rushed to the Philippines. Ordered to sail there at the 
end of April it was ostensibly in search of a suitable place for a German naval station in the Philippines (Nuhn 2002: 100). The suspicion that Germany might try to establish itself on Luzon, the largest island in the north of the archipelago on which Manila is located, gave the presence of the German warships an additional dimension not only with regard to United States. It also made the Philippines conflict of direct concern to Great Britain, not least because, as a British Member of Parliament observed, the island becoming German was 'viewed with considerable anxiety in the Australian Colonies', urging his government to prevent 'any portion of a group situated on the great commercial highway between Australia and the Far East' falling 'into hostile hands'. ${ }^{9}$

The commander of the squadron was Vice-Admiral Diederichs, the same officer who had occupied Jiaozhou, and being a man prepared to fight battles for his country he seemed to have had every intention of making the Kaiser's aim come true. The deployment of German ships would almost immediately lead to complications. What the Americans regarded as running their naval blockade of Manila and assistance to the Spanish war effort, the Germans presented as a legitimate effort to protect Germans and other foreigners (the British navy would send four warships to the Philippines). The German interpretation was rather elastic. In July the German cruiser Irene assisted in defending a Spanish garrison in Subic Bay against an attack by Filipino insurgents, who had joined forces with the Americans. She withdrew after Dewey had dispatched two of his own cruisers to Subic Bay. The incident 'caused war talk' The New York Times (11-5-1918) would write after Diederichs' death, some twenty years later.

Officers of the German East Asia Cruiser Division would behave in the same aggressive, haughty way, that was also so characteristic of a number of German secular and religious representatives in China. On shore they conspicuously showed their sympathy with the Spanish cause; their commander assuring his Spanish hosts at a picnic that Germany would never allow the Americans to take the Philippines (Foreman 1906: 434). Diederichs, the American historian Dulles (1938: 214) writes, displayed a 'boorish, interfering, arrogant attitude' acting 'as if he were doing his best to invite a quarrel and cause one of those "incidents" which so easily lead to open hostilities'. Dewey, also not a paragon of modesty, would have told Diederichs that 'if Germany wants war, alright, we are ready' (Nuhn 2002: 100). The German naval operation put the German business community in

9 Hogan in House of Commons 1-8-1898 (hansard.millbanksystems.com/commons/1898/ aug/o1/future-of-the-philippines). 
the Philippines in a difficult position. After Spain had had to admit defeat, German merchants in Manila hastened to apologise in the newspaper $\mathrm{La}$ Independencia for the pro-Spanish behaviour of the German naval officers, which had evoked the hatred of the population (Foreman 1906: 473-4).

At the end of July Spain accepted defeat. On 12 August 1898 a Protocol of Peace was signed in Washington (with the French ambassador representing Spain). It stated that the United States would 'occupy and hold the city, bay, and harbor of Manila' (which at that moment was still in Spanish hands) and suggested that a final decision about what territory the United States would take possession of depended on the results of a peace treaty still to be negotiated..$^{10}$ The following day American troops took Manila; its centre being an old-fashioned fortified city, complete with a wall, bastions and bulwarks, and moats which could be inundated.

All of a sudden, the United States could become master of the Philippines, for many Americans a faraway, little known island group. Granting the Philippines independence was out of the question; though there were some in America, like the influential anti-imperialist Republican Senator, George F. Hoar, who were in favour of this option, taking the well-known position that it was against the spirit of the American Constitution to impose American rule upon people against their will (Foreman 1906: 495). The opinion that prevailed was different. Though not all shared this view, the general feeling in government circles in the United States, as well as in Japan and Great Britain, was that the Philippines was unfit for self-government. Its population had not yet reached that state of civilisation that Westerners in those days determined was required for this. They were as 'incapable of self-government as children', Lodge would state in the American Senate (Immerman 2010:152). Independence could only result in chaos; an invitation for foreign intervention, maybe by Japan or Germany.

Handing over the Philippines to France or Germany was out of the question. They were, in the words of McKinley, America's 'commercial rivals in the Orient' (Dulles 1938:241), while in the case of Germany the sympathies showed for Spain had also not endeared the Americans. In the United States the German naval presence in the Philippines - or what Bülow described as lying reports about our attitude in the Spanish-American War"11 - had caused an outcry. New complications in Samoa would soon strain

10 Protocol of Peace Embodying the Terms of a Basis for the Establishment of Peace between the Two Countries, Art. 3.

11 Memorandum Bülow 14-3-1899 (E.T.S. Dugdale, German Diplomatic Documents, Ch. IV, Samoa, August, 1898, to November, 1899; www.mtholyoke.edu/acad/intrel/dugdale/samoa.htm). 
American-German relations even more, forcing Bülow to conclude that an 'aggressive Press put American public opinion in a hostile mood' against Germany. ${ }^{12}$

American newspapers mentioned Japan as a possibility but, similarly, this was no alternative, as Japan was emerging in public opinion as a threat to Hawaii and thus to the United States itself. The fact that as early as 1896 Japan was one of the countries to which the Filipino rebels of Emilio Aguinaldo had appealed for moral and military support probably also did not help. McKinley might well have contemplated offering the islands to Great Britain, but the British government was not eager to comply. London informed Washington that, in its opinion, the best option was for the United States to hold on to the Philippines and that in no way should Germany gain a foothold there. To sway public opinion in the United States in favour of annexation, Rudyard Kipling joined in the fray. It was America and the 'new-caught, sullen peoples, half-devil and half-child' of the Philippines he had in mind when he wrote his famous poem The White Man's Burden in February 1899, published just before the American Senate had to decide on the future of the Philippines.

Another option initially considered in the United States was to occupy the Philippines temporarily; keeping only one or two naval bases - Manila and Cavite on the island of Luzon - and returning the rest of the Philippines to Spain, after having sold some of its islands to compensate for the financial costs of war. The Port Arthur and Jiaozhou leases made some waver. The novel argument was advanced that a naval base needed to have a hinterland for defence purposes. Consequently, Luzon, and also the rest of the Philippines, came into view (LaFeber 1998: 414-5). That still left the choice between annexation and protection of either Luzon, should Washington decide to confine American's presence to that island, or the archipelago as a whole.

On 1 October 1898 formal peace negotiations commenced in Paris. Spain argued that the Protocol of Peace of August said nothing about the end of Spanish rule in the Philippines. It only mentioned a temporary occupation of Manila by the United States, which, when it took place on 13 August, had been in violation of the cessation of hostilities agreed upon in the Protocol. Manila should be returned to Spain. Madrid also demanded an indemnity. These demands were unrealistic. The United States wanted land. Initially, McKinley was of the opinion that Luzon and Guam in the Spanish Mariana or Ladrones Islands would suffice (Miller 1982: 20). In the end the United States would claim the entire Philippines. 
In part, this change in objective was due to a powerful military lobby, represented by Major General Merritt who had travelled to Paris to advise the American delegation. His position was clear. As he explained to The New York Times (27-12-1898), the United States should hold on to the Philippines: 'If we dispose them to any other nation it will certainly precipitate a war, and they are not yet capable of governing themselves'. Keeping only Luzon was no option. The island could not be defended should another power occupy other parts of the Philippines (Miller 1982: 20). Partly, the whole of the Philippines became American because, as Miller (1982: 23) concluded, 'expansion was immensely popular' and mid-term elections for the House of Representatives were to take place in November.

McKinley initially made a distinction between a peaceful and a forcible annexation. In a speech to Congress in December 1897 he still observed that the latter 'under our code of morality ... would be criminal aggression' (Foreman 1906: 484). The following year, when he had a real case at hand, McKinley ordered the annexation of the Philippines. Afterwards, McKinley evoked the interception of God to explain his decision. 'I walked the floor of the White House night after night; and I am not ashamed to tell you, gentlemen, that I went down on my knees and prayed Almighty God for light and guidance more than one night', he later told a delegation of clergymen. When it dawned on him, and these are words often quoted, that the United States had 'to educate the Filipinos, and uplift and civilize and Christianize them', he 'went to bed and went to sleep and slept soundly' (Hardy and Dumke 1949: 417). Sincere or not, the confession made an impression. McKinley, the American historian Dulles (1938: 228) wrote, 'took over the Philippines only after long communion with God, as he himself has recorded, had convinced him that it was his duty'. Having made up his mind, McKinley wired to Paris on 28 October that returning the Philippines minus Luzon to Spain could not 'be justified on political, commercial, or humanitarian grounds', also mentioning the possibility that other islands could become 'the subject of future contention' between the powers (Miller 1982: 24).

Madrid yielded and agreed to hand the Philippines over to the United States. In return, Spain received US $\$ 20$ million. Guam also became American, giving the United States a coaling and naval station en route to the Philippines. Spain was promised that its imports in the Philippines would be submitted to the same duties as American goods for a period of ten years. It was an empty gesture. The United States would grant the same right to all other nations.

Conspicuously absent at the negotiating table had been representatives of Aguinaldo and his independence movement. Initially, it appeared that he 
had the full backing of the United States. While still in exile, the American consuls in Hong Kong and Singapore, and also Dewey, had given him the impression that his insurrection could count on American support should it come to war with Spain; overtures which could not meet with the approval of Washington (Miller 1982: 35-7). Aguinaldo had also entered the Philippines on board a dispatch boat of the American navy on 19 May 1898 and had proclaimed Independence on 12 June 1898 . He had probably counted on a brief American occupation, after which the Philippines would be recognised as an independent state with the administration handed over to him and his government, if it had to be under American military protection. In line with this he had urged his countrymen to welcome the Americans as liberators' who fought the war 'for the sake of humanity' (Foreman 1906: 433). In August, addressing the powers, Aguinaldo, and he must have been aware of how native rule was considered there, tried in vain to convince them that the Philippines had 'arrived at a state in which it can and ought to govern itself'. ${ }^{13}$ It was a miscalculation. Aguinaldo and his forces were tolerated as long as they were useful to the war effort. His independence movement was courted, used when it suited American aims, but never considered a serious candidate for taking over Spanish rule. His troops received American arms but at the same time his fighters were kept on the leash, soon leading to frictions between them and the American invasion force. They were ignored, at times bullied, and, for instance, not allowed to participate in the siege and the taking of Manila.

Aguinaldo had urged that his Philippine Republic be allowed to attend the negotiations, but in Paris Major General Merritt referred to him as a Chinese half-breed adventurer (as did others too) and did his best to put him and his movement in a bad light (Miller 1982: 20). In a sense Aguinaldo took revenge. A peace treaty was signed on 10 December 1898 , but not being allowed to participate in the negotiations Aguinaldo did not feel bound to it, and allowed his troops to continue to attack Spanish forces in the Philippines (ibid.: 46).

When the peace treaty between the United States and Spain, also known as the Treaty of Paris, was signed, American troops were only in possession of Manila and Cavite and its naval base, located some thirty kilometres south of the capital on the southern shore of Manila Bay. The rest of the northern Philippines 'was virtually and forcibly held by natives in revolt' (Foreman 1906: 478). Tension between American forces and those of Aguinaldo turned into open warfare when the two fought a battle for 
control over Manila on 4 and 5 February 1899, with the Americans firing the first shots and the Filipino fighters being no match for the much better armed American troops. On 2 June Aguinaldo formally declared war. To most Americans hostilities came as an unpleasant surprise. Many had no idea that Aguinaldo and his co-revolutionaries, acting in the name of the Philippine Republic, had been preparing for guerrilla war. What followed would be one of 'the bloodiest and most costly colonial wars of the $19^{\text {th }}$ century'; costing some 5,000 American lives (Hennessy 1984: 77). To suppress resistance, the American army had to send many more troops than originally envisaged. The strain on the American troops became apparent during the Boxer Rebellion. The Philippines was the obvious place from which to send the first American reinforcements to China; but the American commanders in the Philippines were far from happy to do so, as they needed their soldiers to suppress the insurgency (Silbey 2012: 93, 125).

It would take some two years of brutal fighting, complete with the customary shelling of coastal villages by warships and the setting ablaze of villages in the interior. Racial prejudices contributed. 'Nigger' became a favourite term of reference on the American side. Another one was 'Indian', a word at least as emotionally charged, since it was associated with cruel savages. Many of the American soldiers and officers had fought in the Indian Wars, and in suppressing resistance in the Philippines would resort to the same dirty methods they had used against the American Indians (the Wounded Knee massacre had taken place less than nine years before, in December 189o). Justification was found in the supposed innate cruelty of the uncivilised Filipinos. As Roosevelt and others would argue, the 'cruelty, treachery and total disregard of the rules of civilized warfare' by the insurgents gave good reason to the Americans to act the way they did (Miller 1982: 255). One example was water boarding, in those days called water cure. Roosevelt suggested in private that it was 'an old Filipino method of mild torture', which did little damage and was quite harmless compared to the 'incredible torture' inflicted on American soldiers (Miller 1982: 235).

In March 1901 Aguinaldo was captured. After he had sworn an oath of allegiance to the United States the following month, and had asked his followers to do the same, he was released. The rebellion formally ended on 4 July 1902 when Roosevelt, President since September 1901, issued a Peace Proclamation and Amnesty Grant, but in reality it continued until at least 1910 (Bootsma 1986: 11). The United States also inherited from Spain the equally brutal and much longer war with the Moro, the Muslims living in the southern Philippines, the Sulu Archipelago and Mindanao; the recollection to this day contributing to the anti-American mood among its Islamic population. 
Though a vocal anti-expansion movement remained active, the Philippines gave the American government and part of the American public a taste for territorial expansion with the United States in control of its own shipping routes in the Pacific, not dependent on other nations. One of the problems was the two-thirds majority needed in the Senate. The Senate voted in favour of annexation on 6 February 1899. McKinley and his fellow Republicans had had to work hard to accomplish this; indeed, some spoke of buying votes (Miller 1982: 27-8). In view of widespread aversion in the United States against colonising others, this was coupled with promises of future self-government. Eight days after the Senate had agreed to annexation a resolution, proposed by the Democrat Samuel Douglas McEnery, was accepted. In it, it was observed that the United States intended to prepare the Philippines for 'local self-government' and would not 'permanently annex said islands as an integral part of the territory of the United States'. The resolution also solved another problem. It observed that there was no intention 'to incorporate the inhabitants of the Philippine Islands into citizenship of the United States' (New York Times 7-2-1899). ${ }^{14}$

To Wilhelm II the annexation of the Philippines was an American 'step against the Yangtze'. ${ }^{15}$ In the Netherlands Indies, American rule was greeted with relief. There - and in Australia - Taiwan, in Japanese hands since the Sino-Japanese War, and the Philippines figured as stepping stones in doom scenarios about a Japanese invasion.

Initially, the Philippines was placed under military government. The civil administration that took its place in July 1901, headed by William Howard Taft, soon found itself in a position similar to that of Gordon in Fiji. Taft was accused of unduly siding with the local population. He would disregard the interests of the many Americans who were trying their luck in the newly conquered territory and had been lured to the Philippines by the stories about gold fields waiting to be harvested and other riches to be won (Foreman 1906: 564, 568). The Philippines was granted a kind of protectorate status in 1935, the Commonwealth of the Philippine Islands, and became fully independent in July 1946.

Germany joined in the spoils of the Spanish colonial empire. In February 1899 Spain, down and out and needing money, sold the Caroline, Mariana

14 Cuba became an independent Republic in 1902, but in the true spirit of a protectorate, had to allow American supervision over its foreign and financial policy.

15 Memorandum Wilhelm II 23-8-1901 (E.T.S. Dugdale, German Diplomatic Documents, Ch. X, The Anglo-Japanese Agreement, 1901-02, www.mtholyoke.edu/acad/intrel/dugdale/japan.htm). 
(minus Guam, which the United States had already acquired in December 1898) and Palau Islands to Germany. For economic and strategic reasons there were doubts about the wisdom of the acquisition. Some considered the Carolines to be a number of useless islands, not worth exploiting, while Tirpitz and his navy were not overjoyed by the military value of the islands and had in fact spoken out against acquiring them (Hiery 1995: 1). Prospects for the Palau islands seemed equally bleak. In 1883 the Polish ethnographer Johann Stanislaus Kubary (1885: 139) had observed during a visit to the archipelago that German merchant ships no longer called at the islands because there was no money to be earned, and that a German trading station had long been abandoned. In fact, German trade with the South Pacific, including Samoa, would remain trivial, amounting in 1909 to only 0.15 per cent of total German foreign trade (Conrad 2008: 58). Nevertheless, when he informed the Reichstag about the deal, Bülow presented it as a great success for German diplomacy. The new acquisitions completed the German possessions in the South Sea. Until then, German territory in the Pacific had had the shape a half circle, a long and disjointed line. With the addition of the island groups the circle was closed and the German possessions had become a coherent whole. For that reason, they should not have fallen in the hands of others. His picture was also rosy, resembling what Bismarck had said about New Guinea: The Caroline, Mariana and Palau Islands were located in a region where trade and traffic could only increase. The islands were all well-suited for plantation cultivation and wood industry; coconuts flourished and provided good prospects for the production of copra. The climate was relatively healthy. More importantly, what had failed Germany in the past was a harbour on the route from New Guinea and the Bismarck Archipelago to Jiaozhou, the rest of China and Japan. According to Bülow, the Caroline Islands filled this gap. The group had excellent ports and anchorages (which he said the Marshall Islands lacked). The Mariana Islands could serve as an intermediate German station for shipping between Southeast Asia and Central America. The fact that, as critics said, Germany had paid Spain a huge sum of money, more than the number of inhabitants and German settlers seemed to warrant, was beside the point. In 'large politics' (grosse Politik) more counted than just money (Gründer 1999: 124-5). What Bülow also did not mention was the disposition of the local population. On the Island of Pohnpei (Ponape) in the Carolines, for instance, Germany had to cope with 'islanders possessed by hatred of all white strangers', and had to deploy the navy to keep them in check (Nuhn 2002: 210). Unrest would culminate in the Sokehs Rebellion of 1910. 


\section{The American Empire}

Soon after the start of the Spanish-American War, Hawaii disregarded the laws of neutrality and became a coaling and bunkering station for American ships transporting troops to the Philippines. The war and the 'hysteria' that arose tipped the scale in the United States in favour of annexation (Dulles 1938: 196). In September 1897 the Hawaiian Senate, controlled by Dole and Thurston, had already ratified the Annexation Treaty of June of that year. In the United States getting formal agreement to the annexation was more difficult. As the new annexation treaty mentioned, what was still needed was the consent of the American Senate. Unsure of the required two-thirds majority in the Senate, the less elegant and legally disputed procedure had to be followed: a joint resolution accepted in the Senate and the House of Representatives by a simple majority; a possibility already contemplated by the American government before the earlier Annexation Treaty had been submitted to the Senate in February 1893. A joint resolution, mentioning the main points of the Treaty, was approved on 7 July 1898 . On 12 August 1898 the United States formally incorporated Hawaii. Dole became the first Governor of the new American 'Territory'. Marines from the USS Philadelphia, the flagship of the American Pacific Station, and USS Mohican attended the ceremony. At that moment the Hawaiian government had already allowed new Japanese labourers in. In January 1899 the Island of Wake, one of the Marshall Islands, located between Hawaii and Guam would also become American. It would take until 1958 before Hawaii would become a state of its own.

The American occupation of Hawaii, and the threat emanating from Japan, added to the importance of the Panama Canal. Already for a long time, at least since the 1830 s, a canal cutting through the Central American isthmus, connecting the Pacific and Atlantic Ocean, had been in the minds of those pleading for a greater global commercial and political role of the United States. It would give a boost to the Asian trade of the states on the American East Coast and would allow for a quick deployment of the American fleet stationed along that coast in the Pacific. Among those who were strongly in favour of the Panama Canal, was Mahan, who published an article specifically on the topic; in fact, a political pamphlet capitalising on the racial prejudices and the fear of Japan in the United States and the British colonies. ${ }^{16}$ Apart from this, his main argument was that such a connection would reduce the time in which an American fleet could reach

16 Disgust of Asian immigrants provided Mahan yet another argument in favour of speeding up the digging of the Panama Canal. The new sea route would facilitate the flow of labour from 
Hawaii from the Atlantic Ocean, from four months to less than four weeks (Mahan 1911: 26).

In June 1902 the American Senate agreed to the digging of the Canal. The first obstacle that had to be surmounted was easy to remove. In 1903 the United States, with Roosevelt still as President, actively supported a rebellion in Panama against Colombian rule. It did so after the Colombian Senate had refused to assent to the leasing of land where the Panama Canal was intended to be dug. Panama became independent in November 1903. A few months later, in May 1904, work on the canal commenced. In 1906-07 the emergence of Japan as a potential enemy gave the digging of the canal an additional urgency. A shortcut between the Pacific and Atlantic Ocean became a vital element in American strategic thinking. Work was speeded up, though it would take until 1914 before the first ships sailed the canal.

With the incorporation of the Philippines and Hawaii, a real American Empire had taken shape; and it was proudly referred to as such by contemporaries. Dulles (1938:10) wrote in 1938 that with the acquisition of Hawaii and the Philippines, the United States had taken its 'place as an accepted World Power' and had gained 'a new voice in the determination of the policies of the Far East, a new importance in the balance of power in the Pacific'.

The empire sufficed. Though there were suggestions to establish a foothold in China, the United States stayed aloof from this. Instead, Washington embraced the Open Door policy and free trade in China. Having acquired Hawaii and the Philippines, both presented as being beneficial to American China trade, the United States left no doubt that it wanted unrestricted access to Chinese markets. In the autumn of 1899 John Hay, by then Secretary of State, sent his so-called Open Door Notes to the other powers (including Italy). Apprehensive about the Anglo-Russian Railway Agreement of April 1899, and under the wrong impression that London had come to an agreement with Berlin over Germany's special rights regarding railways and mining concessions in Shandong, to the detriment of American producers of mining machines and other equipment, Hay formally asked the other powers to uphold China's territorial integrity and 'perfect equality of treatment for their commerce and navigation' in the regions in China under their control. ${ }^{17}$ In Hay's own words, his initiative was 'eminently successful', concluding so even before Germany and Italy had responded (New York

Europe to the American west coast. Not having to use the American transcontinental railway would make the journey from Europe considerably cheaper (Mahan 1911: 19-20).

17 Hay to Bülow 6-9-1899 (cited in Millard 1906: 185). In coming to this conclusion Hay may have been misled by the Anglo-German Financial Agreement of 1898 . 
Times 3-1-190o). All reacted positively; providing of course that their rival powers would do the same. Hay's step was hailed in Great Britain as a 'signal success of American policy' and a significant change in American foreign policy, with Washington for the first time taking an active interest in global politics. ${ }^{18}$ In the United States itself, Hay's adviser on Far Eastern affairs, William Woodville Rockhill (who had been instrumental in drafting the Open Door Notes), concluded that Washington had taken over the 'sceptre of Open Door Champion'. ${ }^{19}$ He was also sure that one of the reasons why Hay had succeeded was because of the American presence in the Philippines, not that far away from China (Miller 1982: 135). Hay's name became coupled with America's China policy. About ten years later, Americans still referred to 'Hay's policy of the open door' (New York Times 7-1-1910). America's role in advocating the Open Door in China would only become more pronounced in the years to come, when that other early advocate, Great Britain, assumed a less vocal role on the issue due to political considerations and, some would observe, to its cowardice in confronting Russia and Japan.

18 Walton and Buchanan in House of Commons 30-3-1900 (hansard.millbanksystems.com/ commons/1900/mar/3o/british-commercial and political-interests-in-china).

19 www.americanforeignrelations.com/O-W/Open-Door-Policy-Laying-down-the-policy. 


\section{The Partition of Samoa}

The American Empire was not yet complete. There was still another flashpoint in the Pacific: Samoa. Peace, if one might call it so, had not lasted long in Samoa and the archipelago once more became a focus of intense international rivalries and unpleasantness at the end of the $1890 \mathrm{~s}$. This time the British and Americans were the aggressors, but the Germans with their new Weltpolitik were equally belligerent. Some were convinced that the previous deal had been to the detriment of their country. Or, as Rear Admiral Diederichs wrote to his wife, 'we bear the costs and others earn the profits.' Again, the three powers and their navies became involved in strife in Samoa with Great Britain and the United States supporting one of the domestic warring parties, Germany the other. Tension had increased after Malietoa Laupepa died in August 1898. In Berlin Bülow saw Laupepa's death as an appropriate moment to plead for a partition of the islands, but failed to win the support of Washington and London. What was to follow were, in the words of an Australian journalist, 'events ... as grotesque as one of Gilbert and Sullivan's comic operas, and yet serious enough to unsettle the relationship of three great treaty Powers'. He also observed that 'Americans and English blamed the Germans for the whole trouble. The Germans blamed the British. Both sides blamed the French priests. Some blamed the London Mission' (The Sydney Mail 18-2-1899).

There were two candidates to succeed Laupepa. One was Mata'afa Iosefo, who was allowed to return home from Jaluit in September. He was, the British remarked, 'perhaps the most able Chief in Samoa', but in the past he had not been able to acquire Western support. Being a Catholic did not make him popular among British and American missionaries, while at the Samoa Conference in Berlin in June 1889 Bismarck had made it plain that Germany would never consent to his accession to the throne. In the eyes of the three powers he had disqualified himself because of his 'turbulent disposition' - even his father would have cursed him on his deathbed - and his 'hostility to Europeans.' ${ }^{2}$ Nevertheless, it was Iosefo whom the Germans came to support ten years later. 'Berlin doubtless thought that Mataafa had been sufficiently schooled in the discipline he had undergone in the Marshall Islands', a civil servant of the British Foreign Office wrote; a suspicion

1 Diederichs to his wife 15-11-1897 (Knoll and Hiery 2010: 52).

2 Memorandum Foreign Office 14-6-19oo (PRO FO 534 90). 
shared in Washington (Nuhn 2002: 95). ${ }^{3}$ In November, shortly after his return home, his supporters declared him King. The other candidate was Malietoa Tanumafili, or Tanu for short, the eighteen-year-old son of the deceased King. He received the backing of Great Britain and the United States; his enemies said he was influenced by the London Missionary Society. Of the two, Iosefo was the more popular; Germans would even claim that he had 'the support of go per cent of the Islanders and a majority of the foreign population' (New York Times 9-3-1899).

Realising that it was very likely that civil war was to follow Laupepa's death, the three powers met in Berlin and agreed that any dispute that would evolve over the succession was to be referred to the ChiefJustice William Lea Chambers; in office since 1897, and in his own words 'an American expansionist'. Chambers would add fuel to the fire and embarrass his own government, by having his low opinion of the German behaviour in Samoa published in the American press (New York Times 16-2-1899, 10-3-1899). To the Germans it was clear: '[H]is aim was to drive Germany out of Samoa'. ${ }^{4}$ Chambers and Dr John Raffel, the President of Apia's Municipal Council, a German official appointed by Berlin, could not see eye to eye; their conflict the result of as well as a contributing factor to American-German animosity. A proposal made in November by the German consul to have the 'fighting men' of both sides lined up and counted, giving the throne to the one who could assemble the most warriors, was turned down. This, a civil servant of the British Foreign Office wrote, was not a Samoan custom, admitting that probably Iosefo would have won such a contest. ${ }^{5}$

On New Year's Eve, recalling that at the Samoa Conference of 1889 Iosefo had been excluded from the kingship, Chambers ruled in favour of Malietoa Tanumafili; a decision Raffel blamed the London Missionary Society for. Tupua Tamasese Lealofi became Deputy King. He was a son of Laupepa's old rival, Titimaea, who had died in 1891, and who had risen in rebellion against Laupepa in 1894. He did so, Chambers wrote to his brother, after 'a trial of eleven days, of political investigation, two sessions each day, a hard study of Samoan genealogies, customs, titles, and practices every night' (New York Times 16-2-1899). The American and British consuls came out in support of Chambers' ruling, referring to the 1889 agreement; their German colleague against. The American consul issued a proclamation

3 Ibid.

4 Bülow to Holleben 20-2-1899 (E.T.S. Dugdale, German Diplomatic Documents, Ch. IV, Samoa, August, 1898, to November, 1899; www.mtholyoke.edu/acad/intrel/dugdale/samoa.htm).

5 Memorandum Foreign Office 14-6-190o (PRO FO 534 90). 
starting with the sentence: 'To American Citizens in Samoa: Living many thousand miles away from our native land, the opportunity rarely comes when we can serve our country and preserve its honor' (New York Times 24-2-1899).

Violence erupted immediately. Iosefo and his followers, who had already threatened to kill Chambers, took up arms. On 1 January they occupied Apia with, The New York Times (16-2-1899) reported, 'German sympathisers leading the armed troops of the Mataafa faction, into the streets of the municipality'. Barricades were erected in its streets and Mataafa's men went on the rampage, looting and burning the houses of their opponents and attacking the unarmed supporters of Tanumafili. British and American residents were also targeted. 'Apia was at the mercy of 4,000 exited Mataafans, many of whom were armed with guns', a memorandum by the Foreign Office in London said. ${ }^{6}$ The leaders of the German community, Consul General Friedrich Rose and Captain Victor Schönfelder of the cruiser the Falke, the only German warship in Apia, refused to intervene, and to calm down with words or with military action Iosefo's men, who had taken control of Apia.

Tanumafili and Lealofi had to take refuge on a British cruiser, HMS Porpoise, as had Chambers and his family. Within days, the American and British consuls confronted with Iosefo's position of strength agreed to a proposal by Rose and Schönfelder to form a provisional government. Headed by Iosefo, it had Raffel as its 'chief executive head officer', treasurer and adviser (Nuhn 2002: 98). Next, on 6 January, Raffel also appointed himself interim Chief Justice. He had done so, he would explain later, because the provisional government 'could not recognise a court to whose decision it was in antagonism' (New York Times 9-3-1899). On 7 January a detachment from the Porpoise occupied the court house allowing the British and American consuls to reinstate Chambers. The British and American flags were hoisted over the court house and Chambers' house. It was a futile action. Chambers still had to take refuge on the Porpoise. Iosefo and his followers remained in control of Apia. 'All respect for law vanished under the natives' when the new government was announced, the civil servant of the British Foreign Office noted, stating elsewhere in his report that 'insecurity and anarchy' only became greater after Raffel left Samoa for Germany at the end of February. ${ }^{7}$ He had been relieved from his post because he had acted too 
rashly for Berlin's taste, where it was admitted that Raffel and Rose had made serious mistakes. ${ }^{8}$

In late January a second British warship, the corvette Royalist, arrived, while on 6 March they were joined by the American cruiser, the Philadelphia, the flagship of the American Pacific Station. The arrival of the Philadelphia provided the commander of the Porpoise, Captain F.C. Doveton Sturdee, who was looking forward to joint action, with the much needed support. ${ }^{9}$ With the arrival of the Philadelphia the 'storm in the tea-cup at Apia' (the qualification is from the Semarang newspaper De Locomotief (10-4-1899)), took a nasty turn. On board the Philadelphia was Rear Admiral Albert Kautz, newly appointed Commander-in-Chief of the American Pacific Station. Kautz was set on solving the problem, even if it had to be by force. He had been instructed by his government 'to act in concert with the majority of the Consular Representatives of the Treaty Powers' (Gilson 1970: 429). Thus, with the approval of the British, but against the will of Rose and Schönfelder, he abolished the provisional government of Iosefo on 13 March, and installed Tanumafili on the throne. In response, Rose issued a proclamation in support of Iosefo.

A new upsurge of violence was the result. American and British residents, if they had not already done so, took refuge on the British and American warships. About 300 men, women and children from the Tanumafili camp fled to the British consulate. On 14 and 15 March Kautz twice ordered Iosefo to leave Apia and accept the abolishment of his government. He also threatened to shell Iosefo's troops on land, apparently not caring that such a bombardment might harm DHPG plantations, as indeed it did, forcing the German residents to evacuate to the Falke (Nuhn 2002: 100-1).

When on 15 March, just half an hour after Kautz' ultimatum had expired, Iosefo's men attacked the American and British consulates at noon and others set out by canoe for Mulinu'u, Kautz decided that the time had come to act. The Philadelphia opened fire and together with the two British warships bombarded the coastal villages held by Iosefo and his supporters. Landing parties were sent ashore to burn down villages (ibid.: 101). Sturdee - who would have a successful career in the navy, becoming Admiral of the Fleet in 1921 - was quite happy with this, talking with a reporter of how boring patrols were and how much fun it was to shell the coast (Miller 1982: 164). During one of the raids, a combined American-British

8 Holstein to Hatzfeldt 20-1-1899 (E.T.S. Dugdale, German Diplomatic Documents, Ch. IV, Samoa, August, 1898, to November, 1899; www.mtholyoke.edu/acad/intrel/dugdale/samoa.htm). 9 Sturdee to Pearson 7-3-1899 (Translated in Nuhn 2002: 256). 
force suffered fourteen casualties. As a result of Iosefo's men attacking the British and American consulates Apia also came under fire. One shell from the Philadelphia caused not only physical but also political damage. It hit the American and German consulates. Its pieces battered the leg of an American marine and destroyed the kitchen utensils of the German consulate (De Locomotief 15-5-1899). Berlin protested in Washington and London. McKinley personally apologised to Wilhelm II for Kautz' action and the shelling of the German consulate. Though Washington had had to restrain Kautz, he would later be commended by the American Congress for the resolution he had shown (New York Times 7-2-1907). London refused to take a similar step, blaming all turmoil on manipulations by the German consul (Nuhn 2002: 104).

The fighting added to the German resolve to expand its fleet. The Falke had been powerless against the joint Anglo-American naval operation (at the end of March yet another British cruiser, the Tauranga, had arrived in Apia). When the Falke returned home Wilhelm II addressed her crew, and expressed the hope that the days would be near that Germany could send more, bigger and more powerful warships to distant seas to protect German interests and have other powers 'respect its just aspirations' (Nuhn 2002: 231). Samoa confirmed Wilhelm II in his opinion that Germany needed a strong navy. As he scribbled in the margin of letter from Bülow in April 1899, he had told this to 'those morons of the Reichstag' almost daily (ibid.: 104). The other champion of a strong German fleet, Tirpitz, may even have believed that the Samoa confrontation was part of a devious British plan, a prelude to a pre-emptive war to prevent Germany from realising its ambition to surpass Great Britain as a naval power (ibid.: 104).

In between the fighting and shelling the British and Americans succeeded in installing Tanumafili. On 23 March, accompanied by a military escort with a music band marching in front, he was driven in a barouche to Mulinu'u where he was crowned. The British and American warships fired salutes. The British also took it on themselves to arm his troops (Gilson 1970: 429).

\section{New negotiations}

To find a solution, Berlin suggested sending a joint commission to the islands. London and Berlin briefly quarrelled over the question of whether its decisions and recommendations should be taken unanimously or by a majority of votes. In April, and only after the German government had 
threatened to withdraw its ambassador from London, Great Britain agreed to the first option. The commissioners who arrived in May succeeded in restoring peace. This proved amazingly easy. Samoans and settlers appeared to have been war-weary. As one of its first steps, the commission enforced the disarmament of all Samoans. Tanumafili and Iosefo complied. As the American commissioner Bartlett Tripp reported to the State Department: "The war song is discontinued, the war camp is abandoned, and the happy joyous nature of this unrevengeful people manifests itself in the ready forgiveness of their enemies and their glad welcome of returning peace' (Dulles 1938: 132). The commissioners also agreed that it would be best if the kingship was abolished and Samoa would be administered by the three foreign consuls. On 10 June 1899 Tanumafili abdicated. On the same day, the joint commission declared the kingship abolished. The consuls took over, with Wilhelm H. Solf, the new President of the Municipal Council, as their adviser.

In July the Commission concluded that 'it would be impossible effectually to remedy the troubles and difficulties' in Samoa as long as the islands were 'under joint administration of the three Governments'. ${ }^{10}$ To have London, Washington and Berlin come to an agreement on its partition was not easy, also because what had happened in Samoa and in the Philippines had galvanised public opinion. In Great Britain Salisbury played the AustralianNew Zealand card to turn down German suggestions. If anything, the Pacific colonies wanted Samoa to be British. It definitely should not come under the control of Germany or another power. In the United States, in the words of Bülow, the self-confidence of 'that sensitive nation which is so difficult to deal with' had 'greatly increased by the successes against Spain'." There was, also because of the actions of Diederichs' squadron in the Philippines, a strong lobby for maintaining the American presence in Samoa (Immerman 2010: 142). This was all the more so because the war with Spain and the acquisition of the Philippines had made Washington decide to upgrade the coaling and repair facilities in Pago Pago. In Germany the shelling of villages, the damage done to the German consulate, the destruction of German estates and the sudden reverse in German fortitude made indignation swell. To some, for instance Reichstag member Adolf Lehr, the military intervention had been yet another illustration of Great Britain's

10 Anglo-German Samoa Convention of 14 November 1899, Preamble (Knoll and Hiery 2010: 57).

11 Memorandum Bülow 14-3-1899 (E.T.S. Dugdale, German Diplomatic Documents, Ch. IV, Samoa, August, 1898, to November, 1899; www.mtholyoke.edu/acad/intrel/dugdale/samoa.htm). 
continuous obstruction of Germany's colonial ambitions (De Locomotief 18-5-1899). The political elite joined in. His pride hurt, the Kaiser spoke out in favour of a speedy annexing of Samoa (Nuhn 2002: 103-4).

Initially, the German government tried to solicit British support to persuade the United States to leave Samoa. This was the last thing the American government wanted to do, enthralled as it and its advisers were by Pago Pago. Tripp shared the belief in the strategic location of Pago Pago with the earlier American commissioner Bates. McKinley was of a similar opinion. Citing the needs of the American navy and America's 'growing commerce with the East', he refused to give up Pago Pago, which he said was 'the best anchorage in the Pacific' and had 'been leased to the United States by the first foreign treaty ever concluded by Samoa' (Dulles 1938: 135). This might be an exaggeration, but Pago Pago was certainly a better port than Apia. Salisbury refused to be drawn into a German-American dispute. He did not, as he expressed it, want to put his 'hand into a wasp's nest' (Massie 1993: 257). London also turned down Berlin's next proposal, resembling the Tonga-Samoa swap suggested by Germany in the 1880s, that Great Britain should part with any claim in Samoa in return for compensation elsewhere.

The diplomatic quarrel that Great Britain and Germany became entangled in resembled in intensity the quarrels they had fifteen years earlier over the respective spheres of influence in New Guinea and parts of Africa. For Germany much was at stake, also emotionally. The islands had figured prominently in Germany's colonial policy for almost two decades and, in Bülow's words, were synonymous with 'the birth of our colonial aspirations. ${ }^{12}$ Berlin realised that Samoa mattered much more to Germany than it did to Great Britain, but thought that it could strengthen its negotiating position by threatening to make common cause with London's adversaries. In April 1899 the Russian ambassador in Berlin, Count von der Osten Sacken, had suggested that Russia, France and Germany might 'join mutually in guarding and furthering their respective interests in Asia, e.g. the Persian Gulf'; a possibility Berlin did not fail to make the British government aware of. ${ }^{13}$

The agreement on the joint commission had not improved Anglo-German relations. In early May Bülow complained about the 'harsh and open

12 Bülow to Hatzfeldt 6-5-1899 (E.T.S. Dugdale, German Diplomatic Documents, Ch. IV, Samoa, August, 1898, to November, 1899; www.mtholyoke.edu/acad/intrel/dugdale/samoa.htm).

13 Bülow to Hatzfeldt 10-4-1899, Bülow to Hatzfeldt 6-5-1899 (E.T.S. Dugdale, German Diplomatic Documents, Ch. IV, Samoa, August, 1898, to November, 1899; www.mtholyoke.edu/acad/ intrel/dugdale/samoa.htm). 
hostility' of Great Britain. ${ }^{14}$ The diplomatic conflict became even more delicate when Wilhelm II personally intervened. On 22 May he sent an angry letter to Queen Victoria, his grandmother, complaining about the role of Salisbury in the Samoa affair. Salisbury's behaviour, he wrote, had been 'utterly at variance with the manners which regulate the relations between Great Powers according to the European rules of civility ... and has evoked the impression that Lord Salisbury cares no more for us than for Portugal, Chile, or the Patagonians'. The letter 'greatly astonished' the Queen, who, signing as 'Grand Mama', responded in kind. She doubted, as she stated in her reply, 'whether any Sovereign ever wrote in such terms to another Sovereign, and that Sovereign, his own Grandmother, about their Prime Minister'. What Wilhelm II had done was an affront: 'I never would do such a thing, and I never personally attacked or complained about Prince Bismarck, though I know well what a bitter enemy he was to England and all the harm he did' (Massie 1993: 258-9).

What had irritated Wilhelm II was that Salisbury had not been in a hurry to act, and also had not apologised for the bombardment in March, as Washington had done. Salisbury had his answer ready. He could not think of a letter that had remained unanswered and Great Britain had not apologised because it had been an American warship that had shelled the German consulate, not a British one. ${ }^{15}$ Wilhelm's letter made no difference. Salisbury would, he told the German diplomat Hermann von Eckardstein a kind of go-between between the British and German governments, not 'be dictated to by Berlin with a stop-watch' (Massie 1993: 260). London's silence upset Wilhelm II and the German government even further. Probably on purpose, Salisbury waited for weeks before reacting to the Samoa crisis. Worse, perhaps, he also remained silent on the explicit wish of the Kaiser to visit Great Britain when the latter, to his bitter disappointment, had not been invited to celebrate Queen Victoria's birthday in May.

The Colonial Secretary, Joseph Chamberlain, afraid to offend Australia and New Zealand by abandoning Samoa, did discuss the matter with German ambassador Paul von Hatzfeldt. He did so in a way that did not please Berlin. Claiming that German interests 'were on the decrease at Apia', he suggested that Germany give up the islands in return for the Gilbert Islands,

14 Bülow to Hatzfeldt 6-5-1899 (E.T.S. Dugdale, German Diplomatic Documents, Ch. IV, Samoa, August, 1898, to November, 1899; www.mtholyoke.edu/acad/intrel/dugdale/samoa.htm).

15 Memorandum by Salisbury (E.T.S. Dugdale, German Diplomatic Documents, Ch. IV, Samoa, August, 1898, to November, 1899; www.mtholyoke.edu/acad/intrel/dugdale/samoa.htm). 
'which had good harbours'. ${ }^{16}$ The British also advanced other possibilities for such an exchange in the Pacific (the southern Solomon Islands, Tonga, the Ellice Islands and Zanzibar) and Africa (Nuhn 2002:105). This was not what the German government and navy had in mind. They had no intention at all of parting with Samoa, with its bunkering facilities for German inter-Pacific sea traffic. Tirpitz even started a campaign to mobilise public opinion (Nuhn 2002: 106). In it he underlined the 'great strategic value' of Samoa as a naval station in between China and South America, which would become even more pronounced once the Panama Canal was in operation and 'new routes for the world's trade, and new strategic military routes' would have come into existence. ${ }^{17}$

On 8 November 1899 it was announced that Germany and Great Britain had reached an accord. According to this Anglo-German Samoa Convention, Germany was to stay in Samoa and the British would leave. Tonga was to become a British protectorate, which was formally laid down in the Anglo-Tongan Treaty of Friendship and Protection of 18 May 1900. In spite of earlier German opposition to the idea, Bülow had considered this option at least since August $1898 .{ }^{18}$ The British government could easily part with its claim on Samoa after the Admiralty had informed it that the navy had not the slightest interest in the islands. In the Admiralty's opinion the only port suitable as coaling station was Pago Pago, with which the Americans had no intention to part. Compared to Tonga and its Vava'u coaling station, Samoa was said to be of little value. Contrary to what he said in public Tirpitz seems to have been of a similar opinion. As so often happened in the Pacific, assets which not so long before had been called priceless, suddenly lost their importance. The Samoa ports were not as ideal as had been bandied around. The islands would never become the important German naval station that people had talked and written about.

On 14 November, little more than a fortnight after the signing of the Anglo-German Convention, the three powers agreed in Washington on the dividing up of the islands by the United States and Germany. With the partition of Samoa the last independent Pacific island groups disappeared. In accordance with the Tripartite Convention of 2 December 1899 the United

16 Hatzfeldt to German Foreign Office 25-3-1899 (E.T.S. Dugdale, German Diplomatic Documents, Ch. IV, Samoa, August, 1898, to November, 1899; www.mtholyoke.edu/acad/intrel/ dugdale/samoa.htm).

17 Tirpitz to Bülow 11-10-1899 (E.T.S. Dugdale, German Diplomatic Documents, Ch. IV, Samoa, August, 1898, to November, 1899; www.mtholyoke.edu/acad/intrel/dugdale/samoa.htm).

18 Bülow to Hatzfeldt 31-8-1898 (E.T.S. Dugdale, German Diplomatic Documents, Ch. IV, Samoa, August, 1898, to November, 1899; www.mtholyoke.edu/acad/intrel/dugdale/samoa.htm). 
Figure 30 The Partition of Samoa

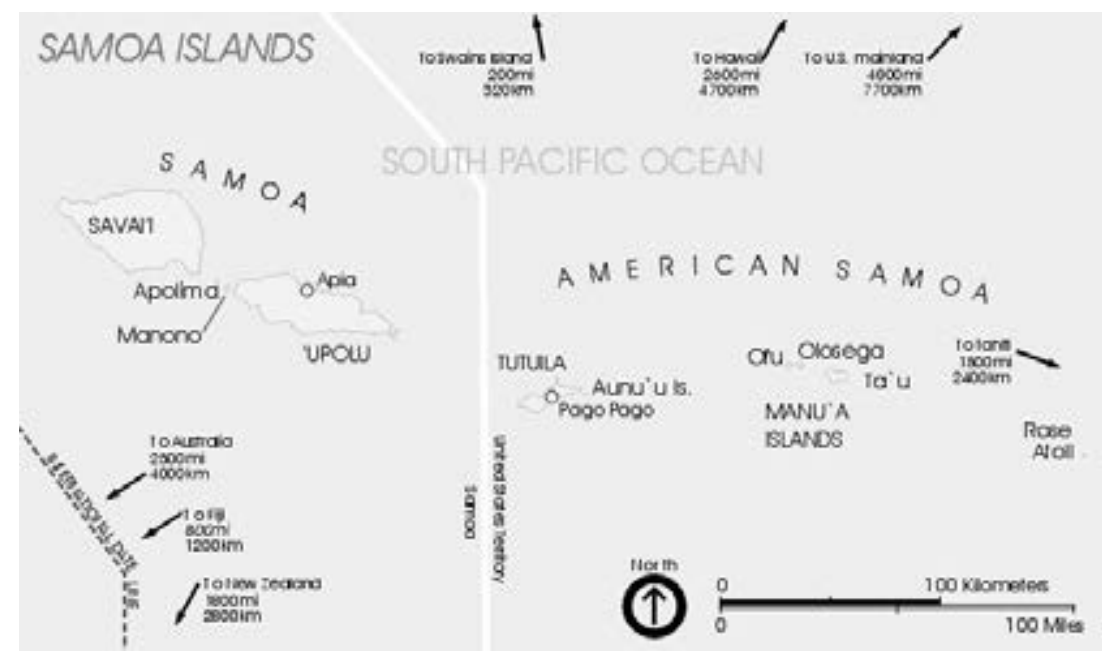

Source: en.wikipedia.org/wiki/File:Samoa_islands_2002.gft

States became the overlord of the eastern portion, while Germany took the western part. The dividing line was at 171 degrees east longitude. The two largest Samoan islands, Upolu and Savai'i, where most of the estates were located, became German; Tutuila and its harbour Pago Pago American. Great Britain's price for withdrawing was, apart from control over Tonga, the incorporation of two German islands, Choiseul and Santa Isabel in the Southern Solomon Islands, adjacent to the Bismarck Archipelago (the islands of Buka and Bougainville remained German, and now form part of Papua New Guinea); and a tract of land along the Gold Coast in Africa. In the Solomon Islands the Germans were allowed to continue to recruit labour albeit 'on the same conditions as ... imposed on British subjects non-residents in those islands'. ${ }^{19}$

The Samoans had to hand in their firearms. To settle the question of damage to property incurred during the fighting in the first months of 1899 the mediation of the King of Sweden and Norway was sought. The arbitrage only concerned the consequences of the military actions by the American, British and German navies. Benevolently, it was accepted that not only requests for compensation by their own subjects were to be dealt with, as had been the initial intent, but also of other foreigners in Samoa. Damage

19 Declaration attached to the Anglo-German Samoa Convention of 14 November 1899 (Knoll and Hiery 2010: $5^{8-9)}$. 
to property inflicted by Samoans was excluded from the mediation. Yet that should also be compensated and by the Samoans themselves, if only, as Salisbury wrote, 'in the interest of peace and order, it is much to be desired that the natives should be made to feel that the property of Europeans cannot be destroyed with impunity'. ${ }^{20}$

In the Reichstag Bülow presented the Samoa treaty as a great diplomatic victory for Germany. The Empire had had to leave Tonga to the British, but this was just a small, insignificant sacrifice. Germany's relations with those islands were 'of the loosest possible description' and trade with them had been 'steadily on the decline'. ${ }^{21}$ Bülow admitted what his predecessor fifteen years earlier had refused to: the commercial interests of Great Britain in Tonga were paramount. British trade was three times as big as that of Germany and with regard to shipping, Bülow explained, the ratio was even one to thirty. What Germany had relinquished was its 'right to protest against an eventual British occupation' and not much more. The same held for the Solomon Islands. Germany had parted with some islands, 'which were as yet underdeveloped, which afforded no favourable harbour accommodation, and possessed an unhealthy climate.. ${ }^{22}$ In return for these trifle gestures, Germany had received Western Samoa and Bülow did his best to present its benefits as impressively as possible. Apart from the material worth, Samoa's 'highest value', Bülow posed, 'was that which it possessed in the affection and pride of the German people'. Samoa's sentimental value, he continued, might be greater than its economic worth, but 'it should be borne in mind that much German blood had been shed and that the acquisition of Samoa had become for Germany a question of national dignity'. ${ }^{23}$ The American Secretary of State, John Hay, was equally jubilant. The United States had got more out of the deal than Germany or Great Britain. Pago Pago was 'absolutely indispensable' (Dulles 1938: 136). Others also considered the deal a success and an indication that the country counted in the South Pacific. The United States had 'appeared for the first time as a World power in the Pacific', H.M. Sewall (1900: 13) wrote.

In Great Britain, where the Boer War (1899-1902) was the political issue of the day, the reactions were more subdued. South Africa and the almost universally hostile reaction outside Great Britain to British aggression

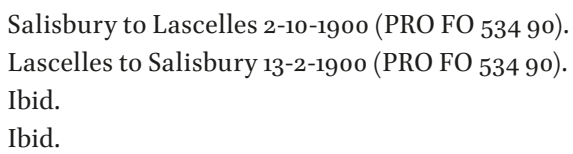


attracted the attention of politicians, the press and the public, not Samoa. It was this background that gave the Anglo-German Convention an additional dimension. For the British government a valuable reward of the Samoa settlement was Germany's reticence over a British annexation of the Boer Republics. As Baron Oswald von Richthofen, Under-Secretary at the Foreign Office, would assure British ambassador Frank Lascelles in February 1900, London no longer had to wonder about the German position. Germany would not meddle in the South Africa question and would reject any proposal of other powers to intervene. ${ }^{24}$ The turn in German policy made for suspicion about Germany having taken advantage of British predicaments and was a reason for at least one British historian to write in retrospect about Germany's 'diplomatic blackmail' (Kennedy 1985: 113).

As a symbol of Anglo-German rapprochement Wilhelm II, who a few years earlier after the Jameson Raid into the Boer Republic of Transvaal of December 1895 had infuriated the British by testifying to his sympathy for the Boers, visited Windsor in November 1899. He had yearned to come to Great Britain for some time, but the British government had been less enthusiastic about the idea (Massie 1993: 262). Wilhelm II's visit, made at a time when strong pro-Boer sympathies prevailed among the public in Germany, signalled the end - for the moment - of talk about a GermanRussian-French coalition directed against Great Britain. The latter now looked less isolated than it had appeared shortly before. The following month Wilhelm II saved London embarrassment by refusing to receive the Boer President, Paul Kruger, who had fled South Africa.

In the negotiations leading up to the Tripartite Convention, London had not consulted Australasian colonies (Nuhn 2002: 106). There, where people had followed London's steps with regard to Samoa so closely and suspiciously for years, there was a mixed reaction to the exchange of territory. The agreement, Lieutenant-Governor of Queensland, Samuel W. Griffith, wrote to Chamberlain, appeared to be 'highly favourable to the interests of the Australasian Colonies'. ${ }^{25}$ In New Zealand Prime Minister Seddon was of a different opinion. He left no doubt that he did not agree with the decision London had taken and used the opportunity to try to strengthen the Pacific position of New Zealand by pressing for an Island Federation, uniting New Zealand, Fiji (where part of the settlers preferred to join Australia) and a number of other island groups. In a memorandum 
to Chamberlain dated April 1900 he wrote that 'Great Britain, that civilised and Christianised them, that first traded with them, that has even now the most trade and the most white population, and that had spent much blood and treasure in the islands' had 'abandoned' the Samoa Archipelago to Germany and the United States. This had 'disheartened the natives of the islands, disappointed the people of Australasia, and lowered the prestige of Great Britain'. Action was needed 'at the earliest opportune moment' and Seddon suggested that the Cook Islands (a British Protectorate since 1888), Fiji, Tonga and Society Islands should be added to New Zealand's territory (The Press 18-7-1901, p.5). ${ }^{26}$ Samoa continued to figure prominently in the evaluations of the Pacific policy of the home government. In 1909 Seddon's successor Joseph Ward would still single out Great Britain leaving Samoa to the United States and Germany, as the moment when British command of the Pacific had become 'so doubtful' (Lawton 1912: 421).

\section{Samoa under foreign rule}

When news of the international agreement reached the islands, the life of the British acting consul, Hamilton Hunter, did not become easier. Coupled with what he described as 'grossly exaggerated accounts of our reverses in the Transvaal, circulated by certain disaffected and mischievous foreigners', it made British prestige in the islands reach a low. Iosefo's followers responded immediately. They who, 'though never very loving, were always respectful', he reported, changed their conduct. ${ }^{27}$

Another victim was Tanumafili. He had to leave Samoa for Fiji in November. The negotiators had agreed that he was to receive a grant of $£_{500}$, financed jointly by the three powers, to study in Australia for two years. Berlin could live with this, providing that Tanumafili would never set foot on Samoan soil again without German permission. After his stay in Australia, Salisbury and Eckardstein agreed in London in March 1900 that Tanumafili should be sent to the Bismarck Archipelago, 'where he would be maintained at the expense of the German Government, and would be able to live comfortably amongst other Samoans already residing there' ${ }^{28}$ His followers had to adapt to the new situation. They now 'willingly paid their

26 In 1900 the Cook Islands were formally annexed by New Zealand through an act of its Parliament.

27 Hunter to Salisbury 22-3-1900 (PRO FO 534 90).

28 Salisbury to Pauncefote 7-3-1900 (PRO FO 534 90). 
taxes, and offered most devoted congratulations at His Imperial Majesty the Emperor's birthday', Solf, the first Governor of German Samoa, wrote contentedly to Hunter in March. ${ }^{29}$ Tanumafili's adversary Iosefo fared better. He would become the German partner in administering West Samoa and as a token of his new status would be presented by Wilhelm II with a ceremonial German-made fly whisk (Graichen and Gründer 2005: 188).

Germany took formal possession of its portion of Samoa on 1 March 1900. Apia, a German eyewitness wrote, was full of German flags, while thousands of Samoans wearing garlands had come to the city from the hinterland (Nuhn 2002: 107). In the morning people went in procession from Apia to Mulinu'u, the old seat of the Samoa government, where the German flag was hoisted. A band from the Cormoran, a German cruiser, led the way, followed by members of the German Concordia Club, the Apia Brass Band and children from the mission schools, 'all dressed nicely, and carrying banners' and 'natives from all parts of the island', the Samoan Weekly Herald reported (Star 19-3-1900). Governor Solf himself had a special uniform fitted by a tailor of the Cormoran, which made him look quite martial with his epaulettes befitting an admiral and his topee, a German merchant remembered (Nuhn 2002: 107). As was usual with such ceremonies, Westerners, among them the American and British consuls, and in this instance also Iosefo and a number of other Samoan chiefs, had pride of place. Other Samoans had to stand further back. During the flag hoisting ceremony, Hunter noted, Iosefo 'was given an chair of honour within the square, on which he sat ... backed by some 4,000 or 5,000 natives, naked to the waist, and armed with axes, knives, spears, and clubs ... in fighting trim'. Chiefs siding with Tanumafili, 'accompanied by a few men ... dressed in white coats and loin cloth' had to take their stand on the road near the flagstaff..$^{30}$ Solf read a proclamation according to which the islands were placed under 'Imperial protection and rule'. Subsequently, the German flag was hoisted. Heil dir im Siegerkranz resounded and salutes were fired from the Cormoran and the American navy collier Abarenda, sent to Samoa to transport material and labourers for the upgrading of the Pago Pago coaling station. The day ended with a ball and other festivities in Apia, but Hunter, who had been present at Mulinu'u, refused to attend. Later, in August, in a speech to the Samoan chiefs in which he introduced Wilhelm II as the Paramount Chief of German Samoa, Solf stated that it was 'the Emperor's 
desire that the whole of Samoa would be happy and would prosper under German rule' (Gründer 1999: 135).

As Hunter's description of the Iosefo warriors indicates, not all was just garlands and nicely dressed school children. The atmosphere, and this must not have escaped many, was tense. It was difficult to reconcile the domestic factions in the Samoa conflict. There was ill-feeling between those backing Iosefo and those who supported Tanumafili and Lealofi. In the days preceding the first of March, Hunter reported to Salisbury, large boats full of Iosefo supporters arrived at Apia, while many others came to the city on foot. Disregarding an order by Solf that there should be no demonstrations and that of each faction only two hundred people were allowed to enter the city, Apia had been 'inundated by some 5,000 men, and the place was virtually in the hands of the rebels. ${ }^{31}$ During the flag hoisting ceremony they had 'grossly insulted' their enemies. It was only Iosefo's interference, and this was also reported in the newspapers, that had 'averted a general row, which must have ended in the slaughter of the Malietoans, and most probably the looting of the European portion of the Municipality'. ${ }^{2}$

The followers of Iosefo do not seem to have been very glad with their new status as German subjects either. They continued to refer to their leader as King and in the evening, Hunter narrated, the ball to celebrate the occasion in the Public Hall of Apia was disturbed by 'a constant shower of stones' thrown on its iron roof, while in the city itself Iosefo's men 'paraded the streets in gangs, many of them armed with sticks, and some of them drunk, singing war songs'.33

In contrast to the violence that had been so rampant in the previous decades the German period was relatively peaceful. Compared to Germany's colonies in Africa, German rule in Samoa, as in New Guinea, was relatively benevolent. Solf, himself an intellectual, had a low opinion of the settlers and was fascinated by Samoan culture, and at times acted 'like a native king' (Conrad 2012: 121). He protected indigenous land ownership and banned the recruitment and employment of Samoans as estate labourers. Labour had to be imported from other German possessions in the South Pacific and from China. DHPG was given the monopoly on labour recruitment in the Bismarck Archipelago and the German Solomon Islands (Hiery 1995: 9). As Taft in the Philippines, Solf was soon to find himself in a position comparable to that of Gordon in Fiji. His resolve to prevent any alienation 
of land owned by Samoans and in general his desire to preserve as much of Samoan culture as possible soon brought him in conflict with the white settlers (Steinmetz 2007: 317-8).

The American part of Samoa had, as a naval station, been placed by McKinley under the control of the Navy on 19 February 19oo. There, a flag raising ceremony took place on Tutuila at Pago Pago on 17 April. Supervising the ceremony was Benjamin Franklin Tilley, commander of the Abarenda, who had been appointed acting Governor. This time the Cormoran joined in the salutes. Absent, as it had been at Mulinu'u, was the Royal Navy. The ceremony took place after the chiefs of the island and those of the small nearby island of Aunu'u had ceded their territory to the United States. In the statement to that effect they expressed regret that the islands had been severed from 'the parent State' of Samoa. This was coupled with the plea that the American government would respect the rights of the Islanders to their land and property, and that an investigation of claims to land titles would be carried out. ${ }^{34}$ On 15 June the American flag was also raised on the Island of Ta'u, but it took until 14 July 1904 before the chiefs of the eastern islands of American Samoa, the Manu'a Islands, officially acknowledged 'full and complete sovereignty' of the United States. In their statement they expressed the hope that there would be no 'discrimination in the suffrages and political privileges' between the Samoans and American settlers. ${ }^{35}$

In the weeks before and after the start of World War One, the strategic location of Samoa and the Carolines would briefly attract international attention. A few days after Japan had declared war on Germany in New York, the Chamber of German-American Commerce, in a telegram to the Governor of California, drew attention to the danger that the Japanese might occupy the Carolines and German Samoa which would give them 'two fortified harbours between the Philippines and the United States'. 'With their enormous army and navy mobilisation' the Japanese might 'use this opportunity to make themselves the complete masters of the Pacific Ocean' $3^{6}$

34 Chief[s] of Tutuila [and Aunu'u] to United States Government, 17-4-1900 (www.asbar.org/ Newcode/treaties.htm, accessed 1-3-2012).

35 King and Chiefs of Manu'a to US Government 14-7-1904 (www.asbar.org/Newcode/treaties. htm, accessed 1-3-2012).

${ }_{36}$ Telegram of the Chamber of German-American Commerce 16-8-1914 (New York Times 17-8-1914). 


\section{The Russo-Japanese War}

After the Boxer Rebellion and the progress Russia had made in Manchuria, Great Britain briefly saw in Germany a partner in trying to prevent the partition of China and to halt a Russian expansion in Asia. Such a pact would have had the additional advantage that Great Britain would have found a European ally that could put pressure on the Russian western frontier; thus pinning down troops there that otherwise could be deployed for a further Russian military advance in northern China and along the frontiers of Afghanistan.

In London one of the people looking for a rapprochement with Berlin was Colonial Secretary Joseph Chamberlain. In doing so, Chamberlain made no friends in France, where one author, Darcy (1904: 22-3), presented him as the quintessential British politician out to harm the interests of France all over the world. One of the reasons was Chamberlain's 'intemperance of language', as Darcy put it. He had offended the French by airing the opinion that for better relations between the two countries it was necessary that France stop obstructing and embarrassing Great Britain all over the world as it had done for so many years. Nowhere, Chamberlain maintained, had the French shown any consideration for British sensitivities and interests, including, in his observation, Thailand and China (ibid.: 23). In March 1898 Chamberlain had already confided to the German ambassador in London, Paul von Hatzfeldt, that the days of British splendid isolation were over and had suggested that London and Berlin should find a solution for the 'few little colonial differences' they had. ${ }^{1}$ Berlin had not warmed to the idea, doubtful as German politicians were that Great Britain would honour an Anglo-German defence treaty, if Germany were to be attacked. ${ }^{2}$ Chamberlain renewed his efforts during Wilhelm II's visit to Windsor. With Salisbury conspicuously absent, he discussed with Wilhelm II and Bülow an alliance of Germany, Great Britain and the United States. Nothing came of it. The German government, Bülow told Chamberlain, did not want to antagonise Russia, with which it shared an extensive border (Massie 1993: 267). Chamberlain was not deterred. After the Kaiser and his entourage

1 Hatzfeldt to German Foreign Office 29-3-1898 (E.T.S. Dugdale, German Diplomatic Documents, Vol. III, The Growing Antagonism, 1898-1910; www.mtholyoke.edu/acad/intrel/dugdale/ Kiao-Chou.htm).

2 Bülow to Hatzfeldt 30-3-1898 (E.T.S. Dugdale, German Diplomatic Documents, Vol. III, The Growing Antagonism, 1898-1910; www.mtholyoke.edu/acad/intrel/dugdale/Kiao-Chou.htm). 
had left, he raised the topic of a 'new Triple Alliance between the Teutonic race and the two great trans-Atlantic branches of the Anglo-Saxon race' in a speech at Leicester at the end of November (Taylor 1971: 389; Massie 1993: 268).

Still, a deal was struck, albeit a feeble one. In October 190o, in the AngloGerman Agreement, Berlin and London pledged 'that the ports on the rivers and the littoral of China should remain free and open to trade and to every other legitimate form of economic activity for the nationals of all countries without distinction' and agreed 'to uphold the same for all Chinese territory so far as they can exercise influence'. Neither Great Britain nor Germany would 'make use of the present complications to obtain for themselves any territorial advantage' and would 'direct their policy towards maintaining undiminished the territorial conditions of the Chinese Empire'. ${ }^{3}$

Those in favour in Germany had their own specific motives for entering the agreement: to safeguard German mercantile activities in the Yangtze Valley; which some British, like Colquhoun (1902: 45), were sure was the object of a stealth German penetration. In July 1900 Eduard von Derenthall, Under-Secretary at the Foreign Office, had stressed this point in a telegram to Bülow: 'The question which governs everything is the Yang-tze. Since we cannot count on monopolising it - at least for a long time to come - we should at least aim at preventing England from doing so'. ${ }^{4}$ Reflecting this view, the treaty was referred to by Bülow, who was attributed with having coined the phrase, and other German politicians as the Yangtze Agreement.

Germany secured its Yangtze object but did not want to risk a confrontation with Russia. Initially, Berlin had even tried to exclude Manchuria altogether from the scope of the Anglo-German Agreement. The formula chosen was, in the end, vague. As the British envoy in Tokyo, Claude Maxwell MacDonald, noted, not mentioning Manchuria by name had resulted in 'manifestations of hostility' in Japan, where there was a suspicion that should it come to a dividing up of China in exclusive spheres of influence, Japanese trade and investments could well be barred in the Russian, German and French zones ${ }^{5}$ (Temple 1902: 286). The way Berlin had wanted to phrase the treaty, on the other hand, had been unacceptable to London. It might have sparked off a new scramble for China, which Great Britain could

3 Agreement between Salisbury and Hatzfeldt 16-10-19oo.

4 Derenthall to Bülow 27-7-19oo (German diplomatic documents, 1871-1914, selected and translated by E.T.S. Dugdale, Ch. VIII, The Boxer Rebellion, www.mtholyoke.edu/acad/intrel/ dugdale/boxer.htm).

5 MacDonald to Lansdowne 9-4-1901 (PRO FO 539). 
not and would not take on. According to the initial draft, Great Britain and Germany would not try to stop the Russians in Manchuria. Were Russia to occupy Manchuria, then the two would hold themselves absolved and prepare to take steps to safeguard their interests in other quarters without troubling about Manchuria in which their interests are but small'. ${ }^{6}$ Within six months, in March 1901, Bülow, speaking in the Reichstag, left no doubts that his country did not feel committed by the Anglo-German Agreement to act to defend the integrity of Manchuria (and certainly would not act as a counterweight against a French fleet coming to the assistance of Russia, as politicians in Great Britain and Japan initially had concluded). ${ }^{7}$ In London Eckardstein had a similar message. He informed British Foreign Secretary Lansdowne that Berlin 'would regard with disapproval the establishment of a Russian Protectorate over Manchuria, [but] did not consider the German interests in that part of China were sufficiently marked to justify Germany in going to war in order to protect them'. ${ }^{8}$ As the German envoy in Japan was also to state, 'Manchuria was nothing to Germany but everything to Japan'. ${ }^{9}$ China was made to understand that for every concession it made to Russia in Manchuria, Germany expected a similar compensation in Shandong. ${ }^{10}$

Publicly, the British government stressed a different interpretation. In the same month that Bülow made his statement the British Under-Secretary of State for Foreign Affairs, Viscount Cranborne, said that the second clause of the agreement regarding the territorial integrity of China was 'without qualification'. ${ }^{11}$ Nevertheless, by that time there was a tendency, also in Great Britain, to accept Russian control over Manchuria as a fait accompli. It even seemed that the British had lost interest in the Far East. Attention focused on South Africa and the Boer War; though some politicians felt compelled to point out that from the perspective of British trade China was of 'greater importance than ever the South African question had been'. ${ }^{22}$

The United States and Japan were other options. They shared with Great Britain the desire for unobstructed trade in China. Or, as Colquhoun

6 MacDonald to Lansdowne 23-1-1901 (PRO FO 539).

7 Lansdowne to MacDonald 16-3-1901 (PRO FO 538 ).

8 Ibid.

9 MacDonald to Lansdowne 21-3-1901 (PRO FO 539).

10 Lessar to Foreign Ministry 2-12-1903 (cited in Soroka 1911: 68).

11 Cranborne in House of Commons 19-3-1901 (hansard.millbanksystems.com/commons/1901/ mar/19/anglo-german-agreement-and-manchuria).

12 Ashmead-Bartlett in House of Commons 10-12-19oo (hansard.millbanksystems.com/ commons/190o/dec/1o/british-interests-in-china). 
(1902: 45) warned, at a certain point in the future their commerce might be confronted with 'a Russian China, a German China, a French China, all under protective tariffs which must effectually put an end to any hope of the open door'. In view of such shared interests Chamberlain had already, in February 1898, suggested concerted Anglo-American action to uphold free trade in China. Washington had reacted with sympathy, but had not committed itself (LaFeber 1998: 358). China was also discussed in the margins of the Samoa talks, but Washington, as adverse to concrete pacts as London had been for so long, and not happy with Germany's new foothold in China, preferred to stay clear of international agreements. Manchuria made the United States not averse to forging closer ties with Great Britain and Japan, but as Hay's Open Door Notes would show, Washington preferred an appeal to endorse free trade over a formal treaty and the commitments this might entail.

It was Japan and Great Britain, both still without formal allies, who found each other in their shared concern over Russia's plans in north Asia. Japan viewed with apprehension Russian efforts to gain military or political hegemony in Manchuria; an anxiety further fortified by belligerent words from St Petersburg. 'Russia has been made, not by diplomacy, but by bayonets ... and must decide the questions at issue with China and Japan with bayonets and not with pens', the new Russian Minister of the Interior, Dmitry Sipyagin, appointed in 1900, was to state (Hopkirk 1994: 509).

\section{Preparing for war}

St Petersburg 'pouring troops into Manchuria', as Beresford (1899:61) phrased it, made London look all the more impotent in defending the interests of its merchants and investors in north China. The latter, from their side, already considered Manchuria to be a Russian province in all but name (ibid.: 40-2). In Japan the Russian military build-up in Manchuria in the closing years of the century made an equally worrying impression, if only because it gave Russia a menacing presence not only with regard to China but also vis-à-vis Korea and, on the opposite side of the Sea of Japan, Japan itself. Tokyo indicated that Japan could live with a Russian Port Arthur, but that Russia should not occupy Manchuria. After all, Russia's position in Port Arthur was temporary, and did not, as Manchuria did, touch the frontier of Korea. ${ }^{13}$ Still, military circles and the press in Japan called for war. 
There was a feeling that Japan had to strike quickly. It could hardly afford the costs involved in expanding its armed forces for a considerable time, while the longer Japan waited the more reinforcements Russia could send from Europe to the Far East over its Trans-Siberian and Trans-Manchurian Railways. Similar financial considerations made others in Japan hesitant to go to war, aware as they were that Japan did not have the money to sustain a prolonged armed confrontation. He was confident, Japanese Minister of Foreign Affairs Kato Takaaki confided to MacDonald in March 1901, that the Japanese army and navy were strong enough to deal a blow to the Russian armed forces, but, he continued, 'that would be the end of our tether - and it certainly wouldn't be the end of the war'. ${ }^{14}$

Russia refused to withdraw its army. St Petersburg persisted that the Russian presence in South Manchuria only concerned Russia and China and that Beijing still held suzerainty over South Manchuria. It also claimed that in view of the rampant disorder in South Manchuria Russia had every right to send in troops. This was even presented as an act of goodwill. Russian Foreign Secretary Lamsdorff, himself in favour of avoiding war with Japan, informed the Japanese government that Russia would not exercise, what he called, its 'right of conquest' in Manchuria. ${ }^{15}$ Troops were only temporarily deployed to protect Russian economic interests and Russian lives and property and would be withdrawn once order had been restored and St Petersburg and Beijing had come to an arrangement over the protection of the Russian railways and other matters, i.e. mining concessions. ${ }^{16}$ No other power should interfere. The British ambassador Charles Scott was told that a Russian occupation of Manchuria 'might be permanent if obstacles were placed by other powers in the way of the Emperor's intentions'. ${ }^{17}$

Lamsdorff's pledge of a future withdrawal of Russian forces defused some of the tension. Tokyo indicated that the immediate cause of 'solicitude' had been removed and it was willing to enter into negotiations once the situation of before November 1900 had been restored.$^{18}$ One sensitive point remained: the Shenyang agreement of Alexeiev and the Chinese commander in Manchuria of November 1900. Tokyo informed Beijing and London that its ratification would be 'a source of danger' to the Chinese government. China should refrain from transferring territorial rights anywhere in its

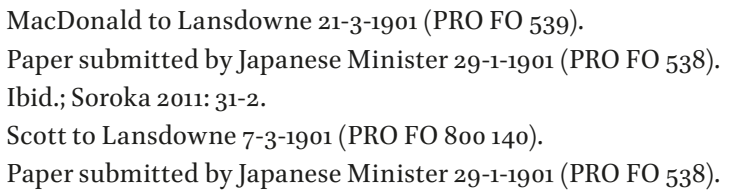


territory to any of the powers. ${ }^{19}$ Should it give Russia preferential treatment in Manchuria, Japan would seek similar concessions elsewhere in China. ${ }^{20}$ In a similar vein, London - claiming to have 'important interests in certain parts of Manchuria' - warned the Chinese government not to conclude 'separate agreements of a political, commercial or financial nature' that were detrimental to the interests of other powers (and expected Germany, in view of the Anglo-German Agreement, to do the same, which it did not). ${ }^{21}$ Russia did not press on. In April 1901 London and Tokyo were informed that there would be no Shenyang treaty.

The Russian assurances did not remove the threat of war. Japan sounded out London and Berlin on how they would react should it come to an armed confrontation. Berlin indicated that Germany would stay out of such a war and introduced the term 'benevolent neutrality'. The phrase bewildered British and Japanese politicians alike. The Japanese ambassador in Berlin took it to mean that Germany had pledged to 'keep the French fleet in check', an interpretation that was initially taken over by his government. ${ }^{22}$ In London Lansdowne also did not know what to make of it, but had doubts about the Japanese interpretation: 'Benevolent neutrality was an expression the precise import [of which] was not evident to me. An attitude which would keep the fleet of another Power in check could scarcely be described as neutral'. ${ }^{23}$ As it turned out, Berlin had only intended to convey that it would observe strict neutrality.

Berlin's stand much annoyed London and Tokyo. Great Britain's hope was definitely dashed that its October 1900 agreement with Germany could halt a further Russian penetration in north Asia. In Tokyo there had been high hopes about the benevolent neutrality Berlin had promised. Berlin's reaction, Kato Takaaki told MacDonald, showed that 'Germany wants us to fight Russia, and she would then act the part of the honest broker and pick up the pieces. ${ }^{24}$ Despite the German reluctance to take sides, Tokyo continued to sound out Berlin and London to come to some kind of agreement. In April 1901 the Japanese ambassador in London, Hayashi Tadasu, who denied having received any instructions from his government to this effect, approached Lansdowne and Eckardstein and suggested drawing

21 Scott to Lansdowne 6-8-1901 (PRO FO 800 140), Lansdowne to MacDonald 12-2-1901, 27-2-1901 (PRO FO 538).

22 MacDonald to Lansdowne 21-3-1901 (PRO FO 539).

23 Lansdowne to MacDonald 16-3-1901 (PRO FO 538).

24 MacDonald to Lansdowne 21-3-1901 (PRO FO 539). 
up a formal understanding in support of China's territorial integrity and against preferential trade arrangements. Lansdowne refused to commit himself without having been presented with 'some substantive proposal. ${ }^{25}$ Similar to Bülow, he did not look forward to complications with Russia and considered the developments of the previous year, which had led to the Anglo-German Agreement concluded by his predecessor Salisbury, a 'misunderstanding'. As he wrote to MacDonald:

I had never concealed from myself that the position of Russia in Manchuria was exceptional and so long as she did not take advantage of it to interfere with the integrity of China or the interests of the other Powers I did not see why we should object to her making her own arrangements with the Chinese as to the conditions of withdrawal [of the Russian troops]. ${ }^{26}$

In Japan Ito Hirobumi had resigned as Prime Minister in May and was replaced after a short interval by General Katsura Taro, an advocate of a pact with Great Britain. Nevertheless, some kind of understanding with Russia was not yet precluded. In October, when formal negotiations with Great Britain were already underway, Ito Hirobumi visited Yale University to accept an honorary degree. From there, and on his own account - though he did inform Katsura Taro about his plans - he travelled on to St Petersburg to try to come to an agreement with Russia over Korea (Nish 2002: 2-3). Had he succeeded, this would have left Great Britain almost powerless in the Far East. Such a prospect suited Germany well. In Berlin there was apparently much speculation about an isolated Great Britain in the Far East. Indeed, Wilhelm II had cooperation between the United States and Japan in mind, Bülow that of Japan and Russia. ${ }^{27}$

\section{The Anglo-Japanese Alliance}

On 30 January 1902 a pact between Great Britain, where people were well aware of Ito's mission, and Japan became a reality. It had come about,

25 Lansdowne to MacDonald 17-4-1901 (PRO FO 538).

26 Lansdowne to MacDonald 18-7-1901 (PRO FO 538).

27 Memorandum Wilhelm II 23-8-1901, Bülow to Metternich 13-3-1902) (E.T.S. Dugdale, German Diplomatic Documents, Ch. X, The Anglo-Japanese Agreement, 1901-02, www.mtholyoke.edu/ acad/intrel/dugdale/japan.htm). 
Bülow in Berlin was sure, because of Great Britain's fear of a Russo-Japanese partnership. ${ }^{28}$

In Great Britain a possible cooperation with Japan had been a topic of speculation since Japan had been forced to withdraw from the Liaodong Peninsula and especially after Great Britain had failed to prevent Russia from taking hold of Port Arthur. The ill feelings over Rosebery's policy during the Sino-Japanese War, his refusal to provide Japan with diplomatic backing, had lingered on in Japan for some time, but waned when Tokyo and London found common ground in their aversion to Russian dominance in Manchuria. Both also experienced the financial stress of having to maintain a strong navy; making both the British First Lord of the Admiralty and the Japanese Minister of the Navy proponents of an Anglo-Japanese alliance (Nish 2002:4). Newspaper reports, also in the United States, putting Russia's hold over South Manchuria in a bad light and praising the achievements of Japan, also prepared the way for an Anglo-Japanese arrangement (Millard 1906 8-14).

In their treaty, to be in force for five years, Great Britain and Japan 'actuated solely by a desire to maintain the status quo and general peace in the extreme East ${ }^{\prime 29}$ - recognised the independence of China (which the British government left no doubt included South Manchuria) and Korea. Concurrently, and at Tokyo's request, Japan's special interests in Korea were recognised. The scope of the treaty was limited to threats to British and Japanese interests in China and Korea by the 'aggressive action of any other Power' or by 'disturbances arising in China or Korea' and the measures each could take for the 'protection of the lives and properties of its subjects'. $3^{\circ}$ Should Japan or Britain become involved in war with one power because of complications over China and Korea, the other was to 'maintain a strict neutrality'. ${ }^{11}$ Should a situation arise in which one of them was confronted with more than one enemy, the other had to come to its assistance and 'conduct war in common'. ${ }^{2}$ The treaty did not include, as the British had suggested, a similar stipulation for an attack on the British position in India; the colony the British worried about so much and felt so vulnerable about might Russia press forward. The text only spoke of the special interests of two countries in the Far East 'of which those of Great

28 Bülow to Metternich 13-3-1902 (E.T.S. Dugdale, German Diplomatic Documents, Ch. X, The Anglo-Japanese Agreement, 1901-02, www.mtholyoke.edu/acad/intrel/dugdale/japan.htm).

29 Anglo-Japanese Treaty, 30-1-1902, Preamble.

30 Ibid., Art.1.

31 Ibid., Art 2.

32 Ibid., Art 3. 
Britain relate principally to China, whilst Japan, in addition to the interests which she possesses in China, is interested in a peculiar degree, politically as well as commercially and industrially in Korea'.33

For some in Great Britain the treaty came too late. It should have been concluded, one Member of Parliament stated, when 'Russia ordered our ships of war out of Port Arthur' ${ }^{34}$ Others worried about the implications, wondering what would happen if Japan and Russia were to go to war over Korea and Manchuria. Balfour, who within months, in July 1902, would become Prime Minister, dreaded that one day Great Britain might have to fight for its 'existence in every part of the globe against Russia and France'. ${ }^{35}$ Others, equally apprehensive about war, could understand that Great Britain could be dragged in because of Manchuria, but Korea was a different matter. Korea was only of importance to Japan. It was 'a worthless country, with a grossly corrupt and incompetent Government' and, worse still, 'in a most dangerous and unstable position'. ${ }^{6}$ There were also people to whom the Alliance was an outrage. Such an opinion was especially vented in the British Pacific colonies where many, for reasons of race and defence, could not understand why London had forged such close ties with Japan, a potential aggressor. When in 1894 Great Britain concluded a Treaty of Commerce and Navigation with Japan (replacing an earlier one of 1854), which allowed for the freedom of their citizens to settle in each other's country, London - aware of such racial feelings - had included a stipulation that the treaty was not in force for India and most of the other British colonies, except when they wanted it to be so. Only Queensland did. Such racist sentiments had seriously complicated Anglo-Japanese negotiations when, little more than a month before Japan and Great Britain concluded their treaty, Australia had promulgated its Immigration Restriction Act (Bennett 2001: 93-4).

In London Lansdowne defended the Alliance in the House of Lords as essential for the status quo in the Far East, the Open Door in China and peace in Asia. Its aim, he said, was 'to protect Japan against ... the greatest peril that might menace her ... a coalition of other powers'. Japan could cope with a war with one power but a fight with more than one would put it, in

33 Ibid., Art 1.

34 Walton in House of Commons 20-3-1902 (hansard.millbanksystems.com/commons/1902/ mar/2o/situation-in-china-general-observations).

35 Balfour to Lansdowne 12-12-1901 (cited in Nish 1902: 6).

36 Norman in House of Commons 13-2-1902 (hansard.millbanksystems.com/1902/feb/13/ anglo-japanese-agreement). 
the words of Lansdowne, in 'imminent peril' ${ }^{37}$ Equally, other proponents in Great Britain hailed the contribution the treaty would make to the maintenance of peace. In fact, the Anglo-Japanese Alliance gave Japan the backing it needed to take on Russia. In St Petersburg, British ambassador Scott could deny in his talks with the Russian Foreign Minister that the treaty was directed against Russia. But in fact, as Lamsdorff observed, this was 'a conclusion generally drawn' $3^{8}$ Scott also described the Anglo-Japanese Alliance as having 'an essential pacific and unaggressive object', but he was far from convincing. ${ }^{39}$ The alliance put a damper on the hopes of Russian protagonists of a further advance in north Asia of any assistance (in word or deed) of the French navy in a confrontation with Japan.

In March France and Russia, in reaction to the Anglo-Japanese Treaty, issued a joint declaration on China; pledging that they also had the independence and territorial integrity of China and Korea in mind. St Petersburg put on a brave face. In a separate statement the Russian government assured the world that it had 'received with the most perfect calm' the Anglo-Japanese Alliance and that peace and furthering of commerce and industry in the Far East had always been what Russia had aspired to. As an example of this intent, the beneficial effect of the 'great Siberian Railway, together with its branch line through Manchuria towards a port always ice-free' was mentioned (New York Times 21-3-1902). In a joint note St Petersburg and Paris also warned Great Britain and Japan that should action by a third power or new unrest in China threaten their interests, Russia and France would consider measures to safeguard these. ${ }^{40}$

Russia responded by rekindling the old British fear of an assault on India. Shortly after London and Tokyo had signed their treaty, a Russian journal published a belligerent speech that the Russian Minister of War, General Kuropatkin, had made a few months earlier in Turkistan. In it he had impressed upon the Russian soldiers present that they might have to fight 'Afghan and English troops, armed and trained as European troops are', warning them that this was an enemy very different from 'the irregular masses of Bokhara and Khokand'. ${ }^{41} \mathrm{~A}$ few months later, to add to the pressure, Kuropatkin had it leaked through the German ambassador in

37 Lansdowne in House of Lords 13-2-1902 (hansard.millbanksystems.com/lords/1902/feb/13/ anglo-japanese agreement).

38 Scott to Lansdowne 3-3-1902 (PRO FO 539 81).

39 Ibid.

40 E.T.S. Dugdale, German Diplomatic Documents, Ch. X, The Anglo-Japanese Agreement, 1901-02, www.mtholyoke.edu/acad/intrel/dugdale/japan.htm.

41 Scott to Lansdowne 3-3-1902 (PRO FO 539 81). 
St Petersburg that he intended to improve the Russian railway link to the Afghan frontier to speed up the transportation of troops enabling Russia to 'strike a crushing blow at England in the event of complications' with that country. ${ }^{42}$

Germany informed Russia and France that its policy 'in the Far East was one of entire reserve and only concerned trade' and that Berlin did not support 'the aspirations of England and Japan in Manchuria and Korea', stressing, as Berlin had done before, that Germany had no intention at all of becoming involved in a conflict in 'those far-off regions'. ${ }^{43}$ Germany's stand caused some unintended irritation in St Petersburg because Berlin had ignored a suggestion by Nicholas II who had wanted Germany to join the Franco-Russian note about the measures that might be taken to safeguard their interests in China. ${ }^{44}$ Wilhelm II reacted remarkably sedately. He congratulated King Edward 'on the conclusion of a new alliance, which we all look upon as a guarantee for peace in the East'. ${ }^{45}$ Behind closed doors the mood was different. From London the new German ambassador, Paul Count Wolff Metternich zur Gracht, had reported home that the 'departure from isolation' had given the British 'increased self-confidence'. ${ }^{46}$ Bülow wondered against whom this new élan would be directed and did not exclude that the new Alliance partners might act to the detriment of German ambitions in the Far East. He also did not rule out that the United States might come out in favour of an Anglo-Japanese undertaking. ${ }^{47}$

The Anglo-Japanese Alliance strengthened Tokyo's case for having the Russian army evacuate South Manchuria. In the Russo-Chinese Convention with regard to Manchuria, signed on 8 April (or 26 March according to the Russian calendar) 1902 - drawn up 'with the object of re-establishing and confirming the relations of good neighbourhood, which were disturbed by the rising in the Celestial Empire of the year 1900', as the preamble claimed ${ }^{48}$ - Russia promised to withdraw its troops within one and a half years and have Chinese authority re-established in Manchuria. However,

42 Scott to Lansdowne 27-5-1902 (PRO FO 539 81).

43 Memorandum Bülow 20-3-1902 (E.T.S. Dugdale, German Diplomatic Documents, Ch. X, The Anglo-Japanese Agreement, 1901-o2, www.mtholyoke.edu/acad/intrel/dugdale/japan.htm).

44 Ibid.

45 Wilhelm II to Edward VII 26-2-1902 (cited in Massie 1993: 340).

46 Bülow to Metternich 13-3-1902 E.T.S. Dugdale, German Diplomatic Documents, Ch. X, The Anglo-Japanese Agreement, 1901-02, www.mtholyoke.edu/acad/intrel/dugdale/japan.htm).

47 Ibid.

48 Convention with regard to Manchuria (www.chineseforeignrelations.net/node/240, accessed 10-1-2011). 
St Petersburg would decide how many soldiers China would be allowed to station in Manchuria after such a Russian retreat. It was only

natural that the maintenance in the above-mentioned district of an over large number of [Chinese] troops must necessarily lead to a reinforcement of the Russian military force in the neighbouring districts, and thus would bring about an increase of expenditure on military requirements undesirable for both States. ${ }^{49}$

China would also not be allowed to construct any railways in South Manchuria without Russian consent (mention in this respect was made of the Anglo-Russian Railway Agreement of 1899, in which London had promised not to build railways north of the Chinese Wall). In return for Russian troops leaving South Manchuria, the Chinese government had to pledge to protect the Manchurian Railway and to guarantee the safety of the Russians living and working in Manchuria. Another condition for the withdrawal of the Russian army was that no disturbances would arise. Finally, no doubt was left that Russia would stay on 'might the action of other Powers' prevent an evacuation of its troops..$^{5^{0}}$

\section{The Korean question}

Korea had, not without reason, been mentioned in the 1902 Anglo-Japanese Treaty and the Russo-French Declaration on China that came in its wake. In the decade after the Sino-Japanese War, Russia and Japan had become entangled in a struggle for hegemony in Korea; as was manifested by the frequent visits of their warships, also keeping a watch over Korea's open ports. To the Japanese, already witnessing how stealthily Russia was taking control of South Manchuria, it was vital that Korea did not fall into Russian hands. A Russian Korea not only implied an incursion into a region Japan wanted to fall within its own sphere of political and economic influence, it also posed a threat to Japan's own security, near as Korea was to its own shores. In 1901 Kato Takaaki had already informed MacDonald that the Japanese government would not go to war over Manchuria but that Korea was a different matter: 'If Korea is touched, our existence is threatened and 
to save our lives we must go to war'. ${ }^{11}$ In its negotiations with Russia, Japan also stressed that Korea was 'an important outpost in Japan's line of defence' and that Japan considered Korea's independence 'absolutely essential to her own repose and safety' (cited in Millard 1906: 81).

Russia continued to press on. In 1899-1900 a crisis had loomed when Russia purchased land to secure a coaling station in Masan, near Busan on the southeast coast of Korea. Tokyo could hardy allow this, if only because such a base might give Russia control over the southern entrance of the Sea of Japan; a position it already had at its northern entrance when it had annexed Sakhalin in 1875 . Japan threatened to act. Russia could only reach an agreement that in Masan no land in the harbour would be ceded or sold to any foreign power, but Japan would circumvent the stipulation by using Japanese settlers as front men and buying land to establish a foreign settlement. It succeeded in turning Masan into an almost exclusively Japanese port, stationing a police force there to protect the Japanese in the city (Hamilton 1904: 199). Another source of Russo-Japanese friction was a Russian lumber concession in north Korea on the bank of the Yalu River, right across the border with Manchuria. Tokyo accused St Petersburg of using the concession to strengthen its economic and military presence in Korea.

Co-players in the background were the United States, France and Great Britain. Around the turn of the century, American commercial interests in Korea were considerable. Instrumental in the American success had been American missionaries, who were 'closely associated with the more important export houses in the leading industrial centres of America' (ibid.: 265). The most prominent among them was Horace Newton Allen. In 1884 he had come to Korea as one of the first of a fast growing number of American missionaries. He learned to speak Korean fluently and developed excellent relations with the Korean court. Starting as secretary of the American legation in Seoul, Allen was appointed American envoy in 1897. In the past, Allen's dealings had brought him in conflict with Japan and the proJapanese faction in the Korean government, but he had to change course after the Russian occupation of Port Arthur and the need for goodwill for the annexations of Hawaii and the Philippines made Washington move closer to Japan. In Seoul Allen, ordered by Washington not to block Japanese interests in Korea, began to present Russia as the greatest threat to American mercantile presence in Korea, betting on an Anglo-Japanese or Anglo-American alliance to protect American commerce in Korea. 
France also had a role to play. It did so, mirroring the international relations of those days, as it did in China, in concert with Russia. In early 1901 the Russian ambassador in Seoul, A. Pavlov, backed by his French colleague, tried to undermine the position of McLeavy Brown for a second time. In planning his move he also gained the cooperation of the Korean Minister of Finance, an avowed opponent of foreign control of customs revenue, and a partly British, partly French company, the Syndicat du Yunnan. Registered in London, its capital was provided by British as well as French investors and, as its name indicates, its primary object had been Yunnan, where the company was after mining concessions. The British government had been asked to plead in favour of the Syndicat du Yunnan interests in Beijing but had remained aloof, having doubts about the loyalties of the syndicate and believing that firms with mixed French-British capital served French rather than British interests (Chandran 1977:320-2). McLeavy Brown threatened to become the victim of what Hamilton (1904: 96) described as the 'abnormal extravagance at the Court'. He had irritated the Korean government by refusing to furnish money from the Customs Office as security for a loan offered by the Syndicat du Yunnan to Emperor Kojong in return for mining concessions.

The scheming in Seoul put an end to any doubts that London might have had in mediating for the Syndicat du Yunnan in Beijing. Lansdowne informed Satow that the company had not been 'altogether straightforward' about its business in Korea and had been 'more inclined to follow French advice than British and refused to have to do anything anymore with the syndicate'. ${ }^{2}$ McLeavy Brown succeeded in maintaining his position. He had the support of the American and Japanese envoys in Seoul, but what tipped the scale was the decisive response of the British government, highly suspicious as it was of any joint Franco-Russian move in Asia. Four British warships were directed to Chemulpo, while in Wei-hai-wei preparations were made for the embankment of British troops. International relations and its experience in China had dictated the British response. There was British prestige to consider as well as the rivalry with Russia and France. 'We have', the British journalist Hamilton (1904: 96) wrote, 'little material interest in Korea, but it must not be forgotten that our position in the kingdom should be superior to that of France, and equal to that of Russia' (ibid.: 96).

52 Lansdowne to Satow 30-4-1902, Minute by Lansdowne to Sanderson 25-4-1902 (cited in Chandran 1977: 321). 


\section{The Russo-Japanese war}

Notwithstanding the Russo-Chinese Convention of the previous year, Russia no longer had any intention of withdrawing its troops from Manchuria. Between May and August 1903 the moderates in the government, Lamsdorff and Witte, who both rejected an aggressive forward strategy in Manchuria and Korea, had to give way to a powerful military group whose aggressive policy found favour with Tsar Nicholas. Lamsdorff became a lame duck when the Tsar made Alexeiev - soon to be appointed as the first Russian Viceroy of the Far East - and not him responsible for Russia's policy in China. He tendered his resignation in May, but was told to stay on. In August, his views no longer being in favour, Witte was forced to relinquish his position as Minister of Finance.

Negotiations between Tokyo and St Petersburg about their respective positions in Manchuria and Korea came to nought and on 6 February 1904 Japan, fearing a Russian military build-up in Manchuria, severed diplomatic relations. Two days later, in the night of 8 February, hours before Japan formally declared war on Russia, surprise attacks on Russian warships in Chemulpo and Port Arthur signalled the start of the Russo-Japanese War.

In Korea Emperor Kojong declared 'the strictest neutrality', but shortly after war had started Japanese troops disembarked at Chemulpo to march to Seoul. On 11 February 1904 Russia protested with the other powers that by invading Korea Japan had attacked a nation of which the independence had been recognised by the Treaty of Shimonoseki of 1895, the Anglo-Japanese Alliance of January 1902 and the Franco-Russian Declaration on China of March of that year. Response was tepid, with Great Britain and the United States tending to sympathise with Japan. On the British side, the traditional anti-Russian mood was coupled with a sense of relief now that Russia had to deploy its army in Manchuria and, for the moment, had to abandon any intent with regard to India. As Lawton (1912: 226) wrote, the war 'would remove, at least for a considerable time, the uneasiness felt in regard to the Indian Frontier'. American politicians and business circles had a different motive: the Russian policy in Manchuria and its impediments for American trade, which it was hoped would be removed after a Japanese victory. The position of Washington and London was reflected in the financial world. Loans to assist the Japanese war effort, popular because of the first Japanese military successes, were raised in Great Britain and the United States, and significantly not in France (Drea 2009: 103). Japan had won the war largely through Anglo-American moral support and Anglo-American gold', Putnam Weale (1908: 518) would conclude a few years later. 
Korea had no option other than to yield to Japan. At the end of February 1904 the Korean Minister of Foreign Affairs had to sign a protocol that virtually turned his country into a Japanese protectorate. In return for a Japanese promise to protect Korea's independence and its monarchy, Korean had to allow Japan to reform its administration and should refrain from a foreign policy that was contrary to the 'principles' of the protocol. Another stipulation was that when foreign aggression or domestic disturbances threatened Korea or its monarchy Japanese troops should be allowed to occupy strategic positions in the country. ${ }^{53}$ The next step came in August when the Emperor and the members of the Cabinet were forced to sign a diktat in which they accepted the appointment of a Japanese adviser to the Ministry of Finance and a foreign expert recommended by Japan to the Ministry of Foreign Affairs. Contracts concluded with foreigners in future needed Japanese approval. Finally, in February 1905, Japan took control of Korea's diplomatic corps while the appointment of foreign advisers became subject to Japanese consent.

The attack on Port Arthur had given Japan superiority at sea. In response, the Russian Baltic fleet, commanded by Admiral Zinovy Petrovich Rozhestvensky, less well-equipped and of older make than its Far Eastern counterpart, set out on its journey to the Far East as the Second Pacific Squadron in October 1904. In 1902, when the Anglo-Japanese Alliance had been concluded, Russia had turned to Germany in an effort to revive the Far Eastern Triple Alliance of 1895. Berlin had declined and had taken a wait-and-see attitude. As the principal adviser for foreign affairs, Friedrich August von Holstein, had put it in a memorandum to Wilhelm II: '[I]t is in our interests to keep our hands free, so that His Majesty will be able to claim appropriate compensation not only for eventual support, but even for remaining neutral..${ }^{54}$ Berlin continued on this course throughout the Russo-Japanese war. Shortly after the outbreak of war, Bülow explained in a memorandum to Wilhelm II that Germany faced two dangers: one was a deterioration of relations with Russia, the other that of being 'pushed forward by Russia against Japan or still more against England'. ${ }^{55}$ Having Russia and Japan fighting it out was not that bad from a German perspective; it weakened Japanese military strength in Asia, and that of Russia in Asia and Europe.

With Wilhelm's sympathies clearly with Russia and not Japan the moment had come to practice benevolent neutrality, the term that had so 
Figure 31 Funeral procession of a Japanese officer at Yokohama

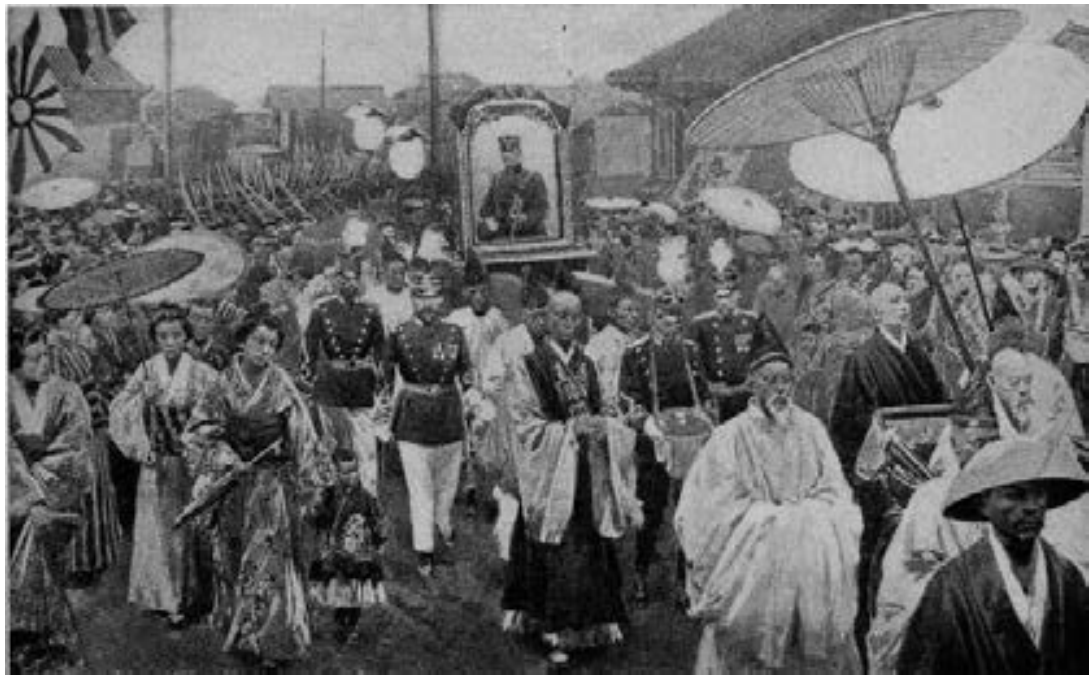

Source: Tyler 1905

confused the international community in 1901. Albert Ballin, director of the Hamburg-Amerika Linie and a close friend of Wilhelm II, earned his shipping company a contract to organise the fuelling of the Russian fleet en route to East Asia; making Lawton (1912: 247) conclude that Germany had wholeheartedly supported the Russian war effort. Such support had the blessing of Wilhelm II who, rabidly anti-Japanese as he was, urged Nicholas II on (Bernstein 1918: 62).

One of the consequences for Great Britain had been that shortly after the outbreak of the war the only British trading house in Vladivostok had been forced to leave due to what Putnam Weale (1908:33) described as 'the spy mania and the unfortunate assumption that British and Japanese had become identical terms'. In London both government and opposition took a low profile, not wanting to become involved in war. As the Liberal Member of Parliament, Sir Charles Wentworth Dilke, said: '[I]n the present state of Europe, with the Russo-Japanese War proceeding, and with our engagement towards Japan', the House of Commons should refrain from discussing Great Britain's relations to the other powers. Acting otherwise 'might easily cause harm ... and silence seemed ... to be the best course'. ${ }^{6}$ Nevertheless, as 
Germany provided some assistance to the Russian war effort, so did Great Britain. It bought two warships to prevent that they would end up in Russian hands, facilitated the purchase by Japan from Argentine of two cruisers just built in Genoa (commanded on their way to Japan by British captains) and closed its ports to the Baltic fleet. Britain had also seen to it that its treaty partner had entered the war as well prepared as it could. British experts had been sent to Japan to advise on the building of warships and Japanese shipbuilders had been allowed to observe state-of-the-art techniques at British shipyards (Steeds 2002: 4; Lawton 1912: 598).

Rozhestvensky's fleet reached the battle zone in East Asia after a chaotic voyage of seven months, to be defeated there by the Japanese navy in the sea battle of Tsushima, fought in the Strait between Korea and Japan on 27 and 28 May 1905. Parts of Russian warships were destroyed, others surrendered. Rozhestvensky ended up as a prisoner of war. On land Japanese troops had also progressed. They had taken Dalian in June 1904 and Port Arthur in January 1905, but by the spring of 1905, when Japan had conquered about half of South Manchuria, a stalemate had developed (Drea 2009: 109). Outside Manchuria, Sakhalin was occupied in July 1905. There, almost immediately, Tokyo carried through a Japanification with Russian geographical names being replaced by Japanese ones.

The resistance put up by the Russians impressed Edward Grey, soon to become British Foreign Secretary, and probably others too. In 1908, speculating about what would have happened when, in the Russo-Japanese war, Tokyo and St Petersburg had come to some kind of early agreement and the Russian army would have been redirected towards Persia, he ventured that in that case Great Britain would have 'been faced with the horrors of a land war of a colossal character'.57

Russia was far from defeated. It could bring in reinforcements and heavy artillery from European Russia by rail, while, as Kato Takaaki had admitted in 1901, Japan could not sustain a prolonged war. Its army was confronted with an increasingly serious shortage of troops, had suffered heavy losses and large numbers of its soldiers suffered from beriberi and other diseases. Overextended lines of supply, failing logistics and a shortage of ammunition only made matters worse (Drea 2009:105-20). Finance was another case in point. The war had burdened the country with a huge debt, with financiers abroad becoming hesitant to provide new loans when the Japanese land offensive came to a standstill (Lawton 1912: 847-8). Russia also had acute 
financial problems. Overconfident that the war would be brief and victorious, St Petersburg had failed to seek loans on the international market to finance a continuation of war (Wcislo 2011: 205). On top of this came the '1905 revolution' with strikes and demonstrations all over the country and discontent in the army and navy culminating in the Potemkin mutiny of June 1905 .

Peace was mediated by the United States. Russian and Japanese negotiators met in Portsmouth, New Hampshire. At the Peace Accord signed on 5 September (or 23 August) 1905, Japan and Russia promised to return Manchuria to China and to evacuate their troops within one and a half years. An exception was made for the Liaodong Peninsula. Its lease - pending the consent of China it was hypocritically promised - was transferred to Japan (which raised some questions about the British position in Wei-hai-wei, leased for the duration that Port Arthur would be Russian). Port Arthur was renamed Ryojun, Dalian became Dairen. Further, Japan took over the southern section of the South Manchurian Railway, the line between Changchun and Port Arthur, including the coal mines which belonged it; giving Japan control of that part of the region, where it proudly flew its own South Manchuria Railway flag.

Both countries promised that the railways they operated in Manchuria (including the Chinese Eastern Railway) would in future only be used for commercial and industrial purposes, not for strategic, military ones. Japan and Russia preserved the right to have soldiers guard their part of the

Figure 32 Peace talks at Portsmouth (the third person from the left is Witte)

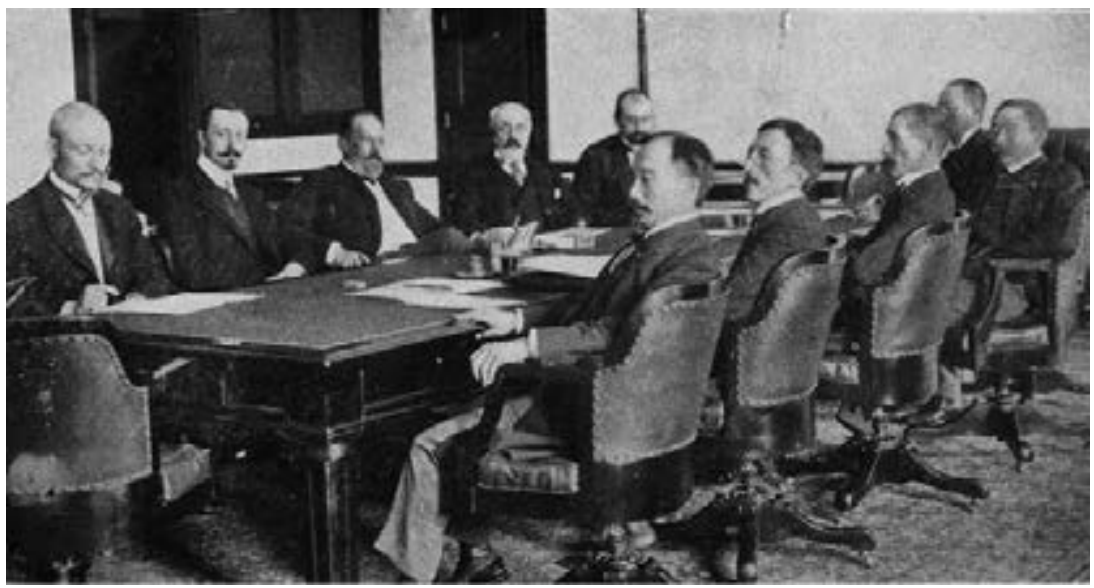


railway. In its section Japan would continue the Russian tradition of ordering railway material in the United States and not in Great Britain (Lawton 1912: 364 ). Similar to Russia, the effort by the Japanese South Manchuria Railway Company to develop its railway zone embittered the Manchurians; among others by expropriating land said to be needed for its enterprises. This would also lead to protests abroad. The South Manchuria Railway Company engaged in a wide range of activities, ranging from mining and urban development to running dairies and loss-making but excellent hotels in cities where the trains stopped (Wertheimer 1913: 41). In its zone the Japanese levied taxes and encouraged the settlement of compatriots. To justify all this Tokyo referred to the Chinese Eastern Railway Conventions concluded between Russia and China in 1896 and 1898 (Lawton 1912:1176). Southern Sakhalin became Japanese. Both countries promised to build no fortifications on their part of the island. Korea remained independent, but in the Portsmouth treaty Russia recognised that Japan had 'paramount political, military and economic interests' in Korea and promised that it would neither 'obstruct nor interfere with measures for guidance, protection and control' which Japan might find necessary to take..$^{8}$

Japan and Russia both had to deal with anti-war sentiments among the population. In Russia unrest spread to Vladivostok in October, where mutinying soldiers and sailors briefly gained hold of the city in January. In Japan the peace terms drew bitter reactions and created widespread discontent, fanned by the press. This resulted in days of rioting in Tokyo, culminating in the Hibiya incident of 5 September 1905. Martial law had to be declared. Those opposing the peace treaty made much of the fact that Japan had not gained the whole of Sakhalin, which Japan had so reluctantly turned over to Russia in 1875 . Another complaint was that Japan had abandoned demands for a war indemnity; Japanese insistence on this point Nicholas II had made clear from the start would be a reason for Russia to resume war (Wcislo 2011: 205). In giving in, Tokyo would have left it to the Japanese population to bear the costs of war by heavy taxation and perhaps by even bringing the country to the brink of bankruptcy. Anti-Western feelings were also vented. The British and American loans provided gave those opposing the Peace Accord the argument that Japan had been fighting America and Great Britain's war to end Russian hegemony in South Manchuria, in which Japan had furnished the men and the United States and Great Britain the money.

At Portsmouth the voice of the Chinese had been ignored. The Chinese government had asked to be allowed to attend the peace negotiations, but 
Japan had said no. Afterwards, China protested about the number of soldiers Russia and Japan were allowed to station in Manchuria. It also regretted that the matter of full restoration of Chinese authority in South Manchuria had not been discussed. China was too weak to persist. In the Sino-Japanese Treaty dated 22 December 1905 relating to Manchuria (also referred to as the Manchurian Treaty or the Beijing Treaty), China consented to the gains the Portsmouth Treaty had brought Japan. In an Additional Agreement Japan, in turn, committed itself to returning Chinese public and private property it had 'occupied or expropriated on account of military necessity ... no longer required for military purposes'. The rest of the Chinese property would be handed back after Japanese troops had left Manchuria. ${ }^{59}$ In return, in one of the secret protocols addended, the Chinese government pledged 'for the interest of the South Manchuria Railway, not to construct ... any main line in the neighborhood of and parallel to that railway or any branch which might be prejudicial' to that line. ${ }^{60}$

The outcome of the Russo-Japanese war for the time being put an end to a further encroachment of the European powers in China. Russia had to recover from the blows it had received, Germany paid the price for the sympathy it had shown to Russia, and France was on its own in the Far East. As Satow saw it: the war 'seemed to knock on the head all Russian schemes of territorial acquisition. ${ }^{6}{ }^{6}$ Russia was defeated, but in Great Britain the spectre of Russia as an aggressive power had not disappeared, nor had the awe in which its army was held. Russia had acquired an image of great resilience, of a country that 'only draws back so as to jump better' (Putnam Weale 1908: 230). Or, as Lawton (1912: 431) put it, and he and Putnam Weale certainly were not alone in their fear: history had shown that while Russia had 'experienced severe reverses from time to time, never has she been thrown back on her original position. Even her defeats have ended in gain, and after each of these she has waited her opportunity, and prepared her way for yet another step forward'. In Japan, the fear of Russia seeking revenge became one of the arguments of maintaining a strong army (Drea 2009: 126-7).

Russia began by consolidating what it still had, a determination that found its symbolic expression in the building of the Saint Sophia Cathedral in Harbin; though the cathedral, built after the Russo-Japanese War and still built of wood, was less impressive than the present-day building completed in 1932. In that part of South Manchuria still under Russian control, it

61 Satow to Grey 31-3-19o6 (PRO FO 80044 ). 
intended to stay, treating its part of the railway and the land surrounding it as Russian territory (making for a kind of partnership with Japan, which had a similar intent in its part of Manchuria). As Putnam Weale (1908: 234-5), who visited the region in early 1907, observed: "The railway is everything, and now that war is over and the military have dispersed, the great railway bureaux resume their old position of absolute masters. Chinese officialdom rules only the agriculturists and nothing more'. With the South Manchurian Railway after the Portsmouth Peace Treaty no longer available for the transportation of armament and troops, work was started on the construction of a new railroad, the Amur Railway, with Vladivostok as terminus. In Vladivostok the fortifications were strengthened. St Petersburg would also claim - in vain - that Article VI of the Chinese Eastern Railway Convention of September 1896 permitted it to turn Harbin (at present a large metropolis which owes its existence to the railways) and a number of other places along its railroads in Manchuria into a kind of Russian-dominated foreign settlements with their own municipalities independent of Chinese control. 


\section{Great Britain's Search for Secure Colonial Frontiers}

On 12 August 1905, two years before it was to expire and about a month before St Petersburg and Tokyo signed their peace treaty, the Anglo-Japanese Alliance of 1902 was adjusted. This time, with the British not ruling out a Russian revenge attack elsewhere to make up for its reversals in Manchuria, India was included in its scope. The preamble mentioned as one of the objectives of the renewal the 'consolidation and maintenance of the general peace in the regions of Eastern Asia and India'. Article IV noted that Great Britain had 'a special interest in all that concerns the security of the Indian frontier' and that Japan recognised the British right 'to take such measures in the proximity of that frontier as she may find necessary for safeguarding her Indian possessions'. The revised treaty, which in its preamble now specifically endorsed the 'principle of equal opportunities for the commerce and industry of all nations in China', could more easily engage Great Britain and Japan in war than before. The 1902 provision about support in a war with two enemies had been changed. Article II of the new treaty stipulated that if 'by reason of an unprovoked attack or aggressive action, wherever arising, on the part of any other Power or Powers' Japan or Great Britain 'should be involved in a war in defense of its territorial rights or special interests' in East Asia or India, the other would 'at once come to the assistance of its ally' and would 'conduct war in common, and make peace in mutual agreement'. ${ }^{1}$

With the Russian fleet in Asia having been cut out and the assurance of Japanese support should the British position in India be endangered, there was no longer any urgent need for the British to have a strong naval presence in Asia. Before the end of the year, London could effectuate plans, which had already been considered at the beginning of the century, to reduce the strength of its fleet in Asia. Five battleships were redirected to Europe (Massie 1993: 462). By doing so Great Britain, as people in the dominions did not fail to notice, ceased to be a naval power in the Pacific,

1 In Article VI Great Britain promised to 'maintain strict neutrality' in the Russo-Japanese War and that it would join in on the side of Japan should any other Power enter into hostilities against Japan. Article VIII stipulated that the treaty would be in force for ten years and that, if at that moment Japan or Great Britain was engaged in war, the alliance would continue until peace was concluded. 
while its negotiation position in China had also suffered. Britain could no longer rely 'on her prestige and naval strength', but had become dependent on 'paper and on promises', Putnam Weale (1908: 627) observed. Japan was a British ally but also a threat. In Great Britain there was concern about Japan's growing economic presence in the Yangtze Valley (Steeds 2002: 10). Pessimists, as they had done before and would continue to, foretold the decline of the British Empire. One of them, Putnam Weale (1908: 636, 638 ), alerted his readers to the determination of Japan to gain the same preponderance in the Yangtze Valley that it had already acquired in Korea and southern Manchuria, warning that steps had to be taken to prevent a British 'commercial downfall' in the Far East.

Besides entering into an alliance with Japan, Great Britain tried to come to an understanding with France over their relations in Africa, Asia and the Pacific. The two powers had to find a solution to the thorny questions of the British position in Egypt and their respective spheres of influence in continental Southeast Asia. A problem less likely to involve the two in a confrontation, but nonetheless of a delicate nature, was the delineation of the British and the French possessions in the South Sea.

\section{The South Pacific}

In France colonialists came to regret that after the 1840 s and 1850 , due to 'unnecessary considerations for foreign reproaches', France had not pressed on in the South Pacific (Lorin 1906: 420). None of the larger islands was French. France only ruled over 'a few scattered archipelagos in the immense Ocean' (ibid.: 420). In 1874, after the British annexation of Fiji, France, much to the disappointment of French advocates of a colonial empire, had not even reciprocated by annexing the New Hebrides. A few years later the situation had changed. Anglo-French conflicts in the South Pacific re-emerged after France, inspired by a recently refound colonial mood, or by what Carnarvon described as a 'desire for territory, and the wise foresight which looked to the opening of the Panama Canal', aimed at colonial expansion, not only in Southeast Asia but also in the South Pacific. ${ }^{2}$

In the Jarnac Convention or Declaration of 19 June 1847 - signed in London and named after the French Chargé d'Affaires Comte de Jarnac - London had recognised the French Protectorate over Tahiti. Great Britain and France

2 Carnarvon in House of Lords 2-5-1887 (hansard.millbanksystems.com/lords/1887/may/2/ questions-observations). 
had also agreed - because of a mistake by the French negotiator, Frenchmen would later claim (Froment-Guieysse 1922:109) - that of the Society Islands the Leeward Islands of Tahiti (Raiatea, Tahaa, Bora-Bora and Huahine) would remain independent. In the early 188 os France strengthened its position in this part of the South Pacific. In 1880 Tahiti was annexed, as were the Tuamotou Islands and Tubuaï and Raivavae, two islands that had been under French protectorate in the Austral Islands since 1842. ${ }^{3}$ In the same year, following visits to the islands in the previous two years by the German warships Ariadne and Bismarck, and indifferent to British protests, France impressed the spectre of a German occupation on its inhabitants and also established protectorates over Raiatea and Tahaa (Froment-Guieysse 1922: 132, Newbury 1967: 13). A German protest put an end to any further French aggrandisements in the Leeward Islands of Tahiti, but an annexation of the Gambier Islands and Rapa followed in 1881. However, the annexation of Rapa, which in those days was considered to be strategically located along the sea route between the United States and the Australasian colonies - and its importance was to increase once ships could sail the Panama Canal - was never effective. What had been agreed upon was, in fact, more of a protectorate, leaving the Islanders in charge of their own administration and legal system (Bambridge \& Ghasarian 2002). In 1887 France re-annexed the island, establishing effective control. A year later it annexed Raiatea, Tahaa, Bora-Bora and Huahine (Germany had dropped its opposition to the islands becoming French in the 1855 Bismarck-de Courcel Protocol). In turn, Great Britain accepted a request for a protectorate from the Cook Islands, which emanated from a fear that, without British patronage, the islands would become French. ${ }^{4}$

In 1887 Carnarvon would, with some exaggeration, speak about 'the enormous amount of recent French annexations' in the South Pacific. One of his concerns was the New Hebrides or Nouvelles-Hébrides, located west of Fiji. Should this archipelago become French, he said, 'there would stretch a great block of intervening islands between Australia and Fiji, all French'. ${ }^{5}$ The New Hebrides, with copra as its major export product, had all the problems associated with a South Pacific island group. Like the Bismarck Archipelago, it was a centre for the recruitment of labour and,

3 The other Austral Islands, Rurutu and Rimatara, became a French Protectorate in 1889 and were annexed the following year. Wallis Island was annexed in 1913.

4 The Cook Islands were annexed by New Zealand in 1900.

5 Carnarvon in House of Lords 2-5-1887 (hansard.millbanksystems.com/lords/1887/may/o2/ question-observations). 
similar to Fiji and Samoa, conflicts between Islanders and white settlers and disputes over land titles were endemic. As late as 1907 Winston Churchill, in his capacity as Under-Secretary of State for the Colonies, would describe the New Hebrides as 'a group of islands over which no Power has exercised any authority ... a sort of no man's land ... [where] ... owing to the habits of cannibalism and other savage customs, a state of grave disorder has always prevailed'. ${ }^{6}$

As elsewhere in the South Pacific, Europeans had settled in significant numbers in the New Hebrides Archipelago only in the early 1870 . Since then, law and order had had moments of relapse, resulting in the usual annexation requests, in which at first nationality was not the overriding factor, but rather the desire to gain armed protection (Pelleray 1922: 66). In 1878, after a meeting of missionaries in Melbourne had urged for a British annexation of the islands, Paris contacted London. Informing the British government that France had no intention of violating the independence of the New Hebrides, Paris asked and also got a similar commitment from London (Pelleray 1922: 68).

For Australia and New Zealand it was imperative that the New Hebrides should not become French. Since the French annexation of New Caledonia in 1853, Australia had 'striven with more or less energy and vigour to stiffen the back of the Colonial Office in combating French claims' regarding the New Hebrides, an indignant Australian Senator, Miles Staniforth Cater Smith, would write in 1904 (Australia 1904:1). Likewise, in France there was a strong lobby for establishing French control over the islands, with proponents of a French annexation accusing the French government of 'excessive timidity', just like their Australian adversaries did London (ibid.: 12).7

Sentiments in Australia and New Zealand were the greater because it was believed there that France considered the New Hebrides a good location for a new convict colony, with newspapers taking up the theme, speculating about scores of hardened French criminals succeeding to escape and reaching the shores of Australia and New Zealand. In 1883, to ward off the danger of the New Hebrides becoming a French convict colony, Victoria had called for their annexation, but failed to get the support of the other Australian colonies. For Queensland, a continued supply of labour was an overriding

6 Churchill in House of Commons 12-2-1907 (hansard.millbanksystems.com/1907/feb/12/ kings-speech-motion-for-an-address).

7 Germany was no contender. Godeffroy had tried to set up business in the islands, but had failed and left in 1883 (Pelleray 1922: 80). In May 1885, when Berlin and London had agreed on their respective sphere of influence in the South Pacific, they had come to the understanding that the New Hebrides were located in the British portion. 
factor. Its Premier, McIlwraith, suspected the calls for annexation to be an attempt by missionaries to end labour trade. ${ }^{8}$ The French also singled them out as the culprits, accusing the missionaries and their campaign against convict labour of having thwarted a French annexation of the New Hebrides (Lorin 1906: 432). In 1886, with the Agent-General for Victoria in London, Graham Berry, still warning the Colonial Office that new French possessions could 'only be regarded as the first landing place, and eventually these sweepings of the French prisons will be precipitated on Australian shores', London showed itself prepared to consider a French proposal to allow France to have its way in the New Hebrides in return for a French commitment to stop sending convicts to the South Pacific. ${ }^{9}$ London had two conditions. France should allow for 'full protection and freedom for religion and for trade'.10 And Great Britain would get the Island of Rapa, which, it was imagined, would become Great Britain's Pago Pago 'on the trade route of the future', but in fact would never gain the importance as a strategically located port that contemporaries attached to it (Colquhoun 1902: 188). London further persisted in its view that the colonies in Australia and New Zealand should be consulted before the two countries came to an agreement. Negotiations came to nothing. Only New South Wales and New Zealand could agree to handing over the New Hebrides to the French.

The discussion took place when the archipelago almost became French. In May 1886, only months after Berlin had indicated in the Bismarck-de Courcel Protocol of 24 December 1885 - which had not remained secret that Germany would not protest, the Governor of French New Caledonia decided to invaded the islands. He did so after over twenty foreigners had been murdered in four years, and new attacks on settlers had taken place. In a move widely seen not just as a punitive expedition, but as an effort to establish French rule, he ordered two warships to the New Hebrides. French garrisons were established and the French flag was raised. After a British protest Paris disavowed the action and entered into negotiations with London. The resulting Anglo-French Convention of 16 November 1887 displeased almost every interested party: British and French settlers, New Caledonia and the Australian colonies. French troops had to leave the islands within four months. The task of guaranteeing law and order came

8 www.schudak.de/timelines/newhebridesı6o6-1948.html.

9 Berry to Knutsford 27-10-189o (PRO FO 534 49).

10 Parliamentary Under-Secretary of State for the Colonies, George Osborne Morgan, in House of Commons 15-5-1886 (hansard.millbanksystems.com/commons1886/may/14/ the-western-pacific-the-new-hebrides). 
to rest with a Joint Naval Commission, 'charged with the duty of maintaining and protecting the lives and property of British subjects and French citizens in the New Hebrides'. ${ }^{11}$ Simultaneously, the Jarnac Declaration of 1847 about Tahiti's Leeward Islands, about which Paris and London had been quarrelling for seven years since the French had taken Raiatea and Tahaa, was abrogated. After a French pledge that British nationals would be treated equally and that no convict colonies would be established, Great Britain consented to the annexation of the island group by France. They formally became French in April of the following year. In Great Britain the government had some explaining to do. Regarding Raiatea, Parliamentary Under-Secretary of State for Foreign Affairs James Fergusson pointed out that it did not appear 'desirable, or, indeed, practicable, to remit to an aboriginal administration an Island which has been for some years under French government. ${ }^{12}$ In the background of the treaty loomed negotiations over the Suez Canal, which would lead to the Suez Canal Convention of 1888. Such an issue was too important to allow discord over the New Hebrides.

By the turn of the century feelings were as strong as ever. On the British side, also at home, they in fact extended to the mere presence of the French in that part of the Pacific. Colquhoun (1902:193, 391-2) would compare these French possessions, according to him badly run, to 'an open sore in a healthy body' and to 'a sore in the side of Australia' that should be removed; not forgetting to mention that a Frenchman had called Noumea, New Caledonia's capital, Criminopolos. And, as late as 1902, a British Member of Parliament, Charles Dilke, played with the idea of an invasion of New Caledonia and the New Hebrides (Hiery 1995: 13). In Australia the Sydney Daily Telegraph wrote that for 'geographical and economic reasons' the New Hebrides were of 'vital national importance' (Australia 1904:10). Frenchmen - in the New Hebrides as well as at home - made similar observations. They considered the New Hebrides to be 'a natural complement of the Caledonian Archipelago' or a 'natural dependency of New Caledonia', while 'the advance which the

11 Convention between Great Britain and France, Respecting Abrogation of the Declaration of the 19th June 1847, Relative to the Islands to the Leeward of Tahiti, and for the Protection of Life and Property in the New Hebrides, Art. 2. In January 1888 Great Britain and France agreed on the details of the Joint Naval Commission. It would have a President (alternatively the Commander of the British and French squadron in the New Hebrides; the lot to decide whether the first President should be French or British), and two British and two French naval officers (Declaration between Great Britain and France, for the Constitution of a Joint Naval Commission for the Protection of Life and Property in the New Hebrides, Art. 2).

12 Fergusson in House of Commons 27-2-1888 (hansard.millbanksystems.com/commons/1888/ feb/27/islands -of-the-southern-pacific-the-convention'-of-1847). 
English race' had made in the South Pacific was said to be 'a danger to French colonisation in New Caledonia' (New York Times 13-6-1886; Australia 1904: 12-4; Pelleray 1922: 98). Frenchmen also wondered why Great Britain, with its vast dominions of Australia and New Zealand, begrudged France, with the few 'miniscule archipelagos' it had in the South Pacific, extra land (Darcy 1904: 24).

The boost of sea traffic expected from the Panama Canal, convicts, composition of the population, land ownership and religion all entered the discussion. Though in 1897 France had stopped sending convicts to New Caledonia - trying in vain to promote its colonisation by colons libres - the phantom of a new convict colony had not disappeared in Australia, nor had the image of New Caledonia as 'a French dumping-ground for criminals' (Colquhoun 1902: 391). To some, the French decision was an empty gesture, only made because New Caledonia was already overcrowded. Should France gain the New Hebrides, the consequence could only be 'a fresh flood of the moral off-scourings of Europe ... emptied out at our doors' (Australia 1904: 8-9). Unfortunately, Australians and New Zealanders had to admit that in the New Hebrides French settlers formed the majority and that French land claims exceeded those of the British. Two-thirds of the land - 'most of the best land' it was moaned in Australia - was owned by Frenchmen ( ibid.: 5-7; Lorin 1906: 432). A culprit could also be identified:John Higginson, one of the earlier settlers in New Caledonia, whose business ventures would earn him the epithet of King of New Caledonia. Being a French national of Irish origin, and well-known for his efforts to expand French influence in the islands to the detriment of that of the British, to Australians he was a 'renegade Englishman'. ${ }^{13}$

Higginson had been the driving force behind the Compagnie calédonienne des Nouvelles-Hebrides (CCNH), founded in New Caledonia in 1882. Besides its other business activities, the $\mathrm{CCNH}$ was involved in the purchase of land in the New Hebrides and the promotion, in close cooperation with the Société française de Colonisation in Paris, of the settlement of Frenchmen from the home country in the islands (Pelleray 1922: 68, 81). As a belated countermove, the Australasian New Hebrides Company was founded on the urging of the Presbyterian Mission in 1889. Its task was to promote trade, purchase land and encourage Australians to settle in the New Hebrides. Though the initiative got the support of an impressive number of leading politicians and businessmen, the company would be defunct within years.

13 John Higginson, New Caledonia \& New Hebrides: threat to the colonies (www.auspostalhistory.com/articles/1849.shtml, accessed 28-6-2011). 
In 1897 its task was relegated to Burns, Philp \& Co., which also opened a subsidised monthly steamer service to the islands, but this also ended in a 'lamentable failure' (Australia 1904: 6). CCNH did not fare well either. After its initial success, it ran into financial difficulties. In 1894 the CCNH was reorganised and renamed the Société française des Nouvelles-Hebrides. A French bank, the Comptoir National d'Escompte, took over and acquired all assets and land, but also failed to make the venture profitable. Though this could not have been the only reason, later, French authors would blame the policy of the then French government to treat imports from the New Hebrides into New Caledonia and elsewhere in the French Empire as foreign products and tax them accordingly (Lorin 1906:432; Pelleray 1922: 82). Only in 1901 were the customs tariffs for products from imports from the New Hebrides removed.

Larger global considerations were also at stake. One option considered by some Frenchmen around 1900 was to allow Great Britain to take possession of the New Hebrides in exchange for concessions in Africa (Australia 1904: 3). Indeed, the New Hebrides became part of a British-French effort in 1903-04 to settle their colonial disputes worldwide, resulting in the Entente Cordiale of April 1904.

\section{The Entente Cordiale}

Conditions allowing for a rapprochement between Great Britain and France had already existed for some time. By mid-1898 doubts had crept in about the Anglo-French 'race for Yunnan' and the rest of south China. At that moment neither the British in Burma nor the French in Indochina had succeeded in constructing a railway penetrating south China. It had dawned on the Foreign Office in London that Yunnan might not be the commercial money spinner some had assumed it to be. On top of this came a growing awareness in London and Paris that what Salisbury had dubbed the 'policy of railways and concessions' in China, had inundated their administration at home and in China with requests for support and investments, which were often unrealistic and had been designed without any knowledge of local circumstances. ${ }^{14}$ In Paris the new Minister of Foreign Affairs, Delcassé, who sought French expansion in Africa, wondered whether Indochina and a possible sphere of influence in south China, compared to other French

14 Buchanan in House of Commons 30-3-1900 (hansard.millbanksystems.com/commons/1900/ mar/3o/british-commercial and political-interests-in-china). 
possessions, were worth the money, effort and political conflicts with Great Britain they might occasion (Chandran 1977: 280, 289). To him, Indochina was militarily 'indefensible' (and it goes without saying that Doumer, to counter that view, stressed what he had achieved in this field, concluding confidently that the defence of Indochina was assured) (ibid.: 292; Doumer 1905: 363). Delcassé also recoiled from becoming entangled in a south China adventure by the exploits of Doumer, fearing a xenophobic reaction by the local population and the trouble China might stir up along the frontier of Indochina (ibid.: 301). Cracks had also appeared in the Franco-Russian Dual Alliance. The Anglo-Russian Railway Agreement of April 1899 indicated that, in China, Russia considered Great Britain to be of more importance to deal with than France, where the agreement had made a bad impression. For Salisbury it had been an indication that Russia had 'ceased to attach more than a formal value to the French alliance'. ${ }^{15}$ The Anglo-Japanese Alliance of 1902 would weaken the strategic importance of the Dual Alliance still further; though in political issues in north Asia France continued to side with Russia.

In 1903 London and Paris made their first moves to come to an amicable understanding. In May King Edward VII visited Paris. He was booed when he arrived but was remarkably successful in turning an anti-British mood in the city around. The following month the French President, Émile François Loubet, reciprocated. Afterwards, there was much praise for both efforts to pave the way for a change in public sentiments in the two countries, also in the press, making political overtures possible.

The Entente Cordiale settled the disputed between Great Britain and France about the shared frontiers of their colonies and spheres of influence. Three documents were signed on 8 April 1904, just two months after the Russo-Japanese war had started. One, generally considered the backbone of the newly found friendship, dealt with Egypt and Morocco, giving Great Britain preponderance in the former and France freedom of action in the latter. In a second agreement France surrendered its fishing rights in Newfoundland in return for territorial compensation on the west coast of Africa. The third accord concerned Thailand, Madagascar and the New Hebrides. With respect to Thailand, and taking the Anglo-French Declaration of January 1896 as the starting point, it was agreed that the territory to the west of the Menam basin, including, it was explicitly stated, the Malay Peninsula and adjacent islands, would fall within the British sphere of influence, and the territory to the east and southeast within the French. Great Britain and 
France had 'liberty of action in their spheres of influence'. Bangkok had no say in this, it had not been consulted. London and Paris further vowed to respect Thailand's territorial integrity - 'disclaiming all ideas of annexing any Siamese territory' - and to honour the principle of free trade in the Menam Valley and the Upper Mekong region. ${ }^{16}$

With respect to the New Hebrides, London and Paris agreed to draft an agreement, 'which without involving any modification of the political status quo' would 'put an end to the difficulties arising from the absence of jurisdiction over the natives of the New Hebrides'. A second objective was 'to settle the disputes of their respective nationals ... with regard to landed property'. ${ }^{17}$ To accomplish this, further talks took place in London in January and February 1906 and on 20 October 1906. This culminated in the French ambassador Pierre Paul Cambon and Grey signing the Anglo-French New Hebrides Convention in London on 20 October 1906. The New Hebrides became a 'region of joint influence'. ${ }^{18}$ An Anglo-French Condominium, dual control, came into existence with a British and a French High Commissioner and a British and French police force. The Joint Naval Commission remained responsible for law and order. A joint Condominium Court, consisting of a British and a French judge and a president appointed by the King of Spain, was also set up, with both French and English as official languages; and which, among other things, had to decide on land title claims. The French fell under the jurisdiction of France, the British under that of Great Britain (other foreigners could choose which legal system they preferred). ${ }^{19}$ The Islanders, regarded as 'minors and incapable', remained stateless and were governed by a Joint Administration(Unrecorded n.d.: 2). Labour recruitment was also regulated. Only vessels sailing under the British or French flag which had a licence issued by the French or British High Commissioner,

16 Declaration concerning Siam, Madagascar, and the New Hebrides (8-4-1904), Art. I, Earl Percy (Under-Secretary of State for Foreign Affairs) in House of Commons 1-6-1904 (hansard. millbanksystems.com/commons/1904/jun/o1/the-anglo-french-convention-bill).

17 Declaration concerning Siam, Madagascar, and the New Hebrides (8-4-1904), Art. III.

18 Protocol between Great Britain and France respecting the New Hebrides, 27-2-19o6, Art. 1 (www.paclii.org/oldpits/english/treaty_database/1906/2.html, accessed 10-5-2011).

19 The Condominium did not put an end to demands for a French annexation; nor did it end the distrust that Great Britain might aim at taking control over the whole island group. One of the reasons for the first was that dual rule generally within a few years came to be considered to have become a failure (Pelleray 1922: 97-8). A joint administration and judiciary did not work. The Condominium Court was slow in coming into existence, and after it had would, at least until 1922, not settle any land title case (Pelleray 1922: 70). A conference was held in London in June 1914 to try to remedy its deficiencies. A new Anglo-French Protocol signed in August of that year was only ratified in 1922 . 
could engage in it. Labour contracts should not exceed a period of three years. As in other cases where European governments took charge, the sale of liquor to Islanders was forbidden.

Taylor (1971: 415) suggests that because of 'the sentimental weight of Egypt', the general feeling in both France and Great Britain was that 'France had paid the higher price'. The reality was more nuanced. Not only Australasians were upset. In Great Britain there was also disappointment, coupled with a feeling that France had gained more, a conclusion fortified by statements by Delcassé and other French politicians and by reports in the French press that treated the accord as a French victory. The suspicion also lingered that France had not discarded its plans to annex the whole of Thailand, with all the worries about the future of British trade in Thailand that such an assessment entailed. In this respect, it was also considered disappointing that London had not succeeded in persuading France to abandon the special tariffs for foreign goods exported to Thailand and southern China via French Indochina. Still others were uncomfortable about British and French spheres of influence touching each other.

In Australia and New Zealand the reaction was outright negative; one of the suggestions there had been to offer Mauritius (which the British had conquered from the French during the Napoleonic Wars) to France in exchange for a British annexation of the New Hebrides. Balfour, at that time leader of the Opposition, observed that people 'were extremely indignant'. ${ }^{20}$ Once again, London had succeeded in upsetting its Pacific Dominions, whose politicians were confronted with a fait accompli. In London the French had stood their ground and an accord had been hammered out that the British government considered the best result possible. London had communicated this to the governments of Australia and New Zealand and had informed them that they had to take the Declaration as it was. The proceedings made the Australian Prime Minister, Alfred Deakin, complain that the accord favoured France and that the suggestions made by him and his New Zealand colleague, Richard Seddon, 'appeared to have had no effect except, possibly, in very minor matters' (Hawera \& Normanby Star 24-10-1906). Angrily, he and the new Prime Minister of New Zealand, Joseph George Ward, left 'the responsibility for the completion of the Convention on the shoulders of the Colonial Office' (ibid. 2-11-1906). Disappointed as Australians and New Zealanders were, the Entente Cordiale did not alter their opinions about the French a great deal. As late as April 1914 it was

20 Balfour in House of Commons 12-2-1907 (hansard.millbanksystems.com/commons/1907/ feb/12/kings-speech-motion-for-an-address). 
observed that though the Entente Cordiale had made London and Paris partners, the rapprochement had not removed the suspicion in Australia and New Zealand of the French intentions in the South Pacific (Hiery 1995: 14).

In Germany the Entente Cordiale infuriated Wilhelm II, who, in his correspondence with Nicholas II, would depict Delcassé as an 'anglophile enragé'. ${ }^{21}$ It had also robbed Germany of a political advantage that Bismarck, as early as 1877 , had considered essential to containing France, and which successive German governments had tried to exploit as leverage to gain concessions from Great Britain: 'Separation of England because of Egypt and the Mediterranean from France' (Steinberg 2011: 355). Germany, which had not been consulted about the Moroccan deal in advance, tried to hit back by presenting itself as the champion of Morocco's independence and the Open Door in the country. The result was a low in the relations between Germany and France, whereas until that moment the German colonial policy of Weltpolitik had hardly caused any commotion and thus had not added to Anglo-German frictions (Grupp 1980: 51-3). To highlight the German case, Wilhelm II travelled to Tangiers at the end of March 1905. Germany urged for an international conference about the future of Morocco. During the meeting, which took place in Algeciras in early 1906, Berlin did not get the international support it had counted on. ${ }^{22}$

The Anglo-French rapprochement caused Satow, in faraway Beijing, to conclude in 1906 that since the signing of the Entente Cordiale his French colleague, while not 'quite trustworthy', had become 'very friendly'. ${ }^{23}$ Nanning was no longer a bone of contention between London and Paris. In January 1907 the city was opened up to foreign trade.

Yet also in France, as in Great Britain, scepticism about the intentions of the other had not disappeared. Ignoring the anti-German sentiments in the country, champions of French expansion initially continued to view Germany as a counterweight against Great Britain colonialism; persisting in this even after the Morocco crisis (Grupp 1980: 159-60, 217). One point of concern was Indochina, threatened more by Japan than by Great

21 Wilhelm II to Nicholas II 14-10-1904 (Bernstein 1918: 68).

22 Morocco only became a French protectorate in March 1912 after a second German-instigated crisis. The 'Agadir' conflict over Morocco in July 1911 had misfired after Great Britain, with Grey evoking the country's treaty obligations to France and probably also not looking forward to a German base along the Moroccan coast, came out on the side of France (Massie 1973: 729). In November 1911 Germany gave up its objections to French control over Morocco in return for part of French Congo.

23 Satow to Grey 8-2-19o6 (PRO FO 80044 ). 
Britain. After the Entente was signed, Cambon concluded that its future was secured. ${ }^{24}$ The renewal of the Anglo-Japanese Alliance of 1905 and speculations about its implication for Indochina made for renewed worries.

\section{The Anglo-Russian Convention}

A rapprochement with St Petersburg was also in the making. The shock of the Boer War, the prospect of a military confrontation with Germany and the disappointment over the position taken by Berlin with regard to the Anglo-German Agreement of October 1900, made some in Great Britain consider Russia a potential treaty partner. A new, additional factor was that the Persian Gulf was emerging as a target of German ambitions. Germany, already a political factor of importance in the Ottoman Empire, would only attain a greater presence in Persia once the Berlin-Baghdad railway (complete with special concessions in a 20-kilometre zone on both sides of the track) would have given it a foothold - perhaps even a naval base - in the Persian Gulf. Neither London nor St Petersburg was looking forward to such a new economic and political competitor in Persia. By the turn of the century, German had entered the British mind as one of the 'other and sometimes rival nations' interested in the Persian Gulf. ${ }^{25}$ In Russia the prospect of a greater German presence made for pleas to push forward to the Persian Gulf before the Berlin-Baghdad railway was completed (Soroka 2011: 3).

In 1901 there were pleas, e.g. in The Times and other British papers, in favour of Russia and Great Britain solving their differences. Reconciliation was also on the agenda of Lansdowne who, in the lead-up to the AngloJapanese Alliance, in October 1901 had sounded out St Petersburg regarding whether the two countries could come to an understanding over Persia and north Asia (Nish 2002:3). In Russia the Anglo-Japanese Alliance of January 1902 made for some overtures to London, but this time Lansdowne was not forthcoming (Soroka 2011: 34). The Tibet expedition of 1903 put an end to any concrete steps to come to a rapprochement. By the end of that year the Russian ambassador in London confided to Lansdowne that

it was most unfortunate that, at the present moment, when the Russian Government were, as I am aware, disposed to enter into an amicable 
discussion of our relations at the various points where British and Russian interests were in contact, an event of this kind, so calculated to create mistrust on the part of Russia, should have occurred. ${ }^{26}$

Lansdowne continued to work on some kind of agreement. In May 1904 he conveyed to Tsar Nicholas II, through King Edward, a champion of reconciliation not only with France but also with Russia, that Great Britain had the 'earnest desire ... that at the conclusion of the [Russo-Japanese] war our two countries may come to a satisfactory settlement regarding many difficult matters. ${ }^{27}$ France was also strongly in favour of a British-Russian rapprochement, partly out of fear that its Dual Alliance with Russia might somehow involve it in a war, party in an effort to isolate Germany on the European continent (Soroka 2011: 35).

It took three more years before the Anglo-Russian Convention was signed in St Petersburg on 31 August 1907 (or 18 August according to the Russian calendar). It hammered out an agreement about the main sources of conflict in Central Asia which for so long had poisoned Anglo-Russian relations: Tibet, Afghanistan and Persia (without, of course, consulting the local governments concerned). Other controversial topics stayed out of the deal. Initially, Russian diplomats had hoped that the negotiations might lead to British support for Russia's position in the Far East, but Great Britain, having to consider its ties with Japan, was not receptive (ibid.: 127, 134).

Russia and Great Britain pledged to respect Persia's integrity and independence and spoke out in favour of 'equal advantages for the trade and industry of all other nations'. ${ }^{28}$ At the same time, to avoid 'all cause of conflict between their respective interests', Persia was divided into a Russian zone in the north, south of the Russian-Persian frontier (which included the capital Tehran), where, as London later had to admit, Russia had already been the dominant power for decades; ${ }^{29}$ a much smaller British zone in the southeast (about half of the Russian zone); and a neutral zone in between. The two countries would not seek concessions in each other's

26 Lansdowne to Spring-Rice 17-11-1903 (cited in hansard.millbanksystems.com/lords/1904/ $\mathrm{feb} / 26 /$ the-mission-to-tibet). In February 1904 the Under-Secretary of State for India, the Earl of Hardwicke, and Lansdowne both denied in the House of Lords that the Russian ambassador's remark had anything to do with the Tibet expedition (hansard.millbanksystems.com/ lords/1904/feb/26/the-mission-to-tibet).

27 Edward to Nicholas 12-5-1904 (cited in Carter 2010: 308-9), see also Soroka 2011.

28 Agreement Concerning Persia, Preamble.

29 Grey in House of Commons 21-2-1912 (hansard.millbanksystems.com/commons/1912/feb/21/ persia-anglo-russian-agreement). 
Figure 33 The British and Russian sphere of influence in Persia and the neutral zone

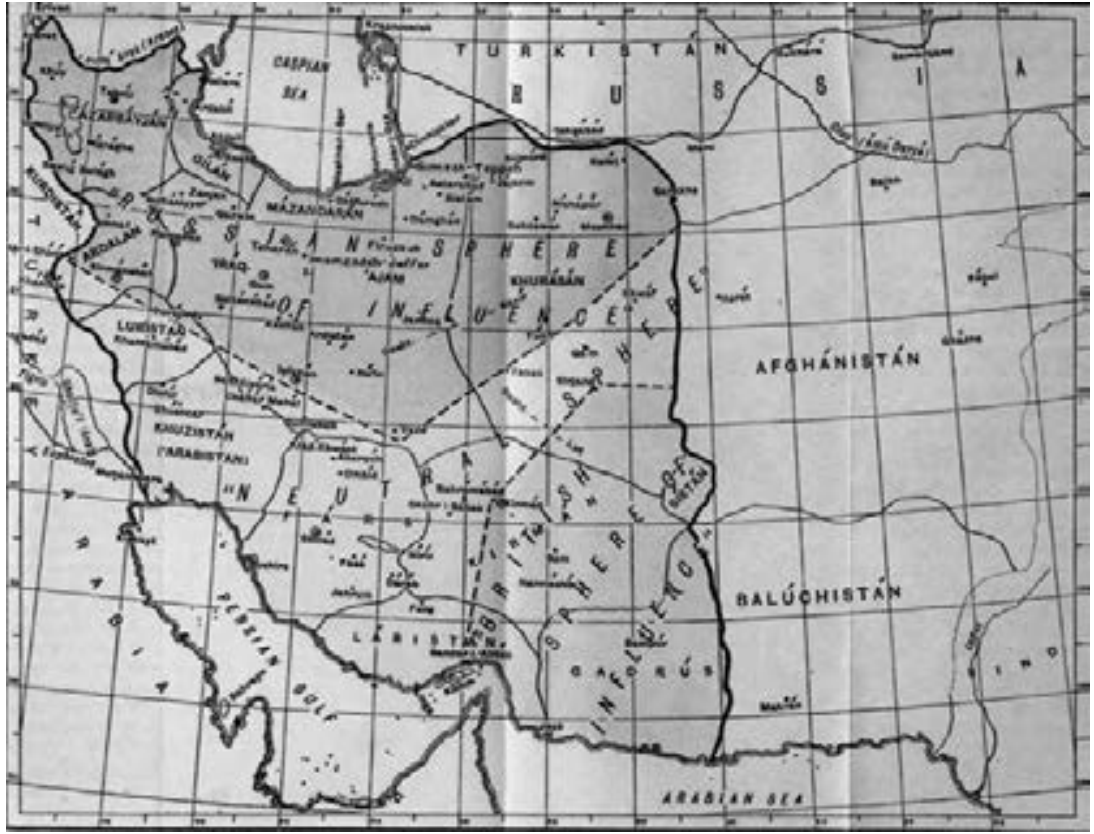

Source: Shuster 1912

zone 'of a political or commercial nature - such as Concessions for railways, banks, telegraphs, roads, transport, insurance, etc. ${ }^{30}$ In the neutral zone there were no such restrictions. Carefully, the British had seen to it that the Russian zone and the Persian-Afghan frontier touched nowhere.

The Convention remained silent about the Persian Gulf. London had wanted to include a clause confirming the British preponderance there, but Russia had refused, playing the card that it was a matter that also concerned Germany (Soroka 211: 137-8). When queried about this later, the British government could only draw attention to a letter by Grey to the British ambassador in St Petersburg in which he mentioned an assurance by the Russian Minister of Foreign Affairs that Russia did not 'deny the special interests of Great Britain in the Persian Gulf' ${ }^{31}$ Not all British were happy with this. They would have preferred a Russian commitment in writing.

30 Agreement Concerning Persia, Art. I and II.

31 Grey to Hardinge 29-8-1907 cited by Percy in House of Commons 17-2-1908 (hansard. millbanksystems.com/commons/19o8/feb/17/the-anglo-russian-convention). 
For some, it was even a reason to moan that also in the Persian Gulf, once a British reserve, Russia had made considerable headway.

In Persia, the content of the Convention only became known on 4 September. It was immediately concluded that the treaty was a first step on the way to real partition and that it would not take long before Russia and Great Britain would intervene. A week later, a joint Anglo-Russian Note of 11 September finally informed Persia about the Convention. It maintained that Great Britain and Russia, 'desiring to avoid any cause of conflict between their respective interests' in the north and the east of Persia, had signed a 'friendly agreement'. Twice in the document Tehran was assured that the integrity and independence of Persia would be respected and that London and St Petersburg desired 'the pacific development of that country, as well as the permanent establishment of equal advantages for the commerce and industry of all other nations'.$^{32}$ Tehran responded by informing London and St Petersburg that it could not accept the Convention and its implicit division of the country into spheres of influence.

Regarding Tibet, Great Britain and Russia recognised 'the suzerain rights of China' and the 'special interest [of the British] in the maintenance of the status quo in the external relations of Thibet' ${ }^{3}$ Consequently, both promised not to enter into direct negotiations with Tibet, nor send 'Representatives' to Lhasa or seek concessions. Two other sensitive points were also settled. Great Britain would allow religious contacts between Russian Buddhists and the Dalai Lama and other Tibetan religious leaders, in the past identified as a source of anti-British sentiments in Tibet, while in an appendix London reaffirmed its commitment to withdrawing from the Chumbi Valley after Tibet had fulfilled its commitments.

Afghanistan remained within the British sphere of influence. In the convention, which endeavoured to 'ensure perfect security on their respective frontiers ... and to maintain ... a solid and lasting peace', St Petersburg acknowledged that Afghanistan was 'outside the sphere of Russian influence'. ${ }^{34}$ Russia also promised that it would not 'send any Agents into Afghanistan' and that it would consult the British government should political complications arise in its relationship with Afghanistan. London, in turn, promised to respect Afghanistan's independence and not interfere in domestic Afghan affairs. In an effort to remove Russian worries, Great

32 Joint Note Russia and Great Britain 11-9-1907 (cited in Shuster 1912: 286-7).

33 Convention between Great Britain and Russia, Arrangement Concerning Tibet, Preamble (www.tibetjustice.org/materials/treatiesı2.html).

34 Convention concerning Afghanistan, Preamble, Art. I. 
Britain also pledged to exercise the influence it had 'in a pacific sense' and not to 'encourage Afghanistan to take any measures threatening Russia'.35 Confident in their status as powers, Russia and Great Britain made their agreement dependent on the assent of the Amir of Afghanistan. He was not as pliable as the British government had expected (others from the beginning had had their doubts). Angry that he had only been informed afterwards, the Amir waited a year before announcing that he could not agree with what the British and the Russians had concocted.

On the British side, the Convention was inspired by two old-standing interconnected fears: one about the security of India and the other about a Russian advance into Persia, which, after a brief interlude, St Petersburg was to resume with vigour in order to compensate for the territory lost in Manchuria. Both had acquired a new dimension. In August 1904 Prime Minister Balfour had dismissed earlier scares about a Russian invasion of India as 'most foolish', but he did so to call attention to a new danger to India's security. In the past, logistics had been Russia's greatest problem, making an incursion into India unlikely. This had changed. Russia had a railway line reaching the Afghan frontier, and soon it might have a second one as well..$^{6}$ The Persian Question had assumed an additional urgency as Persia seemed to be in a state of collapse, making the British government fear that without some sort of understanding with Russia, an Anglo-Russian confrontation might well be in the making. Such an escalation, Foreign Secretary Grey told the House of Commons, was what he had wanted to avoid. The choice was between an agreement with Russia and having to counter 'Russian encroachment in the north ... by corresponding measures to protect British interests in the south'. ${ }^{37}$ Grey refused to go 'forward':

[W] hatever you gain and whatever you take, you have always to push your influence further still to protect what you have recently taken, and while you think all the time that you are making yourself safer, you are increasing the burden of your expenditure. $3^{8}$

British anxieties were matched by Russian ones. In Russia, which was weakened by the war with Japan and domestic unrest, the bogey was a British

35 Ibid., Art. I.

36 Balfour in House of Commons 2-8-1904 (hansard.millbanksystems.com/commons/1904/ aug/02/class-ii-1).

37 Grey in House of Commons 17-2-1908 (hansard.millbanksystems.com/commons/19o8/feb/17/ the-anglo-russian-convention).

$3^{8}$ Ibid. 
advance, even an invasion of Persia, its army passing through Afghanistan (Soroka 2011: 124, 129-30, 133, 139).

Persia was an important British consideration, India even more so. By concluding the Convention, the British government was sure - at least this was the position it took publicly - that a Russian invasion of Afghanistan and India had been averted once and for all. The Convention was, in the words of Secretary of State for India John Morley, 'undoubtedly first and foremost an Indian treaty'. ${ }^{9}$ To him, the Convention was 'an enormous gain'. ${ }^{40}$ Grey, in this respect, stressed that Great Britain had gained control over Sistan (Seistan), which was in the British zone and was now presented as 'the key to the whole of it', 'the main point of danger to Indian interests', and 'a new land door of advance into India'. ${ }^{41}$ It could no longer serve as an intermediate station for a Russian railway, right down to the port of Bandar Abbas (Bunder Abbas) on the Persian Gulf; for which the Russians would continue to press. Without the Convention, Grey also posed, Russia might one day have gained the right to build a railway to the Indian frontier, to which Great Britain could only react by advancing in Persia, resulting in the partition of that country and a joint Russian-British frontier. ${ }^{42}$ Now that India was considered safe, there were immediately calls to lower its defence budget.

In Russia the Convention was not popular and met with hostility by the press (Soroka 2011: 141). A Russian advance in Afghanistan and Tibet had been blocked, while with respect to Persia even Foreign Secretary Alexander Isvolsky had to admit that the British had gained more (ibid.: 142, 146). In Great Britain there were also objections, as in the case of the Anglo-French Entente, in part inspired by long-standing anti-Russian sentiments and aversion to making deals with the autocratic Russian regime. Curzon even spoke of 'humiliation'. ${ }^{43}$ Critics pointed out that the British government, eager - maybe even desperate - to come to an agreement, had conceded too much; some, such as Balfour, even argued that Russia had made no

39 Morley in House of Commons 17-2-1908 (hansard.millbanksystems.com/commons/1908/ feb/17/the-anglo-russian-convention).

40 Ibid.

41 Grey in House of Commons 17-2-1908 (hansard.millbanksystems.com/commons/19o8/feb/17/ the-anglo-russian-convention).

42 Grey in House of Commons 21-2-1912 (hansard.millbanksystems.com/commons/1912/feb/21/ persia-anglo-russian-agreement).

43 Norman in House of Commons 17-2-1908 (hansard.millbanksystems.com/commons/1908/ feb/17/the-anglo-russian-convention). 
concessions at all. ${ }^{44}$ In Tibet, it was said, the British had failed to exploit the position of strength the Younghusband expedition had given them, which critics did not fail to mention had cost a lot of British money and suddenly, according to some, also a lot of British blood. With regard to Afghanistan, it was pointed out that the British promise to keep out had not been balanced by the Russian undertaking not to build a railway to the Afghan frontier. London had refrained from asking for this, so Grey explained, to prevent Russia from counter-demanding that Great Britain would not construct a railway line to the Indian-Afghan frontier. ${ }^{45}$ The fifth article of the Afghanistan Convention also drew much criticism. Referring to 'the principle of equality of commercial opportunity in Afghanistan', it stipulated that 'any facilities ... obtained for British and British-Indian trade and traders, shall be equally enjoyed by Russian trade and traders'. It was wondered why London had not pressed for a similar construction for Russian territory along the Afghan border. Causing equal, if not greater, commotion was the clause that should 'progress of trade establish the necessity for Commercial Agents', London and St Petersburg would consult each other about how to proceed. The possibility of Russian trade agents in Afghanistan was received with some horror, given the double function such functionaries could have and often had.

\section{The Persian Question}

What the British government had consented to regarding Persia, at times received sharp condemnation in Great Britain. The Convention was called a setback for free trade in Persia, detrimental to the prospects of British commercial activities there. Furthermore, it was seen as a blow to the process of democratisation, which was slowly taking form in Persia where, in the second half of 1906, the Shah, Muzaffar ad-Din, had been forced to accept a Constitution and Parliament, the Medjlis. Important trade routes came under Russian control, with few British putting much faith in Russian assurances about free trade. What the British themselves had received was 'a triangle of desert and sparsely populated country half the size of

44 Balfour in House of Commons 17-2-1908 (hansard.millbanksystems.com/commons/1908/ feb/17/the-anglo-russian-convention).

45 Grey in House of Commons 17-2-1908 (hansard.millbanksystems.com/commons/19o8/feb/17/ the-anglo-russian-convention). 
the Russian sphere'.$^{46}$ (Oil would become an economic and political factor only a few years later.) People also wondered - as they had done at the time of Port Arthur - what the effect of giving in to Russia would have on the British image in India and the rest of Asia. There was also some fear that, over time, the zones might be turned into leased territories $a$ la those in China, but then much larger and in closer proximity to one another, with the concomitant danger of serious international complications, if not an armed confrontation.

Berlin's reaction to the Convention was different from that to the Entente Cordiale of April 1904. Before formal negotiations were started, Isvolsky had sounded out Germany. Berlin was not to object, he was told, as long as German interests were not infringed upon (Massie 1993: 598; Soroka 2011: 123). There was no Morocco-like attempt to hit back. In fact, one month after the conclusion of the Convention, Tirpitz pleaded for an acceleration of the German fleet programme, advancing as one of his arguments that, contrary to two years before, there was no 'foreign political danger' (Steinberg 2005: 134). But there were always Germany's economic interests to consider. Assurances were needed. Wilhelm II was to visit Great Britain in November 1907 and, in advance, Grey suggested that he should be informed that 'care had been taken' to ensure that German commercial interests in Persia would not be damaged by the Convention (ibid.:136). Soon, however, Germany, tending (as France did) to side with Russia when conflicts over Persia arose, and evoking the principles of free trade and an Open Door (just as it had done regarding Morocco), was bitterly complaining about supposed commercial restrictions imposed by the British.

Domestic unrest, if not chaos, in Persia, so detrimental to trade and the security of their nationals, gave both Russia and Great Britain a reason to act. To restore order Russian troops entered north Persia in April 1909, with St Petersburg pledging that the incursion would only be temporary. In the south, where the situation, in the words of Grey, was 'very unsatisfactory', with frequent robberies and telegraph wires being cut, Great Britain reacted in a similar way. In October 1910 Persia was presented with what was widely called an ultimatum. Officers of the British-Indian Army should be allowed to take charge in restoring order along the trade routes in the south (with Tehran having to bear the costs). A year later, in October 1911, in view of what Grey now called 'the chaos in Persia', some 400 to 500 cavalry troops from India were deployed to protect British lives, property and trade. They

46 Earl of Ronaldshay in House of Commons 17-2-19o8 (hansard.millbanksystems.com/ commons/19o8/feb/17/the-anglo-russian-convention). 


\section{Figure 34 William Morgan Shuster}

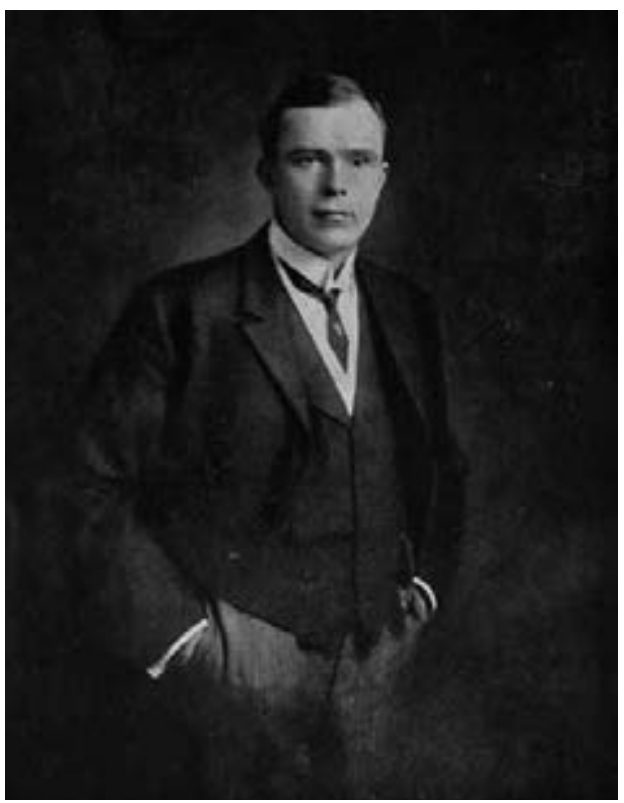

Source: Shuster 1912

were, the phrase went, and the same terminology was used for the Russian build-up in the north, to reinforce the consular guards. India was also a factor. As Grey explained, Great Britain could not 'allow the part of Persia which adjoins the Indian Frontier to be in a condition which threatened the security of that country'. ${ }^{47}$

In 1911 internal strife and power struggles made for a brief indirect American involvement in Persian affairs when the American lawyer William Morgan Shuster became Treasurer-General, a position which, for obvious reasons, could not go to a Russian or Briton. In May 1911 Shuster arrived in Tehran with three American assistants. His stay was short and eventful. Not a diplomat by nature - Grey said he was 'quite innocent of any political intrigue ${ }^{48}$ - almost from the first day Shuster provoked the Russians and, by doing so, irritated the British government, which was not looking for complications. In June the Persian Parliament passed a law, drafted by Shuster himself, giving him, in his own words, 'plenary powers

47 Grey in House of Commons 27-11-1911 (hansard.millbanksystems.com/commons/1911/nov/27/ sir-edward-greys-statement).

48 Ibid. 
in matters fiscal' (Shuster 1912: 313). His effort to control all Persian financial proceeds, including those of the customs offices in the north, brought about his first confrontation with Russia. The north was Russian 'territory'. To make matters worse, to collect taxes Shuster instituted a special Treasury Gendarmerie, which, he hoped, would eventually consist of 12,000 to 15,000 men (ibid.: 338). He did not think anything was wrong with this. Collecting taxes from the rich in this way had 'always been the procedure' (ibid.: 158). The gendarmerie was to be under Shuster's control and, his plan was, should be headed by Major C.B. Stokes, an officer of the Indian Army and member of the British Legation, whose contract as military attaché would soon expire. Shuster never tired of arguing that his decision was 'actuated by no political motive in the faintest degree' (ibid.: 321). Stokes was the perfect man for the job because of his military experience, knowledge of Persia and fluency in Persian (and French). ${ }^{49}$ The British ambassador, George Barclay, saw nothing at fault in his appointment, as long as Stokes would resign from the Indian Army (which he did), but London did, expecting 'some international jealousy'. ${ }^{\circ}$ When it learned that Russia would protest, Tehran was warned 'not to persist in the appointment of Major Stokes unless he is not to be employed in Northern Persia', adding that otherwise London would recognise 'Russia's right' to safeguard its interests there (Shuster 1912: 99). Stokes' appointment, Grey would later explain, went against the 'spirit' of the Anglo-Russian Convention. ${ }^{51}$ Stokes left Persia for India in December. Shuster had to settle for American officers to command his gendarmerie.

Another one of Shuster's faults was the appointment, against Grey's advice, of Lecoffre (in spite of his name a British subject; though there was some confusion about his nationality, as some thought he was a Frenchman), an official of the Persian Ministry of Finance, acting as treasurer in Tabriz in the north near the Russian frontier; again presenting as one of the reasons for his decision Lecoffre's fluency in Persian. In London unease increased. Grey thought it unwise and 'absolutely contrary to the spirit of the Anglo-Russian Agreement' to appoint Britons or Russians to 'administrative posts on the frontiers of Russia or India respectively'..$^{2}$ The 'constant appointments of British subjects in the north of Persia' might

Shuster to Stokes 6-7-1911, Shuster to Barclay 14-7-1911 (Shuster 1912: 327-8).

Barclay to Shuster 14-7-1911 (Shuster 1912: 328).

$5^{1}$ Grey in House of Commons 8-8-1911 (hansard.millbanksystems.com/commons/1911/aug/o8/ persia).

$5^{2}$ Grey in House of Commons 14-11-1911 and 12-12-1911 (hansard.millbanksystems.com/ commons/1911/nov/14/persia, hansard.millbanksystems.com/commons/1911/dec/12/ adjourned-debate). 
give the impression that Russian influence there was replaced by British, which, he feared, could 'provoke counter-measures on the part of Russia'.53

For Russia, Shuster's gendarmes occupying, in early October, the properties of two noblemen who had taken up arms against the government in Tehran and could count on Russian sympathy, was the last straw. On 11 November St Petersburg threatened to sever diplomatic relations with Persia if the gendarmerie did not withdraw. Grey advised Tehran to yield to the Russian demand, which it eventually did (Shuster 1912:162). A second Russian ultimatum followed on 29 November. Shuster and Lecoffre had to be dismissed and the Persian government had to promise not to employ foreigners 'without first obtaining the consent of the Russian and British Legations'. Grey refused to come to Tehran's assistance. He could agree to two of the Russian demands, though not to a third one: an indemnity to compensate Russia for the costs involved in directing troops to Persia, which, the Russian ambassador in Tehran explained to the Persian government, it had been forced to 'owing to the recent insulting acts of Mr. Shuster towards Russia' (ibid.: 165). For one, Persia could not 'pay anything', but more importantly, it was 'adverse to British trade interests'. ${ }^{54}$ The consequences could be that Persia would lack the money to restore order and tranquillity in the 'British' south.

On 15 December Russia increased pressure. If the Persian government did not comply with its latest ultimatum, Russian troops would march on Tehran. On 25 December Shuster was fired. He left Persia on 14 January, boarding a Russian steamer bound for Baku in Enzeli. Once back in the United States, Shuster would start an anti-Russian campaign, stressing how devious St Petersburg's policy in Persia was, giving lectures and publishing The strangling of Persia: A record of European diplomacy and Oriental intrigue. Shuster not only blamed Russia but also Great Britain. For instance, he wrote about Anglo-Russian condominium in Persia and lashed out at 'the scarcely less injurious timidity of England so far as thwarting Russia's evident designs' on Persia was concerned (Shuster 1912: 287, 43).

53 Grey in House of Commons 14-11-1911 (hansard.millbanksystems.com/commons/1911/nov/14/ persia).

54 Grey in House of Commons 12-12-1911 (hansard.millbanksystems.com/commons/1911/dec/12/ adjourned-debate). 



\section{The United States, Japan and the Pacific Ocean}

On 29 July 1905, just before the start of the Russo-Japanese peace negotiations, American Secretary of War William H. Taft and Japanese Prime Minister Katsura Taro signed a secret memorandum in Japan in which Washington recognised Japanese control over Korea and Tokyo that of the United States over the Philippines (an easier target of a Japanese attack than Hawaii). In doing so, Washington conveniently forgot that the Treaty of Peace, Amity, Commerce, and Navigation that it had concluded with Korea in 1882 held the mutual obligation to mediate and 'bring about an amicable arrangement' should 'other Powers deal unjustly or oppressively' with the other treaty partner. ${ }^{1}$ London also gave Tokyo a free hand. Sacrificing Korea had been on the mind of British politicians at least since 1901, when Ashmead-Bartlett had suggested in the House of Commons that to prevent an alliance between Russia and Japan, Great Britain could 'offer Japan a protectorate over Korea'. ${ }^{2}$ In the adjusted Anglo-Japanese Alliance, concluded in August 1905, this became a reality. There was no longer any mention, as there had been in 1902, of respecting Korea's independence. Article III spoke of Japan 'possessing paramount political, military and economic interests in Corea' and of Great Britain recognising the right of Japan 'to take such measures of guidance, control and protection of Corea as she may deem proper and necessary to safeguard and advance those interests'. Tokyo did not wait long to act. On 17 November 1905, in yet another Japanese-Korean Agreement, also known as the Eulsa Treaty or Japanese-Korean Protectorate Treaty, the Korean government had to confirm Japanese indirect rule. The following month Japan instituted the position of a Resident-General in Korea and appointed Ito Hirobumi. In retrospect, the Japanese Ministry of Foreign Affairs would argue that Japan's decision to establish a protectorate over Korea had been inspired by 'grave concern' over the situation in Korea, 'which proved to be fruitful sources of difficulty in the Extreme East, involving Japan in serious complications' (Lawton 1912: 1093). The protectorate only added to the anti-Japanese feelings. Resistance was brutally suppressed (McKenzie n.d.: 185-90). In London

1 United States-Korea Treaty of Peace, Amity, Commerce, and Navigation of 1882, Art. I.

2 Ashmead-Bartlett in House of Commons 2-4-19o1 (hansard.millbanksystems.com/ commons/1901/apr/o2/china-crisis-russia-and-manchuria). 
Figure 35 Garden party at the Japanese Residency-General (picture taken between 1906 and 1909; the third person from the left is Ito Hirobumi)

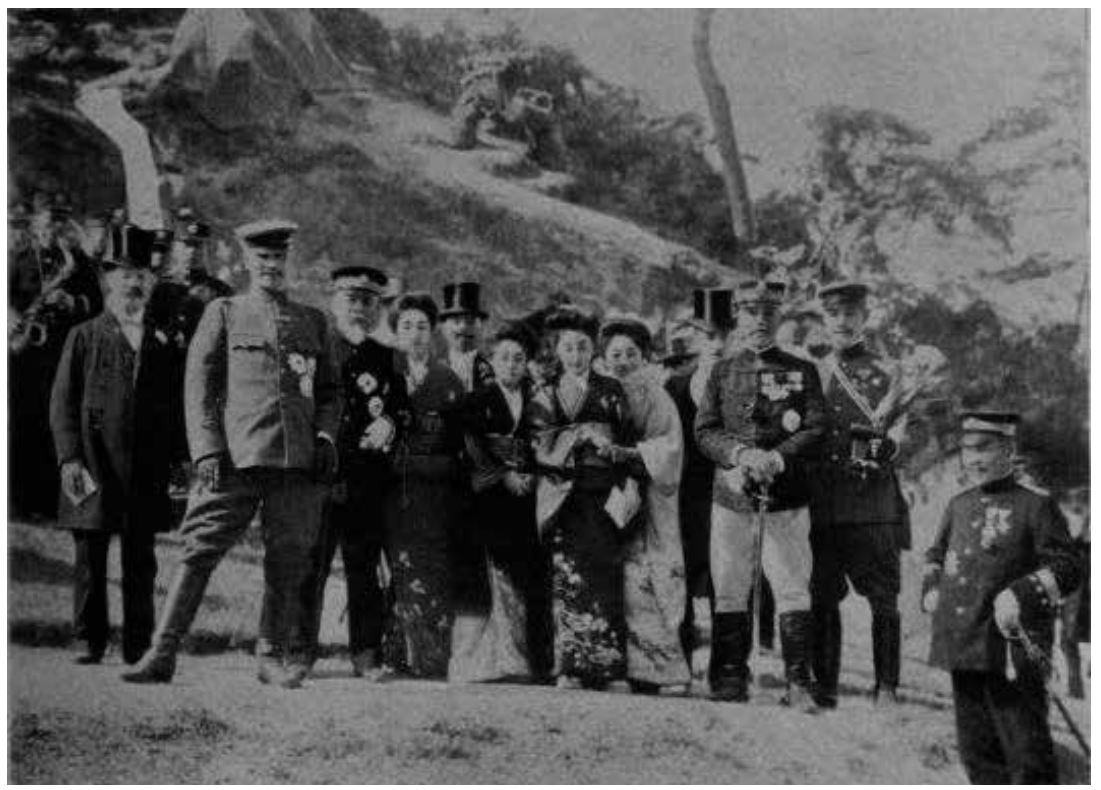

Source: Putnam Weale 1908

Grey, anxious not to jeopardise Great Britain's special relationship with Japan, turned a blind eye to what was happening in Korea (Cockburn 2012). The Houses of Parliament also remained silent.

In August 1905 McLeavy Brown left Korea. Ambassador Allen soon followed. He was recalled at the request of Japan. Shortly after their departure, Japan dismantled Korea's foreign relations. Five days after the signing of the Eulsa Treaty, Tokyo announced that Japan had taken charge of Korea's foreign policy and that it would see to it that the treaties with and the 'legitimate commercial and industrial interests' of other countries in Korea would be respected. ${ }^{3}$ The foreign legations in Seoul were closed or downgraded to Consulates General. All matters regarding Korea had to be taken up with the Japanese Ministry of Foreign Affairs.

In 1907 Japan would tighten its hold over Korea still further. In July Emperor Kojong was forced to abdicate. His fault had been that he had sent a delegation to the Second Hague Peace Conference to call the attention of

3 Circular note Japanese Government 22-11-1905, quoted by Earl Stanhope in House of Lords 273-1911 (hansard.millbanksystems.com/lords/1911/mar/27/british-interests-in-japan-and-korea). 
the world to Japan's aggression in Korea. Japan reacted with a vengeance. Tokyo demanded that the Emperor personally sign the Protectorate Treaty of November 1905, that he should appoint a regent, and that he should travel to Tokyo to apologise in person to the Japanese Emperor. On 19 July 1907 Kojong abdicated in favour of the Crown Prince. Five days later, in a yet another treaty and ostensibly to promote 'a speedy development' of the country and the welfare of its people, Korea had to promise not to take any domestic measure without Japanese approval. ${ }^{4}$

\section{Japan's role in the Pacific}

Japan's performance in the war with Russia had made a deep impression in the Asian colonies and foreign settlements, where the foreign community had to come to terms with the fact that Japan, already hailed as a nation which had closed the gap with the West, became a source of inspiration for nationalist movements. In China, where pictures of the war decorated the walls of houses, contemporaries noted a sudden upsurge of patriotism, which earlier had been absent. A 'new nationalism', as Putnam Weale (1908: 579) put it, had made its appearance, with 'cries of "China for the Chinese" resounding all over the Empire'. It 'spread like a wildfire through the length and breadth of the land' (Lawton 1912: 570, 1368). Elsewhere, an 'awakening of the East', as it was generally called, could be observed. In the Netherlands Indies colour pictures depicting the Japanese victory could be seen in houses, even in remote villages in Java, while within a few years Indonesian nationalist leaders came to tease the Dutch with their Japanophobia, or 'Japanitis' as the press chose to dub this (Thijs 1965:17-8; Van Dijk 2007: 84). In Indochina pictures were seized hailing the Japanese victory as the beginning of Asia's revenge on Europe (Lorin 1906: 370). From India a Japanese journal was informed that after the fall of Port Arthur Indians had shared the Japanese 'joy and pride to not a small degree, and the city of Calcutta and many other towns and villages were gay with illumination' (Lawton 1912: 8o6). In Singapore Japan was praised as 'the first successful champion of the Asiatic race to have arisen since the Tartar invasion of Russia, at any rate since, in the eighteenth and nineteenth century, Holland, Russia, France and Great Britain had conquered and controlled all that in 
Asia was worth having, except Japan'. ${ }^{5}$ The United States was also a target. In 1905 and 1906 Chinese anger over the American Chinese Exclusion Act found its expression in a boycott of American products.

Disquieted by the enthusiasm with which the Japanese victory was received, Europeans in Europe and its colonies, alarmed as the latter in particular tended to be by any sign of unrest among the population, began to speculate about Japan's active role in stirring up anti-colonial sentiments. In Paris rumours circulated about plans for an invasion of Indochina drafted by the Japanese general Kodama Gentaro, Chief of Staff of the Japanese army (Lorin 1906: 370). The British journalist Lawton (1912: 808) was sure that Japan had become 'one of the principal centres from which anarchy in India' was directed. He also noted that the Japanese victory had 'exercised a widespread influence for evil throughout the country'. Also in the United States 'many', a Japanese scholar living there noted, believed that Japan lusted after India (Goto 2002: 12).

In New Zealand, Australia and the United States Japan came to figure even more prominently as the potential enemy. An unnerving thought was that Japan had destroyed the Russian fleet, but that this had not stopped the country from aiming to build one of the strongest navies in the world. This, Putnam Weale $(1908: 487,490)$ wrote, caused 'acute uneasiness to the serious student of Far Eastern politics'. Either Japan aimed, after the Anglo-Japanese Alliance had expired, to prevent a repeat of 1895 when it had been forced out of Manchuria, or was it arming itself in preparation of a confrontation over supremacy in the Pacific. Among those who joined in was no less a person than Rear Admiral A.D. Fanshawe, Commander of the Australian naval station, who shortly after the defeat of the Baltic fleet warned of war with Japan (Hiery 1995: 15).

In Australia and New Zealand the news of the adjustment of the AngloJapanese Alliance, and the decision of London to withdraw its battleships to Europe, was greeted with 'a sentiment almost akin to alarm' (Lawton 1912: 422). It was not understood why Great Britain would abandon the Pacific Ocean to the Japanese. This step was not only presented as a threat to the existence of Australia and New Zealand, but also as disastrous for the British prestige in Asia. In New Zealand Prime Minister Joseph Ward in 1909 went as far as to hint that New Zealand might leave the British Empire if London asked it to join in a war Great Britain would have to fight together with Japan (Hiery 1995: 14).

5 Dutch Consul General in Calcutta to Van Tets van Goudriaan 21-1-1907 (ARA FO A-dos. Box $450)$. 
Strengthening the home defences became imperative, all the more so because soon it was deemed unlikely that the Anglo-Japanese Alliance would be renewed in 1915. In Australia plans were developed to expand the fleet and by early 1910, at the request of Australia and New Zealand at the end of 1909, the famous Field Marshal Horatio Herbert Kitchener, 'Hero of Khartoum', visited the dominions to advise on their defences; that is how to repulse a Japanese attack. Compulsory military training was introduced in New Zealand in 1909. In the same year a conscription bill was introduced in Australia, which was passed into law two years later.

The matter gained additional urgency during the British Naval Scare of March 1909 when, in and outside the British Parliament, a heated debate took place about how many battleships Great Britain needed to maintain superiority over the German navy and what the financial implications were. The opposition even submitted a motion (which was defeated) in the House of Commons that the number of warships the government intended to build would not 'sufficiently secure the safety of the Empire' in the near future. ${ }^{6}$ The reaction in the Dominions was quick. New Zealand and Australia each promised to finance the building of a dreadnought, aptly named the New Zealand and the Australia, both laid down in June 1910. A year later the launching of the New Zealand presented Ward with another opportunity to deplore the loss of British command of the Pacific, which, he said, was 'so vital' to New Zealand (Lawton 1912: 421). Australia, which had its own navy, kept the battle cruiser under its own administration. The British First Sea Lord, John Fisher, had decided that the HMAS Australia should become the nucleus of an Australian fleet capable of taking on 'the Yankees, Japs, and Chinese, as occasion required out there'. The Australia would join in the operation against German colonies and German raiders in the Pacific in the first months of World War One. New Zealand, which had no navy, presented the New Zealand to the British navy. HMS New Zealand would visit New Zealand, where its arrival caused a patriotic outburst, but was ultimately deployed for British defence interests and would see battle in the North Sea.

In Germany reactions to the new Anglo-Japanese Treaty were different from those in 1902. In 1906 Satow in Beijing would venture that the new German ambassador in Tokyo had as his 'chief duty ... to weaken the

6 Lee in House of Commons 29-3-1909 (hansard.millbanksystems.com/commons/19o9/ mar/29/vote-of-censure).

7 Fisher to Esher 13-9-1909 (Navy 2009: 1). 
Anglo-Japanese Alliance'. ${ }^{8}$ Strengthening the British fleet in European waters challenged Tirpitz' premise that sometime in the future Great Britain could be defeated, or at least seriously weakened, in an all-out sea battle in Europe because the British navy could not bring into action its complete fleet in European waters, as some warships were needed elsewhere in the world (Nuhn 2002: 232). Newspapers rekindled the fear of the yellow peril and accused Great Britain of taking a stand hostile to Europe; an opinion also voiced outside Germany. Reflecting this mood, Wilhelm II hinted at a confrontation of the West with Japan in the Pacific. In his infamous interview published in the Daily Telegraph of 28 October 1908 , almost universally seen as a political blunder, he asserted that the German navy plans were not directed against Great Britain. Germany needed its warships to protect its commerce and its 'manifold interests in even the most distant seas'. Pointing at 'the accomplished rise of Japan' and the 'possible national awakening of China', Wilhelm II suggested that the day might well come - and perhaps was even near - that the European powers would have to defend their interests in the Pacific. When they would be 'on the same side in the great debates of the future', the British would be 'glad' that Germany had a strong fleet. On another occasion, Wilhelm II went as far as to speculate about a Japanese fleet entering European waters (Putnam Weale 1908: 498).

In the United States politicians and others had reason to worry as well. Washington might have mediated peace between Japan and Russia and have recognised Japan's position in Korea, but American-Japanese relations were soon to deteriorate, with bellicose language used on both sides. The seeds of tension were already there: the Hawaiian annexation and the persistent anti-Japanese sentiments in the United States which evoked strong patriotic reactions in Japan. The 'equal right' treaty that the United States and Japan had concluded in 1894 had allowed for unrestricted immigration of Japanese to the United States. Though their numbers remained small, the arrival of cheap Japanese labour led, in particular in California, to anti-Japanese outbursts. The proposal in early 1905 for the actual exclusion of Asian children from white primary schools in San Francisco and its implementation in December 1906, attacks on Japanese in that city in the wake of the earthquake of April 1906, and later instances of undisguised discrimination and violence against Japanese triggered anti-American demonstrations and calls for war in Japan. In February 1907 Tokyo, in return for a commitment 
by Washington to put an end to discrimination against the Japanese in California, promised to halt labour migration to the United States. ${ }^{9}$

A transformation of Korea and South Manchuria, exactly those regions in the Far East where American mercantile interests were greatest, into Japanese economic satellites formed a new source of tension. Taiwan had already shown what might be expected of regions that came under Japanese control. Import tariffs had been instituted and within years British companies in Taiwan had been forced to leave, unable to compete with Japanese imports (Colquhoun 1902: 355, 374). Tokyo repeated this policy in Korea and South Manchuria. It earned Japan the accusation of violating the Open Door principle, and American protest in early 1906, when Secretary of State Elihu Root expressed the fear that returning sovereignty over the Japanese part of Manchuria to China might have little real substance (Lawton 1912:1160).

In the background loomed the fact that America was losing the Manchurian market for cotton and piece goods, which the Americans had almost monopolised before 1904, to Japan (Lawton 1912: 1180, 1184, 1261). Shrewd competition was one reason for this, but what was highlighted was that Japan delayed the normalisation of international trade and tried to promote Japanese trade via Dalian at the expense of American trade via Yingkou. Rates for goods transported by rail from Dalian into Manchuria along the main line were lower than those partly sent along the Yingkou branch line of the South Manchuria Railway. For some time after the Russo-Japanese War there was also no Chinese customs office in Dalian, while in Yingkou a customs station did levy duties on the mainly non-Japanese imports in that port. Yet another much contested reality was that, initially, non-Japanese merchants were not allowed to settle in Shenyang and other cities in Japanese-conquered Manchuria (ibid.: 1158-61). Another point at issue was the expropriation of land along the South Manchuria Railway line over which Japan then claimed jurisdiction, and the Fushun and Yentai coal mines, which Japan had 'inherited' from Russia and was further developing. For similar reasons, there were growing reservations among the British, at home and abroad, about the treaty with Japan, or as a British Member of Parliament observed: the Anglo-Japanese Alliance was 'not so popular among British residents in the Far East'. ${ }^{10}$

9 Labour migration to Hawaii was restricted. In March 1907 the American government banned migration of Japanese labourers from Hawaii and the Philippines to the continent.

10 Stanhope in House of Lords 8-11-1909 (hansard.millbanksystems.com/lords/1909/nov/o8/ railway-interprise-in-china). 
American and British indignation was the greater because initially it had been assumed that, with Japan's statements in favour of an Open Door in China, the southern portion of Manchuria would be wide open to investments and trade after the Russian retreat. As a British Member of Parliament expressed it, the Japanese victory over Russia had 'awakened fresh interest in China as a field for British capital and enterprise'. ${ }^{11}$ Manchuria, moreover, had become a region of great economic expectations. A contemporary Japanese industrialist, expecting far greater opportunities for Japanese commerce in Manchuria than in Korea, spoke highly of the purchasing power of the Manchurians. It was 'almost boundless'. Lawton agreed: Manchuria was 'one of the richest of underdeveloped territories in the world' and had become 'the scene of one of the keenest commercial struggles that has been witnessed at any time in any part of the world' (Lawton 1912: 1180, 1109-11).

Illustrative of the frustration over the Japanese trade policy was the change in assessment of the way foreign investors were treated in Korea by Millard, an American. In 1906 he could still write that American economic activities profited from the Japanese occupation of Korea, and that the Japanese authorities were more lenient towards American and British interests than to those of France and Germany (Millard 1906: 95). Three years later he had come to the conclusion that Japan was turning Korea 'as she has already done with Formosa, into a Japanese commercial and industrial closed preserve' (ibid.: 162). A similar opinion was expressed by British the author Putnam Weale (1908: 518), who noted that Korea and Manchuria were becoming 'a closed market'. In the same vein, Lawton also concluded that in Manchuria the Japanese had 'acquired a stronger hold ... than the Russians ... prior to the war, when British traders were loud in their complaints against the discriminating policy of the Administration' (Lawton 1912: 1112).

When the deadline of March 1907 for the evacuation of foreign troops from Manchuria, which had been agreed upon in Portsmouth, approached, the Japanese army withdrew from Yingkou and other Manchurian cities (as did the Russian units in the north). A sense of formal economic normality returned. The Japanese opened Dalian again to non-Japanese foreign trade on 1 September 1906 and in June 1907 China and Japan concluded a provisional customs agreement for Guandong. This did not put an end to criticism abroad. The American State Department complained about the preferential treatment of Japanese companies by the Dalian port authorities

11 Steward in House of Commons 15-6-1910 (hansard.millbanksystems.com/commons/1910/ jun/15/consolidated-fund-no-2-bill). 
and the problems foreign merchants (and the American Consul General) encountered in finding accommodation and office space; with practically all houses vacated by the Russians, being claimed by the Japanese military, only a few of which, according to the Americans, were actually occupied (Lawton 1912: 1158).

\section{American-Japanese relation}

On the global level, the question of mastery in the Pacific and the possibility of an American-Japanese confrontation emerged. The United States turning to the Pacific and China was at the same time the starting point - at first in the background - of a struggle with Japan for hegemony of the Pacific. The 'threatening question of Asiatic immigration' and the 'awakening of the East', both appearing more frightful than they were in reality, made people in the United States like Mahan (1911: 20, 28) expect a confrontation in the Pacific in which the West European nations (he did not include Russia) would eventually join in with the United States to defend their colonies. In the British Pacific Dominions a similar scenario was sketched. Xenophobic Australians and New Zealanders harboured the view, as did white settlers in Hawaii and their American supporters, that an unrestricted immigration of Japanese would hand over their colony to Japan. Or, as British Foreign Secretary Grey, told Japanese ambassador Kato Takaati in 1911, their Prime Ministers feared that 'a pacific invasion of their territory by the Japanese ... would displace their own population' (Hotta-Lister 2002: 13).

Some twenty years earlier, fortifications had been erected in the United States to defend the east coast against a European power; now the west coast became a cause for concern. Japan had become the potential invader, the enemy who might strike there and in Hawaii and the Philippines. This prospect in 1905 made Roosevelt order an investigation into 'the coast defences of the United States and the insular possessions' (Dorrance 1995: 147-8). The following year the National Coast Defence Board, also known as the Taft Board (after its Chairman), presented its recommendations for the fortifications to be constructed in ports in the United States, Hawaii and the Philippines, and in the Panama Canal Zone. Consequently, the defence of the American Pacific coast was improved, while in the Philippines fortifications were built on Corregidor Island and elsewhere in Manila Bay. In Hawaii, where American military experts and others considered the presence of a large Japanese population an additional complication, special attention went to the defence of Pearl Harbor and nearby Honolulu (ibid.: 152). 
Soon there would be predictions of war, the first war scare hitting the United States in 1906-07. People called for the stationing of the American fleet in the Pacific to defend the country's west coast. The adjusted AngloJapanese Alliance and the launching in October 1906 of HMS Dreadnought added to the worries. How Great Britain would react if the United States and Japan should engage in war was keenly discussed not only by Americans in their country but also between Americans and Englishmen in all parts of the world' (Lawton 1912: 368 ). The Philippines was considered especially vulnerable, being within easier reach of a Japanese than an American fleet. Roosevelt now seemed to regret its acquisition. The islands were America's 'heel of Achilles ... the only thing that made the Japanese situation dangerous'. His conclusion was that the United States had better get rid of them (Bootsma 1986: 16). The Philippines, for which the Americans had fought a costly war, was hardly an economic success story, having made for calls for an American retreat at least since 1903 (Miller 1982: 261). Hawaii was different. It became an integral part of the defence of the American west coast. When, in 1908, a decision had to be taken about the home base of the American Pacific fleet, Hawaii and not the Philippines was selected.

In a demonstration of naval strength, Roosevelt ordered sixteen American battleships to sail from the Atlantic to the Pacific Ocean in July 1907. Two other battleships would join them there. The move, presented as an exercise, only added to speculations of war. Without informing London, New Zealand and Australia invited the fleet to call at its ports (Hiery 1995: 15). In New Zealand Ward used the visit of the 'Great White Fleet' to allude to the coming struggle for supremacy between 'white men' and 'Orientals' in the Pacific and to an American fleet fighting 'shoulder to shoulder with the Old World' (Lawton 1912: 374). Local newspapers took up the visit to speculate about a union of Great Britain and the United States to prevent Japan from gaining control of the Pacific, occasioning a similar discussion in the American press (ibid.: 374-5). The 'Great White Fleet' also got a warm welcome when it called in at Yokohama in October 1908. School children sang the American national anthem, the Emperor received the officers in audience and a garden party and a ball were hosted by, respectively, Admiral Togo Heihachiro, responsible for the defeat of the Baltic fleet, and Prime Minister Katsura Taro.

About a month after the warships had left Japan, the United States and Japan concluded the Root-Takahira Agreement; considered by some to be a direct result of the show of force of the fleet's voyage. The new agreement, a repeat of the Taft-Katsura Taro accord, was laid down in a letter of 30 November 1908 from the Japanese ambassador in Washington, Takahira Kogoro, to 
Root, accepted on the same day. Tokyo and Washington, 'uninfluenced by any aggressive tendencies', agreed to maintain the status quo in the Pacific Ocean and to 'respect the territorial possessions belonging to each other in the said region'. They also promised - as almost every agreement regarding the Far East in those years did - to respect the Open Door principle and the integrity of China. ${ }^{12}$ The agreement did not accomplish much. It did not make a great impression in China, where the press dismissed it as 'somewhat meaningless' and lacking in sincerity (Putnam Weale 1908: 606). In the United States Japanese economic policy in Manchuria and Korea remained a source of displeasure, while the Agreement also did not abate suspicion about Japan's aggressive intentions in the Pacific. Lawton (1912:1350-1) even wrote about 'the ever-present fear' in the United States 'that Japan is about to attack her in the Pacific'.

For Japan the Root-Takahira Agreement was one of a series in which it gained formal recognition of its position in Asia. On 10 June 1907 a FrancoJapanese Treaty had already been signed in Paris. Equally, it vowed to 'respect the independence and integrity of China' and spoke about 'the equal treatment in that country for the commerce and subjects or citizens of all nations'. Further, it was acknowledged that France and Japan had 'a specific interest to have the order and pacific state of things preserved, especially in the regions of the Chinese Empire adjacent to the territories where they have the rights of sovereignty, protection, or occupation'. To maintain the territorial rights of France and Japan on the Asian continent, Tokyo and Paris further pledged to 'support each other for assuring the peace and security in those regions' (ibid.: 1150). A month after the Franco-Japanese Treaty came a Russo-Japanese one. Signed on 30 (17) July 1907, it was mainly about hammering out the respective positions of Russia and Japan in Manchuria and Korea. The two promised to 'respect the actual territorial integrity' of each other and to recognise the rights Russia and Japan had obtained in their 'treaties, conventions, and contracts' with China and in the Portsmouth Treaty (ibid.: 1150-1). A secret convention was added in which Russia and Japan promised not to aim at railway and telegraph concessions in the portion of Manchuria that fell within the sphere of influence of the other. Russia, 'recognising the relations of political solidarity between Japan and Korea', vowed 'not to interfere with nor to place any obstacles in the way of the further development of these relations'. Japan, in return, recognised 'the special interest of Russia in Outer Mongolia', a region which after Russia had lost part of Manchuria came to feature more prominently in Russian plans in north Asia; and where 
contemporaries speculated Russia might seek compensation should Japan seek further expansion in Manchuria (Putnam Weale 1908: 274-5). ${ }^{13}$

Still, irritants remained. One was the Japanese demand that the Songhua River, a tributary of the Amur, flowing to Harbin, should be open to merchantmen of all nations. Russia countered that in the $185^{8}$ Treaty of Aigun Russia and China had agreed that the river would remain closed to foreign vessels, except Russian ones. Pressured by both sides, China first, in 1909, allowed merchantmen of other nations to sail the river. Subsequently, after protests by St Petersburg, on 9 August 1910 China had to conclude an agreement with Russia, reconfirming the stipulation of the Treaty of Aigun; a solution not accepted by Japan and the United States. What Russia

and Japan wanted to reserve for themselves became clearer in 1912 during negotiations over an international loan to China. St Petersburg claimed 'special rights and interests' in 'northern Manchuria, Mongolia, and western China', and Tokyo in South Manchuria and 'the eastern portion of Inner Mongolia adjacent to South Manchuria' (Young 1979: 178).

The only power no treaty was concluded with was Germany. Germany had made its position clear in the Anglo-German Agreement of October 1900 in which it had pledged to maintain the territorial integrity of China and free trade (Lawton 1912: 1151).

\section{Russia and Japan guarding their spheres of influence}

Around 1910 the question of how to react to the way Russia in the north of Manchuria and Japan in the south tried to gain economic dominance had become an important international issue. Even war could not be ruled out as the impression was that Russia and Japan were arming themselves for a new confrontation to decide on the fate of Manchuria and, beyond this, on their spheres of influence in Mongolia to the west; a conflict, contemporaries speculated, that might decide the fate of China - the spectre of dismemberment of the Chinese Empire had re-emerged - and worse, could draw in other powers. In the words of American Secretary of State Philander C. Knox, a new Russo-Japanese war would be a 'great conflict of world-wide consequences, a conflict which would of a certainty secure to the victor domination over the whole of Manchuria, and in all probability, preponderating influence throughout the length and breadth of the Chinese Empire'. ${ }^{14}$ 
Figure 36 Page from Gascoyne-Cecil's Changing China

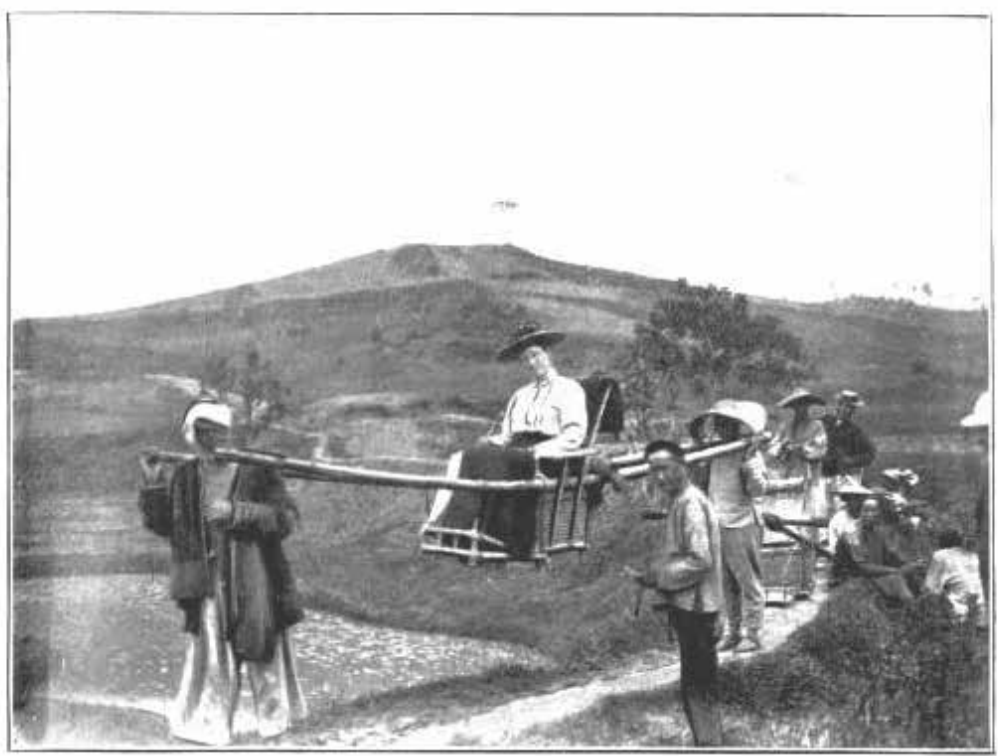

THAVELLING IX (HAXA-OLD STYLE

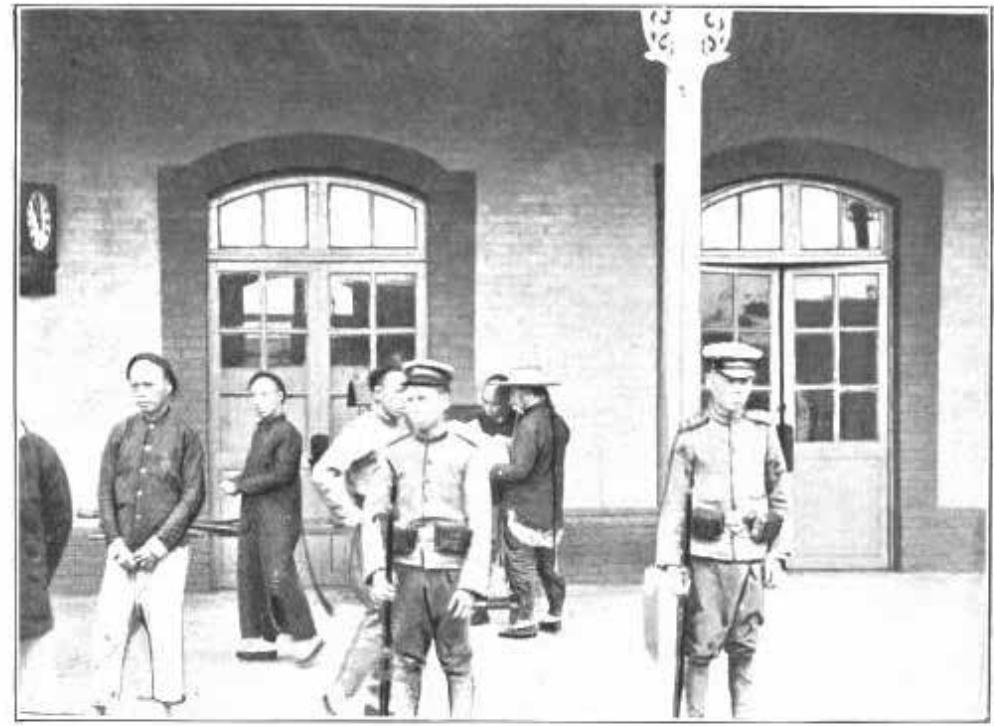

A RALWAY STATHS-NEW FTYLE

Source: Gascoyne-Cecil 1911 
The protectionist policy of Russia and Japan put the British government in an awkward position, reluctant as it was to give its treaty partners offence. It made London, in the words of Lawton (1912: 1347), the object of 'much hostile criticism from Englishmen who are intimately acquainted with the existing situation'. As in the case of Persia, the government was blamed for its faint-heartedness. Lawton (1912: 1332, 1343) wrote of a 'British policy of surrender', inspired, he suggested, by the fear that an armed conflict over China would turn into 'a world conflagration' and possibly the partition of China. Others looked at the growing tension in Europe and accused London of making the British position in China subservient to Germany threats in Europe. ${ }^{15}$ The topic had also come up during the discussion of the Anglo-Russian Convention. The point in question had been why, in contrast to the Entente Cordiale, which had been global in nature, its scope had been confined to Central Asia and had not included the Near and Far East, where British and Russian interests were also at variance. In response to such criticism, Grey had explained that the government's considerations had been strategic and not commercial. A few months later he too had to admit the Anglo-Russian Convention had been confined to Central Asia in order not to give offence to other powers. ${ }^{16}$ The British position also earned criticism from the United States, by now presenting itself as the champion of the Open Door in China.

As so often, railway concessions became the foci of conflict. Japan and Russia were set to maintain their railway monopolies in Manchuria, at times using threatening language to keep China in line. In 1907 Japan opposed an extension of the Chinese Northern Railways running parallel to the South Manchuria Railway from Hsinmin, the terminus of a rail line from Yingkou, northward to Faku (Fakumen) on the banks of the Liao River (perhaps later to be extended to the frontier with Russia). Tokyo evoked one of the secret protocols attached to the Sino-Japanese Treaty of December 1905 in which the Chinese government had promised not to build a railway line 'prejudicial' to the South Manchuria Railway (which proponents of the proposed line stressed it would not). To strengthen its hand even more, Tokyo also referred to the clause in the April 1902 Russo-Chinese Convention with regard to Manchuria, according to which Russian consent was

15 Grey in House of Commons 17-2-1908 (hansard.millbanksystems.com/commons/19o8/feb/17/ the-anglo-russian-convention).

16 Grey in House of Commons 17-2-1908, 27-7-1908 (hansard.millbanksystems.com/ commons/19o8/feb/17/the-anglo-russian-convention, hansard.millbanksystems.com/ commons/1908/jul/27/class-ii). 
needed for a Chinese railway in South Manchuria. In an effort to forestall a Japanese protest and gain diplomatic backing from London, Beijing had awarded the contract to construct the line to a British firm. London did not react as hoped. Referring to the secret protocol, it pointed out that it was for those who wanted to build the line to demonstrate that the interests of the South Manchuria Railway were not hurt.

Beijing demanded, as it had every right to according to the South Manchuria Railway agreement of July 1898 , that the branch line between Tashihchiao and Yingkou (built with the express purpose of making the construction of the main line possible) be demolished (Asakawa 1909). ${ }^{17}$ Amidst criticism abroad about Japan's mining policy and China contesting Japan's claim to part of the Fushun concession and other mines, Japan and China, in the name of 'the desire to consolidate the relations of amity and good neighbourhood' between the two countries, concluded the Manchurian Agreement of 4 September 1909. China promised that, before proceeding with its plans for the railway line, it would 'arrange previously with the Government of Japan'. ${ }^{18}$ Mining was included in the new understanding. The Japanese government was given the right to work mines in Fushun and Yantai (the tax paid upon the coals produced would be arranged upon the basis of the lowest tariff for coals won in any other places of China'), while mines along the South Manchuria Railway (and the line between Antung (Andong) and Shenyang constructed by Japan during the Russo-Japanese War) would be exploited by Sino-Japanese joint ventures. ${ }^{19}$ In return, Tokyo recognised Chinese sovereignty in Jiandao (Kando, Gando, Yanbian, Chientao), a region in southeast Manchuria with a large Korean population. Earlier, its status had been disputed between China and Korea, when in 1907 Japanese troops invaded Jiandao to put down Korean resistance. Tokyo did so in a separate agreement - the Korean Boundary Agreement or the Jiandao Agreement - which was concluded on the same day 'to secure for Chinese and Korean inhabitants in the frontier regions the blessings of permanent peace and tranquility', and, of course, was an expression of 'cordial friendship and good neighbourhood'. ${ }^{20}$ But

17 A counter-proposal by Japan to construct a railway connecting Fakumen with the South Manchuria Railway line, found no favour in the eyes of the foreign commercial community in Yingkou.

18 Agreement concerning mines and railways in Manchuria, Preamble, Art. I (Manchuria 1921: 129).

19 Agreement concerning mines and railways in Manchuria, Preamble, Art. III and IV (Manchuria 1921: 129).

20 Agreement relating to the Chientao region, Preamble (Manchuria 1921: 135). 
there was a catch. China undertook to connect the Jilin (Kirin)-Changchun Railway with the Korean railway system.

In the United States the Manchurian Agreement created a furore about American industry being excluded from mining activities in the area controlled by the South Manchuria Railway. Washington, however, did not want to bring the matter in northeast China to a head. In October 1909 Charles Richard Crane, appointed ambassador to China only a few months earlier, was even forced by Secretary of State Knox to resign before he could take up his post. Crane had been too frank in his denunciation of the Japanese policy in Manchuria. The following month the State Department came with a statement that assurances had been received from Japan and China that they did not aim at a mining monopoly and that, consequently, the United States did not object to the Manchurian Agreement (New York Times 16-11-1909).

With Japan being given specific privileges in the south, Russia could not be denied the same in the north. There, the status of Harbin and the other cities along the railway that Russia wanted to administer was a source of international irritation. The matter evolved after the American consul in Harbin, Frederick D. Fisher, on his arrival in the city in January 1907 had refused to ask for Russian permission to take on his job. He was only prepared to deal with the Chinese government. Fisher also supported a protest by the head of the local Chinese administration against the Russian effort to establish independent municipalities in its railway zone; for Russia this was, in turn, a reason to protest in Washington. A pattern developed: France sided with Russia, Japan did the same, while Great Britain made some noises, but did not press on (in this case Germany also protested the Russian policy). The commotion would eventually cause Russia to sign an agreement with China, on 10 May (27 April) 1909, to clarify the status of the tracts of land the Russian railroad ran through. They did so, the preamble noted, because differences in interpretation had arisen between the two governments over the 1896 Chinese Eastern Railway Convention. In the new agreement Chinese sovereign rights were recognised as 'a matter of fundamental principle. ${ }^{21}$ Regulating the establishment of municipal bodies in 'commercial centres of a certain importance' it was stipulated that the property and land directly required for the running of the railway would still be managed by the Chinese Eastern Railway Company, as would land and

21 Preliminary agreement between Russia and China in regard to municipal administration in the Chinese Eastern Railway Zone, Art. I (Manchuria 1921: 155). 
buildings not handed over to the municipalities 'by mutual arrangement'. ${ }^{22}$ It was a feeble compromise. At first Washington protested, but in the end, and on the advice of Rockhill, now ambassador in St Petersburg, it consented (Lawton 1912: 1311).

In spite of such concessions, the new Taft administration, in office since March, was to follow an assertive China policy. The focus was on railways and the loans China needed to build them. In December 1909 Taft, in a message to Congress stressed the importance of American banks having a share in loans granted to China (Young 1979: 171-2). The immediate cause was provided by reports about a new Anglo-French-German consortium set up for the construction of railways in China and backed by their respective governments. Washington wanted to join. Or, as the unfortunate Crane disclosed in a speech when he was appointed ambassador to China, in 'a perfectly legitimate and friendly way', Knox had 'determined' that the United States should have its share in the development of China (Lawton 1912: 1319-20). Knox himself explained in an interview in The New York Times (7-1-1910) that it was 'of the greatest importance that the United States should participate' in the railway scheme. This would provide the American government with the opportunity as 'an interested party to exercise an influence equal to that of any of the other three powers'.

In the name of fair trade, Knox even suggested a 'complete commercial neutralization of Manchuria., ${ }^{23}$ Manchurian railways should be taken 'out of the eastern politics' and be placed 'under an economic and impartial administration by vesting in China the ownership of its railroads'. ${ }^{24}$ In notes to Tokyo and St Petersburg Knox suggested that Japan and Russia should sell their shares in the railways in Manchuria to China. A loan to the Chinese government raised by an international group of financiers, citizens of 'all countries interested', should make the deal possible. Convinced that his suggestion would become reality, and Manchuria would cease to be a major source of international tension, Knox tried to sell his idea as aiming at the restoration of 'unimpaired Chinese sovereignty, the commercial and industrial development of the Manchurian provinces' and 'as a large contribution to the peace of the world by converting the provinces of Manchuria into an immense commercial neutral zone'. ${ }^{25}$

22 Preliminary agreement between Russia and China in regard to municipal administration in the Chinese Eastern Railway Zone, Art. VI, XVI (Manchuria 1921: 155-6).

23 Interview with Knox in The New York Times 7-1-1910.

24 Ibid.

25 Ibid. 
The neutralisation proposal was bound to fail. Russia and Japan were not prepared to let go what they had gained or had succeeded to cling on to after so many sacrifices, financially as well in terms of lives. Or, as the Japanese newspaper Jiji Shinpo wrote, the United States wanted to 'rob Japan of her single prize of war' (Lawton 1912: 1329).

The neutralisation proposal ran tandem with plans by American financiers and a British firm to build a rival railway between Aigun (Aihui) in north Manchuria, on the border with Siberia, and Jinzhou. In return for a loan to China they gained the necessary approval in January 1910. The railway would cross with the Chinese Eastern Railway in Qiqihar (Tsitsihar), but at no point would it come closer to the South Manchuria Railway than some 150 miles. Still, it was politically sensitive. Like the Yingkou-Faku line, it was a test of how far Tokyo's influence reached. Touching upon its political implications, the Chinese Viceroy of Manchuria said that the line implied a check on further expansion of Japanese influence westwards (ibid.:1346). The plan had the full support of Taft and was presented as being part and parcel of the internationalisation deal suggested by Knox.

Russia and Japan, invited to participate in the building of the new line, both used strong language to dissuade China from proceeding. Japan referred to the 1905 secret protocols. It informed China that the proposed railway ‘vitally' affected Japan's interests in Manchuria and that if China did not discuss the matter beforehand with Japan it would 'not be hard to estimate the seriousness of the trouble that may be caused in the relationship of the two countries'. ${ }^{26}$ Russia left no doubt that it considered the matter of 'extreme importance' and it also threatened 'trouble' in Sino-Russian relations. ${ }^{27}$ Besides pointing at the 1899 agreement with Great Britain, which allowed only Russia or China to build a railway north of the Chinese Wall, St Petersburg called attention to the economic and political consequences. The proposed railway would link up with the Chinese Eastern Railway and might well hurt the Russian railways in eastern Mongolia and northern Manchuria. ${ }^{28}$ And, as the new line and the existing South Manchuria Railway reached up to the Russian frontier with China, it could well be used to transport enemy troops to Siberia and Vladivostok. France joined in, advising China not to undertake anything that might 'occasion

26 Japanese ambassador to Chinese Ministry of Foreign Affairs (Wai Wu Pu) 31-1-1910 (Lawton 1912: 1352).

27 Russian ambassador to Chinese Ministry of Foreign Affairs 2-2-1910 (Lawton 1912: 1352).

28 Russian ambassador to Chinese Ministry of Foreign Affairs 4-3-1910, Memorandum transmitted to the Chinese Government by the Russian ambassador (Lawton 1912: 1365, 1354). 
complications or difficulties' and would complicate the relations between the powers in the Far East. ${ }^{29}$

In presenting his idea, Knox had tried to convince the Russians that his neutralisation plan formed an international guarantee that the Manchurian railroads indeed would not be used for military purposes and that, when realised, Russia could stop worrying about a Japanese thrust into Siberia (Lawton 1912: 1316). Russia was not impressed. The Aigun-Jinzhou railway would, as was communicated to the Chinese government, 'result in serious injury both to the Russian frontier defences and to her commercial interests' $^{30}$ Consequently, Washington was told that Russia had no intention at all of participating in the construction of the line. It was a clear veto. ${ }^{1}$ As the Russian ambassador in Beijing informed the Chinese government, Washington was 'conscious of having made a mistake' and had put an end to the negotiations about a loan to finance the railway. ${ }^{32}$

Knox' proposal put the British government in a delicate if not embarrassing position, having to choose between Russia and Japan and the United States. London, Lawton (1912:1567) would conclude two years later, in view of the situation that was developing in Europe, needed the friendship of Tokyo and St Petersburg too much. The British government did not support the neutralisation plan. It also refused to provide diplomatic backing to the Aigun-Jinzhou railway. To justify this position, Grey referred to the 1899 agreement with Russia about Great Britain not seeking railway concessions north of the Great Wall and to the Anglo-Russian Convention. His government could hardly be asked to promote a railway 'constructed by foreigners with money lent by foreigners, which ... is going to have a considerable influence on Russia's strategical position' ${ }^{33}$ China should first consult Russia and Japan.

29 French ambassador to Chinese Ministry of Foreign Affairs 18-2-1910 (Lawton 1912: 1354).

30 Russian ambassador to Chinese Ministry of Foreign Affairs 4-3-1910 (Lawton 1912: 1356).

31 Russia came with a counter-proposal: a Trans-Mongolia Line connecting the Beijing-Shenyang railway via Zhangjiakou (Kalgan) northwest of Beijing to Ulan Bator (Urga) in northwest Mongolia and from there to Kiakhta (Kyakhta, Kiakta) on the Russian border; roughly following the trading route officially recognised in the Convention of Beijing of 1860 . For strategic reasons the suggestion was rejected by China. France sided with Russia and endorsed the plans for an alternative line.

32 Russian ambassador to Chinese Ministry of Foreign Affairs 4-2-1910 (Lawton 1912: 1353).

33 Grey in House of Commons 15-6-1910 (hansard.millbanksystems.com/commons/1910/jun/15/ consolidated-fund-no-2-bill). 
The British stand caused 'considerable hostile comment in America'. ${ }^{34}$ In Great Britain the British position was also not well-understood by everybody. It earned the government the accusation that it was 'the cat's paw of Japan in regard to Manchuria and Mongolia'. ${ }^{35}$ There was also criticism in British business circles and their supporters who saw in a new non-Japanese railway line in Manchuria not only a new opportunity for British industry, but also a means to open up 'a vast territory ... for British enterprise and British capital'. ${ }^{36}$ The resentment was the greater because in the Yangtze Valley, which in British minds was 'British', commercial activities by other foreigners were on the increase, and - even more sensitive - these foreigners also aimed at the construction of railways there, all activities which were interpreted as a blow to British prestige and British might.

The neutralisation plan brought Russia and Japan closer together. On 4July (21 June) 1910 they signed a new Russo-Japanese Convention, superseding the 1907 convention. ${ }^{37}$ Vowing 'to lend each other their friendly cooperation with a view to the improvement of their respective lines of railroad in Manchuria', they agreed not to engage in competition which would be to the detriment of their railway companies. ${ }^{38}$ St Petersburg and Tokyo also came out in support of the status quo in Manchuria and of the treaties concluded so far with respect to that region. Should that status quo be threatened, they would consult with each other to decide on an appropriate course of action. As the earlier convention, the new one had a secret treaty, which spoke of 'common action or mutual support' to safeguard their interests in Manchuria. ${ }^{39}$ In it Russia and Japan also reconfirmed the 'boundaries of their specific spheres of influence in Manchuria', which they had agreed upon in 1907, giving the other a free hand to defend their interests there. ${ }^{40}$ Both countries promised to 'refrain from all political activity' in the sphere

34 Arbuthnot in House of Commons 15-6-1910 (hansard.millbanksystems.com/commons/1910/ jun/15/consolidated-fund-no-2-bill).

35 Stanhope in House of Lords 27-4-1910 (hansard.millbanksystems.com/lords/1910/apr/27/ the-anglo-russian-convention).

36 Arbuthnot in House of Commons 15-6-1910 (hansard.millbanksystems.com/commons/1910/ jun/15/consolidated-fund-no-2-bill).

37 Just prior to the new agreement press speculation had it that Great Britain would also be a partner in this new treaty (Arbuthnot in House of Commons 15-6-1910, hansard.millbanksystems. com/commons/1910/jun/15/consolidated-fund-no-2-bill).

38 Russo-Japanese convention in regard to Manchuria, Art. I (Manchuria 1921: 141).

39 Secret treaty between Russia and Japan Art. V (Manchuria 1921: 142).

40 Secret treaty between Russia and Japan Art. I (Manchuria 1921: 142). 
of the other and not to seek 'privileges and concessions ... that might be injurious to the special interests' of the other there. ${ }^{41}$

\section{Japan and Russia consolidate their position in China}

On 29 August 1910 Japan finally announced that it had annexed Korea. From a joint Japanese-Korean declaration it becomes clear that one of the reasons to do so was the broadly based resistance against Japan, which had culminated in the assassination of Ito Hirobumi in the Manchurian city of Harbin in October 1909. Ito Hirobumi (who a few months earlier had resigned as Resident-General in Korea and had taken up the new position of Chairman of the Japanese Senate) had travelled to Harbin to discuss Russo-Japanese relations in northeast China. The declaration spoke of the Korean government not being able to maintain public order and of 'a spirit of suspicion and misgiving' all over Korea (Lawton 1912:1090-1). In yet another statement the Japanese Ministry of Foreign Affairs, besides stressing the good intentions Japan had in developing Korea, also mentioned 'unrest and disquietude ... throughout the whole peninsula' (ibid. 1093). The annexation meant that treaties that Korea had concluded in the past ceased to be operative and would be replaced by Japanese ones. One of the implications was that an end had come to the extraterritorial status foreigners had enjoyed in Korea; and which Japan itself had successfully annulled in the $1890 s$. Existing tariffs would remain in force for a period of ten years. Suddenly, in British public opinion, British trade with Korea counted. Commercial circles in Great Britain feared that, ten years hence, Japan would do as it pleased, which could result in a terrible blow to British trade with Korea. ${ }^{42}$

Tokyo proceeded to incorporate Chosen, as it had renamed Korea (Seoul became Keijo), but only after it had made certain that the British government would not object. In Great Britain there was some grumbling about the ease with which London had assented without gaining anything worth in return, especially not with regard to future British trade with Korea. In reply, Grey pointed at the Japanese assurance of the ten-year period and the fact that existing British land and mining rights in Korea would be

41 Secret treaty between Russia and Japan Art. IV (Manchuria 1921: 142).

42 Lord Avebury and Earl of Stanhope in House of Lords 27-3-1911 (hansard.millbanksystems. com/lords/1911/mar/27/british-interests-in-japan-and-korea). 
respected. ${ }^{43}$ In the Dominions, British compliance also did not go down well. In Australia the 'public's fear of an imminent Japanese invasion escalated into hysteria' (Hiery 1995: 15).

The Chinese revolution of 1911, and the subsequent Proclamation of the Republic of China on 1 January 1912, almost immediately caused a new source of conflict between St Petersburg and Tokyo, and in the wider world people once again speculated about a dismemberment of China and about Russia and Japan seizing upon the instability of China to act and gain additional influence. ${ }^{44}$ One area of concern was Mongolia. Following the installation of a new Chinese Viceroy in March 1910, efforts were stepped up to exercise direct rule and a programme of Sinification, similar to what Beijing had done in Tibet - and for the same reasons -, was started. Colonisation by Chinese farmers was promoted. The reaction was almost instantaneous. Mongolians rose in rebellion and turned to St Petersburg for help. Russia, in turn, informed China and the new Mongolian government that, for political and commercial reasons, it could do without trouble across its Siberian border. At the end of November 1911 the Chinese Viceroy had to take refuge in the Russian consulate. On 1 December 1911 Outer Mongolia proclaimed independence. The Chinese Viceroy and the Chinese army were forced to leave; their departure being made possible by Russian military escorts. Briefly, Dorjiev made his appearance, travelling to Ulan Bator (Urga), the Mongolian capital, to broker a Tibetan-Mongolian Treaty, signed in January 1913. In it both countries recognised each other's independence.

Russia showed itself prepared to mediate; using the occasion to press for a railway from Siberia into Outer Mongolia to Kyakhta (Kiakhta) and Ulan Bator and from there to Zhangjiakou. What it wanted was a Tibet-like solution, bringing Mongolia well and truly within the Russian sphere of influence and keeping China intact, without causing too much international uproar and complications. On 3 November (21 October) 1912 a Russo-Mongolian Treaty was concluded in Ulan Bator. Under the agreement, also known as the Urga Treaty, after the old name of the Mongolian capital, Russia only acknowledged the 'autonomous régime' established, a terminology not well understood in Mongolia and China, where the conclusion was drawn that Russia had recognised Mongolia's independence (Williams 1916: 806). The

43 Grey in House of Commons (hansard.millbanksystems.com/commons/1911/may/23/ corea-british-interests).

44 Great Britain also would use the occasion and dispatched the Pianma Expedition to enforce its claim along the frontier between Burma and Yunnan in December 1910 (McGrath 2003). 
treaty also underscored the rights of Mongolia to have an army of its own and to refuse entrance to Chinese soldiers and settlers. ${ }^{45}$

At the same time, there was no doubt that Mongolia should not enter into arrangements with China or other nations without consulting Russia first. As the treaty had been made 'in view of the necessity of defining exactly the system regulating trade between Russia and Mongolia', much attention went to Russian prerogatives in this field. ${ }^{6}{ }^{4} \mathrm{~A}$ protocol annexed to the treaty gave Russia the right to station consuls in Mongolia wherever it deemed necessary, and it also allowed for the establishment of Russian enclaves in Mongolia; 'factories' controlled by Russians and set aside for 'various branches of industry and the residence of Russian subjects'. ${ }^{47}$ It also gave Russian citizens freedom of movement and of trade and industry in Mongolia, it exempted them from customs duties (in this respect, it was explicitly stated that the stipulation was not in force for Russo-Chinese undertakings) and gave them the right to lease vacant land. The New York Times (19-1-1913) concluded that Mongolia had been taken from the young Republic of China and placed under Russian 'protection', and that commercially Mongolia had become 'part of the Russian Empire'.

The Russian position was confirmed in the treaty that Russia and China concluded on 5 November (23 October) 1913. Russia recognised China's suzerainty over Outer Mongolia. China acknowledged Outer Mongolia's autonomy and promised not to interfere in 'questions of a commercial and industrial nature'..$^{8}$ Explicitly it was stated that China would not send troops into Outer Mongolia or continue with its colonisation programme. Russia promised to refrain from stationing troops in Mongolia, but made an exception for consular guards. Japan also made its overtures, afraid as Tokyo was that an independent Outer Mongolia would absorb Inner Mongolia, a region to which Japan itself looked for its trade. Events necessitated a new demarcation of spheres of influence. In the Russo-Japanese Secret Convention of 8 July (25 June) 1912, Inner Mongolia was divided in an eastern and western part, the former falling within the Japanese sphere of influence, the latter in that of Russia. ${ }^{49}$

45 Agreements in regard to relations between Russia and autonomous Mongolia 3 November 1912, Preamble (Outer Mongolia 1921: 17).

46 Ibid.

47 Protocol annexed to the Russo-Mongolian Agreement of the $21^{\text {st }}$ October ( $3^{\text {rd }}$ November), 1912, Art. 9 (Outer Mongolia 1921: 20).

48 Declaration, and accompanying Exchange of Notes, in regard to Outer Mongolia, November 5, 1913, Art. III (Outer Mongolia 1921: 26).

49 Russo-Japanese Secret Convention of 25 June (8 July) 1912, Art. II (Price 1933: 117). 
In commercial circles in the United States there seems to have been a feeling of relief that Russia took control of Mongolia and not Japan, the Americans now arguing that the Russians had put up no obstacles to their trade in Manchuria while the Japanese had (New York Times 19-1-1913). In Great Britain Grey, in an initial reaction to the 1912 Russo-Mongolian Treaty, only stated in the House of Commons that it was 'intended to confirm the right and privileges for Russian subjects which existed under previous treaties of many years' standing, and generally to secure the status, practically amounting to autonomy, which was the normal condition of Outer Mongolia'. ${ }^{\circ}$

In wider society litanies could be heard about British impotence, now increasingly linked with the observation that fear of Germany in Europe made Great Britain dependent on its allies Russia and Japan. Accepting Russia's position in Mongolia was one of the reasons for such voices, but Great Britain's policy in Persia and with regard to Korea and Manchuria were even stronger grounds.

\section{Japan and the Pacific}

On 13 July 1911, 'in view of the important changes which have taken place', the Anglo-Japanese Alliance was adjusted for a third time; as in August 1905, years before it would transpire..$^{5^{1}}$ Changing international circumstances had made the previous treaty obsolete. The Anglo-Russian Convention had removed much of the British worries about India's frontiers. Hence, an explicit mention of a special British concern regarding 'the security of the Indian frontier' was no longer needed. The preamble now simply spoke of the 'consolidation and maintenance of the general peace in the regions of Eastern Asia and India' and of the special interests Japan and Great Britain had there. In the new, revised Alliance treaty the formula about Chinese territorial integrity and the adherence to an Open Door were maintained, as was the 'one enemy' article. ${ }^{52}$ Dropped was any direct reference to Korea, now Japanese territory.

$5^{0}$ Grey in House of Commons 21-11-1912 (hansard.millbanksystems.com/commons/1912/ nov/21/russo-mongolian-agreement).

51 Anglo-Japanese Treaty, 13-7-1911, Preamble.

52 In August 1914 Japan would refer to the treaty when it declared war on Germany on the $13^{\text {th }}$ after Great Britain had pointed out that the operations of German warships in the East threatened its interests there. 
When negotiations had been started on the initiative of Japan, a renewal in 1915 was not a foregone conclusion. Support for the Alliance was waning in Great Britain, and in 1908 the Committee of Imperial Defence (established in 1902) had begun in earnest to discuss what measures must be taken when the treaty expired (Navy 2009:1). The prime reason advanced for not renewing the Alliance was that it might oblige Great Britain to side with Japan if, for whatever reason, it should come to war between Japan and the United States (HottaLister 2002: 5-6). Such reservations appear to have been especially pungent in New Zealand and Australia. A specific hurdle in Anglo-Japanese relations had also come up. In early 1909 Tokyo had indicated that Japan wanted to do away with the last reminder of Japan's subordinate position on the world stage, which had survived the revision of the unequal treaties in the 189os; that is the obligation to consult other nations before it could adjust its import duties. In Great Britain, the first of the countries with which negotiations were started, the prospect of higher Japanese tariffs evoked strong sentiments in business circles. The Japanese demands were said to be prohibitive and would mean the end of British export to Japan. Much misery, especially in Lancashire and Yorkshire (both producers of textiles and ever-present when Britons predicted economic disasters), was predicted to be the result (Hotta-Lister 1999:5-6).

To soften up British public opinion, Tokyo made a number of tariff concessions in the commercial treaty concluded with Great Britain, the Anglo-Japanese Tariff Treaty of April 1911, at times referred to as the new Anglo-Japanese Commercial Treaty. One of the obstacles to extending the Anglo-Japanese Alliance had been removed. The other was tackled in the Alliance treaty itself. New was article IV in which it was stipulated that the obligation to join in a war did not apply when a treaty of general arbitration existed between Japan or Great Britain and the country the other was at war with. It was all about the United States, where, in 1910, Taft had suggested that London enter into such an arbitration treaty. London would have preferred to mention the United States by name in the Alliance treaty, but Tokyo insisted on a more indistinct text (Hotta-Lister 2002: 6). Significantly, the new clause made the press in Japan wonder what the country gained from the Anglo-Japanese Alliance (Lawton 1912:10).

Also new was that while negotiating with Japan, London consulted its Pacific Dominions. The support they gave not only pleased the government of Great Britain but also that of Japan (Hotta-Lister 2002: 8-9). As a newspaper in New Zealand, the Grey River Argus, wrote, it gave the Alliance 'new authority and moral force'. ${ }^{3}$ Yet, when discussing the Alliance in the House 
of Commons, Under-Secretary of State for Foreign Affairs Thomas McKinnon Wood dodged the question about whether, during war, Japan could ask for the assistance of the Australian navy. ${ }^{54}$ On the British side, India was no longer the main consideration. Misgivings about Japan's intentions in the Pacific had crept in not only in its Pacific colonies, but also in London. As a formal ally, Japan would refrain from acts of aggression against the British Empire, and the British navy was well aware that it would be no match for the Japanese fleet in the Pacific (Navy 2009: 2). Without Japan as a treaty partner it was less certain how Japan would act. Or, as the British Foreign Office formulated it, without the Anglo-Japanese Alliance 'Japan would be left with free hands without restraint ... and her fleet might array against us in the Pacific or allied with that of some other Power' (Hotta-Lister 2002: 9). 


\section{Epilogue}

The Anglo-Russian Convention did not bring the British government what it had hoped. One setback was that as a follow-up to a meeting in Potsdam between Nicholas II and Wilhelm II in November 1910, the Potsdam Agreement was signed in St Petersburg on 19 August 1911. Germany and Russia had come to an understanding on the construction of a railway from Baghdad to Khanikin on the Ottoman-Persian border and from there to Tehran, giving Russia a rail link with the Baghdad Railway and providing Germany access to north Persia. In the eyes of contemporaries and later historians, Potsdam caused the alliance in the making between Great Britain, Russia and France to waver. As Taylor (1971:464) wrote, in 1911 the 'Triple Entente seemed in process of disintegration'. Grey tried, as he would with regard to every complication arising over Persia, to give the impression that nothing was wrong. The British government welcomed any attempt of other powers to reach a better understanding with Germany, and such efforts did not affect the cordial relations of Great Britain with Russia. ${ }^{1}$

Developments in Persia itself also did not help. Within five years AngloRussian rivalry there was as intense as ever, complete with British fears about a Russian army invading the country that was far stronger than any army Great Britain could muster, but also with the British wanting to advance into the neutral zone (Soroka 1911: 211, 244). For the British the uncomfortable prospect arose of St Petersburg aiming for a real partition of Persia, complete with the daunting idea of a joint land frontier with Russia. Some presented an even worse scenario. Shuster (1912: 174) was sure that because of London's reluctance to take firm countermeasures Russia was 'absolutely free to push forward her long-cherished plans for the absorption of Persia and the establishment of a naval base on the Persian Gulf'. Britons also began to worry again about India. By 1912, to some the Russian position in Persia once more constituted 'a grave menace' to the British position there. ${ }^{2}$

The apparent failure of the Convention gave rise to a campaign in Great Britain for its annulment. In response, those defending the agreement stressed that it had prevented the domestic situation in Persia from

\footnotetext{
1 Grey in House of Commons 13-3-1911 (hansard.millbanksystems.com/commons/1911/mar/13/ army-and-navy-expenditure).

2 Ponsonby in House of Commons 21-2-1912 (hansard.millbanksystems.com/commons/1912/ feb/21/persia-anglo-russian-agreement).
} 
becoming worse and Anglo-Russian relations from deteriorating. Or, as Grey explained in a speech in Manchester in February 1912: 'Without it Russia, in the event of internal revolution, would have advanced to Teheran, and England would have been compelled to secure the Indian frontiers against Russian aggression' (Hawera \& Normanby Star 19-2-1912). His explanation did not carry 'universal conviction', The New York Times (12-9-1912) wrote.

In fact, British disenchantment with Russia's Persia policy only increased. In 1914 it had become such that in June King George V, in a letter to Tsar Nicholas II, suggested 'a frank and friendly exchange of views on the whole situation in Persia'. He did so, he wrote, because his 'great desire to see a friendly feeling towards Russia preserved in British public opinion and in both political parties' (Carter 2010: 417).

At the end of the following month Austria-Hungary invaded Serbia. On 1 August Germany declared war on Russia and on the $3^{\text {rd }}$ on France. On the $4^{\text {th }}$, after Germany had invaded Belgium, Great Britain declared war on Germany and Austria-Hungary. Japan joined the war on 23 August (while China would declare war on Germany in August 1917; one of the victims being the humiliating text on the Ketteler Memorial Arch, which was removed (Titus 2012: 46)). In the South Pacific, where no preparations had been made to hold off invasions, Germany lost its possessions in quick succession. In late August 1914 New Zealand occupied Samoa. Australia took New Guinea and the Bismarck Archipelago in September, but its forces failed to press on. Nauru, one of the Marshall Islands, was occupied on 6 November 1914, but in between Yap and the other smaller German islands in the South Pacific, those belonging to the Caroline, Marshall, Mariana and Palau groups, had already fallen to the Japanese fleet, which, according to the official explanation, had sailed south in search of German warships. The islands remained Japanese and some would see fierce fighting in World War Two. After World War Two they became trust territories of the United States. The Marshall Islands became independent in 1986. In that same year, the Caroline Islands became the Federated States of Micronesia. The Republic of Palau was constituted in 1994. The Marianas and Guam are still part of the United States.

To the north, in the Bay of Jiaozhou, a real battle was fought, even though, as a consequence of Tirpitz' planning for a war at sea against Great Britain in the North Sea, German naval command considered holding on to Qingdao inconsequential. It had also been realised that it was impossible to defend Qingdao against a determined foe, as the naval base was too far away from Germany. Defences were constructed, but after 1906 no new troops were stationed in Qingdao (Graichen and Gründer 2005:225-7). The plan was that 
in case of war the German warships in Qingdao should take to the sea and act as raiders (Nuhn 2002:135). In late October the port and its fortifications were attacked by Japanese forces, and a token British one, and after days of bombardments and fierce fighting they fell on 7 November 1914. Those German warships that had not left port were scuttled.

In the Bay of Jiaozhou Japan allowed itself the same prerogatives Germany had wrestled from China. Japan's position in Shandong formed the first section of the so-called twenty-one demands Tokyo submitted to Beijing in January 1915. On 25 May, after Japan had reduced the number of its demands to thirteen and had issued an ultimatum, two separate treaties were signed. One was the Treaty Respecting the Province of Shandong, concluded 'with a view to the maintenance of general peace in the Extreme Orient and the further strengthening of the relations of friendship and good neighbourhood' between the two countries. ${ }^{3}$ China had to promise to 'give full assent' to all that Japan and Germany were to agree on about the transfer of the 'rights, interests, and concessions' of Germany in Shandong. ${ }^{4}$ China also had to open ports in the province. Such a stipulation, in this case on the coast of eastern Inner Mongolia, was also mentioned in the second agreement, the Treaty Respecting South Manchuria and Eastern Inner Mongolia, signed by China and Japan, more modestly "with a view to developing their economic relations. ${ }^{5}$ In South Manchuria Japanese citizens were given the right to lease land for the purposes of trade, manufacture and agriculture, while the duration of the leases of Port Arthur and Dalian and the railway contracts were extended to 99 years. Japan invaded Manchuria in 1931.

Germany formally lost its overseas possessions at the Peace Conference of Versailles where it was castigated for 'its failure in the field of colonial civilisation' (Conrad 2012: 186). The decision and the denunciation of the German colonial record, the koloniale Schuldlüge, or 'fabrication of colonial culpability', caused almost general dismay in Germany. Millions of Germans signed a statement protesting 'the theft of their colonies' (Knopp 2011: 256). Under a mandate from the League of Nations, New Zealand came to govern German Samoa; German New Guinea, the Bismarck Archipelago and Nauru went to Australia; and Japan was assigned Jiaozhou Bay and the islands its navy had occupied in the South Pacific. ${ }^{6}$ France remained

3 Treaty respecting the Province of Shantung 25-5-1915, Preamble (www.chinaforeignrelations.net/node/179).

4 Ibid., Art. 1 (www.chinaforeignrelations.net/node/179).

5 Treaty respecting South Manchuria and Eastern Inner Mongolia, Preamble (Manchuria 1921: 157-9).

6 Japan returned Jiaozhou to China after the Washington Naval Conference of 1921-1922. 
empty-handed. This did not go down well. France had supported Tokyo's claims to the islands that had fallen into Japanese hands, a French warship had assisted the Australian navy in occupying New Guinea and the Bismarck Archipelago, yet France had received nothing in return. None of the former German possessions in the Pacific was assigned to it. France was not even awarded an annexation of the New Hebrides (Pelleray 1922: 98-9).

New Zealand granted West Samoa independence in 1962. East Samoa remains an unincorporated territory of the United States, self-governing since 1967. A similar status was given to the Cook Islands by New Zealand in 1965. Papua New Guinea (including the Bismarck Archipelago) became independent in 1975. Of the other Pacific island groups, Fiji became an independent Dominion in 1970. In the same year the British protectorate over the kingdom of Tonga was terminated. In 1978 Great Britain granted independence to Tuvalu (the Ellice Islands) and the Solomon Islands and in 1979 to the Gilbert Islands (Kiribati). The New Hebrides became the Republic of Vanuatu in 1980. New Caledonia remained French.

The desire to make a good profit, expectations about the natural richness and trade potentials of regions hardly known, being lured by short-lived booms, religious sentiments, national pride and distrust of the intentions of other nations were a hazardous mix. Some of the territories and settlements acquired in the Far East and the South Pacific by European nations, the United States and Japan became profitable. A number of the treaty ports in China thrived, Rangoon would become one of the major ports in British India, the Malay Peninsula would have its rubber and tin, and Samoa became a 'model colony', which as of 1909 no longer needed any financial assistance from Berlin (Nuhn 2002: 107-8).

Other acquisitions turned out to be less of a success. Germany's brief and noisy exploits in the Pacific had served a political aim. Acquiring a foothold in the Pacific had been a matter of pride for successive German governments. It linked up with a nationalist drive, with Germans rejoicing in Germany's new status as a world power that stood its ground. In retrospect, there was less to be proud of economically. As early as 1889 the Neu-Guinea-Compagnie had run into serious problems in Kaiser-WilhelmsLand and the Bismarck Archipelago. In October 1898, when it was evident that the company was no longer capable of administering the region, Berlin reclaimed the rights and duties it had delegated. In return, the Neu-GuineaCompagnie received a capital injection of 4 million Marks.

In Jiaozhou Bay, investments by Krupp and other German companies failed to materialise (Steinmetz 2007: 438). Though the city of Qingdao and its port facilities gained admiration in Germany and abroad and trade 
increased over time, within years it was realised that the leased area, now advertised as a Handelskolonie, or trade colony, was too small to be commercially viable. Only the railway (opened on 1 June 1904) was a success. The German mining activities were not. The coals were expensive and not of the quality expected (Conrad 2012: 62; Gründer 1999: 109). The mining company Shantung-Bergbau-Gesellschaft could only survive thanks to its mother company, which also owned the railway and offered low transportation prices for the coals (Wertheimer 1913: 93).

With its function as a strong naval base in doubt, Tirpitz and the navy had set their eyes on developing the territory into a Musterkolonie, or model colony, highlighting such features as urban planning, measures to promote hygiene (which the Western nations prided themselves made them different from the rest of the world) and the education of the Chinese population. Qingdao was, as Wertheimer (1913: 95-6) put it, turned into a 'big German permanent exhibition in the Far East'. The bay became Germany's most expensive colonial possession. Much of its development had to be financed by the state. An aggregate sum of 200 million Marks in government money was spent between 1898 and 1914, of which only 36 million Marks came from local taxes (Gründer 1999: 110). Such realities made German newspapers suggest that Germany had better terminate the lease at least from 1906.7 The financial burden also gave opponents of a German colonial policy the ammunition they needed. The leading social democrat, Ferdinand August Bebel, stressing the evils of colonialism as well as the money overseas territories cost Germany, even suggested selling Jiaozhou Bay to Japan (Graichen and Gründer 2005: 224; Knopp 2011: 21).

The colonial race in the Western Pacific had also saddled Great Britain with some liabilities. When the British took possession of New Guinea some had vented the same optimistic fantasies about the island's potential that others had done to justify expansion elsewhere. Among them was Samuel Griffith, Premier of Queensland, who in 1886 wrote about Europeans who would settle there and 'the gradual attraction of natives to industrial pursuits' (Legge 1956: 47). When British New Guinea came under Australian administration in 1906, similar confidence was expressed by a Royal Commission which had to map out its future; but maybe such institutions have to come up with something positive. It wrote about awaking 'the Papuan from his lotus-eater's dream' and made suggestions about how to develop British New Guinea economically (ibid.: 128). It was not to be. The region was far from self-supporting. As Legge (1956:3) concluded: 'Development 
of the territory was on too small a scale to provide a sufficient revenue to meet the costs of administration' (which were kept to a bare minimum). Investors stayed away, while another problem was shortage of labour, still enhanced by the fact that in British New Guinea, as part of Australia, nonwhite workers could not be recruited (ibid.: 155).

As contemporaries had prophesied, Wei-hai-wei did not turn out to be a great asset. Any plans to transform it into a defensible naval station had to be cancelled when the Boer War strained the British budget. Two years after Great Britain had leased Wei-hai-wei, almost nothing had been done yet to turn the place into a naval base of some sort. Or, as one contemporary politician noticed, 'not a single fort' had been constructed, 'not a gun mounted; practically no buildings ... erected ... Beyond a little dredging ... nothing seems to have been done. ${ }^{8}$ Another politician called Wei-hai-wei 'a miserable little station. ${ }^{9}$ On the Admiralty's advice the government decided to withdraw the about 1,100 troops stationed there and to stop fortification works in early 1902. Wei-hai-wei was to be maintained, in the words of the Colonial Office, as 'a flying naval base, and as a depôt and drillground and sanatorium for the China Squadron in North China' (Wright and Cartwright 1908: 773). After the Russo-Japanese War, Wei-hai-wei lost much of its rationale, making the British diplomat Satow suggest in 1906 that should Germany abandon the Bay of Jiaozhou, there was not much reason for Great Britain to hold on to Wei-hai-wei. ${ }^{10}$ The concession did have one clear function. It served as a beach resort for sailors of the British fleet and for members of the diplomatic corps in Beijing and their families, who in summer would leave the capital for the temple-converted-villas of Wei-haiwei; a reason for some to mockingly ask why the British government was still spending money on a 'bathing station.." But German Qingdao - which among its attractions boasted 'charming scenery, excellent bathing, and a good band' (Wright and Cartwright 1908: 812) - became a more popular holiday destination for foreigners. Wei-hai-wei was returned to China in 1930. Hong Kong remained British until July 1997 when it became a Special Administrative Region of China. Two years later Macau was returned to China and got the same status.

8 Walton in House of Commons 30-3-19oo (hansard.millbanksystems.com/commons/1900/ mar/3o/british-commercial and political-interests-in-china).

9 Lord Balcarres in House of Commons 30-3-19oo (hansard.millbanksystems.com/commons/1900/mar/30/british-commercial and political-interests-in-china).

10 Satow to Grey 5-4-1906 (PRO FO 800 44).

11 Whitley in House of Commons 12-7-1905 (hansard.millbanksystems.com/commons/1905/ jul/12/navy-estimates-1905-6). 
Great Britain's hold over Afghanistan turned out to be weak. After the Third Anglo-Afghan War of 1919 the country regained its full independence. According to the Rawalpindi Agreement of 8 August 1919, Kabul no longer had to turn to London for directives for its foreign policy. In 1921 Russia and Afghanistan signed a Treaty of Friendship.

Similar to Great Britain, and in spite of its initial optimism, France did not succeed in turning the leasing of Guangzhouwan into something worthwhile. The territory was returned to China under the Sino-French agreement of 28 February 1946. Only in recent decades, with China's economy booming, has Guangzhouwan grown into an important economic centre, as have Wei-hai-wei, Chongqing in Sichuan, the object of Anglo-British rivalry, and Yingkou and Harbin in Manchuria. In Vietnam and the South Pacific colonisation proved a problem. The actual number of Frenchmen prepared to settle in the new possessions was much lower than advocates of a French Empire would have been pleased with. In New Caledonia, after efforts to have convicts cultivate the soil had become a failure, a not-well-thought-out scheme between 1895 and 1902 to attract French settlers for the cultivation of coffee and other tropical products became a fiasco as well (Lorin 1906: 424-6). With respect to Indochina, there were complaints about Frenchmen not wanting to settle and capital staying away (Étienne 1897: xxi). People who travelled to Indochina in the late nineteenth century were not only struck by how French Saigon and Hanoi looked with their boulevards and pavement cafés. They also noted how dominant the military and civil service were in colonial society. One of them, Norman (1900: 78 ), estimated that in Saigon 'nine out of ten Frenchmen [were] occupied in purveying either French luxuries or French personal services to the official and military classes'. He was sure that without 'the shop-keepers, the barbers, the tailors, the wine-merchants, the tobacconists and the restaurant keepers [there] would be virtually no Frenchmen left who was not a soldier, a sailor, or a civil servant'. Throughout the French period the number of French settlers remained relatively small (Cooper 2005: 82).

Russia, following its military defeats and the Revolution, re-emerged as a power in a relatively short span of time, which confirmed what British observers had said on earlier occasions about Russian reverses. By 1921 intense British-Russian rivalry in Persia had reappeared. In the Far East, in the aftermath of the Revolution, Russia lost control over Manchuria. Due to 'complete political disorganisation in Russia', as it was formulated in an agreement between the Russo-Asiatic Bank and China in October 1920, the Chinese Eastern Railway had stopped functioning. The situation allowed China, as the Agreement stated, to 'assume provisionally ... supreme 
control' over the railway. It did so 'not only for the safeguarding of security in the region served by the railway and for the maintenance of communications which are of world interest, but also for effective protection over the property of the said railway.'.2 By 1924 Russia was back and strong enough to present China with what The Argus (21-3-1924) concluded was a 'virtual ultimatum'. The Sino-Russian Treaty of 31 May 1924 reconfirmed the railway zone and its joint administration. The Chinese Eastern Railway continued to be a bone of contention until, finally, Russia formally handed over the railway and its property to China in $195^{\circ}$ without compensation. This became effective at the end of 1952 (Elleman 1994: 459, Shengfa 2010: 185). In 1955 Russia also returned Port Arthur and Dalian, which it had conquered from the Japanese in August 1945, to China.

The colonies, protectorates and international settlements in Asia and the Western Pacific are a thing of the past. Their legacy include the office buildings, houses and railway stations which have survived time. The presence of a significant number of foreign administrators, advisers, soldiers, businessmen and other temporary settlers also accelerated the spread of Western dress, music and sports, and influenced the way soldiers are still marching, saluting and shouting. By initiating or accelerating movement of labour new ethnic tensions were created that to this day can be a source of violence and discrimination. The unwanted consequence of Gordon's decision in the 1870 s to turn to India to solve Fiji labour problem is that tense relations between Indians and indigenous Fijians still dominate the country's politics today. In Malaysia relations between Malay, Chinese and Indians are also uneasy, but here the British only accelerated a development that was already underway.

The boundaries fixed, and in some cases imprecisely mapped, by the colonial powers to protect their interests presented, and continue to present, their problems. The Durand Line of 1893 remains a sensitive topic in Afghanistan and gave Pakistan a frontier area that is difficult to control. In 1962 India and China fought a war over their border in the Himalayas and they are still quarrelling about it now (in 1963 Pakistan and China concluded a Frontier Agreement, settling their differences). In 1969 Russia and China had their armed conflict over the Ussuri and Xinjiang frontiers. When in 1991, with the dissolution of the Soviet Union, Kazakhstan, Kyrgyzstan and Tajikistan became independent states they inherited Russia's boundary

12 Agreement supplementary to the contract for the construction and operation of the Chinese Eastern Railway between the Russo-Asiatic Bank and China, 2-10-1920, Preamble (Manchuria 1921: 210-1). 
disputes with China. All three signed their own agreements with Beijing, returning some - but not that much - disputed territory to China. China (and Taiwan) and Japan are still quarrelling over the Senkaku or Diaoyu Islands, which Japan occupied during the Sino-Japanese War. One recent manifestation of tense Sino-Japanese relations was the opening of an Ahn Jung-geun Memorial Hall in the railway station of Harbin in January 2014 in honour of the person who shot Ito Hirobumi there in 1909. South Korea and Japan are in dispute about the Takeshima or Dokdo Islands (also known as the Liancourt Rocks), located in the Sea of Japan (or, if one prefers its Korean name, the East Sea), formally claimed by Japan in January 1905 during the Russo-Japanese War. A dispute between Thailand and Cambodia over a small piece of land surrounding the Preah Vihear Temple, which can be traced back to the March 1907 treaty between Thailand and France, escalated into exchanges of fire between 2008 and 2011. 



\section{Bibliography}

Agreement (1897) Agreement between Great Britain and China, modifying the Convention of March 1, 1894, relative to Burmah and Thibet. Signed at Peking, February 4,1897 (Ratifications exchanged at Peking, June 5, 1897). London: Harrison and Sons.

Allen, H.G. (1988) Sanford Ballard Dole: Hawaii's only President, 1844-1926. Glendale, California: The Arthur H. Clark Company.

Asakawa, Kanichi (1909) The Manchurian Conventions, Yale Review, November 1909 (Yale Review Reprints, No. 9 (www.2o.big.or.jp/-asayale/asakawa\%20a\%2oto\%20z/kasa/man19og. htm, accessed 17-7-2011).

Australia (1904) Australia and the New Hebrides. Reprint from Sydney Daily Telegraph of an article by Senator Staniforth Smith, and extracts from the Australian and French Press.

Australië's (1886) Australië's droombezit van Polynesië en Nieuw-Guinea, Tijdschrift voor Nederlandsch-Indië, 14, 2, pp. 53-63.

Bambridge, Tamatoa \& Christian Ghasarian (2002) Juridiction française et droit coutumier à Rapa. Les enjeux d'une traduction, Droit et Cultures, 44, pp. 153-181.

Baranowski, Shelly (2011) Nazi Empire. German colonialism and imperialism from Bismarck to Hitler. Cambridge [etc.]: Cambridge University Press.

Bell, R. (1984) Last among equals: Hawaiian statehood and American politics. Honolulu: University of Hawai'i Press.

Bennet, Neville (2001) White discrimination against Japan: Britain, the Dominions and the United States, 1908-1928, New Zealand Journal of Asian Studies, 3, 2, pp. 91-105.

Bennion, Tom (2004) Treaty-making in the Pacific in the Nineteenth Century and the Treaty of Waitangi, Victoria University of Wellington Law Review (www.austlii.edu.au/nz/journals/ VUWLRev/2004/6.html).

Beresford, Charles (1899) The break-up of China. With an account of its present commerce, currency, waterways, armies, railways, politics, and future prospects. London [etc.]: Harper.

Berghahn, V.R. (1993) Germany and the approach of war in 1914. $2^{\text {nd }}$ ed. Houndmills and London: The Macmillan Press.

Bernstein, Herman (1918) The Willy-Nicky correspondence. Being the secret and intimate telegrams exchanged between the Kaiser and the Tsar. New York: The New York Herald Company.

Berryman, John (2002) British Imperial Defence Strategy and Russia: The Role of the Royal Navy in the Far East, International Journal of Naval History, 1, 1 (ijnonline.org/volume1_number1_Apro2/article_berryman_royalnavy_fareast.doc).

Bickers, Robert (2011) The Scramble for China. Foreign Devils in the Qing Empire, 1832-1914. London [etc.]: Allen Lane.

Blackbourn, David (1997) The Fontana history of Germany 1780-1918. The long nineteenth century. London: HarperCollings Publishers.

Bogaars, George (1955) The effect of the opening of the Suez Canal in the trade and development of Singapore, Journal of the Malayan Branch of the Royal Asiaic Society, 28, 1, pp. 99-143.

Bootsma, N.A. (1986) Buren in de koloniale tijd: De Philippijnen onder Amerikaans bewind en de Nederlandse, Indische en Indonesische reacties daarop, 1898-1942. Dordrecht \& Riverton: Foris Publications (VKI 119).

Bourne, F.S.A. (1898) Report of the Mission to China of the Blackburn Chamber of Commerce 1896-7. Blackburn: The North-East Lancashire Press Company. 
Bowra, Cecil A.V. (1908) Amoy, in: Arnold Wright and H.A Cartwright (eds.), Twentieth century impressions of Hongkong, Shanghai, and other treaty ports of China, pp. 813-28. London [etc.]: Lloyd's Greater Britain Publishing Company.

Brookes, Jean Ingram (1941) International rivalry in the Pacific Islands: 1800-1875. Berkely and Los Angeles: University of California Press.

Brown, Arthur Judson (1919) The mastery of the Far East: the story of Korea's transformation and Japan's rise to supremacy. London: Bell.

Browne, Edmond Charles (1888) The coming of the Great Queen, a narrative of the acquisition of Burma. London: Harrison and Sons.

Buckley, Charles Burton (1902) An anecdotal history of old times in Singapore. Singapore: Fraser \& Neave.

Bugravo, Maria (n.d.) The British expeditions to China in XIX century (bumali.com/ozexpeditions. shtml).

Caraway, William M. (n.d.) Korea in the eye of the tiger (www.koreanhistoryproject.org/Ket).

Carter, Miranda (2010) The Three Emperors. Three cousins, three empires and the road to World War One. London [etc.]: Penguin Group.

Cartwright, H.A. (1908) Hongkong (Descriptive), in: Arnold Wright and H.A. Cartwright (eds.), Twentieth century impressions of Hongkong, Shanghai, and other treaty ports of China, pp. 145-87. London [etc.]: Lloyd's Greater Britain Publishing Company.

- (1908a) Shanghai, in: Arnold Wright and H.A. Cartwright (eds.), Twentieth century impressions of Hongkong, Shanghai, and other treaty ports of China, pp. 368-98. London [etc.]: Lloyd's Greater Britain Publishing Company.

- (1908b) Canton, in: Arnold Wright and H.A. Cartwright (eds.), Twentieth century impressions of Hongkong, Shanghai, and other treaty ports of China, pp. 782-97. London [etc.]: Lloyd's Greater Britain Publishing Company.

Casserly, Gordon (1903) The land of the Boxers; or, China under the Allies. London, New York and Bombay: Longmans, Green, and Co.

Castle, Alfred L. (1999) U.S. Commercial Policy and Hawai'i, 1890-1894, The Hawaiian Journal of History, 33, pp. 69-82.

Cecil, Lamar (1998) Wilhelm II. und die Juden, in: Werner E. Mosse (ed.) Juden im Wilhelminischen Deutschland: 1880-1914, pp. 313-48. $2^{\text {nd }}$ ed.Tübingen: Mohr Siebeck.

Chambre (1898) Chambre de Commerce de Lyon La mission lyonnaise d'exploration commerciale en Chine 1895-1897. Lyon: A. Rey.

- (1898a) La mission lyonnaise d'exploration commerciale en Chine 1895-1897. Deuxième partie. Rapports commerciaux et notes diverses. Lyon: A. Rey.

Chandran, Jeshurun (1971) The British Foreign Office and the Siamese Malay States, 1890-97, Modern Asian Studies, 5, pp. 143-61.

- (1971a) The Burma-Yunnan railway:Anglo-French rivalry in mainland Southeast Asia and South China, 1895-1902. Athens, Ohio: Ohio University Center for International Studies Southeast Asia Program.

- (1977) The contest for Siam, 1889-1902: a study in diplomatic rivalry. Kuala Lumpur: Penerbit Universiti Kebangsaan Malaysia.

Cockburn, Patrick (2012) A Prehistory of extraordinary rendition, London Review of Books, 13-9-2012, pp. 32-3.

Coffman, Tom (2009) Nation Within. The history of the American occupation of Hawai'i. Rev. ed. Kihei, Hawai'i: Koa Books.

Colquhoun, Archibald R. (1902) The mastery of the Pacific. London: William Heinemann. 
Conrad, Sebastian (2012) German colonialism. A short history. Cambridge [etc.]: Cambridge University Press.

Cooper, Nicola (2005) Disturbing the colonial order. Dystopia and disillusionment in colonial Indochina, in: Kathryn Robson and Yennifer Yee (eds.), France and Indochina. Cultural representations, pp. 79-94. Lexington: Lexington Books.

Cooper, T.T. (1871) Travels of a pioneer of commerce in pigtails and petticoats; or, An overland journey from China towards India. London: Murray.

Courten, L. de (2009) The Chinese Enigma in Politics and in the Economy: Italy in the Far East 1900-1947, The Journal of European Economic History, 38, 2, pp. 341-65.

Cunningham, Alfred (1902) The French in Tonkin and South China. Hong Kong: Hongkong Daily Press.

Curzon, George N. (1892) Persia and the Persian Question. London: Longmans, Green, and Co.

- (1896) Problems of the Far East; Japan-Korea-China. New and revised edition $4^{\text {th }}$ ed. Westminster: Archibald Constable and Co.

Danusaputro, Munandjat (1986) The perspective changes in the Pacific Ocean, The Indonesian Quarterly, 14, 3, July 1986, pp. 313-39.

Darcy, Jean (1904) France et Angleterre. Cent années de rivalité coloniale. L'Afrique. Paris: Perrin et Cie.

Darwent, C.E. (1905) Shanghai. A handbook for travellers and residents to the chief objects of interest in and around the foreign settlements and native city. Shanghai [etc.]: Kelly and Walsh.

Day, A.G. (1984) History makers of Hawaii:A biographical dictionary. Honolulu: Mutual Publishing of Honolulu.

Department [of the Navy, Naval Historical Center] (2001) The U.S. Navy in Hawaii 1826-1945. An Administrative History (www.rootsweb.ancestry.com/??hihawaii/tusnih.html).

Dijk, Kees van (2007) The Netherlands Indies and the Great War, 1914-1918. Leiden: KITLV Press.

- (2008) From Raja to Prime Minister. Stranger-rulers and Economic Exploitation in Borneo and the Pacific in the Nineteenth Century, Moussons, 12, pp. 103-35.

Dikötter, Frank (2007) Things Modern. Material Culture and Everyday Life in China. London: C. Hurst and Co.

Dodwell (ed.) (1932) The Cambridge history of the British Empire. Vol. VI. The Indian Empire, 1858-1918. Cambridge: Cambridge University Press (archive.org/details/cambridgehistoryo35143mbp).

Dorrance, William H. (1995) Land Defences of Oáhu's Forts, 1908-1920, The Hawaiian Journal of History, 29, pp. 147-61.

Doumer, Paul (1905) L'Indo-Chine française (Souvenirs). Paris: Vuibert \& Nony.

Drea, Edward J. (2009) Japan's Imperial Army. Its Rise and Fall, 1853-1945. Lawrence, Kansas: University Press of Kansas.

Dulles, Foster Rhea (1938) America in the Pacific. A Century of Expansion. Boston and New York: Houghton Mifflin Company, The Riverside Press Cambridge.

Echenberg, Myron (2007) Plague ports. The global urban impact of bubonic plague 1894-1901. New York and London: New York University Press.

Eitel, E.J. (1895) Europe in China. The history of Hongkong from the beginning to the year 1882. London \& Hongkong: Luzac \& Co., Keley and Walsh.

Elleman, Bruce (1994) The Soviet Union's secret diplomacy concerning the Chinese Eastern Railway, 1924-1925, The Journal of Asian Studies, 53, 2, pp. 459-486.

Esherick, Joseph W. (1987) The origins of the Boxer Rebellion. Berkeley [etc.]: University of California Press. 
Étienne, Eugène (1897) Les compagnies de colonisation. Paris: Augustin Challamel.

Ferry, Jules (1890) Le Tonkin et la Mère-Patrie. $10^{\text {th }}$ ed. Paris: Victor-Havard.

Field, James A. (2001) History of United States Naval Operations: Korea. Washington DC: Naval Historical Center (www.history.navy.mil/books/field/chı.htm).

Figes, Orlando (2010) Crimea. The last crusade. London [etc.]: Allen Lane.

Finsch, Otto (1888) Samoafahrten. Reisen in Kaiser Wilhelms-Land und English-Neu-Guinea in den Jahren 1884 u. 1885 an Bord des Deutschen Dampfers 'Samoa'. Leipzig: Ferdinand Hirt \& Sohn. Fleming, P. (1989) The siege at Peking. $3^{\text {rd }}$ ed. Hong Kong, Oxford, New York: Oxford University Press. Oxford in Asia paperbacks.

Forbes, Litton (1875) Two years in Fiji. London: Longmans, Green, and Co.

Foreman, John (1906) The Philippine Islands: a political, geographical, ethnographical, social and commercial history of the Philippine Archipelago, embracing the whole period of Spanish rule, with an account of the succeeding American insular government. $3^{\text {rd }}$ rev. ed. London: Fisher Unwin.

Forsyth, Peter (1986) Economic problems of international transport for the South Pacific island economies, in: R.V. Cole and T.G. Parry (eds.), Selected issues in Pacific Island Development, pp. 176-207. Canberra: The Australian National University, National Centre for Development Studies (Pacific Policy Papers, no. 2).

Fournereau, Lucien (1998 [1894]) Bangkok in 1892. Translated and with an introduction by Walter E.J. Tips. Bangkok: White Lotus Press.

Froment-Guieysse, Georges (1922) Les Établissements français de l'Océanie, in: G. Regelsperger, E. Pelleray and Georges Froment-Guieysse, L'Océanie française. La Nouvelle-Calédonie, Les Nouvelles-Hébrides. Les Établissements français de l'Océanie, pp. 105-58. Paris: Notre Domaine Colonial.

Garnier, Francis (1864) La Cochinchine française en 1864. Paris: E. Dentu.

- (1873) Voyage d'exploration en Indo-Chine effectuépendant les années 1866, 1867 et 1868 par une commission française présidée par M. Doudart de Lagrée et publié par les ordres du Ministre de la Marine sous la direction de M. le lieutenant de vaisseau Francis Garnier. Vol. 1. Paris: Libraire Hachette.

Gascoyne-Cecil, William (1911) Changing China. $4^{\text {th }}$ ed. London: James Nisbet.

Geiss, Imanuel (1990) Der lange Weg in die Katastrophe. Die Vorgeschichte des Ersten Weltkrieg 1815-1914. Munich: Piper Verlag.

Gilson, R.P. (1970) Samoa 1830 to 19oo: The politics of a multi-cultural community. Melbourne [etc.]: Oxford University Press.

Göbel, Katja (2008) Samoa: Kirchliche Vielfalt und kirchlicher Einfluss auf das Leben, in: Frank Kürschner-Pelkmann, Pazifik: Glaube, Kultur, Gesellschaft.Jahrbuch Mission 20o8. Hamburg: Missionshilfe Verlag, pp. 193-7.

Goto, Ken'ichi (2003) Tension of Empire. Japan and Southeast Asia in the Colonial \& Postcolonial World. Athens and Singapore: Ohio University Press and Singapore University Press.

Gottschall, Terrell D. (2003) By order of the Kaiser. Otto von Diederichs and the rise of the Imperial German Navy, 1865-1902. Annapolis: Naval Institute Press.

Graichen, Gisela and Horst Gründer (2005) Deutsche Kolonien. Traum und Trauma. Berlin: Ullstein.

Gray, John Alexander Clinton (1960) American Samoa. A history of American Samoa and its United States naval administration. Annapolis, MD: United States Naval Institute.

Gravelle, Kim (1983) Fiji's times: A history of Fiji. Suva: The Fiji Times and Herald Limited. 
Gründer, Horst (1999) '... da und dort ein junges Deutschland gründen'. Rassismus, Kolonien und kolonialer Gedanke vom 16. bis zum 20.Jahrhundert. Munich: Deutscher Taschenbuch Verlag.

Grupp, Peter (1980) Deutschland, Frankreich und die Kolonien. Der französische 'Parti colonial' und Deutschland von 1890 bis 1914. Tübingen: J.C.B. Mohr (Paul Siebeck).

Halpern, Paul G. (1994) A Naval History of World War I. London: UCL Press.

Hamilton, Angus (1904) Korea. $2^{\text {nd }}$ ed London: William Heinemann.

Handelingen ... Verslag der Handelingen van de Staten-Generaal gedurende de zitting van ... The Hague: Algemeene Landsdrukkerij.

Harcave, Sidney (1990) The memoirs of Count Witte. A portrait of the twilight years of Tsarism by the man who built modern Russia. Trans. and ed. by Sidney Harcave. Armonk, New York [etc.]: Sharpe.

Hardy, O. and G.S. Dumke (1949) A history of the Pacific area in modern times. Boston [etc.]: The Riverside Press.

Hennessy, Alistair (1984) Colonials wars in Cuba and the Philippines in the Nineteenth Century, Itinerario, 8, 2, pp. 59-79.

Hertslet, Godfrey E.P. (1908) Hertslet's China Treaties, \&c., between Great Britain and China; and between China and Foreign Powers; and Orders in Council, Rules, Regulations, Acts of

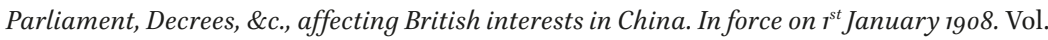
1. London: Harrison and Sons.

Hiery, Hermann Joseph (1995) The Neglected War. The German South Pacific and the Influence of World War I. Honolulu: University of Hawai'i Press.

Hoffman, J.E. (1990) New perspectives on the history of Australia and Indonesia, and some educational implications, Indonesian Studies, 7, 1-2, pp. 3-25.

Hopkins-Weise, Jeff (2002) Pacific Islanders involvement in the pastoral industry of the Gulf of Carpentaria, Journal of the Royal Australian Historical Society (www.articlearchives.com/ labor-employment/compensation-benefits-salaries).

Hopkirk, Peter (1994) The Great Game. The struggle for Empire in Central Asia. New York, Tokyo and London: Kodansha International.

Hotta-Lister, Ayako (1999) The Anglo-Japanese Treaty revision of 1911, conference paper. The Suntory Centre, Suntory and Toyota International Centres for Economic and Related Disciplines, London School of Economics and Political Science.

- (2002) The Anglo-Japanese Alliance of 1911 , conference paper. The Suntory Centre, Suntory and Toyota International Centres for Economic and Related Disciplines, London School of Economics and Political Science.

Immerman, Richard H. (2010) Empire for Liberty. A History of American Imperialism from Benjamin Franklin to Paul Wolfowitz. Princeton and Oxford. Princeton University Press.

Inagaki, Manjiro (1890)Japan and the Pacific and a Japanese view of the Eastern Question. London: T. Fisher Unwin.

Jukichi, Inouye (1895a) The Japanese-China War: The Fall of Wei-hai-wei. Yokohama [etc.]: Kelly \& Walsh.

— (1895b) The Japanese-China War:The Naval Battle of Haiyang. Yokohama [etc.]: Kelly \& Walsh.

Keene, Donald (1998) Modern Japanese diaries. The Japanese at home and abroad as revealed through their diaries. New York: Columbia University Press. 
Kennedy, Paul (1985) The realities behind diplomacy. Background influences on British policy 1865-1980. London: Fontana Press.

Knoll, Arthur J. and Hermann J. Hiery (2010) The German colonial experience. Select documents on German rule in Africa, China, and the Pacific 1884-1914. Lanham [etc.]: University Press of America.

Knopp, Guido (2011) Das Weltreich der Deutschen: Von koloniale Träumen, Kriegen und Abenteuern. Munich: Piper Verlag.

Koloniaal Verslag (1880). The Hague: Algemeene Landsdrukkerij.

Koschitzky, Max von (1887-88) Deutsche Colonialgeschichte. Leipzig: Frohberg.

Kotting, Adriaan Nicola (1902) Bescherming voor de Nederlandse scheepvaart. Vlugschrift. Amsterdam: J.H. de Bussy.

Krahmer, G. (1899) Russland in Ost-Asien (mit besonderer Berücksichtigung der Mandschurei). Leipzig: Verlag von Zuckschwerdt \& Co. (Russland in Asien Band IV).

Krout, Mary H. (1898) Hawaii and a revolution. The personal experiences of a newspaper correspondent in the Sandwich Islands during the crisis of 1893 and subsequently. London: John Murray.

Kubary, J. (1885) Ethnographische Beiträge zur Kenntniss der Karolinischen Inselgruppe und Nachbarschaft. Heft I. Die socialen Einrichtungen der Pelauer. Berlin:Verlag von A. Asher \& Co.

Lanessan, J.-L. de (1895) La colonisation française en Indo-Chine. Paris. Ancienne Librairie Germer Bailliére et Co.

Landon, Perceval (1905) Lhasa. An account of the country and people of Central Tibet and of the progress of the mission sent there by the English Government in the year 1903-4. 2 vols. London: Hurst and Blackett.

LaFeber, Walter (1998) (1963) The New Empire. An interpretation of American expansion 1860-1898. Thirty-Fifth Anniversary Edition. Ithaca and London: Cornell University Press.

Lawton, Lancelot (1912) Empires of the Far East. A study of Japan and her colonial possessions, of China and Manchuria and of the political questions of Eastern Asia and the Pacific. 2 vols. London: Grant Richards.

Lee, Robert (1989) France and the exploitation of China. A study in economic imperialism. Hong Kong: Oxford University Press.

Legge, J.D. (1956) Australian colonial policy: a survey of native administration and European development in Papua. Sydney [etc.]: Angus and Robertson.

- (1958) Britain in Fiji, 1858-1880. London and New York: Macmillan \& Co. and St. Martin's Press.

Letters (1920) Letters from the Kaiser to the Czar. Copied from government archives in Petrograd unpublished before 1920. New York: Frederick A. Stokes (www.archive.org/stream/letters fromkaiseoowill/ letters fromkaiseoowill_djvu.txt).

Li, Zhaojin (2003) A history of modern Shanghai banking. Armonk, NY: M.E. Sharpe.

Locher-Scholten, Elsbeth (2004) Sumatran sultanate and colonial state. Jambi and the rise of Dutch imperialism, 1830-1907. Ithaca, NY: Cornell Southeast Asia Program.

Lorin, Henri (1906) La France, puissance coloniale. Étude d'histoire et de géographie politiques. Paris: Augustin Challamel.

Lowe, John (2001) Rivalry and accord: International relations 1870-1914. London: Hodder \& Stoughton.

Lyne, Charles E. (1885) New Guinea: An account of the establishment of the British protectorate over the southern shores of New Guinea, London: Sampson Low, Marston, Searle \& Rivington. 
McGrath, Thomas E. (2003) A Warlord Frontier: The Yunnan-Burma Border Dispute, 1910-1937, Ohio Academy of History Proceedings (www.ohioacademyofhistory.org/2003/McGrath, accessed 10-3-2011).

McKay, Alex (1997) Tibet and the British Raj. The Frontier Cadre 1904-1947. Richmond, Surrey: Curzon Press.

MacMillan, Margaret (1988) Women of the Raj. New York: Thames and Hudson.

McKenzie (n.d.) The Tragedy of Korea. New York: E.P. Dutton \& Co.

Mahan, A.T. (1900) The problem of Asia and its effect upon international politics. London: Sampson Low, Marston \& Company.

- (1911/1981) The Panama Canal and sea power in the Pacific. An original study in naval strategy. Albuquerque: The American Classical College Press.

Manchuria (1921) Manchuria: treaties and agreements. Washington: Carnegie Endowment for International Peace, Division of International Law.

Mann, Golo (1992) Deutsche Geschichte des 19. und 20.Jahrhunderts. Frankfurt am Main: Fischer Taschenbuch Verlag.

Marshall, Norman S., Robert Tucker and Margaret A. Owens (n.d.) California's Ships: California's Battleships: The Story of the USS Oregon (www.militarymuseum.org/Oregon2.html).

Massie, Robert K. (1993) Dreadnought. Britain, Germany and the coming of the Great War. London: Pimlico.

Masterman, S. (1934) The origins of international rivalry in Samoa, 1845-1884. London, George Allen \& Unwin.

Matzat, Wilhelm (1985) Die Tsingtauer Landordnung des Chinesenkommissars Wilhelm Schrameier. Studien und Quellen zur Geschichte Schantungs und Tsingtaus, 2. Bonn: published by the author on his own (www.tsingtau.org).

Military Notes (1898) Military Notes on the Philippines. Washington: War Department, Adjutant General's Office.

Millard, Thomas F. (1906) The new Far East. An examination into the new position ofJapan and her influence upon the solution of the Far Eastern question, with special reference to the interests of America and the future of the Chinese Empire. London: Hodder \& Stoughton.

- (1909) The Far Eastern Question. An examination of the Far Eastern Question, including the new activities and policy ofJapan and the situation of China. London and Leipsic: T. Fisher Unwin.

Miller, Stuart Creighton (1982) 'Benevolent assimilation' The American Conquest of the Philippines, 1899-1903. New Haven and London: Yale University Press.

Mommsen, Wolfgang J. (1995) Imperial Germany 1867-1918. Politics, culture and society in an authoritarian state. London [etc.]: Arnold.

Moresby, John (1876) New Guinea and Polynesia. Discoveries and surveys in New Guinea and the d'Entrecasteaux Islands: a cruise in Polynesia and visits to the pearl-shelling stations in Torres Straits of H.M.S. Basilisk. London: Murray.

Morris-Suzuki, Tessa (1994) The technological transformation of Japan from the seventeenth to the twenty-first century. Cambridge: Cambridge University Press.

Morrison, G.E. (1895) An Australian in China. Being the narrative of a quiet journey across China to Burma. London: Horace Cox.

Musick, John R. (1898) Hawaii, our new possessions. An account of travels and adventure, with sketches of the scenery, customs and manners, mythology and history of Hawaii to the present, and an appendix containing the Treaty of Annexation to the United States. New York and London: Funk \& Wagnalls Company. 
Nabijan, Salim (1979) Sejarah pembinaan keretapi Negeri Kedah, Jebat, Malaysian Journal of History, Politics and Strategy, 9, pp. 109-27.

Nasution, Khoo Salma (2006) More than merchants. A history of the German-speaking community in Penang, 180os-1940s. Penang: Areca Books.

Navy (2009) The Australian Navy and the 1909 Imperial Conference on Defence, Semaphore, 8 (www.navy.gov.au/w/images/Semaphore_2009_8.pdf, accessed 7-7-2011).

Neton, Albéri (1904) L'Indo-Chine et son avenir économique. Paris: Perrin et Cie.

Neville, H. and H. Bell (1898) Report of the Mission to China of the Blackburn Chamber of Commerce 1896-7. Blackburn: The North-East Lancashire Press Company.

Newbury, Colin W. (1967) La représentation politique en Polynésie française, 1880-1903. Étude d'un cas d'assimilation, Journal de la Société des Océanistes, 23, pp. 11-27.

Nish, Ian (2002) The first Anglo-Japanese alliance treaty, conference paper. The Suntory Centre, Suntory and Toyota International Centres for Economic and Related Disciplines, London School of Economics and Political Science.

Norman, C.B. (1884) Tonkin or France in the Far East. London: Chapman \& Hall.

Norman, Henry (1900) The peoples and politics of the Far East. Travels and studies in the British, French, Spanish and Portuguese colonies, Siberia, China, Japan, Korea, Siam and Malaya. $5^{\text {th }}$ ed. London: T. Fisher Unwin.

Nuhn, Walter (2002) Kolonial Politikund Marine. Die Rolle der Kaiserlichen Marine bei der Gründung und Sicherung des Deutschen Kolonialreiches 1884-1914. Bonn: Bernard \& Graefe Verlag.

Onze handel (1899) Onze handel met China, Tijdschrift voor Nederlandsch-Indië, 3, pp. 433-40. One Man - One Bank (2003) One Man - One Bank: Adolph von Hansemann died one hundred years ago, Bank and History Historical Review, 3 (www.bankgeschichte.de/e/downloads/ hr_e_2003_03.pdf).

Orléans, Henri-Ph. d' (1894) Autour du Tonkin. Paris: Ancienne Maison Michel Lévy Frères.

Outer Mongolia (1921) Outer Mongolia. Treaties and arrangements. Washington: Carnegie Endowment for International Peace, Division of International Law.

Padfield, Peter (2009) Maritime dominion and the triumph of the free world. Naval campaigns that shaped the modern world 1852-2001. London: John Murray.

Paine, S.C.M. (2010) The Chinese Eastern Railway from the First Sino-Japanese War until the Russo-Japanese War, in: Bruce A. Elleman and Stephen Kotkin (eds.), Manchurian railways and the opening of China. An international history, pp. 13-36. New York: M.E. Sharpe.

Pakenham, Thomas (1992) The Boer War. London: Abacus.

Palmer, Alan (1992) The decline and fall of the Ottoman empire. London: John Murray.

Papers (1882) Papers relating to the affairs of Sulu and Borneo and to the granting of a Charter of incorporation to the 'British North Borneo Company'. Part I Correspondence respecting the claims of Spain; Part II Correspondence respecting the claims of Holland. London: Harrison.

Pawlik, Peter-Michael (1996) Von Siberien nach Neu Guinea. Kapitän Dallmann, seine Schiffe und seine Reisen 1830-1896. Ein Lebensbild in Selbst-und Zeitzeugnissen. Bremen: Hauschild Verlag.

Pelleray, Emmanuel (1922) Les Nouvelles-Hébrides, in: G. Regelsperger, E. Pelleray and Georges Froment-Guieysse, L'Océanie française. La Nouvelle-Calédonie, Les Nouvelles-Hébrides. Les Établissements français de l'Océanie, pp. 65-101. Paris: Notre Domaine Colonial.

Pickering, W.A. (1898) Pioneering in Formosa: Recollections of adventures among mandarins, wreckers, head-hunting savages. With an appendix on British policy and interests in China and the Far East. London: Hurst and Blackett. 
Pratt, R.W. (n.d.) The expatriate post offices operating in Shanghai-prior to 1911. www.cpsl.org. uk?articles/expat.html (accessed 24-3-2009).

Press, Michael (2008) Die Christianisierung Oceaniens - der Weg zur Entstehung von Volkskirchen, in: Frank Kürschner-Pelkmann, Pazifik: Glaube, Kultur, Gesellschaft. Jahrbuch Mission 2008. Hamburg: Missionshilfe Verlag, pp. 46-54.

Price, Ernest B. (1933) The Russo-Japanese Treaties of 1907-1916 concerning Manchuria and Mongolia. Baltimore: The Johns Hopkins Press.

Putnam Weale, B.L. (1908) The coming struggle in Eastern Asia. London: Macmillan and Co.

Reid, A.J.S. (1965) A Russian in Kelantan?, Peninjau Sejarah, 1, 2, pp. 42-7.

Richthofen, F. von (1877-1911) China, Ergebnisse eigener Reisen und daraufgegründeter Studien. 5 vols. Berlin: Dietrich Reimer.

Saniel, J.M. (1962)Japan and the Philippines, 1868-1898. Quezon City: University of the Philippines. Scarr, Deryck (1990) The history of the Pacific Islands: kingdoms of the reefs. Melbourne: Macmillan. Scott, James George (1885) France and Tongking. A narrative of the campaign of 1884 and the occupation of Further India. London: T. Fisher Unwin.

Sentupéry, Léon (189o) Témoignages et Documents, in: Jules Ferry (ed.), Le Tonkin et la MèrePatrie, pp. 59-404. Paris: Victor-Havard.

Seth, Michael J. (2006) A Concise History of Korea. From the Neolithic Period through the Nineteenth Century. London [etc.]: Rowman \& Littlefield Publishers.

Sewall, H.M. (1900) Partition of Samoa and the past relations between that group and the United States, Seventh annual report of the Hawaiian Historical Society. Honolulu: The Robert Grieve Publishing Company.

Shantung (1921) Shantung Treaties and Agreements. Washington: Carnegie Endowment for International Peace, Division of International Law.

Shengfa, Zhang (2010) Return of the Chinese Changchun Railway to China by the USSR, in: Bruce A. Elleman and Stephan Kotkin (eds.), Manchurian railways and the opening of China. An international history, pp. 171-94. New York: M.E. Sharpe.

Shennan, Margaret (2000) Out in the midday sun. The British in Malaya 1880-1960. London: John Murray.

Shuster, W. Morgan (1912) The strangling of Persia: A record of European diplomacy and Oriental intrigue. London and Leipsic: Fisher Unwin.

Sieg, Dirk (2005) Die Ära Stosch. Die Marine im Spannungsfeld der deutschen Politik 1872 bis 1883. Bochum: D. Winkler (www.winklerverlag.com/vo39ox/vo39o-oo.pdf).

Silbey, David J. (2012) The Boxer Rebellion and the Great Game in China. New York: Hill and Wang.

Snow, K.A. (1994) The Russian Consulate in Singapore and the British expansion in Southeast Asia (1890-1905), Journal of Southeast Asian Studies, 25, 2, pp. 344-67.

Soest, G.H. van (1885) Het kolonisatievraagstuk in den tegenwoordige tijd, Tijdschrift voor Nederlandsch-Indië, 17, 2, pp. 423-57.

Soroka, Marina (2011) Britain, Russia and the road to the First World War. The fateful embassy of Count Aleksandr Benckendorff(1903-16). Farnham and Burlington: Ashgate.

Staley, Eugene (1935) War and the Private Investor. A study in the Relations of International Politics and International Private Investment. Chapter 5. Type Cses; Samoa; Episodes from Persia, Venezuela, Haiti, Mexico. New York: Doubleday, Doran \& Company (net.lib.byu.edu/estu/ wwi/comment/investor/Staleyo5.html).

Stathis, Stephen W. (1982) Albert B. Steinberger: President Grant's man in Samoa, Hawaiian Journal of History, 16. pp. 86-111. 
Steeds, David (2002) The second Anglo-Japanese Alliance and the Russo-Japanese War, conference paper. The Suntory Centre, Suntory and Toyota International Centres for Economic and Related Disciplines, London School of Economics and Political Science.

Steel, Robert (1880) The New Hebrides and Christian missions. London: James Nisbet.

Steinberg, Jonathan (2005) The Kaiser and the British: the state visit to Windsor, November 1907, in: John C.G. Röhl and Nicolaus Sombart (eds.), Kaiser Wilhelm II, new interpretations: the Corfu papers, pp. 121-42 (paperback ed.). Cambridge [etc.]: Cambridge University Press.

- (2011) Bismarck: A life. Oxford [etc.]: Oxford University Press.

Steinmetz, George (2007) The devil's handwriting: Precoloniality and the German colonial state in Qingdao, Samoa, and Southwest Africa. Chicago and London: The University of Chicago Press.

Stevenson, Robert Louis (1892) A Footnote to History. Eight Years of Trouble in Samoa. London, Paris \& Melbourne: Cassel \& Company.

Swettenham, Frank (1907) British Malaya. An account of the origin and progress of British influence in Malaya. London and New York: John Lane the Bodley Head and John Lane Company.

- (1948) British Malaya. An account of the origin and progress of British influence in Malaya. Rev. ed. London: George Allen and Unwin.

Taylor, A.J.P. (1971) The struggle for mastery in Europe, 1848-1918. Oxford and New York: Oxford University Press.

Taylor, Basil (1908) Harbour and shipping, in: Arnold Wright and A.H. Cartwright (eds.), Twentieth century impressions of Hongkong, Shanghai, and other treaty ports of China, pp. 188-234. London [etc.]: Lloyd's Greater Britain Publishing Company.

Temple, Richard (1902) Progress of India, Japan, and China in the century. Toronto [etc.]: The Linscott Publishing Company \& W. and R. Chambers.

Thijs, J.D. (1965) De invloed van de opkomst van Japan en van de Japanse overwinning op Rusland in Azië. Kampen: J.H. Kok.

Thio, Eunice (1969) Britain's search for security in North Malaya, 1886-97, Journal of Southeast Asian Studies, 10, 2, 279-303.

Thomas, Nicholas (2010) Islanders. The Pacific in the age of Empire. New Haven and London: Yale University Press.

Titus, Felicitas (2012) Old Beijing. Postcards from the Imperial City. North Clarendon: Tuttle Publishing.

Townsend, Mary Evelyn (1930) The rise and fall of Germany's colonial empire, 1884-1918. New York: Macmillan.

- (1939) The Suez Canal. Its past, present and future. $2^{\text {nd }}$ ed. London: Oxford University Press.

Tregonning, K.G. (1964) How Germany Made Malaya British, Asian Studies, 2, 2, pp. 180-7.

Turnbull, C.M. (1981) A short history of Malaysia, Singapore and Brunei. Singapore: Graham Brash.

Tyler, John (1842) Special Message to Congress (rohan.sdsu.edu/dept/polsciwb/brianl/ docs/1842TylerDoctrine.pdf).

Tyler, Sydney (1905) The Japan - Russia War. An illustrated history of the war in the Far East. Philadelphia: P.W. Ziegler.

United States Department of State (1902) Papers relating to the foreign relations of the United States, with the annual message of the President to Congress December 2, 1902. Washington: U.S. Government Printing Office.

Unrecorded (n.d.) Unrecorded judgements of the Joint Court of the New Hebrides (www.vanuatu. usp.ac.fj/library/Paclaw/vanuatu/Varobaravu.pdf). 
Ven, Hans van de (2006) Robert Hart and Gustav Detring during the Boxer Rebellion, Modern Asian Studies, 40, 3, pp. 631-62.

Ward, John M. (1976) British policy in the South Pacific (1786-1893). A study of British policy in the South Pacific islands prior to the establishment of Governments by the great powers. Westport, CT: Greenwood Press.

Waters, Theodore (1900) The Trans-Siberian Railway, FrankLeslie's Popular Monthly, March 1900 (www.catskillarchive.com/rrextra/stsib.Html).

Wcislo, Francis W. (2011) Tales of Imperial Russia: The life and times of Sergei Witte, 1849-1915. Oxford [etc.]: Oxford University Press.

Weicker, Hans (1908) Kiautschou. Das deutsche Schutzgebiet in Ostasien. Berlin: Verlagbuchhandlung Alfred Schall.

Wertheimer, Fritz (1913) Deutsche Leistungen und Deutsche Aufgaben in China. Berlin: Julius Springer.

Williams, E.T. (1916) The relations between China, Russia and Mongolia, American Journal of International Law, 10, 4, pp. 798-808.

Wright, Arnold (1908) Hongkong, Shanghai, and other treaty ports. Early history and development, in: Arnold Wright and H.A Cartwright (eds.), Twentieth century impressions of Hongkong, Shanghai, and other treaty ports of China, pp. 32-99. London [etc.]: Lloyd's Greater Britain Publishing Company.

Wright, Arnold and H.A. Cartwright (eds.) (1908) Twentieth century impressions of Hongkong, Shanghai, and other treaty ports of China. Their history, people, commerce, industries, and resources. London [etc.]: Lloyd's Greater Britain Publishing Company.

X (1900) De groote oorlog, Indisch Militair Tijdschrift, 31, pp. 293-6.

Xiang, Lanxin (2003) The Origins of the Boxer War: A Multinational Study. London: RoutledgeCurzon.

Young, Walter (1979) (1931) Japan's special position in Manchuria. Repr. ed. Baltimore: Johns Hopkins University Press.

Young-Sik, Kim (2003) A BriefHistory of the US-Korea Relations prior to 1945. A paper presented at the University of Oregon (www.freerepublic.com/focus/f-news/943949/posts).

Zachmann, Urs Matthias (2005) Imperialism in a nutshell: Conflict and the 'Concert of Powers' in the tripartite intervention, 1895, Japanstudien, 17, pp. 57-82.

Zimmermann, Alfred (1901) Weltpolitisches: Beiträge und Studien zurneueren Kolonialbewegung. $2^{\text {nd }}$ ed. Berlin: Allgemeiner Verein für Deutsche Literatur. 



\section{Index}

Afghanistan 26-7, 29, 147-8, 150, 351, 454-5

- border 150-2, 154-8, 454-5, 457

- Pamir Crisis 157-8, 295, 312, 295

- Penjdeh Crisis 147, 154-7, 194, 223, 249

- Russia advancing on $38,138,147,150,157$, 322

- Second Anglo-Afghan War 151, 218

Aguinaldo, Emilio 387-8, 392-5

Aigun-Jinzhou railway line 480-1

Aihui see Aigun

Alexander II 148

Alexander III 154, 312

Alexeiev, E.I. 345, 421, 431

Allen, Horace Newton 429, 464

American-Spanish War 386-94

Amur River 155, 248-9, 474

Andaman Sea 16, 155, 283

Angkor 201, 238-43, 287, 292

Anglo-Burmese War

- Second 217

- Third 221-5

Anglo-French Entente 40-1, 292, 446-451

Annam 201-17, 227, 234, 278-9, 283, 286

Anzer, Johann Baptist von 179-80, 303

Apia 5o, 81-2, 96,164, 166, 171-2, 175, 402-5, 407-8, 414-5

Ashley, Evelyn 117, 130

Austral Islands 65-6, 441

Australia

- concerns about foreign attacks 25,44 , $66,83,85,104-5,113-7,129,132,390,406$

- concerns about foreign penal colonies $66,104,116,124,442-5$

- concerns about Japanese aggression 40-1, 26o, 396, 425, 466-7, 471-2, 484

- navy $467,488,490,492$

- territorial aspirations $25,44,67,70-1$, $74,79,83,87,102-7,113,118,125^{-} 6,131-2$, $137,144,169,382,406,408,412,442-6$, 448-50, 490-1

Australian New Hebrides Company 445-6

Ava, Kingdom of 217-26

Bai River see Hai River

Balfour, A.J. 237, 256, 266, 313, 317-22, 326-7, $334-5,349,354,425,449,455^{-7}$

Bamberger Ludwig 100, 109, 137

Bangkok 185, 229, 236, 239

Bass Islands 66

Bates, George H. 165, 171, 407

Battambang 201, 238-43, 280, 287, 292

Bay of Bengal 16, 155, 283

Bayard, Thomas F. 81, 165, 171-2

Beihai 338

Beijing 256, 319, 340-5
Beresford, Charles 22, 28, 35-9, 189, 191, 256, 261, $267,274,298,313,318,321-3,327,332$

Berlin-Baghdad railway 451,489

Bhamo 205-6, 218, 275

Bhutan 357

Binh Thuan 211, 214

Bismarck, Herbert von 138-40, 144, 170

Bismarck, Otto von 19, 25, 44, 47, 67, 97-101, 108-12, 122-5, 131-9, 143-4, 163-5, 167, 170-4, 180-1, 192-3, 284, 307, 312, 365, 401, 408

Bismarck Archipelago 44, 49-52, 55-6, 60-1, $101-2,112,118,121-5,133-5,140-1,144,167,413$, $415,490-2$

Blackburn trade mission 191, 255, 277, 297, 330

Blaine, James G. 29, 174, 195, 366-7, 369-70

Bleichröder, Gerson von 102, 109, 111-2, 121

Blount, James Henderson 377-8

Blue River see Yangtze

Boer War 38, 158, 323, 411-3, 419, 451, 494

Bohai Sea 253, 256, 261, 299, 308, 312, 315, 323, 326-7, 340, 345

Bombay-Burmah Trading Corporation 220-1, 224

Bora-Bora 441

Bougainville 143, 410

Boxer Rebellion 256, 281, 295, 340-6, 395, 427, 490

Brandeis, Eugen 170, 172-3

Brodrick, William St John Fremantle 299, 349-50, 354-5

Broglie, J-V-A Duc de 204-5

Brown Islands 143-4

Browne, Horace A. 270, 346

Buffer state $28,150,157-8,229-31,236-7,240-1$, $288,295^{-6}$

Buka Island 143, 410

Buller, Alexander 265, 312

Bülow, Prince Bernhard Heinrich Karl Martin von 178, 299, 303, 308, 311, 334, 391-2, 397, 401-2, 406-11, 417-9, 423-4, 427, 432

Burma 205, 208, 212, 217, 295-6; see also Ava

- east border 230-1, 236-8, 241, 484

- railways 219, 272-8

Burns, Philp \&Co. 56,446

Busan 189, 249, 263-5, 429

Cakobau 68-71, 73

Cambodia 201-2, 211-2, 216, 227, 234, 239, 278-9, 292, 497

- railways 292

Cambon, Pierre Paul 448, 451

Canada 15, 20, 43-4, 72, 190, 296, 370, 382

Cantabun see Chantaboon

Canton see Guangzhou

Caprivi, Count Leo von 235

Carnarvon, Earl of 6o, 67, 70-1, 75-6, 98, 102-6, $115,125^{-6}, 440^{-1}$ 
Caroline Islands 46, 56, 140, 142-3, 396-7, 416, 490

Cavendish, Spencer Compton 317, 319

CCNH see Compagnie calédonienne des

Nouvelles-Hebrides

Cedercrantz, Otto Conrad Waldemar 175

Central Asia 25, 31, 33-4, 39, 41, 147-52, 158, 223 , $355,45^{2}, 476$

Central Polynesian Land and Commercial Company (CPLCC) 56, 82-91

Chamberlain, Joseph 286, 288, 321, 323-4, 408, 417,420

Chambers, William Lea 402-3

Chantaboon 238-43, 292, 351

Chantaboum see Chantaboon

Chantaburi see Chantaboon

Chao Phraya Valley see Menam Valley

Chartered companies 99-100, 112, 144, 231-2

Chemulpo 250-1, 263, 431

Chester, Henry Marjoribanks 113

Chientao see Jiandao

China 33-8, 203, 218, 245-66, 295-8, 417, 465-6, 473,490

- armed forces 184, 187, 214, 253, 295, 305, 319,322

- border, northern 32, 248, 319-20, 496-7

- border, southern 32, 218, 226, 230, 271-5, 295, 337, 357

- border, western 148-9, 474, 496-7

- Inland Steam Navigation Regulations 329-30

- loans 261-2, 277, 301-2, 312, 317, 320, 329-30, 337, 474, 479

- partition 215, 296, 298, 314, 317, 322, 327-9, 36o, 417-9, 423-6, 437, 473-6, 484

- railways $15,23,36,181,215,261,267$, 272-7, 280-1, 297-301, 309, 317-8, 326, $330-5,338,340,345,428,446$

- revolution 282,484

China trade $177,296-8,329$

- American 187-9, 359-61, 382, 386-7, 398-9, 429, 431, 469, 479, 486

- British 31, 153, 177, 212, 217-8, 221-4, 260-1, 268-9, 271, 277, 328-30, 346-8, 352, 356, $419,430,446,482-3$

- French 202-8, 212, 267-9, 277, 280, 299, 338,446

- German 180-5, 258, 300-1, 309-10

- Japanese 190-1, 254-6, 26o, 299, 360-1, 440, 469; see also Guandong and Port Arthur

- Korea 360, 429-30, 483

- Manchuria 328, 345, 361, 431, 469

- Russian 148-9, 248, 310-5, 345, 485; see also Guandong and Port Arthur

Chinese Eastern Railway 311-2, 331-2, 435-8, 478-8o, 495-6

Chinese Eastern Railway Convention 311, 331, $436,438,478$

Chitral 157-9, 238

Choiseul 143, 410
Chongqing 254-5, 267, 271, 299, 495

Chumbi Valley 352-6, 454

Chungking see Chongqing

Churchill, Randolph 223

Churchill, Winston 442

Chusan see Zhoushan

Clarke, Andrew 285

Cleveland, Stephen Grover 173, 176, 363, 373-81

Coal mining 17, 180, 202, 208, 301, 327, 338, 435 , 493

Coaling stations $16-22,55-6,72,84-5,93-5,99$, $101,103-5,111,122-3,155,167-8,176,186,192-3$ 210-2, 216, 233, 257-8, 265-6, 286, 289-9o, $301-2,307,312,328,337,362,366,382,393$, 398, 406, 409, 414, 429-30

Cochin China 97, 201-5, 209, 211, 216-8, 298

Compagnie calédonienne des NouvellesHebrides (CCNH) 445-6

Consuls and commercial agents 19, 22, 24-6, 43, $58,64,97$

- in Asia 46, 183, 190, 207-8, 219-21, 271, 277, 279-80, 289, 350-2, 353, 394

- in Fiji 59, 67-9, 71, 75, 77

- in Samoa 84, 89-96, 162-6, 170-4, 402-6; see also Weber

Cook Islands 413, 441, 492

Cooper, Thomas Thornville 205-6, 218

Courcel, Baron Alphonse Chodron de 140

Crimean War 33, 148, 154, 179, 247

Curzon, George Nathaniel 19, 24, 30-1, 39, $148-50,153-6,223,241-3,249,255,263,265$, $275,277-8,288,291,298,312,319-20,327-30$, $334,339,346,351-3,456$

Dagu Forts 256, 341, 345

Dalai Lama 349, 355-7, 454

Dalian(wan) 262, 311-5, 317, 320, 434-5, 469-7o, 491, 496

Dallmann, Eduard 121, 123

Dalny see Dalian

Danang 211

De factor rule see Principle of Effectivity

Deakin, Alfred 449

Deer Island 265, 312

Delcassé, Théophile 282-3, 340, 446-50

Denison, W. 48

Derby, Earl of 27-8, 44, 102-4, 113-8, 124-6, 135

Deutsche Handels- und Plantagen-Gesellschaft der Südsee-Inseln zu Hamburg 108-12, 118-9, $121,124,130,161,164,170,176,404,415$

Dewey, George 387-90, 394

DHPG see Deutsche Handels- und PlantagenGesellschaft der Südsee-Inseln zu Hamburg

Diederichs, Otto von 303-6, 390, 401, 406

Disraeli, Benjamin 18, 31

Dole, Sanford Ballard 372-74, 378-9, 384, 398

Dorjiev, Agvan 349-50, 354, 484

Douglas, John 130-1 
Doumer, J.A.P. 15, 235, 255, 278-83, 289, 292, 338-9, 447

Dual Alliance, Franco-Russian 28-32, 40, 236, $240,257,272,274,289,311,320-2,425-6$, $430-1,447,452$

Dufferin, Earl of 219, 221-5, 227

Duke of York Islands 56, 133, 141

Dupré, Marie-Jules 203-8

Dupuis, Jean 202-6

Durand Line 156-7, 496

East Cape (New Guinea) 123, 125-6, 131

Eckardstein, Hermann von 408, 413, 419, 422 Edward VII 447, $45^{2}$

Egypt 13, 18-9, 26, 30, 115, 126, 137-8, 140, 211, $232-4,273,292,385,440,447-50$

Elgin, Earl of 157, 240, 272-3

Ellice Islands 140, 145, 409, 492

Erskine, James Elphinstone 126, 128-9

Étienne, Eugène 227, 232, 278

Eulenburg, Count Friedrich zu 194, 247, 300

Faipule 87, 90-6

Far Eastern Triple Alliance 34, 241, 258-60, 301, $341,360,407,418,424,432,466$

Ferry, Jules 209-11, 214-5, 227, 231, 278

Fiji 43-4, 47-79, 83, 87, 89, 90-1, 93, 97, 99, 102, $106,108,114,130-7,140,161-2,167-9,175,192$, $194,364,396,412-3,415,440-2,492,496$

Finsch, Otto 51, 121-4, 127, 131-2, 140

Fish, Hamilton $85-8$

Fisher, John 467

Formosa see Taiwan

Fort-Bayard 339

Foster, John Watson 367, 369, 371, 374-6

Foster, S.S. 89-90

France 187, 256-9

- associations promoting colonialism 131, $274,278,445$

- navy in Asia 38, 201, 204-11, 232-4, 247, $337-8,342$

- navy in South Pacific 58-9, 64, 443

- territorial aspirations 26, 30-1, 64, 102-3, 208-11, 227, 231-3, 240, 273-4, 278, 280-1, 286-7, 440-5, 448, 491-2

Franco-Chinese War 213-6

Franco-Prussian War 13, 97, 208, 210, 232, 284

Franco-Russian cooperation 215, 232, 235-6; see also Dual Alliance

Franco-Thai War 233-5

Free trade 27, 34-6; see also protectionism and Open Door

- France 339

- Germany 44, 55, 309-10

- Great Britain 27, 36, 26o, 317-8, 348

- Persia 452-8

- United States 34-7, 360-1, 376, 399

Frelinghuysen, Frederick Theodore 364

Freycinet, Charles de 209, 220, 232
Friedrich-Wilhelms-Hafen 123

Fujian 260, 299, 342

Fukien see Fujian

Fusan see Busan

Gambier Islands 65, 441

Gando see Jiandao

Garnier, Francis 202-9, 218, 269, 28o

Gartok 356

Gensan see Wonsan

George V $49^{\circ}$

Germany 13-4, 177-85

- associations promoting colonialism 110, 194

- and China 177, 247, 253, 321, 389, 397; see also Jiaozhou

- and Japan 247, 253, 256-9

- and the Philippines 388-92

- and Southeast Asia 221, 233, 235, 247, 283-93

- $\quad$ navy $26,38,98-100,141,192-4,258,302$, $307,405,458,468$

- navy in North Pacific 300, 304-8, 320, 341-2

- navy in South Pacific 55, 74, 83-4, 91-6, $122-3,142-3,162-5,171-4,403-5,441$

- Roman Catholics 179-80, 300-4

- territorial aspirations 19, 21, 25-6, 41, 44-6, 66-7, 97-101, 109-11

- Weltpolitik 178, 299-300, 303, 307-8, 389, 401, 405, $45^{\circ}$

Gibson, Walter Murray 364-6

Gilbert Islands 140, 145, 408-9, 492

Gladstone, William Ewart 26, 32, 224

Godeffroy \& Sohn 54-5, 67, 76, 81-3, 85, 89, 91, 108-9, 121, 143, 192, 442; see also DHPG

Goodenough, James Graham 71

Gordon, Arthur Hamilton 77-8, 83, 90-5, 104, $396,415,496$

Grandière, Pierre-Paul de la 201-2

Grant, Ulysses S. 84-6, 88

Granville, Earl 46, 69, 78, 125, 134-5, 138-40

Great Britain

- and Japan 39, 41, 253, 259, 320-1, 452, $476,423-8,431,434,439-40,451,463$, $466-9,472,483-8$

- $\operatorname{army} 38,323$

- $\quad$ navy $26,193-5,424,494$

- navy in Asia 155, 212-3, 233-6, 247, 265, 270, 312-3, 322-8, 341-2, 430, 439-40

- navy in South Pacific 58-61, 64, 69-70, $75,89-90,93,117,126-9,173-4,403-5,416$

- territorial aspirations $25^{-8}, 33,44,49-50$, $64,70-2,74,87,91-2,102,105-6,118,221-4$, $284-7,317,321,326,329,382$

Gresham, Walter Quintin 253, 259, 373

Grey, Edward 27, 30, 37, 230, 234, 236-7, 252, 298, $328,375,434,448,45^{0}, 45^{2-61}, 464,471,476$, $481,483-4,486,489-90$ 
Griffin, Gilderoy W. 91-3

Griffith, Samual W. 412, 493

Guam 392-3, 490

Guangdong 267, 269, 272, 337-8

Guandong Leased Territory 314-5, 320, 470; see also Port Arthur

Guangxi 261-2, 267, 269, 272-3, 337-8

Guangzhou 185, 245, 269, 280, 328, 337, 359

Guangzhouwan 22, 337-40, 473

Guizhou 267

Gyantse 351-6

Haas, Frederick 219-20, 271

Hai River 345

Hainan 29, 337-8

Haiphong 207-8, 217, 280

Hanoi 202, 204, 206-9, 213-4, 283, 495

Hamilton, George 150, 156, 159, 238, 270, 347, 349-53

Hangzhou 254, 300

Hankou 246, 280, 301

Hankow see Hankou

Hansemann, Adolph von 102, 108-9, 111-2, 121

Harbin 438, 474, 478, 495

Hardwicke, Earl of 351, 354, 483, $45^{2}$

Harmand, François-Jules 209-11

Harrison, Benjamin 176, 195, 367, 369, 374-6, 379

Hart, Robert 203-4, 245, 262, 264, 296, 323, 329

Hatzfeldt, Count Paul von 165-6, 169, 408-9, 417

Hawaii 28-9, 45, 53, 66, 69-70, 84, 106, 171, 186, 190,

196, 359-86, 392, 398-9, 429, 463, 468-9, 471-2

- American interests 361-4

- American residents 363, 365-6, 369-72

- annexation campaign 368-72, 375

- Annexation Treaty $375-7,382-5,398$

- Bayonet Constitution 366, 369-71

- Citizens' Committee of Public Safety 371, 375

- commercial reciprocity 363-4, 366, 369-70, 380

- coup d'état 371-2, 378-9

- invasion fears $374-5,382-4,473$

- Japanese immigrants $363-4,375,385$, $398,469,471$

- protectorate $373-4,377$

- Republic of Hawaii 371-80, 383-4

Hay, John Milton 48, 340, 36o, 388, 399-40o, 411,420

- Open Door Notes 399-400, 420

Hayashi Tadasu 40, 422

Hayes, Rutherford B. 93, $25^{\circ}$

Hebei Province see Zhili Province

Heinrich, Prince of Prussia 307-8, 333

Henan 299

Hennings Company 55, 67, 69, 72-3, 76

Herat 32, 148, 151, 154-6

Heyking, Edmund Friedrich Gustav von 300, 304

Hicks-Beach, Michael 317

Higginson, John 445
High Commission(er) for the Western Pacific $60-1,74,91,115,117,130,134,163$

Ho Chi Min City see Saigon

Hohenlohe-Schillingsfürst, Chlodwig Karl Viktor zu 258, 300, 303, 306-7

Hokkaido 97, 197, 249

Hong Kong 16-8, 29, 110, 181-4, 205, 208, 213, 245, $247,257,267,269,280,297,300,317,324,328$, $339,386,388,494$; see also Kowloon

Honolulu 173, 361, 363-7, 370-4, 379-80, 383, 471

Huahine 441

Hué 210-1, 283

Hunter, Hamilton 413-4

Huon Gulf 124-5, 134-5, 139

Îles Australes see Austral Islands

Îles de Bass see Bass Islands

Îles Loyauté see Loyalty Islands

Îles Marquises see Marquesas Islands

Îles de la Société see Society Islands

Îles sous le Vent see Leeward Islands

Ili 148-9, 248, 359

Incheon see Chemulpo

India

- borders 156-7, 357, 459

- concerns about armies approaching 28$34,38-9,138,147-8,156,219,221,229-30$, $234,238,240,271,286,288,311,345,355$, 426-7, 431, 439, 455-7, 486, 489-9o

- nationalism 465-6

Indochina $36,201-17,223,233-4,255,278-83$,

337-9, 446-7, 449-51, 465-6, 473, 495

- border with Burma 218, 228, 230-1, 236-43; with China 215-6, 271-4, 447; with Thailand 201, 218, 227-30, 233-43

- concerns about foreign competition 203-6, 212, 215-6, 308

- railways $211,215-6,276-81$

- trade 202, 208

Iosefo see Mata'afa Iosefo

Iran see Persia

Irrawaddy River 205, 218, 225

Islamic rebellion in China 149, 203, 269

Isvolsky, Alexander 456, $45^{8}$

Italy 103-4, 218-21, 235, 340, 399

Ito Hirobumi 19o, 251, 264, 423, 463, 483, 497

Jaluit $56,142,172,175$

- Jaluit-Gesellschaft 144

Japan 189-191, 247

- and Hawaii 363-4, 374-5, 382-5

- and the Philippines 387, 391-2

- Asia for the Asians 255, 260, 189-90, 387, 465

- invasion fears 197, 429

- navy 39, 197-9, 424, 466

- navy in Asia 189, 249-50, 253, 341-2, 434, 486

- navy in the Pacific 471-2, 488, 490 
- territorial aspirations 40, 255, 260, 420-1; see also Korea and Manchuria

- war loans 431, 434, 436

- unequal treaties 190, 384, 468, 487

Jäschke, Otto 309

Jiandao 477

Jiaozhou 33, 37, 190, 300-9, 318, 320-7, 332-4, $337-40,360,382,386,392,397,490-4$

Johor 285,289

Kaing Khen see Keng Cheng

Kalakaua 363-70, 377

Kalgan see Zhangjiakou

Kamehameha III 362, 365

Kamehameha IV 362

Kando see Jiandao

Kashgar see Kashi

Kashi 149

Kato Takaaki 421-2, 428, 434, 471

Katsura Taro 423, 463, 472

Kautz, Albert 404-5

Kay-Shuttleworth, Ughtred 217, 221

Kedah 284, 286, 290-1

Keisuke Otori 252-3

Kelantan 240, 286, 288-9, 291

Keng Cheng 230, 237-8, 240-2

Keng Hung 230, 237, 271-2, 275, 277, 337, 339

Keng Tung 237-8

Ketteler, Klemens Baron von 340, 343-4

Khiva 148

Kiang Hung see Keng Hung

Kiaochow see Jiaozhou

Kiautschou see Jiaozhou

Kimberley, Earl of 28, 33, 39, 76, 87, 217, 221-3 $229,234,240,259,284-5,288,295$

Kimberley, L.A 173-4

Kipling, Rudyard 303, 392

Kiribati Islands see Gilbert Islands

Kitchener, Horatio Herbert 467

Knappe, Wilhelm 173-4

Knorr, Eduard von 55, 91, 165

Knox, Philander, C. 474, 478-81

Kojong 251, 263-6, 430-1, 464-5

Kokang 275

Korea 34, 40, 155-6, 181, 83, 187, 189-90, 197 , 248-56, 259, 263-6, 295-6, 299, 311-2, 331, 343, 359-6o, 375, 420, 423-32, 436, 440, 468-70, $473,477-8,486,497$

- Japanese annexation 432, 463-5, 463, $472-3,483,486$

Kowloon Peninsula 245, 317, 339, 388

Kra Isthmus 230, 241, 283, 287-8, 290

Krupp 184, 194, 256, 295, 305, 341, 492

Kubary, Johann Stanislaus 143, 397

Kulja 148-9

Kunlong Ferry 273, 275, 278

Kunming 271-2, 280-2, 338

Kuril Islands 248-9

Kuropatkin, Aleksey N. 34, 158, 426
Kwangchowan see Guangzhouwan

Kwangsi see Guangxi

Kwantung (Leased Territory) see Guandong

Kwantung (Peninsula) see Liaodong

Kweichow see Guizhou

Kyaing Chaing see Keng Cheng

Labour recruitment South Pacific 52-4, 58-62, $64,69,72,74,77,82,89,91,102,115-7,140$, 144-5, 161-2, 410, 415, 441-3, 448-9, 494, 496

Ladrones Islands see Mariana Islands

Lagrée, Ernest-Marc-Louis Doudart de 201-2, 269

Lamsdorff, Vladimir N. 188, 350, 421, 426, 431

Landownership South Pacific 57, 59, 63, 67-9, 74-9, 82-4, 86-9, 91, 93-5, 106, 118, 121-4, 127$9,132,142,144,162-4,172,175^{-6}, 415-6,448$

Langkawi Islands 290-1

Lansdowne, Marquess of 40, 198, 348-50, 419, $422-3,425-6,430,451^{-2}$

Laos 202, 227-9, 232-5, 241, 286-7

Laupepa see Malietoa Laupepa

Layard, E.L. 71

Lealofi see Tupua Tamasese Lealofi

Leeward Islands 140, 441, 444

Liaodong Peninsula 34, 97, 197, 235, 254, 256-6o, 262, 311, 314-5, 424, 435; see also Guandong and Port Arthur

Li Hongzhang 251, 310-11

Liaotung see Liaodong

Liliuokalani, Lydia Kamakaeha Kaolamalii 366-38o

Lobanov-Rostovsky, Prince Aleksei 258, 264 $310-1$

Lodge, Henry Cabet 188, 378, 381, 391

Long Island (New Guinea) 134,139

Louangphrabang see Luang Prabang

Louisiade Islands 133-4

Louisiana Lottery Company 370, 372, 375

Loyalty Islands 65

Luang Prabang 238-9, 241, 292

Lüda see Port Arthur

Lüshun see Port Arthur

Luzon 389-90, 392-3

Lyon Chamber of Commerce 227, 255, 267, 282

Ma'afu, 68-70, 73

Macau 29, 245, 269, 494

MacDonald, Claude Maxwell 308, 334, 418

Mahan, Alfred Thayer 37, 48, 153, 191-2, 195-6, 378, 398-9, 471

Malay Peninsula 185, 240-1, 283-4, 289-9o; see also Straits Settlements and individual states - railways 288,291

Malet, Edward 135, 137, 140, 168, 170

Malietoa Laupepa 83-4, 86-9o, 92, 94-6, 161-5, 171-2, 174, 365, 401-2

Manchuria 34, 38-40, 151, 190, 197, 248-9, 254 $256,263,266,310-23,331-2,335,340,343$, $345,359-60,417-29,431,434-40,455,466$, 
469-82, 477, 486, 491; see also Guandong,

Liaodong and Port Arthur

- American economic interests 359-6o

- railways 262, 310-1, 311-2, 322, 331-2, 335, $345,421,428,435-8,473,476-83,491$, 495-6

- Fushun coal mine 469, 477

Maori Wars $47-8$

Margary, Augustus Raymond 270

Mariana Islands 392, 396-7, 490

Marquesas Islands 65

Marshall Islands 56, 140, 142, 144, 397-8, 401, 490

Mata'afa Iosefo 87, 96, 161, 172, 174-5, 401-6, 413-5

McIlwraith, Thomas 113-4, 132, 443

McKinley William 196, 369, 381-3, 386, 391-3, $396,405,407,416$

McLeavy Brown, John 264-5, 430, 464

McMahon Line 357

Manila 386, 389, 390-2, 394-5

Masan 429

Meade, R.H. 133,167

Meade, Richard W. 85

Mekong 201-3, 227-31, 234-42, 269, 273, 288, 291-2, 448

Menam Valley 229, 236, 447-8

Mengtze 272, 282-3

Merrit, Wesley 388, 393-4

Meung Lem 230, 271, 277

Midway 66, 186

Mikhailovich, Grand Duke Alexander 312

Mining 23, 48, 106-7, 153-4, 190, 202, 205, 211, $279,281,284,286,307,317,331-5,345,350$, $355,360,399,421,430,436,469,477-8,483$, 493; see also coal mining

Mioko 56, 112, 122-4

Missionaries

- in Asia 22, 179, 187, 201, 246-7, 250, 296, 300, 302-5, 308-9, 341, 429, 442-3

- in Hawaii 363, 366, 372

- in South Pacific 49-50, 53, 62, 65, 68, 79, $81,87,89-90,107-8,126-9,132,134,169$, 401-2

Mong Sing 237-8, 241, 272

Mongolia 248, 355, 473-4, 480-2, 484-6, 491

Morocco 447, $45^{\circ}$

Mulinu'u 9o, 162-4, 171-2, 404-5, 414

Mukden see Shenyang

Mumbai see Bombay

Munglem see Meung Lem

Münster, G.H. Count von 55, 78, 125, 134-5, 137, 139

Muong-Sing see Mong Sing

Muraviev, Count M.N. 306, 312-3

Myanmar see Burma

Namwan Assigned Tract 275

Nanning 215, 262, 275, 277, 320, 330, 350, $45^{\circ}$

Nationalism 190, 465-6, 468, 471

Nauru 490-1

Navigators' Island see Samoa
Negeri Sembilan 285

Nepal 349-5o

Netherlands (Indies) 9, 21, 97, 112-4, 141, 144, 175, $178,190,198,232,255,260,289,364-5,396,465$

Neuguinea-Konsortium 112, 118

Neu-Guinea-Compagnie 121-2, 140-4, 492

Neu-Lauenburg Inseln see Duke of York Islands

Neu-Mecklenburg see New Ireland

Neu-Pommern see New Britain

New Britain 51, 111, 118, 133, 141

New Britain Archipelago see Bismarck Archipelago

New Caledonia 49, 61, 65-6, 104, 442-6, 492, 495

New Guinea 18, 44, 53, 56, 62, 79, 97-8, 100-8, $111-145,181,223,362,397,407,410,415,490-4$

- failed Australian annexations 105-6, $113-7,121,128$

- partition 125-6, 133-5, 138-40

New Hebrides 44, 65-6, 91, 104, 118, 133, 140, 440-9, 492

New Ireland 51, 53, 111, 118, 133, 141

New Zealand 25, 44, 66-7, 74, 79, 83, 85, 87, 102, 104, 117-8, 131-2, 137, 144, 162-4,169, 296, 382, $406,408,412-3,441-5,449-50,487,490-2$

- concerns about Japanese aggression 40-1, 425, 466-7, 471-2

Newchwang see Yingkou

Nicholas II 158, 249, 257-9, 261, 302, 304, 312, $314-5,317,344,35^{0}, 427,431,433,436,45^{0}$, 452, 489-9o

Nishi Tokujiro 266

Nouvelle-Calédonie see New Caledonia

Nouvelles-Hébrides see New Hebrides

Oertzen, Gustav von 122, 141

Okinawa $25^{0}$

Oparo see Rapa

Open Door

- China 35-6, 177, 189, 26o-1, 310, 317-9, $321,328,334,360-1,386,399-400,418-20$, 423-5, 439, 473, 476, 486

- Korea 469, 473

- Manchuria 38-9, 469-70, 473

- Morocco 450

- Persia $45^{8}$

Opium War

- First 36, 186, 245

- Second 201, 245, 247-8, 324

Ottoman Empire 13, 23, 29, 32-3, 148, 317

Pacific Ocean

- assessments $20,28,38,43,48$

- supremacy in 40-1, 196-9, 386, 416, 466-8, 471-2

Pago Pago 84-6, 92-3, 171, 173, 176, 406-7, 409-11, 414, 416, 443

Pahang 285,287

Pakhoi see Beihai

Paknam Crisis see Thailand 
Palau Islands 46, 140, 143, 397, 490

Palmerston, Viscount 148, 245

Pamir Crisis see Afghanistan

Panama Canal 19-20, 43, 66, 83, 171, 187, 196, 198, 378, 398-9, 409, 440-1, 445, 471

Panjdeh/Panjeh see Penjdeh

Partition of preponderance 23, 317, 319, 335

Patabang see Battambang

Patani 286, 291

Pearl Harbor 171, 366-7, 471

Pechili Gulf see Bohai Sea

Pei-ho River see Hai River

Peking see Beijing

Penang 16, 185, 284, 289, 290

Penghu Islands 214, 254, 300

Penjdeh Crisis see Afghanistan

Perak 285, 287

Perlis 286, 291

Perry, Matthew Calbraith 64, 186, 260, 362

Persia

- Anglo-Russian rivalry 24, 30, 38, 148-54, $158,407,434,451-61,476,486,489-90,495$

- border 152, 158, 456, 459, 490

- railways $451,453,455^{-6,489}$

Persian Gulf 15, 150-3, 158, 407, 451-6, 489

Pescadores Islands see Penghu Islands

Philastre, Paul-Louis-Felix 207

Philippines 46, 97, 178, 185, 190, 196-7, 255, 260 , $344,361,376,386-400,406,415-6,429,463$, 469, 471-3

- independence movement 387-8, 390, 393-5

- Moro's 395-6

- peace negotiations 391-4

Plessen, Baron von 118, 125, 168-9

Polynesia Company 56, 68-9

Polynesian federation $364-5$

Pope Leo XIII 143, 308

Porapora see Bora-Bora

Port Arthur 36-8, 194, 253, 256, 258, 260, 266, $311-28,331,335,339,360,382,385-6,392$, $420,424-5,429,431-5,458,465,491,496$

Port Hamilton $155^{-7}, 249^{-50}$

Port Lazareff 249-50

Port Moresby 105, 113

Portugal 21, 245

Powell, Wilfred $165^{-6}$

Principle of Effectivity 46-7, 103, 189

Protectionism 35-6, 177, 319; see also Open Door and free trade

- Germany 334

- France 36, 208, 212-3, 239, 271, 449; 443, 446

- Great Britain 97, 334-5

- Japan 469-71, 438, 476-8

- Russia 334, 470, 474, 476, 486-7

Providence Islands 143-4

Pusan see Busan
Qingdao 300, 305-10, 321, 490-4

Quang Tchéou Wan see Guangzhouwan

Racism

- anti Chinese 256-7, 296, 342-3, 376, $383-5,398,466,468$

- anti Japanese 190, 256-7, 383-5, 398, 425, 468-9, 471

- Philippines 395

- South Pacific $5^{\circ}$

Raffel, John 402-4

Raiatea 441, 444

Railway rivalries, 23, 36, 177, 298, 311, 330-1, 334

- American railway interests in China 335, 399, 469, 478-82

- Anglo-German 291, 451, 489

- Anglo-French 215, 219-20, 261, 267, 272-3, 277, 280-1, 338, 446

- Anglo-Russian 152-4, 262, 317-8, 322, $334-7,345,35^{\circ}, 355,427,453,455^{-7}, 489$

- Russo-Japanese 249, 310-1, 421, 435-7, 473

- Sino-Japanese 197, 473, 476-8, 480-2, 491

- Sino-Russian 335, 421, 428, 476-8, 480-2

Railway zones 331-4, 436-8, 451, 478, 496

Railways 14-5, 20, 23, 261, 275, 300-1, 310, 318

- see also individual countries and lines and railway rivalries

Raivavae 65, 441

Rangoon 185, 492

Rapa 66, 441, 443

Rathbone, Féez, and Co. 56, 73, 76

Red River 202-9, 217, 226, 269-71, 277, 280, 330

Ribot, Alexandre 228

Richthofen, Ferdinand Freiherr von 300-1, 389

Rivière, Henri Laurent 209, 213

Roads 23, 28, 158, 189, 211, 214, 241, 279, 355, 453

Robertson \& Hernsheim Company 52-3, 55-6, 112, 121, 141-2

Robinson, Hercules George Robert 73

Rockhill, William Woodville 183, 400, 479

Romilly, Hugh Hastings 127, 134

Rook Island 134, 139

Roosevelt, Theodore 188, 192, 196, 381, 387, 395 ,

399, 471-2

Root, Elihu 469, 472-3

Rose, Friedrich 403-4

Rosebery, Earl of 32, 34, 157, 229-31, 234-9, 242, $253,256,259,287-8,295,346,348,424$

Rosen, Roman Romanovich 266

Rotuma 77, 127

Russia

- and Southeast Asia 221, 288-90

- army 39, 256, 321-2, 434

- $\operatorname{navy} 38,40$

- navy in Asia 149, 155, 197, 247, 263-4, 312-4, 319, 341-2, 431-4, 439

- Siberian border 480-1, 484 
- territorial aspirations 25-6, 29-34, 39, 103-4, 148-9, 248, 310; see also Manchuria and Persia

Russo-Chinese Bank 261, 331

Russo-Japanese War 40, 150, 199, 420-2, 426, $431-8,465,474,480,497$

Ryojun 435

Ryukyu Islands 189, $25^{\circ}$

Sabah 99

Sahl, Karl L. 73, 77

Saigon 17, 185, 201, 203, 208, 210, 495

Sakhalin 197, 248-9, 429, 434, 436

Salisbury, Marquess of 23, 26, 39, 153, 165, 16870, 223-5, 229-30, 236, 240-3, 259, 262, 265, 274-5, 288-9, 291, 314, 317-21, 323-4, 327-9, $335,340,406-8,411,413,417,423,446-7$

Samoa 25-6, 44-60, 63-4, 73, 81-97, 99, 102, 106, 108-9, 112, 118-9, 121, 130-1, 133, 140-1, 161-76, $178,181,194-5,306,365,367,391,397,401-16$, 442, 490-2

- Chief Justice 175, 402-3

- international conferences 170-1, 174-6, $367,401-2,409,420$

- military operations of Germany 163-5, 171-3, 410

- military operations of Great Britain and the United States 404-5, 410

- partition 401, 406-10, 414, 416

- treaties with Germany, Great Britain and the United States 92-5, 162-3

Samoan Subsidy Bill 108-10, 112

San Mun Bay see Sanmen Bay

Sanderson, Thomas 287-8, 329

Sandwich Islands see Hawaii

Sanmen Bay 340, 349

Santa Isabel 143, 410

Sarawak 284

Satow, Ernest Mason 323, 356, 437, 450, 467-8, 494 Schönfelder, Victor 403-4

Scott, Charles 125-6

Scott, Charles Stewart 30, 153, 312, 335, 426

Scratchley, Peter Henry 51, 130

Sea of Japan 249, 429, 497

Seddon, Richard 382, 412-3, 449

Seistan see Sistan

Selangor 284-5, 289

Se-mao see Szemao

Senfft von Pilsach, Arnold Freiherr 175

Service, James 62, 131

Se-Tchouan see Sichuan

Seoul 250-2, 265, 360, 483

Sewall, Harold Marsh 165, 170, 381, 411

Seward, William H. 66, 84, 186-8, 362-3

Shandong $179,300-10,333-5,340$

Shanghai $18,181-5,191,194,205^{-6}, 215,217,246-7$, $255,257,273,297,300,303,307,324,328$, $340,342,345,359,389$

Shanhaiguan 335,345
Shantung see Shandong

Shantung-Bergbau-Gesellschaft 333-4, 493

Shantung-Eisenbahn-Gesellschaft 332-4, 493

Shenyang 345, 469, 477, 481

Shenyang Agreement 345, 421-2

Sherman, John 360,383

Shipping

- river traffic $23,255,274,278,280,329$ $30,345,361$; see also individual rivers

- ocean shipping 13-20, 180-3, 185, 191, 195, 216, 263, 297, 299, 363, 370, 382, 398-9, 407, 409, 441, 443

Shufeldt, Robert W. 187, 250, 359

Shuster, William Morgan 459-61, 489

Sichuan 254-5, 267-9, 271, 273, 277-8, 280, 330, 348,495

Siemreap/Siem-Réap see Angkor

Sikiang see West River

Sikkim 348-52

Simao see Szemao

Sinkiang see Xinjiang

Singapore $16-8,181,185,213,236,245,247,283-7$, $298,465-6$

Sino-French War 213-6, 295, 337

Sino-Japanese War 189, 197, 241, 251-62, 277, 299, 310, 424, 466, 497

Sipyagin, Dmitry 420

Sistan 456

Sladen, Edward Bosc 28, 219-20, 222-4, 269

Society Islands $64-5,413,440-1$

Sokehs rebellion 397

Solf, Wilhelm H. 406, 414-6

Solomon Islands 44, 49, 70, 140, 143, 145, 409-11, 415

Songhua River 474

South Manchuria Railway 331-2, 421, 431-2, $435-8,469,476-8,480-1,492$

- Yingkou-Tashihchiao line 332, 477

Spain 21, 34, 46, 67, 142-3, 201, 386-97, 406, 448

Spheres of interest $23,35,178,35^{1}$

- in Afghanistan 150-1, 157, 454

- in China 28, 32-3, 35, 245, 267-9, 272-3, 279-80, 283, 298-9, 301-2, 306-13, 317, 325, $329,334-9,342,360,418-20,446-7,474$

- in Hawaii 29, 360-3, 367-8, 374-6, 379-84

- in Korea 29, 40, 264, 266, 299, 428-9, $436,463,473$

- in Persia 152-4, 452-4, 457-8, 460-1, 489

- in Manchuria 29, 266, 418-22, 427-8, $473-4,482-3$

- in Mongolia 473-4, 484-5

- in the South Pacific 102-3, 125-6, 132-4, 138-40, 161, 167, 169, 441-2, 448-9

- in Southeast Asia 217-20, 225, 282-5, 288, 290-1, 440, 447-8; see also Thailand

- in Thailand 28, 227-43, 273, 288, 291, 447-9

- in Tibet 346-51, 355-7

St Julian, Charles James Herbert de Courcy 365 
Steinberger, Albert B. 86-9o, 94

Stevens, John Leavitt $367-80,383$

Stevens, R.N. 89-9o

Straits of Malacca 18, 185, 283, 289

Straits Settlements 185, 284-6, 289; see also Penang and Singapore

Stübel, Otto Wilhelm 162-6, 174

Sturdee, F.C. Doveton 404

Sudan 273-4, 281

Suez Canal 13-20, 150, 444

Sulu Archipelago 46, 98

Sungari River see Songhua River

Swettenham, James Alexander 285, 290-1

Syndicat du Yunnan 430

Szechuan see Sichuan

Szemao 272, 275, 277

Tahaa 441, 444

Taft, William Howard 396, 415, 463, 471, 479-8o, 487

Tahiti 49, 64-5, 140, 440-1, 444

Ta'imua 86, 90-6

Taiwan 97, 186, 189, 214-5, 250, 254, 26o, 269, 299-300, 342, 396, 469, 497

Taku Forts see Dagu Forts

Talavou 86, 95-6, 161

Talienwan see Dalianwan

Tanumafili 402-6, 413-5

Tchoung-king see Chongqing

Telegraph 16, 211, 264, 297, 311, 331, 355-6, 367, 453,473

Terengganu 240, 286, 288, 290-1

Thailand $185,201-2,227-38,241-3,279,282,417$,

447-9

- border, eastern 201, 218, 227-30, 233-43, 287, 292-3

- border, southern 240, 286-92

- Paknam Crisis 233-4

- railways $280,291-3$

Thibaw Min 218-25

Thurston, John Bates 70, 163-70

Thurston, Lorrin Andrews 365-6, 369-71, 384, 398

Tianjin 184, 191, 256, 297, 301, 341, 345

Tibet $346-357,454$

- borders 348, 357

- British military expedition 346-55, 451-2, 457

- Outer Tibet 357

- Tibet Trade Regulations 348-9

Tientsin see Tianjin

Tirpitz, Alfred 74, 144, 192-3, 300-1, 309, 397 405, 409, 458, 468, 490, 493

Titimaea see Tupua Tamasese Titimaea

Tonga 44, 49, 53-5, 68, 91, 131, 140, 162, 167-70, $181,365,407,409-11,413,492$

Tonkin 22, 202-17, 226-7, 261, 269, 271-3, 277-8, $280,283,338$

Tonkin River see Red River

Torres Strait 105-6, 113
Tourane see Danang

Trans-Caspian Railway 152, 310

Transcontinental Railway

- Canada 15, 20, 370, 382

- United States 14, 48, 84, 171, 363, 399

Trans-Mongolia Railway 481, 484

Trans-Siberian Railway 15, 20, 197, 249, 274, 310-1, 314-5, 321-2, 331-2, 421, 426, 434

Travers, G. $165-8$

Treaty ports

- in China 245, 254-5, 261, 296

- in Indochina 207

- in Japan 186

- in Korea 189, 250, 428

Triple Entente see Anglo-French Entente and Anglo-Russian Convention

Triple Intervention see Far Eastern Triple Alliance

Tripp, Bartlett 406-7

Tsingtao/Tsingtau see Qingdao

Tuamotou Islands 65,441

Tubuaï 65,441

Tu Duc 205, 211

Tupua Tamasese Lealofi 402-3, 415

Tupua Tamasese Titimaea 83-4, 161-6, 170-2, 402

Tuvalu Islands see Ellice Islands

Tyler, John 186, 359, 361

- Tyler Doctrine 361

Ulan Bator 248, 481, 484

United States 186-9, 465

- and China 36-7, 177, 186, 253, 259, 321, 340-1, 359-62, 382, 385-7, 399-400, 476-83

- Chinese Exclusion Act 376, 384-5, 466, 471

- invasion fears 362

- Japan as potential enemy 196-7, 466, 471-3, 487, 498-9

- large policy $188,399-400$

- navy $195^{-6}$

- navy in Asia 186-7, 341-2

- navy in Hawaii 364, 367-71, 374-8o

- navy in South Pacific 58-9, 64, 68-9, 85, 92-3, 173-4, 403-5, 472

- territorial aspirations $26,29,64,66$, $85-8,176,186,188,362,367-9,376-82$, $386-7,391,393,396,398-9,402$

Urga see Ulan Bator

Ussuri River 248, 496

Uvea see Wallis Island

Vanuatu see New Hebrides

Vava'u Island 55, 167, 409

Victoria 154, 162-3, 235, 259, 408

Vietnam see Indochina

Vladivostok 155, 184, 197, 248, 315, 337, 433, 436, 438

Wake Island 398

Waldersee, Alfred Count von 344 
Wallis Island 65, 441

Ward, Joseph George 449, 466-7, 472

Webb, William H. 84-6, 88

Weber, Theodore 54-5, 81-95, 161-4, 166, 170,

$$
172,175
$$

Wei-hai-wei 253, 255, 323-9, 340, 430, 435, 494-5

Werner, Bartholomäus von 55-6, 101

West River 262, 267, 269, 274-5, 277, 28o, 330, 338

Wilcox, Robert W. 367

Wilhelm I 13,19,140, 163, 307

Wilhelm II 154, 173, 177-80, 192-3, 235, 256-8, 296, 299-308, 311, 315, 342-4, 388-9, 396, 405, 407-8, $412,414,417,423,427,432-3,450,458,468,489$

Williams, S.F. 89-9o

Willis, Albert Shelby 378

Wiltse, G.C. 371, 373

Witte, Count Sergei 150, 310-2, 345, 431

Wonsan 249-50, 263-4, 266

Wuchou 277

Xi River see West River

Xiamen 299, 301, 342

Xinjiang 148-9, 248, 496

Yalu River 429

Yamagata Aritomo 20, 197, 264, 295
Yanbian see Jiandao

Yangon see Rangoon

Yangtze/ Yang-Tsze-Kiang 188, 190, 202, 245-6, 254, 267, 271-3, 280, 298-9, 301, 310, 324, 329-30, 335, 337, 345, 396, 418, 440, 482

Yap 142-3, 490

Yatung 348,356

Yellow Sea 33, 312, 315, 331

Yili see Ili

Yingkou 38-9, 315, 332, 335, 345, 359,469-70, 476-7, 495-6

- Yingkou-Faku railline 476, 480

Yining see Kulja

Younghusband, Francis Edward 157, 352, 355-7, 457

Yunnan 149, 202-6, 208, 218, 226, 233, 237, 267, $269-83,330,337-8,446,484$

Yunnanfu see Kunming

Yunnan-Sen see Kunming

Zanzibar 409

Zhangjiakou 248, 481, 484

Zhanjiang see Guangzhouwan and Fort Bayard

Zhejiang 299

Zhili Province 256, 340

Zhoushan 215, 245, 300-1, 389 


\section{List of Treaties, Agreements and Joint Statements mentioned}

Global treaties

Anglo-French Entente (1904) 40-1, 292, 446-51

Anglo-Japanese Alliance

- $(1902) 39,41,423-8,431,434$

- (1905) 439-40, 451, 463, 466-9, 472

- $(1911)$ 486-8

Anglo-Russian Convention (1907) 41, 451-7, 46o, 476, 481, 486, 489-9o

Dual Alliance, Franco-Russian (1894) 28-32, 40, 236, 240, 257, 272, 274, 289, 311, 320-2, 425-6, 430-1, $447,45^{2}$

Entente Cordiale see Anglo-French Entente

Far Eastern Triple Alliance (1895) 34, 241, 258-60, 301, 341, 360, 407, 418, 424, 432, 466

Triple Entente see Anglo-French Entente and Anglo-Russian Convention

\section{China}

American-Chinese Treaty of Tianjin (Tientsin) (1858) 245

Anglo-Chinese Agreement modifying the 1894 Convention (1897) 275-7, 308, 337

Anglo-Chinese Convention relative to Burmah and China (1894) 271, 274-5

Anglo-Chinese Convention relating to Burma and Thibet (1886) 226, 346

Anglo-Chinese Convention relating to Sikkim and Tibet (189o) 348-9

Anglo-Chinese Convention respecting Tibet (1906) $35^{6}$

Anglo-Chinese Treaty of Tianjin (Tientsin) (1858) 245-6

Anglo-German Agreement (1900) 418-9, 422-3, 451, 474

Anglo-German Financial Agreement (1898) 335, 399

Anglo-Russian Agreement respecting Spheres of Influence in China (1899) 334-7, 345, 399, 428, 447, 480

Anglo-Russian Railway Agreement see Anglo-Russian Agreement (1899)

Anglo-Tibetan Convention (1904) 355-6

Anglo-Tibetan Declaration (1914) 357

Boxer Protocol 345

Chefoo Convention see Yantai Convention

Chinese Eastern Railway Convention $(1896,1898)$ 311, 331, 436, 438, 478

Convention respecting an Extension of Hong Kong Territory (1898) 339

Convention between the German Empire and China respecting the Lease of Kiai-chau (1898) 308

Convention between Great Britain and China respecting Wei-hai-wei (1898) 324

Conventions of Beijing (1860) 149, 245-8, 481

- Second (Anglo-Chinese) Convention of Beijing (1898) see Convention Respecting an Extension of Hong Kong Territory

Engagement between Japan and China respecting Formosa (1874) 189

Franco-Chinese Convention Delimiting the Frontier between Tonkin and China (1887) 215, 271

Franco-Chinese Supplementary Convention

- $(1887) 215,271$

- $\quad(1895)$ 271-4, 338

Franco-Chinese Treaty of Commerce \& Supplement $(1886,1887) 215,271$

Franco-Chinese Treaty of Tianjin (Tientsin)

- $(1858) 245^{-7}$

- $(1884) 214$

- $(1885) 214-7,223$

Franco-Japanese Treaty (1907) 473

Franco-Russian Declaration on China (1902) 426, 431

Li-Lobanov Treaty see Sino-Russian Treaty (1896)

Livadia Treaty (Ch-R 1879) 149

Russo-Chinese Agreements in regard to Mongolia (1913) 485

Russo-Chinese Treaty of Tianjin (Tientsin) (1858) 245-6 
Russo-Japanese Secret Convention

- $(1907) 473$

- $(1912) 485$

Russo-Mongolian Treaty (1912) 484-5

Sino-Japanese Treaty respecting the Province of Shandong (1915) 491

Sino-Russian Treaty (1896) 310-1

Tibet Trade Regulations (1893) 348-9

Tibetan-Mongolian Treaty (1913) 484

Treaty of Aigun (R-Ch, 1858) 248, 474

Treaty of Beijing (1860) see Conventions of Beijing

Treaty of Ili see Treaty of St Petersburg (1881)

Treaty of Kulja (R-Ch, 1851) 148

Treaty of Nanjing (GB-Ch, 1842) 245

Treaty of Shimonoseki (J-Ch, 1895) 254-62, 269, 272, 431

Treaty of St Petersburg (R-Ch, 1881) 149, 248

Urga Treaty see Russo-Mongolian Treaty

Yangtze Agreement

- (GB-Ch, 1898) 329

- (1900) see Anglo-German Agreement

Yantai Convention (GB-Ch, 1876) 270, 346

Hawaii

Anglo-French Declaration (1843) 361-2, 367

Convention for Commercial Reciprocity (US-Hawaii)

- (1875) 363-4

- (1887) 366-7, 369-70

Hawaii Annexation Treaty 375-7, 382-5, 398

Japanese-Hawaiian Treaty of Amity and Commerce (1871) 383-5

\section{Korea}

American-Korean Treaty of Peace, Amity, Commerce and Navigation (1882) 187, 250, 463 Eulsa Treaty see Japanese-Korean Treaty 1905

Japanese-Korean Treaty

- (1894) 253

- $(1905) 463$

- $(1907) 465$

- other arrangements 432

Korean Boundary Agreement see Manchuria

Li-Ito Treaty (1885) 251

Nishi-Rosen Protocol (R-J, 1898) 266

Root-Takahira Agreement (1908) 472-3

Russo-Japanese Secret Convention (1907) 473

Russo-Korean Treaty of Amity and Commerce (1884) 250

Sino-Japanese Treaty of Tianjin (Tientsin) (1885) 251

Taft-Katsura Memorandum (1905) 463, 472

Treaty of Chemulpo (J-Korea,1882) $25^{\circ}$

Treaty of Kanghwa (Ganghwa) (J-Korea, 1876) 189, 250

Yamagata-Lobanov Agreement (R-J, 1896) 264

\section{Manchuria}

Beijing Treaty (1905) see Sino-Japanese Treaty relating to Manchuria Convention of Beijing (R-Ch 1860) 248

Jiandao Agreement see Sino-Japanese Agreement relating to the Chientao Region

Korean Boundary Agreement see Sino-Japanese Agreement relating to the Chientao Region Manchurian Agreement see Sino-Japanese Agreement concerning Mines and Railways in

Manchuria

Manchurian Treaty see Sino-Japanese Treaty relating to Manchuria

Russo-Chinese Convention for the lease of the Liaotung (Liaodong) Peninsula (1898) 314-5

Russo-Chinese Convention with regard to Manchuria (1902) 427-8, 431, 476-7 
Russo-Japanese Secret Convention

- (1907) 473

- $(1910) 482$

Sino-Japanese Agreement relating to the Chientao Region (1909) 477-8

Sino-Japanese Agreement concerning Mines and Railways in Manchuria (1909) 477-8

Sino-Japanese Treaty relating to Manchuria (1905) 437, 476-7, 480

Treaty of Aigun (R-Ch, 1858) 248, 474

Treaty of Portsmouth (R-J, 1905) 435-7, 470, 473

\section{South Pacific}

American-Samoan Treaty of Friendship and Commerce (1878) 92

Anglo-French Convention respecting the New Hebrides (1887) 443-4

Anglo-French New Hebrides Convention (1906) 448-9

Anglo-German Samoa Convention (1899) 409

Anglo-Samoan Treaty of Friendship (1879) 95

Anglo-Tongan Treaty of Friendship and Protection (1900) 409

Bismarck-de Courcel Protocol 140, 441, 443

Final Act of the Conference on the Affairs of Samoa (1889) 174-5

German-Samoan Agreement (1884) 162

German-Samoan Treaty of Friendship (1878) 93

Jarnac Convention/Declaration (GB-F, 1847) 440, 444

Samoa Convention see Final Act of the Conference on the Affairs of Samoa

Tripartite Convention (Samoa, 1899) 409-12

\section{Southeast Asia}

Anglo-French Declaration of London regarding Siam, the Niger and Tunis (1896) 241-3, 271, 273, 283, 291,447

Anglo-French Protocol (1893, border Upper Mekong) 236

Anglo-Siamese Secret Convention (1897) 290

Anglo-Siamese Treaty (1909) 291

Bangkok Treaty see Anglo-Siamese Treaty (1909)

Burney Treaty (GB-Th) (1826) 286

Franco-Annamese Treaty

- (1874) 207-9

- (1884) 213-4

Franco-Cambodian Treaty of Friendship and Trade (1863) 201

Franco-Siamese Treaty

- $\quad(1867) 201,239$

- $\quad(1904) 292$

- $\quad(1907) 292,497$

Franco-Siamese Treaty and Convention (1893) 235, 242

Pangkor Engagement (GB-Perak, 1874) 285

Treaty of Hué (Fr-Annam)

- (1863) 201

- $(1883)$ 211-2

Treaty of Paris (US-Spain, 1898) 393

Treaty of Saigon (Fr-Annam, 1862) 201

\section{Others}

American-Japanese Treaty of Commerce and Navigation (1894) 468

Anglo-Japanese Tariff (Commercial) Treaty (1911) 487

Anglo-Japanese Treaty of Commerce and Navigation $(1854,1894) 425$

Potsdam Agreement (1910) 489

Russo-Japanese Treaty of Commerce, Navigation and Delimination (1855) 248

Treaty of Gandamak (GB-Afgh, 1879) 151

Treaty of Punakha (GB-Bhutan, 1910) 357

Treaty of Shimoda (R-J, 1855) 248 



\section{IIAS Publications}

International Institute
for Asian Studies

\section{Global Asia}

Michiel Baas (ed.): Transnational Migration and Asia. The Question of Return Global Asia 4, 2015, ISBN 9789089646583

Frédéric Bourdier, Maxime Boutry, Jacques Ivanoff and Olivier Ferrari: From Padi States to Commercial States. Reflections on Identity and the Social Construction of Space in the Borderlands of Cambodia, Vietnam, Thailand and Myanmar

Global Asia 3, 2015, ISBN 978908964659 o

Volker Gottowik (ed.): Dynamics of Religion in Southeast Asia. Magic and Modernity

Global Asia 2, 2014, ISBN 9789089644244

Matthias Maass (ed.): Foreign Policies and Diplomacies in Asia. Changes in Practice, Concepts, and Thinking in a Rising Region

Global Asia 1, 2014, ISBN 9789089645401 
